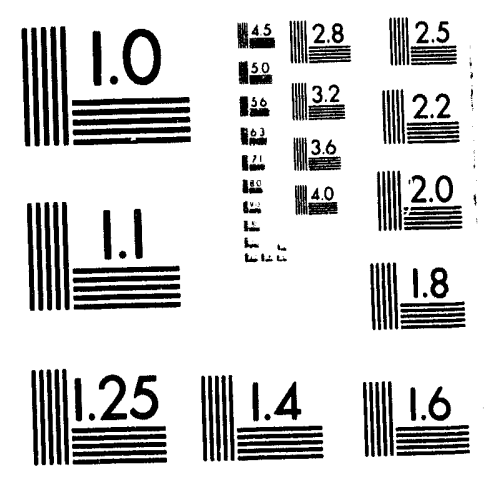



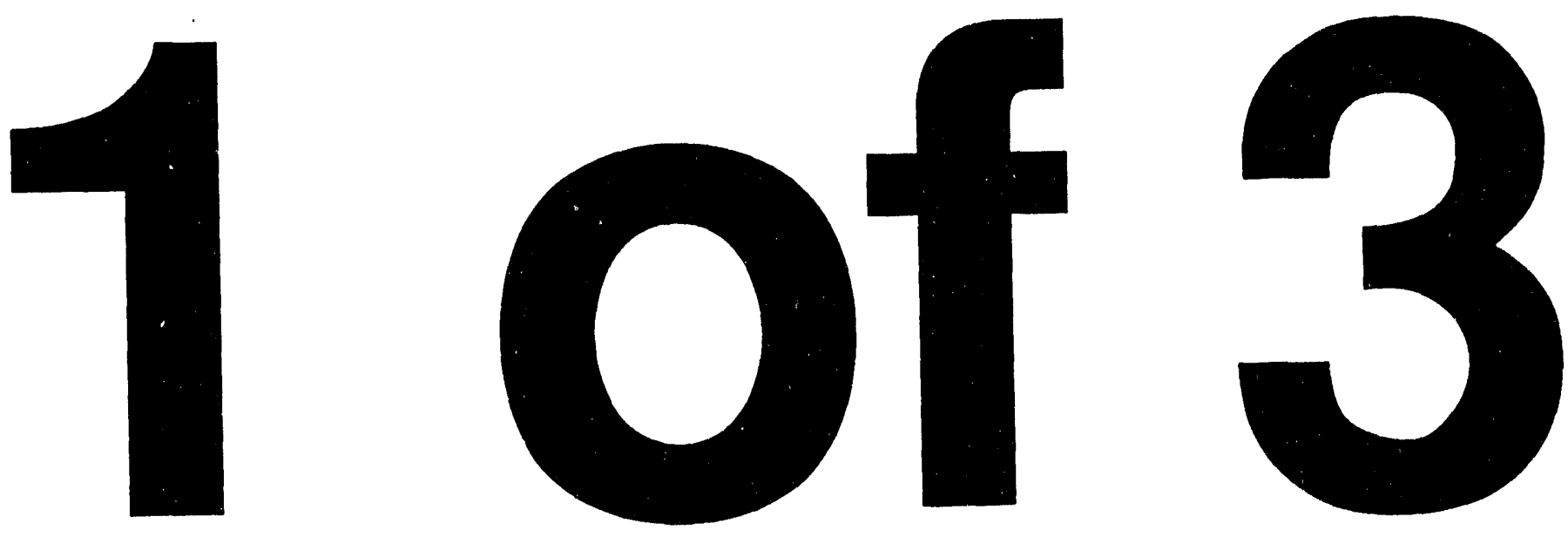
DOE/EIA-0131(92)/S

Distribution Category UC-950

\title{
Natural Gas Annual 1992 Supplement: Company Profiles
}

\author{
January 1994
}

\author{
Energy Information Administration \\ Office of Oil and Gas \\ U.S. Department of Energy \\ Washington, DC 20585
}

This report was prepared by the Energy Information Administration, the independent statistical and analytical agency within the Department of Energy. The information contained herein should not be construed as advocating or reflecting any policy position of the Department of Energy or any other organization.

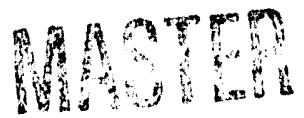




\section{Contacts}

The Natural Gas Annual Supplement is prepared by the Energy Information Administration, Office of Oil and Gas, Reserves and Natural Gas Division under the direction of Diane W. Lique.

General information for this document may be obtained from Kendrick E. Brown, Jr. (202/586-6077), Chief of the Data Operations Branch. Questions and comments concerning the contents of the Natural Gas Annual Supplement may be directed to Ann M. Ducca
(202/586-6137) and Margo Natof (202/586-6303). Inquiries about specific companies may be referred to Ellis Maupin (202/586-6178). Inquiries about data presented in the tables may be directed to Dolly Tolson (202/586-6664) and Sylvia Norris (202/586-6106).

The data reported on the Form EIA-176, "Annual Report of Natural and Supplemental Gas Supply and Disposition," are available on diskette. Contact Sheila Darnell (202/586-6165) for information about diskettes. 


\section{Preface}

The Natural Gas Annual provides information on the supply and disposition of natural gas to a wide audience including industry, consumers, Federal and State agencies, and educational institutions. This report, the Natural Gas Annual 1992 Supplement: Company Profiles, presents a detailed profile of selected companies.

The data in the Natural Gas Annual publications are taken from surveys conducted by the Energy Information Adninistration (EIA), U.S. Department of Energy (DOE), to fulfill its responsibilities for gathering and reporting energy data. All of the information presented in this volume is taken from the mandatory
Form EIA-176, "Annual Report of Natural and Supplemental Gas Supply and Disposition." Beginning with the collection of data for 1990, data reported on the Form EIA-176 are no longer proprietary.

All volumes of natural gas in this publication are reported at 14.73 pounds per square inch absolute and 60 degrees Fahrenheit, except where noted. A glossary of terms is provided to assist users in understanding the data presented. A description of the data collection surveys appears in Appendix A of the Natural Gas Annual 1992, Volume 1. 


\section{Contents}

Overview $\ldots \ldots \ldots \ldots \ldots \ldots \ldots \ldots \ldots \ldots \ldots \ldots \ldots \ldots \ldots \ldots \ldots \ldots \ldots \ldots$

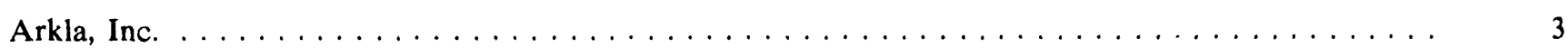

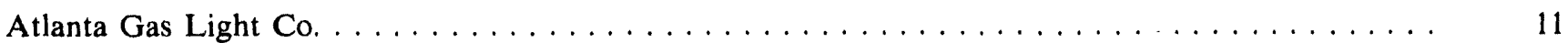

Baltimore Gas and Electric Co. $\ldots \ldots \ldots \ldots \ldots \ldots \ldots \ldots \ldots \ldots \ldots \ldots \ldots \ldots \ldots$

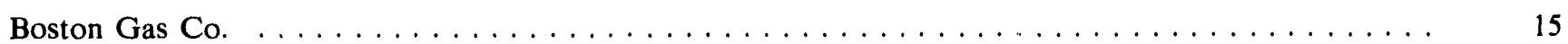

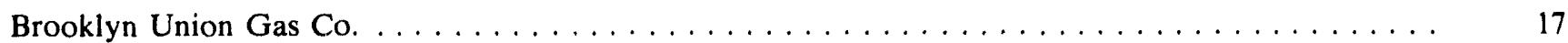

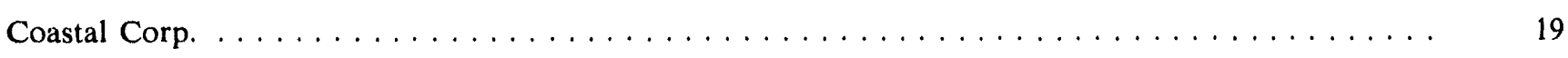

Columbia Gas Systems, Inc. . . . . . . . . . . . . . . . . . . . . . . . . . . . . . . 29

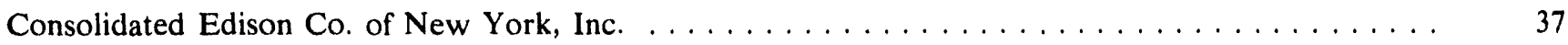

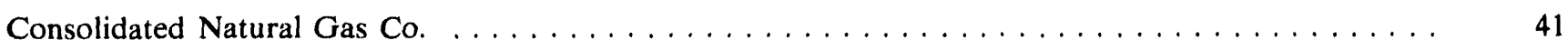

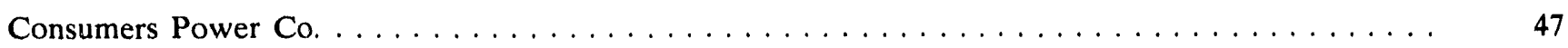

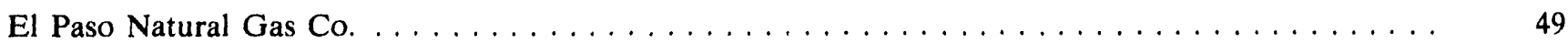

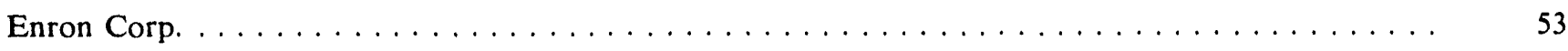

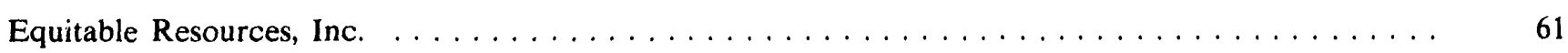

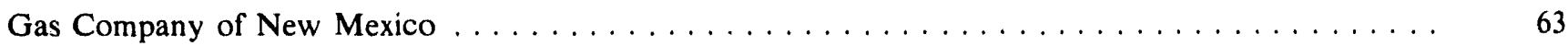

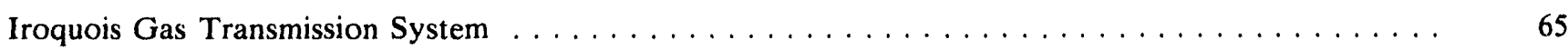

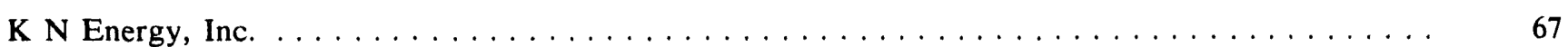

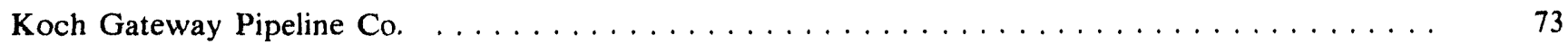

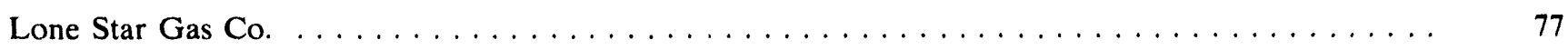

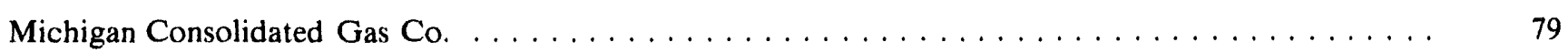

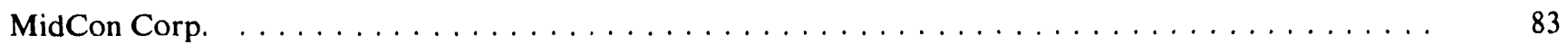

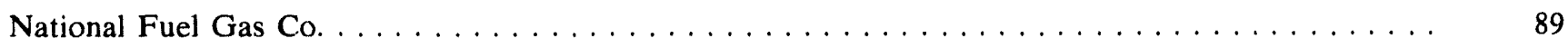

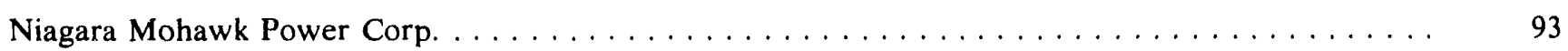

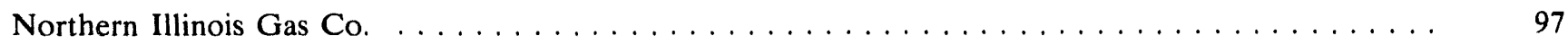

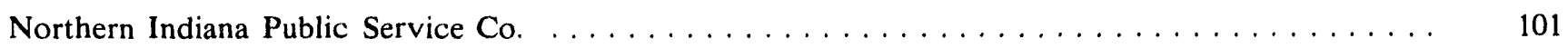

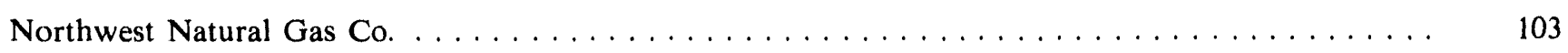

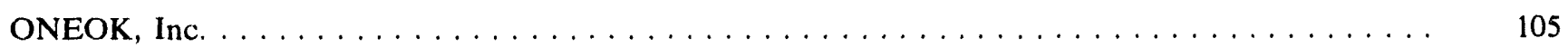

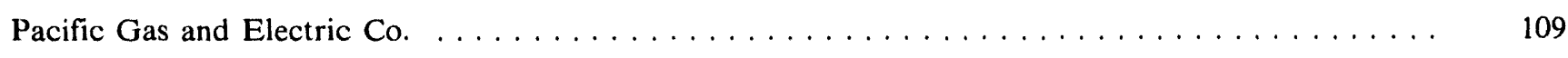

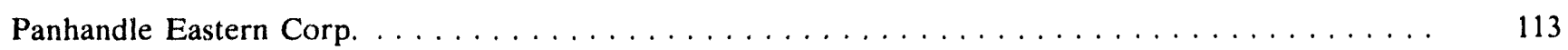

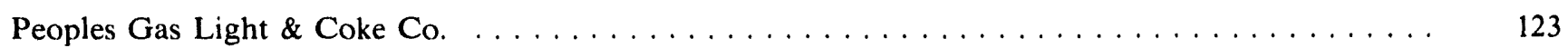

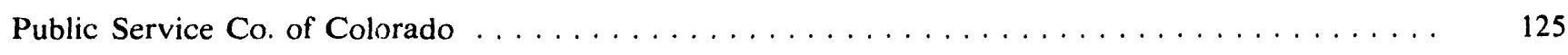

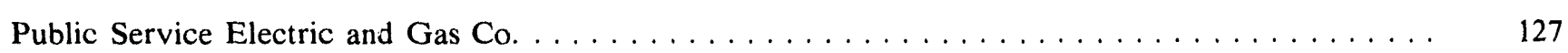

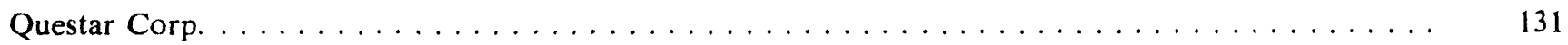




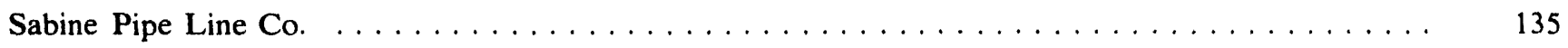

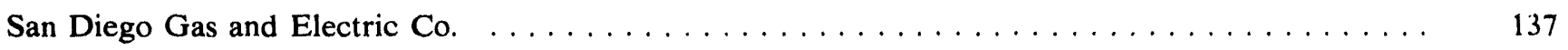

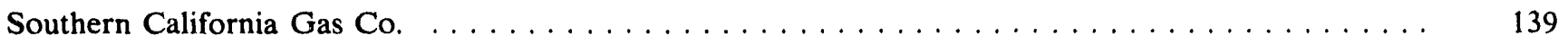

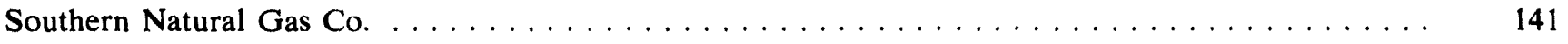

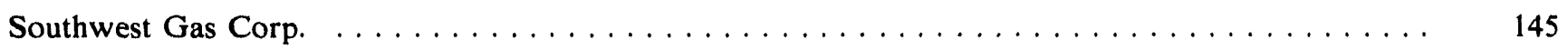

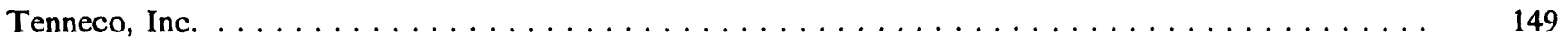

Transco Gas Co. . . . . . . . . . . . . . . . . . . . . . . . . . . 157

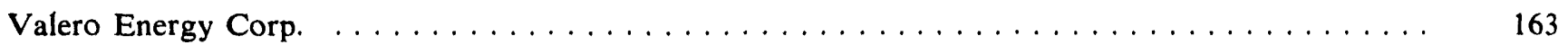

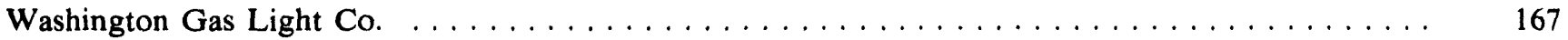

Western Resources, Inc. $\ldots \ldots \ldots \ldots \ldots \ldots \ldots$

The Williams Companies, Inc. $\ldots \ldots \ldots \ldots \ldots$

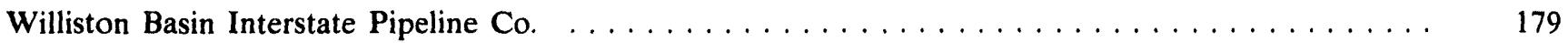

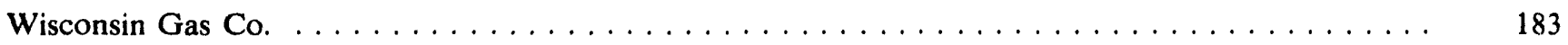

Appendices

A. Summary of Data Collection and Report Methodology $\ldots \ldots \ldots \ldots$

B. Selected Natural Gas and Related Reports . . . . . . . . . . . . . . . . . . . . . . . 203

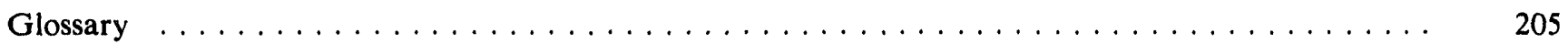




\section{Tables}

1. Arkla, Inc., Natural Gas Data, $1992 \ldots \ldots \ldots \ldots \ldots \ldots \ldots$

Page

2. Arkla, Inc, Interstate Flows of Natural Gas, $1992 \ldots \ldots \ldots \ldots \ldots$

3. Atlanta Gas Light Co. Natural Gas Data, $1992 \ldots \ldots \ldots \ldots \ldots \ldots$

4. Baltimore Gas and Electric Co. Natural Gas Data, $1992 \ldots \ldots \ldots \ldots \ldots$

5. Boston Gas Co. Natural Gas Data, $1992 \ldots \ldots \ldots \ldots \ldots \ldots \ldots \ldots$

6. Brooklyn Union Gas Co. Natural Gas Data, $1992 \ldots \ldots \ldots \ldots \ldots \ldots$

7. Coastal Corp. Natural Gas Data, $1992 \ldots \ldots \ldots \ldots \ldots \ldots \ldots$

8. Coastal Corp. Interstate Flows of Natural Gas, $1992 \ldots \ldots \ldots \ldots \ldots \ldots$

9. Columbia Gas System, Inc., Natural Gas Data, $1992 \ldots \ldots \ldots \ldots \ldots \ldots \ldots$

10. Columbia Gas System, Inc., Interstate Flows of Natural Gas, $1992 \ldots \ldots \ldots$

11. Consolidated Edison Co. of New York, Inc. Natural Gas Data, $1992 \ldots \ldots$. . . . . . . . . . .

12. Consolidated Natural Gas Co. Natural Gas Data, 1992 . . . . . . . . . . . . . . . . . . . . .

13. Consolidated Natural Gas Co. Interstate Flows of Natural Gas, $1992 \ldots \ldots$. . . . . . . . . . .

14. Consumers Power Co. Natural Gas Data, $1992 \ldots \ldots \ldots \ldots \ldots \ldots \ldots$

15. El Paso Natural Gas Co. Natural Gas Data, $1992 \ldots \ldots \ldots \ldots \ldots \ldots \ldots \ldots$

16. El Paso Natural Gas Co. Interstate Flows of Natural Gas, $1992 \ldots \ldots \ldots \ldots$ 
59. Washinton Gas Light Co. Interstate Flows of Natural Gas, $1992 \ldots \ldots$

60. Western Resources, Inc. Natural Gas Data, $1992 \ldots \ldots \ldots \ldots$

61. The Williams Companies, Inc. Natural Gas Data, $1992 \ldots \ldots \ldots \ldots$

62. The Williams Companies, Inc. Interstate Flows of Natural Gas, $1992 \ldots \ldots$. . . . . . . . . . 178

63. Williston Basin Interstate Pipeline Co. Natural Gas Data, $1992 \ldots \ldots$

64. Williston Basin Interstate Pipeline Co. Interstate Flows of Natural Gas, $1992 \ldots \ldots 2$

65. Wisconsin Gas Co. Natural Gas Data, $1992 \ldots \ldots \ldots \ldots \ldots$

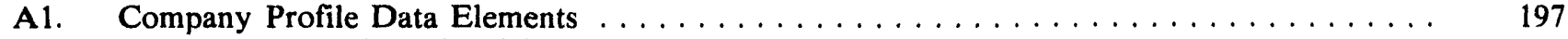

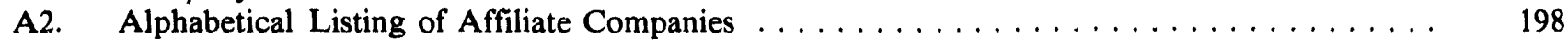




\section{Illustrations}

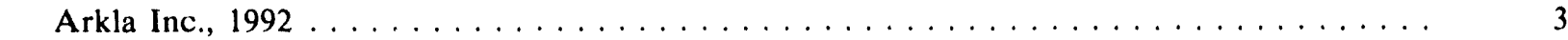

Minnegasco, Inc., $1992 \ldots \ldots \ldots \ldots \ldots \ldots \ldots \ldots \ldots$

Atlanta Gas Light Co., $1992 \ldots \ldots \ldots \ldots \ldots \ldots \ldots$

Baltimore Gas and Electric Co., $1992 \ldots \ldots \ldots \ldots \ldots$

Boston Gas Co., $1992 \ldots \ldots \ldots \ldots \ldots \ldots \ldots \ldots \ldots \ldots$

Brooklyn Union Gas Co., $1992 \ldots \ldots \ldots \ldots \ldots \ldots \ldots \ldots$

Coastal Corp., $1992 \ldots \ldots \ldots \ldots \ldots \ldots \ldots$

Columbia Gas Systems, Inc., $1992 \ldots \ldots \ldots \ldots \ldots$

Consolidated Edison Co. of New York, Inc., $1992 \ldots \ldots \ldots \ldots$

Consolidated Natural Gas Co., $1992 \ldots \ldots \ldots \ldots \ldots \ldots$

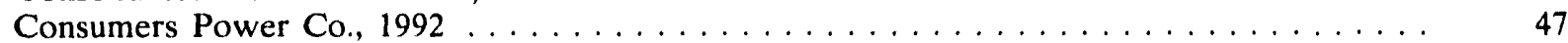

El Paso Natural Gas Co., $1992 \ldots \ldots \ldots \ldots \ldots \ldots \ldots \ldots \ldots \ldots$

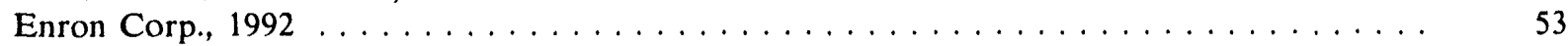

Equitable Resources, Inc., $1992 \ldots \ldots \ldots \ldots \ldots \ldots \ldots$

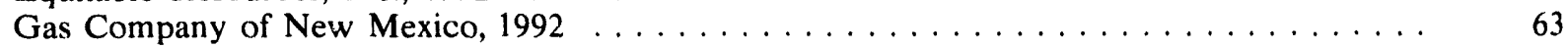

Iroquois Gas Transmission System, $1992 \ldots \ldots \ldots \ldots \ldots$

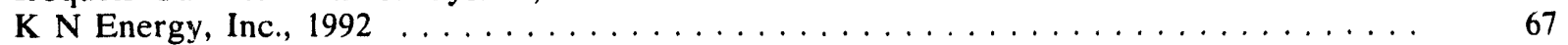

Koch Gateway Pipeline Co., $1992 \ldots \ldots \ldots \ldots \ldots \ldots$

Lone Star Gas Co., $1992 \ldots \ldots \ldots \ldots \ldots \ldots$

Michigan Consolidated Gas Co., $1992 \ldots \ldots \ldots \ldots \ldots$

MidCon Corp., $1992 \ldots \ldots \ldots \ldots \ldots \ldots$

National Fuel Gas Co., $1992 \ldots \ldots \ldots \ldots \ldots \ldots$

Niagara Mohawk Power Corp., $1992 \ldots \ldots \ldots \ldots \ldots$

Northern Illinois Gas Co., $1992 \ldots \ldots \ldots \ldots \ldots \ldots$

Northern Indiana Public Service Co., $1992 \ldots \ldots \ldots \ldots \ldots 1$

Northwest Natural Gas Co., $1992 \ldots \ldots \ldots \ldots$

ONEOK, Inc., $1992 \ldots \ldots \ldots \ldots \ldots \ldots$

Pacific Gas and Electric Co., $1992 \ldots \ldots \ldots \ldots \ldots \ldots \ldots$

Panhandle Eastern Corp., $1992 \ldots \ldots \ldots \ldots \ldots \ldots \ldots \ldots \ldots$

Peoples Gas Light \& Coke Co., $1992 \ldots \ldots \ldots \ldots \ldots \ldots$

Public Service Co. of Colorado, $1992 \ldots \ldots \ldots \ldots \ldots \ldots$

Public Service Electric and Gas Co., $1992 \ldots \ldots \ldots \ldots \ldots \ldots \ldots$

Questar Corp., $1992 \ldots \ldots \ldots \ldots \ldots \ldots \ldots \ldots \ldots$

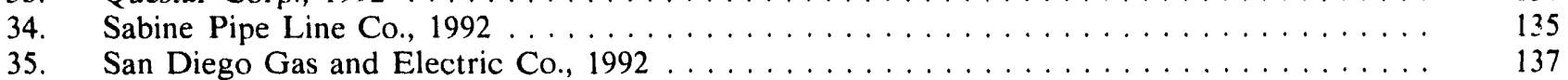

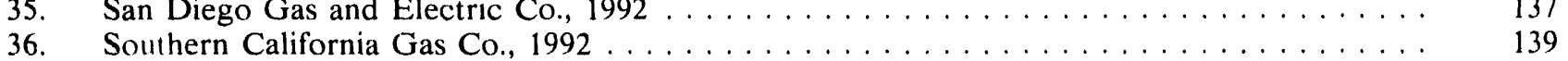

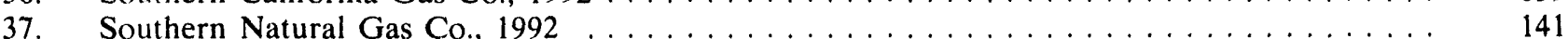

38. Southwest Gas Corp., $1992 \ldots \ldots \ldots \ldots \ldots \ldots$

39. Tenneco, Inc, $1992 \ldots \ldots \ldots \ldots \ldots \ldots$

40. Transco Gas Co., $1992 \ldots \ldots \ldots \ldots \ldots \ldots \ldots \ldots$

41. Valero Energy Corp., $1992 \ldots \ldots \ldots \ldots \ldots$

42. Washington Gas Light Co., $1992 \ldots \ldots \ldots \ldots \ldots$

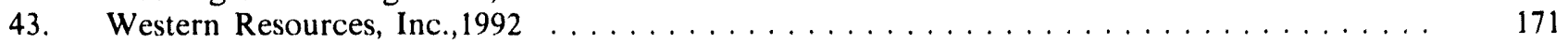

44. The Williams Companies, Inc., $1992 \ldots \ldots \ldots \ldots \ldots$

45. Williston Basin Interstate Pipeline Co. $1992 \ldots \ldots \ldots \ldots \ldots$

46. Wisconsin Gas Co., $1992 \ldots \ldots \ldots \ldots \ldots$

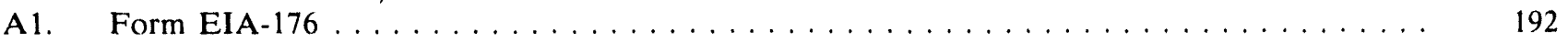




\section{Overview}

A complex grid of natural gas pipelines, extending a quarter of a million miles, crisscrosses the Nation and connects all States except Alaska, Hawaii, and Vermont. This extensive network reaches more than 50 million residential customers and more than 4 million other customers. The demand along this complex grid is met by the operations of natural gas pipeline companies and local distribution companies.

The companies appearing in this report, the Natural Gas Annual 1992 Supplement: Company Profiles, are major interstate natural gas pipeline companies, large distribution companies, or combination companies with both pipeline and distribution operations. The report contains profiles of 45 corporate families. The profiles describe briefly each company, where it operates, and any important issues that the company faces.

The tables accompanying each profile present data reported on Form EIA-176, "Annual Report of Natural and Supplemental Gas Supply and Disposition." Other sources of information include industry literature and corporate annual reports.

Companies were selected for the profiles in a multistep process using knowledge of the industry and specific information included on Form EIA-176 submissions. First, the 20 interstate pipeline companies (representing distinct corporate families) with the greatest reported volumes of gas transported were selected. The other companies, not in the same corporate family as any of the first group, were selected from the top companies in volumes delivered to end users. Finally, additional companies belonging to the same corporate family as companies in either of the first two groups were included in the profiles.

Form EIA-176 is submitted by all respondents from an identified universe of operators of fields, wells, or natural gas processing plants that distribute gas to end users or transport gas to or across a State border; operators of synthetic natural gas plants; natural gas distributors; natural gas pipeline companies; and companies that operate underground natural gas storage $f a-$ cilities. Each respondent reports a supply and disposition balance for each State in which he operates. For the 1992 survey, 2,064 responses were received from approximately 1,800 companies.
Data are reported on a custody basis. All volumes of natural gas physically received onsystem are reported regardless of ownership. Concurrently, all volumes owned by the respondent company but not in its possession are not reported. Thus, double-counting is avoided. Natural gas not owned but in the possession of the respondent is reported as received or transported for the account of others, as appropriate. Exchange agreements are treated similarly.

The purpose of this report is to show the movement of natural gas through the various States served by the 45 large companies profiled. The companies in the report are interstate pipeline companies or local distribution companies (LDC's). Interstate pipeline companies acquire gas supplies from company-owned production, purchases from producers, and receipts for transportation for the account of others.

The Federal Energy Regulatory Commission (FERC) promulgated its Order 636, which provides for the "unbundling" of all services and rates for those services. More specifically, pipeline companies are required by the new rule to separate transmission and storage services from the sale of natural gas. All pipeline companies are required to file a plan to "unbundle" the product and services, and upon FERC approval of the plan, to implement the plan on November 1, 1993.

LDC's deliver natural gas directly to consumers, including individual residences, commercial operations, industrial facilities, and electric utilities. Nine of the companies profiled are major LDC's. They are Atlanta Gas Light Co., serving the Atlanta and Chattanooga areas; Consolidated Edison Co. of New York, Inc., serving New York City; Consumers Power Co., serving the central area of Michigan's Lower Peninsula; Michigan Consolidated Gas Co., serving the metropolitan area of Detroit and northern and western Michigan; Northern Illinois Gas Co., serving the northern third of Illinois, except Chicago; Northern Indiana Public Service Co., serving the northern third of Indiana; $\mathrm{Pa}$ cific Gas and Electric Co., serving northern and central California; Public Service Electric and Gas Co., serving northern and central New Jersey; and Southern California Gas Co., serving southern California.

Natural gas company profiles are presented with pipeline system and service area maps. Company supply and disposition data are presented for the States of operation as reported on the Form EIA-176. 


\section{Arkla, Inc.}

Arkla, Inc., operates an extensive pipeline network more than 14,000 miles long and a natural gas distribution system serving more than 2.6 million customers, making it a major company in the natural gas industry. The company's pipeline system and service areas are located primarily in the southcentral United States, with another major service area in Minnesota.

The Arkla Pipeline Group is comprised of two interstate pipelines, Arkla Energy Resources (AER) and Mississippi River Transmission (MRT), and a marketing group, Arkla Energy Marketing. The AER system serves as a primary conduit for bringing mid-continent natural gas production to pipeline systems reaching midwestern and eastern markets. The MRT system extends from the city of St. Louis, Missouri, through Arkansas and into northern Louisiana. It also provides connections from mid-continent supplies to midwestern and eastern markets.

Arkla's Line AC transports gas from the Arkoma basin of Oklahoma to eastern and midwestern markets. Currently the company is working with Panhandle Eastern's Texas Eastern pipeline system to extend Line AC from eastern Arkansas to northeastern Mississippi.

Three divisions form the distribution operations: Arkansas Louisiana Gas Company (ALG), Entex, and

Figure 1. Arkla Inc., 1992

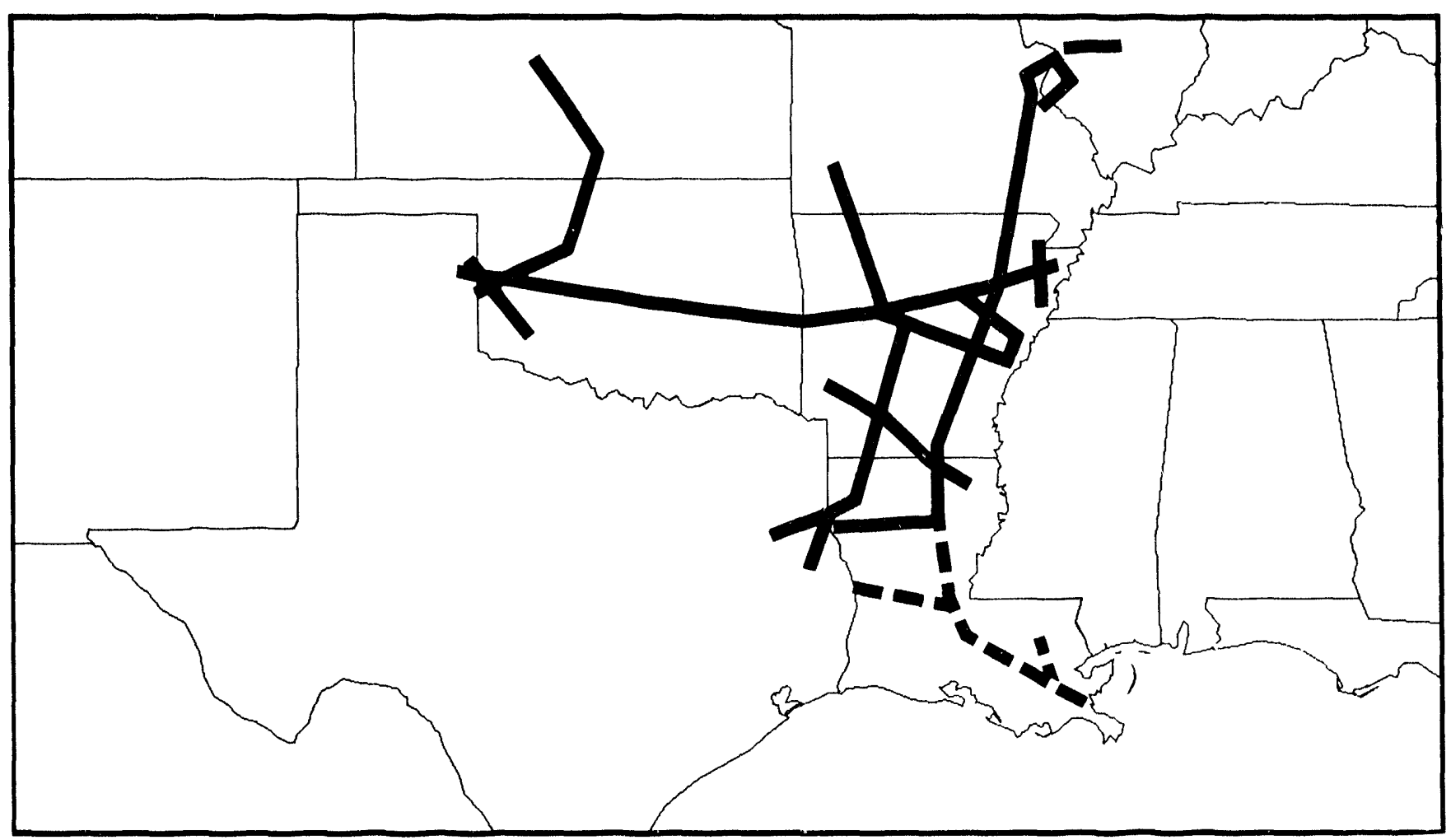

Energy Information Administration/Natural Gas Annual 1992 Supplement: Company Profiles 
Minnegasco. During 1992 ALG served over 735,000 customers in Arkansas, Oklahoma, east Texas, northern Louisiana, and southern Kansas, including the cities of Little Rock, Arkansas and Shreveport, Louisiana. Entex had over 1.3 million customers in Louisiana, Mississippi, and Texas, including the city of Houston, Arkla's single largest market. Minnegasco's service areas were in Minnesota, including Minneapolis; $\mathrm{Ne}$ braska; and South Dakota. Its customers in Minnesota number approximately 580,000.

In Arkansas, ALG delivered 71 percent of the natural gas consurned by the residential sector and 60 percent of the commercial sector consumption in 1992. New applications for ALG include providing service to gasfueled desiccant cooling equipment and a cogeneration facility. Entex delivered 27 percent of the 1992 residential gas consumption in Texas.
Minnegasco's service areas in the Northcentral United States have extremely cold winter weather. During 1992, Minnegasco delivered 48 percent of the gas consumed by the residential sector and 54 percent of the gas consumed by the commercial sector in Minnesota. Minnegasco added the Mall of America to its customer base in 1992. This mall, North America's largest, consumes more than 300 million cubic feet of natural gas each year.

The Arkla distribution divisions have used natural gas vehicles (NGV's) for more than 10 years. Entex has 254 fleet vehicles that use natural gas, Minnegasco has 116, and ALG has 50. Enfuels, a joint venture of Entex, Enron, Transco Energy and Autogas, opened the first public NGV fueling station in Houston in 1992. Enfuels also operates a facility for converting and repairing NGV's. ALG will open a NGV fueling station in its territory in 1993.

Figure 2. Minnegasco, Inc., 1992

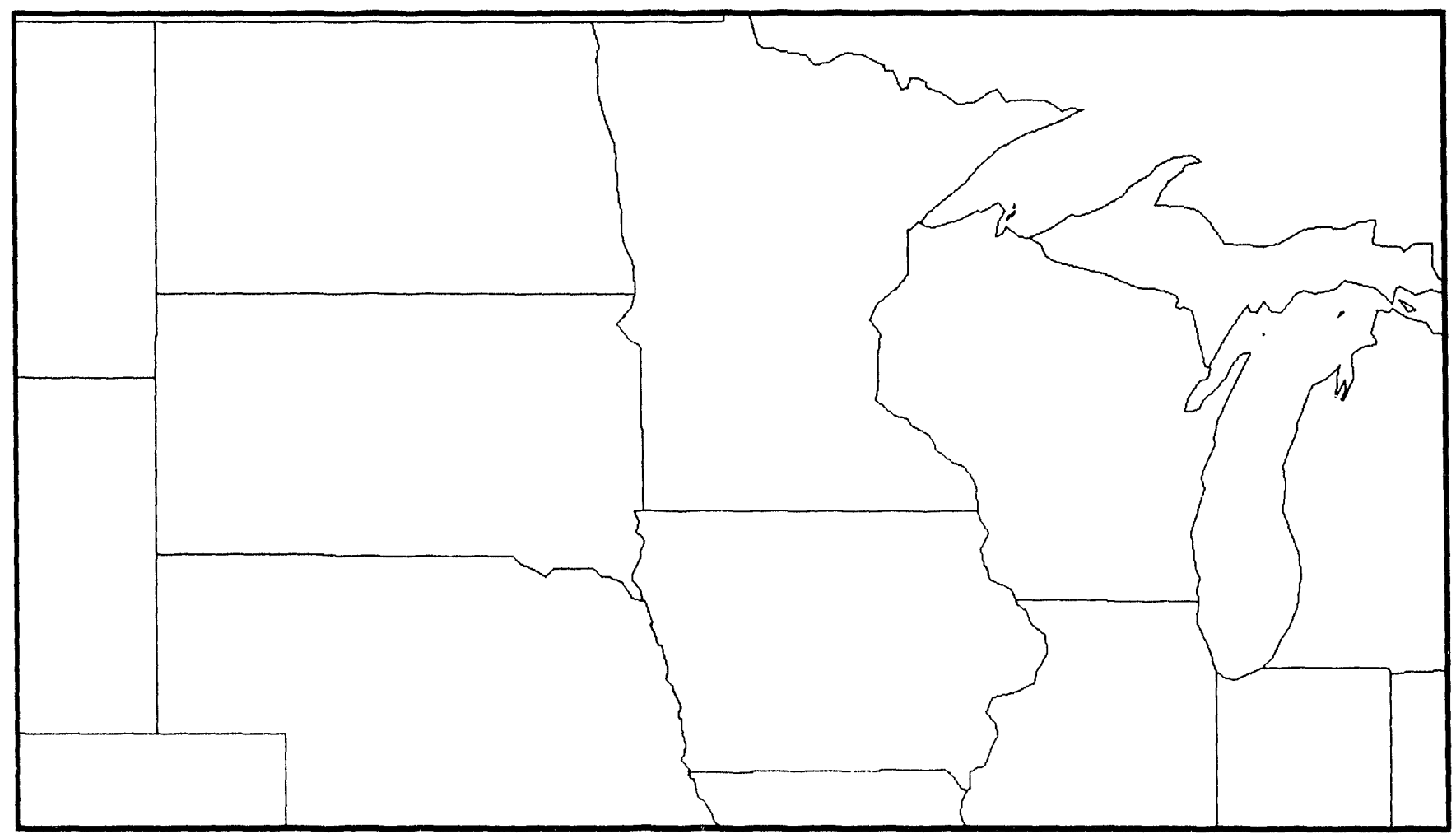

Energy information Administration/Natural Gas Annual 1992 Supplement: Company Proflles

Service Areas 
Table 1. Arkla, Inc., Natural Gas Data, 1992

(Thousand Cubic Feet)

\begin{tabular}{l|c|c|c|c|c|c}
\hline \multirow{2}{*}{ Supply/Disposition } & \multicolumn{2}{|c|}{ Arkansas Louisiana Gas Co. } & \multicolumn{3}{|c}{ Arkla Energy Resources } \\
\cline { 2 - 6 } & Louisiana & Arkansas & Louisiana & Arkansas & Missouri \\
\hline
\end{tabular}

SUPPLY

Produced Onsystem

Receipts

Purchases

Transported/Exchange Gas

Interstate Movements

Company-owned Gas

Transported/Exchange Gas

Storage Withdrawals

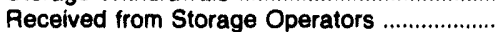

Other Supplies

Total Supplies

\section{DISPOSITION}

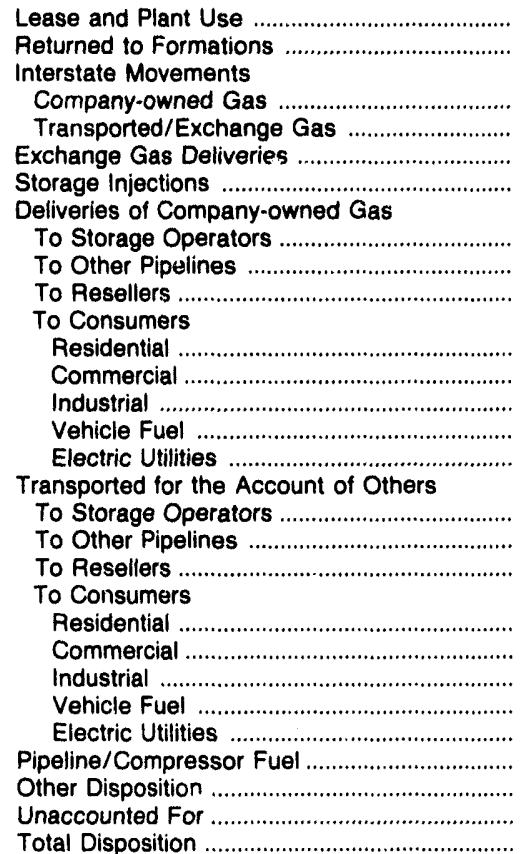

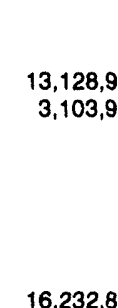

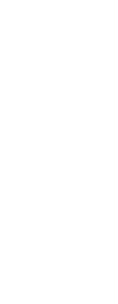

0
0

0
0

0

0

0

$8,288,187$

$3,517,168$

722,222

222
0

$28,128,297$
$15,228,816$

$5,320,300$

0

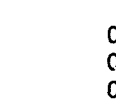

0
$3,103,923$
0
0
0
0
0
601,368
$16,232,868$

$51,181,522$

$14,527,957$

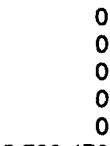

$65,709,479$

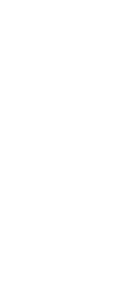

0
0
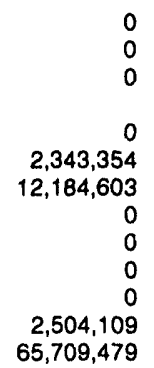

0
0
0
0
0
0
0
0

333,09

0
$16,835,944$
$3,128,472$

$1,015,516$

$6,975,037$

0
$8,379,228$

0

0
0
0
0

0
0
0

$3,822,956$
$281,942,049$

0
$34,978,951$
$1,853,494$

$8,972,616$

$331,570,066$

0
$19,926,479$
$245,914,952$

0
0
$21,054,169$

0
$1,690,590$

359,652

$5,956,931$

$331,570,066$
0

$\begin{array}{rr}13,284,139 & 0 \\ 130,827,564 & 0 \\ 0 & 0 \\ 344,055,302 & 272,754 \\ 0 & 0 \\ 0 & 0 \\ 0 & 0 \\ 488,167,005 & 272,754\end{array}$

$\begin{array}{rr}0 & 0 \\ 0 & 0 \\ 0 & 0 \\ 6,474,063 & 0 \\ 4,210,099 & 195,322 \\ 0 & 0 \\ 0 & 0 \\ 0 & 0 \\ 27,589,724 & 0\end{array}$

0

0
0
0 0
0
0

2,754 
Table 1. Arkla, Inc., Natural Gas Data, 1992 (Continued) (Thousand Cubic Feet)

\begin{tabular}{|c|c|c|c|c|c|}
\hline \multirow{2}{*}{ Supply/Disposition } & \multicolumn{3}{|c|}{ Arkla Energy Resources } & \multicolumn{2}{|c|}{ Entex Division of Arkla, Inc. } \\
\hline & Texas & Oklahoma & Kansas & Louisiana & Texas \\
\hline \multicolumn{6}{|l|}{ SUPPLY } \\
\hline $\begin{array}{l}\text { Produced Onsystem } \\
\text { Receipts }\end{array}$ & 0 & 0 & 0 & 0 & 19 ח \\
\hline $\begin{array}{l}\text { Purchases } \\
\text { Transported/Exchange Gas } \\
\text { Interstate Movements }\end{array}$ & $\begin{array}{l}11,319,466 \\
51,582,227\end{array}$ & $\begin{array}{r}30,722,049 \\
355,857,172\end{array}$ & $\begin{array}{r}150,063 \\
3,511,753\end{array}$ & $\begin{array}{r}23,356,756 \\
0\end{array}$ & $\begin{array}{r}113,210,366 \\
8,064,124\end{array}$ \\
\hline 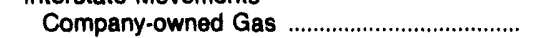 & 0 & 0 & 0 & 0 & 0 \\
\hline 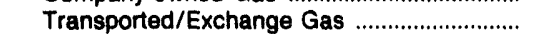 & $6,923,882$ & $7,186,984$ & $7,250,835$ & 0 & 0 \\
\hline Storage Withdrawals & 0 & $20,628,287$ & 441,783 & 0 & 0 \\
\hline 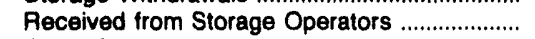 & 0 & 0 & 0 & 0 & 0 \\
\hline 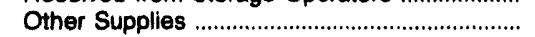 & 0 & 0 & 0 & 0 & 0 \\
\hline 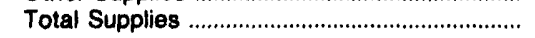 & $69,825,575$ & $414,394,492$ & $11,354,434$ & $23,356,756$ & $121,274,490$ \\
\hline \multicolumn{6}{|l|}{ DISPOSITION } \\
\hline Returned to Formations & 0 & 0 & 0 & 0 & 0 \\
\hline Interstate Movements & & & & & $\therefore$ \\
\hline 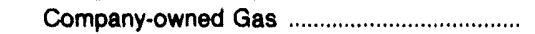 & 0 & 0 & 0 & 0 & 0 \\
\hline 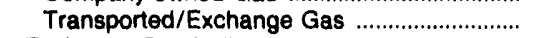 & $40,894,302$ & $336,464,399$ & 0 & 0 & 0 \\
\hline 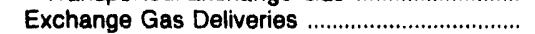 & $6,141,902$ & $6,573,485$ & 107,054 & 0 & 0 \\
\hline $\begin{array}{l}\text { Storage Injections } \\
\text { Deliveries of Company-owned Gas }\end{array}$ & 0 & $17,144,694$ & 0 & 0 & 0 \\
\hline $\begin{array}{l}\text { Deliveries of Company-owned Gas } \\
\text { To Storage Operators }\end{array}$ & \multicolumn{3}{|c|}{ Deliveries of Company-owned Gas } & 0 & 0 \\
\hline 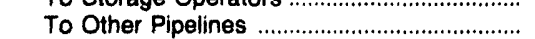 & 0 & 0 & 0 & 0 & 0 \\
\hline 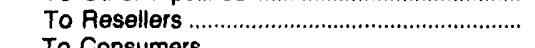 & $3,155,714$ & $10,441,186$ & $2,576,891$ & 0 & 0 \\
\hline $\begin{array}{l}\text { To Consumers } \\
\text { Residential }\end{array}$ & 0 & 0 & 0 & $6,644,152$ & $57,933,317$ \\
\hline 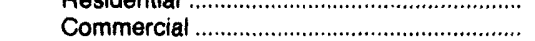 & 0 & 0 & 0 & $\begin{array}{l}0,644,152 \\
2,548,844\end{array}$ & $39,199,408$ \\
\hline 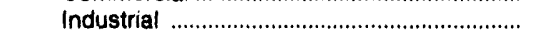 & 0 & 0 & 0 & $14,168,578$ & $17,167,612$ \\
\hline 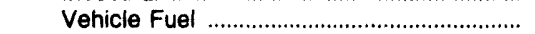 & 0 & 0 & 0 & 0 & 0 \\
\hline 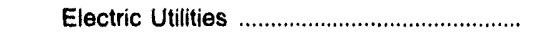 & 0 & 38,076 & 116,320 & 0 & 0 \\
\hline \multicolumn{6}{|l|}{ Transported for the Account of Others } \\
\hline To Storage Operators & 0 & 0 & 0 & 0 & 0 \\
\hline 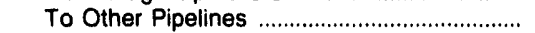 & 0 & 0 & 0 & 0 & 0 \\
\hline 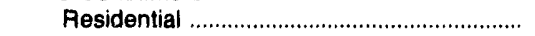 & 0 & 0 & 0 & 0 & 0 \\
\hline 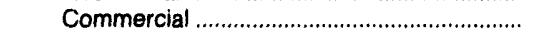 & 0 & 0 & 0 & 0 & $8,064,124$ \\
\hline Industrial & $10,675,368$ & $1,324,790$ & $3,550,029$ & 0 & 0 \\
\hline 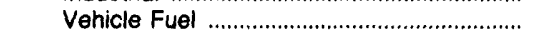 & 0 & 0 & 0 & 0 & 0 \\
\hline 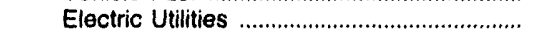 & 0 & 530,911 & $1,081,987$ & 0 & 0 \\
\hline 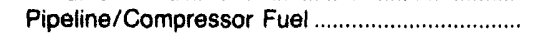 & 427,110 & $2,437,238$ & 6,849 & 0 & 0 \\
\hline 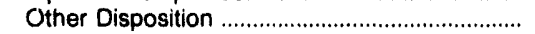 & 1,716 & 0 & 0 & 0 & 0 \\
\hline 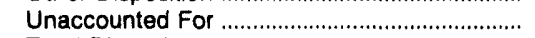 & $-1,242,553$ & $1,193,376$ & 460,547 & $-4,818$ & $-1,089,971$ \\
\hline 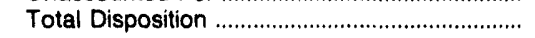 & $69,825,575$ & $414,394,492$ & $11,354,434$ & $23,356,756$ & $121,274,490$ \\
\hline
\end{tabular}

division of Utilicorp United. These properties are somewhat remote from ALG's core distribution properties. This agreement was signed in May 1993.

- The exchange of Minnegasco's South Dakota distribution properties for Midwest Gas Co.'s Min- nesota properties which are contiguous to Minnegasco's existing service markets. This exchange became effective in September 1993 and included a $\$ 38$ million payment by Arkla to Midwest Gas. Minnegasco's service areas are now located entirely in the State of Minnesota. 
Table 1. Arkla, Inc., Natural Gas Data, 1992 (Continued) (Thousand Cubic Feet)

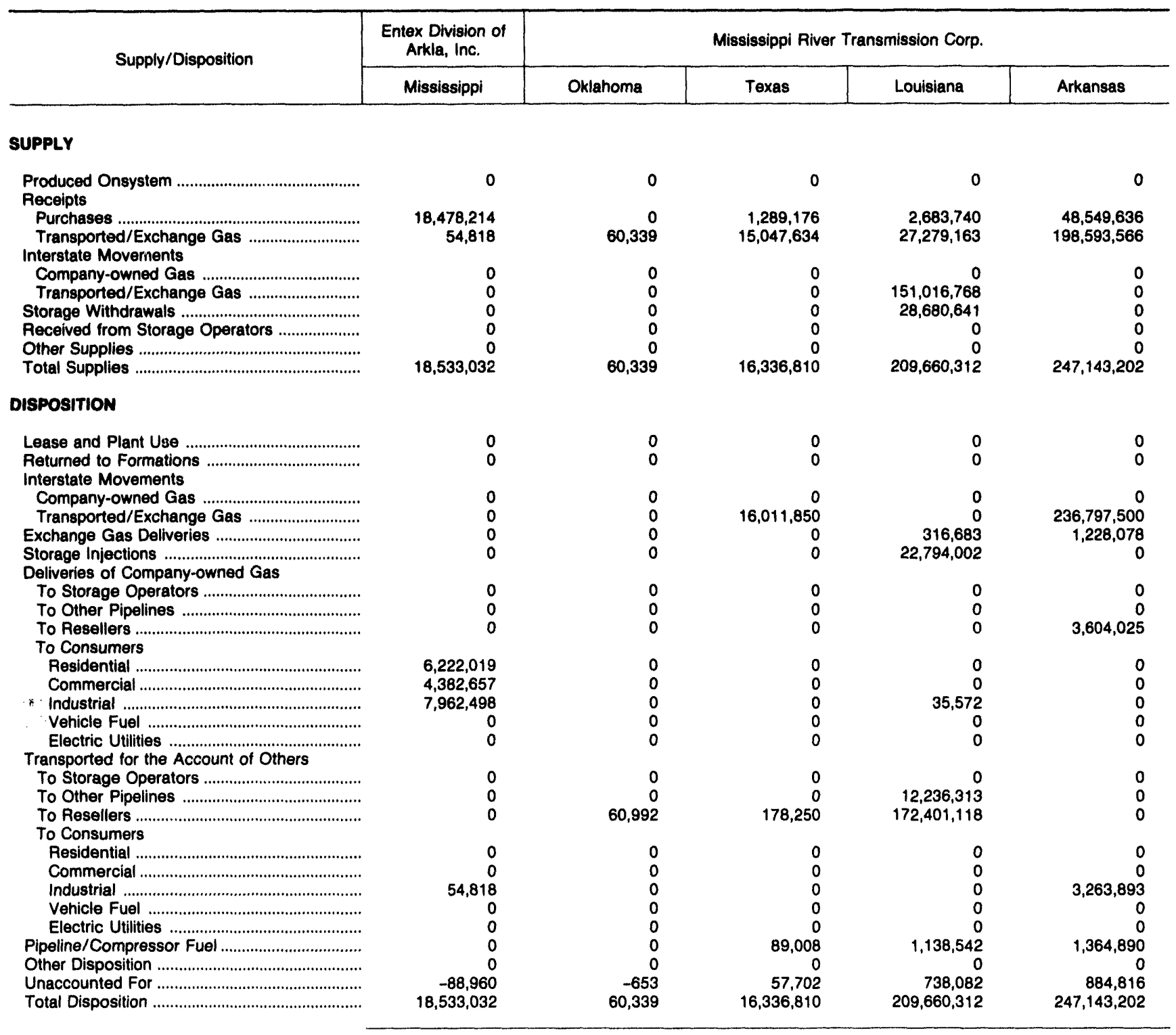


Table 1. Arkla, Inc., Natural Gas Data, 1992 (Continued) (Thousand Cubic Feet)

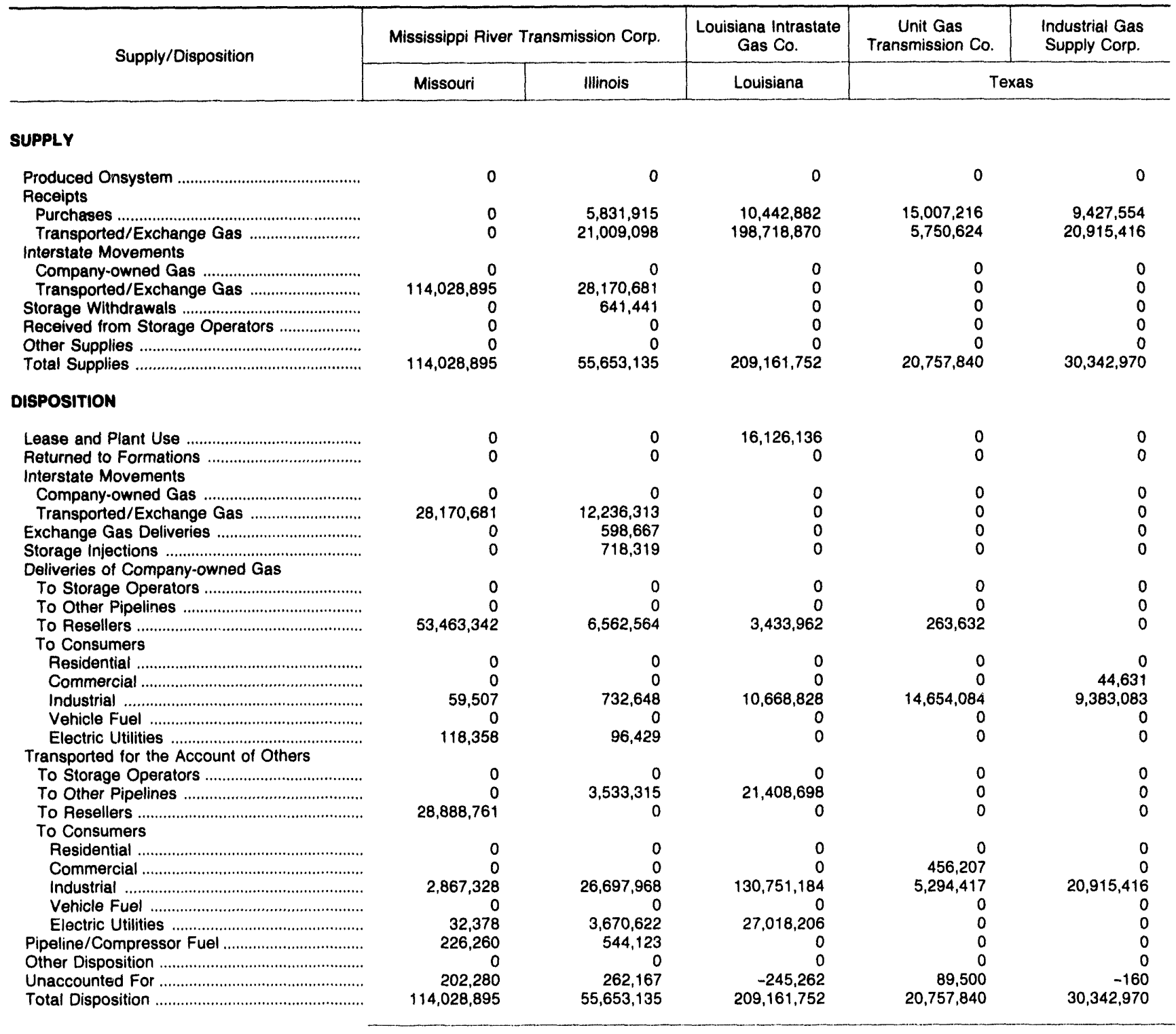


Table 1. Arkla, Inc., Natural Gas Data, 1992 (Continued)

(Thousand Cubic Feet)

\begin{tabular}{|c|c|c|c|c|}
\hline \multirow{2}{*}{ Supply/Disposition } & \multirow{2}{*}{$\frac{\text { Tuscaloosa Pipeline Cc. }}{\text { Louisiana }}$} & \multicolumn{3}{|c|}{ Minnegasco, Inc. } \\
\hline & & Minnesota & South Dakota & Nebraska \\
\hline \multicolumn{5}{|l|}{ SUPPLY } \\
\hline \multicolumn{3}{|l|}{ Receipts } & 0 & 0 \\
\hline 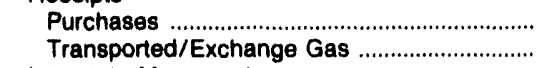 & $\begin{array}{r}6,784,380 \\
0\end{array}$ & $\begin{array}{r}111,140,498 \\
8,497,618\end{array}$ & $\begin{array}{r}7,862,666 \\
484,759\end{array}$ & $\begin{array}{r}20,302,803 \\
3,599,855\end{array}$ \\
\hline \multicolumn{5}{|l|}{ Interstate Movements } \\
\hline Company-owned Gas & 0 & 0 & 0 & 0 \\
\hline Transported/Exchange Gas & 0 & 0 & 0 & 0 \\
\hline 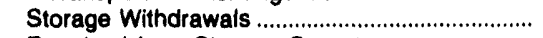 & 0 & $1,519,556$ & 0 & 0 \\
\hline Received from Storage Operators ......................... & 0 & 0 & 0 & 0 \\
\hline 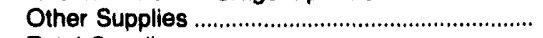 & 0 & 28,633 & 117 & 176 \\
\hline 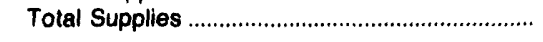 & $6,784,380$ & $121,186,305$ & $8,347,542$ & $23,902,834$ \\
\hline \multicolumn{5}{|l|}{ DISPOSITION } \\
\hline Lease and Plant Use & 0 & 0 & 0 & 0 \\
\hline $\begin{array}{l}\text { Returned to Formations } \\
\text { Interstate Movements }\end{array}$ & 0 & 0 & 0 & 0 \\
\hline 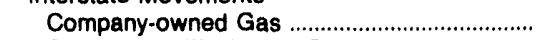 & 0 & 0 & 0 & 0 \\
\hline Transported/Exchange Gas ............................... & 0 & 0 & 0 & 0 \\
\hline 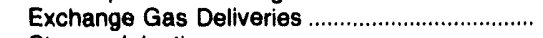 & 0 & 0 & 0 & 0 \\
\hline 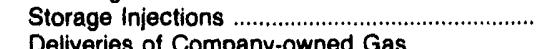 & 0 & $1,643,974$ & 0 & 0 \\
\hline \multicolumn{5}{|l|}{ Deliveries of Company-owned Gas } \\
\hline $\begin{array}{l}\text { To Storage Operators } \\
\text { To Other Pipelines }\end{array}$ & $\begin{array}{l}0 \\
0\end{array}$ & 0 & $\begin{array}{l}0 \\
0\end{array}$ & $\begin{array}{l}0 \\
0\end{array}$ \\
\hline 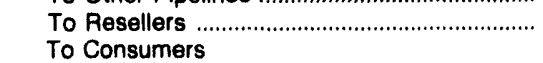 & $6,855,385$ & 0 & 0 & 0 \\
\hline 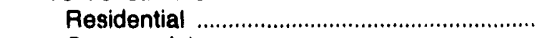 & 0 & $54,574,608$ & $4,005,776$ & $10,044,811$ \\
\hline 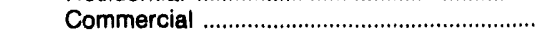 & 0 & $44,764,799$ & $3,474,410$ & $6,607,302$ \\
\hline 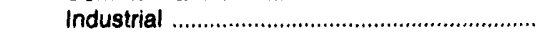 & 46,408 & $11,204,657$ & 321,724 & $3,456,326$ \\
\hline 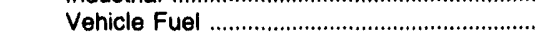 & 0 & 0 & 0 & 0 \\
\hline 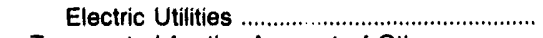 & 0 & 320,895 & 34,805 & 128,372 \\
\hline \multicolumn{5}{|l|}{ Transported for the Account of Others } \\
\hline 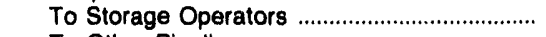 & 0 & 0 & 0 & 0 \\
\hline 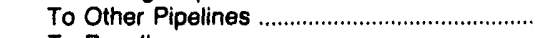 & 0 & 0 & 0 & 0 \\
\hline $\begin{array}{l}\text { To Resellers } \\
\text { To Consumers }\end{array}$ & \multicolumn{4}{|c|}{ To Consumers } \\
\hline 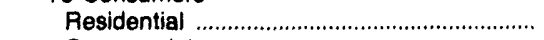 & 0 & 0 & 0 & 0 \\
\hline 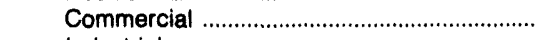 & 0 & 833,485 & 32,104 & $1,382,308$ \\
\hline 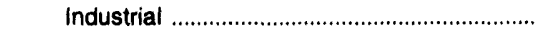 & 0 & $7,416,139$ & 447,325 & $2,173,510$ \\
\hline 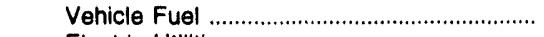 & 0 & 0 & 0 & $\begin{aligned} 0 \\
0\end{aligned}$ \\
\hline 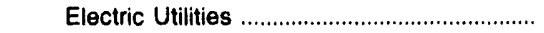 & 0 & 247,994 & 5,330 & 44,037 \\
\hline Pipeline/Compressor Fuel ................................... & 0 & 129,095 & 8,628 & 11,510 \\
\hline 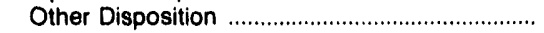 & 0 & 0 & 0 & 0 \\
\hline Unaccounted For & $-117,413$ & $\begin{array}{r}50,659 \\
\end{array}$ & $\begin{array}{r}17,440 \\
\end{array}$ & $\begin{array}{r}54,658 \\
3902,834\end{array}$ \\
\hline 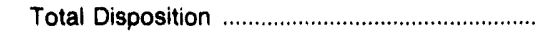 & $6,784,380$ & $121,186,305$ & $8,347,542$ & $23,902,834$ \\
\hline
\end{tabular}

Source: Energy Information Administration (EIA), Form EIA-176, "Annual Report of Natural and Supplemental Gas Supply and Disposition." 
Table 2. Arkla, Inc., Interstate Flows of Natural Gas, 1992 (Thousand Cubic Feet)

\begin{tabular}{|c|c|}
\hline Company and State & Volume \\
\hline \multicolumn{2}{|l|}{$\begin{array}{l}\text { Arkla Energy Resources } \\
\text { Louisiana To }\end{array}$} \\
\hline 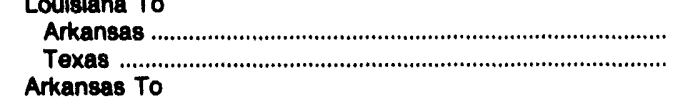 & $\begin{array}{r}14,964,305 \\
1,871,639\end{array}$ \\
\hline 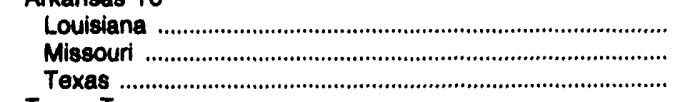 & $\begin{array}{r}1,271,633 \\
272,754 \\
4,929,676\end{array}$ \\
\hline $\begin{array}{l}\text { Texas To } \\
\text { Louigiana } \\
\text { Oklahoma } \\
\text { Oklahoma To }\end{array}$ & $\begin{array}{r}33,707,318 \\
7,186,984\end{array}$ \\
\hline 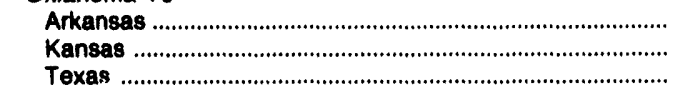 & $\begin{array}{r}329,090,997 \\
7,250,835 \\
122,567\end{array}$ \\
\hline \multicolumn{2}{|l|}{$\begin{array}{l}\text { Mississippi River Transmission Corp. } \\
\text { Texas To }\end{array}$} \\
\hline Louisiana & $16,011,850$ \\
\hline $\begin{array}{l}\text { Louisiana } \\
\text { Missouri } \\
\text { Missouri To }\end{array}$ & $\begin{array}{l}135,004,918 \\
101,792,582\end{array}$ \\
\hline 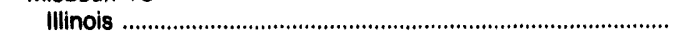 & $28,170,681$ \\
\hline
\end{tabular}

Source: Energy Information Administration (EIA), Form EIA-176, "Annual Report of Natural and Supplemental Gas Supply and Disposition." 


\section{Atlanta Gas Light Co.}

The largest natural gas distributor in the Southeastern United States is the Atlanta Gas Light Company. It's predominant business is the distribution of natural gas, with several other diversified operations as well. Atlanta Gas Light Company, incorporated in 1856 to serve the City of Atlanta, is the oldest corporation in Georgia to operate continuously under its original charter. The company has two wholly owned subsidiaries: Chattanooga Gas Company, which serves Chattanooga and Clevelend, Tennessee; and Georgia Gas Company, which is primarily engaged in gas production. The Company's four pipeline suppliers are Southern Natural Gas Company (Southern), Transcontinental Gas Pipe Line Corporation (Transco), East
Tennessee Natural Gas Company (East Tennessee), and South Georgia Natural Gas Company (South Georgia). Southern and East Tennessee also supply gas service to Chattanooga Gas Company.

Atlanta Gas Light Company distributes natural gas in 227 cities and communities in Georgia and serves nearly 1.2 million customers. Chattanooga Gas Company serves more than 42,000 customers. In 1992, combined deliveries were 93 billion cubic feet of natural gas to residential customers, 49 billion cubic feet to commercial customers, and 123 billion cubic feet to industrial customers.

Figure 3. Atlanta Gas Light Co., 1992

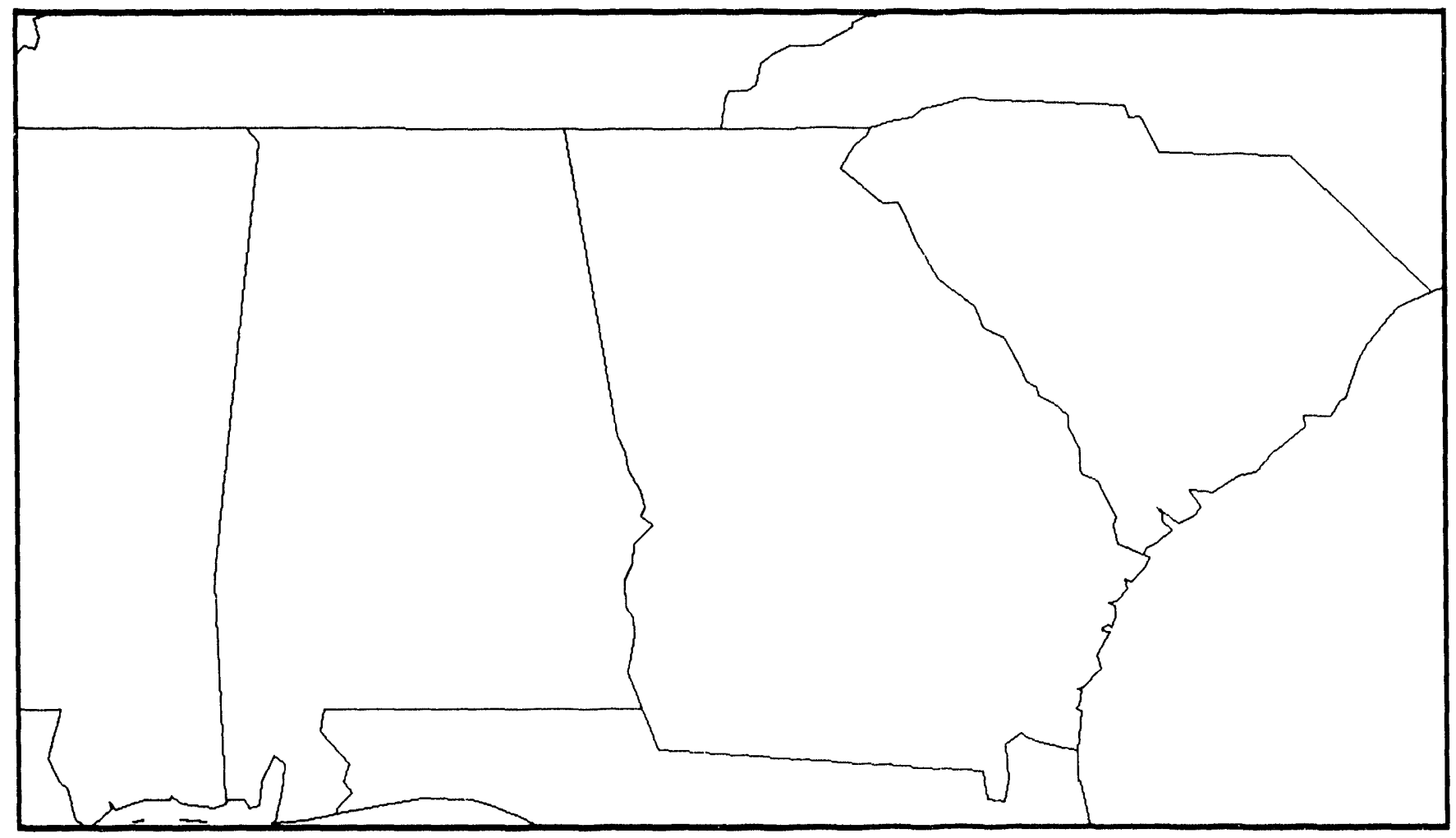

Energy Information Administration/Natural Gas Annual 1992 Supplement: Company Proflles

Service Area 
Table 3. Atlanta Gas Llght Co. Natural Gas Data, 1992 (Thousand Cubic Feet)

\begin{tabular}{|c|c|c|}
\hline \multirow{2}{*}{ Supply/Disposition } & Atlanta Gas Light Co. & Chattanooga Gas Co. \\
\hline & Georgia & Tennessee \\
\hline \multicolumn{3}{|l|}{ SUPPLY } \\
\hline \multicolumn{3}{|l|}{ 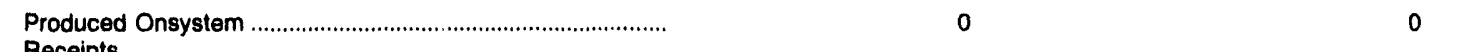 } \\
\hline 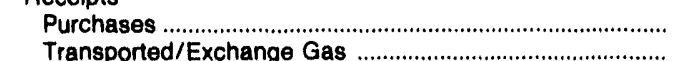 & $\begin{array}{r}169,309,703 \\
86,043,177\end{array}$ & $\begin{array}{r}12,349,712 \\
3,877,732\end{array}$ \\
\hline \multicolumn{3}{|l|}{ Interstate Movements } \\
\hline Company-owned Gas ............. & 0 & 0 \\
\hline 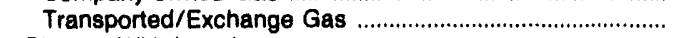 & 0 & 0 \\
\hline Storage Withdrawals & $1,346,025$ & 562,030 \\
\hline Received trom Storage Operators ..................................... & 0 & 0 \\
\hline 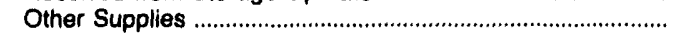 & 154,390 & 0 \\
\hline 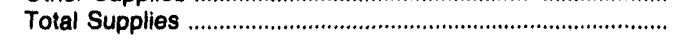 & $256,853,295$ & $16,789,474$ \\
\hline \multicolumn{3}{|l|}{ DISPOSITION } \\
\hline Lease and Plant Use & 0 & 0 \\
\hline \multirow{2}{*}{\multicolumn{3}{|c|}{$\begin{array}{l}\text { Returned to Formations } \\
\text { Interstate Movements }\end{array}$}} \\
\hline & & \\
\hline 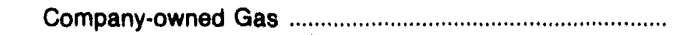 & 0 & 0 \\
\hline 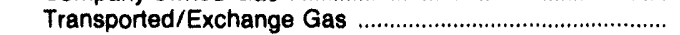 & 0 & 0 \\
\hline 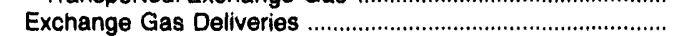 & 0 & 0 \\
\hline \multirow{2}{*}{\multicolumn{3}{|c|}{$\begin{array}{l}\text { Deliveries of Company-owned Gas } \\
\text { Deltions }\end{array}$}} \\
\hline & & \\
\hline To Storage Operators & 0 & 0 \\
\hline 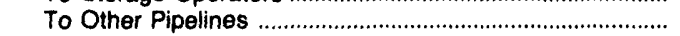 & 0 & 0 \\
\hline \multirow{2}{*}{\multicolumn{3}{|c|}{ To Consumers }} \\
\hline & & \\
\hline 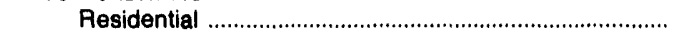 & $89,413,341$ & $3,140,414$ \\
\hline 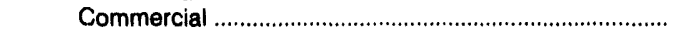 & $39,542,476$ & $3,140,520$ \\
\hline 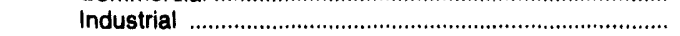 & $36,138,043$ & $5,544,886$ \\
\hline 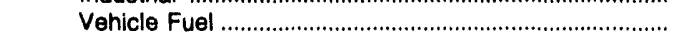 & 0 & 0 \\
\hline \multirow{2}{*}{\multicolumn{3}{|c|}{ Transported for the Account of Others }} \\
\hline & & \\
\hline To Storage Operators & 0 & 0 \\
\hline 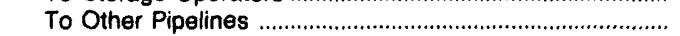 & 0 & 0 \\
\hline \multirow{2}{*}{\multicolumn{3}{|c|}{ To Consumers }} \\
\hline & & \\
\hline 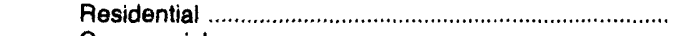 & 0 & 0 \\
\hline 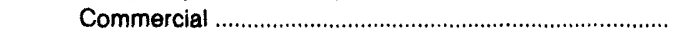 & $6,167,656$ & 0 \\
\hline 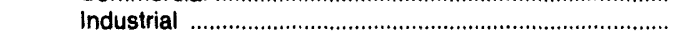 & $77,885,845$ & $3,877,732$ \\
\hline 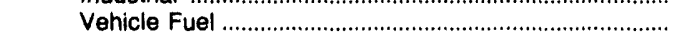 & 0 & 0 \\
\hline Electric Utilities ................................................... & 0 & 0 \\
\hline Pipeline/Compressor Fuel .......................................... & 760,014 & 10,988 \\
\hline Other Disposition & 0 & 0 \\
\hline 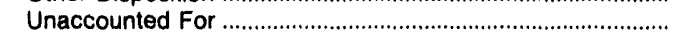 & $4,483,368$ & 130,376 \\
\hline 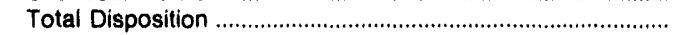 & $256,853,295$ & $16,789,474$ \\
\hline
\end{tabular}

In 1992, the company, in conjunction with Amoco Oil Company, worked to open the first public natural gas vehicle (NGV) refueling station, located in the city of Atlanta. Several other recently completed projects include: the Atlanta Water Department converted over 20 meter-reading vehicles to run on natural gas, and the Savannah police department converted 75 of its squad cars as well. Both cities have opened refueling stations. These efforts reinforce Atlanta Gas Light's commitment to NGV's.
Currently, other NGV projects are under way. The first, in its final stages, is the opening of a full-scale natural gas technology center in Atlanta that will highlight NGV's. The second project involves ensuring that NGV's receive high visibility at the upcoming 1996 Summer Olympics. The latter project will receive assistance from the Department of Energy when its NGV demonstration project visits several cities, starting in Atlanta, as part of its program to test alternate fuels for vehicles. The Company also expects to direct its focus on natural gas cooling for which interest has increased significantly, due to the exclusion of chlorofluorocarbons from gas equipment. 


\section{Baltimore Gas and Electric Co.}

Baltimore Gas and Electric Company (BG\&E) is a publicly held corporation whose central operation is that of a local utility providing both natural gas service and electricity to the central Maryland region. BG\&E has been involved in the natural gas industry for 177 years. In 1816, Rembrandt Peale formed the Gas Light Company of Baltimore, the first natural gas utility in the United States, to light the streets and homes of Baltimore. During the 1800 's, the company merged with the People's Gas Light Company, Brush Electric Light Company, and the United States Electric Light and Power Company. In 1955, the Consolidated Gas Electric Light and Power Company of Baltimore was renamed the Baltimore Gas and Electric Company (BG\&E).

In addition to its utility operations, BG\&E also has nonutility operations in the form of the Constellation Companies. Constellation Holdings is a wholly owned subsidiary involved in real estate development, senior living and health care, energy and environmental projects, and investments and financial services. Another wholly owned subsidiary of BG\&E is BNG, Inc., primarily involved in investing in natural gas reserves and obtaining gas from nontraditional sources.

Figure 4. Baltimore Gas and Electric Co., 1992

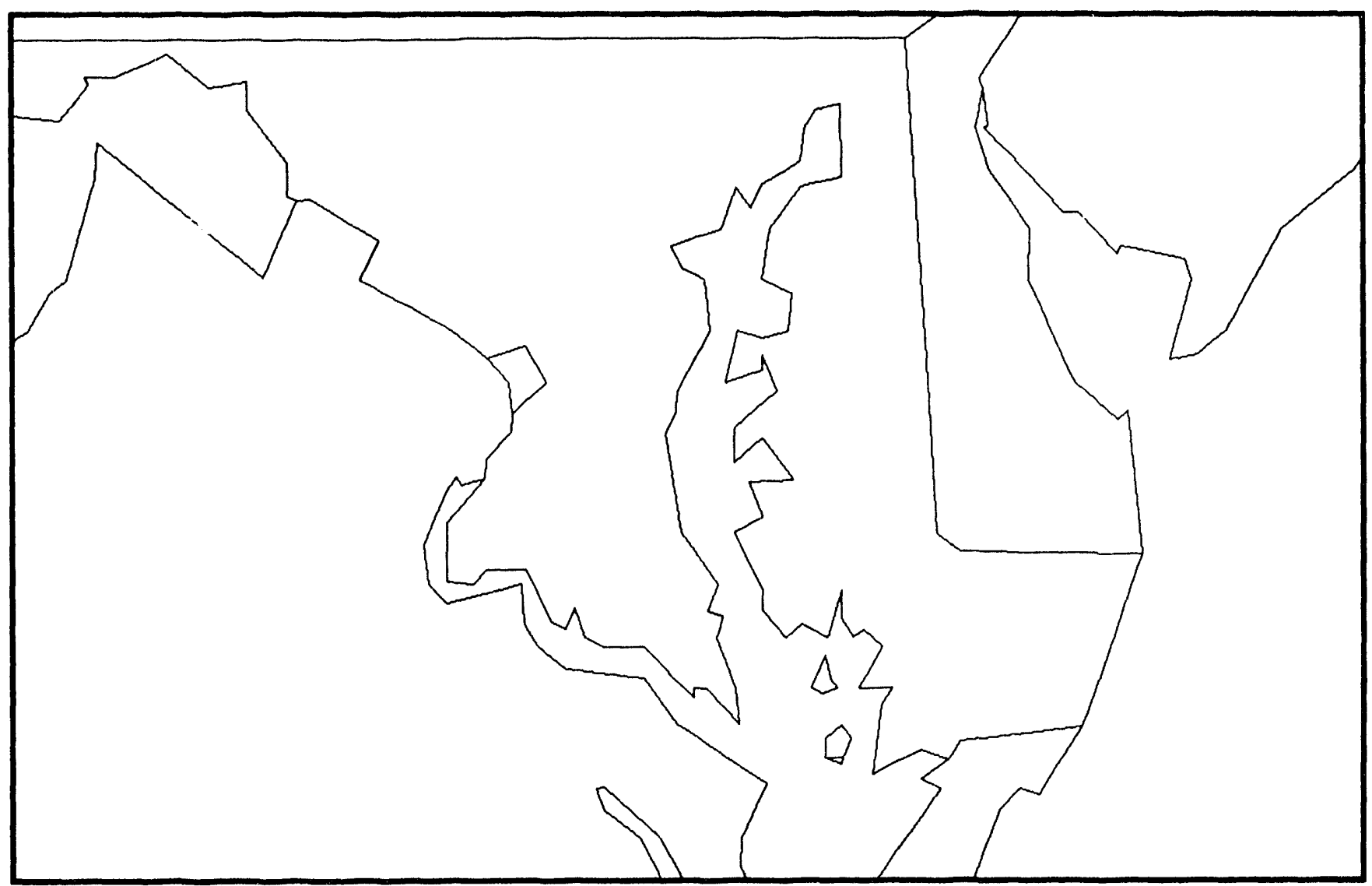

Source: Energy Information Administration (EIA), Form EIA-176, "Annual Report of Natural and Supplemental Gas Supply and Disposition." 
Table 4. Baltimore Gas \& Electric Co. Natural Gas Data, 1992

(Thousand Cubic Feet)

\begin{tabular}{c|c}
\hline \multirow{2}{*}{ Supply/Disposition } & Baltimore Gas and Electric Co. \\
\cline { 2 - 2 } & Maryland \\
\hline
\end{tabular}

SUPPLY

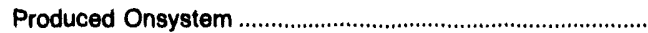

Receipts

Purchases

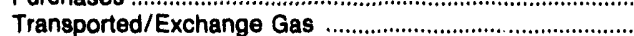

Interstate Movements

Company-owned Gas

Transported/Exchange Gas .

Storage Witho

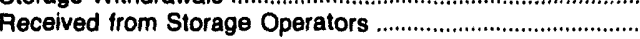

Other Supplies

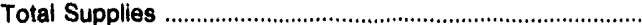

\section{DISPOSITION}

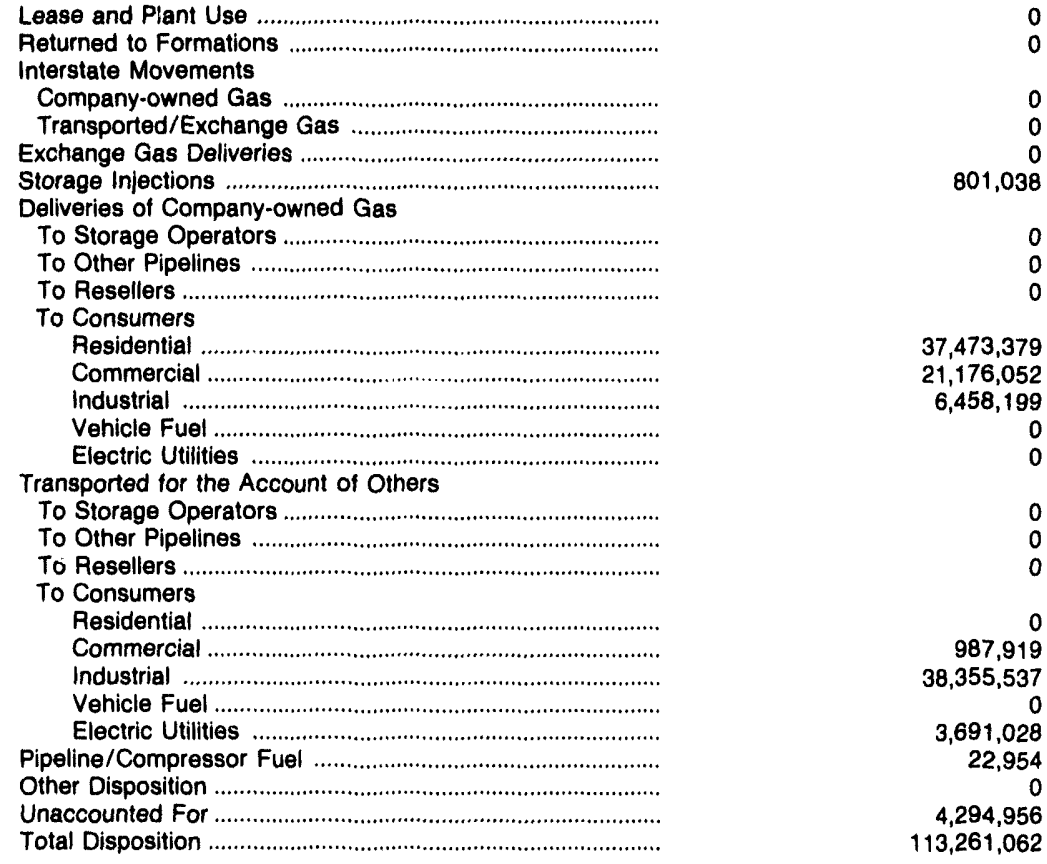

Source: Energy Information Administration (EIA), Form EIA-176, "Annual Report of Natural and Supplemental Gas Supply and Disposition."

A 2,300-square-mile service area in Central Maryland encompasses all of BG\&E's electric and natural gas markets. The company supplies natural gas to over 500,000 customers residing in an area of approximately 600 square miles. The majority of this natural gas is supplied through purchases from pipeline suppliers and natural gas producers. Facilities at three plants located in central Maryland are maintained by BG\&E to provide for the production and storage of liquefied natural gas (LNG), substitute natural gas, and propane as a supplemental supply.

BG\&E maintains a natural-gas-fueled fleet of more than 100 vehicles. During 1992, in an effort to service more new homes in the area, BG\&E built three compressed natural gas fueling stations and connected over 3,800 new homes to gas mains. Gas sales during 1992 rose primarily due to colder weather during the heating season. 


\section{Boston Gas Co.}

Boston Gas Company is the largest gas distribution company in New England. It is a subsidiary of Eastern Enterprises, a diversified holding company. Boston Gas operates in the city of Boston and over 70 other cities and towns throughout eastern and central Massachusetts. The company serves over 500,000 residential, commercial, industrial, and electric utility users, and delivered over 100 billion cubic feet of natural gas to end users during 1992.
Boston Gas Company has only a 21 percent market share of the potential commercial or industrial users in their area. In the residential sector, 46 percent of Boston Gas Company's potential customers do not use natural gas for home heating. These two factors plus the cost and environmental advantages of natural gas, gives the company a very good growth potential to increase gas sales in the future. New market products like gas air-conditioning and natural gas vehicles also have future market potential.

Figure 5. Boston Gas Co., 1992

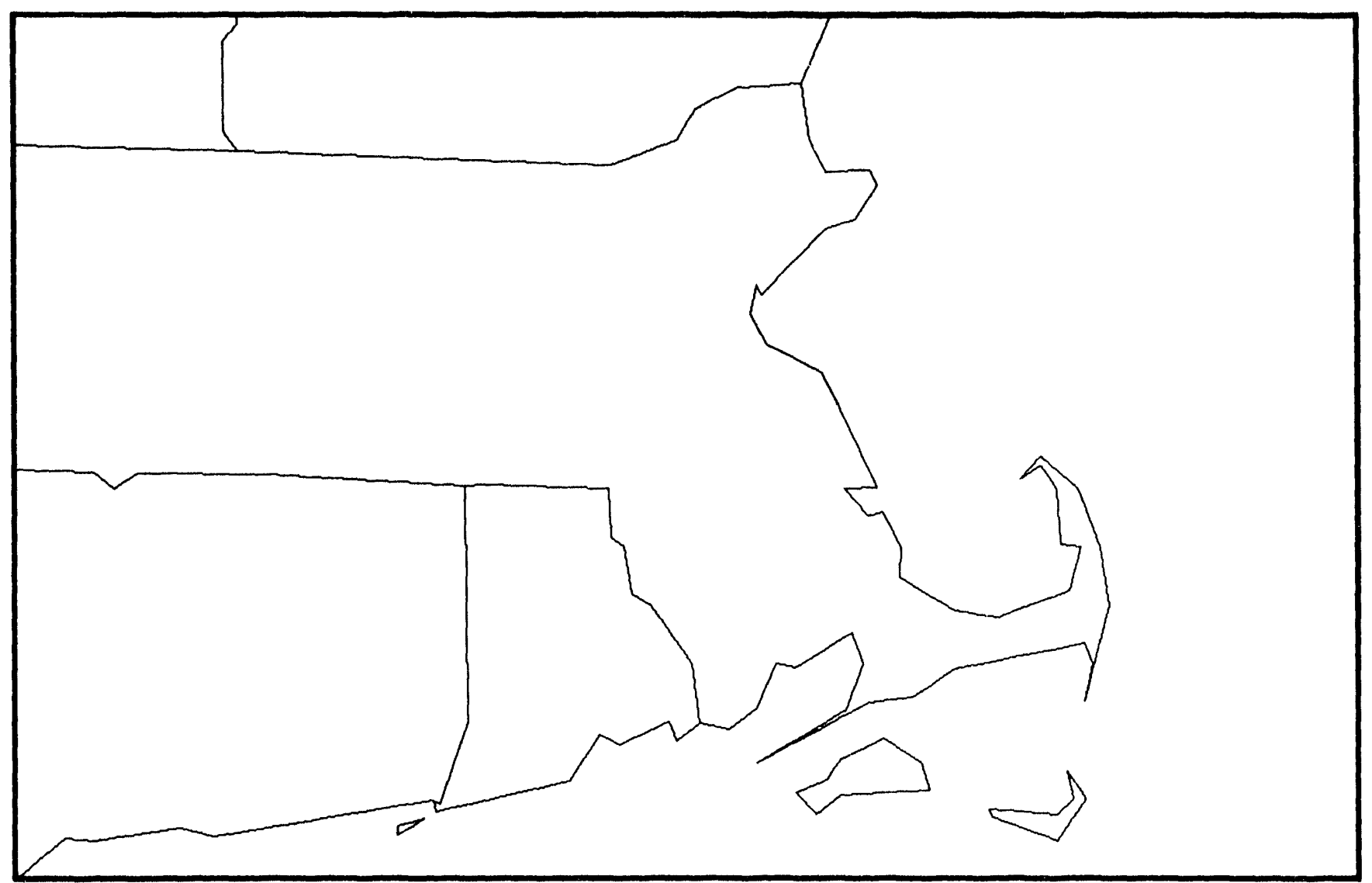

Source: Energy Information Administration (EIA), Form EIA-176, "Annual Report of Natural and Supplemental Gas Supply and Disposition."

Service Areas 
Table 5. Boston Gas Co. Natural Gas Data, 1992 (Thousand Cubic Feet)

\begin{tabular}{c|c}
\hline \multirow{2}{*}{ Supply/Disposition } & Boston Gas Co. \\
\cline { 2 - 2 } & Massachusetts \\
\hline
\end{tabular}

\section{SUPPLY}

Produced Onsystem

\section{Receipts}

Purchases

Transported/Exchange Gas

Interstate Movements

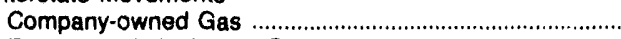

Transported/Exchange Gas

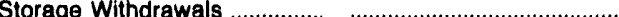

Received from Storage Operators .........................................

Other Supplies

Total Supplies

\section{DISPOSITION}

Lease and Plant Use.......

Returned to Formations

Interstate Movements

Company-owned Gas

Transported/Exchange Gas

Exchange Gas Deliveries

Storage Injections

Deliveries of Company-owned Gas

To Storage Operators

To Other Pipelines

To Resellers

To Consumers

Residential

Indugtrial

Vehicle Fuel....

Electric Utilities

Transported for the Account of Others

To Storage Operators

To Other Pipelines

To Resellers .....

To Consumers

Residential

Commercial

industrial

Vehicle Fuel ....

Electric Utilities

Pipeline/Compressor Fue

Other Disposition

Total Disposition
0

$92,356,371$

$32,723,684$

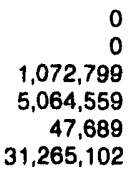

$31,265,102$

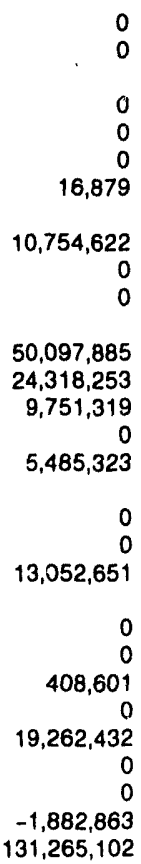

Source: Energy Information Administration (EIA), Form EIA.176, "Annual Report of Natural and Supplemental Gas Supply and Disposition."

The company has submitted a proposal to the Massachusetts Department of Public Utilities for the purchase and consolidation of the 10 gas distribution companies in Massachusetts into 1 large utility. This plan is not a firm proposal to buy any or all of the other gas distribution companies in the State, but implemented, it could save $\$ 100$ million yearly and improve the overall service in the State. The savings would come from greater purchasing power, consolidating functions, and eliminating redundant services. 


\section{Brooklyn Union Gas Co.}

Brooklyn Union Gas Co. distributes natural gas to over 1 million customers, mostly residential, in Brooklyn, Queens, and Staten Island in New York City. It is also involved through its subsidiaries in gas exploration and production, cogeneration, propane distribution, and pipeline projects. In addition, Brooklyn Union is expanding its markets in such areas as natural gas vehicles, fuel cells, and air-conditioning.

Brooklyn Union is actively pursuing the conversion of apartment houses to natural gas by offering volume discount rates. In 1992, over 300 new customers were added, bringing the 5-year total to over 1,000 new customers.
Cogeneration projects include a 50-megawatt plant, which has been providing power and heat to Grumman Aerospace for 3 years. This year, Brooklyn Union began development of a 100-megawatt plant at the John F. Kennedy International Airport and continued development of a 40-megawatt plant at the State University of New York at Stony Brook. Fuel cell activity is highlighted by a 200-kilowatt demonstration project at a Staten Island hospital.

In June 1992, Brooklyn Union opened the first natural gas refueling facility in New York State to the public. The company is planning on participating in the opening of six more facilities by the end of 1993. New York

Figure 6. Brooklyn Union Gas Co., 1992

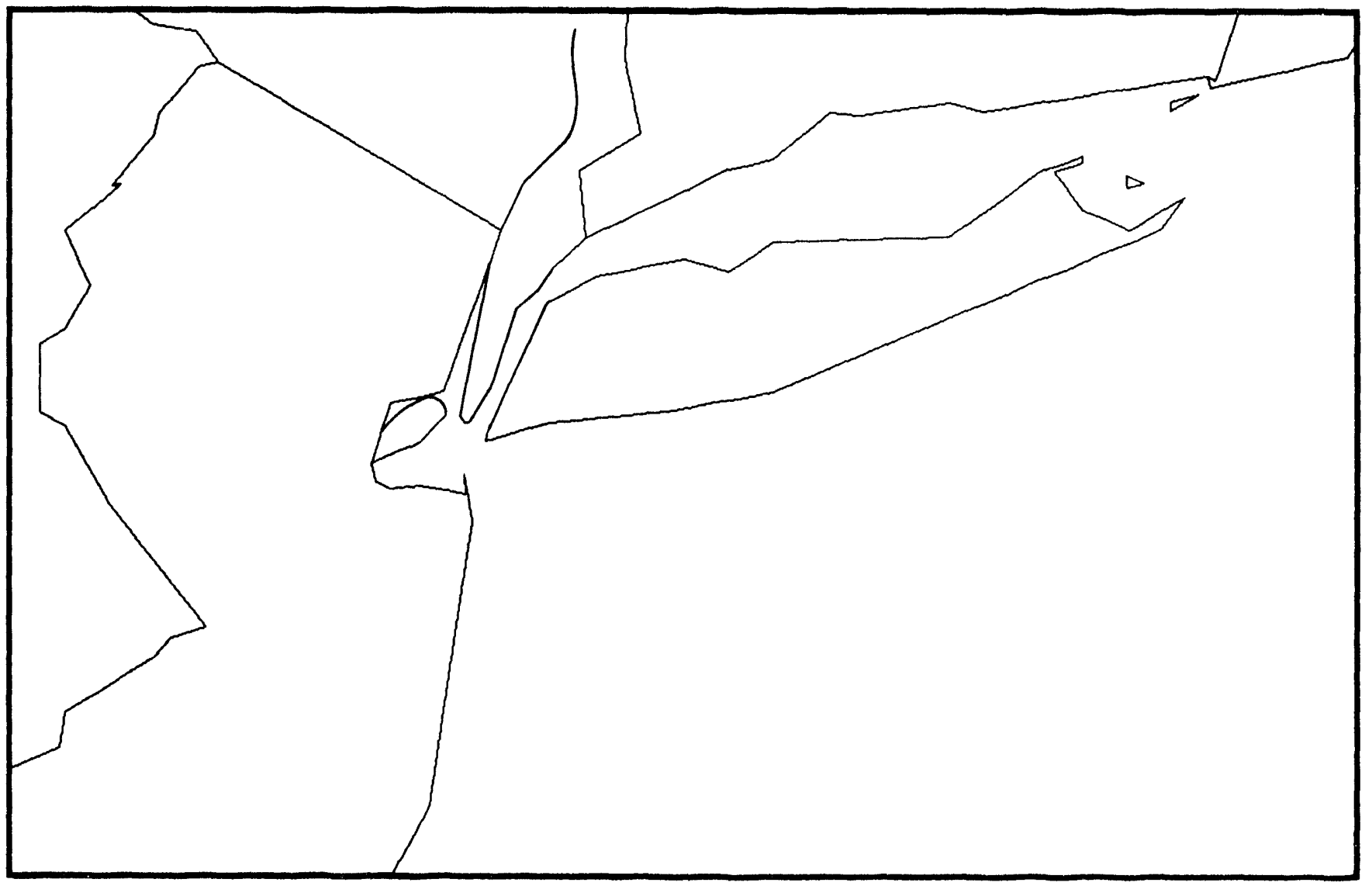

Source: Energy Information Administration (EIA), Form EIA-176, "Annual Report of Natural and Supplemental Gas Supply and Disposition." 
Table 6. Brooklyn Union Gas Co. Natural Gas Data, 1992 (Thousand Cubic Feet)

\begin{tabular}{c|c}
\hline \multirow{2}{*}{ Supply/Disposition } & Brooklyn Union Gas Co. \\
\cline { 2 - 2 } & Now York \\
\hline
\end{tabular}

\section{SUPPL.Y}

Produced Onsystem

Receipts

Purchases

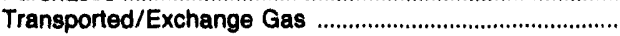

Interstate Movements

Company-owned Gas

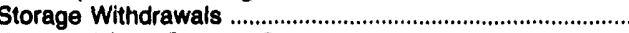

Received from Storage Operators ............................................

Other Supplies

Total Supplies

\section{DISPOSITION}

Lease and Plant Use

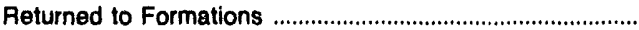

Interstate Movements

Company-owned Gas

Transported/Exchange Gas ................

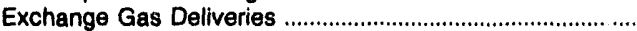

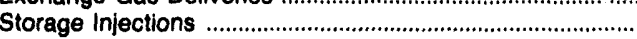

Deliveries of Company-owned Gas

To Storage Operators

To Resellers .

To Consumers

Residential

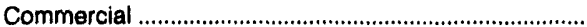

Industrial

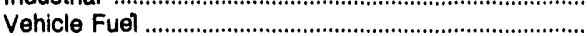

Electric Utilities

Transported for the Accoun

To Storage Operators

To Other Pipelines

To Resellers ....

To Consumers

Residential

Commercial .

Industrial.....

Vehicle Fuel ....

Electric Utilities

Pipeline/Compressor Fue

Other Disposition

Unaccounted For
0

$9,168,083$

$128,833,326$
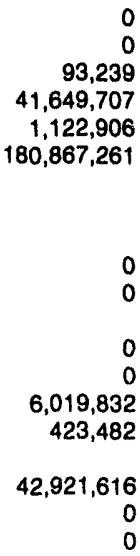

$97,723,952$

$20,882,285$

$4,366,700$

5,998

0

0

$2,341,646$

$1,061,827$

$1,527,869$

0

0

$3,592,054$

$180,867,261$

Source: Energy Information Administration (EIA), Form EIA-176, "Annual Report of Natural and Supplemental Gas Supply and Disposition."

City plans to buy over 50 buses which run on natural gas in the next year and to convert over 350 cars to natural gas. In addition, the United States Postal Service opened a natural gas refueling station to service its fleet of 50 vehicles.

To assure itself of adequate supplies of natural gas, Brooklyn Union has entered into long-term contracts with various producers in the Gulf Coast, western Canada, and Appalachia. It was one of the sponsors of the Iroquois Pipeline, which is now bringing supplies of natural gas from Canada to the Northeast and New York. Brooklyn Union is also involved in the new Liberty Pipeline which will run between New Jersey and Queens when it is completed in 1994. This pipeline will increase the availability of natural gas by approximately 200 million cubic feet per day. 


\section{Coastal Corp.}

The Coastal Corporation is involved in natural gas marketing, transmission, and storage as well as other energy-related operations. Its natural gas subsidiaries include Coastal Gas Services Co., ANR Pipeline Co., Colorado Interstate Gas Co. (CIG), Wyoming Interstate Co., and ANR Storage Co. Coastal also is involved in joint ventures including Great Lakes Gas Transmission Ltd. (50-percent owned), High Island Offshore System (40-percent owned), and U-T Offshore System (33 1/3 percent owned).

Coastal Gas Services Co. has emerged in response to FERC Order 636, which provided for unbundling of gas sales and transmission. This subsidiary will manage sales and delivery of natural gas as well as service to utility customers while Coastal's pipeline companies provide unbundled transmission service.

Coastal's pipelines transport natural gas from major production areas of the Gulf of Mexico; the Anadarko Basin in Texas, Oklahoma, and Kansas; and the Rocky Mountains to consuming areas in the Rocky Mountain States and the Midwest. In recent years, Coastal has embarked on a number of pipeline expansion projects to expand its natural gas markets. The Uinta Pipeline from eastern Utah to southern Wyoming was completed by CIG in 1992. The Empire State Pipeline runs from Niagara Falls to Syracuse, New York. It began

Figure 7. Coastal Corp., 1992

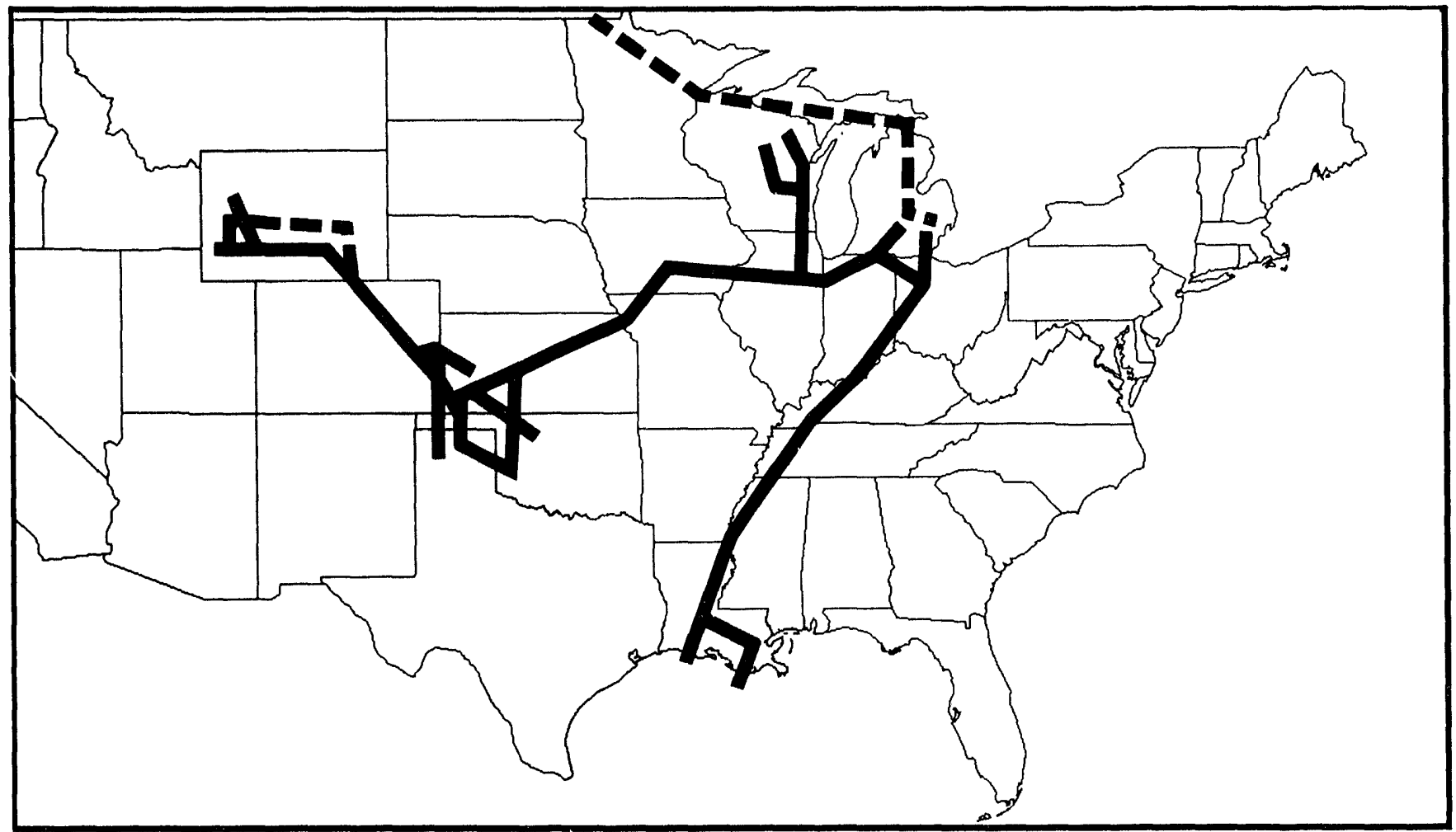

Source: Energy Information Administration (EIA), Form EIA-176, "Annual Report of Natural and Supplemental Gas Supply and Disposition."

Supply Areas

ANR Pipeline Co.

Wyoming interstate Co.
Colorado Interstate Gas Co.

m areat Lakes Transmission Ltd. 
Table 7. Coastal Corp. Natural Gas Data, 1992

(Thousand Cubic Feet)

\begin{tabular}{|c|c|c|c|c|c|c|}
\hline \multirow{2}{*}{ Supply/Disposition } & \multicolumn{6}{|c|}{ ANR Pipeline Co. } \\
\hline & Louisiana & Arkansas & Mississippi & Tennessee & Kentucky & Indiana \\
\hline \multicolumn{7}{|l|}{ SUPPLY } \\
\hline $\begin{array}{l}\text { Produced Onsystem } \\
\text { Receipts }\end{array}$ & 0 & 0 & 0 & 0 & 0 & 0 \\
\hline Purchases & $21,576,282$ & 0 & 30,549 & 0 & 0 & 0 \\
\hline Transported/Exchange Gas ........................... & $798,208,453$ & 0 & 0 & 0 & 0 & $2,731,352$ \\
\hline \multicolumn{7}{|l|}{ Interstate Movements } \\
\hline 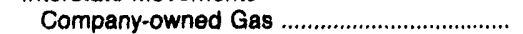 & 0 & 0 & 0 & 0 & 0 & 0 \\
\hline Transported/Exchange Gas ........................... & 0 & $331,141,350$ & $331,279,146$ & $328,356,611$ & $324,494,361$ & $321,345,551$ \\
\hline Storage Withdrawals & 0 & 0 & 0 & 0 & 0 & 0 \\
\hline Received from Storage Operators ..................... & 0 & 0 & 0 & 0 & 0 & 0 \\
\hline 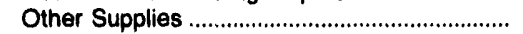 & 0 & 0 & 0 & 0 & 0 & 0 \\
\hline 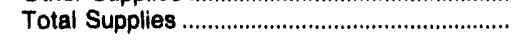 & $819,784,735$ & $331,141,350$ & $331,309,685$ & $328,356,611$ & $324,494,361$ & $324,076,903$ \\
\hline \multicolumn{7}{|l|}{ DISPOSITION } \\
\hline Lease and Plant Use & 69.467 & 0 & 0 & 0 & 0 & 0 \\
\hline $\begin{array}{l}\text { Returned to Formations .......................................... } \\
\text { Interstate Movigments }\end{array}$ & 0 & 0 & 0 & 0 & 0 & 0 \\
\hline 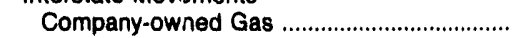 & 0 & 0 & 0 & 0 & 0 & 0 \\
\hline 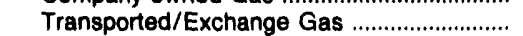 & $331,141,350$ & $331,279,146$ & $328,356,611$ & $324,494,361$ & $321,345,551$ & $255,753,826$ \\
\hline 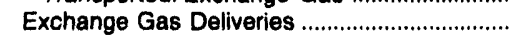 & $39,203,769$ & 0 & 0 & 0 & 0 & 0 \\
\hline Storage Injections & 0 & 0 & 0 & 0 & 0 & 0 \\
\hline \multicolumn{7}{|l|}{ Deliveries of Company-owned Gas } \\
\hline 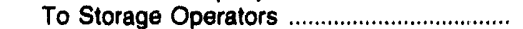 & 0 & 0 & 0 & 0 & 0 & 0 \\
\hline 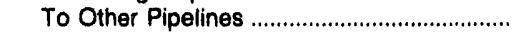 & 0 & 0 & 0 & 0 & 0 & 0 \\
\hline $\begin{array}{l}\text { To Resellers ........................................................ } \\
\text { To Consumers }\end{array}$ & 0 & 0 & 0 & 490,594 & 0 & $2,848,580$ \\
\hline 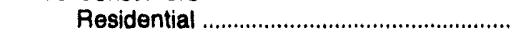 & 0 & 0 & 0 & 0 & 0 & 0 \\
\hline 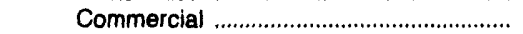 & 0 & 0 & 0 & 0 & 0 & 0 \\
\hline 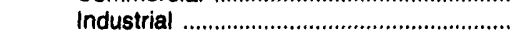 & 0 & 0 & 0 & 0 & 0 & 0 \\
\hline 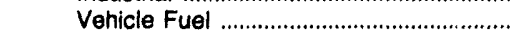 & 0 & 0 & 0 & 0 & 0 & 0 \\
\hline 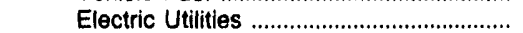 & 0 & 0 & 0 & 0 & 0 & 0 \\
\hline \multicolumn{7}{|l|}{ Transported for the Account of Others } \\
\hline 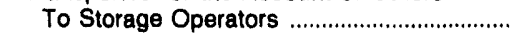 & 0 & 0 & 0 & 0 & 0 & 0 \\
\hline 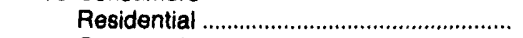 & 0 & 0 & 0 & 0 & 0 & 0 \\
\hline 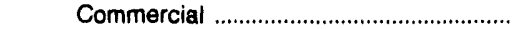 & 0 & 0 & 0 & 0 & 0 & 0 \\
\hline 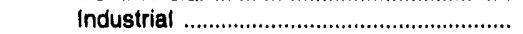 & 0 & 0 & 0 & 0 & 0 & 0 \\
\hline 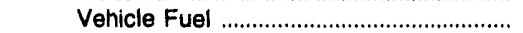 & 0 & 0 & 0 & 0 & 0 & 0 \\
\hline 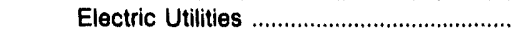 & 0 & 0 & 0 & 0 & 0 & 0 \\
\hline Pipeline/Compressor Fuel ................................. & $5,101,716$ & 27,961 & $2,282,235$ & $2,299,751$ & 935,791 & $2,930,699$ \\
\hline 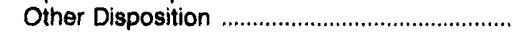 & 0 & 0 & 0 & 0 & 0 & 0 \\
\hline 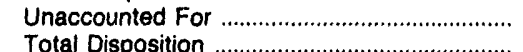 & $\begin{array}{r}2,812,430 \\
819,784,735\end{array}$ & $\begin{array}{r}-165,757 \\
331,141,350\end{array}$ & $\begin{array}{r}670,849 \\
331,309,685\end{array}$ & $\begin{array}{r}1,071,905 \\
328,356,611\end{array}$ & $\begin{array}{r}518,493 \\
324,494,361\end{array}$ & $\begin{array}{r}1,618,326 \\
324,076,903\end{array}$ \\
\hline
\end{tabular}

operation in November 1993. The Liberty Pipeline, running from New Jersey to JFK International Airport on Long Island, will be completed in 1994. The Uinta Pipeline carries approximately 178 million cubic feet per day, the Empire State Pipeline can carry up to 600 million cubic feet per day, and the Liberty Pipeline will have a capacity of approximately 500 million cubic feet per day.

Other expansion projects include the InterCoastal Pipe Line, the Mayflower Pipeline, and the SunShine Pipeline. The InterCoastal Pipe Line will transport approximately 230 million cubic feet per day from Toronto to Sarnia, Ontario, upon completion in late 1994. ANR Pipeline, in partnership with a Canadian company, is converting a crude oil pipeline to natural gas. The Mayflower Pipeline will run from an interconnect with the Iroquois Pipeline at Canajoharie, New York to Boston. It is expected to be completed in 1996. Finally,
Coastal is hoping to complete the SunShine Pipeline from Pascagoula, Mississippi to Polk County, Florida and possibly later to Okeechobee County, Florida. The initial capacity would be 250 million cubic feet per day in 1995 possibly expanding to 600 million cubic feet per day in 1999.

FERC Order 636 requires companies to unbundle their storage services as well. To this end, Coastal is expanding its storage capacity along with its pipeline capacity. ANR Storage Company and an affiliate of Michigan Consolidated Gas Company are involved in the Blue Lake Storage project in Michigan. This project will add 42 billion cubic feet of capacity. CIG started development of 17 new injection/withdrawal wells in 1992 to increase its peak-day deliverability in three of its storage fields in Kansas and Colorado. One of these wells was the deepest successful horizontal gas storage well ever drilled in the United States. 
Table 7. Coastal Corp. Natural Gas Data, 1992 (Continued) (Thousand Cubic Feet)

\begin{tabular}{|c|c|c|c|c|c|c|}
\hline \multirow{2}{*}{ Supply/Disposition } & \multicolumn{6}{|c|}{ ANR Pipeline Co. } \\
\hline & Ohio & Michigan & Texas & Wyoming & Oklahoma & Kansas \\
\hline \multicolumn{7}{|l|}{ SUPPLY } \\
\hline 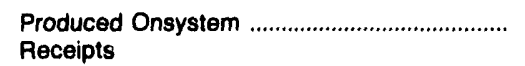 & 0 & 0 & 0 & 0 & 0 & 0 \\
\hline 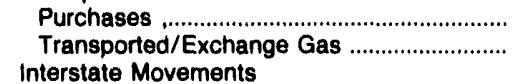 & $\begin{array}{r}0 \\
13,691,066\end{array}$ & $\begin{array}{r}0 \\
612,869,699\end{array}$ & $\begin{array}{r}31,088,230 \\
339,407,482\end{array}$ & $\begin{array}{l}31,887,269 \\
15,861,325\end{array}$ & $\begin{array}{r}29,821,251 \\
201,813,324\end{array}$ & $\begin{array}{r}349,157 \\
5,827,960\end{array}$ \\
\hline 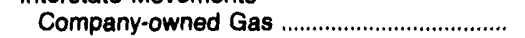 & 0 & 0 & 0 & 0 & 0 & 0 \\
\hline 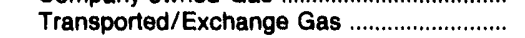 & $200,460,161$ & $147,220,737$ & 0 & 0 & $57,563,484$ & $239,264,022$ \\
\hline 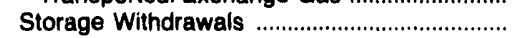 & 0 & $108,057,764$ & 0 & 0 & 0 & 0 \\
\hline Received from Storage Operators ................... & 0 & $18,421,624$ & 0 & 0 & 0 & 0 \\
\hline Other Supplies & 0 & 0 & 0 & 0 & 0 & 0 \\
\hline Total Supplies & $214,151,227$ & $886,569,824$ & $370,495,712$ & $47,748,594$ & $289,198,059$ & $245,441,139$ \\
\hline \multicolumn{7}{|l|}{ DISPOSITION } \\
\hline 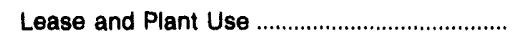 & 0 & 801 & 0 & 0 & $1,178,339$ & 0 \\
\hline $\begin{array}{l}\text { Returned to Formations ........................................ } \\
\text { Interstate Movements }\end{array}$ & 0 & 0 & 0 & 0 & 0 & 0 \\
\hline 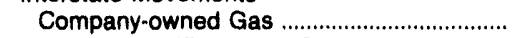 & 0 & 0 & 0 & 0 & 0 & 0 \\
\hline 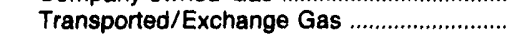 & $147,220,737$ & 0 & $57,563,484$ & 0 & $239,264,022$ & $232,858,386$ \\
\hline 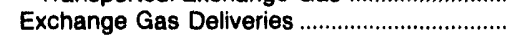 & 0 & $187,153,384$ & 0 & 158,911 & $8,489,813$ & 0 \\
\hline 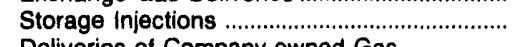 & 0 & $122,420,985$ & 0 & 0 & 0 & 0 \\
\hline \multicolumn{7}{|l|}{ Deliveries of Company-owned Gas } \\
\hline 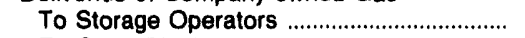 & 0 & $17,155,671$ & 0 & 0 & 0 & 0 \\
\hline 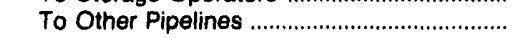 & 0 & 0 & 0 & 0 & 0 & 0 \\
\hline $\begin{array}{l}\text { To Resellers ...................................................... } \\
\text { To Consumers }\end{array}$ & 28,598 & $53,652,953$ & 0 & 0 & 0 & 51,765 \\
\hline 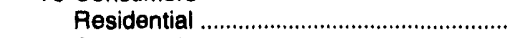 & 0 & 0 & 0 & 0 & 0 & 0 \\
\hline 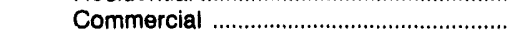 & 0 & 0 & 0 & 0 & 0 & 0 \\
\hline 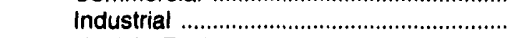 & 0 & 0 & 0 & 0 & 0 & 0 \\
\hline 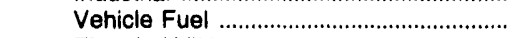 & 0 & 0 & 0 & 0 & 0 & 0 \\
\hline 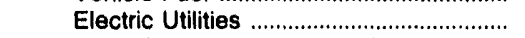 & 0 & 0 & 0 & 0 & 0 & 0 \\
\hline \multicolumn{7}{|l|}{ Transported for the Account of Others } \\
\hline 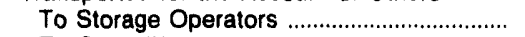 & 0 & 0 & 0 & 0 & 0 & 0 \\
\hline To Other Pipelines ............................................ & $41,067,460$ & $502,372,577$ & $312,600,969$ & $47,589,683$ & $36,769,968$ & $9,787,855$ \\
\hline 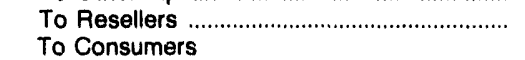 & 0 & 0 & 0 & 0 & 0 & 0 \\
\hline 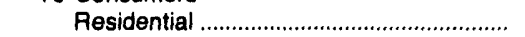 & 0 & 0 & 0 & 0 & 0 & 0 \\
\hline 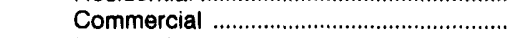 & 0 & 0 & 0 & 0 & 0 & 0 \\
\hline 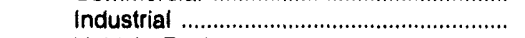 & $24,691,703$ & 0 & 0 & 0 & 0 & 0 \\
\hline 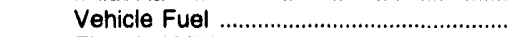 & 0 & 0 & 0 & 0 & 0 & 0 \\
\hline 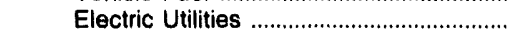 & 0 & 0 & 0 & 0 & 0 & 0 \\
\hline Pipeline/Compressor Fuel ................................ & 734,220 & $2,462,230$ & $1,404,695$ & 0 & $2,254,677$ & $2,960,509$ \\
\hline 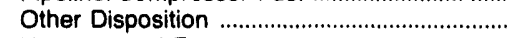 & 0 & 0 & 0 & 0 & 0 & 0 \\
\hline 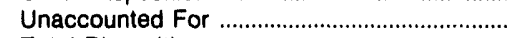 & 408,509 & $1,351,223$ & $-1,073,436$ & 0 & $1,241,240$ & $-217,376$ \\
\hline 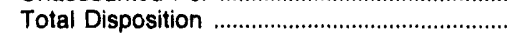 & $214,151,227$ & $886,569,824$ & $370,495,712$ & $47,748,594$ & $289,198,059$ & $245,441,139$ \\
\hline
\end{tabular}


Table 7. Coastal Corp. Natural Gas Data, 1992 (Continued) (Thousand Cubic Feet)

\begin{tabular}{|c|c|c|c|c|c|}
\hline \multirow{2}{*}{ Supply/Disposition } & \multicolumn{5}{|c|}{ ANR Pipeline Co. } \\
\hline & Nebraska & Missouri & lowa & Illinois & Wisconsin \\
\hline \multicolumn{6}{|l|}{ SUPPLY } \\
\hline $\begin{array}{l}\text { Produced Onsystem } \\
\text { Receipts }\end{array}$ & 0 & 0 & 0 & 0 & 0 \\
\hline Purchases & 0 & 0 & 0 & 0 & $13,334,778$ \\
\hline 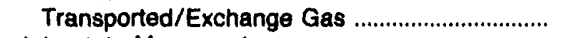 & 0 & 0 & $9,062,533$ & $17,209,848$ & $88,596,864$ \\
\hline \multicolumn{6}{|l|}{ Interstate Movements } \\
\hline 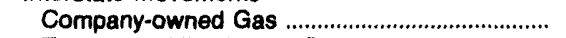 & 0 & 0 & 0 & 0 & 0 \\
\hline 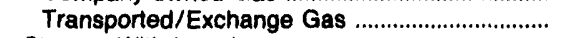 & $232,858,386$ & $232,880,315$ & $230,275,321$ & $265,809,384$ & $124,564,122$ \\
\hline 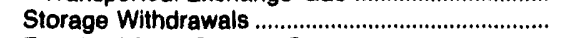 & 0 & 0 & 0 & 0 & 0 \\
\hline Received from Storage Operators .............................. & 0 & 0 & 0 & 0 & 0 \\
\hline Other Supplies & 0 & 0 & 0 & 0 & 0 \\
\hline Total Supplies & $232,858,386$ & $232,880,315$ & $239,337,854$ & $283,019,232$ & $226,495,764$ \\
\hline \multicolumn{6}{|l|}{ DISPOSITION } \\
\hline Lease and Plant Use & 0 & 0 & 0 & 0 & 0 \\
\hline $\begin{array}{l}\text { Returned to Formations } \\
\text { Interstate Movements }\end{array}$ & 0 & 0 & 0 & 0 & 0 \\
\hline 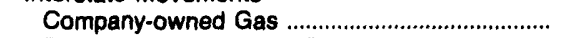 & 0 & 0 & 0 & 0 & 0 \\
\hline 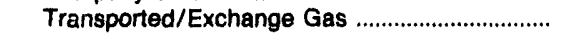 & $232,880,315$ & $230,275,321$ & $210,515,719$ & $124,564,122$ & $\mathbf{0}$ \\
\hline Exchange Gas Deliveries ........................................... & 0 & 0 & 0 & 0 & 0 \\
\hline Storage Injections & 0 & 0 & 0 & 0 & 0 \\
\hline \multicolumn{6}{|l|}{ Deliveries of Company-owned Gas } \\
\hline 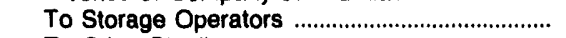 & 0 & 0 & 0 & 0 & 0 \\
\hline 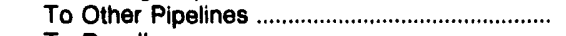 & 0 & 0 & 0 & 0 & 0 \\
\hline $\begin{array}{l}\text { To Resellers } \\
\text { To Consumers }\end{array}$ & 0 & 776,963 & $1,185,706$ & 303,055 & $87,510,710$ \\
\hline 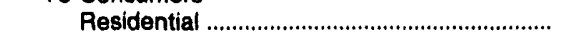 & 0 & 0 & 0 & 0 & 0 \\
\hline 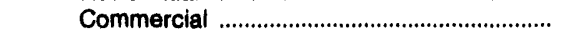 & 0 & 0 & 0 & 0 & 0 \\
\hline 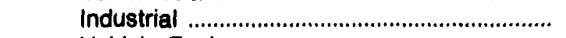 & 0 & 0 & 0 & 0 & 0 \\
\hline 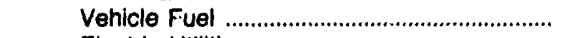 & 0 & 0 & 0 & 0 & 0 \\
\hline 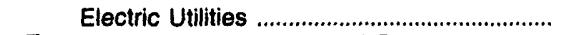 & 0 & 0 & 0 & 0 & 0 \\
\hline \multicolumn{6}{|l|}{ Transported for the Account of Others } \\
\hline 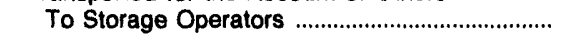 & 0 & 0 & 0 & 0 & 0 \\
\hline To Other Pipelines & 0 & 778,734 & $25,252,598$ & $155,728,392$ & $136,948,133$ \\
\hline 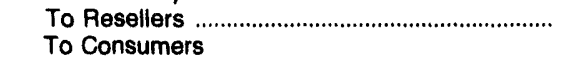 & 0 & 0 & 0 & 0 & 0 \\
\hline 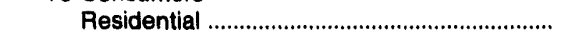 & 0 & 0 & 0 & 0 & 0 \\
\hline 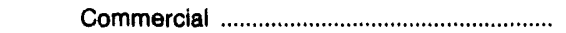 & 0 & 0 & 0 & 0 & 0 \\
\hline 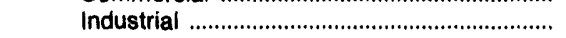 & 0 & 0 & 0 & 0 & 0 \\
\hline 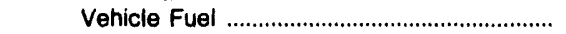 & 0 & 0 & 0 & 0 & 0 \\
\hline 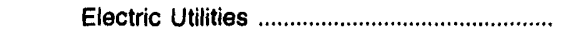 & 0 & 0 & 0 & 0 & 0 \\
\hline 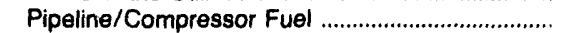 & 3,995 & 672,211 & $1,535,388$ & $1,559,508$ & $1,314,174$ \\
\hline Other Disposition & 0 & 0 & 0 & 0 & 0 \\
\hline Unaccounted For & $-25,924$ & 377,086 & 848,443 & 864,155 & 722,747 \\
\hline 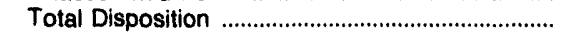 & $232,858,386$ & $232,880,315$ & $239,337,854$ & $283,019,232$ & $226,495,764$ \\
\hline
\end{tabular}


Table 7. Coastal Corp. Natural Gas Data, 1992 (Continued) (Thousand Cubic Feet)

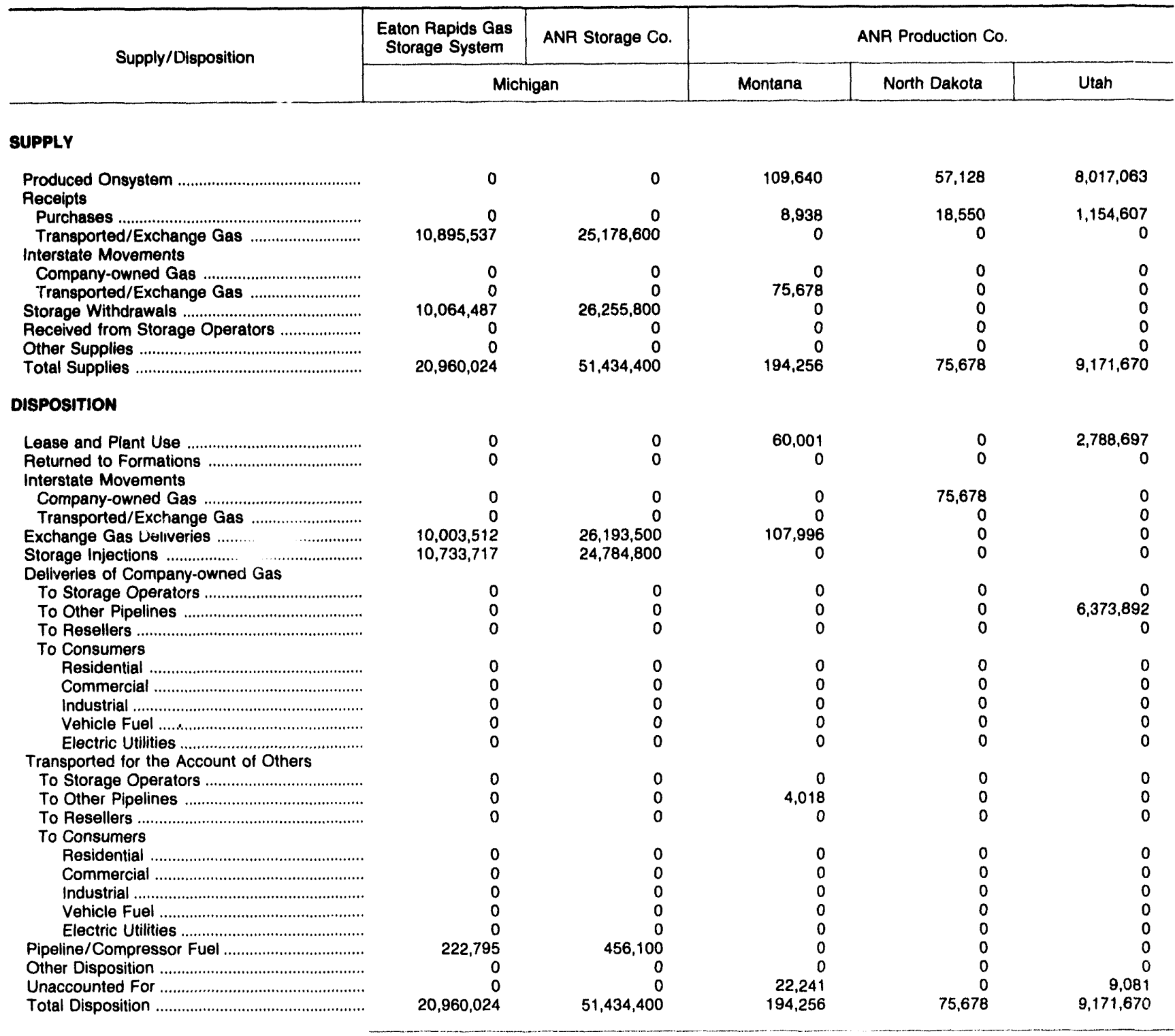


Table 7. Coastal Corp. Natural Gas Data, 1992 (Continued) (Thousand Cubic Feet)

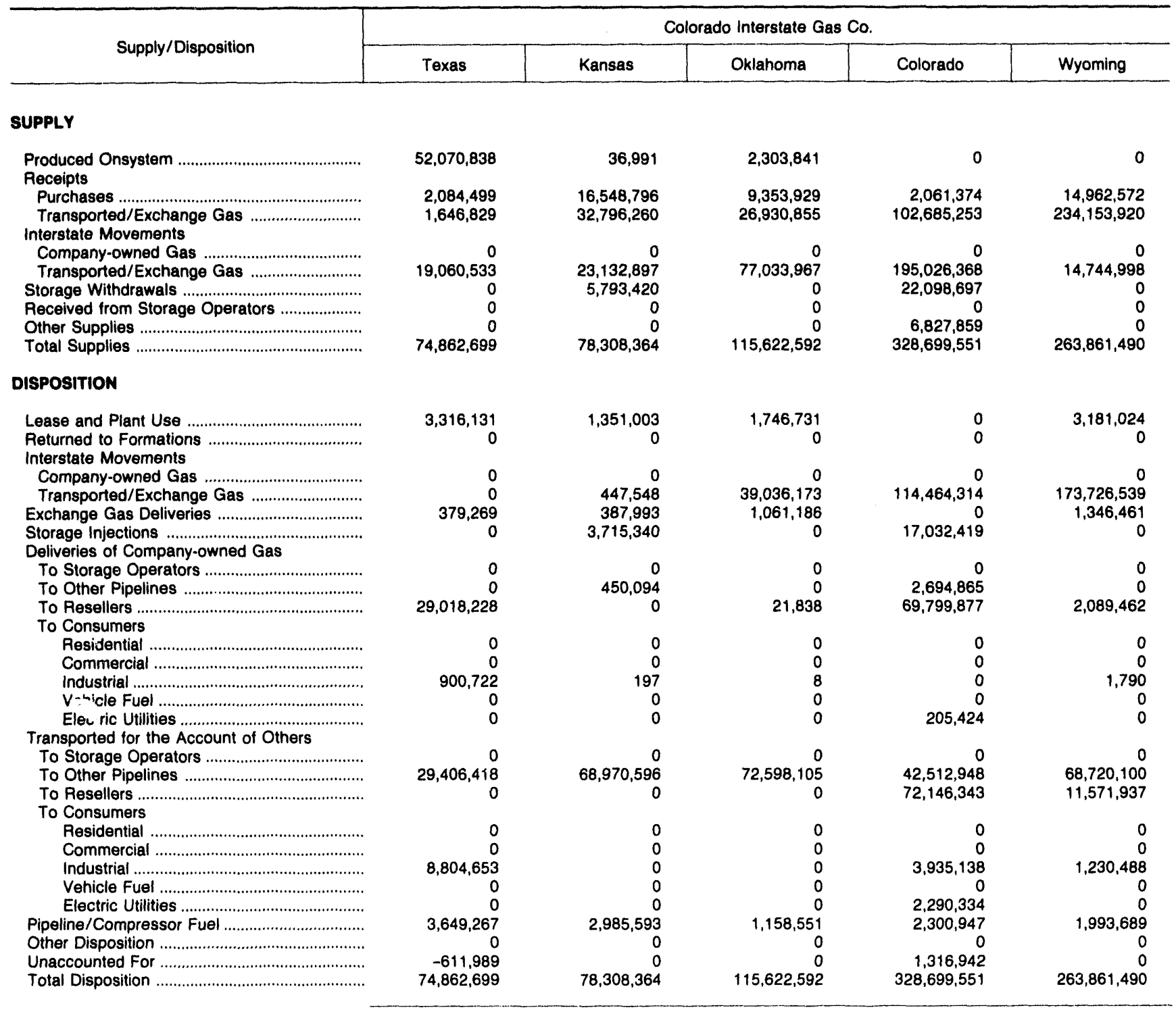


Table 7. Coastal Corp. Natural Gas Data, 1992 (Continued)

(Thousand Cubic Feet)

\begin{tabular}{|c|c|c|c|c|c|}
\hline \multirow{2}{*}{ Supply/Disposition } & \multicolumn{2}{|c|}{ Wyoming Interstate Co. } & \multicolumn{3}{|c|}{ Great Lakes Gas Transmission Ltd. } \\
\hline & Wyoming & Colorado & Minnesota & Wisconsin & Michigan \\
\hline \multicolumn{6}{|l|}{ SUPPLY } \\
\hline $\begin{array}{l}\text { Produced Onsystem } \\
\text { Receipts }\end{array}$ & 0 & 0 & 0 & 0 & 0 \\
\hline 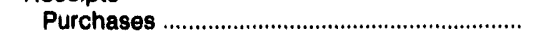 & 0 & 0 & 0 & 0 & 0 \\
\hline $\begin{array}{l}\text { Transported/Exchange Gas } \\
\text { Interstate Movements }\end{array}$ & $95,532,691$ & 0 & 562,506 & 0 & $127,998,243$ \\
\hline 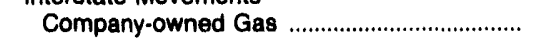 & 0 & 0 & 0 & 0 & 150,000 \\
\hline 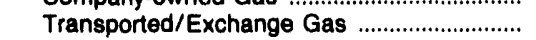 & 0 & $95,352,171$ & $685,435,029$ & $685,721,242$ & $707,495,308$ \\
\hline Storage Withdrawals & 0 & 0 & 0 & 0 & 0 \\
\hline Received from Storage Operators ...................... & 0 & 0 & 0 & 0 & 0 \\
\hline 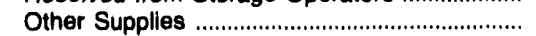 & 0 & 0 & 0 & 0 & 0 \\
\hline 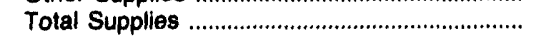 & $95,532,691$ & $95,352,171$ & $685,997,535$ & $685,721,242$ & $835,643,551$ \\
\hline \multicolumn{6}{|l|}{ DISPOSITION } \\
\hline Lease and Plant Use & 0 & 0 & 0 & 0 & 0 \\
\hline Returned to Formations & 0 & 0 & 0 & 0 & 0 \\
\hline \multicolumn{6}{|l|}{ Interstate Movements } \\
\hline 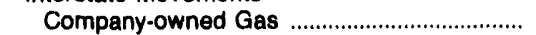 & 0 & 0 & 0 & 0 & 0 \\
\hline 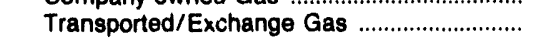 & $95,352,171$ & 0 & $679,453,133$ & $682,886,269$ & $486,143,643$ \\
\hline 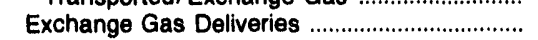 & 0 & 0 & 68,092 & 0 & $78,851,882$ \\
\hline Storage Injections & 0 & 0 & 0 & 0 & 0 \\
\hline \multicolumn{6}{|l|}{ Detiveries of Company-owned Gas } \\
\hline 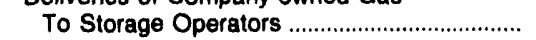 & 0 & 0 & 0 & 0 & 0 \\
\hline 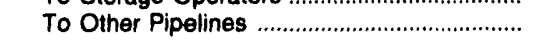 & 0 & 0 & 0 & 0 & $3,828,505$ \\
\hline 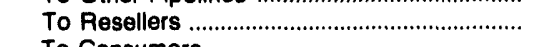 & 0 & 0 & 0 & 0 & 0 \\
\hline To Consumers & & & & 0 & \\
\hline 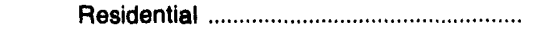 & 0 & 0 & 0 & 0 & 0 \\
\hline 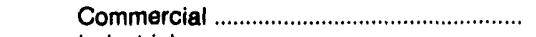 & 0 & 0 & 0 & 0 & 0 \\
\hline 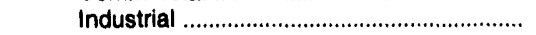 & 0 & 0 & 0 & 0 & 0 \\
\hline 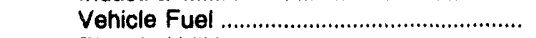 & 0 & 0 & 0 & 0 & 0 \\
\hline 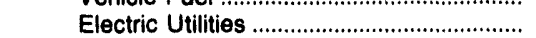 & 0 & 0 & 0 & 0 & 0 \\
\hline \multicolumn{6}{|l|}{ Transported for the Account of Others } \\
\hline 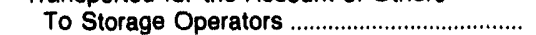 & 0 & 0 & 0 & 0 & 0 \\
\hline 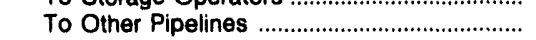 & 0 & $95,423,579$ & $51,860,654$ & 627,413 & $249,112,827$ \\
\hline $\begin{array}{l}\text { To Resellers ............................................................ } \\
\text { To Consumers }\end{array}$ & 0 & 0 & 0 & 0 & 0 \\
\hline 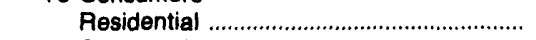 & 0 & 0 & 0 & 0 & 0 \\
\hline 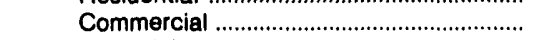 & 0 & 0 & 0 & 0 & 0 \\
\hline 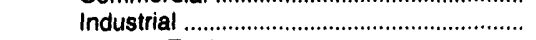 & 0 & 0 & 0 & 0 & 0 \\
\hline 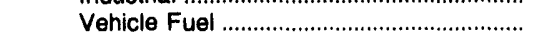 & 0 & 0 & 0 & 0 & 0 \\
\hline Electric Utilities & 0 & 0 & 0 & 0 & 0 \\
\hline 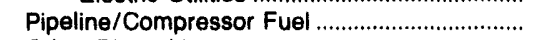 & 0 & 0 & $11,713,307$ & $2,197,768$ & $13,097,397$ \\
\hline Other Disposition & 180,520 & 0 & 90,567 & 11,580 & 256,569 \\
\hline 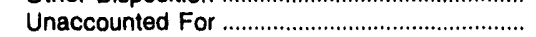 & 0 & $-71,408$ & $-57,188,218$ & $-1,788$ & $4,352,728$ \\
\hline 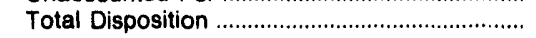 & $95,532,691$ & $95,352,171$ & $685,997,535$ & $685,721,242$ & $835,643,551$ \\
\hline
\end{tabular}


Table 7. Coastal Corp. Natural Gas Data, 1992 (Continued) (Thousand Cubic Feet)

\begin{tabular}{|c|c|c|c|c|}
\hline \multirow{2}{*}{ Supply/Disposition } & \multirow{2}{*}{$\begin{array}{c}\begin{array}{c}\text { Steuben Gas } \\
\text { Storage Co. }\end{array} \\
\text { Now York }\end{array}$} & \multicolumn{2}{|c|}{ High Island Offshore System } & $\begin{array}{l}\text { U-T Offshore } \\
\text { System }\end{array}$ \\
\hline & & Texas & \multicolumn{2}{|c|}{ Louisiana } \\
\hline \multicolumn{5}{|l|}{ SUPPLY } \\
\hline $\begin{array}{l}\text { Produced Onsystem } \\
\text { Receipts }\end{array}$ & 0 & 0 & 0 & 0 \\
\hline 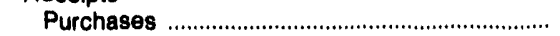 & 0 & 0 & 0 & 0 \\
\hline 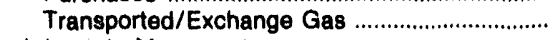 & $5,471,970$ & $379,278,780$ & $14,595,142$ & $191,386,973$ \\
\hline \multicolumn{5}{|l|}{ Interstate Movements } \\
\hline 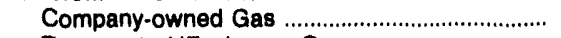 & 0 & 0 & 0 & 0 \\
\hline 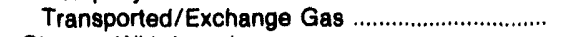 & 0 & 0 & $374,992,625$ & 0 \\
\hline 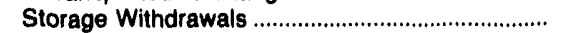 & $2,777,031$ & 0 & 0 & 0 \\
\hline Received from Storage Operators ............................ & 0 & 0 & 0 & 0 \\
\hline 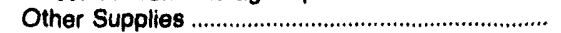 & 0 & 0 & 0 & 0 \\
\hline 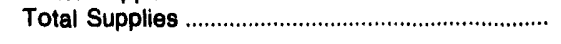 & $8,249,001$ & $379,278,780$ & $389,587,767$ & $191,386,973$ \\
\hline \multicolumn{5}{|l|}{ DISPOSITION } \\
\hline Lease and Plant Use & 0 & 0 & 0 & 0 \\
\hline Returned to Formations & 0 & 0 & 0 & 0 \\
\hline Interstate Movements & & & & \\
\hline 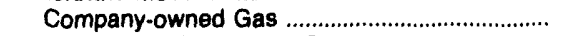 & 0 & 0 & 0 & 0 \\
\hline 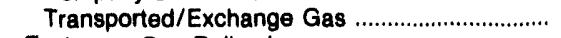 & 0 & $374,992,625$ & 0 & 0 \\
\hline 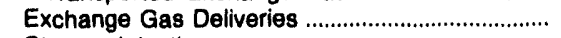 & $2,773,454$ & 0 & 0 & $191,452,181$ \\
\hline Storage Injections & $5,420,717$ & 0 & 0 & 0 \\
\hline \multicolumn{5}{|l|}{ Deliveries of Company-owned Gas } \\
\hline 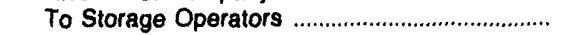 & 0 & 0 & 0 & 0 \\
\hline 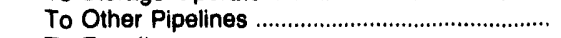 & 0 & 0 & 0 & 0 \\
\hline 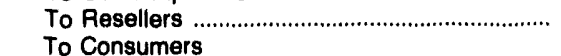 & 0 & 0 & 0 & 0 \\
\hline 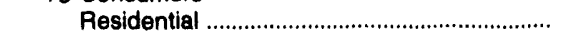 & 0 & 0 & 0 & 0 \\
\hline 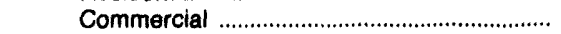 & 0 & 0 & 0 & 0 \\
\hline 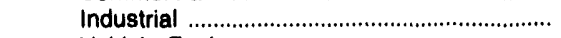 & 0 & 0 & 0 & 0 \\
\hline 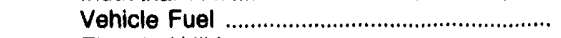 & 0 & 0 & 0 & 0 \\
\hline 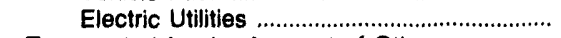 & 0 & 0 & 0 & 0 \\
\hline \multicolumn{5}{|l|}{ Transported for the Account of Others } \\
\hline To Storage Operators & 0 & 0 & 0 & 0 \\
\hline 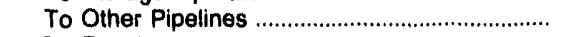 & 0 & 0 & $388,452,253$ & 0 \\
\hline 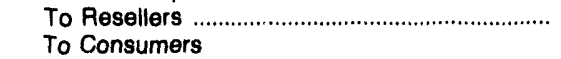 & 0 & 0 & 0 & 0 \\
\hline 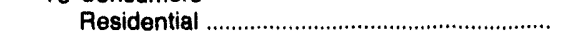 & 0 & 0 & 0 & 0 \\
\hline 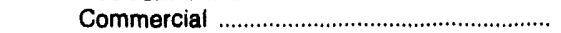 & 0 & 0 & 0 & 0 \\
\hline 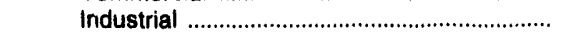 & 0 & 0 & 0 & 0 \\
\hline Vehicle Fuel & 0 & 0 & 0 & 0 \\
\hline 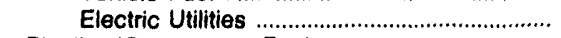 & 0 & 0 & 0 & 0 \\
\hline 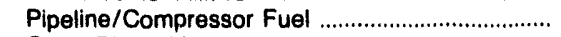 & 54,830 & $1,541,165$ & 408,295 & 0 \\
\hline Other Disposition & 0 & 0 & 0 & 0 \\
\hline 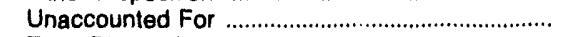 & 0 & $2,744,990$ & 727,219 & $-65,208$ \\
\hline 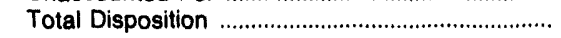 & $8,249,001$ & $379,278,780$ & $389,587,767$ & $191,386,973$ \\
\hline
\end{tabular}

Source: Energy Information Administration (EIA), Form EIA-176, "Annual Report of Natural and Supplemental Gas Supply and Disposition." 
Table 8. Coastal Corp. Interstate Flows of Natural Gas, 1992 (Thousand Cubic Feet)

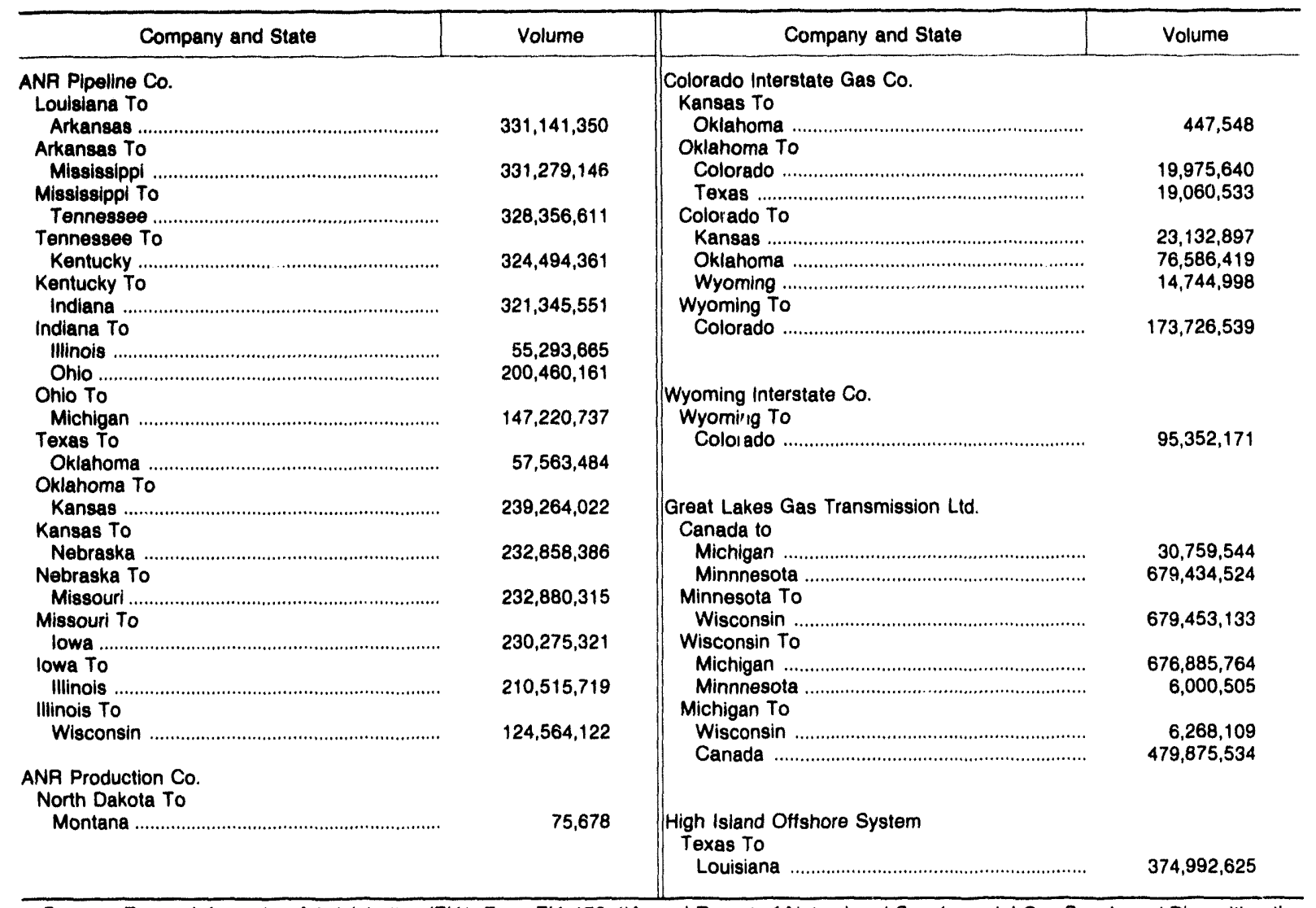

Source: Energy Information Administration (EIA), Form ElA-176, "Annual Report of Natural and Supplemental Gas Supply and Disposition." 


\section{Columbia Gas Systems, Inc.}

Columbia Gas Systems is an integrated energy company whose principle interest is the production, transportation, and sale of natural gas. Other energy interests include petroleum, coal gasification, and cogeneration. Columbia holds interests in 19 other corporations, all associated with gas service. Additionally, the company holds interests in Trailblazer, Overthrust, and Ozark pipelines.

Columbia Gas Systems and its subsidiary Columbia Gas Transmission (CGT) filed separate petitions in bankruptcy July 31, 1991. Both companies have operated as debtors in possession since that time. As debtors in possession, much of the decision making is subject to bankruptcy court oversight and jurisdiction. Both companies have had to request extensions for the submission of restructuring plans to the court. Complicating the bankruptcy issues is the FERC's issuance of its Order 636.

The Federal Energy Regulatory Commission issued Order 636 and required all pipeline companies to implement it no later than November 1993. The order requires pipeline companies to "unbundle" their services and to price the sales of natural gas separately from the cost of transportation and storage. The

Figure 8. Columbia Gas Systems, Inc., 1992

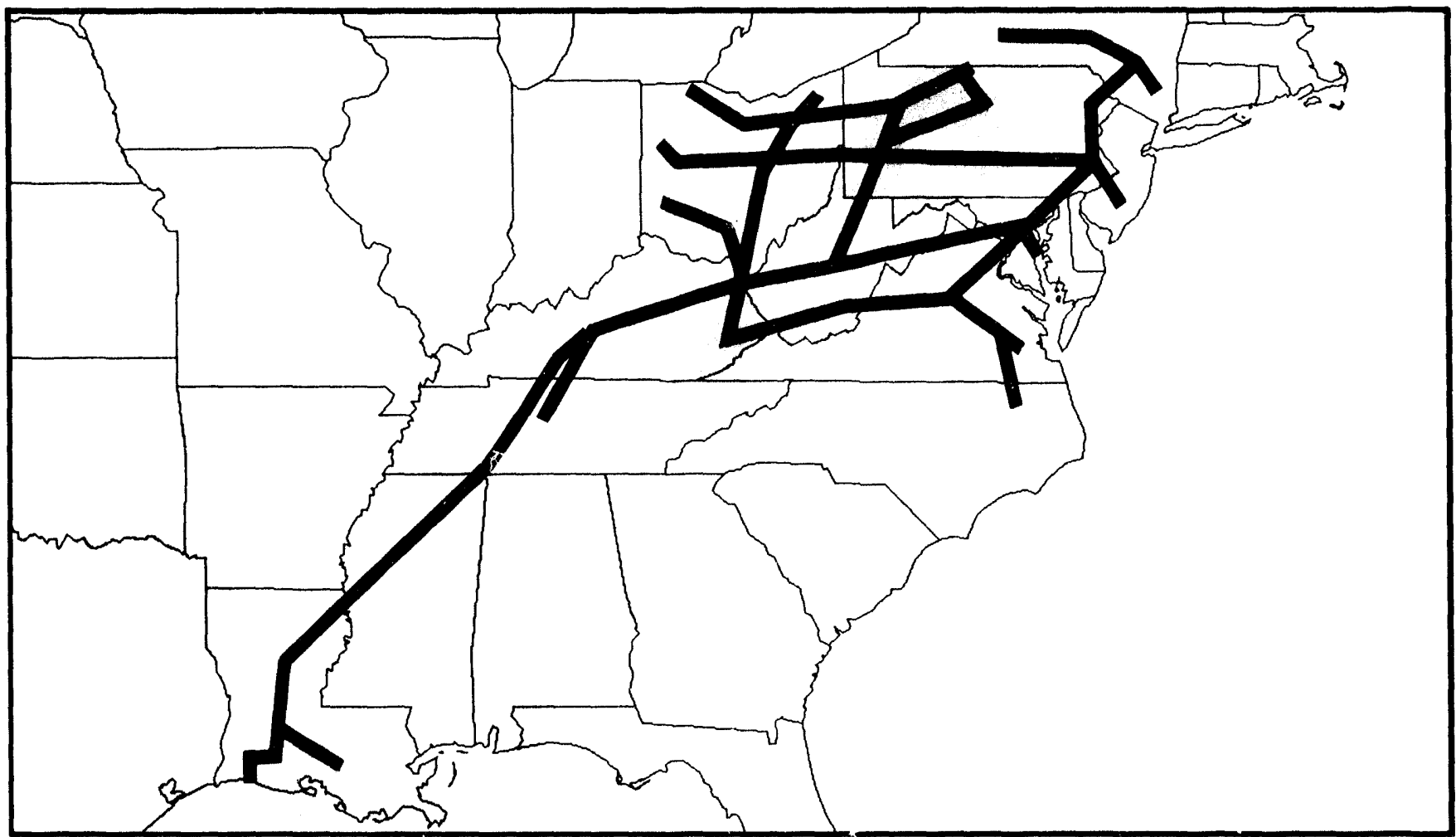

Source: Energy Information Administration (EIA), Form EIA-176, "Annual Report of Natural and Supplemental Gas Supply and Disposition."

Supply Areas 
Table 9. Columbla Gas Systems, Inc., Natural Gas Data, 1992 (Thousand Cubic Feet)

\begin{tabular}{|c|c|c|c|c|c|c|}
\hline \multirow{2}{*}{ Supply/Disposition } & \multicolumn{6}{|c|}{ Columbia Gas Transmission Corp. } \\
\hline & Tennessee & Kentucky & West Virginia & Virginia & Maryland & Delaware \\
\hline \multicolumn{7}{|l|}{ SUPPLY } \\
\hline $\begin{array}{l}\text { Produced Onsystem } \\
\text { Receipts }\end{array}$ & 0 & 0 & 0 & 0 & 0 & 0 \\
\hline 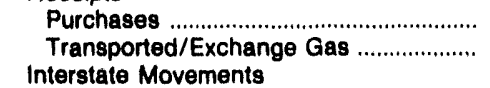 & $\begin{array}{l}0 \\
0\end{array}$ & $\begin{array}{r}83,080,316 \\
568,795,900\end{array}$ & $\begin{array}{r}1,723,977 \\
167,976,939\end{array}$ & $\begin{array}{r}3,919,029 \\
272,542\end{array}$ & $\begin{array}{r}3,732 \\
0\end{array}$ & $\begin{array}{l}0 \\
0\end{array}$ \\
\hline 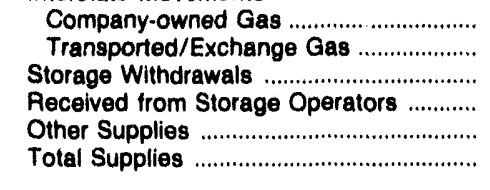 & $\begin{array}{r}0 \\
1,201,945 \\
0 \\
0 \\
0 \\
1,201,945\end{array}$ & $\begin{array}{r}0 \\
0 \\
0 \\
0 \\
0 \\
651,876,216\end{array}$ & $\begin{array}{r}0 \\
603,020,657 \\
81,143,412 \\
0 \\
0 \\
853,864,985\end{array}$ & $\begin{array}{r}0 \\
343,631,770 \\
0 \\
0 \\
0 \\
347,823,341\end{array}$ & $\begin{array}{r}0 \\
202,927,721 \\
0 \\
0 \\
0 \\
202,931,453\end{array}$ & $\begin{array}{r}0 \\
8,478,676 \\
0 \\
0 \\
0 \\
8,478,676\end{array}$ \\
\hline \multicolumn{7}{|l|}{ DISPOSITION } \\
\hline 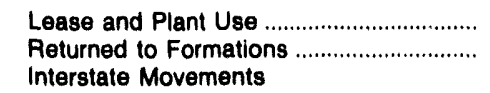 & $\begin{array}{l}0 \\
0\end{array}$ & $\begin{array}{l}0 \\
0\end{array}$ & $\begin{array}{r}3,817,461 \\
0\end{array}$ & $\begin{array}{l}0 \\
0\end{array}$ & $\begin{array}{l}0 \\
0\end{array}$ & $\begin{array}{l}0 \\
0\end{array}$ \\
\hline 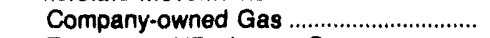 & 0 & $480,219,634$ & 0 & 0 & 0 & 0 \\
\hline Transported/Exchange Gas ........................ & 0 & $130,494,050$ & $690,486,162$ & $209,564,587$ & $47,826,500$ & 0 \\
\hline Exchange Gas Deliveries ............................. & 0 & 0 & 0 & 0 & 0 & 0 \\
\hline \multicolumn{6}{|l|}{ Deliveries of Company-owned Gas } & 0 \\
\hline 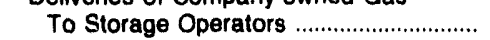 & 0 & 0 & 0 & 0 & 0 & 0 \\
\hline 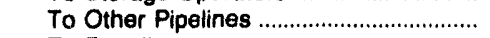 & 0 & 0 & 0 & 0 & 0 & 0 \\
\hline $\begin{array}{l}\text { To Resellers ............................................... } \\
\text { To Consumers }\end{array}$ & $1,201,945$ & $6,117,293$ & $7,894,315$ & $29,114,477$ & $33,759,782$ & $1,065,406$ \\
\hline 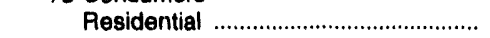 & 0 & 0 & 0 & 0 & 0 & 0 \\
\hline 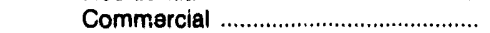 & 0 & 0 & 0 & 0 & 0 & 0 \\
\hline 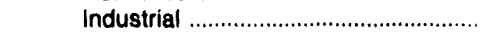 & 0 & 0 & 0 & 0 & 0 & 0 \\
\hline 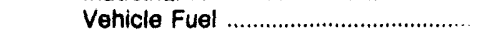 & 0 & 0 & 0 & 0 & 0 & 0 \\
\hline 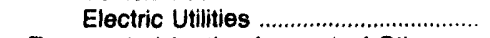 & 0 & 0 & 0 & 0 & 0 & 0 \\
\hline \multicolumn{7}{|l|}{ Transported for the Account of Others } \\
\hline To Storage Operators ............................... & 0 & 0 & 0 & 0 & 0 & 0 \\
\hline 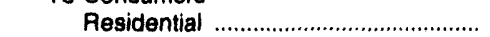 & 0 & 0 & 0 & 0 & 0 & 0 \\
\hline 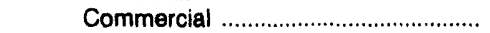 & 0 & 0 & 0 & 0 & 0 & 0 \\
\hline 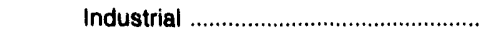 & 0 & 0 & 0 & $17,285,931$ & 0 & 0 \\
\hline 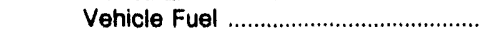 & 0 & 0 & 0 & 0 & 0 & 0 \\
\hline 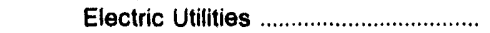 & 0 & 0 & 0 & 0 & 0 & 0 \\
\hline Pipeline/Compressor Fuel .............................. & 0 & 0 & $4,247,277$ & 0 & 0 & 0 \\
\hline 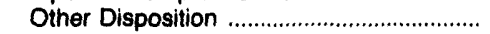 & 0 & 0 & 0 & 0 & 0 & 0 \\
\hline Unaccounted for & 0 & $-1,693,180$ & $9,938,514$ & $-1,623,869$ & 0 & 0 \\
\hline 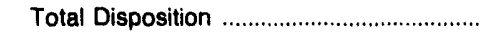 & $1,201,945$ & $651,876,216$ & $853,864,985$ & $347,823,341$ & $202,931,453$ & $8,478,676$ \\
\hline
\end{tabular}

cost associated with converting to the New Order 636 operating environment may be recovered by the companies as transition costs. The recovery of these costs in the case of Columbia Gas and CGT will be determined in accordance with the bankruptcy courts review. The courts have informed Columbia that it will not be able to recover some producer costs as gas realignment costs recoverable under Order 636. It is believed that this will make the company's recovery from bankruptcy even more difficult. Transition costs may be recovered over a 3 to 5 year period but must be justified as gas supply realignment (GSR) costs.

TriStar Ventures, another Columbia Gas subsidiary, and already a participant in two cogeneration projects in New Jersey and New York, has signed on to two more cogeneration projects, one in New York and another in Washington, D.C.
CGT is further involved in the cogeneration area providing firm transportation to the Eagle Point cogeneration facility in New Jersey. A new compressor station is under construction (the Rutledge Compressor Station in Harford County, Maryland) to provide full service to the Eagle Point project. Rutledge will also furnish 59 million cubic feet per day to New England Power in Massachusetts. The Rutledge station is scheduled to begin operation in 1994. Another cogeneration project is slated for the Olean, Cattaraugus County, area of New York. CGT will provide 15.7 million cubic feet per day of firm transportation service to that location. Service is scheduled to begin in December 1993. CGT increased service to the cogeneration project in Binghamton, New York, adding 11.7 million cubic feet per day. 
Table 9. Columbla Gas Systems, Inc., Natural Gas Data, 1992 (Continued) (Thousand Cubic Feet)

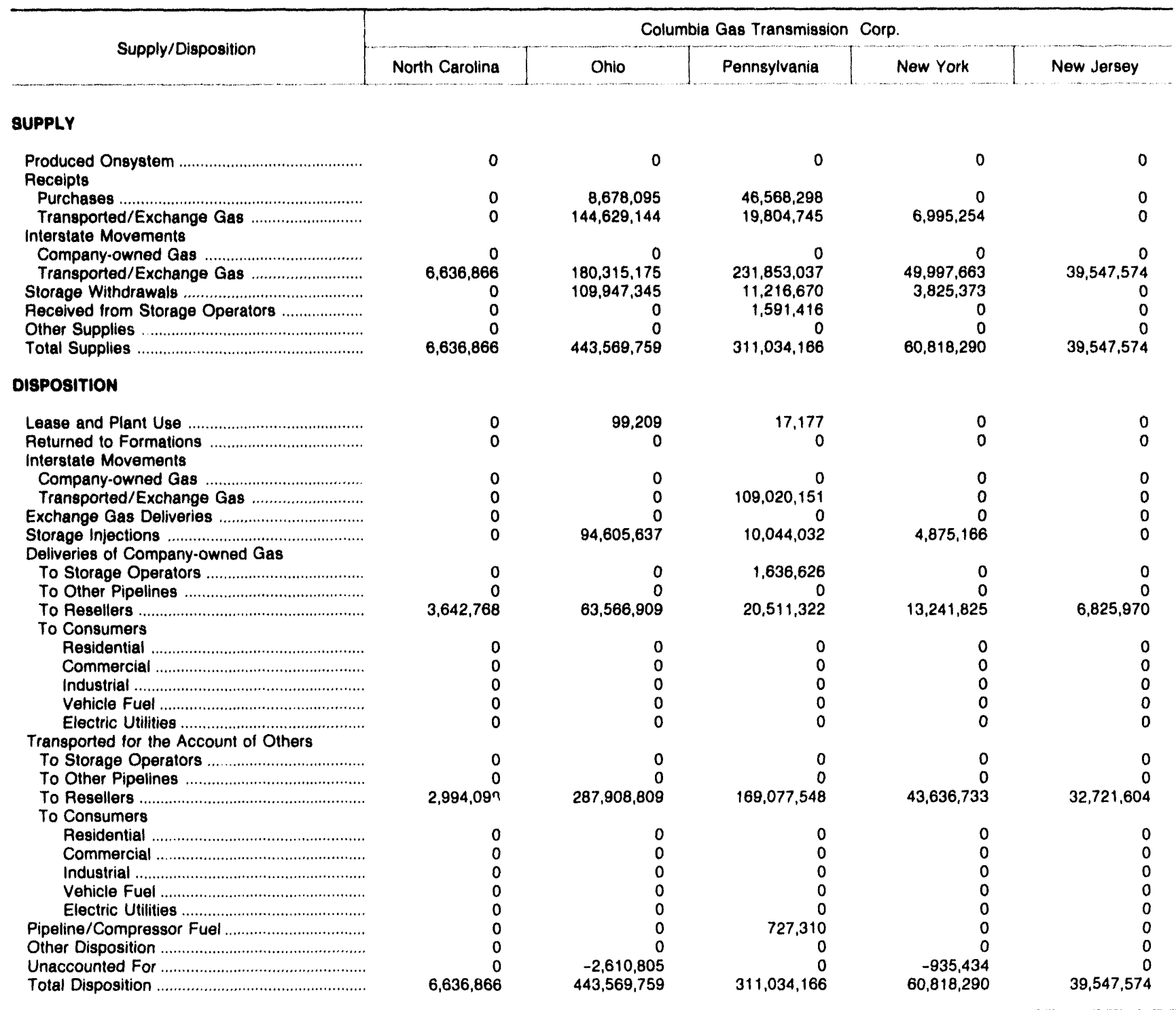

Columbia Liquefied Natural Gas, owner of the "mothballed" LNG facility at Cove Point, Maryland, filed a new business plan with the FERC. It calls for the terminal to provide both terminalling services as well as a new peaking service to its customers. The cost to reactivate the facility for these services is $\$ 40$ million for the peaking service and $\$ 55$ million if both services are offered. The Columbia LNG terminal has a potential sendout capacity of 1 billion cubic feet of regasified LNG per day; no other LNG terminal in the United States has such capability. 
Table 9. Columbla Gas Systems, Inc., Natural Gas Data, 1992 (Continued) (Thousand Cubic Feet)

\begin{tabular}{|c|c|c|c|c|c|c|}
\hline \multirow{2}{*}{ Supply/Disposition } & \multicolumn{6}{|c|}{ Columbia Gulf Transmission Corp. } \\
\hline & Louisiana & Mississippi & Tennessee & Kentucky & Wyoming & Texas \\
\hline \multicolumn{7}{|l|}{ SUPPLY } \\
\hline 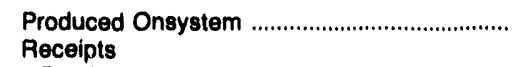 & 0 & 0 & 0 & 0 & 0 & 0 \\
\hline 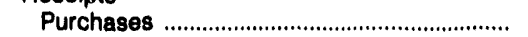 & 0 & 0 & 0 & 0 & 0 & 0 \\
\hline $\begin{array}{l}\text { Transported/Exchange Gas ............................... } \\
\text { Interstate Movements }\end{array}$ & $833,883,324$ & 0 & 0 & $3,664,746$ & $33,795,561$ & 684,269 \\
\hline 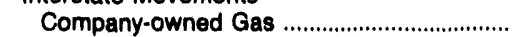 & 0 & 0 & 0 & 0 & 0 & 0 \\
\hline 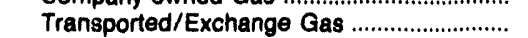 & 0 & $583,538,974$ & $575,139,189$ & $562,238,729$ & 0 & 0 \\
\hline Storage Withdrawals & 0 & 0 & 0 & $\begin{array}{r}00,200,1<0 \\
0\end{array}$ & 0 & 0 \\
\hline 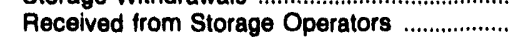 & 0 & 0 & 0 & 0 & 0 & 0 \\
\hline Other Supplies & 0 & 0 & 0 & 0 & 0 & 0 \\
\hline Total Supplies & $833,883,324$ & $583,538,974$ & $575,139,189$ & $565,903,475$ & $33,795,561$ & 684,269 \\
\hline \multicolumn{7}{|l|}{ DISPOSITION } \\
\hline 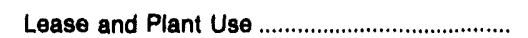 & $3,965,731$ & 0 & 0 & 0 & 0 & 0 \\
\hline $\begin{array}{l}\text { Returned to Formations ........................................ } \\
\text { Interstate Movements }\end{array}$ & 0 & 0 & 0 & 0 & 0 & 0 \\
\hline 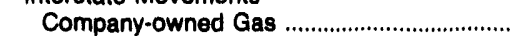 & 0 & 0 & 0 & 0 & 0 & 0 \\
\hline 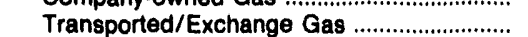 & $583,538,974$ & $575,139,189$ & $562,238,729$ & 0 & 0 & 0 \\
\hline 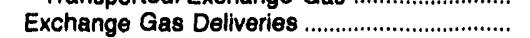 & $237,086,910$ & $1,470,510$ & $8,520,247$ & $563,263,474$ & $33,513,915$ & 684,269 \\
\hline $\begin{array}{l}\text { Storage Injections ........................................... } \\
\text { Deliveries of Company-owned Gas }\end{array}$ & 0 & 0 & 0 & 0 & 0 & 0 \\
\hline To Storage Operators & 0 & 0 & 0 & 0 & 0 & 0 \\
\hline 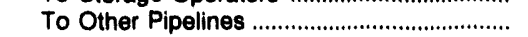 & 0 & 0 & 0 & 0 & 0 & 0 \\
\hline 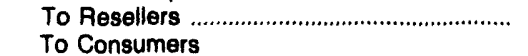 & 0 & 0 & 0 & 0 & 0 & 0 \\
\hline 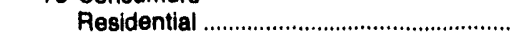 & 0 & 0 & 0 & 0 & 0 & 0 \\
\hline 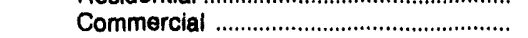 & 0 & 0 & 0 & 0 & 0 & 0 \\
\hline 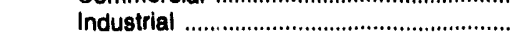 & 22,376 & 0 & 0 & 0 & 0 & 0 \\
\hline Vehicle Fuel & 0 & 0 & 0 & 0 & 0 & 0 \\
\hline 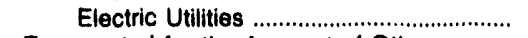 & 0 & 0 & 0 & 0 & 0 & 0 \\
\hline \multicolumn{7}{|l|}{ Transported for the Account of Others } \\
\hline 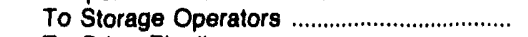 & 0 & 0 & 0 & 0 & 0 & 0 \\
\hline 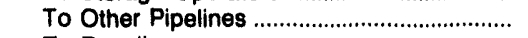 & 0 & 0 & 0 & 0 & 0 & 0 \\
\hline 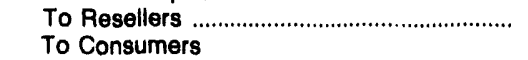 & 0 & 0 & 0 & 0 & 0 & 0 \\
\hline 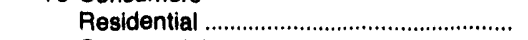 & 0 & 0 & 0 & 0 & 0 & 0 \\
\hline 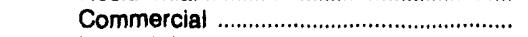 & 0 & 0 & 0 & 0 & 0 & 0 \\
\hline 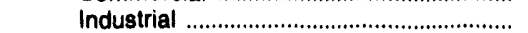 & 0 & 0 & 0 & 0 & 0 & 0 \\
\hline 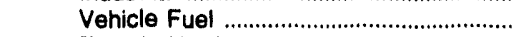 & 0 & 0 & 0 & 0 & 0 & 0 \\
\hline 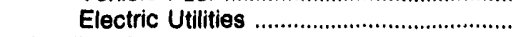 & 0 & 0 & 0 & 0 & 0 & 0 \\
\hline 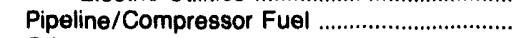 & $7,371,817$ & $5,510,791$ & $3,483,544$ & $2,099,570$ & 53,078 & 30,613 \\
\hline 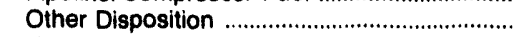 & 0 & 0 & 0 & 0 & 0 & 0 \\
\hline 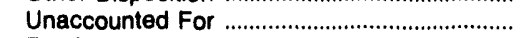 & $1,897,516$ & $1,418,484$ & 896,669 & 540,431 & 228,568 & $-30,613$ \\
\hline 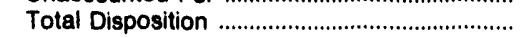 & $833,883,324$ & $583,538,974$ & $575,139,189$ & $565,903,475$ & $33,795,561$ & 684,269 \\
\hline
\end{tabular}


Table 9. Columbla Gas Systems, Inc., Natural Gas Data, 1992 (Continued) (Thousand Cubic Feet)

\begin{tabular}{|c|c|c|c|c|c|c|}
\hline \multirow{2}{*}{ Supply/Disposition } & \multicolumn{2}{|c|}{ Ozark Gas Transmission System } & \multicolumn{4}{|c|}{ Delhi Gas Pipeline Corp. } \\
\hline & Oklahoma & Arkansas & Texas & Oklahoma & Kansas & Loulsiana \\
\hline \multicolumn{7}{|l|}{ SUPPLY } \\
\hline $\begin{array}{l}\text { Produced Onsystem } \\
\text { Recelpts }\end{array}$ & 0 & 0 & 20,305 & 0 & 0 & 0 \\
\hline 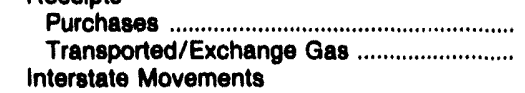 & $\begin{array}{r}0 \\
8,175,401\end{array}$ & $\begin{array}{r}0 \\
20,680,385\end{array}$ & $\begin{array}{r}35,080,545 \\
189,897,644\end{array}$ & $\begin{array}{r}20,410,229 \\
111,737,260\end{array}$ & $\begin{array}{l}1,165,130 \\
1,066,196\end{array}$ & $\begin{array}{r}39,663 \\
3,976,850\end{array}$ \\
\hline 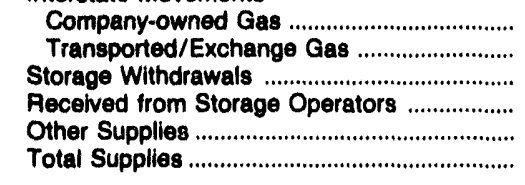 & $\begin{array}{r}0 \\
0 \\
0 \\
0 \\
0 \\
8,175,401\end{array}$ & $\begin{array}{r}0 \\
7,942,189 \\
0 \\
0 \\
0 \\
28,602,574\end{array}$ & $\begin{array}{r}0 \\
0 \\
1,436,427 \\
0 \\
0 \\
226,434,921\end{array}$ & $\begin{array}{r}0 \\
0 \\
0 \\
0 \\
0 \\
132,147,489\end{array}$ & $\begin{array}{r}0 \\
0 \\
0 \\
0 \\
0 \\
2,231,326\end{array}$ & $\begin{array}{r}0 \\
0 \\
0 \\
0 \\
0 \\
4,016,513\end{array}$ \\
\hline \multicolumn{7}{|l|}{ DIBPOSITION } \\
\hline 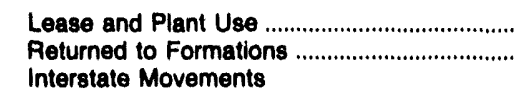 & $\begin{array}{l}0 \\
0\end{array}$ & $\begin{array}{l}0 \\
0\end{array}$ & $\begin{array}{r}122,543 \\
0\end{array}$ & $\begin{array}{r}118,295 \\
0\end{array}$ & $\begin{array}{l}0 \\
0\end{array}$ & $\begin{array}{r}8,112 \\
0\end{array}$ \\
\hline 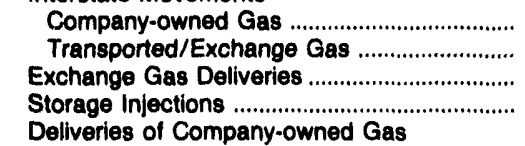 & $\begin{array}{r}0 \\
7,942,189 \\
0 \\
0\end{array}$ & $\begin{array}{l}0 \\
0 \\
0 \\
0\end{array}$ & $\begin{array}{r}0 \\
0 \\
42,747,490 \\
1,326,287\end{array}$ & $\begin{array}{r}0 \\
0 \\
24,690,874 \\
0\end{array}$ & $\begin{array}{r}0 \\
0 \\
152,606 \\
0\end{array}$ & $\begin{array}{l}0 \\
0 \\
0 \\
0\end{array}$ \\
\hline 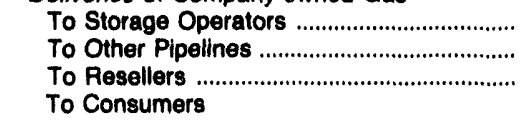 & $\begin{array}{l}0 \\
0 \\
0\end{array}$ & $\begin{array}{l}0 \\
0 \\
0\end{array}$ & $\begin{array}{r}0 \\
8,898,342 \\
5,551,909\end{array}$ & $\begin{array}{r}0 \\
163,770 \\
19,830,106\end{array}$ & $\begin{array}{r}0 \\
0 \\
551,980\end{array}$ & $\begin{array}{r}0 \\
238,803 \\
0\end{array}$ \\
\hline 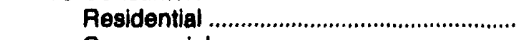 & 0 & 0 & 0 & 0 & 0 & 0 \\
\hline 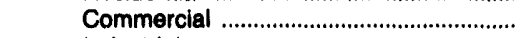 & 0 & 0 & 758,856 & 0 & 0 & 0 \\
\hline 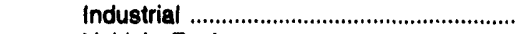 & 0 & 0 & $1,906,397$ & 0 & 0 & 0 \\
\hline 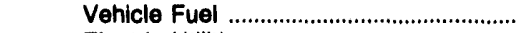 & 0 & 0 & 0 & 0 & 0 & 0 \\
\hline $\begin{array}{l}\text { Electric Utilities } \\
\text { Transported for the Account of Others }\end{array}$ & 0 & 0 & $9,393,868$ & 0 & 496,036 & 0 \\
\hline 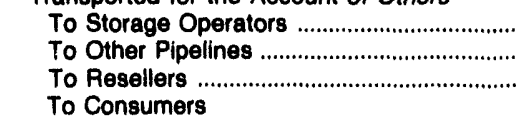 & $\begin{array}{r}0 \\
30,374 \\
0\end{array}$ & $\begin{array}{r}0 \\
27,986,247 \\
0\end{array}$ & $\begin{array}{r}0 \\
150,223,624 \\
438,813\end{array}$ & $\begin{array}{r}0 \\
85,176,077 \\
0\end{array}$ & $\begin{array}{r}0 \\
920,604 \\
0\end{array}$ & $\begin{array}{r}0 \\
3,694,954 \\
0\end{array}$ \\
\hline 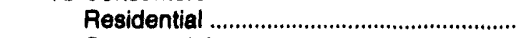 & 0 & 0 & 0 & 0 & 0 & 0 \\
\hline 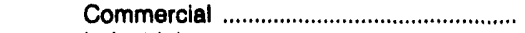 & 0 & 0 & 0 & 0 & 0 & 0 \\
\hline 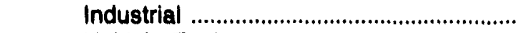 & 0 & 0 & 113,804 & 0 & 0 & 0 \\
\hline 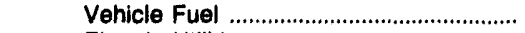 & 0 & 0 & 0 & 0 & 0 & 0 \\
\hline 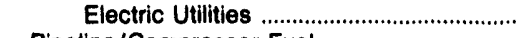 & 0 & 0 & 0 & 121,291 & 0 & 0 \\
\hline 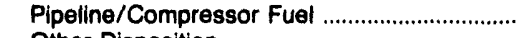 & 211,631 & 638,547 & $6,064,590$ & $3,030,857$ & 75,609 & 118,737 \\
\hline 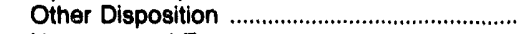 & 0 & 0 & 0 & 0 & 1,693 & \\
\hline $\begin{array}{l}\text { Unaccounted For } \\
\text { Total Disposition }\end{array}$ & $\begin{array}{r}-8,793 \\
8,175,401\end{array}$ & $\begin{array}{r}-22,220 \\
28,602,574\end{array}$ & $\begin{array}{r}-1,111,602 \\
226,434,921\end{array}$ & $\begin{array}{r}-983,781 \\
132,147,489\end{array}$ & $\begin{array}{r}32,788 \\
2,231,326\end{array}$ & $\begin{array}{r}-44,093 \\
4,016,513\end{array}$ \\
\hline
\end{tabular}


Table 9. Columbla Gas Systems, Inc., Natural Gas Data, 1992 (Continued) (Thousand Cubic Feet)

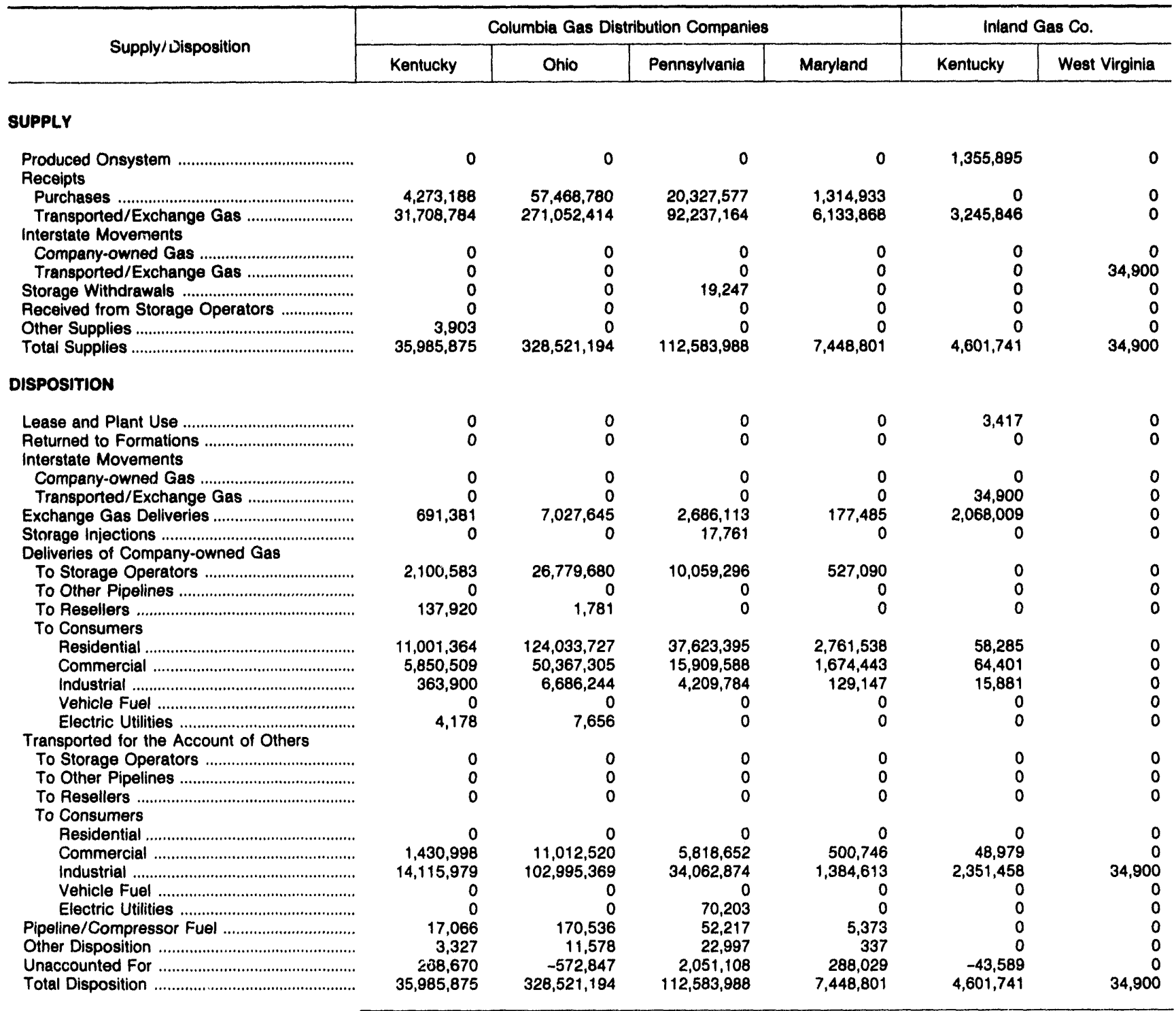


Table 9. Columbla Gas Systems, Inc., Natural Gas Data, 1992 (Continued) (Thousand Cubic Feet)

\begin{tabular}{|c|c|c|c|c|}
\hline \multirow{2}{*}{ Supply/Disposition } & \multirow{2}{*}{$\begin{array}{c}\begin{array}{c}\text { Commonwealth Gas } \\
\text { Service, Inc. }\end{array} \\
\text { Virginia }\end{array}$} & \multicolumn{2}{|c|}{ Columbia LNG Corp. } & \multirow{2}{*}{ Nueces Co. } \\
\hline & & Maryland & Virginia & \\
\hline \multicolumn{5}{|l|}{ SUPPLY } \\
\hline $\begin{array}{l}\text { Produced Onsystem } \\
\text { Receipts }\end{array}$ & 0 & 0 & 0 & 0 \\
\hline Purchases & $11,663,318$ & 0 & 0 & 47,134 \\
\hline 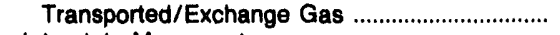 & $45,211,151$ & 0 & $7,316,879$ & $1,291,262$ \\
\hline \multicolumn{5}{|l|}{ Interstate Movements } \\
\hline 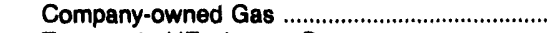 & 0 & 0 & 0 & 0 \\
\hline 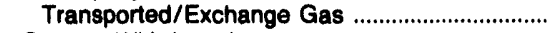 & 0 & $7,316,879$ & 0 & 0 \\
\hline Storage Withdrawals & 0 & 0 & 0 & 0 \\
\hline Received from Storage Operators ............................. & 0 & 0 & 0 & 0 \\
\hline Other Supplies & 159,005 & 0 & 0 & 0 \\
\hline 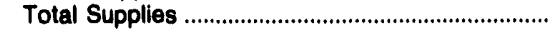 & $57,033,474$ & $7,316,879$ & $7,316,879$ & $1,338,396$ \\
\hline \multicolumn{5}{|l|}{ DISPOSITION } \\
\hline 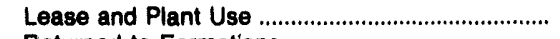 & 0 & 0 & 0 & 0 \\
\hline 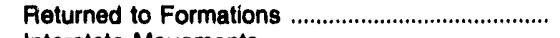 & 0 & 0 & 0 & 0 \\
\hline Interstate Movements & & & & \\
\hline 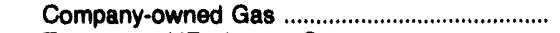 & 0 & 0 & 0 & 0 \\
\hline 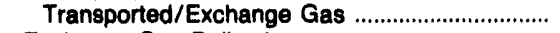 & 0 & 0 & $7,316,879$ & 0 \\
\hline 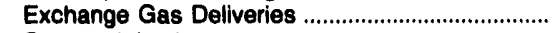 & 545,800 & 0 & 0 & 0 \\
\hline 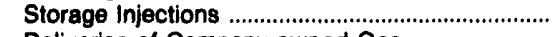 & 0 & 0 & 0 & 0 \\
\hline \multicolumn{5}{|l|}{ Deliveries of Company-owned Gas } \\
\hline To Storage Operators & $1,696,369$ & 0 & 0 & 0 \\
\hline 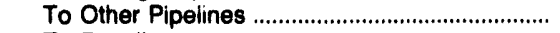 & 0 & 0 & 0 & 0 \\
\hline 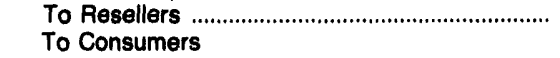 & 0 & 0 & 0 & 46,585 \\
\hline 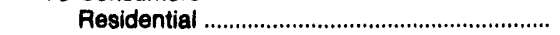 & $10,775,723$ & 0 & 0 & 0 \\
\hline 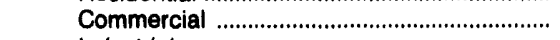 & $8,016,913$ & 0 & 0 & 0 \\
\hline 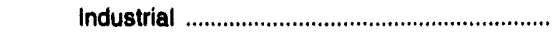 & $3,411,449$ & 0 & 0 & 0 \\
\hline Vehicle Fuel ................................................. & 0 & 0 & 0 & 0 \\
\hline 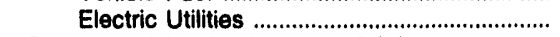 & 400 & 0 & 0 & 0 \\
\hline \multicolumn{5}{|l|}{ Transported for the Account of Others } \\
\hline 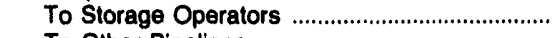 & 0 & 0 & 0 & 0 \\
\hline 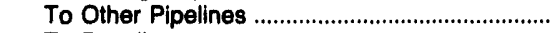 & 0 & 0 & 0 & $1,301,257$ \\
\hline 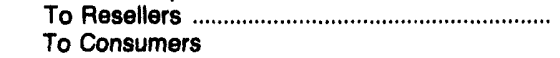 & 0 & $7,316,879$ & 0 & 0 \\
\hline 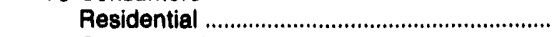 & 0 & 0 & 0 & 0 \\
\hline 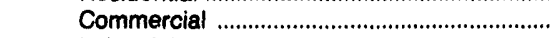 & $1,550,876$ & 0 & 0 & 0 \\
\hline 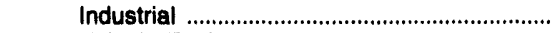 & $21,091,182$ & 0 & 0 & 0 \\
\hline 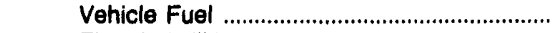 & 0 & 0 & 0 & 0 \\
\hline 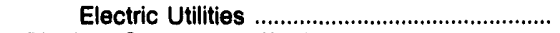 & $9,681,138$ & 0 & 0 & 0 \\
\hline 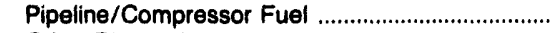 & 14,689 & 0 & 0 & 1,573 \\
\hline Other Disposition & 4,316 & 0 & 0 & 1,122 \\
\hline Unaccounted For & 244,619 & 0 & 0 & $-12,141$ \\
\hline 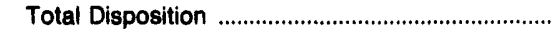 & $57,033,474$ & $7,316,879$ & $7,316,879$ & $1,338,396$ \\
\hline
\end{tabular}


Table 10. Columbia Gas Systems, Inc., Interstate Flows of Natural Gas, 1992 (Thousand Cubic Feet)

\begin{tabular}{|c|c|c|c|}
\hline Company and State & Volume & Company and State & Volume \\
\hline 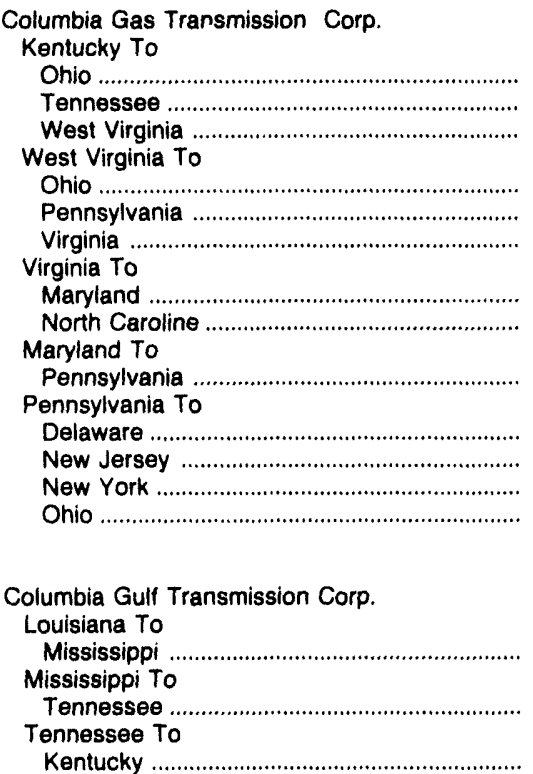 & $\begin{array}{r}6,491,082 \\
1,201,945 \\
603,020,657 \\
\\
162,827,855 \\
184,026,537 \\
343,631,770 \\
202,927,721 \\
6,636,866 \\
47,826,500 \\
8,478,676 \\
39,547,574 \\
49,997,663 \\
10,996,238\end{array}$ & 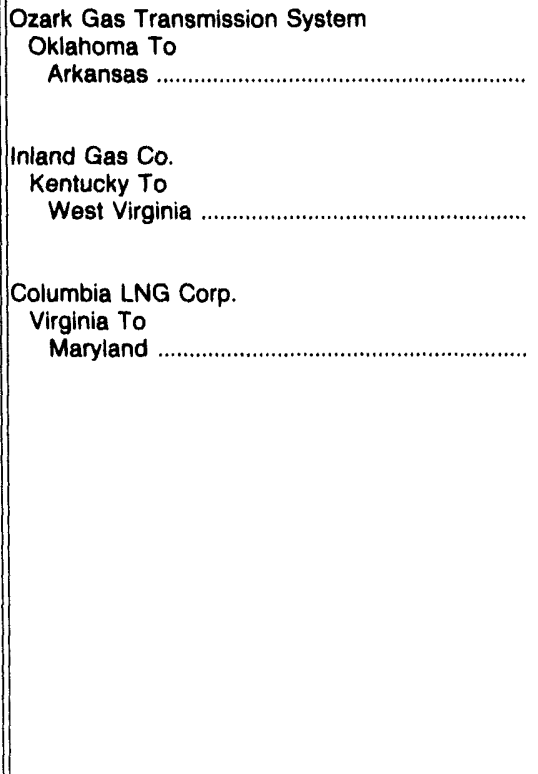 & 34,900 \\
\hline
\end{tabular}




\section{Consolidated Edison Co. of New York, Inc.}

Consolidated Edison Company of New York (Con Edison) was incorporated in 1884. Since that time Con Edison, a publicly held utility, has provided electric, gas, and steam supply system services throughout most of New York City. Operating revenues in 1992 indicate that, while Con Edison is principally engaged in the generation, transmission, and distribution of electricity (82.4 percent) and operation of a steam supply system ( 5.3 percent), the distribution of natural gas accounts for 12.3 percent of the company's revenues. Con Edison supplies natural gas to New York City in Manhattan, the Bronx, and parts of Queens, and to Westchester County, it supplies steam in part of Manhattan. The company also provides electric service in all of New
York City (except part of Queens) and most of Westchester County, both of which comprise a 660-square-mile area with a population of more than 8 million. Electric service is provided to most governmental customers within Con Edison's service area from the New York Power Authority through Con Edison's facilities.

The Con Edison natural gas system consists of approximately 4,200 miles of distribution pipeline, 438 miles of plastic mains, and 2,495 miles of service line. During 1992, Con Edison received more than 255 billion cubic feet of gas from seven interstate pipeline companies, three suppliers of Canadian gas, six non-pipeline sup-

Figure 9. Consolidated Edison Co. of New York, Inc., 1992

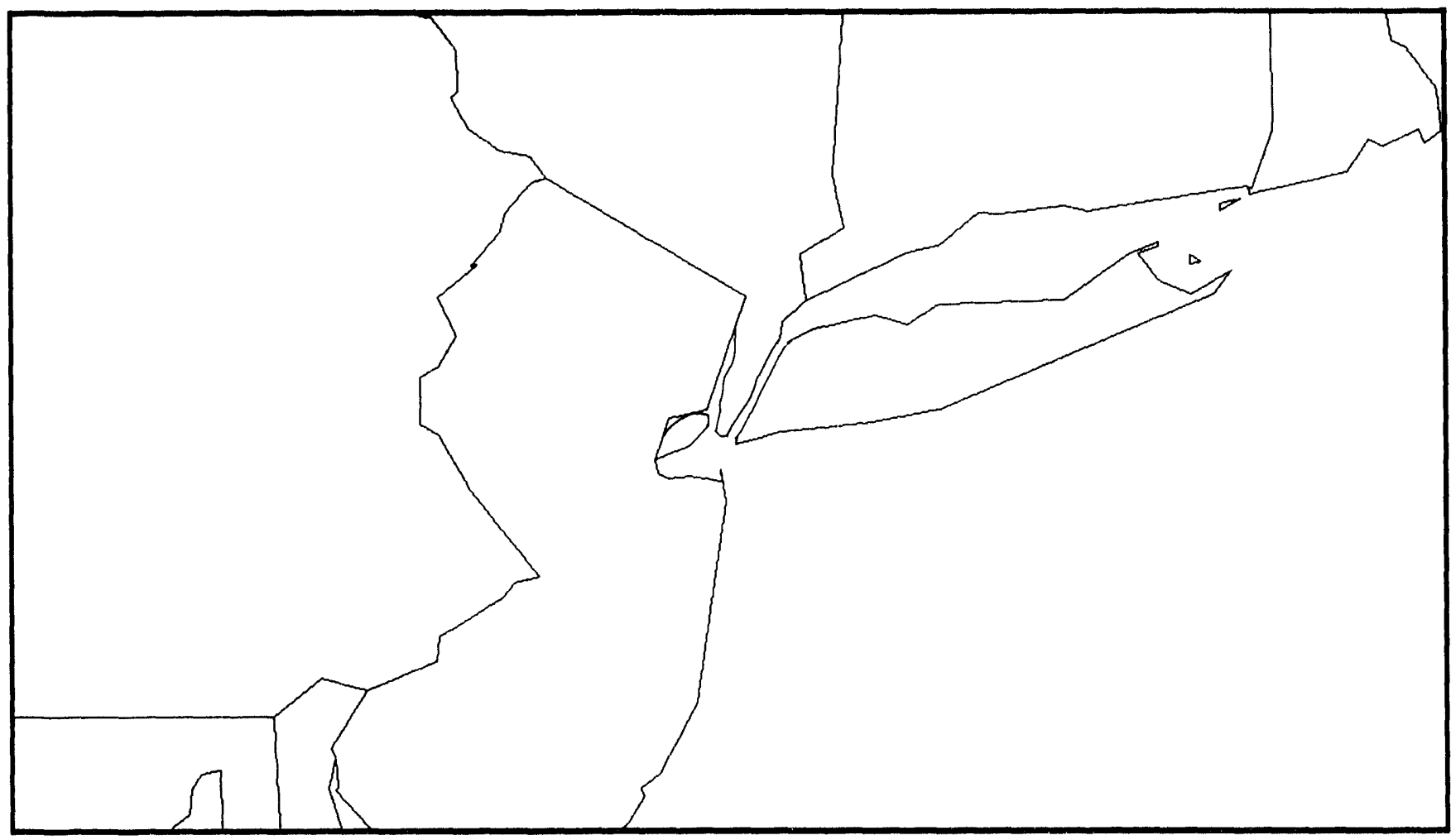

Source: Energy Information Administration (EIA), Form ElA-176, "Annual Report of Natural and Supplemental Gas Supply and Disposition."

Service Area 
pliers, and others. Con Edison delivered more than 236 billion cubic feet of gas for consumption by more than one million customers in New York City in Manhattan, the Bronx, Queens, and in Westchester County. Deliveries to commercial consumers totaled 55.5 billion cubic feet or 23 percent of total consumer deliveries; residential consumers received 51.7 billion cubic feet $(22$ percent); and the industrial sector deliveries were 11 billion cubic feet ( 5 percent). Con Edison itself burned more than 118 billion cubic feet of natural gas to generate 37 percent of the electricity used in its service area. The remainder of the electricity generated was produced by nuclear power ( 23 percent), oil ( 22 percent), coal (11 percent), hydropower ( 6 percent), and refuse ( 1 percent).

Con Edison, along with two neighboring utilities, owns a controlling interest in Honeoye Storage Corporation, of Canandaigua, New York. Formed in 1973, Honeoye is principally engaged in the storage and transmission of natural gas. Con Edison also has a natural gas liquefaction facility and a liquefied gas storage tank at its Astoria property in Queens, New York.

New business opportunities are available in the natural gas industry due to restructuring. Con Edison has applied for approval to form a new unregulated subsidiary for gas marketing as a result of the changes in the industry. The New York Public Service Commission (PSC) early in 1993 agreed to allow Con Edison to spend up to $\$ 4$ million to set up a gas-marketing subsidiary, but the commission refused to allow the marketing company to do business in the Con Edison service territory. Con Edison has asked the PSC to reconsider its ban.
There are areas in New York City where Con Edison (as the electric utility) and Brooklyn Union (as the gas utility) service territories overlap. In 1992, Con Edison and Brooklyn Union began marketing gas air-conditioning together. These two companies also worked together to provide Governors Island in New York with natural gas and thereby convert all of the U.S. Coast Guard buildings (116) to gas from oil. Brooklyn Union installed an underwater pipeline and Con Edison built the distribution system.

A partnership of Con Edison and several other companies is requesting regulatory approvals to build the Liberty Pipeline to transport natural gas across the lower New York Bay from New Jersey to Kennedy International Airport. The Liberty is a 47-mile pipeline built, owned, and operated by this partnership. This project is scheduled for completion in the mid-1990's.

In 1991, Con Edison completed the second phase of a multiyear project aimed at reinforcing the gas main system in northern Westchester County. The 1992 segment of the project involved installing 2 miles of 12-inch-diameter plastic high-pressure gas main.

Con Edison is actively encouraging owners of vehicle fleets to switch to compressed natural gas as a fuel. The company itself has 130 vehicles fueled by natural gas and plans to increase this number in coming years. In a demonstration project with New York City and a taxicab fleet owner, Con Edison has converted six taxis to be fueled by compressed natural gas. In 1992, the company opened two additional fueling stations for natural gas vehicles for its own fleet, those fleets operated by New York City, and some privately owned fleets. 
Table 11. Consolidated Edison Co. of New York, Inc., Natural Gas Data, 1992

(Thousand Cubic Feet)

\begin{tabular}{c|c}
\hline \multirow{2}{*}{ Supply/Disposition } & Consolidated Edison Co. of New York, Inc. \\
\cline { 2 - 2 } & Now York \\
\hline
\end{tabular}

\section{SUPPLY}

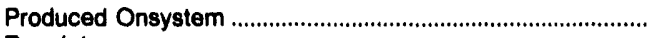

Receipts

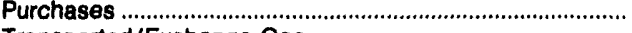

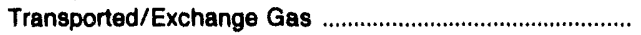

interstate Movements

Company-owned Gas

Transported/Exchange Gas

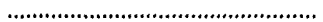

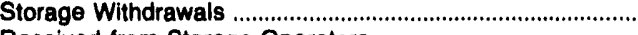

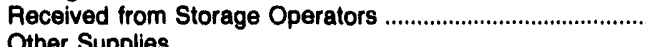

Supplies

Total Supplies

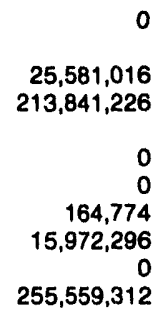

Disposition

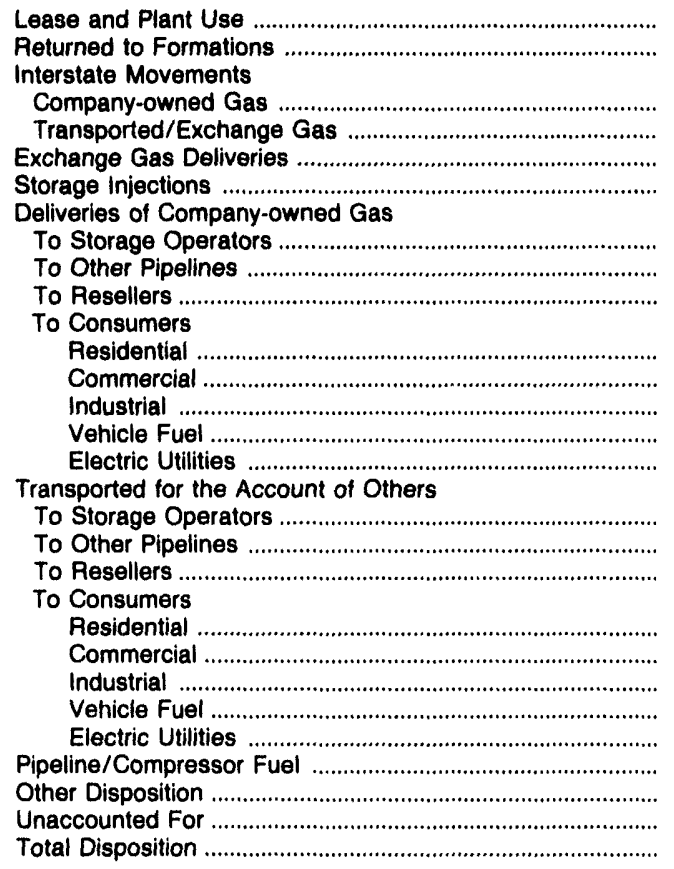

Source: Energy Information Administration (EIA), Form EIA-176, "Annual Report of Natural and Supplemental Gas Supply and Disposition.' 


\section{Consolidated Natural Gas Co.}

Consolidated Natural Gas (CNG), founded in 1942, consists of 15 subsidiaries that make up the Consolidated system. CNG explores for, produces, and purchases natural gas throughout the United States. The company operates one of the Nation's largest natural gas systems as well as one of the country's largest network of underground gas storage fields. It sells and transports gas to markets in the Midwest, Mid-Atlantic, and Northeast, serving both utilities and consumers, including other operations such as gas byproducts and petroleum production.

Consolidated owns six local utilities--The East Ohio Gas Company, The Peoples Natural Gas Company,
Virginia Natural Gas Inc., Hope Gas Inc., West Ohio Gas Company, and The River Gas Company. Collectively these utilities deliver natural gas to homes, businesses and factories, serving more than 1.7 million customers in Ohio, Pennsylvania, West Virginia, and Virginia. During the 1980's, Consolidated added more than 20 major utilities on the East Coast extending from Virginia to Ohio, Pennsylvania, and upstate New York, and added two large Canadian import projects to its service network as well.

CNG completed one of its largest single projects, the Lebanon-to-Leidy pipeline, in 1993. This stretch of pipeline will transport natural gas from a Midwest sup-

Figure 10. Consolidated Natural Gas Co., 1992

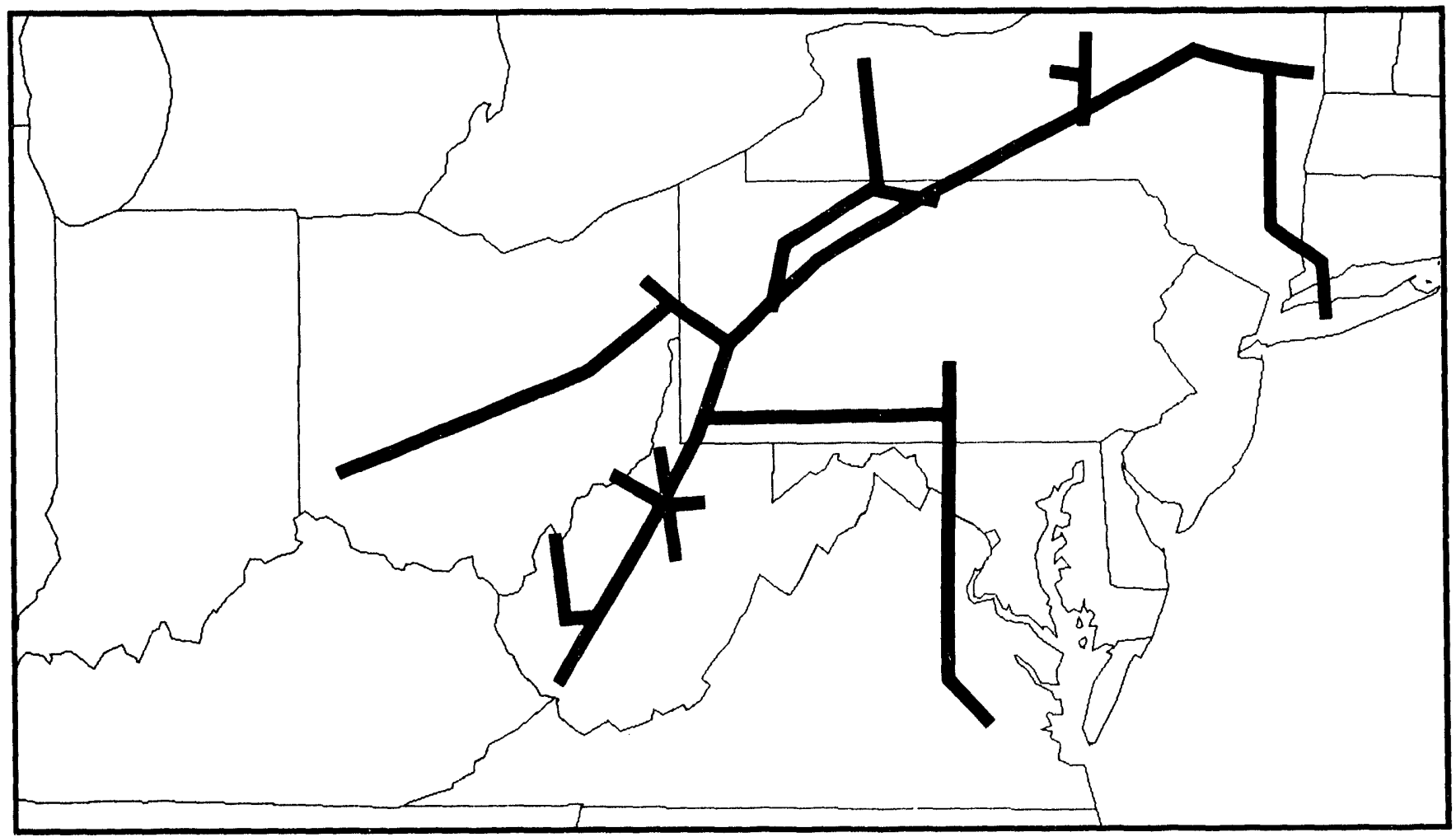

Source: Energy Information Administration (EIA), Form ElA-176, "Annual Report of Natural and Supplemental Gas Supply and Disposition."

Service Areas

CNG Transmission Corp. 
Table 12. Consolidated Natural Gas Co. Natural Gas Data, 1992 (Thousand Cubic Feet)

\begin{tabular}{|c|c|c|c|c|c|}
\hline \multirow{2}{*}{ Supply/Disposition } & \multicolumn{5}{|c|}{ CNG Transmission Corp. } \\
\hline & Louisiana & Pennsylvania & Maryland & Virginia & West Virginia \\
\hline \multicolumn{6}{|l|}{ SUPPLY } \\
\hline $\begin{array}{l}\text { Produced Onsystem } \\
\text { Receipts }\end{array}$ & 0 & $2,858,857$ & 0 & 0 & $10,856,498$ \\
\hline $\begin{array}{l}\text { Purchases ... Exchange Gas ......................... } \\
\text { Transported/Exterstate Movemi nts }\end{array}$ & $\begin{array}{l}18,505,785 \\
16,172,456\end{array}$ & $\begin{array}{r}37,171,850 \\
505,178,890\end{array}$ & $\begin{array}{l}0 \\
0\end{array}$ & $\begin{array}{r}371,683 \\
1,019,453\end{array}$ & $\begin{array}{r}13,216,505 \\
174,256,829\end{array}$ \\
\hline 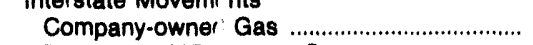 & 0 & 0 & 0 & 0 & 0 \\
\hline 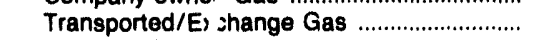 & 0 & $146,190,968$ & $40,733,605$ & $23,314,897$ & 371,683 \\
\hline Storage Withdrawals & 0 & $279,989,219$ & 0 & 0 & $42,588,795$ \\
\hline 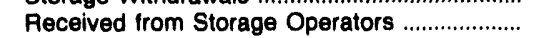 & 0 & 0 & 0 & 0 & 0 \\
\hline Other Supplies & 0 & 0 & 0 & 0 & 0 \\
\hline 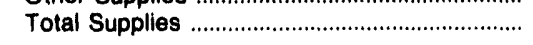 & $34,678,241$ & $971,389,784$ & $40,733,605$ & $24,706,033$ & $241,290,310$ \\
\hline \multicolumn{6}{|l|}{ DISPOSITION } \\
\hline Lease and Plant Use & 0 & 0 & 0 & 0 & $7,942,532$ \\
\hline $\begin{array}{l}\text { Returned to Formations } \\
\text { Interstate Movements }\end{array}$ & 0 & 0 & 0 & 0 & 0 \\
\hline 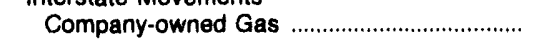 & 0 & 0 & 0 & 0 & 0 \\
\hline 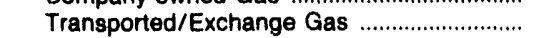 & 0 & $240,693,297$ & $23,314,897$ & 371,683 & $136,665,106$ \\
\hline 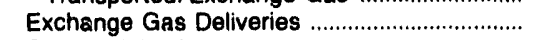 & 151,280 & $1,708,071$ & 0 & 0 & $2,095,249$ \\
\hline $\begin{array}{l}\text { Storage Injections } \\
\text { Deliveries of Company-owned Gas }\end{array}$ & 0 & $285,346,329$ & 0 & 0 & $37,784,144$ \\
\hline 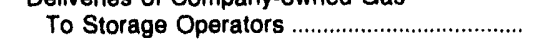 & 0 & 0 & 0 & 0 & 0 \\
\hline 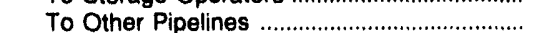 & 0 & 0 & 0 & 0 & 0 \\
\hline 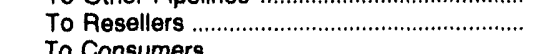 & 0 & $14,628,232$ & $1,539,154$ & $1,941,172$ & $11,803,681$ \\
\hline $\begin{array}{l}\text { To Consumers } \\
\text { Residential }\end{array}$ & 0 & 0 & 0 & 0 & 0 \\
\hline 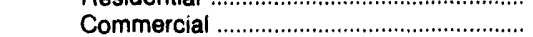 & 0 & 0 & 0 & 0 & 0 \\
\hline Industrial & 0 & 0 & 0 & 0 & 0 \\
\hline 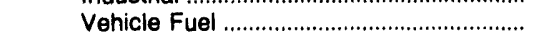 & 0 & 0 & 0 & 0 & 0 \\
\hline 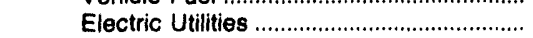 & 0 & 0 & 0 & 0 & 0 \\
\hline \multicolumn{6}{|l|}{ Transported for the Account of Others } \\
\hline 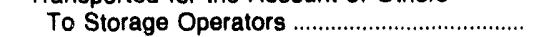 & 0 & 0 & 0 & 0 & 0 \\
\hline 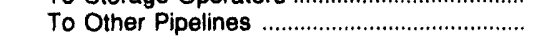 & $33,824,334$ & $404,917,083$ & 0 & 0 & $13,191,759$ \\
\hline 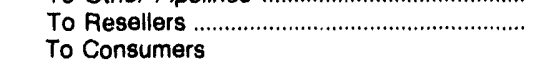 & 0 & $28,097,121$ & $15,863,354$ & $22,362,183$ & $15,422,932$ \\
\hline 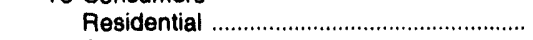 & 0 & 0 & 0 & 0 & 0 \\
\hline 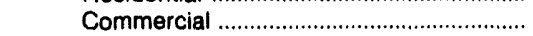 & 0 & 0 & 0 & 0 & 0 \\
\hline 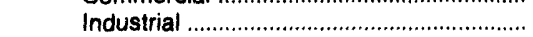 & 0 & 0 & 0 & 0 & 29,722 \\
\hline Vehicle Fuel & 0 & 0 & 0 & 0 & 0 \\
\hline 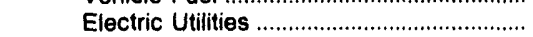 & 0 & 0 & 0 & 0 & 0 \\
\hline 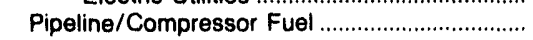 & $3,414,858$ & $7,690,804$ & 3,296 & 30,995 & $12,100,494$ \\
\hline Other Disposition & 0 & 362,783 & 12,904 & 0 & $4,254,691$ \\
\hline Unaccounted For & $-2,712,231$ & $-12,053,936$ & 0 & 0 & 0 \\
\hline Total Disposition & $34,678,241$ & $971,389,784$ & $40,733,605$ & $24,706,033$ & $241,290,310$ \\
\hline
\end{tabular}

ply hub at Lebanon, Ohio, just north of Cincinnati, to the Leidy underground storage field in north-central Pennsylvania. Lebanon- Leidy will carry an additional 370 million cubic feet of natural gas to Consolidated's main west-to-east pipeline.

In August 1992, Consolidated put into service the final segment of the 135-mile natural gas pipeline in Virginia that links directly to the interstate pipeline network. This project, the largest natural gas project in Virginia in 30 years, runs from suburban Washington, D.C., to the Norfolk, Virginia, area. This service added 8,500 new customers to the CNG customer base and eight Virginia counties where natural gas has historically been unavailable.

In 1992, CNG also completed construction work on the second phase of the new North Summit underground storage field raising the total deliverability to
13 billion cubic feet. Eventually this field near Pittsburgh will have a capacity of 21.5 billion cubic feet. It will primarily serve east coast markets. CNG operates 27 underground storage facilities with a capacity of almost 900 billion cubic feet.

Consolidated, is engaged in a number of innovative projects that will expand the use of natural gas. In 1992, Consolidated provided approximately 1.7 billion cubic feet of natural gas to 11 customers with cofiring capability. Cofiring is a method pioneered to cut the pollutants by burning a small amount of natural gas in a coal-fired boiler. Reburn is a more advanced version of cofiring being tested at an electric utility in Niles, Ohio.

Natural gas is the fuel of choice for many cogenerators, who produce electricity, and at the same time, capture the heat that is ordinarily lost in conventional power 
Table 12. Consolidated Natural Gas Co. Natural Gas Data, 1992 (Continued) (Thousand Cubic Feet)

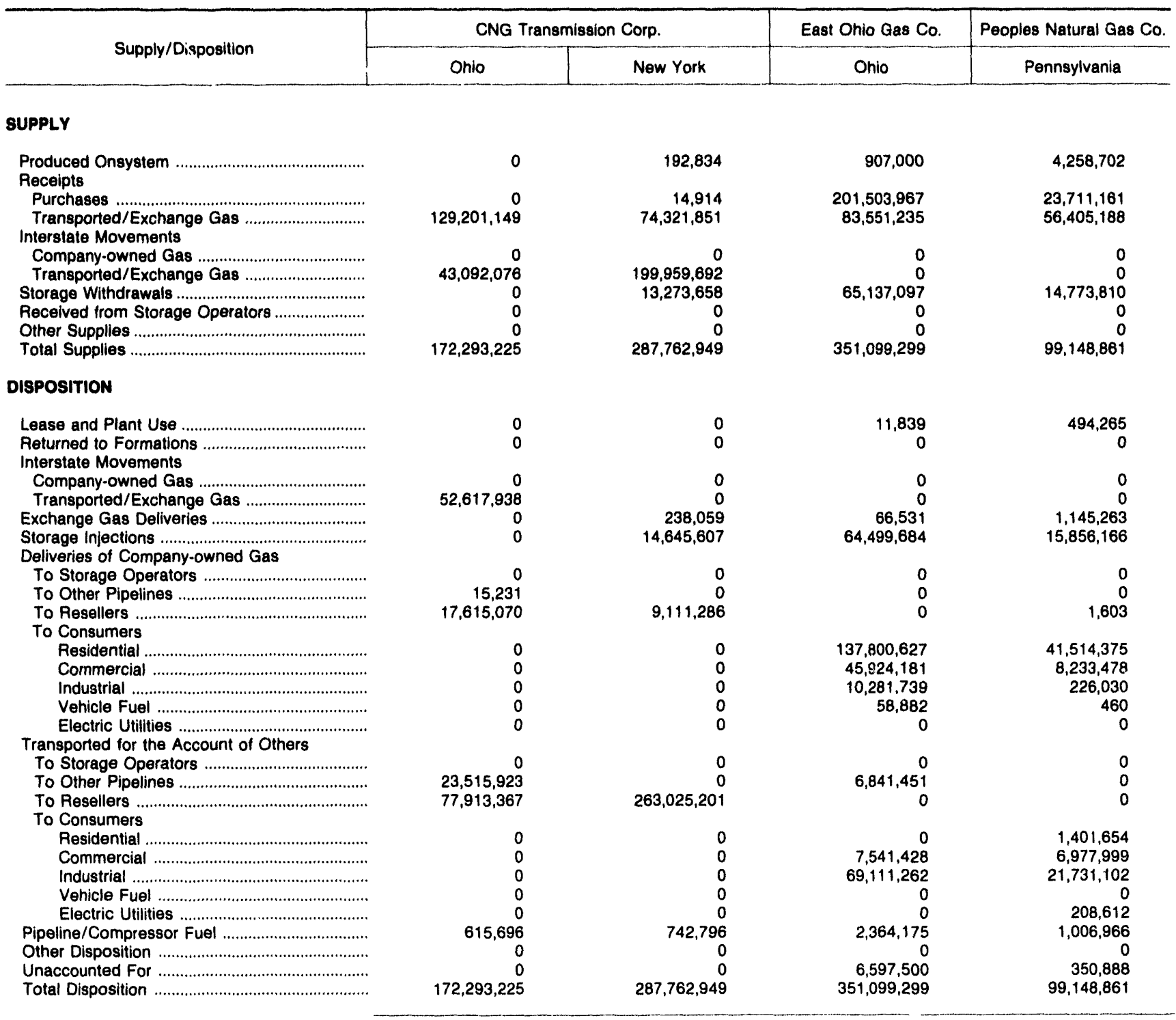

generators. The recaptured heat is then used to produce steam for industrial use or hot water for space heating. In 1992, Consolidated broke ground for a natural gas field cogeneration plant in Lakewood, New Jersey, expected to be completed in 1994. This plant will provide electricity to Jersey Central Power and Light Company, and steam to businesses in the nearby municipal industrial park. Consolidated owns interests in five other cogeneration projects and supplies and transports more than 60 billion cubic feet of natural gas a year to 21 cogeneration facilities in the Eastern and Midwestern United States.

Consolidated is currently working with the Department of Energy on two projects. One project converts methane emitted by landfills into liquefied natural gas used as fuel by the same garbage trucks that use the landfills. Another project extracts pure sulfur from "sour" natural gas. Consolidated also has a joint venture with U.S. Air, Duquesne Light Company, and Allegheny County, Pennsylvania, to demonstrate fuel cells technology at the Pittsburgh International Airport.

Consolidated is also entering the natural gas vehicle market. One of its utilities, Hope Gas, opened a refueling station in Vienna, West Virginia, the first in CNG's market area. Other areas of interest include injecting natural gas into blast furnaces, the gas cooling market, and fume incineration for industrial customers. The gas heat pump, a new technology being tested in the market by CNG, should be available in 1994 . 
Table 12. vonsolidated Natural Gas Co. Natural Gas Data, 1992 (Continued) (Thousand Cubic Feet)

\begin{tabular}{|c|c|c|c|c|}
\hline \multirow{2}{*}{ Supply/Disposition } & Virginia Natural Gas, Inc. & Hope Gas, Inc. & West Ohio Gas Co. & River Gas Co. \\
\hline & Virginia & West Virginia & \multicolumn{2}{|c|}{ Onio } \\
\hline \multicolumn{5}{|l|}{ 8UPPLY } \\
\hline $\begin{array}{l}\text { Produced Onsystem } \\
\text { Receipts }\end{array}$ & 0 & 975,211 & 0 & 2,911 \\
\hline 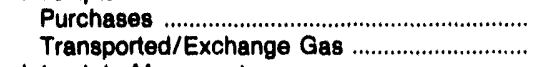 & $\begin{array}{l}24,340,228 \\
15,618,101\end{array}$ & $\begin{array}{l}14,361,636 \\
15,991,767\end{array}$ & $\begin{array}{l}9,712,212 \\
4,683,506\end{array}$ & $\begin{array}{l}2,452,645 \\
3,885,768\end{array}$ \\
\hline \multicolumn{5}{|l|}{ Interstate Movements } \\
\hline 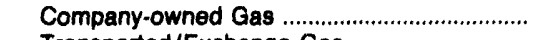 & 0 & 0 & 0 & 0 \\
\hline 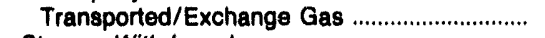 & 0 & 0 & 0 & 0 \\
\hline 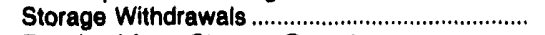 & 0 & 0 & 0 & 0 \\
\hline Received from Storage Operators ......................... & 0 & $1,396,934$ & $1,750,112$ & 809,908 \\
\hline 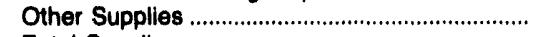 & 65,408 & 0 & 0 & 0 \\
\hline Total Supplies & $40,023,737$ & $32,725,548$ & $16,145,830$ & $7,151,232$ \\
\hline \multicolumn{5}{|l|}{ DISPOSITION } \\
\hline Lease and Plant Use & 0 & 0 & 0 & 19 \\
\hline 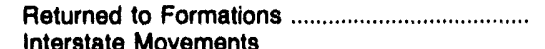 & 0 & 0 & 0 & 0 \\
\hline 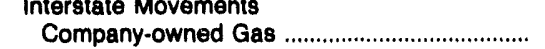 & 0 & 0 & 0 & \\
\hline 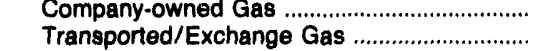 & 0 & 0 & 0 & $\begin{array}{l}0 \\
0\end{array}$ \\
\hline & 0 & 0 & 0 & 0 \\
\hline Storage injections & 0 & 0 & 0 & 0 \\
\hline \multicolumn{5}{|l|}{ Deliveries of Company-owned Gas } \\
\hline 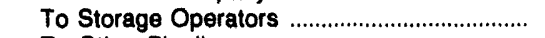 & 0 & $1,265,533$ & 0 & 711,578 \\
\hline 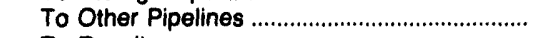 & 0 & 0 & 0 & 0 \\
\hline $\begin{array}{l}\text { To Resellers } \\
\text { To Consumers }\end{array}$ & 0 & 363,708 & 0 & 0 \\
\hline 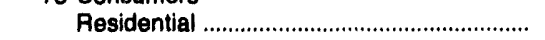 & $11,266,136$ & $10,501,557$ & $5,611,817$ & $1,634,670$ \\
\hline 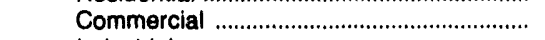 & $10,398,010$ & $3,393,329$ & $3,202,349$ & 644,058 \\
\hline 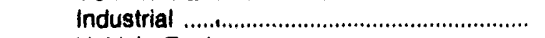 & $2,108,005$ & 316,498 & 316,421 & 88,157 \\
\hline 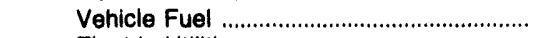 & 0 & 0 & 0 & 0 \\
\hline 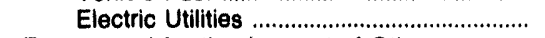 & 0 & 0 & 0 & 0 \\
\hline \multicolumn{5}{|l|}{ Transported for the Account of Others } \\
\hline 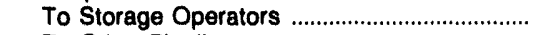 & 0 & 0 & $1,748,803$ & 0 \\
\hline 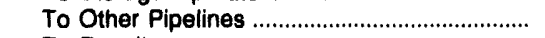 & 0 & 0 & 0 & $1,840,178$ \\
\hline $\begin{array}{l}\text { To Resellers ..................................................... } \\
\text { To Consumers }\end{array}$ & 0 & 0 & 0 & 0 \\
\hline 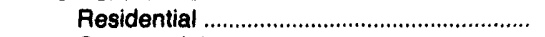 & 0 & 0 & 0 & 80,614 \\
\hline 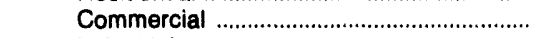 & $1,818,592$ & $1,155,816$ & 501,004 & $1,964,976$ \\
\hline 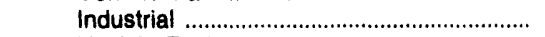 & $11,325,319$ & $13,208,109$ & $4,182,502$ & 0 \\
\hline 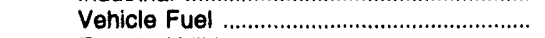 & 0 & 0 & 0 & 0 \\
\hline 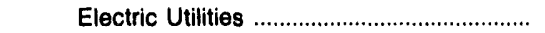 & $1,987,561$ & 0 & 0 & 0 \\
\hline 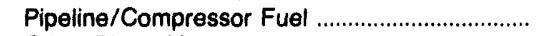 & 17,390 & 16,431 & 0 & 11,519 \\
\hline 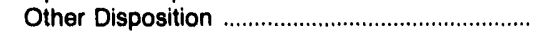 & 0 & 261,291 & 0 & 0 \\
\hline 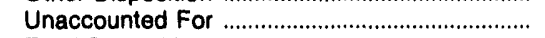 & $1,102,724$ & $2,243,276$ & 582,934 & 175,463 \\
\hline 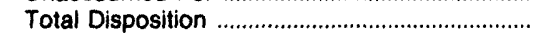 & $40,023,737$ & $32,725,548$ & $16,145,830$ & $7,151,232$ \\
\hline
\end{tabular}

Source: Energy Information Administration (ElA), Form ElA-176, "Annual Report of Natural and Supplemental Gas Supply and Disposition." 
Table 13. Consolldated Natural Gas Co.

Interstate Flows of Natural Gas, 1992

(Thousand Cubic Feet)

\begin{tabular}{|c|c|}
\hline Company and State & Volume \\
\hline \multicolumn{2}{|l|}{$\begin{array}{l}\text { CNG Transmission Corp. } \\
\text { Pennsylvania To }\end{array}$} \\
\hline $\begin{array}{l}\text { Maryland } \\
\text { New York } \\
\text { Maryland To }\end{array}$ & $\begin{array}{r}40,733,605 \\
199,959,682\end{array}$ \\
\hline $\begin{array}{l}\text { Virginia } \\
\text { Virginia To }\end{array}$ & $23,314,897$ \\
\hline 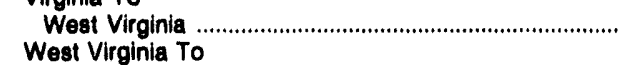 & 371,683 \\
\hline 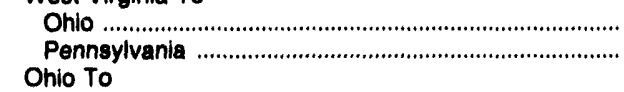 & $\begin{array}{l}43,092,076 \\
93,573,030\end{array}$ \\
\hline 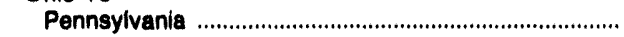 & $52,617,838$ \\
\hline
\end{tabular}

Source: Energy Information Administration (EIA), Form EIA-176, "Annual Report of Natural and Supplemental Gas Supply and Disposition." 


\section{Consumers Power Co.}

CMS Energy Corporation was incorporated in Michigan in 1987 to become the parent holding company of Consumers Power Company (Consumers) and its subsidiaries. In February 1987, CMS Enterprises was formed to conduct CMS Energy's nonutility energyrelated business. Consumers and Enterprises represent CMS Energy's two principal subsidiaries. In addition, CMS Enterprises has five other direct subsidiaries.

Consumers Power Company is a combination Gas and Electric Utility. Through its natural gas utility operations, Consumers Power Company purchases, produces, transports, stores, and distributes gas and supplies gas service in 40 of the 68 counties in Michigan's lower peninsula. Through its electric utility operations, Consumers generates, purchases, and distributes electricity in 40 of the 68 counties in the Lower Michigan Peninsula.

The company's gas distribution and transmission systems consist of approximately 20,000 miles of distribution mains and 1,100 miles of transmission lines throughout the Lower Peninsula of $M$ higan. The company owns and operates five compressor stations with a total of 116,070 installed horsepower.

In 1992, Consumers purchased approximately 77 percent of its required gas supply of 505 billion cubic feet

Figure 11. Consumers Power Co., 1992

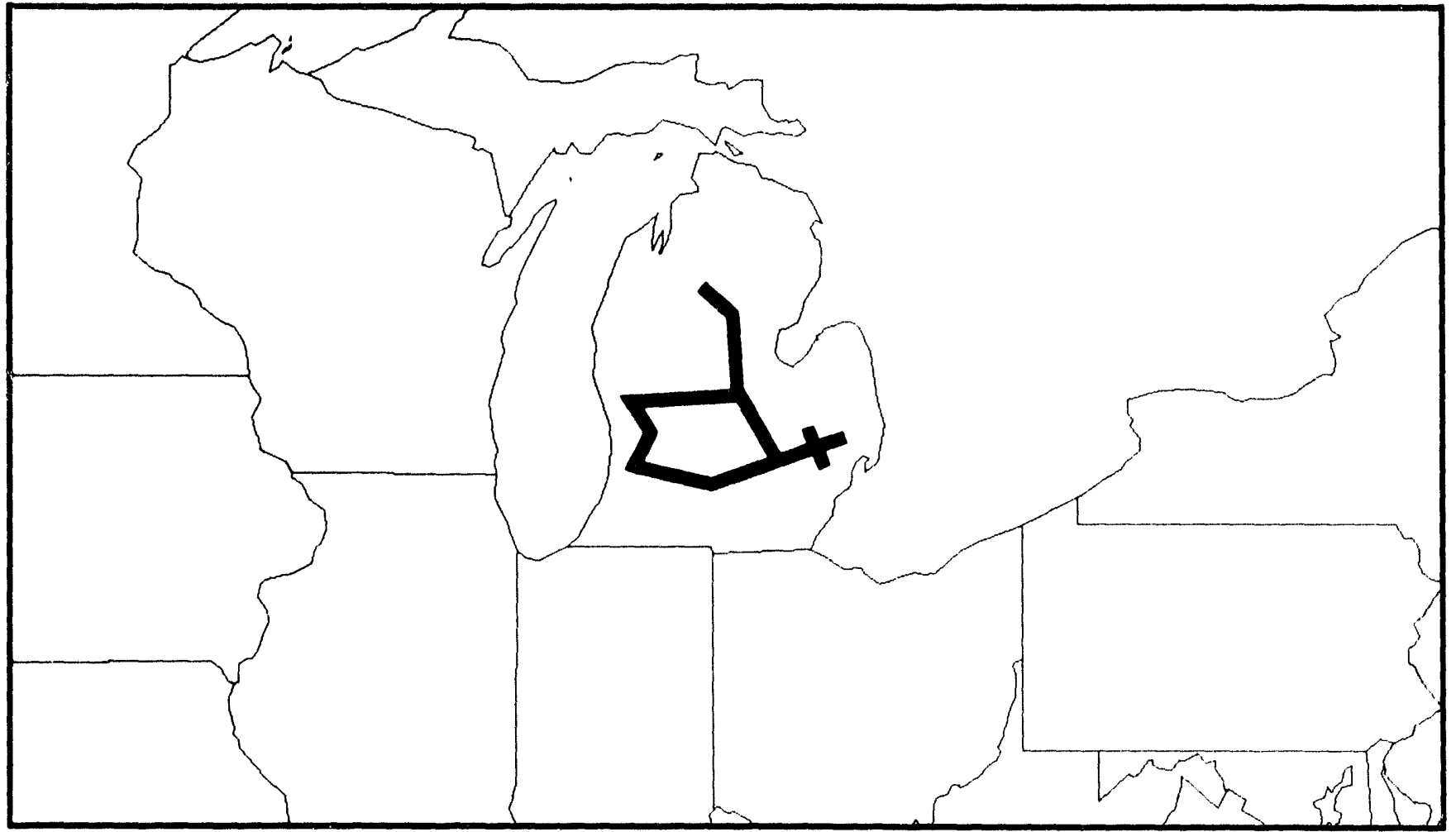

Source: Energy Information Administration (EIA). Form ElA-176, "Annual Report of Natural and Supplemental Gas Supply and Disposition." 
Table 14. Consumers Power Co. Natural Gas Data, 1992

(Thousand Cubic Feet)

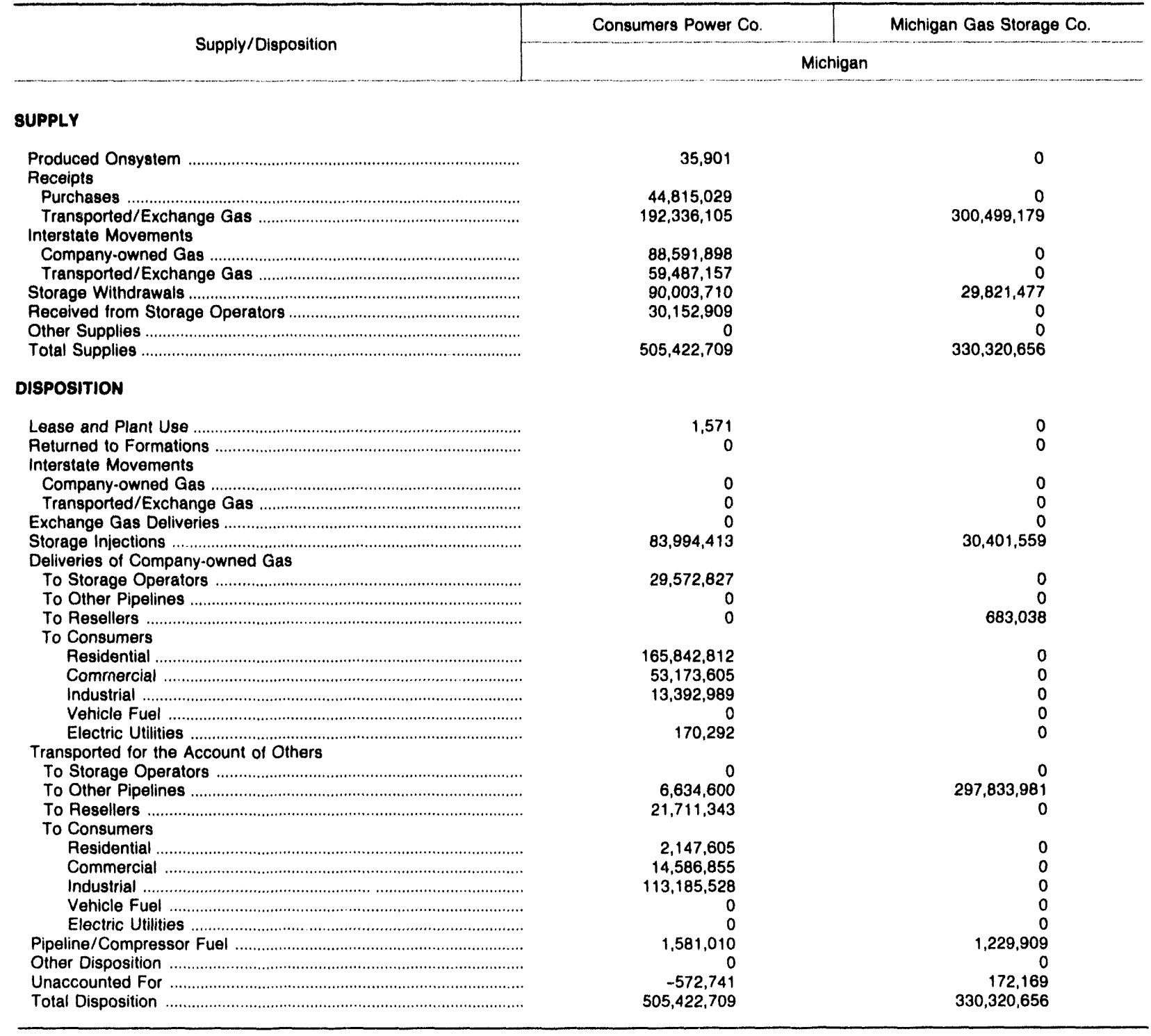

Source: Energy Information Administration (EIA). Form EIA-176, "Annual Report of Natural and Supplemental Gas Supply and Disposition."

from producers under long-term contracts. Approximately 20 percent came from Michigan producers. Purchases on the spot market provided the remaining 23 percent of Consumers 1992 gas supply. Panhandle Eastern Pipeline Company and Trunkline Gas Company delivered most of the gas acquired through purchase, transportation, and exchange agreements. The company's remaining natural gas supply comes from Michigan Gas Storage Company Incorporated (MGS), a wholly owned subsidiary of Consumers. MGS purchases, stores, transmits, and sells natural gas to Consumers Power Company, providing about 25 percent of its needs.
MGS owns 693 miles of gas pipelines of which 545 miles are transmission lines and 148 miles are storage lines, and two compressor stations. The company has three gas storage fields located in Clare, Osceola, and Missaukee Counties. Total capacity of the storage fields is approximately 117 billion cubic feet, of which approximately 46 billion cubic feet is working storage.

Consumers' deliveries to consumers in 1992 totaled more than 362 billion cubic feet, 42 percent of total deliveries to all consumers in Michigan. Of Consumers' total deliveries to consumers, 130 billion cubic feet, or nearly 36 percent, were transported and delivered for the account of others. 


\section{El Paso Natural Gas Co.}

El Paso Natural Gas Company owns and operates one of the Nation's largest field and mainline natural gas transmission systems, connecting natural gas supply regions in New Mexico, Texas, Oklahoma and Colorado to markets in California, Nevada, Arizona, New Mexico and Texas. During the past year, the company has made major changes. Previously a wholly owned subsidiary of Burlington Resources, Inc., EI Paso has again become an independent, publicly owned company. Two capacity additions account for the largest single system expansion in its history: a 835-millioncubic-feet per day expansion in capacity from the San Juan Basin in New Mexico, and a 400-million-cubic-feet per day expansion of its North Mainline System to California.

In November 1992, El Paso formed El Paso Gas Marketing Company (EPGM), a wholly owned subsidiary. All new marketing business will be conducted by EPGM, which will act as El Paso's agent, to reduce El Paso's role as a natural gas merchant. With operations for EPGM in progress, it will buy and sell natural gas with a primary concentration on Southwestern U.S. supplies and markets. It expects to buy and sell natural gas under both short-term and long-term transactions.

Figure 12. El Paso Natural Gas Co., 1992

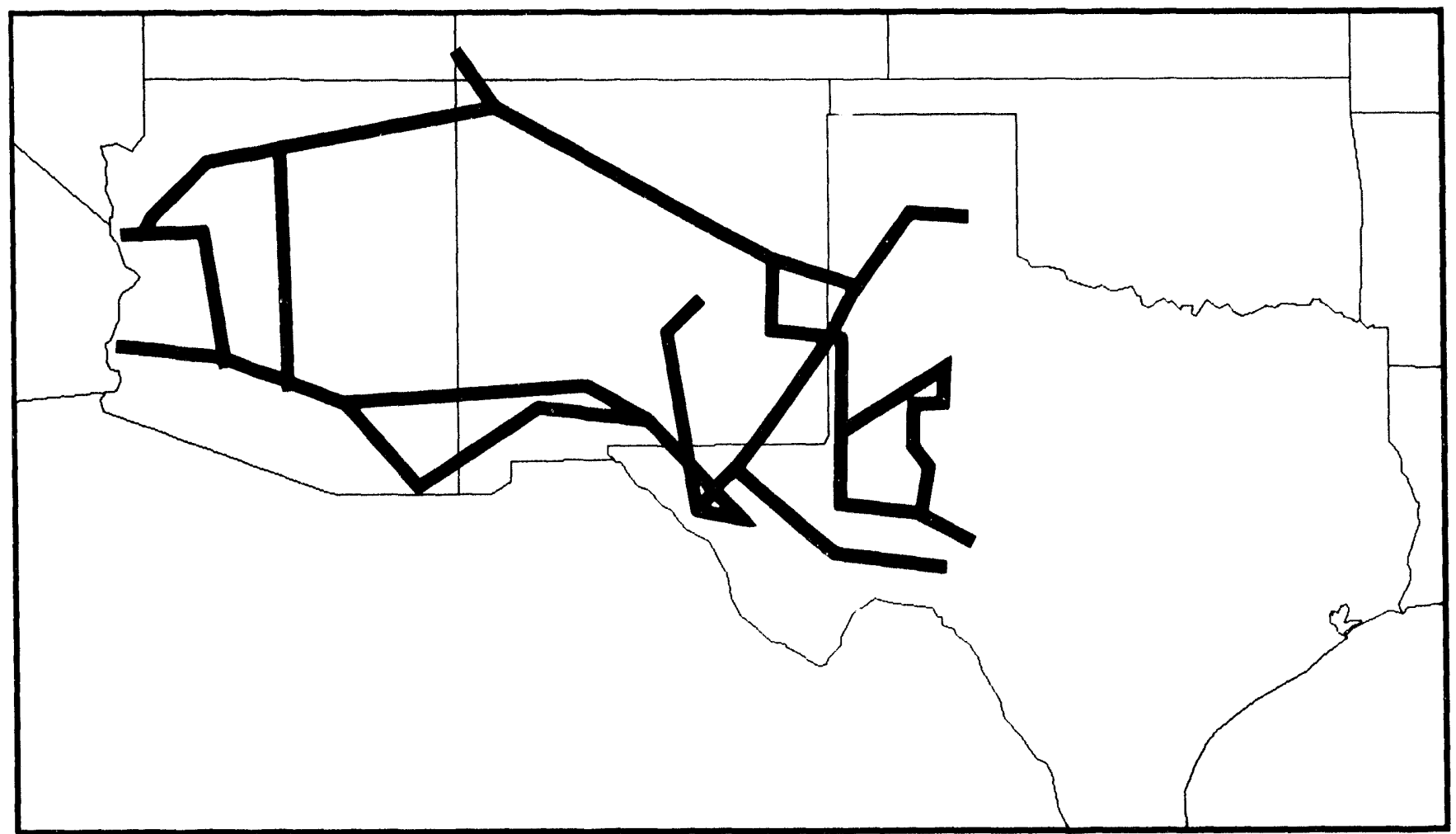

Source: Energy Information Administration (EIA), Form EIA-176, "Annual Report of Natural and Supplemental Gas Supply and Disposition." 
Table 15. El Paso Natural Gas Co. Natural Gas Data, 1992 (Thousand Cubic Feet)

\begin{tabular}{|c|c|c|c|c|c|}
\hline \multirow{2}{*}{ Supply/Disposition } & \multicolumn{5}{|c|}{ El Paso Natural Gas Co. } \\
\hline & New Mexico & Texas & Oklahoma & Arizona & Colorado \\
\hline \multicolumn{6}{|l|}{ SUPPLY } \\
\hline $\begin{array}{l}\text { Produced Onsystem } \\
\text { Receipts }\end{array}$ & 0 & 0 & 0 & 0 & 0 \\
\hline $\begin{array}{l}\text { Purchases ... } \\
\text { Transported/Exchange Gas ................................. } \\
\text { Interstate Movements }\end{array}$ & $\begin{array}{r}26,616,563 \\
803,574,611\end{array}$ & $\begin{array}{r}13,899,893 \\
412,885,901\end{array}$ & $\begin{array}{r}946,612 \\
36,636,983\end{array}$ & $\begin{array}{r}0 \\
191,834\end{array}$ & $\begin{array}{r}8,989,254 \\
149,586,926\end{array}$ \\
\hline 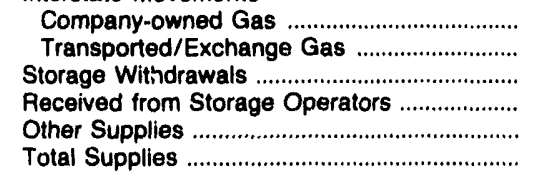 & $\begin{array}{r}0 \\
354,043,865 \\
16,275,992 \\
0 \\
0 \\
1,200,511,031\end{array}$ & $\begin{array}{r}0 \\
17,993,039 \\
0 \\
0 \\
0 \\
444,778,833\end{array}$ & $\begin{array}{r}0 \\
0 \\
0 \\
0 \\
0 \\
37,583,595\end{array}$ & $\begin{array}{r}0 \\
1,101,168,961 \\
0 \\
0 \\
0 \\
1,101,360,795\end{array}$ & $\begin{array}{r}0 \\
0 \\
0 \\
0 \\
0 \\
158,576,180\end{array}$ \\
\hline \multicolumn{6}{|l|}{ DISPOSITION } \\
\hline $\begin{array}{l}\text { Lease and Plant Use } \\
\text { Returned to Formations } \\
\text { Interstate Movements }\end{array}$ & $\begin{array}{r}10,111,517 \\
0\end{array}$ & $\begin{array}{l}0 \\
0\end{array}$ & $\begin{array}{l}0 \\
0\end{array}$ & $\begin{array}{l}0 \\
0\end{array}$ & $\begin{array}{l}0 \\
0\end{array}$ \\
\hline 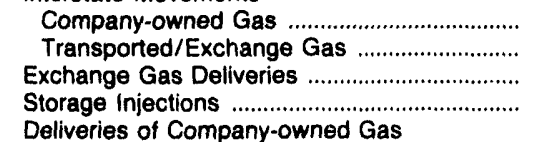 & $\begin{array}{r}0 \\
1,101,168,961 \\
1,531,909 \\
15,288,766\end{array}$ & $\begin{array}{r}0 \\
196,524,314 \\
18,501,109 \\
0\end{array}$ & $\begin{array}{r}0 \\
17,993,039 \\
8,352,841 \\
0\end{array}$ & $\begin{array}{r}0 \\
918,506,616 \\
0 \\
0\end{array}$ & $\begin{array}{r}0 \\
157,519,551 \\
C \\
0\end{array}$ \\
\hline 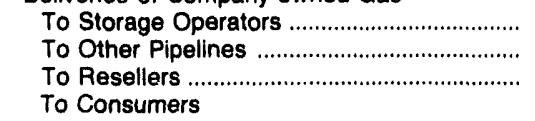 & $\begin{array}{l}0 \\
0 \\
0\end{array}$ & $\begin{array}{l}0 \\
0 \\
0\end{array}$ & $\begin{array}{l}0 \\
0 \\
0\end{array}$ & $\begin{array}{l}0 \\
0 \\
0\end{array}$ & $\begin{array}{l}0 \\
0 \\
0\end{array}$ \\
\hline 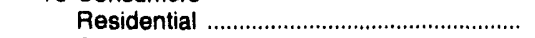 & 0 & 0 & 0 & 0 & 0 \\
\hline 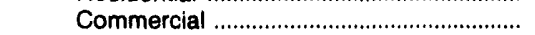 & 0 & 0 & 0 & 0 & 0 \\
\hline 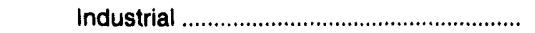 & 0 & 0 & 0 & 0 & 0 \\
\hline 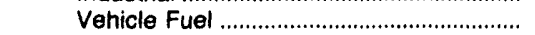 & 0 & 0 & 0 & 0 & 0 \\
\hline 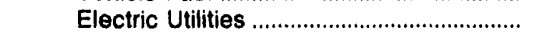 & 0 & 0 & 0 & 0 & 0 \\
\hline \multicolumn{6}{|l|}{ Transported for the Account of Others } \\
\hline 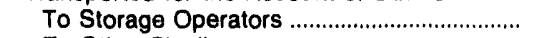 & 0 & 0 & 0 & 0 & 0 \\
\hline 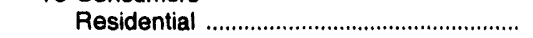 & 0 & 0 & 0 & 0 & 0 \\
\hline 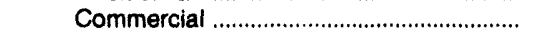 & 0 & 0 & 0 & 0 & 0 \\
\hline 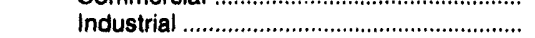 & $4,748,690$ & $3,266,487$ & 0 & $7,820,060$ & 0 \\
\hline 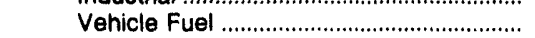 & 0 & 0 & 0 & 0 & 0 \\
\hline 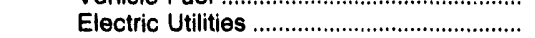 & $6,302,308$ & 212,846 & 0 & $38,036,867$ & 0 \\
\hline 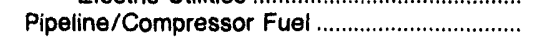 & $40,880,755$ & $16,159,534$ & 537,559 & $21,317,490$ & 847,931 \\
\hline Other Disposition & 0 & 0 & 0 & 0 & 0 \\
\hline 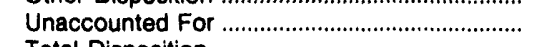 & 0 & $-2,000,000$ & 0 & $53,731,382$ & 0 \\
\hline 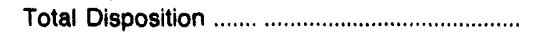 & $1,200,511,031$ & $444,778,833$ & $37,583,595$ & $1,101,360,795$ & $158,576,180$ \\
\hline
\end{tabular}

Also, in March 1993 El Paso and Enron Corp., signed an agreement under which El Paso acquired Enron's 50 percent interest in Mojave Pipeline Company. Mojave operates a 361-mile interstate pipeline from Topock, Arizona to Kern County, California, with a 400 million cubic feet per day capacity. The Mojave Pipeline project was completed in April 1992 and runs from the Arizona/California border to Bakersfield, California, where it provides natural gas for use in the heavy oil fields.

El Paso is directly connected to three of the Nation's most prolific gas-producing areas: the San Juan, Permian, and Anadarko Basins. Currently, El Paso provides 53 percent of California's total interstate pipeline capacity with a transmission capacity of approximately 3.3 billion cubic feet per day to the California border. In 1992, El Paso again provided approximately 50 percent of all the natural gas consumed in California.
Deliveries to its east-of-California markets are about 1.2 billion cubic feet per day which includes deliveries in northern Mexico to the cities of Ciudad Juarez, Cananea and Hermosillo, and the Samalayuca Power Plant just outside of Ciudad Juarez.

The earlier jurisdictional disputes raised by Pacific Gas and Electric Co. and the California Public Utilities Commission (CPUC) suggesting that Mojave's proposed $\mathbf{4 7 5}$ million cubic feet expansion project be regulated by the CPUC instead of the Federal Energy Regulatory Commission (FERC) have been settled. The FERC will regulate the companys northward extension as an interstate pipeline.

The Sacramento Municipal Utility District Board of Directors unanimously approved a long-term natural gas transportation agreement with Mojave for 55 million cubic feet per day, about 12 percent of Mojave's 
Table 15. El Paso Natural Gas Co. Natural Gas Data, 1992 (Continued) (Thousand Cubic Feet)

\begin{tabular}{l|c|c}
\hline \multirow{2}{*}{ Supply/Disposition } & \multicolumn{2}{|c}{ Mojave Pipeline Co. } \\
\cline { 2 - 3 } & Callornia & Arizona \\
\hline
\end{tabular}

\section{SUPplY}

Produced Onsystem ..................................................

Receipts

Purchases

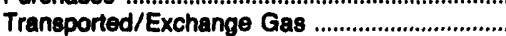

Interstate Movements

Company-owned Gas

Transported/Exchange Gas

Storage Withdrawals

Received from Storage Operators ...........................

Other Supplies

Total Supplies

\section{DISPOSITION}

Lease and Plant Use

Returned to Formations

Interstate Movements

Company-owned Gas

Transported/Exchange Gas

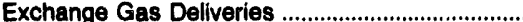

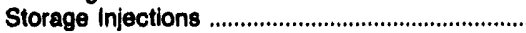

Deliveries of Company-owned Gas

To Storage Operators

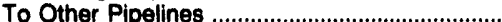

To Resellers ..........................................................

To Consumers

Residential

Commercial

Industrial ...

Vehicle Fuel

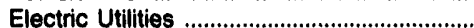

Transported for the Account of Others

To Storage Operators

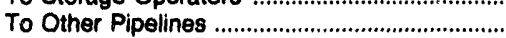

To Resellers

To Consumers

Residential.

Commercial

Industrial

Vehicle Fuel

Electric Utilities

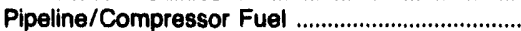

Other Disposition

Unaccounied For

Total Disp

$\begin{array}{rr}0 & 0 \\ 0 & 0 \\ 0 & 60,583,073 \\ 0 & 0 \\ 60,129,168 & 0 \\ 0 & 0 \\ 0 & 0 \\ 0 & 0 \\ 60,129,168 & 60,583,073\end{array}$

0

$0,583,073$

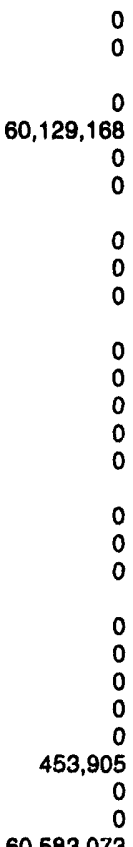

$60,583,073$

Source: Energy Information Administration (EIA), Form EIA-176, "Annual Report of Natural and Supplemental Gas Supply and Disposition."

planned capacity, to anchor its proposed northward expansion project. With a planned capacity of 475 million cubic feet per day, it will serve manufacturing, cogeneration, industrial and municipal utility customers in northern and central California. This expansion would extend a 214-mile, 30-inch pipeline northward from near Bakersfield, then branch into a 59-mile, 12-inch pipeline north to Sacramento and a 20-inch pipeline to the west, with smaller diameter lines to serve the East Bay, South Bay and Palo Alto areas.

To enhance gas service to Mexico, El Paso is seeking authorization to construct and operate a $\$ 57$ million, 36-mile, 24-inch diameter pipeline expansion. This ex- pansion, the Samalayuca Lateral Expansion Project, will principally serve the existing Samalayuca Power Plant, located approximately 30 miles south of Ciudad Juarez, Mexico. It will connect gas resources in New Mexicoand west Texas with the Pemex pipeline system, and greatly benefit Ciudad Juarez and the state of Chihuahua, Mexico. (Pemex, Petroleos Mexicanos, is the state-controlled oil and gas company in Mexico.) The Samalayuca Lateral Expansion Project will provide up to 300 thousand cubic feet per day of firm and interruptible transportation to Mexico, with about 175 million cubic feet per day serving the Samalayuca Power Plants. If approved, El Paso expects the pipeline to become operational in late 1995. 
Table 16. El Paso Natural Gas Co. Interstate

Flows of Natural Gas, 1992

(Thousand Cubic Feet)

\begin{tabular}{|c|c|}
\hline Company and State & Volume \\
\hline \multicolumn{2}{|l|}{$\begin{array}{l}\text { El Paso Natural Gas Co. } \\
\text { Oklahoma To }\end{array}$} \\
\hline $\begin{array}{l}\text { Texas } \\
\text { Texas To }\end{array}$ & $17,993,039$ \\
\hline $\begin{array}{l}\text { New Mexico } \\
\text { New Mexico To }\end{array}$ & $196,524,314$ \\
\hline $\begin{array}{l}\text { Arizona } \\
\text { Arizona To }\end{array}$ & $1,101,168,961$ \\
\hline 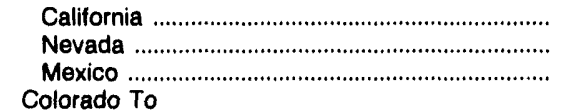 & $\begin{array}{r}881,565,717 \\
34,375,819 \\
2,565,080\end{array}$ \\
\hline 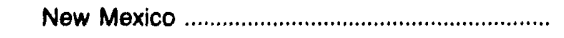 & $157,519,551$ \\
\hline \multicolumn{2}{|l|}{ Mojave } \\
\hline California & $60,129,168$ \\
\hline
\end{tabular}

Source: Energy Information Administration (EIA), Form EIA-176, "Annual Report of Natural and Supplemental Gas Supply and Disposition." 


\section{Enron Corp.}

Enron Corporation operates a pipeline network of over 40,000 miles that handles natural gas transported through one intrastate (Houston Pipe Line) and four interstate pipelines. Florida Gas Transmission, Northern Border Pipeline, Northern Natural Gas, and Transwestern Pipeline make up the Enron interstate system.

Northern Natural Gas, the largest of Enron's five pipeline systems, delivers to local distribution companies serving the residential and commercial markets in the upper Midwest. Northern Natural Gas' 3,200-mile pipeline system extends from Enron's producing areas in
Texas and Oklahoma to Iowa, Minnesota, and Nebraska. In its major residential areas, Northern Natural Gas transports gas for the account of others that ultimately serves more than 6 million residential consumers in Iowa and Minnesota. Other core customers include large and small commercial customers and industrial customers. Transportation accounts for 90 percent of volumes delivered, with regulated sales making up the other 10 percent. A modernization plan, which includes the replacement of dated compressor facilities with more efficient equipment, is now being implemented by Northern Natural Gas. It is estimated that the entire project will be completed by 1997 .

Figure 13. Enron Corp., 1992

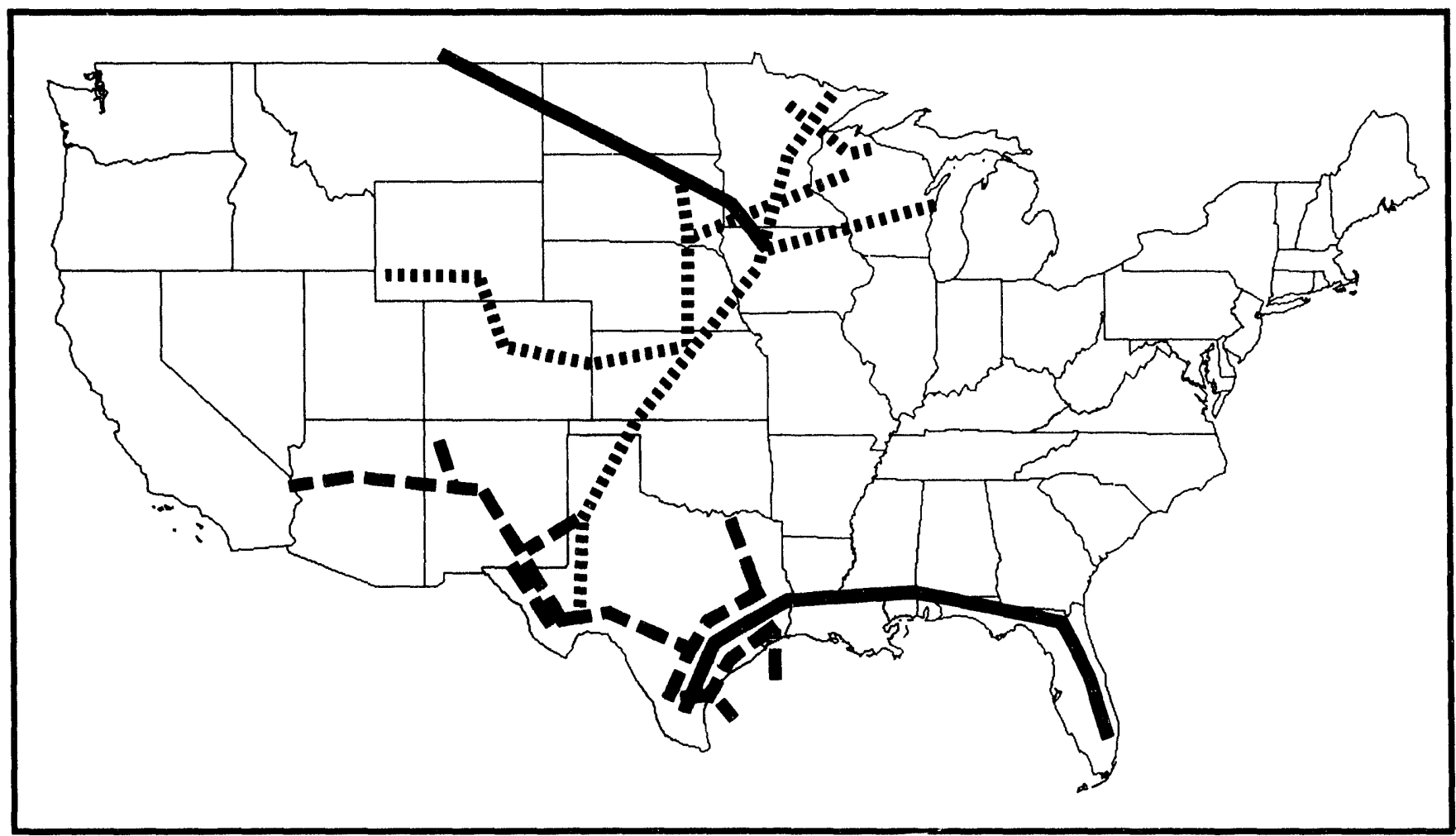

Source: Energy Information Administration (E|A), Form ElA-176, "Annual Report of Natural and Supplemental Gas Supply and Disposition."

Supply Areas
Northern Border Pipeline Co. - Transwestern Pipeline Co. 


\begin{tabular}{l|c|c|c|c|c|c|c|}
\hline \multirow{2}{*}{ Supply/Disposition } & \multicolumn{4}{|c|}{ Florida Gas Transmission Co. } & $\begin{array}{c}\text { Houston Pipe } \\
\text { Line Inc. }\end{array}$ \\
\cline { 2 - 7 } & Texas & Louisiana & Mississippi & Alabama & Florida & Texas \\
\hline
\end{tabular}

\section{SUPPLY}

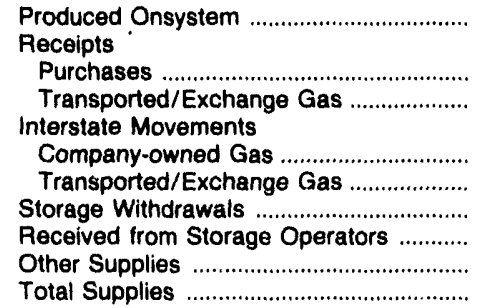

DISPOSITION

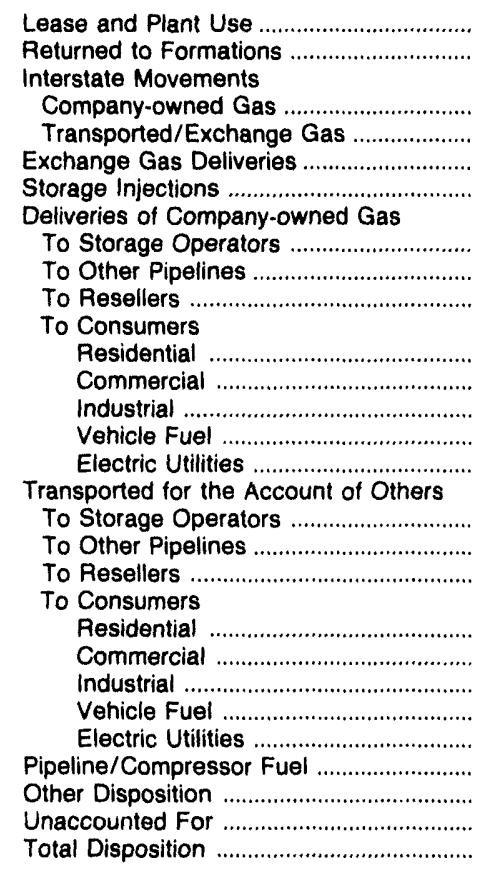

0
$9,982,890$
$79,342,347$
0
0
0
0
0
$89,325,237$

0
$33,834,827$
$199,502,296$
0
$75,654,683$
0
0
0
$308,991,806$

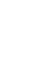

0
$1,995,146$
$17,815,432$
0
0
$267,679,039$
0
0
0
$287,429,617$

0
196,426
$7,787,935$
0
$285,494,330$
0
0
0
$293,478,691$

0
279,379
$4,233,940$
0
$292,878,833$
0
0
0
$297,392,152$

$4,081,170$
$865,493,904$
0
0
$35,945,126$
0
0
$905,520,200$
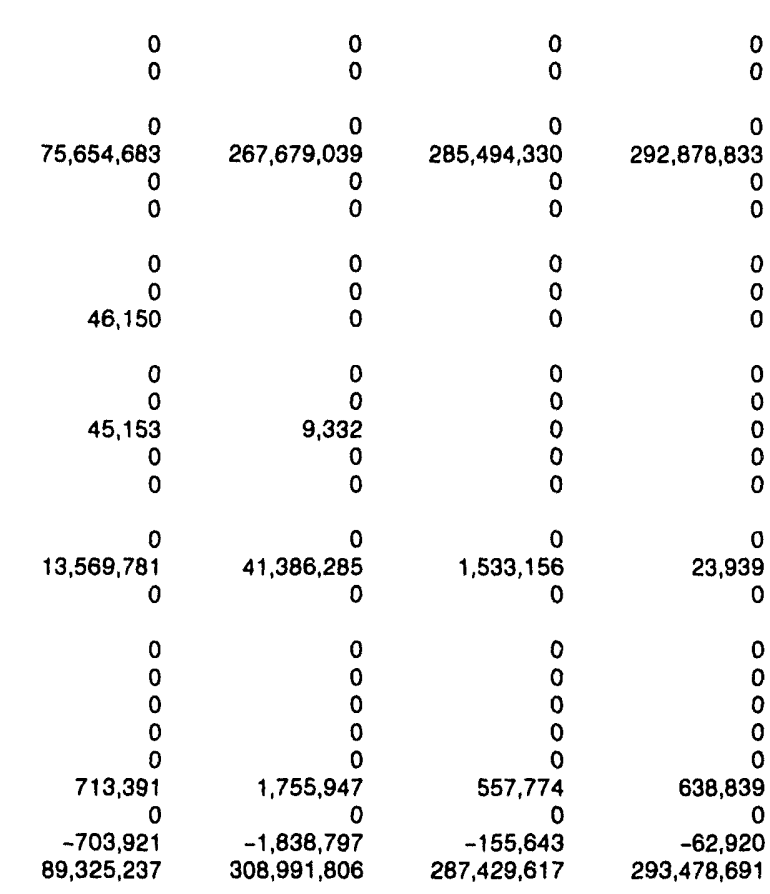

0
$1,533,156$
0

0
0
0

0
0
0

557,774

$-155,643$ $287,429,617$

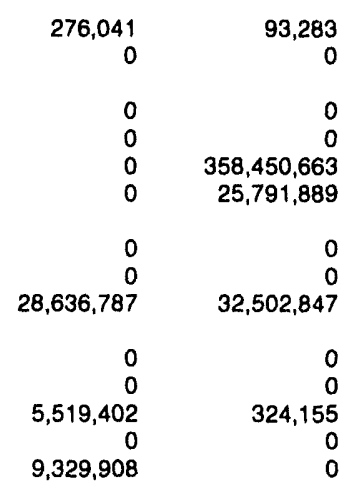

$\begin{array}{rr}0 & 0 \\ 0 & 201,628,498 \\ 73,470,626 & 39,362,338\end{array}$$$
73,470,626 \quad 39,362,338
$$$$
\begin{array}{rr}
0 & 0 \\
0 & 539,105 \\
6,716,117 & 213,976,539
\end{array}
$$$$
\begin{array}{rr}
0 & 0 \\
0 & 213,976,539 \\
169,213,452 & 43,606,022 \\
4,265,386 & 503,868 \\
0 & 0 \\
-35,567 & -11,259,007
\end{array}
$$

$-35,567 \quad-11,259,007$ $297,392,152 \quad 905,520,200$
The Transwestern Pipeline system consists of nearly 4,500 miles of pipeline extending from western Texas to the California border. Transwestern moves gas through its system from producing areas in Texas and northwestern Oklahoma westward for almost exclusive delivery to Southern California Gas Company. The company makes some deliveries to resellers and small customers, but is primarily a transporter of gas to the California market. The recently completed 'Topock Interconnect' between Transwestern's mainline and Mojave Pipeline Co. makes an additional 525 million cubic feet per day of natural gas available to the growing California market. The completed 520 million cubic feet per day extension into the San Juan Basin went into service in February 1992. Transwestern is developing a posture for increased growth potential in areas such as Baja California (west end of the system) and markets in Texas and the Mid- west (east end of the system). Some of these markets are at present noncore markets or under utilized.

Enron Corporation owns 35 percent of Northern Border Pipeline and operates the company through its Northern Plains Natural Gas subsidiary. Northern Border transports gas from a point on the Montana/ Canadian border southeastward to markets in Iowa. Acquisition of a 147-mile pipeline in Iowa, and construction of four new compressor stations along the 822-mile pipeline, provided an additional 313 million cubic feet per day of capacity beginning in November of 1992.

Florida Gas Transmission Company, the sole supplier of natural gas to the Florida Peninsula, is owned by Citrus Corporation which is a $50 / 50$ joint venture between Enron and Southern Natural Gas Company, op- 
Table 17. Enron Corp. Natural Gas Data, 1992 (Continued)

(Thousand Cubic Feet)

\begin{tabular}{|c|c|c|c|c|c|c|}
\hline \multirow{2}{*}{ Supply/Disposition } & \multirow{2}{*}{$\begin{array}{c}\text { Enron Industrial } \\
\text { Natural Gas Co. } \\
\text { Texas }\end{array}$} & \multicolumn{5}{|c|}{ Northern Natural Gas Co. } \\
\hline & & Louisiana & New Mexico & Texas & Oklahoma & Wyoming \\
\hline \multicolumn{7}{|l|}{ SUPPLY } \\
\hline $\begin{array}{l}\text { Produced Onsystem } \\
\text { Receipts }\end{array}$ & 0 & 0 & 9,836 & 25,230 & 23,865 & 0 \\
\hline 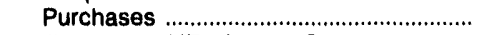 & 0 & $4,047,365$ & $5,541,099$ & $40,445,323$ & $6,217,860$ & $16,134,567$ \\
\hline Transported/Exchange Gas ........................ & $169,203,779$ & $21,356,036$ & $46,300,617$ & $324,058,917$ & $149,450,786$ & 0 \\
\hline \multicolumn{7}{|l|}{ Interstate Movements } \\
\hline 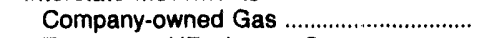 & 0 & 0 & 0 & 0 & 0 & 0 \\
\hline Transported/Exchange Gas .................... & 0 & 0 & 0 & $90,180,269$ & $123,183,710$ & 0 \\
\hline 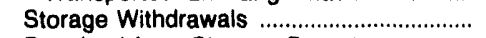 & 0 & 0 & 0 & 0 & 0 & 0 \\
\hline Received from Storage Operators ............ & $10,572,732$ & 0 & 0 & 0 & 0 & 0 \\
\hline Other Supplies & 0 & 0 & 0 & 0 & 0 & 0 \\
\hline 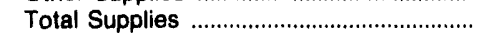 & $179,776,511$ & $25,403,401$ & $51,851,552$ & $454,709,739$ & $278,876,221$ & $16,134,567$ \\
\hline 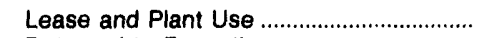 & 0 & 0 & $3,705,041$ & 0 & 0 & 0 \\
\hline $\begin{array}{l}\text { Returned to Formations } \\
\text { Interstate Movements }\end{array}$ & 0 & 0 & 0 & 0 & 0 & 0 \\
\hline 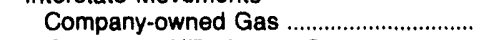 & 0 & 0 & 0 & 0 & 0 & 0 \\
\hline Transported/Exchange Gas .................... & 0 & 0 & $41,035,818$ & $123,183,710$ & $236,536,714$ & 0 \\
\hline 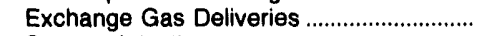 & 0 & 0 & 0 & 0 & 0 & 0 \\
\hline 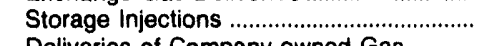 & 0 & 0 & 0 & 0 & 0 & 0 \\
\hline \multicolumn{7}{|l|}{ Deliveries of Company.owned Gas } \\
\hline To Storage Operators ................................. & $11,535,781$ & 0 & 0 & 0 & 0 & 0 \\
\hline 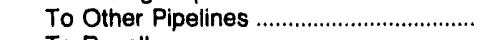 & $9,440,505$ & 0 & 0 & 0 & 0 & 961,955 \\
\hline 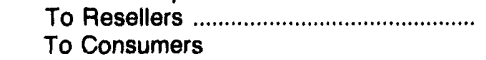 & $3,242,666$ & 0 & 415,863 & $76,528,491$ & $11,423,071$ & 0 \\
\hline 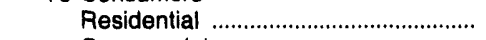 & 0 & 0 & 0 & 0 & 0 & 0 \\
\hline Commercial .......................................... & 0 & 0 & 0 & 0 & 0 & 0 \\
\hline 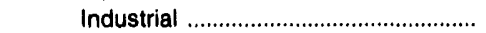 & $91,661,712$ & 0 & 0 & 0 & 0 & 0 \\
\hline Vehicle Fuel ......................................... & 0 & 0 & 0 & 0 & 0 & 0 \\
\hline 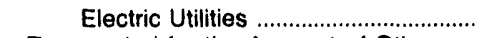 & $63,895,844$ & 0 & 0 & 0 & 0 & 0 \\
\hline \multicolumn{7}{|l|}{ Transported for the Account of Others } \\
\hline 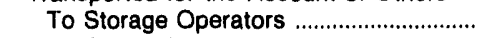 & 0 & 0 & 0 & 0 & 0 & 0 \\
\hline 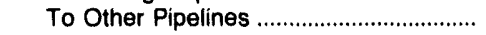 & 0 & $25,968,758$ & $3,513,908$ & $246,214,314$ & $24,872,403$ & $14,138,376$ \\
\hline $\begin{array}{l}\text { To Resellers ............................................... } \\
\text { To Consumers }\end{array}$ & 0 & 0 & 0 & 0 & 0 & 0 \\
\hline 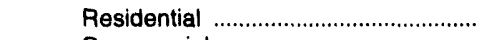 & 0 & 0 & 0 & 0 & 0 & 0 \\
\hline 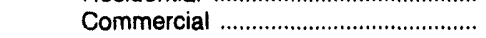 & 0 & 0 & 0 & 0 & 0 & 0 \\
\hline 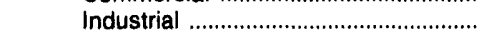 & 0 & 0 & 0 & 0 & 0 & 0 \\
\hline 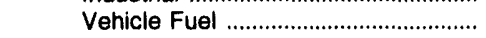 & 0 & 0 & 0 & 0 & 0 & 0 \\
\hline 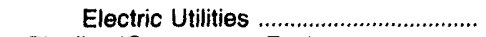 & 0 & 0 & 0 & 0 & 0 & 0 \\
\hline Pipeline/Compressor Fuel .............................. & 0 & 0 & $2,631,123$ & $4,728,552$ & $4,242,678$ & 17,353 \\
\hline 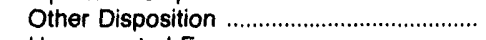 & 0 & 0 & 0 & 0 & 0 & 0 \\
\hline 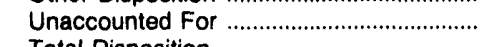 & 3 & $-565,357$ & 549,799 & $4,054,672$ & $1,801,355$ & $\begin{array}{r}1,016,883 \\
\end{array}$ \\
\hline Total Disposition ............................................. & $179,776,511$ & $25,403,401$ & $51,851,552$ & $454,709,739$ & $278,876,221$ & $16,134,567$ \\
\hline
\end{tabular}

erated by Enron. Gas supplies are purchased or are received for transportation in Texas and Louisiana for delivery to resellers and consumers in Florida. The largest volumes of deliveries, split almost evenly between sales and transportation, were to electric utilities. Direct deliveries to industrial and electric utility consumers accounted for two-thirds of the gas handled in Florida.

Florida's rapid population growth has increased demand for gas supplies, spurring interest in increasing capacity. Preliminary approval, pending decisions on environmental issues, has been granted for a 760-mile expansion project which could increase capacity by 550 million cubic feet per day by 1995 . The expansion is aimed at meeting a growing demand for natural gas in Florida, particularly for electric generation.
Houston Pipe Line, the country's largest intrastate system, serves as a hub for the Enron natural gas transmission network. Serving the Texas intrastate market Houston Pipe Line transports gas between the State's producing areas, the Bammel underground storage field, industrial and electric utility consumers, and other pipelines.

Enron Corporation, through its Enron Gas Services Division, is the largest nonprice regulated merchant in North America. This division was formed to compete for the merchant function being relinquished by the pipeline industry. Enron Gas Services offers marketing services that allow customers to choose from a variety of gas supply and marketing options tailored to specific needs. 
Table 17. Enron Corp. Natural Gas Data, 1992 (Continued) (Thousand Cubic Feet)

\begin{tabular}{|c|c|c|c|c|c|c|}
\hline \multirow{2}{*}{ Supply/Disposition } & \multicolumn{6}{|c|}{ Northern Natural Gas Co. } \\
\hline & Colorado & Kansas & Nebraska & lowa & Montana & South Dakota \\
\hline \multicolumn{7}{|l|}{ SUPPLY } \\
\hline \multicolumn{6}{|l|}{ Recolpts } & 0 \\
\hline 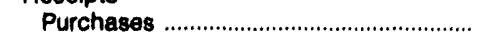 & $1,262,279$ & $4,988,888$ & 0 & $91,123,215$ & $18,025,968$ & 0 \\
\hline 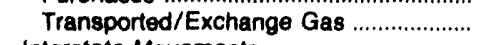 & 0 & $141,062,607$ & $23,001,996$ & $216,669,026$ & 0 & $7,639,751$ \\
\hline \multicolumn{7}{|l|}{ Interstate Movements } \\
\hline 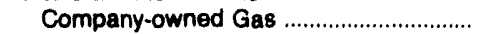 & 0 & 0 & 0 & 0 & 0 & 0 \\
\hline 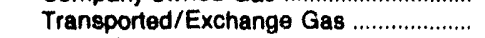 & 0 & $187,392,263$ & $298,611,130$ & $264,908,976$ & 0 & $10,678,509$ \\
\hline 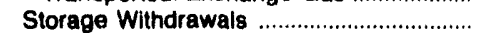 & 0 & $38,374,527$ & 0 & $32,865,533$ & 0 & 0 \\
\hline Peceived from Storage Operators ............ & 0 & 0 & 0 & 0 & 0 & 0 \\
\hline Other Supplies & 0 & 0 & 0 & 0 & 0 & 0 \\
\hline 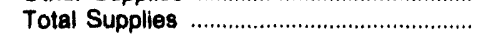 & $1,262,279$ & $371,818,328$ & $321,613,126$ & $605,666,750$ & $18,025,968$ & $18,318,260$ \\
\hline \multicolumn{7}{|l|}{ DISPOSITION } \\
\hline 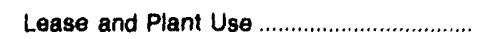 & 0 & 0 & 0 & 0 & 0 & 0 \\
\hline \multicolumn{7}{|l|}{ Interstate Movements } \\
\hline 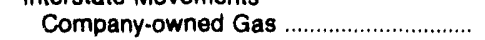 & 0 & 0 & 0 & 0 & 0 & 0 \\
\hline Transported/Exchange Gas .................... & 0 & $298,611,130$ & $270,005,955$ & $362,570,059$ & $14,554,398$ & 651,148 \\
\hline Exchange Gas Deliveries ............................. & 0 & 0 & 0 & 0 & 0 & 0 \\
\hline 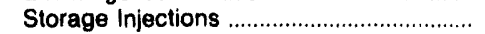 & 0 & $35,829,744$ & 0 & $29,899,055$ & 0 & 0 \\
\hline \multicolumn{7}{|l|}{ Deliveries of Company-owned Gas } \\
\hline 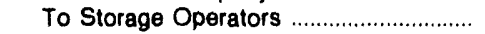 & 0 & 0 & 0 & 0 & 0 & 0 \\
\hline 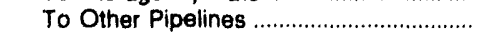 & 82,868 & 0 & 0 & 0 & 0 & 0 \\
\hline $\begin{array}{l}\text { To Resellers .................................................... } \\
\text { To Consumers }\end{array}$ & 0 & $10,111,325$ & $8,176,786$ & $40,131,777$ & 4,000 & $1,956,467$ \\
\hline 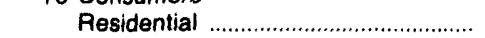 & 0 & 0 & 0 & 0 & 0 & 0 \\
\hline 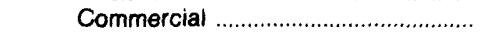 & 0 & 0 & 0 & 0 & 0 & 0 \\
\hline 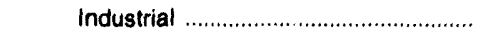 & 0 & 0 & 0 & 0 & 0 & 0 \\
\hline 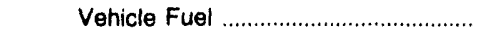 & 0 & 0 & 0 & 0 & 0 & 0 \\
\hline 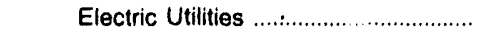 & 0 & 0 & 0 & 0 & 0 & 0 \\
\hline \multicolumn{7}{|l|}{ Transported for the Account of Others } \\
\hline 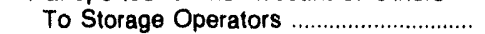 & 0 & 0 & 0 & 0 & 0 & 0 \\
\hline 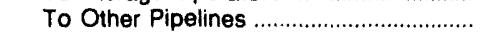 & $1,078,378$ & $16,685,042$ & $40,975,249$ & $167,714,378$ & $3,420,870$ & $15,591,824$ \\
\hline 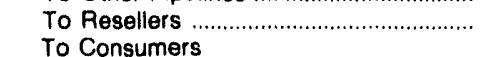 & 0 & 0 & 0 & 0 & 0 & 0 \\
\hline 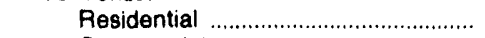 & 0 & 0 & 0 & 0 & 0 & 0 \\
\hline 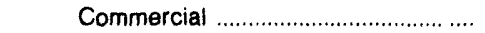 & 0 & 0 & 0 & 0 & 0 & 0 \\
\hline 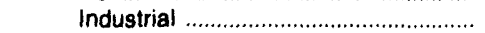 & 0 & 0 & 0 & 0 & 0 & 0 \\
\hline 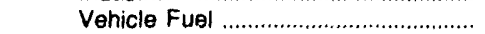 & 0 & 0 & 0 & 0 & 0 & 0 \\
\hline 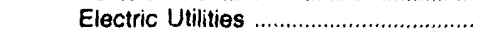 & 0 & 0 & 0 & 0 & 0 & 0 \\
\hline Pipeline/Compressor Fuel ............................ & 0 & $7,779,258$ & $1,461,630$ & $1,954,513$ & 463,368 & 12,207 \\
\hline 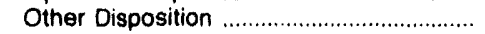 & 0 & 0 & 0 & 0 & 0 & 0 \\
\hline 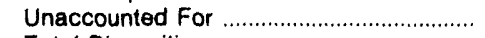 & 101,033 & $2,801,829$ & 993,506 & $3,396,968$ & $-416,668$ & 106,614 \\
\hline Total Disposition & $1,262,279$ & $371,818,328$ & $321,613,126$ & $605,666,750$ & $18,025,968$ & $18,318,260$ \\
\hline
\end{tabular}

Enron Oil and Gas Company of the Exploration and Production Division of Enron is a leading independent producer of natural gas. Enron holds an 80-percent interest in this company. Enron Oil and Gas increased wellhead production in 1992 primarily due to tight gas sand activity. Production from tight gas sand qualified wells averaged approximately 210 million cubic feet per day during the year.

Other divisions of Enron are Enron Power and Enron International. The Enron Power unit has responsibility for the management and operations of five power units in the U.S. with a total electric generating capacity of approximately 1,500 megawatts, as well as power development and integrated natural gas projects in the Americas, the Near East and the Pacific Rim. The Enron International unit has similar responsibilities for development and operations in Europe, the Middle East and the former Soviet Union, and for the operation of the Teeside Power Project and related facilities in the United Kingdom. 
Table 17. Enron Corp. Natural Gas Data, 1992 (Continued) (Thousand Cubic Feet)

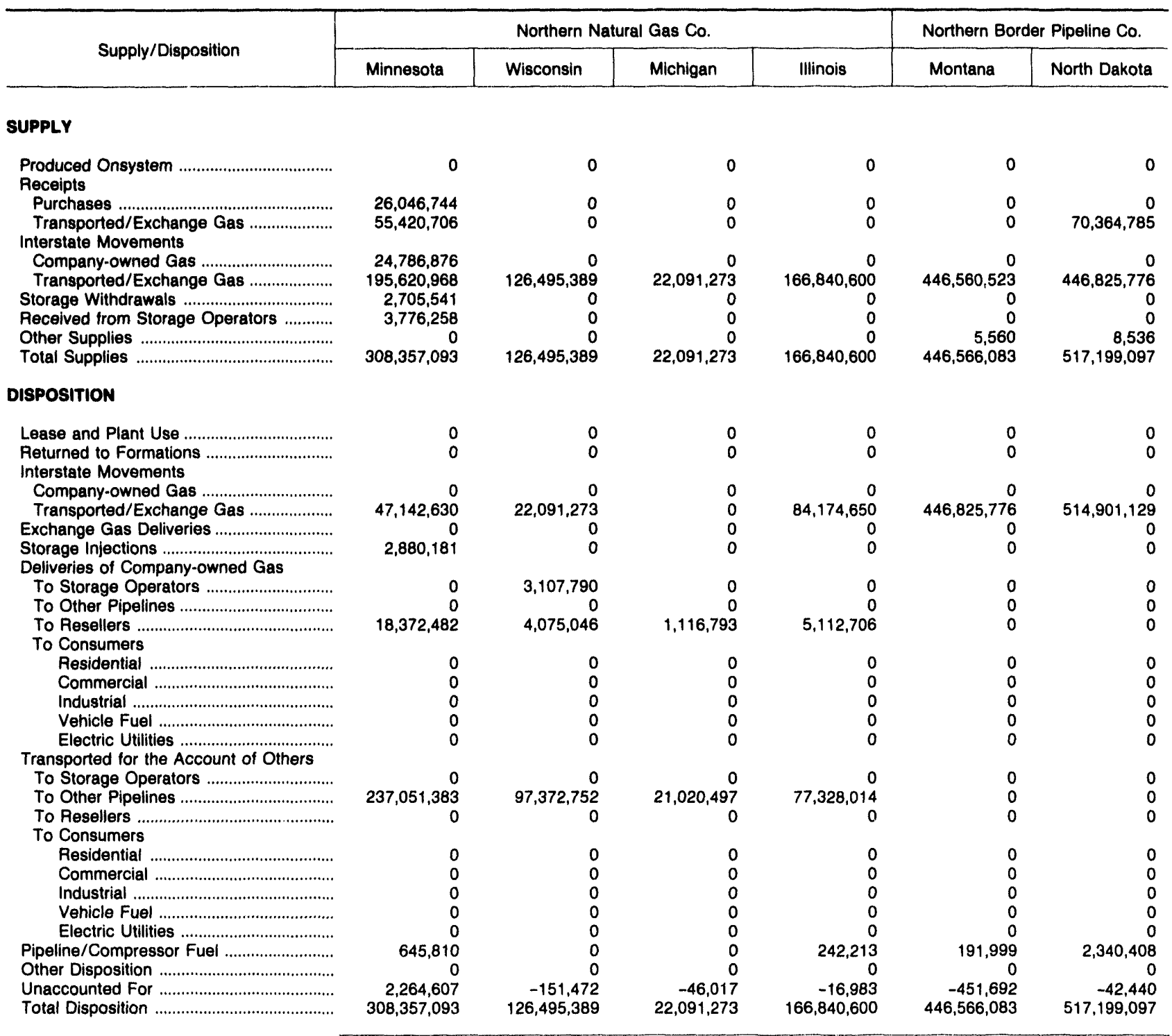


Table 17. Enron Corp. Natural Gas Data, 1992 (Continued) (Thousand Cubic Feet)

\begin{tabular}{|c|c|c|c|c|c|c|}
\hline \multirow{2}{*}{ Supply/Disposition } & \multicolumn{3}{|c|}{ Northern Border Pipeline Co. } & \multicolumn{3}{|c|}{ Transwestern Pipeline Co. } \\
\hline & South Dakota & Minnesota & lowa & Oklahoma & Texas & New Mexico \\
\hline \multicolumn{7}{|l|}{ SUPPLY } \\
\hline $\begin{array}{l}\text { Produced Onsystem } \\
\text { Receipts }\end{array}$ & 0 & 0 & 0 & 0 & 0 & 0 \\
\hline 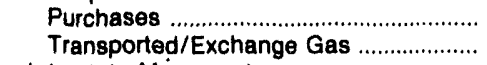 & $\begin{array}{l}0 \\
0\end{array}$ & $\begin{array}{l}0 \\
0\end{array}$ & $\begin{array}{l}0 \\
0\end{array}$ & $\begin{array}{r}1,710,524 \\
21,118,118\end{array}$ & $\begin{array}{r}1,937,945 \\
117,863,955\end{array}$ & $\begin{array}{r}7,061,886 \\
172,242,893\end{array}$ \\
\hline \multicolumn{7}{|l|}{ Interstate Movements } \\
\hline Company-owned Gas ................................... & 0 & 0 & 0 & 0 & 0 & 0 \\
\hline Transported/Exchange Gas ..................... & $514,901,129$ & $505,007,481$ & $457,006,481$ & 0 & $8,295,755$ & $78,637,038$ \\
\hline 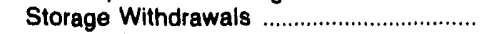 & 0 & 0 & 0 & 0 & 0 & 0 \\
\hline Received from Storage Operators ........... & 0 & 0 & 0 & 0 & 0 & 0 \\
\hline 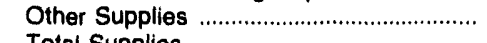 & 5,606 & $\begin{array}{r}4,007 \\
\end{array}$ & $\begin{array}{r}2,291 \\
\end{array}$ & $\begin{array}{r}0 \\
0\end{array}$ & $\begin{array}{r}0 \\
0\end{array}$ & $\begin{array}{r}0 \\
257017\end{array}$ \\
\hline 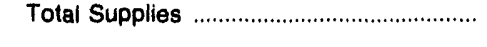 & $514,906,735$ & $505,011,488$ & $457,008,772$ & $22,828,642$ & $128,097,655$ & $257,941,817$ \\
\hline \multicolumn{7}{|l|}{ DISPOSITION } \\
\hline 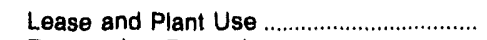 & 0 & 0 & 0 & 0 & 5,612 & 1,045 \\
\hline $\begin{array}{l}\text { Returned to Formations } \\
\text { Interstate Movements }\end{array}$ & 0 & 0 & 0 & 0 & 0 & 0 \\
\hline 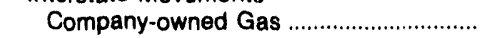 & 0 & 0 & 0 & 0 & 0 & 0 \\
\hline 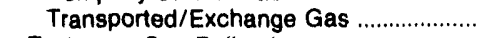 & $505,007,481$ & $457,006,481$ & 0 & $8,295,755$ & $78,637,038$ & $143,053,862$ \\
\hline Exchango Gas Deliveries ............................ & 0 & 0 & 0 & 0 & 0 & 0 \\
\hline $\begin{array}{l}\text { Storage Injections .......................................... } \\
\text { Deliveries of Company-owned Gas }\end{array}$ & 0 & \multicolumn{4}{|c|}{ Deliveries of Company-owned Gas } & 0 \\
\hline 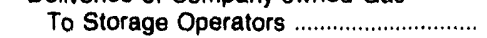 & 0 & 0 & 0 & 0 & 0 & 0 \\
\hline 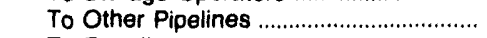 & 0 & 0 & 0 & 0 & 0 & 0 \\
\hline 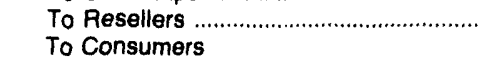 & 0 & 0 & 0 & 0 & $11,231,424$ & 143,072 \\
\hline 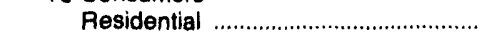 & 0 & 0 & 0 & 0 & 0 & 15 \\
\hline 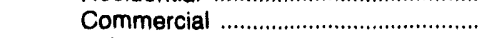 & 0 & 0 & 0 & 0 & 90,017 & 56,445 \\
\hline 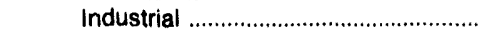 & 0 & 0 & 0 & 0 & 0 & 0 \\
\hline 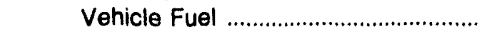 & 0 & 0 & 0 & 0 & 0 & 0 \\
\hline 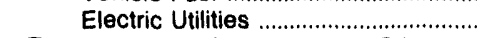 & 0 & 0 & 0 & 0 & 0 & 0 \\
\hline \multicolumn{7}{|l|}{ Transported for the Account of Others } \\
\hline 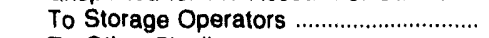 & 0 & 0 & 0 & 0 & 0 & 0 \\
\hline 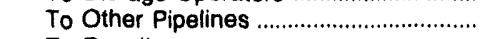 & $8,279,642$ & $47,717,242$ & $457,019,479$ & 0 & 0 & 0 \\
\hline 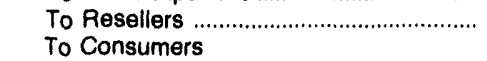 & 0 & 0 & 0 & $14,300,768$ & $34,870,858$ & $110,715,588$ \\
\hline 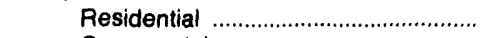 & 0 & 0 & 0 & 0 & 0 & 0 \\
\hline 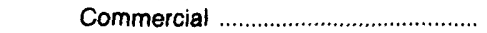 & 0 & 0 & 0 & 11,321 & 0 & 0 \\
\hline 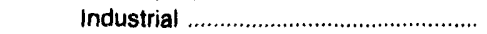 & 0 & 0 & 0 & 0 & 0 & 0 \\
\hline 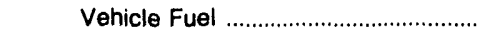 & 0 & 0 & 0 & 0 & 0 & 0 \\
\hline 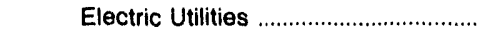 & 0 & 0 & 0 & 0 & 0 & 0 \\
\hline Pipeline/Compressor Fuel ............................. & $1,647,483$ & 307,686 & 682 & 220,798 & $3,262,706$ & $3,971,790$ \\
\hline 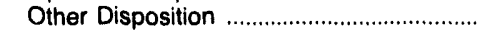 & 0 & 0 & 0 & 0 & 0 & 0 \\
\hline 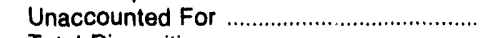 & $-27,871$ & $-19,921$ & $-11,389$ & 0 & 0 & 0 \\
\hline 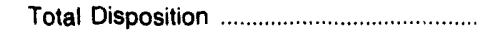 & $514,906,735$ & $505,011,488$ & $457,008,772$ & $22,828,642$ & $128,097,655$ & $257,941,817$ \\
\hline
\end{tabular}


Table 17. Enron Corp. Natural Gas Data, 1992 (Continued) (Thousand Cubic Feet)

\begin{tabular}{l|c|c|c|c}
\hline \multirow{2}{*}{ Supply/Disposition } & Transwestern Pipeline Co & Black Marlin Pipeline Co. & Intratex Gas Co. \\
\cline { 2 - 5 } & Arizona & Texas & Oklahoma & Texas \\
\hline
\end{tabular}

\section{SUPPLY}

Produced Onsystem Receipts

Purchases

Transported/Exchange Gas

Interstate Movements

Company-owned Gas ..............................

Transported/Exchange Gas

Storage Withdrawals

Received from Storage Operators

Other Supplies

coposition

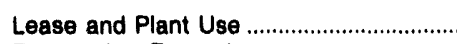

Returned to Formations ............................

Interstate Movements

Company-owned Gas

Transported/Exchange Gas

Exchange Gas Deliveries

Storage Injections .............

Deliveries of Company-owned Gas

To Storage Operators

To Other Pipelines

To Resellers ......

To Consumers

Residential

Commercial

Industrial

Vehicle Fuel

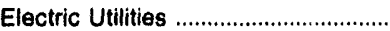

Transported for the Account of Others

To Storage Operators

To Other Pipelines

To Resellers

To Consumers

Pesidential

Commercial

Industrial

Vehicle Fuel

Electric Utiities

Pipeline/Compressor Fuel

Other Disposition

Unaccounted For
0

0
$143,053,862$
0
0
0
$143,053,862$

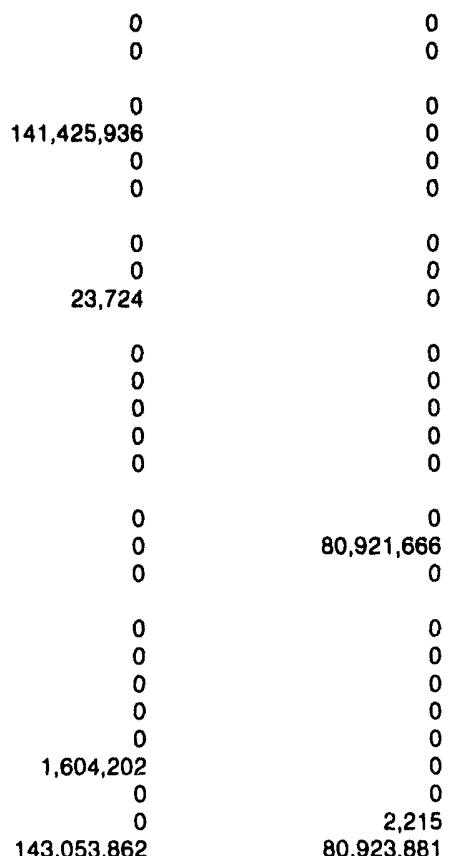

$29,146,364$

$51,775,302$

$80,923,881$
0
$51,775,302$

$1,697,618$

0

$51,775,302$

$299,715,986$

$\begin{array}{rr}0 & 0 \\ 0 & 0 \\ 0 & 0 \\ 0 & 0 \\ 0 & 0 \\ 51,775,302 & 299,715,986\end{array}$

$\begin{array}{rr}0 & 1,172,593 \\ 0 & 0 \\ 0 & 0 \\ 51,775,302 & 0 \\ 0 & 0 \\ 0 & 0 \\ 0 & 0 \\ 0 & 0 \\ 0 & 0 \\ 0 & 1,028,450 \\ 0 & 0 \\ 0 & 0 \\ 0 & 0 \\ 0 & 0 \\ 0 & 0 \\ 0 & 0 \\ 0 & 0 \\ 0 & 0 \\ 0 & 0 \\ 0 & 273,870,876 \\ 0 & 2,574,306 \\ 0 & 0 \\ 0 & 18,371,014 \\ 0 & 1,760,237 \\ 0 & 0 \\ 51,775,302 & 938,510 \\ & 299,986\end{array}$

Source: Energy Information Administration (EIA), Form ElA-176, "Annual Report of Natural and Supplemental Gas Supply and Disposition." 
Table 18. Enron Corp. Interstate Flows of Natural Gas, 1992 (Thousand Cubic Feet)

\begin{tabular}{|c|c|c|c|}
\hline Company and State & Volume & Company and State & Volume \\
\hline \multicolumn{2}{|l|}{$\begin{array}{l}\text { Florida Gas Trans Co. } \\
\text { Texas To }\end{array}$} & \multicolumn{2}{|l|}{$\begin{array}{l}\text { Northern Border Pipeline Co. } \\
\text { Canada To }\end{array}$} \\
\hline 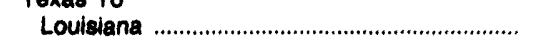 & $75,654,683$ & 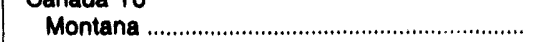 & $446,560,523$ \\
\hline Louisiana To & & Montana To & \\
\hline $\begin{array}{l}\text { Mississippi } \\
\text { Mississippi To }\end{array}$ & $267,679,039$ & 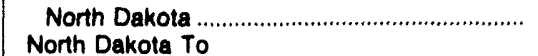 & $446,825,776$ \\
\hline $\begin{array}{l}\text { Alabama } \\
\text { Alabama To }\end{array}$ & $285,494,330$ & 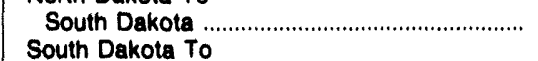 & $514,901,129$ \\
\hline Florida & $292,878,833$ & $\begin{array}{l}\text { Minnnesota } \\
\text { Minnesota To }\end{array}$ & $505,007,481$ \\
\hline & & lowa & $457,006,481$ \\
\hline \multicolumn{4}{|l|}{ Northern Natural Gas Co. } \\
\hline $\begin{array}{l}\text { Minnnesota } \\
\text { Minnesota To }\end{array}$ & $24,786,876$ & $\begin{array}{l}\text { Transwestern Pipeline Co. } \\
\text { Oklahoma To }\end{array}$ & \\
\hline $\begin{array}{l}\text { lowa } \\
\text { Wisconsin }\end{array}$ & $\begin{array}{r}4,821,891 \\
42,320,739\end{array}$ & Texas & $8,295,755$ \\
\hline Wisconsin To & & 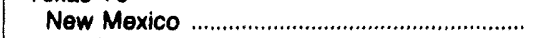 & $78,637,038$ \\
\hline 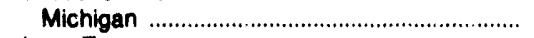 & $22,091,273$ & New Mexico To & \\
\hline lowa To & & Arizona ............... & $143,053,862$ \\
\hline Illinois & $166,840,600$ & Arizona To & \\
\hline $\begin{array}{l}\text { Minnnesota } \\
\text { South Dakota }\end{array}$ & $\begin{array}{r}195,238,720 \\
490,739\end{array}$ & California ........................ & $141,425,936$ \\
\hline \multicolumn{4}{|l|}{ Illinois To } \\
\hline $\begin{array}{l}\text { Wisconsin } \\
\text { South Dakota To }\end{array}$ & $84,174,650$ & $\begin{array}{l}\text { Black Marlin Pipeline Co. } \\
\text { Oklahoma To }\end{array}$ & \\
\hline lowa & 268,900 & 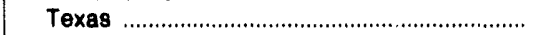 & $51,775,302$ \\
\hline \multicolumn{4}{|l|}{ Oklahoma To } \\
\hline Kansas & $\begin{array}{r}187,392,263 \\
49,144,451\end{array}$ & & \\
\hline \multicolumn{4}{|l|}{ Kansas To } \\
\hline \multicolumn{4}{|l|}{$\begin{array}{l}\text { Nebraska } \\
\text { Nebraska To }\end{array}$} \\
\hline $\begin{array}{l}\text { lowa } \\
\text { South Dakota } \\
\text { New Mexico To }\end{array}$ & $\begin{array}{r}259,818,185 \\
10,187,770\end{array}$ & & \\
\hline Texas & $41,035,818$ & & \\
\hline 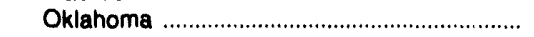 & $123,183,710$ & & \\
\hline
\end{tabular}




\section{Equitable Resources, Inc.}

Equitrans, Inc., Kentucky West Virginia Gas Company, and Equitable Gas Company are subsidiaries of Equitable Resources, Inc. The pipeline operations in Pennsylvania and West Virginia are conducted by Equitrans, Inc., and in Kentucky by Kentucky West Virginia Gas Company. The 264,000 customers in parts of West Virginia, Kentucky, and southwestern Pennsylvania, including the city of Pittsburgh are served by Equitable Gas Company. Equitrans was formed in 1988 to operate the interstate transmission and underground storage facilities in Pennsylvania and West Virginia. Kentucky West Virginia Gas Co. provides producers in eastern Kentucky with gathering services and transportation to other pipelines. Other subsidiaries are involved in natural gas marketing, contract drilling and well services in the Appalachian Basin, and the development of a coalbed methane program in Virginia.

With the advent of FERC Order 636, which unbundles natural gas services, there will be a greater reliance on storage. Transportation, storage, balancing and peaking were formerly packaged together with the gas sale. They will be unbundled, priced separately, and offered to the market on a competitive and non-discriminatory basis under the new tariffs. Equitrans proposed new storage offerings in its Order 636 filing, including 10 , 30 , and 60-day winter peaking service, for which it

Figure 14. Equitable Resources, Inc., 1992

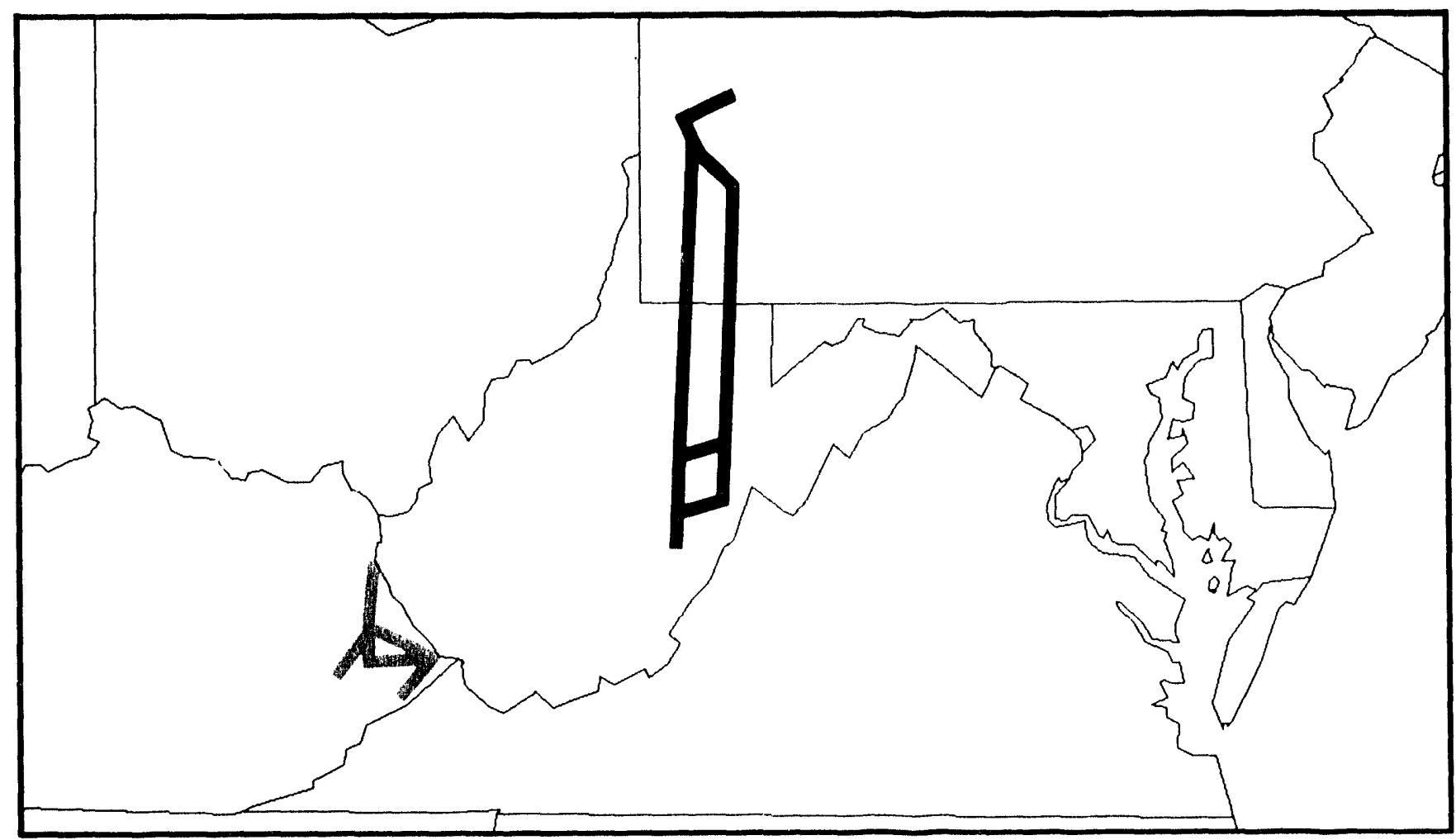

Source: Energy Information Administration (EIA), Form EIA-176, "Annual Report of Natural and Supplemental Gas Supply and Disposition." 
Table 19. Equitable Resources, Inc., Natural Gas Data, 1992

(Thousand Cubic Feet)

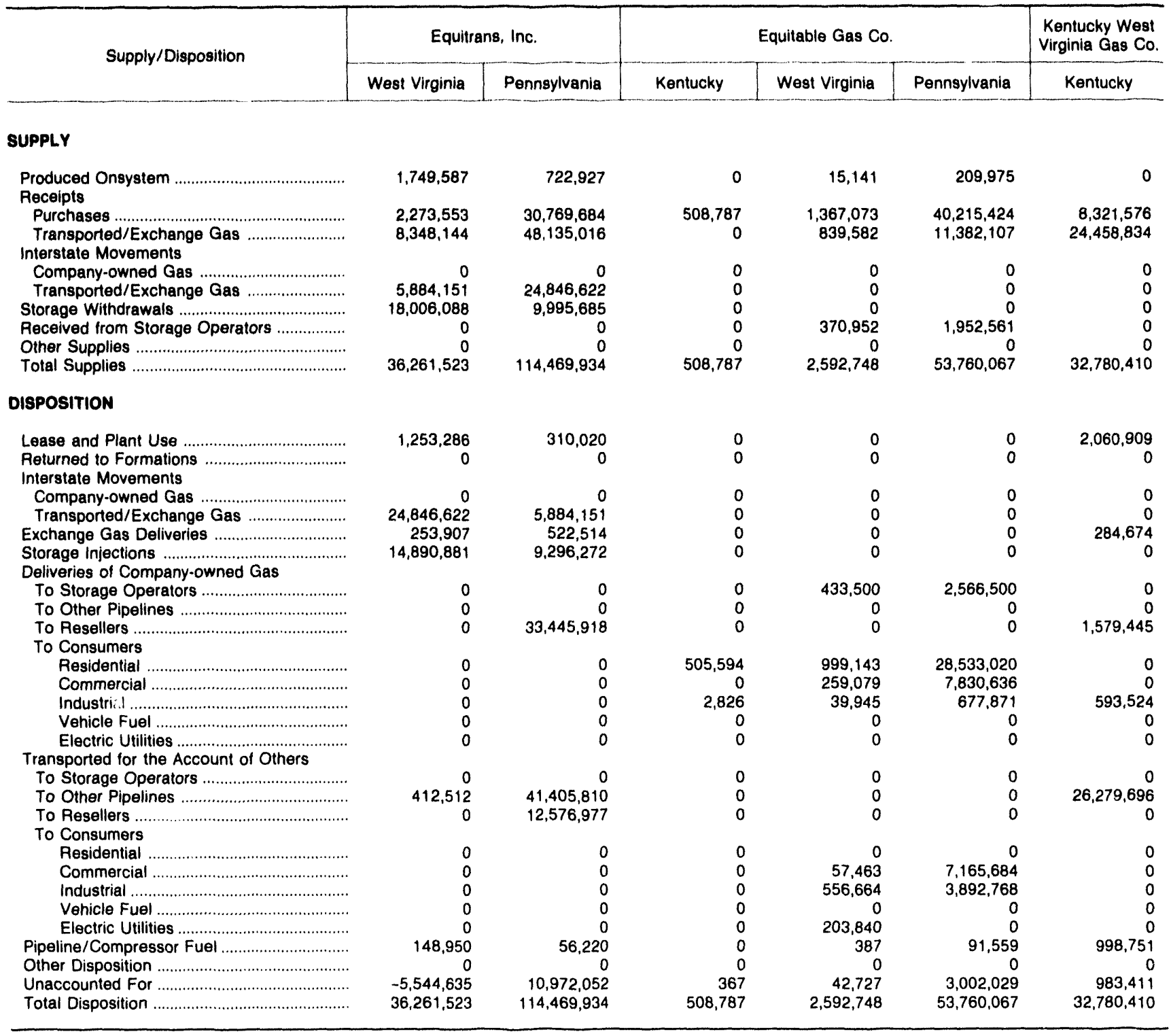

Source: Energy Information Administration (EIA), Form ElA-176, "Annual Report of Natural and Supplemental Gas Supply and Disposition."

would use approximately 4.5 billion cubic feet of its existing capacity.

Equitrans is adding 5 billion cubic feet to its existing 25 billion cubic feet of underground storage working capacity over the next 3 years. Several new storage ventures are also planned. The Avoca project, located south of Rochester, New York, will be the first salt strata market-area storage developed on the east coast. It is expected to be completed in 1995.

Equitable is also quite active in the natural gas vehicle market. Two of its buses took part in the inauguration ceremonies, one being used to transport the vice pres- idential party. By the end of 1992, Equitable was operating 10 natural gas refueling stations and hoped to add another 6 by the end of 1993 . Pittsburgh is planning on adding 15 new buses and 18 other natural gas vehicles during 1993. This and other fleet expansions will lead the number of natural gas vehicles supported by Equitable to more than double the 70 vehicles supported at the end of 1992.

In addition, Equitable is involved in natural gas cooling, fuel cells, and the power generation market. It has added new customers including a hospital, bank, school, and office complex to its natural gas cooling load. It also participates in fuel cell demonstration projects. 


\section{Gas Company of New Mexico}

Public Service Company of New Mexico (PSNM) is a publicly owned combination gas and electric utility company serving numerous communities in the State of New Mexico. PSNM also owns facilities for the storage, transmission, distribution, and sale of water in Santa Fe, New Mexico. In 1992, PSNM derived 70 percent of its utility operations revenues from electric operations, 28.5 percent from natural gas operations, and 1.5 percent from water operations.

Natural gas distribution operations are conducted by PSNM's subsidiary, Gas Company of New Mexico (GasCo). Other subsidiaries, Sunterra Gas Gathering
Company and Sunterra Gas Processing Company provide gathering and processing services, respectively.

GasCo distributes natural gas to approximately 362,000 customers in Albuquerque and Santa $\mathrm{Fe}$ and other communities, with Albuquerque accounting for slightly more than half of the company's total natural gas customers. During 1992, GasCo provided both sales and transportation services to commercial and industrial customers, and sales services only to residential customers. Sales and transportation services accounted for around 68 percent and 32 percent, respectively, of GasCo's total gas deliveries to end users.

Figure 15. Gas Company of New Mexico, 1992

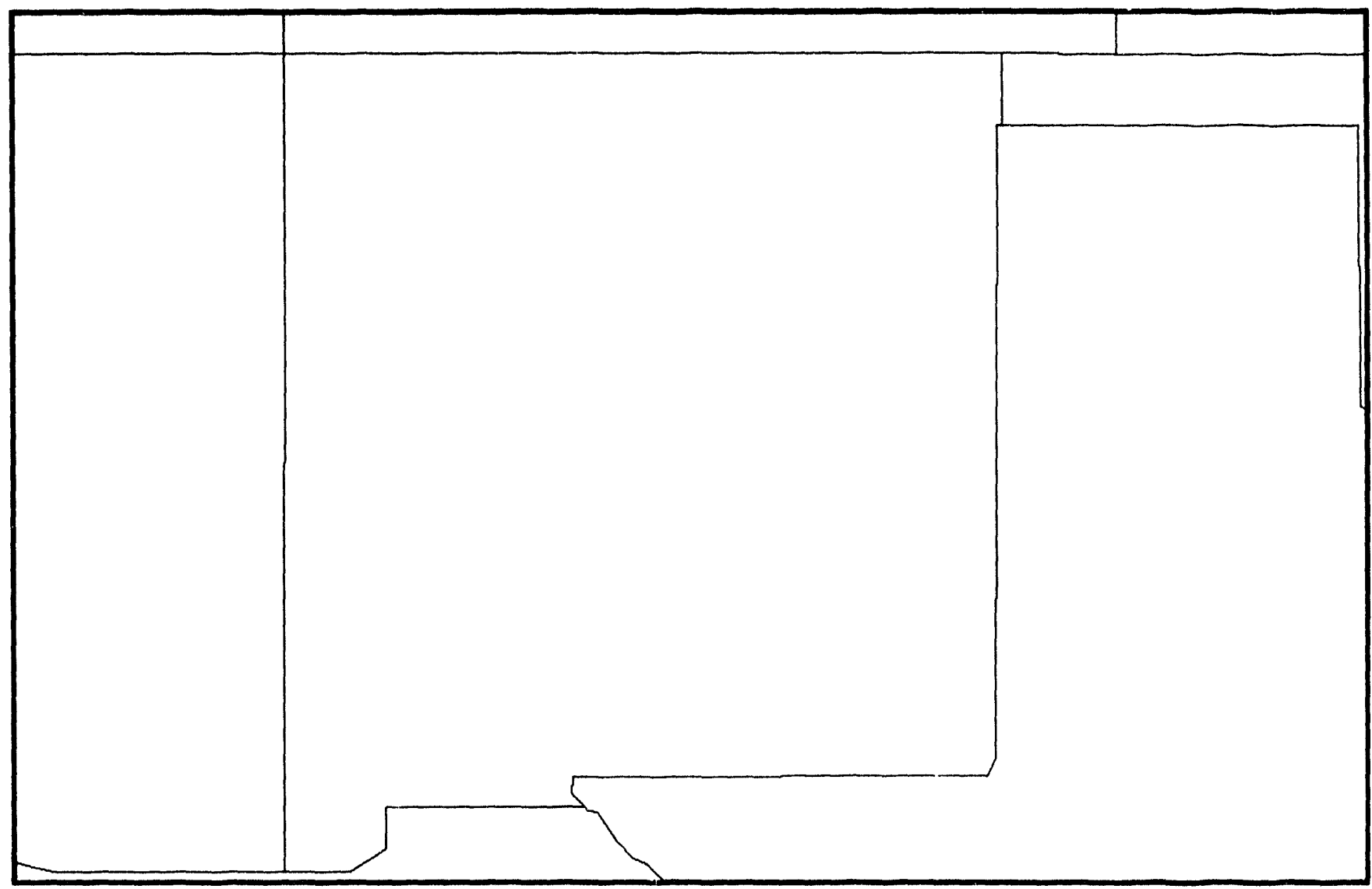

Source: Energy Information Administration (EIA), Form EIA-176, "Annual Report of Natural and Supplemental Gas Supply and Disposition." 
Table 20. Gas Company of New Mexico Natural Gas Data, 1992 (Thousand Cubic Feet)

\begin{tabular}{l|c}
\hline \multirow{2}{*}{ Supply/Disposition } & Gas Company of New Mexico \\
\cline { 2 - 2 } & New Mexico \\
\hline
\end{tabular}

SUPPLY

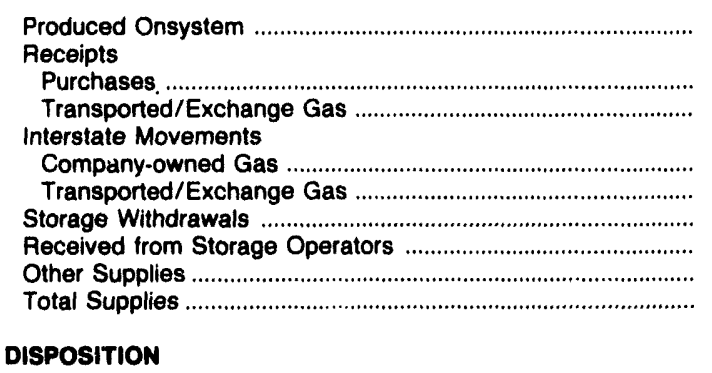

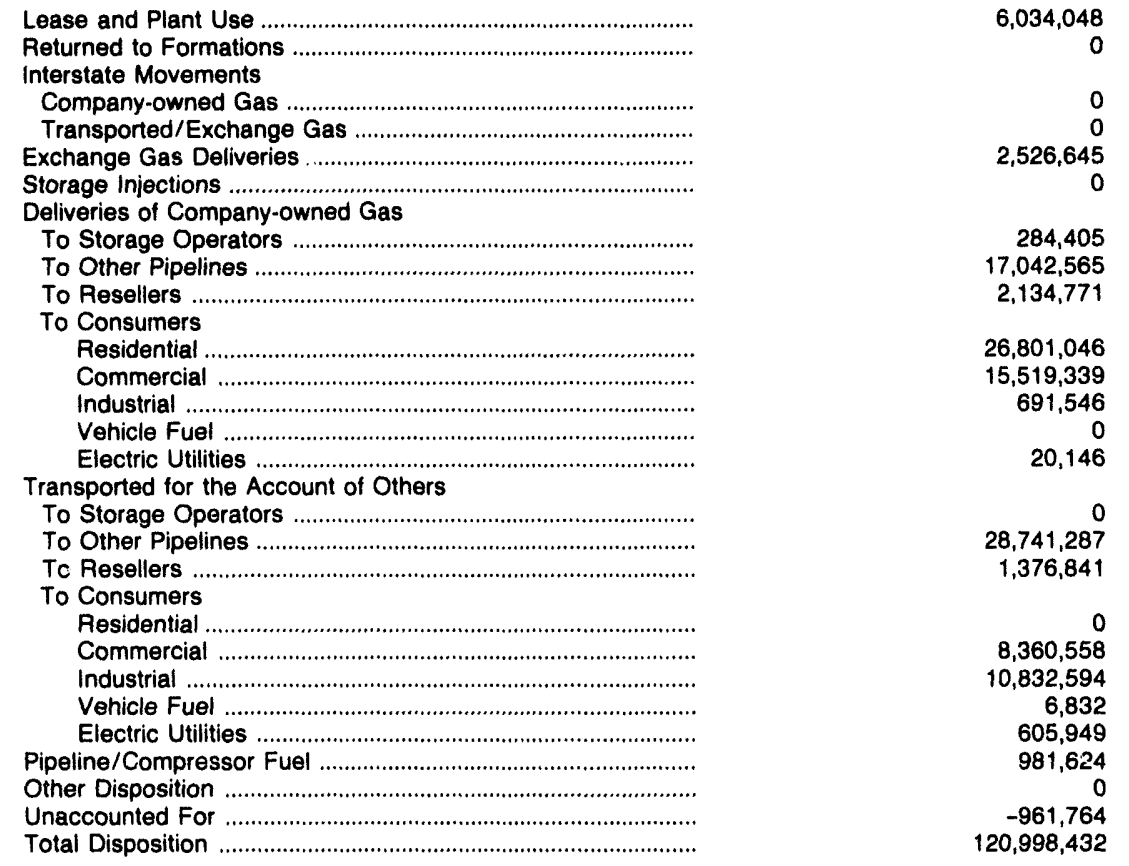

\section{0}

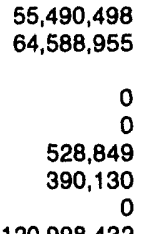

$120,998,432$

Source: Energy Information Administration (EIA), Form EIA-176, "Annual Report of Natural and Supplemental Gas Supply and Disposition."

At the end of 1992, GasCo owned 9,200 miles of distribution lines, 550 miles of gathering pipe, and 1,300 miles of transmission lines. It held leases on 130 miles of pipe from the Department of Energy for transportation of natural gas to Los Alamos and other northern New Mexico communities. The Company's processing facilities in northwestern New Mexico have the capacity for processing 300 thousand cubic feet of gas per day.

PSNM submitted a plan to the New Mexico Public Service Commission in the summer of 1993 to propose a restructuring framework for the Company with an emphasis on lower prices, expanded customer choices, and reduced corporate debt by consolidation of certain electric and gas operations. The purpose of this filing was to focus on the Company's goal of service to retail customers in New Mexico. One of the specific actions PSNM is proposing is the disposal of all or major parts of its natural gas gathering and processing assets, along with their related contractual obligations. These sales would be structured so that GasCo would maintain an adequate supply of reasonably priced natural gas.

GasCo uses natural gas powered vehicles as a part of the Company's fleet of service vehicles. The company and the State worked together to promote the use of natural gas vehicles in a program that won a President's Environment and Conservation Challenge Award. 


\section{Iroquois Gas Transmission System}

Iroquois Gas Transmission is a transportation-only pipeline, providing gas service from Canada to the Northeastern United States. The pipeline began operations in December 1991, with an initial 192 miles of transport service, stretching from the Canadian border to Wright, New York. The entire 375-mile Iroquois system, completed in January 1992, transports gas to customers in Connecticut, Massachusettes, Rhode Island, New Hampshire, New York, and New Jersey. With its newly operational compressor station in Wright, New York, Iroquois' capacity was boosted to 607 million cubic feet per day.
The Company provides direct deliveries to various shippers as well as upstream transportation service for shippers on the Tennessee and Algonquin systems. It extends from the U.S./Canada border at Waddington, New York, across the States of New York and Connecticut to South Commack and Long Island, New York. Iroquois interconnects with Tennessee Gas Pipeline Co. at Wright, New York, and Shelton, Connecticut; with Consolidated Natural Gas Transmission at Canajoharie, New York; and with Algonquin at Brookfield, Connecticut. Of the gas delivered, 80 percent is delivered to local distribution companies and the remaining 20 percent is delivered directly to power generators. New York and New Jersey will use 56 per-

Figure 16. Iroquois Gas Transmission System, 1992

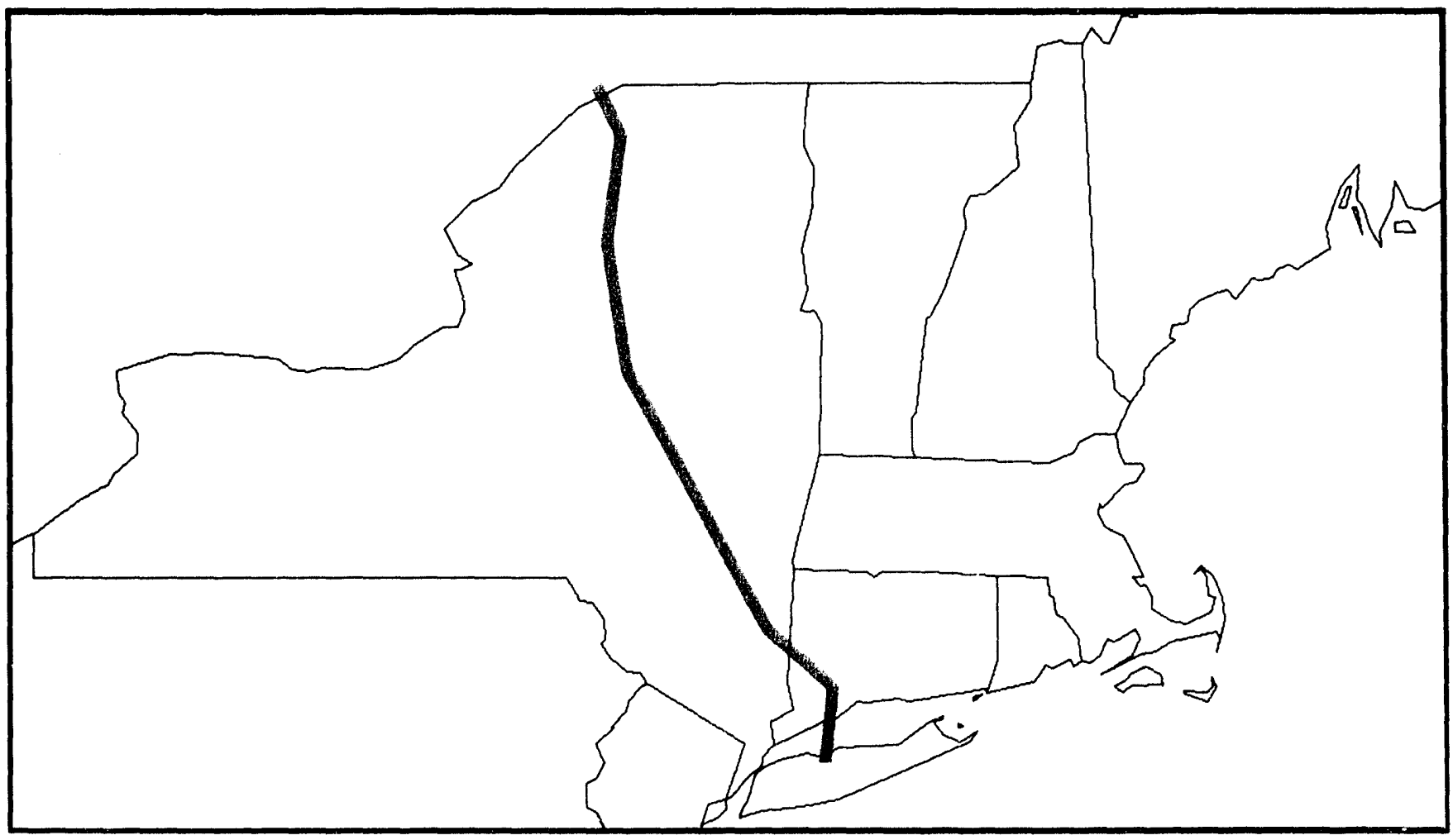

Source: Energy information Administration (ElA), Form ElA-176, "Annual Report of Natural and Supplemental Gas Supply and Disposition."

troquois Gas Transmission System 
Table 21. Iroquols Gas Transmission System Natural Gas Data, 1992 (Thousand Cubic Feet)

\begin{tabular}{l|c|c}
\hline \multirow{2}{*}{ Supply/Disposition } & \multicolumn{2}{|c}{ Iroquois Gas Transmission System } \\
\cline { 2 - 3 } & New York & Connecticut \\
\hline
\end{tabular}

SUPPLY

Produced Onsystem

Receipts

Purchases

Transported/Exchange Gas

Interstate Movements

Company-owned Gas

Exchange Gas

Storage Withdrawals

Received from Storage

Other Supplies

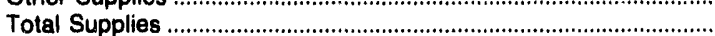

DISPOSITION

Lease and Plant Use...

Returned to Formations

Interstate Movements

Company-owned Gas

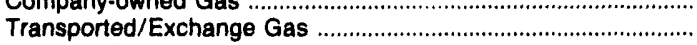

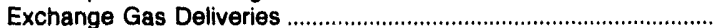

Storage Injections ........

Deliveries of Company-owned Gas

To Storage Operators

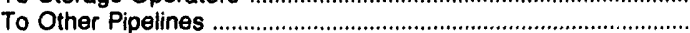

To Resellers ...........

To Consumers

Residential

Commercial

Industrial ....

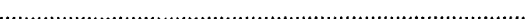

Vehicle Fuel

Electric Utilities

Transported for the Account of Others

To Storage Operators

To Resellers

To Consumers

Residential

Commercial

Industrial

Vehicle Fuel

Electric Utilities

Pipeline/Compressor Fuel

Other Disposition

Unaccounted For

Fition

$\begin{array}{rr}0 & 0 \\ 0 & 0 \\ 2,741,708 & 0 \\ 0 & \\ 246,014,203 & 0 \\ 0 & 83,255,236 \\ 0 & 0 \\ 677,376 & 0 \\ 249,433,287 & 0 \\ & 83,255,236\end{array}$

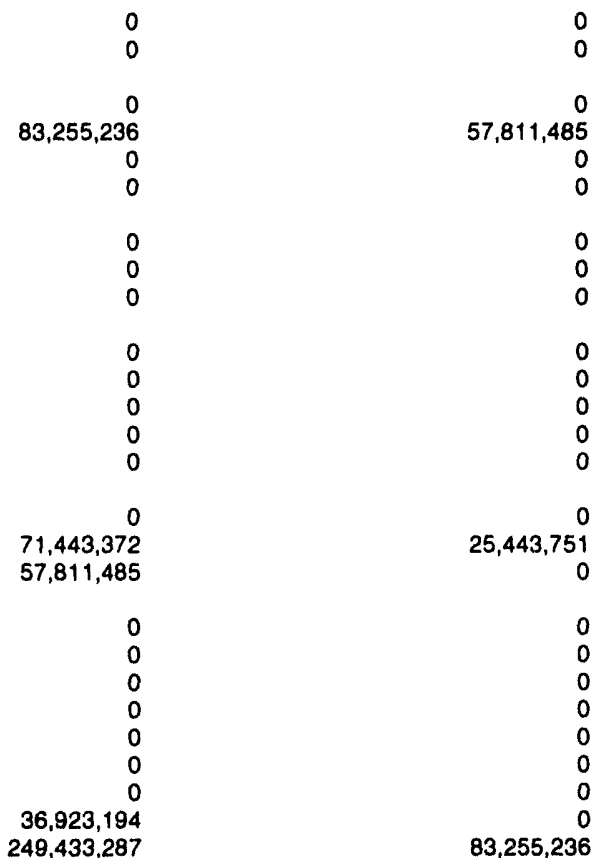

Source: Energy Information Administration (EIA), Form EIA-176, "Annual Report of Natural and Supplemental Gas Supply and Disposition."

cent of the gas while the balance, 44 percent, will be used in Connecticut, Massachusetts, Rhode Island and New Hampshire.

Iroquois expects to build two new facilities. The first will provide 55 million cubic feet of gas per day to Selkirk Cogen Partners, in Selkirk, New York. This facility, which will begin operations in November 1994, will interconnect between Tennessee Gas and Iroquois at Wright, New York, for delivery to Selkirk, New York. The second facility will provide 44.5 million cubic feet of gas per day to a power project in
Rotterdam, New York, and anticipates an in-service date of July 1995.

Iroquois is owned by TransCanada Pipeline Limited; Tennessee Gas Pipeline Company; Brooklyn Union Gas Company; Yankee Energy Systems, Inc.; CNG Transmission Corporation; ANR Pipeline Company, Inc.; AEC Pipelines; J. Makowski Company, Inc.; New Jersey Resources Corporation; Connecticut Natural Gas Corporation; New York Power Authority, and the Long Island Lighting Company. 


\section{K N Energy, Inc.}

$\mathrm{K} \mathrm{N}$ Energy, Inc. $(\mathrm{KN})$ is a natural gas service company providing gas to residential, commercial, industrial, and electric utility customers. Unlike most companies in the natural gas industry, KN serves as both a transmission pipeline and a local distribution company. KN operates in 7 States and serves its customers through three pipeline systems, covering over 18,000 miles. KN's interstate pipeline system acquires gas from producing areas in Texas, Oklahoma, Kansas, Colorado, Wyoming, and Montana and distributes it to resellers and end users throughout its service area.

Northern Gas Company, a KN subsidiary, operates a 1,700-mile intrastate pipeline in Wyoming. Northern
Gas reports on the Form EIA-176 as two separate divisions: Northern Gas Co. and Northern Gas of Wyoming. Rocky Mountain Natural Gas Company (RMNG) operates a 2,100-mile intrastate pipeline in Colorado, which receives natural gas from another KN subsidiary, TCP Gathering, in Utah. RMNG also reports on the Form EIA-176 as two divisions: Rocky Mountain Natural Gas Co. and Rocky Mountain Natural Gas Division.

Several additions to $\mathrm{KN}$ 's pipeline system were completed during 1992. In Northeast Wyoming, KN's Northern Gas Division purchased a natural gas distribution system serving almost 7,000 direct retail cus-

Figure 17. K N Energy, Inc., 1992

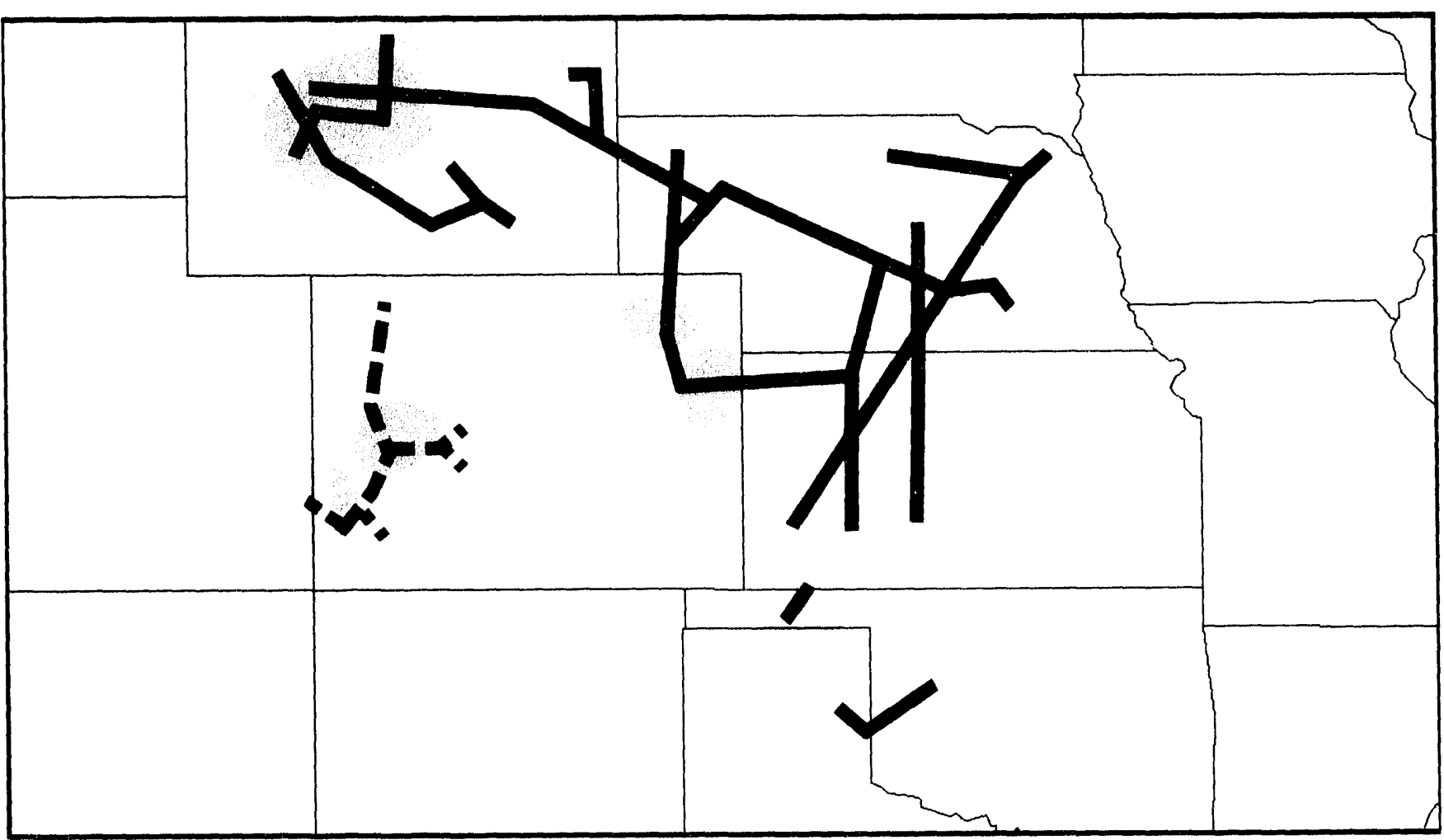

Source: Energy Information Administration (EIA), Form EIA-176, "Annual Report of Natural and Supplemental Gas Supply and Disposition."

Supply Areas

Service Areas
K N Energy, Inc.

$=$ Colorado Intrastate System
Wyoming Intrastate System 
Table 22. K N Energy, Inc., Natural Gas Data, 1992 (Thousand Cubic Feet)

\begin{tabular}{|c|c|c|c|c|c|}
\hline \multirow{2}{*}{ Supply/Disposition } & \multicolumn{5}{|c|}{ K N Energy, Inc. } \\
\hline & Texas & Oklahoma & Kansas & Nebraska & Colorado \\
\hline \multicolumn{6}{|l|}{ SUPPLY } \\
\hline $\begin{array}{l}\text { Produced Onsystem } \\
\text { Receipts }\end{array}$ & 0 & 0 & 0 & 0 & 0 \\
\hline 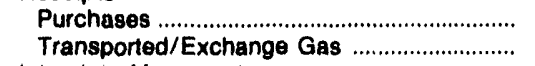 & $\begin{array}{r}118,484 \\
24,653,701\end{array}$ & $\begin{array}{r}3,015,174 \\
19,864,178\end{array}$ & $\begin{array}{r}39,250,560 \\
7,500,205\end{array}$ & $\begin{array}{l}572,877 \\
632,910\end{array}$ & $\begin{array}{r}11,273,615 \\
5,216,938\end{array}$ \\
\hline \multicolumn{6}{|l|}{ Interstate Movements } \\
\hline 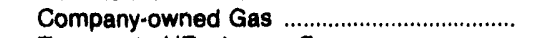 & 0 & 0 & 0 & 0 & 0 \\
\hline 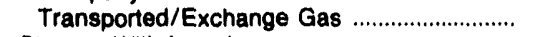 & 0 & $1,695,024$ & $5,372,178$ & $47,552,242$ & $4,496,212$ \\
\hline 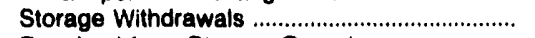 & 0 & 0 & 212,690 & $9,847,836$ & 87,007 \\
\hline Received from Storage Operators ..................... & 0 & 0 & 0 & 0 & 0 \\
\hline 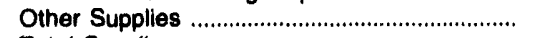 & 0 & 0 & 0 & $1,419,665$ & 0 \\
\hline 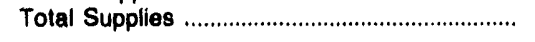 & $24,772,185$ & $24,574,376$ & $52,335,633$ & $60,025,530$ & $21,073,772$ \\
\hline \multicolumn{6}{|l|}{ DISPOSITION } \\
\hline 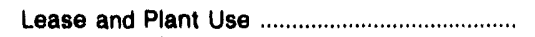 & 0 & $1,407,765$ & $6,141,088$ & 0 & 136,026 \\
\hline $\begin{array}{l}\text { Returned to Formations } \\
\text { Interstate Movements }\end{array}$ & 0 & 0 & 0 & 0 & 0 \\
\hline 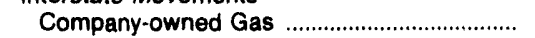 & $1,695,024$ & 0 & $17,308,618$ & $4,498,646$ & $7,737,535$ \\
\hline 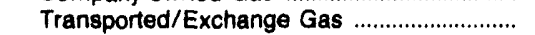 & 0 & 0 & 0 & 0 & 0 \\
\hline 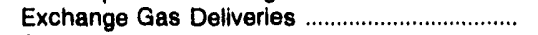 & 0 & $2,283,657$ & $3,614,315$ & 0 & 0 \\
\hline Storage Injections & 0 & 0 & 88,606 & $10,254,494$ & 93,903 \\
\hline \multicolumn{6}{|l|}{ Deliveries of Company-owned Gas } \\
\hline 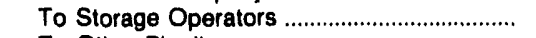 & 0 & 0 & 0 & 0 & 0 \\
\hline 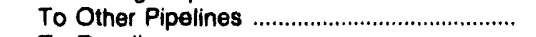 & 0 & 58,115 & 0 & 0 & 0 \\
\hline 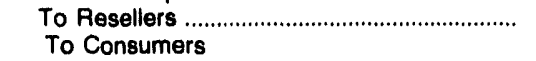 & 0 & 0 & $4,289,698$ & $9,826,880$ & $9,921,222$ \\
\hline Residential . & 226 & 1,784 & $2,437,249$ & $7,540,650$ & 530,544 \\
\hline 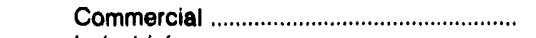 & 670 & 39,144 & $5,961,315$ & $10,347,507$ & 568,517 \\
\hline 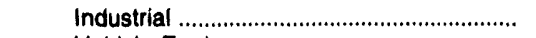 & 0 & 0 & 61,782 & 20,674 & 130,830 \\
\hline Vehicle Fuel ..................................................... & 0 & 0 & 0 & 0 & 0 \\
\hline 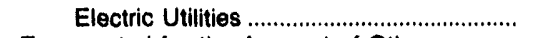 & 0 & 0 & 40,437 & 22,186 & 0 \\
\hline \multicolumn{6}{|l|}{ Transported for the Account of Others } \\
\hline To Storage Operators & 0 & 0 & 0 & 0 & 0 \\
\hline 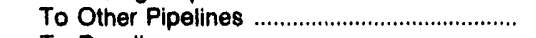 & $22,904,845$ & $20,582,266$ & $12,440,845$ & 0 & 749,556 \\
\hline $\begin{array}{l}\text { To Resellers ........................................................ } \\
\text { To Consumers }\end{array}$ & 0 & 0 & 0 & $11,375,989$ & 0 \\
\hline 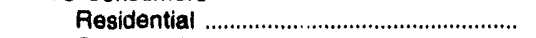 & 0 & 0 & 0 & 0 & 0 \\
\hline 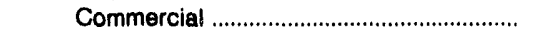 & 0 & 0 & 0 & $2,364,525$ & 0 \\
\hline 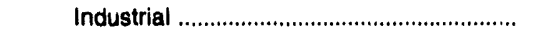 & 0 & 0 & 745,080 & $2,172,116$ & 0 \\
\hline 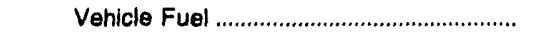 & 0 & 0 & 0 & 0 & 0 \\
\hline 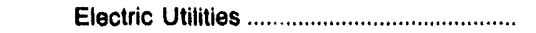 & 0 & 0 & 0 & 975,903 & 0 \\
\hline Pipeline/Compressor Fuel ....................................... & 285,633 & 98,347 & $1,797,656$ & 569,825 & 338,430 \\
\hline 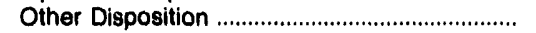 & 0 & 0 & 0 & 0 & 0 \\
\hline 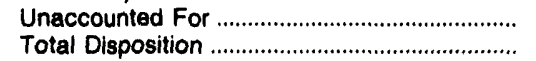 & $\begin{array}{r}-114,213 \\
24,772,185\end{array}$ & $\begin{array}{r}103,298 \\
24,574,376\end{array}$ & $\begin{array}{l}-2,591,056 \\
52,335,633\end{array}$ & $\begin{array}{r}56,135 \\
60,025,530\end{array}$ & $\begin{array}{r}867,209 \\
21,073,772\end{array}$ \\
\hline
\end{tabular}

tomers and providing an additional 1.1 billion cubic feet of natural gas sales. KN Gas Gathering, Inc., a KN subsidiary, acquired a nonregulated natural gas gathering and processing facility located near Douglas, Wyoming. Another KN subsidiary, GASCO, Inc., bought oil and gas producing property in the Piceance Basin, located in western Colorado. $\mathrm{KN}$ has also acquired two natural gas gathering systems, located in the major Rocky Mountain production areas. The first was the 1,250-mile Wattenberg system in the DenverJulesburg Basin in Colorado. Ine second comprises 110 miles of natural gas pipeline and related field facilities in the Wind River Basin of Wyoming.

Currently pending is the TransColorado transmission pipeline project, a joint venture among KN subsidiaries, Questar Corporation, and Public Service Company of Colorado. It is expected to have a daily capacity of 300 million cubic feet of gas and will access various Rocky Mountain region reserve basins. Construction is expected to begin in 1994.

Distribution of KN's gas sales in 1992 continue to demonstrate the company's diversity. The company delivered 63 billion cubic feet to other pipelines, 54 billion cubic feet to resellers, 18 billion cubic feet to residential customers, 25 billion cubic feet to commercial customers, 19 billion cubic feet to industrial customers, and a small amount to electric utility customers. Additionally, the company's major storage fields located at Huntsman and Big Springs, Nebraska, enable it to meet heavy winter demand without disruption of its normal distribution patterns. 
Table 22. K N Energy, Inc., Natural Gas Data, 1992 (Continued) (Thousand Cubic Feet)

\begin{tabular}{|c|c|c|c|c|c|}
\hline \multirow{2}{*}{ Supply/Disposition } & \multicolumn{2}{|c|}{ K N Energy, Inc. } & Northern Gas Co. & $\begin{array}{c}\text { Northern Gas of } \\
\text { Wyoming }\end{array}$ & \multirow{2}{*}{$\begin{array}{l}\text { Rocky Mountain } \\
\text { Natural Gas Div } \\
\text { Colorado }\end{array}$} \\
\hline & Wyoming & Montana & \multicolumn{2}{|c|}{ Wyoming } & \\
\hline \multicolumn{6}{|l|}{ SUPPLY } \\
\hline $\begin{array}{l}\text { Produced Onsystem } \\
\text { Receipts }\end{array}$ & 0 & 0 & 2,393 & 0 & 0 \\
\hline 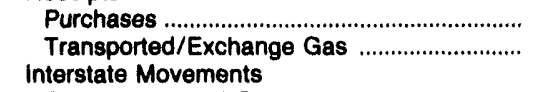 & $\begin{array}{r}9,186,045 \\
29,786,904\end{array}$ & $\begin{array}{r}5,786,098 \\
12,481\end{array}$ & $\begin{array}{r}5,779,725 \\
16,449,960\end{array}$ & $\begin{array}{r}7,154,427 \\
62,070\end{array}$ & $\begin{array}{r}4,796,155 \\
38,532\end{array}$ \\
\hline 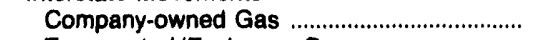 & 0 & 0 & 0 & 0 & 0 \\
\hline 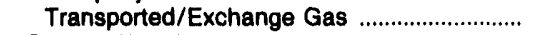 & 0 & 0 & 0 & 0 & 107,492 \\
\hline 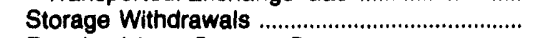 & 0 & 0 & $2,068,220$ & 0 & 0 \\
\hline Received from Storage Operators .................... & 0 & 0 & 0 & 0 & 0 \\
\hline 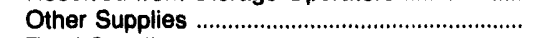 & 0 & 0 & 0 & 0 & 0 \\
\hline Total Supplies & $38,972,949$ & $5,798,579$ & $24,300,298$ & $7,216,497$ & $4,942,179$ \\
\hline \multicolumn{6}{|l|}{ DISPOSITION } \\
\hline 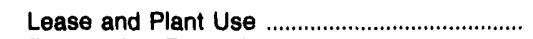 & 591,754 & 0 & 0 & 0 & 0 \\
\hline Returned to Formations ................................... & 0 & 0 & 0 & 0 & 0 \\
\hline \multicolumn{6}{|l|}{ Interstate Movements } \\
\hline 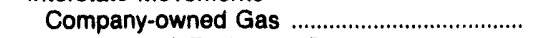 & $27,875,833$ & 0 & 0 & 0 & 0 \\
\hline 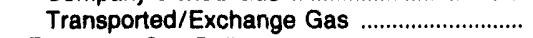 & 0 & 0 & 0 & 0 & 0 \\
\hline Exchange Gas Deliveries ................................... & 0 & $5,891,342$ & 0 & 0 & 0 \\
\hline Storage Injections & 0 & 0 & $2,361,539$ & 0 & 0 \\
\hline \multicolumn{6}{|l|}{ Deliveries of Company-owned Gas } \\
\hline 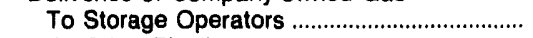 & 0 & 0 & 0 & 0 & 0 \\
\hline 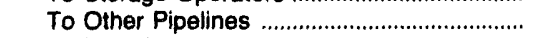 & 0 & 0 & 0 & 0 & 0 \\
\hline To Resellers .................................................. & $4,184,496$ & 0 & $6,465,844$ & 0 & 0 \\
\hline 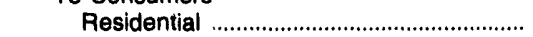 & 816,024 & 0 & 0 & $3,931,428$ & $2,605,417$ \\
\hline 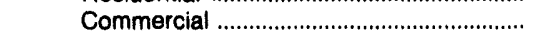 & 582,047 & 0 & 0 & $2,999,779$ & $2,072,707$ \\
\hline 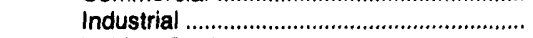 & 0 & 0 & 179,073 & 0 & 25,039 \\
\hline 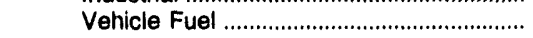 & 0 & 0 & 0 & 0 & 0 \\
\hline 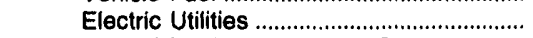 & 0 & 0 & 0 & 0 & 0 \\
\hline \multicolumn{6}{|l|}{ Transported for the Account of Others } \\
\hline To Storage Operators ........................................ & 0 & 0 & 0 & 0 & 0 \\
\hline 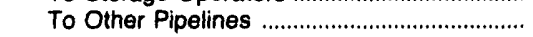 & $5,973,811$ & 12,356 & 0 & 0 & 0 \\
\hline $\begin{array}{l}\text { To Resellers ..................................................... } \\
\text { To Consumers }\end{array}$ & 0 & 0 & 0 & 0 & 0 \\
\hline 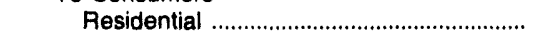 & 0 & 0 & 0 & 0 & 0 \\
\hline 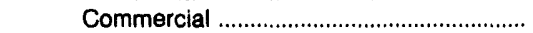 & 0 & 0 & 0 & 106,049 & 0 \\
\hline 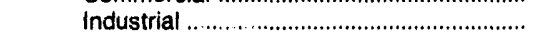 & 16,908 & 0 & $15,228,413$ & 0 & 35,254 \\
\hline 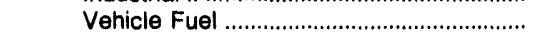 & C & 0 & 0 & 0 & 0 \\
\hline 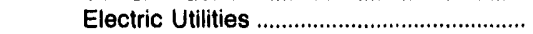 & 0 & 0 & 0 & 0 & 0 \\
\hline Pipeline/Compressor Fuel ................................. & 436,491 & 53,802 & 111,589 & 666 & 20,377 \\
\hline 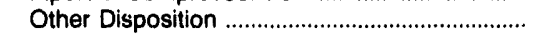 & 0 & 0 & 0 & 0 & 0 \\
\hline 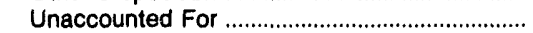 & $-1,504,415$ & $-158,921$ & $-46,160$ & 178,575 & 183,385 \\
\hline Total Disposition & $38,972,949$ & $5,798,579$ & $24,300,298$ & $7,216,497$ & $4,942,179$ \\
\hline
\end{tabular}


Table 22. K N Energy, Inc., Natural Gas Data, 1992 (Continued) (Thousand Cubic Feet)

\begin{tabular}{|c|c|c|c|}
\hline \multirow{2}{*}{ Supply/Disposition } & $\begin{array}{c}\text { Rocky Mountain Natural } \\
\text { Gas Co. }\end{array}$ & TCP Gathering & RMNG Gathering Co. \\
\hline & Colorado & Utah & Colorado \\
\hline \multicolumn{4}{|l|}{ SUPPLY } \\
\hline $\begin{array}{l}\text { Produced Onsystem } \\
\text { Receipts }\end{array}$ & 0 & 0 & 0 \\
\hline 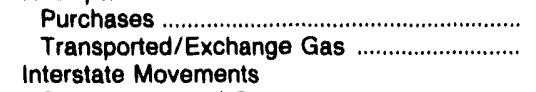 & $\begin{array}{l}4,784,534 \\
2,176,923\end{array}$ & $\begin{array}{r}0 \\
107,492\end{array}$ & $\begin{array}{r}423,660 \\
1,193,097\end{array}$ \\
\hline $\begin{array}{l}\text { Company-owned Gas } \\
\text { Transported/Exchange Gas } \\
\text { Storage Withdrawals } \\
\text { Received from Storage Operators } \\
\text { Other Supplies } \\
\text { Total Supplies }\end{array}$ & $\begin{array}{r}0 \\
0 \\
717,015 \\
0 \\
0 \\
7,678,472\end{array}$ & $\begin{array}{r}0 \\
0 \\
0 \\
0 \\
0 \\
107,492\end{array}$ & $\begin{array}{r}0 \\
0 \\
0 \\
0 \\
0 \\
1,616,757\end{array}$ \\
\hline \multicolumn{4}{|l|}{ DISPOSITION } \\
\hline 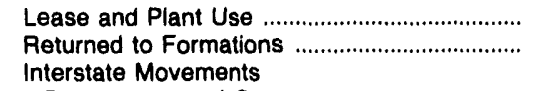 & $\begin{array}{l}0 \\
0\end{array}$ & $\begin{array}{l}0 \\
0\end{array}$ & $\begin{array}{l}0 \\
0\end{array}$ \\
\hline 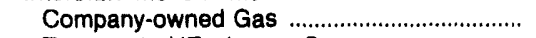 & 0 & 0 & 0 \\
\hline 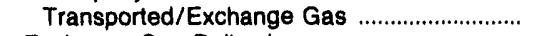 & 0 & 107,492 & 0 \\
\hline 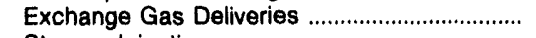 & 0 & 0 & 0 \\
\hline \multicolumn{2}{|l|}{ Deliveries of Company-owned Gas } & 0 & 0 \\
\hline 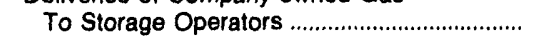 & 0 & 0 & 0 \\
\hline 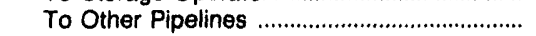 & 0 & 0 & 0 \\
\hline $\begin{array}{l}\text { To Resellers ............................................................. } \\
\text { To Consumers }\end{array}$ & $4,460,486$ & 0 & 420,948 \\
\hline 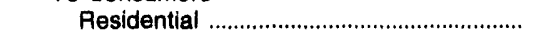 & 0 & 0 & 0 \\
\hline 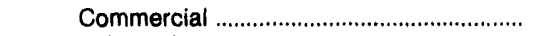 & 0 & 0 & 0 \\
\hline 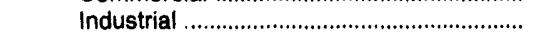 & 0 & 0 & 0 \\
\hline 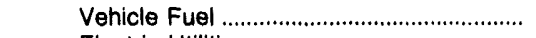 & 0 & 0 & 0 \\
\hline 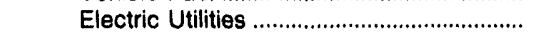 & 0 & 0 & 0 \\
\hline \multicolumn{4}{|l|}{ Transported for the Account of Others } \\
\hline 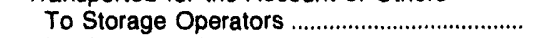 & 0 & 0 & 0 \\
\hline 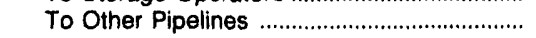 & 0 & 0 & 0 \\
\hline $\begin{array}{l}\text { To Resellers .............................................................. } \\
\text { To Consumers }\end{array}$ & $2,064,516$ & 0 & $1,180,087$ \\
\hline 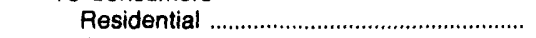 & 0 & 0 & 0 \\
\hline 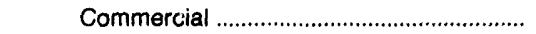 & 0 & 0 & 0 \\
\hline 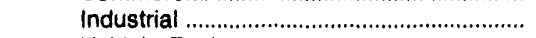 & 0 & 0 & 0 \\
\hline 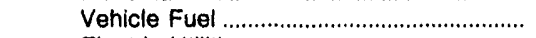 & 0 & 0 & 0 \\
\hline Electric Utilities .............................................. & 0 & 0 & 0 \\
\hline Pipeline/Compressor Fuel ....................................... & 361,248 & 0 & 0 \\
\hline 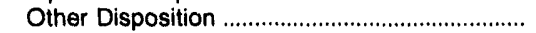 & 0 & 0 & 0 \\
\hline 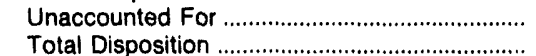 & $\begin{array}{r}-65,084 \\
7,678,472\end{array}$ & $\begin{array}{r}0 \\
107,492\end{array}$ & $\begin{array}{r}15,722 \\
1,616,757\end{array}$ \\
\hline
\end{tabular}

Source: Energy Information Administration (EIA), Form ElA-176, "Annual Report of Natural and Supplemental Gas Supply and Disposition." 
Table 23. K N Energy, Inc., Interstate Flows of Natural Gas, 1992 (Thousand Cubic Feet)

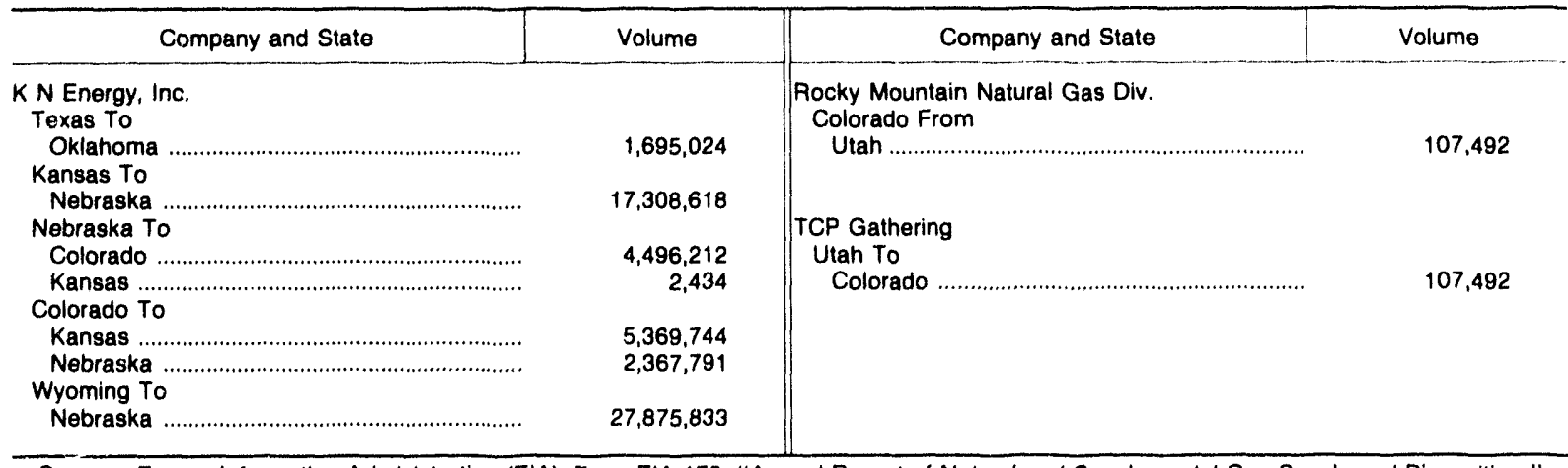

Source: Energy Information Administration (ElA), Form ElA-176, "Annual Report of Natural and Supplemental Gas Supply and Disposition." 


\section{Koch Gateway Pipeline Co.}

United Gas Pipe Line Company, previously a wholly owned subsidiary of United Gas Holding Corporation, was acquired by Koch Industries Inc., in November 1992. United filed bankruptcy in July 1990 and at the time of Koch Industries' acquisition, the company had not made significant progress towards restructuring financially. Industry reports suggest that Koch, because of its stability, should provide the management and financial support to make United a profitable company again. No terms of the acquisition were disclosed to the public; however that practice is one of long standing in the United Gas Pipe Line history. Koch is also a privately held company.
At the time of its acquisition by Koch, United held interests in 12 other corporations, all associated with the company's main interest, natural gas service. All, except UER Pipeline Services, are engaged in natural gas transmission. UER is an administrative services company specializing in pipeline administration. The other subsidiaries are Gateway Pipeline Company, Trans-Anadarko Pipeline Company, United Offshore Company, Cypress Pipeline Company, Unisouth Pipeline Company, Laser Marketing Company, Gulf South Pipeline Company, Texas Gulf South Pipeline Company, Mississippi Gulf South Pipeline Company, Florida Gulf South Pipeline Company, and Alabama Gulf

Figure 18. Koch Gateway Pipeline Co., 1992

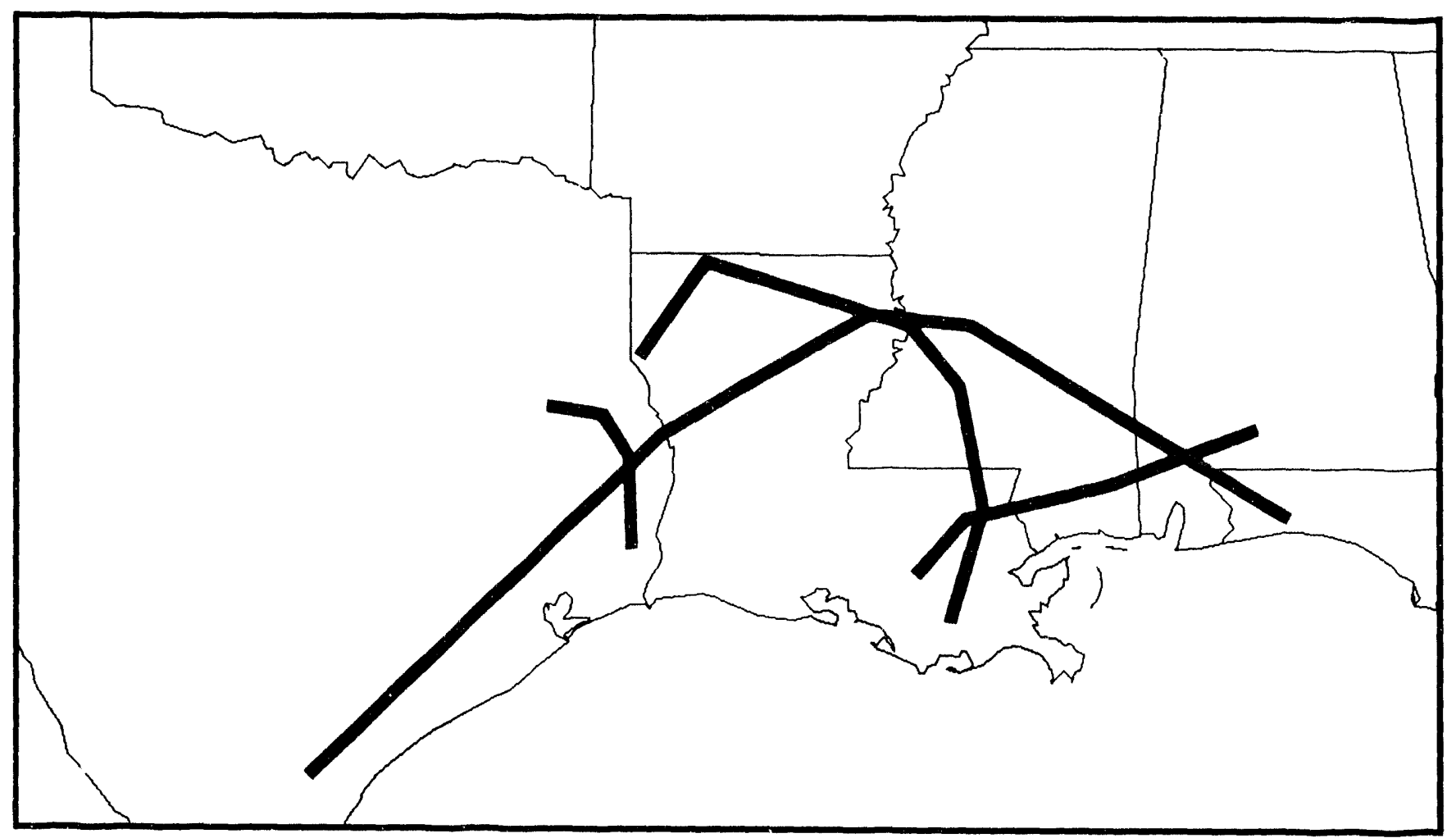

Source: Energy Information Administration (EIA), Form EIA-176, "Annual Report of Natural and Supplemental Gas Supply and Disposition."

Supply Areas Koch Gateway Pipeline Co. 
Table 24. Koch Gateway Pipeline Co. Natural Gas Data, 1992 (Thousand Cubic Feet)

\begin{tabular}{l|c|c|c|c|c|c|c|}
\hline \multirow{2}{*}{ Supply/Disposition } & \multicolumn{8}{|c}{ "och Gatoway Pipeline Co. } \\
\cline { 2 - 8 } & Oklahoma & Texas & Luusiana & Mississippi & Alabama & Florida \\
\hline
\end{tabular}

\section{SUPPLY}

Produced Onsystem

Receipts

Purchases

xchange Gas

Interstate Movements

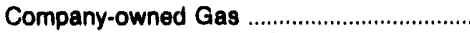

Transported/Exchange Gas

Storage Withdrawals

Operators

Other Supplies

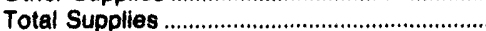

DISPOSITION

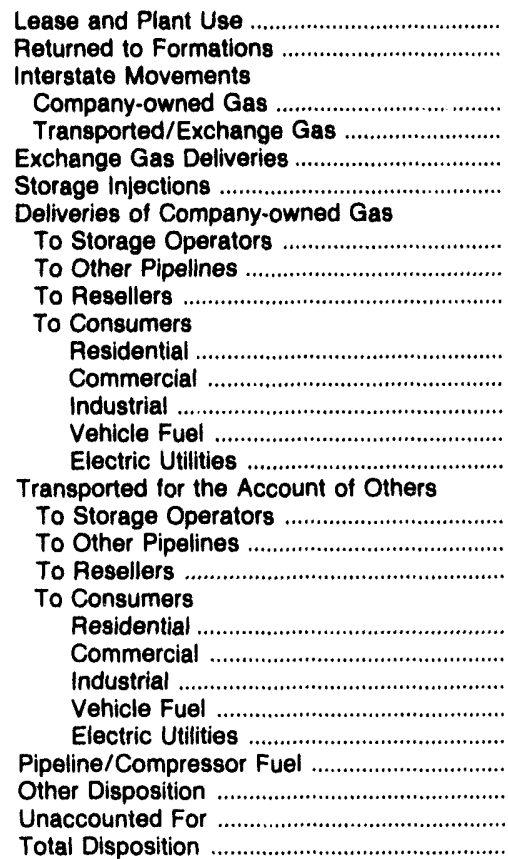

\begin{tabular}{|c|c|c|c|c|c|}
\hline 0 & 0 & 0 & 0 & 0 & 0 \\
\hline $\begin{array}{r}0 \\
36,313\end{array}$ & $\begin{array}{r}12,681,389 \\
272,229,345\end{array}$ & $\begin{array}{r}26,112,605 \\
427,680,712\end{array}$ & $\begin{array}{r}1,623,848 \\
51,710,183\end{array}$ & $\begin{array}{r}1,302,148 \\
31,338,632\end{array}$ & 0 \\
\hline $\begin{array}{r}0 \\
0 \\
0 \\
0 \\
0 \\
36,313\end{array}$ & $\begin{array}{r}0 \\
0 \\
0 \\
0 \\
0 \\
284,910,734\end{array}$ & $\begin{array}{r}0 \\
165,861,334 \\
61,066,462 \\
0 \\
0 \\
680,721,113\end{array}$ & $\begin{array}{r}0 \\
145,267,050 \\
6,694,607 \\
0 \\
0 \\
205,295,688\end{array}$ & $\begin{array}{r}0 \\
27,499,435 \\
0 \\
0 \\
0 \\
60,140,215\end{array}$ & $34,677,645$ \\
\hline
\end{tabular}

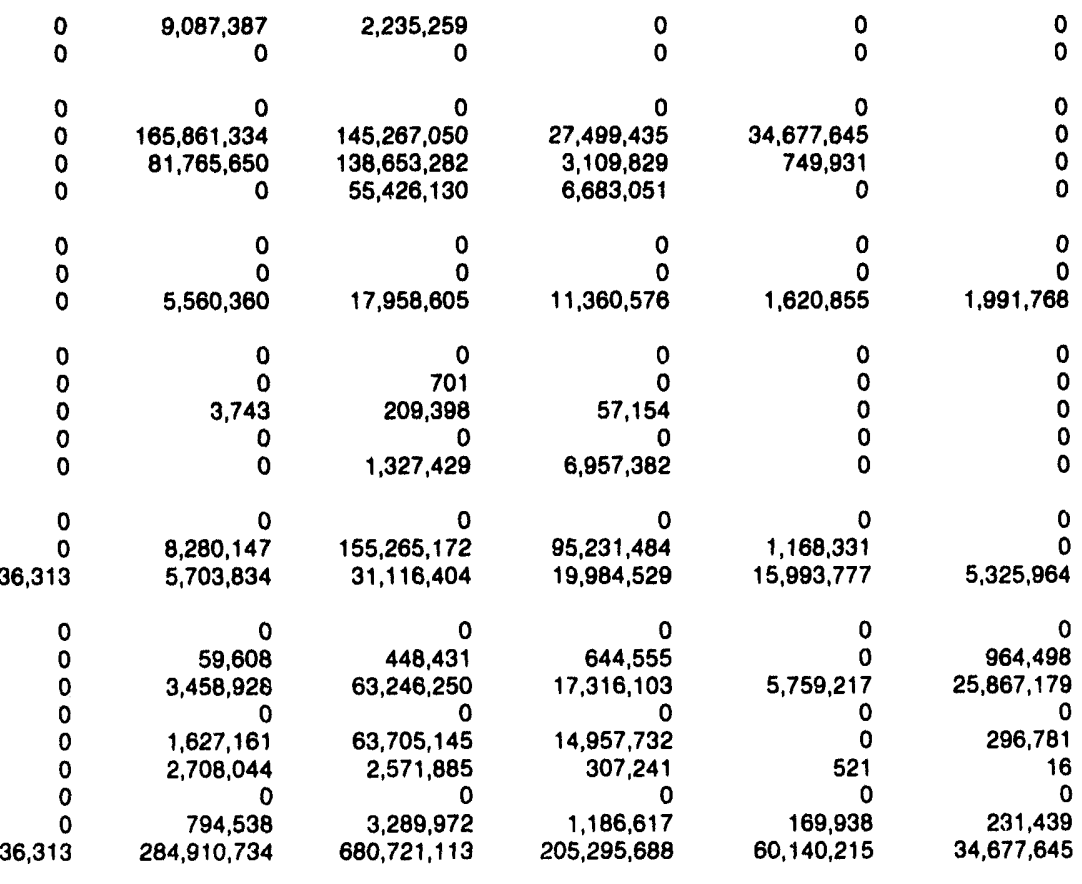

Source: Energy Information Administration (EIA), Form ElA-176, "Annual Report of Natural and Supplemental Gas Supply and Disposition."
South Pipeline Company. All subsidiaries were 100 percent held by United.

After the collapse of its Suncoast joint venture with ANR Pipeline Company, United continued on its own to pursue the project which was intended to provide service to the Florida natural gas market. ANR also continued its interest in the Florida gas market with plans to build a parallel pipe line under the name SunShine Pipeline. A heated competition for Florida markets has developed since Florida Gas Transmission has also undertaken a project to further expand its service to the Florida market.

Koch's acquisition of United is timely as it provides the necessary financing to complete the Suncoast project. United has announced its intent to begin service on the new system during the winter of 1995-96. In a move important to the success of the Suncoast project, United was granted an exemption from FERC regulations when it was determined that the pipeline would be regulated under Florida State law as an intrastate pipeline. 
Table 25. Koch Gateway Pipeline Co. Interstate

Flows of Natural Gas, 1992

(Thousand Cubic Feet)

\begin{tabular}{|c|c|}
\hline Company and State & Volume \\
\hline \multicolumn{2}{|l|}{$\begin{array}{l}\text { Koch Gateway Pipeline Co. } \\
\text { Texas To }\end{array}$} \\
\hline 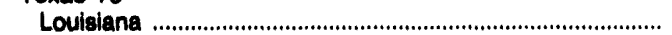 & $165,861,334$ \\
\hline Loulsiana To & \\
\hline 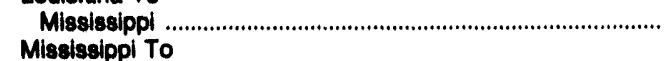 & $145,267,050$ \\
\hline $\begin{array}{l}\text { Alabama } \\
\text { Alabama To }\end{array}$ & $27,489,435$ \\
\hline Florida & $34,677,645$ \\
\hline
\end{tabular}

Source: Energy Information Administration (EIA), Form ElA-176, "Annual Report of Natural and Supplemental Gas Supply and Disposition." 


\section{Lone Star Gas Co.}

Lone Star Gas Company, in business since 1909, serves over 1.25 million customers in Texas. Lone Star is owned by ENSERCH Corporation, an integrated company with interests in natural gas exploration, production, processing, transportation, and marketing. This integration gives Lone Star a wellhead to end-use position in the industry.

ENSERCH's system is made up of more than 32,000 miles of transportation, gathering, and transmission lines. It is an intrastate system which links major producing areas on the Texas Gulf Coast, South Texas, and West Texas with markets throughout the Country by means of interconnections with interstate pipelines within Texas.

Lone Star serves nearly 1.3 million customers in 550 cities in Texas through its nearly 9,000-mile pipeline system. The majority of Lone Star's customers are in the Dallas/Fort Worth area. A warmer than normal winter in 1992 caused lower sales to customers. The lowered sales were somewhat offset by increased penetration of the residential market. Lone Star installed gas distribution lines into more than 99 percent of new residential construction in 1992 in its service area. The company's share of gas usage in new homes rose to an

Figure 19. Lone Star Gas Co., 1992

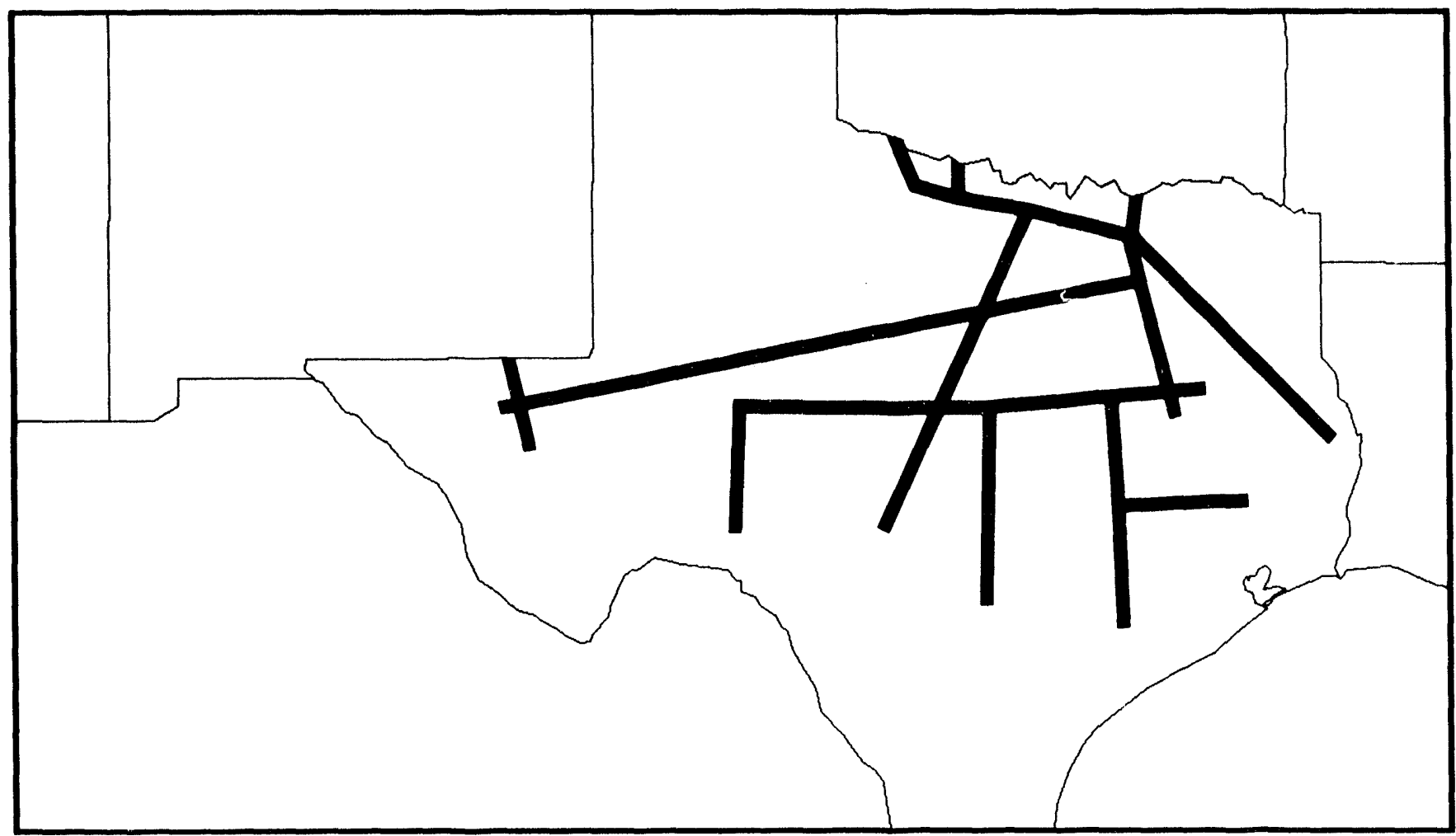

Source: Energy Information Administration (EIA), Form ElA-176, "Annual Report of Natural and Supplemental Gas Supply and Disposition." 
Table 26. Lone Star Gas Co. Natural Gas Data, 1992 (Thousand Cubic Feet)

\begin{tabular}{|c|c|c|}
\hline \multirow{2}{*}{ Supply/Disposition } & Lone Star Gas Co. & National Pipeline Co. \\
\hline & Texas & Oklahoma \\
\hline \multicolumn{3}{|l|}{ 8UPPLY } \\
\hline $\begin{array}{l}\text { Produced Onsystem } \\
\text { Receipts }\end{array}$ & 0 & 0 \\
\hline Purchases & $\begin{array}{l}174,050,972 \\
342,012,119\end{array}$ & $2,020,826$ \\
\hline \multicolumn{3}{|l|}{ Interstate Movements } \\
\hline Company-owned Gas & $\begin{array}{l}0 \\
0\end{array}$ & $\begin{array}{l}0 \\
0\end{array}$ \\
\hline 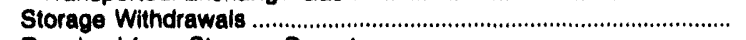 & $26,291,210$ & 0 \\
\hline 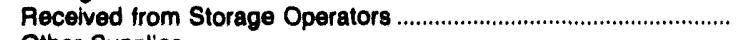 & 0 & 0 \\
\hline Other Supplies & $\begin{array}{r}1,170 \\
542,355,471\end{array}$ & $\begin{array}{r}0 \\
2.020 .826\end{array}$ \\
\hline 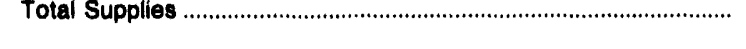 & $542,355,471$ & $2,020,826$ \\
\hline \multicolumn{3}{|l|}{ DISPOSITION } \\
\hline Lease and Plant Use & $5,680,962$ & 0 \\
\hline 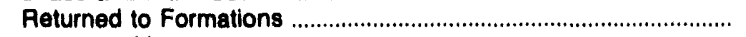 & 0 & 0 \\
\hline \multicolumn{3}{|l|}{ Interstate Movements } \\
\hline 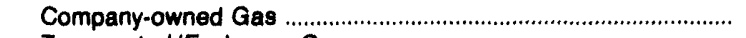 & 0 & 0 \\
\hline 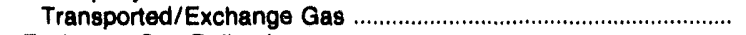 & $9,374,399$ & 0 \\
\hline 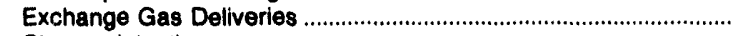 & $24,343,581$ & 0 \\
\hline 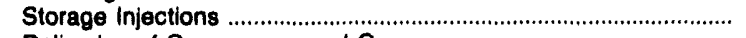 & $18,869,281$ & 0 \\
\hline \multicolumn{3}{|l|}{ Deliveries of Company-owned Gas } \\
\hline 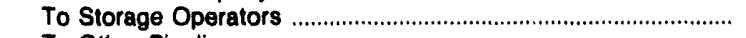 & 0 & 0 \\
\hline 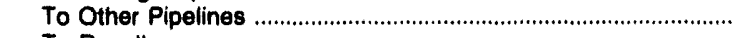 & 0 & 0 \\
\hline 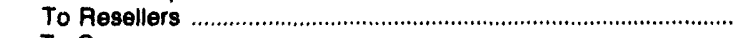 & 9,467 & 0 \\
\hline To Consumers & & \\
\hline 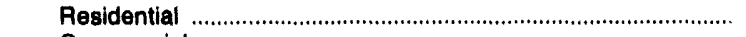 & $86,971,921$ & 0 \\
\hline 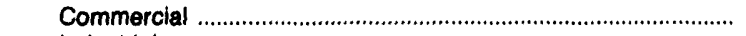 & $37,197,394$ & 0 \\
\hline Industrial & $15,950,242$ & 0 \\
\hline 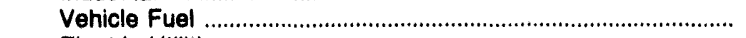 & 0 & 0 \\
\hline 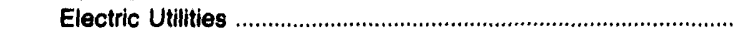 & $21,258,130$ & 0 \\
\hline \multicolumn{3}{|l|}{ Transported for the Account of Others } \\
\hline To Storage Operators & 0 & 0 \\
\hline 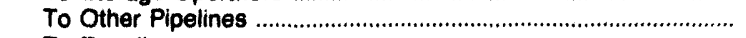 & 0 & $2,020,826$ \\
\hline To Resellers . . & 0 & 0 \\
\hline \multicolumn{3}{|l|}{ To Consumers } \\
\hline Residential . & 0 & 0 \\
\hline 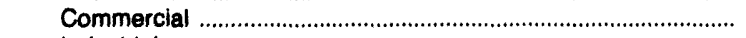 & $1,061,403$ & 0 \\
\hline Industrial & $266,481,885$ & 0 \\
\hline 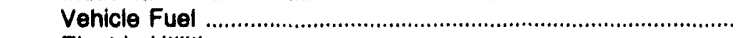 & 0 & 0 \\
\hline 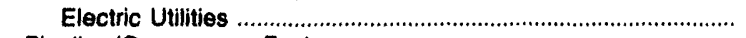 & $44,709,701$ & 0 \\
\hline 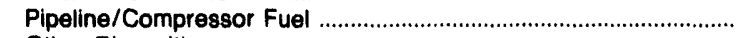 & 0 & 0 \\
\hline 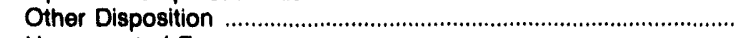 & 0 & 0 \\
\hline Unaccounted For & $10,447,105$ & 0 \\
\hline Total Disposition . & $542,355,471$ & $2,020,826$ \\
\hline
\end{tabular}

Source: Energy Information Administration (EIA), Form EIA-176, "Annual Report of Natural and Supplemental Gas Supply and Disposition."

estimated 84 percent in 1992, up from 58 percent in 1988.

Lone Star's utility operations are augmented by other ENSERCH subsidiaries operating in Texas. ENSERCH has 18 natural gas liquids processing plants located on Lone Star Gas Company's system. Lone Star delivers the residue natural gas from these plants to its customers. Through its marketing subsidiaries, ENSERCH provides agreements with several major apartment developers to offer individually metered, gas-served apartments with combination space and wa- ter heating systems, gas logs, and other amenities. The company has also marketed natural gas cooling systems. Commercial gas air-conditioning grew dramatically in 1992. Almost 8,000 tons of gas cooling equipment, or 19 systems, were sold or ordered.

Several successful fleet-vehicle conversions were accomplished in 1992. The Company also expanded its network of natural gas fueling stations. Four compressed natural gas stations were opened for public use and construction was begun on two more. By the end of 1993, 15 stations are expected to be in operation. 


\section{Michigan Consolidated Gas Co.}

Michigan Consolidated Gas Company (MichCon) is owned by MCNCorporation. MCNalso owns Citizens Gas Fuel Company and MichCon Trading Company. MichCon is a natural gas distribution, transmission, and storage company which serves 3.5 million residents in over 500 Michigan communities. Citizens is a natural gas utility serving 12,000 customers in Lenawee County in southern Michigan. MichCon Trading Company buys and sells natioral gas for commercial and industrial customers in Michigan.

Natural gas gained market share in MichCon's service area as a result of slightly colder weather, the addition of new customers, and a gain of customers switching from coal. The company estimates that gas delivered to displace coal gained 35 percent in 1992 over 1991. New housing and improved economic conditions contributed to the company's improved market. In a program to capture new customers, MichCon has added 55 communities to its service area since 1983 , sixteen of those in 1992.

Over 90 percent of gas supplies bought in 1992 for residential and small commercial sales customers were from long-term supplies, primarily Michigan gas producers, interstate pipelines, and Canadian suppliers. The remainder was purchased on the spot market. Gas supplies for MichCon totaled 651 billion cubic feet in

Figure 20. Michigan Consolidated Gas Co., 1992

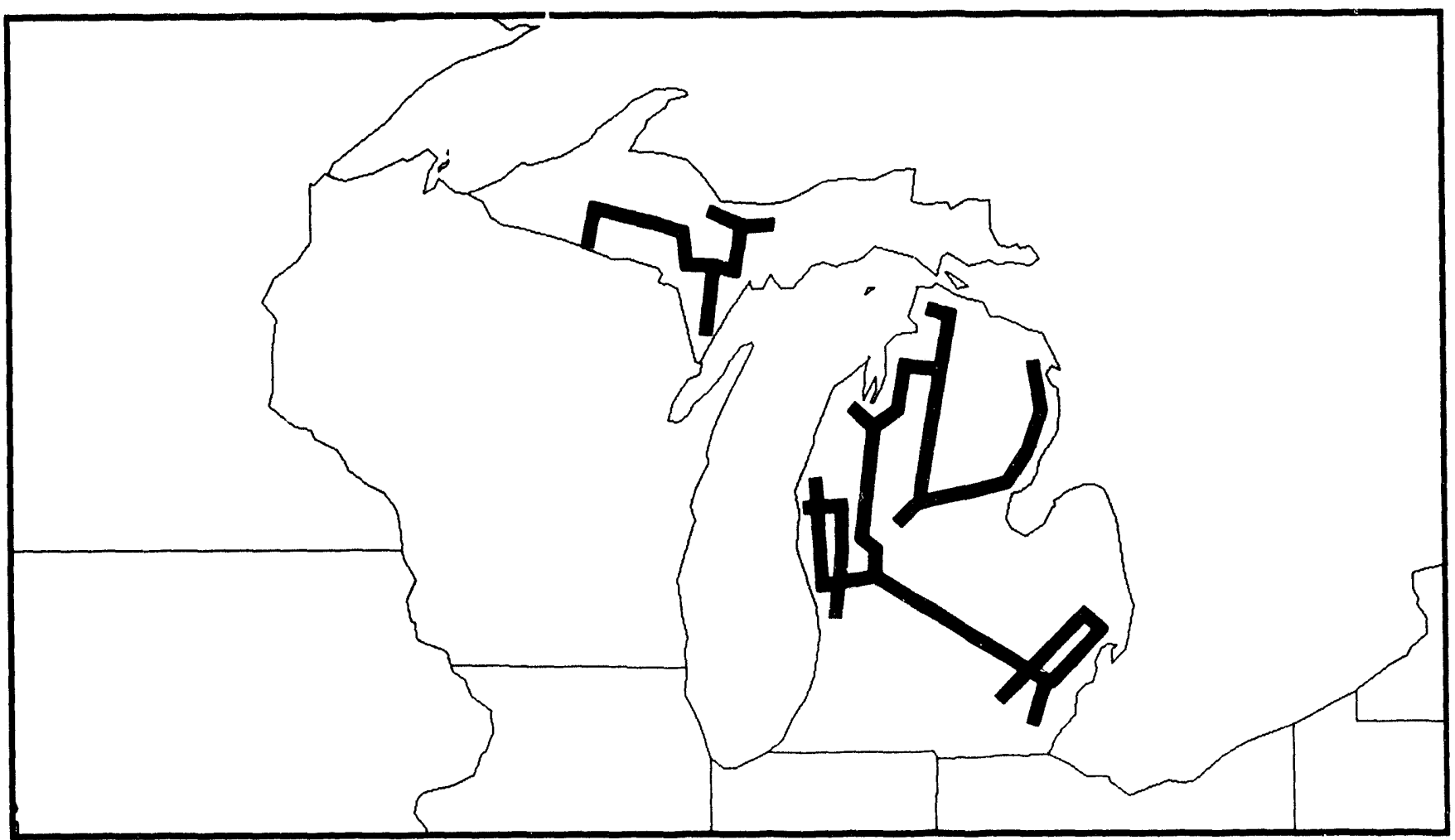

Source: Energy Information Administration (EIA), Form ElA-176, "Annual Report of Natural and Supplemental Gas Supply and Disposition."

Service Areas

Michigan Consolidated Gas Co. 
a 1992, a 20-percent increase over gas supplies the previous year. For two consecutive years, onsystem production provided less than 1 percent of gas supplies. The total natural gas delivered to end-users in 1992 was 331 billion cubic feet, with 46 percent to residential consumers, 26 percent to commercial consumers, and 27 percent to industrial consumers.

MichCon owns and operates 130 billion cubic feet of natural gas storage capacity. The Blue Lake Storage project was a joint venture of MCN Corp. and ANR Storage Company. Through a subsidiary, Blue Lake Holdings, MCN invested in the partnership which developed a large gas storage field with a capacity of 42 billion cubic feet. The Blue Lake Storage Project was put into operation by ANR in 1993. Depleted gas fields in Michigan make possible the development of new storage reservoirs at a lower cost than in nearby States.

The Company has also been developing an Adsorbed Natural Gas (ANG) technology for natural gas pow- ered vehicles that will permit the storing of volumes of natural gas at approximately one-tenth of the pressure required currently. When this patented technological process is used, the Company says that costs are lowered, fuel container designs can be more flexible, and shorter refueling times are permitted. The adsorbent technology would expand the driving range of a natural gas vehicle to more than 200 miles per tankful for a typical minivan. This technology is still being tested by MichCon.

The Company has developed marketing plans to promote gas-fueled cogeneration and air-conditioning. MCN provided technical and financial assistance to the development of 33 cogeneration projects in 1992.

MichCon is also involved in the development of a compact residential furnace which uses computercontrolled pressurized combustion technology. This development is expected to provicie increased efficiency and heat uniformity. 
Table 27. Michigan Consolidated Gas Co. Natural Gas Data, 1992 (Thousand Cubic Feet)

\begin{tabular}{|c|c|c|}
\hline \multirow{2}{*}{ Supply/Disposition } & MichCon Gas Co. & Citizens Gas Fuel Co. \\
\hline & \multicolumn{2}{|c|}{ Michigan } \\
\hline \multicolumn{3}{|l|}{ SUPPLY } \\
\hline \multicolumn{3}{|l|}{$\begin{array}{l}\text { Produced Onsystem } \\
\text { Receipts }\end{array}$} \\
\hline Pransported/Exchange Gas & $\begin{array}{l}151,732,633 \\
356,930,588\end{array}$ & $\begin{array}{r}3,243,826 \\
212,938\end{array}$ \\
\hline \multicolumn{3}{|l|}{ Interstate Movements } \\
\hline Company-owned Gas & 0 & 0 \\
\hline 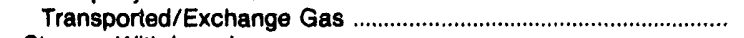 & $7,808,801$ & 0 \\
\hline Storage Withdrawals & $113,020,149$ & 0 \\
\hline 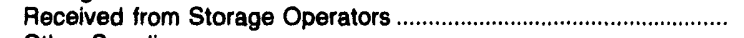 & $19,289,137$ & 0 \\
\hline Other Supplies & 0 & 2,386 \\
\hline 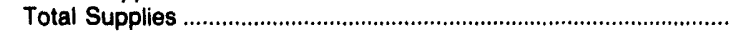 & $650,826,461$ & $3,459,150$ \\
\hline \multicolumn{3}{|l|}{ DISPOSITION } \\
\hline Lease and Plant Use & $4,409,948$ & 0 \\
\hline \multicolumn{3}{|l|}{ Interstate Movements } \\
\hline 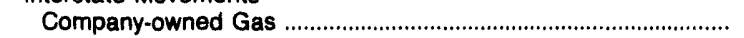 & 0 & 0 \\
\hline 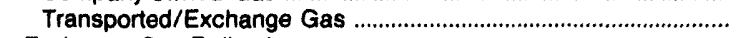 & $36,621,868$ & 0 \\
\hline 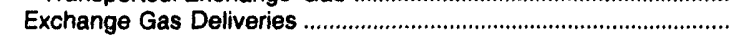 & 0 & 0 \\
\hline $\begin{array}{l}\text { Storage Injections } \\
\text { Deliveries of Company-owned Gas }\end{array}$ & $103,994,291$ & 0 \\
\hline $\begin{array}{l}\text { Deliveries of Company-owned Gas } \\
\text { To Storage Operators }\end{array}$ & \multicolumn{2}{|c|}{ Deliveries of Company-owned Gas } \\
\hline To Other Pipelines & 0 & 0 \\
\hline 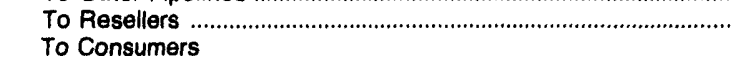 & 0 & 409,181 \\
\hline 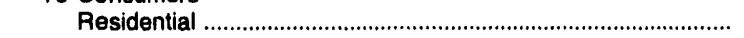 & $149,006,221$ & $1,339,073$ \\
\hline 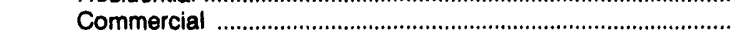 & $47,223,792$ & 584,646 \\
\hline Industrial & $2,646,944$ & 906,760 \\
\hline 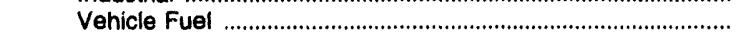 & 0 & 0 \\
\hline 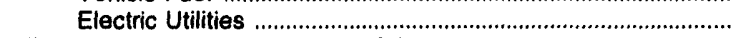 & 169,404 & 0 \\
\hline \multicolumn{3}{|l|}{ Transported for the Account of Others } \\
\hline To Storage Operators & $28,455,349$ & 0 \\
\hline 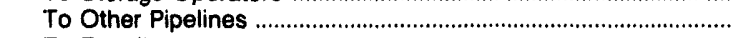 & $146,349,609$ & 0 \\
\hline 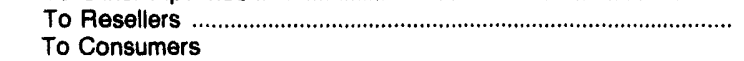 & 0 & 0 \\
\hline 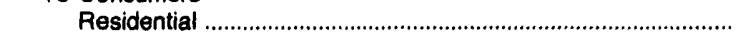 & $1,973,672$ & 0 \\
\hline Commercial . . . & $37,381,042$ & 0 \\
\hline Industrial & $87,247,598$ & 218,202 \\
\hline 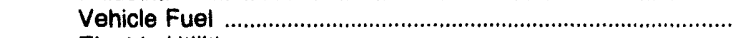 & 0 & 0 \\
\hline 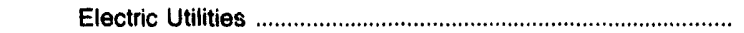 & $2,193,168$ & 0 \\
\hline 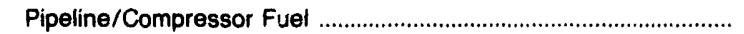 & $2,233,042$ & 0 \\
\hline 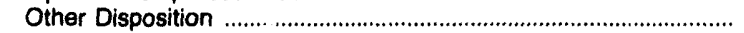 & 0 & 0 \\
\hline Unaccounted For & 920,513 & 1,288 \\
\hline 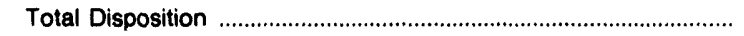 & $650,826,461$ & $3,459,150$ \\
\hline
\end{tabular}

Source: Energy Information Administration (EIA), Form EIA-176, "Annual Report of Natural and Supplemental Gas Supply and Disposition." 


\section{MidCon Corp.}

MidCon Corporation is a subsidiary of Occidental Petroleum Corporation, an energy resource company with oil, gas, and coal operations. MidCon owns and operates nearly 1,700 miles of pipeline located in 12 States. MidCon is the owner of two pipeline subsidiaries: Natural Gas PipeLine Company of America (NGPL), and United Texas Transmission Company. NGPL, one of the Nation's top storage operators, increased its working gas storage capacity by 16 percent during 1992. NGPL owns total storage capacity of approximately 600 billion cubic feet.

MidCon's gas division has completed the first of two storage facilities in Texas with a combined total capac- ity of 8.8 billion cubic feet. NGPL ; xpects to effect a new menu gas sales business on December 1, 1993 and is in the process of reforming existing gas supply contracts.

MidCon's operations have been reorganized into two reporting divisions. Under the new organization, the regulated business division will manage all of MidCon's pipeline operations, including the marketing and sales of NGPL's regulated transportation and storage services, and manage volume control for the pipelines. The nonregulated business division will include United Texas Transmission, MidCon Marketing, as well as NGPL's previous gas supply, marketing and sales func-

Figure 21. MidCon Corp., 1992

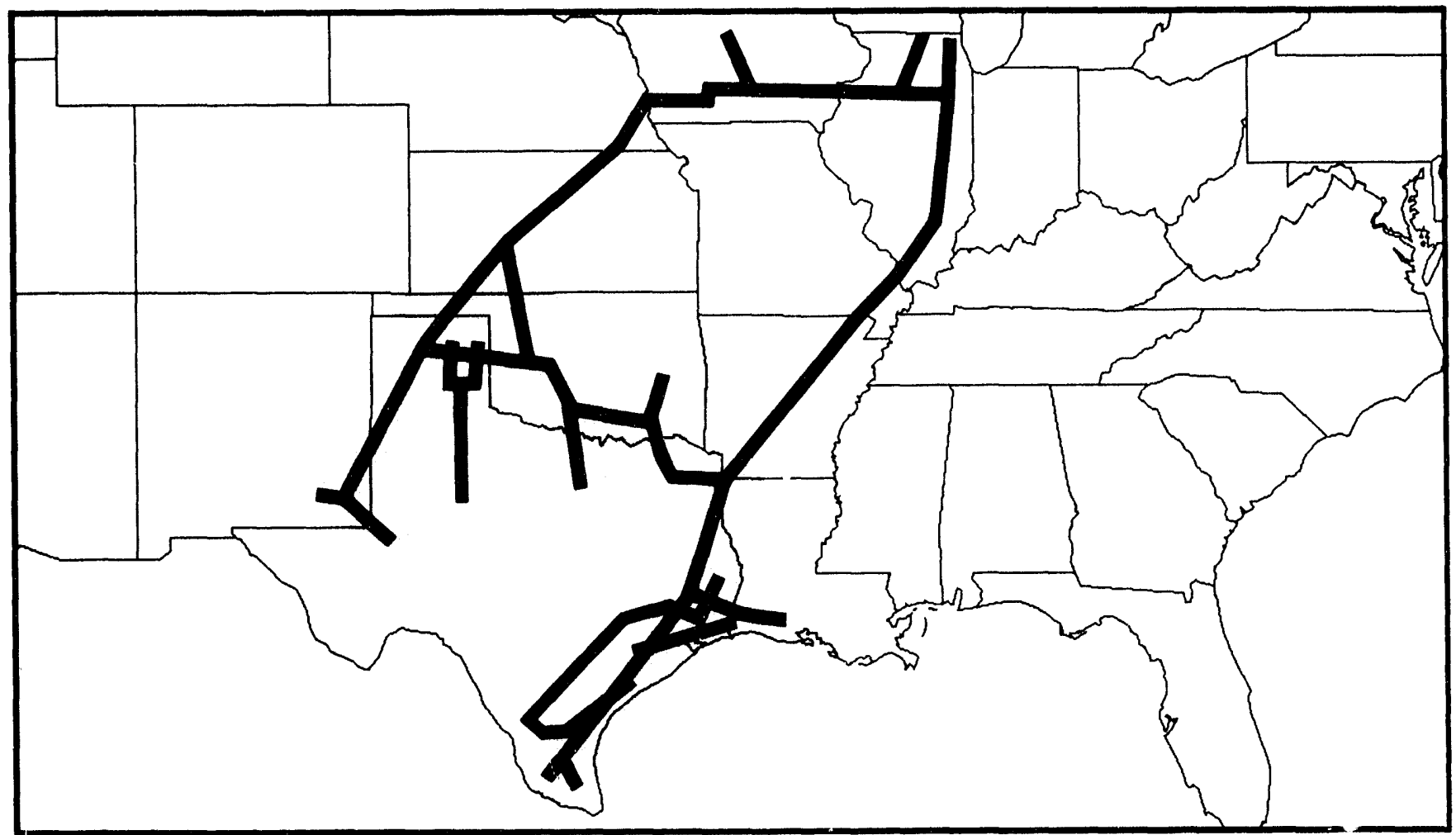

Source: Energy Information Administration (E|A), Form ElA-176, "Annual Report of Natural and Supplemental Gas Supply and Disposition." 
Table 28. MidCon Corp. Natural Gas Data, 1992 (Thousand Cubic Feet)

\begin{tabular}{|c|c|c|c|c|c|}
\hline \multirow{2}{*}{ Supply/Disposition } & \multicolumn{5}{|c|}{ Natural Gas Pipeline Co. of America } \\
\hline & Louisiana & Texas & Arkansas & Missouri & Illinois \\
\hline \multicolumn{6}{|l|}{ SUPPLY } \\
\hline $\begin{array}{l}\text { Produced Onsystem } \\
\text { Receipts }\end{array}$ & 0 & $6,356,996$ & 0 & 0 & 0 \\
\hline 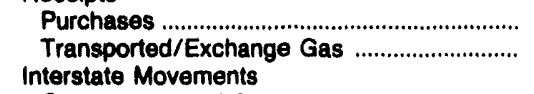 & $\begin{array}{r}5,335,619 \\
260,437,084\end{array}$ & $\begin{array}{r}70,618,668 \\
355,258,246\end{array}$ & $\begin{array}{r}3,990,674 \\
36,360,561\end{array}$ & $\begin{array}{l}0 \\
0\end{array}$ & $\begin{array}{r}9,504 \\
56,177,476\end{array}$ \\
\hline 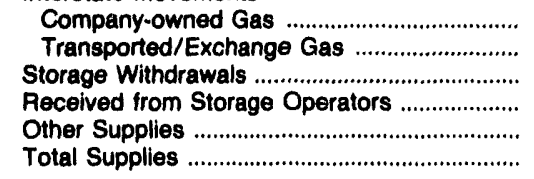 & $\begin{array}{r}0 \\
56,018,137 \\
0 \\
0 \\
30,412 \\
321,821,252\end{array}$ & $\begin{array}{r}0 \\
237,309,813 \\
233,394,747 \\
1,659,495 \\
318,179 \\
904,916,144\end{array}$ & $\begin{array}{r}0 \\
272,832,246 \\
0 \\
0 \\
109,524 \\
313,293,005\end{array}$ & $\begin{array}{r}0 \\
304,824,398 \\
0 \\
0 \\
36,829 \\
304,861,227\end{array}$ & $\begin{array}{r}0 \\
756,434,016 \\
56,776,021 \\
0 \\
208,695 \\
869,605,712\end{array}$ \\
\hline \multicolumn{6}{|l|}{ DISPOSITION } \\
\hline $\begin{array}{l}\text { Lease and Plant Use } \\
\text { Returned to Formations } \\
\text { Interstate Movements }\end{array}$ & $\begin{array}{l}0 \\
0\end{array}$ & $\begin{array}{r}5,126,094 \\
0\end{array}$ & $\begin{array}{r}73,792 \\
0\end{array}$ & $\begin{array}{l}0 \\
0\end{array}$ & $\begin{array}{l}0 \\
0\end{array}$ \\
\hline 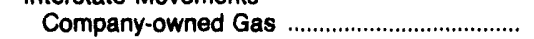 & 0 & 0 & 0 & 0 & $24,946,101$ \\
\hline 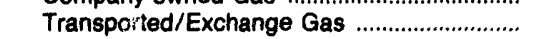 & 0 & $493,669,338$ & $304,824,398$ & $302,246,110$ & $156,782,936$ \\
\hline 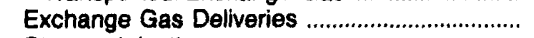 & $4,695,152$ & $34,238,704$ & 90,290 & 0 & $2,685,110$ \\
\hline $\begin{array}{l}\text { Storage Injections } \\
\text { Deliveries of Company-owned Gas }\end{array}$ & 0 & $225,633,928$ & 0 & 0 & $48,197,180$ \\
\hline 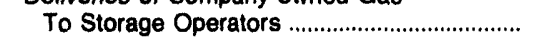 & 0 & 0 & 0 & 0 & 0 \\
\hline 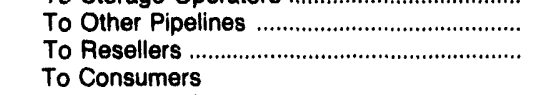 & $\begin{array}{r}27,740,921 \\
0\end{array}$ & $\begin{array}{r}13,135,893 \\
114,955\end{array}$ & $\begin{array}{l}0 \\
0\end{array}$ & $\begin{array}{r}0 \\
435,450\end{array}$ & $\begin{array}{r}766,237 \\
233,480,017\end{array}$ \\
\hline 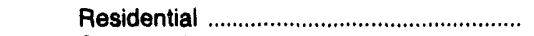 & 0 & 0 & 0 & 0 & 0 \\
\hline 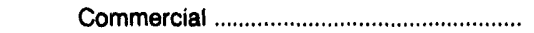 & 0 & 0 & 0 & 0 & $1,941,001$ \\
\hline 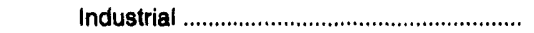 & 0 & 8,025 & 0 & 0 & 0 \\
\hline 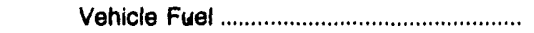 & 0 & 0 & 0 & 0 & 0 \\
\hline 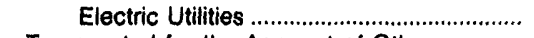 & 0 & 0 & 0 & 0 & 0 \\
\hline Transported for the Account of Others & & & & & \\
\hline To Storage Operators ...................................... & 0 & $4,800,283$ & 0 & 0 & 0 \\
\hline 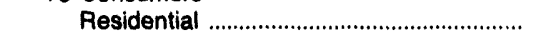 & 0 & 0 & 0 & 0 & 0 \\
\hline 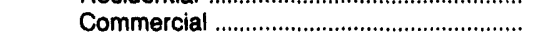 & 0 & 0 & 0 & 0 & $2,634,133$ \\
\hline 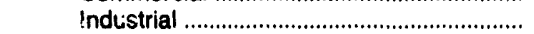 & 0 & 804,370 & $4,070,957$ & $i$ & $5,728,796$ \\
\hline 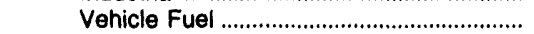 & 0 & 0 & 0 & 0 & 0 \\
\hline 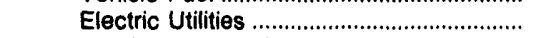 & 0 & 0 & 0 & 0 & 0 \\
\hline 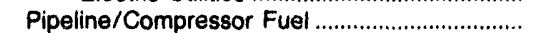 & 441,174 & $4,656,817$ & $2,177,783$ & 520,144 & $2,716,492$ \\
\hline 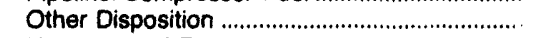 & 0 & 0 & 0 & 0 & 0 \\
\hline $\begin{array}{l}\text { Unaccounted For } \\
\text { Total Disposition }\end{array}$ & $\begin{array}{r}453,099 \\
321,821,252\end{array}$ & $\begin{array}{r}4,741,141 \\
904,916,144\end{array}$ & $\begin{array}{r}1,632,045 \\
313,293,005\end{array}$ & $\begin{array}{r}548,822 \\
304,861,227\end{array}$ & $\begin{array}{r}3,109,730 \\
869,605,712\end{array}$ \\
\hline
\end{tabular}

tions. New market development has also been aligned with this part of the organization.

However, NGPL's sales and marketing activities currently regulated by Federal Energy Regulatory Commission will continue to be managed separately from nonregulated activities until implementation of the company's Order No. 636 restructuring program. During 1992, the last full year of operation under traditional pipeline rules, MidCon's operating subsidiaries sold nearly 764 billion cubic feet of natural gas and transported more than 1.6 trillion cubic feet. 
Table 28. MidCon Corp. Natural Gas Data, 1992 (Continued) (Thousand Cubic Feet)

\begin{tabular}{|c|c|c|c|c|c|}
\hline \multirow{2}{*}{ Supply/Disposition } & \multicolumn{5}{|c|}{ Natural Gas Pipeline Co. of America } \\
\hline & New Mexico & Oklahoma & Kansas & Nebraska & lowa \\
\hline \multicolumn{6}{|l|}{ SUPPLY } \\
\hline 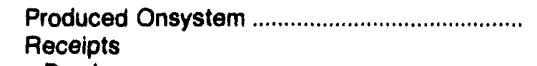 & 688 & 9,436 & 0 & 0 & 0 \\
\hline 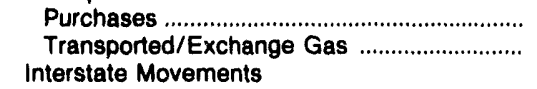 & $\begin{array}{r}6,063,853 \\
63,536,283\end{array}$ & $\begin{array}{r}23,364,388 \\
217,665,669\end{array}$ & $\begin{array}{r}62,037 \\
25,956,568\end{array}$ & $\begin{array}{r}875,537 \\
82,694,186\end{array}$ & $\begin{array}{r}874,671 \\
221,477,461\end{array}$ \\
\hline 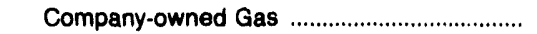 & 0 & 0 & 0 & 0 & 0 \\
\hline 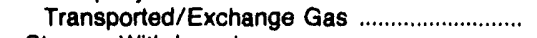 & 0 & $164,818,955$ & $199,060,861$ & $222,131,954$ & $287,212,973$ \\
\hline 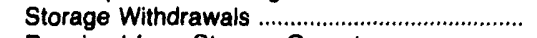 & $2,598,538$ & $28,907,440$ & 0 & 0 & $40,978,904$ \\
\hline Received from Storage Operators ....................... & 0 & 0 & 0 & 0 & 0 \\
\hline $\begin{array}{l}\text { Other Supplies } \\
\text { Total Supplies }\end{array}$ & $\begin{array}{r}31,289 \\
72,230,651\end{array}$ & $\begin{array}{r}88,288 \\
434,854,176\end{array}$ & $\begin{array}{r}109,367 \\
225,188,833\end{array}$ & $\begin{array}{r}34,227 \\
305,735,904\end{array}$ & $\begin{array}{r}96,777 \\
550,640,786\end{array}$ \\
\hline \multicolumn{6}{|l|}{ DISPOSITION } \\
\hline Lease and Plant Use & 0 & 0 & 0 & 0 & 0 \\
\hline $\begin{array}{l}\text { Returned to Formations } \\
\text { Interstate Movements }\end{array}$ & 0 & 0 & 0 & 0 & 0 \\
\hline 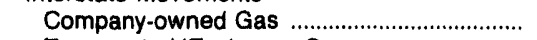 & 0 & 0 & 0 & 0 & 0 \\
\hline 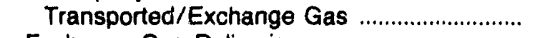 & $40,057,003$ & $396,313,671$ & $222,131,954$ & $287,212,973$ & $454,187,906$ \\
\hline Exchange Gas Deliveries .................................. & 0 & 0 & 0 & 0 & 0 \\
\hline $\begin{array}{l}\text { Storage Injections } \\
\text { Deliveries of Company-owned Gas }\end{array}$ & 0 & $32,200,915$ & 0 & 0 & $40,189,381$ \\
\hline 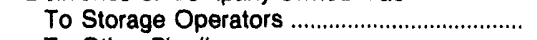 & 0 & 0 & 0 & 0 & 0 \\
\hline 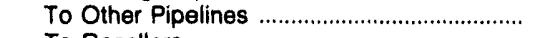 & 629,311 & 183,273 & 0 & 37,997 & 642,762 \\
\hline $\begin{array}{l}\text { To Resellers ................................................ } \\
\text { To Consumers }\end{array}$ & 0 & 21,408 & 96,170 & 298,836 & $7,260,249$ \\
\hline Residential & 0 & 0 & 0 & 0 & 0 \\
\hline 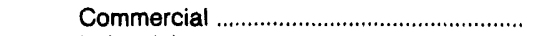 & 0 & 0 & 0 & 0 & 0 \\
\hline 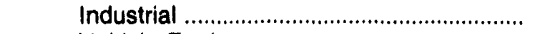 & 0 & 0 & 0 & 0 & 9,080 \\
\hline Vehicle Fuel & 0 & 0 & 0 & 0 & 0 \\
\hline 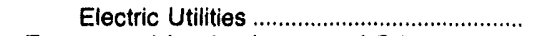 & 0 & 0 & 0 & 0 & 0 \\
\hline \multicolumn{6}{|l|}{ Transported for the Account of Others } \\
\hline 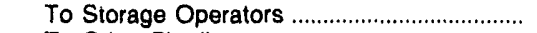 & 484,589 & 0 & 0 & 0 & 0 \\
\hline 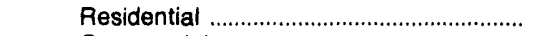 & 0 & 0 & 0 & 0 & 0 \\
\hline Commercial ................................................. & 0 & 0 & 0 & 0 & 0 \\
\hline 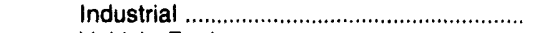 & 296,257 & 0 & 0 & $6,077,684$ & $5,608,039$ \\
\hline Vehicle Fuel ................................................... & 0 & 0 & 0 & 0 & 0 \\
\hline Electric Utilities ............................................. & 0 & 638,376 & 0 & 0 & 0 \\
\hline Pipeline/Compressor Fuel ....................................... & 175,724 & $1,102,847$ & $1,228,237$ & 489,978 & $3,445,767$ \\
\hline 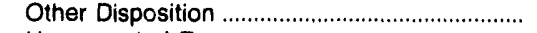 & 0 & 0 & 0 & 0 & 0 \\
\hline 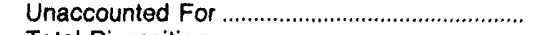 & 466,253 & $1,315,557$ & $1,629,510$ & 509,994 & $1,442,026$ \\
\hline 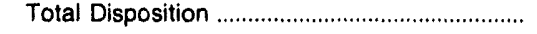 & $72,230,651$ & $434,854,176$ & $225,188,833$ & $305,735,904$ & $550,640,786$ \\
\hline
\end{tabular}


Table 28. MidCon Corp. Natural Gas Data, 1992 (Continued)

(Thousand Cubic Feet)

\begin{tabular}{|c|c|c|c|c|c|c|}
\hline \multirow{2}{*}{ Supply/Disposition } & \multirow{2}{*}{$\begin{array}{c}\begin{array}{c}\text { United Texas } \\
\text { Transmission Co. }\end{array} \\
\text { Texas }\end{array}$} & \multicolumn{2}{|c|}{ Moraine Pipeline Co. } & \multicolumn{3}{|c|}{ Trailblazer Pipeline System } \\
\hline & & Illinois & Wisconsin & Colorado & Wyoming & Nebraska \\
\hline \multicolumn{7}{|l|}{ SUPPLY } \\
\hline $\begin{array}{l}\text { Produced Onsystem } \\
\text { Receipts }\end{array}$ & 0 & 0 & 0 & 0 & 0 & 0 \\
\hline $\begin{array}{l}\text { Purchases } \\
\text { Transported/Exchange Gas .............................. } \\
\text { Interstate Movements }\end{array}$ & $\begin{array}{l}167,358,190 \\
481,098,032\end{array}$ & $\begin{array}{r}0 \\
16,153,160\end{array}$ & $\begin{array}{l}0 \\
0\end{array}$ & $\begin{array}{r}0 \\
115,809,555\end{array}$ & $\begin{array}{l}0 \\
0\end{array}$ & $\begin{array}{l}0 \\
0\end{array}$ \\
\hline 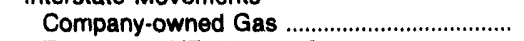 & 0 & 0 & 0 & 0 & 0 & 0 \\
\hline 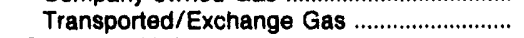 & 0 & 0 & $16,153,160$ & $104,037,413$ & $104,056,029$ & $219,777,872$ \\
\hline 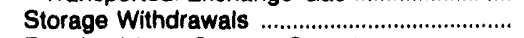 & 0 & 0 & 0 & 0 & 0 & 0 \\
\hline Received from Storage Operators .................... & 0 & 0 & 0 & 0 & 0 & 0 \\
\hline $\begin{array}{l}\text { Other Supplies } \\
\text { Total Supplies }\end{array}$ & $\begin{array}{r}0 \\
648,456,222\end{array}$ & $\begin{array}{r}0 \\
16,153,160\end{array}$ & $\begin{array}{r}0 \\
16,153,160\end{array}$ & $\begin{array}{r}4,445 \\
219,851,413\end{array}$ & $\begin{array}{r}221 \\
104,056,250\end{array}$ & $\begin{array}{r}12,134 \\
219,790,006\end{array}$ \\
\hline \multicolumn{7}{|l|}{ DISPOSITION } \\
\hline Lease and Plant Use & 253,100 & 0 & 0 & 0 & 0 & 0 \\
\hline $\begin{array}{l}\text { Returned to Formations } \\
\text { Interstate Movements }\end{array}$ & 0 & 0 & 0 & 0 & 0 & 0 \\
\hline 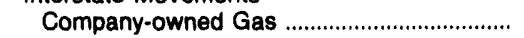 & 0 & 0 & 0 & 0 & 0 & 0 \\
\hline 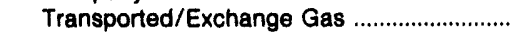 & 0 & $16,153,160$ & 0 & $219,781,143$ & $104,052,758$ & $104,037,413$ \\
\hline 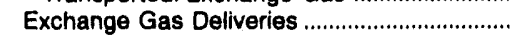 & $200,117,076$ & 0 & 0 & 0 & 0 & 0 \\
\hline Storage Injections & 0 & 0 & 0 & 0 & 0 & 0 \\
\hline Deliveries of Company-owned Gas & & & & & & \\
\hline 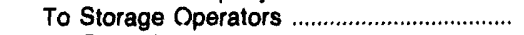 & 0 & 0 & 0 & 0 & 0 & 0 \\
\hline 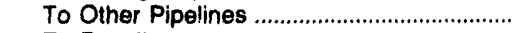 & $25,243,429$ & 0 & 0 & 0 & 0 & 0 \\
\hline 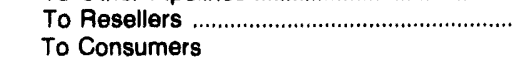 & $18,264,598$ & 0 & 0 & 0 & 0 & 0 \\
\hline 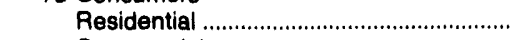 & 0 & 0 & 0 & 0 & 0 & 0 \\
\hline 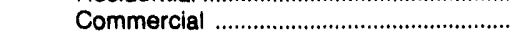 & 0 & 0 & 0 & 0 & 0 & 0 \\
\hline 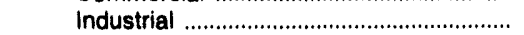 & $64,757,051$ & 0 & 0 & 0 & 0 & 0 \\
\hline 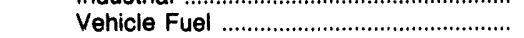 & 0 & 0 & 0 & 0 & 0 & 0 \\
\hline 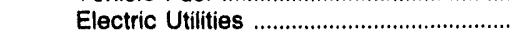 & $56,743,417$ & 0 & 0 & 0 & 0 & 0 \\
\hline Transported for the Account of Others & & & & & & \\
\hline 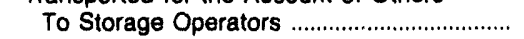 & 0 & 0 & 0 & 0 & 0 & 0 \\
\hline 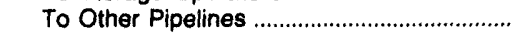 & $41,542,164$ & 0 & 0 & 0 & 0 & $115,560,746$ \\
\hline $\begin{array}{l}\text { To Resellers } \\
\text { To Consumers }\end{array}$ & $33,961,292$ & 0 & $16,153,160$ & 0 & 0 & 0 \\
\hline 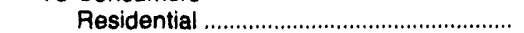 & 0 & 0 & 0 & 0 & 0 & 0 \\
\hline 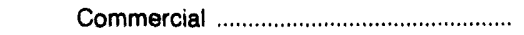 & 0 & 0 & 0 & 0 & 0 & 0 \\
\hline 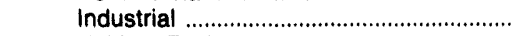 & $153,565,141$ & 0 & 0 & 0 & 0 & 0 \\
\hline 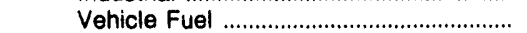 & 0 & 0 & 0 & 0 & 0 & 0 \\
\hline 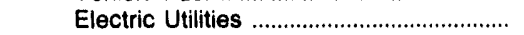 & $51,992,382$ & 0 & 0 & 0 & 0 & 0 \\
\hline 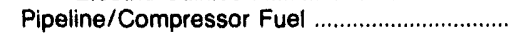 & $2,844,834$ & 0 & 0 & 1,059 & 53 & 2,892 \\
\hline 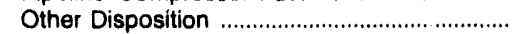 & 0 & 0 & 0 & 0 & 0 & 0 \\
\hline 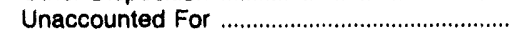 & $-828,262$ & 0 & 0 & 69,211 & 3,439 & 188,955 \\
\hline 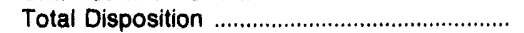 & $648,456,222$ & $16,153,160$ & $16,153,160$ & $219,851,413$ & $104,056,250$ & $219,790,006$ \\
\hline
\end{tabular}


Table 28. MidCon Corp. Natural Gas Data, 1992 (Continued) (Thousand Cubic Feet)

\begin{tabular}{|c|c|c|c|c|c|}
\hline \multirow{2}{*}{ Supply/Disposition } & \multicolumn{2}{|c|}{ Stingray Pipeline Co. } & \multirow[t]{2}{*}{$\begin{array}{c}\text { Texas Industrial } \\
\text { Energy Co. }\end{array}$} & \multirow[t]{2}{*}{$\begin{array}{l}\text { Palo Duro Pipeline } \\
\text { Co. }\end{array}$} & \multirow{2}{*}{$\begin{array}{c}\begin{array}{c}\text { Kansas Gas Supply } \\
\text { Corp. }\end{array} \\
\text { Kansas }\end{array}$} \\
\hline & Texas & Louisiana & & & \\
\hline \multicolumn{6}{|l|}{ SUPPLY } \\
\hline $\begin{array}{l}\text { Produced Onsystem } \\
\text { Recelpts }\end{array}$ & 0 & 0 & 0 & 0 & 0 \\
\hline 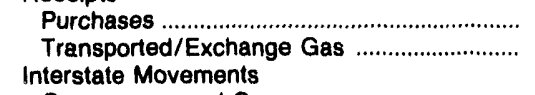 & $\begin{array}{r}0 \\
4,871,102\end{array}$ & $\begin{array}{r}0 \\
260,261,760\end{array}$ & $\begin{array}{r}0 \\
1,929,959\end{array}$ & $\begin{array}{r}0 \\
16,646,876\end{array}$ & $\begin{array}{r}8,975,483 \\
11,522,458\end{array}$ \\
\hline 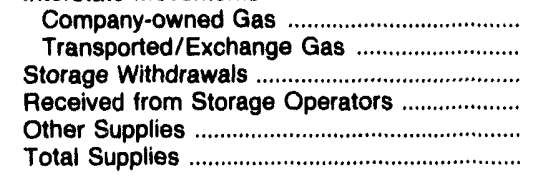 & $\begin{array}{r}0 \\
0 \\
0 \\
0 \\
0 \\
4,871,102\end{array}$ & $\begin{array}{r}0 \\
4,873,735 \\
0 \\
0 \\
0 \\
265,135,495\end{array}$ & $\begin{array}{r}0 \\
0 \\
0 \\
0 \\
0 \\
1,929,959\end{array}$ & $\begin{array}{r}0 \\
0 \\
0 \\
0 \\
0 \\
16,646,876\end{array}$ & $\begin{array}{r}0 \\
0 \\
0 \\
0 \\
0 \\
20,497,941\end{array}$ \\
\hline \multicolumn{6}{|l|}{ DISPOSITION } \\
\hline 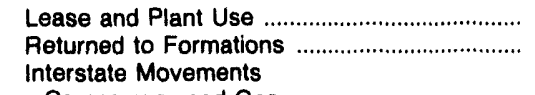 & $\begin{array}{l}0 \\
0\end{array}$ & $\begin{array}{r}2,546,252 \\
0\end{array}$ & $\begin{array}{l}0 \\
0\end{array}$ & $\begin{array}{l}0 \\
0\end{array}$ & $\begin{array}{r}1,684,429 \\
0\end{array}$ \\
\hline Company-owned Gas & 0 & 0 & 0 & 0 & 0 \\
\hline 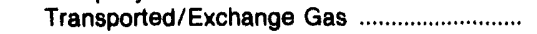 & $4,873,735$ & 0 & 0 & 0 & 0 \\
\hline Exchange Gas Deliveries ................................. & 0 & 0 & 0 & 4,450 & 0 \\
\hline \multicolumn{6}{|l|}{ Deliveries of Company-owned Gas } \\
\hline 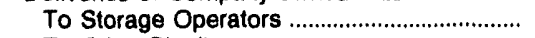 & 0 & 0 & 0 & 0 & 0 \\
\hline 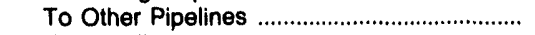 & 0 & 0 & 0 & 0 & 0 \\
\hline 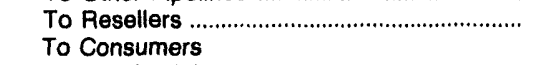 & 0 & 0 & 0 & 0 & 685,399 \\
\hline 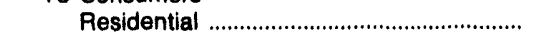 & 0 & 0 & 0 & 0 & 11,386 \\
\hline 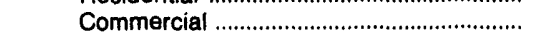 & 0 & 0 & 0 & 0 & 204,389 \\
\hline 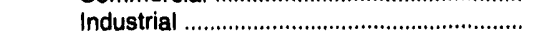 & 0 & 0 & 0 & 33,87 & 578,510 \\
\hline 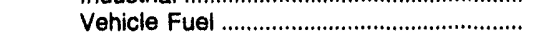 & 0 & 0 & 0 & 0 & 0 \\
\hline 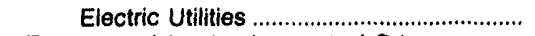 & 0 & 0 & 0 & 0 & $4,526,560$ \\
\hline \multicolumn{6}{|l|}{ Transported for the Account of Others } \\
\hline 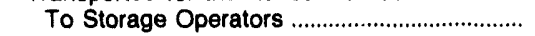 & 0 & 0 & 0 & 0 & 0 \\
\hline 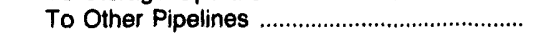 & 0 & $261,622,017$ & 0 & $16,224,172$ & $12,013,820$ \\
\hline 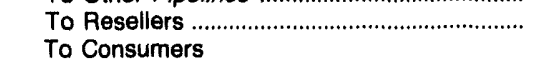 & 0 & 0 & 0 & 0 & 0 \\
\hline 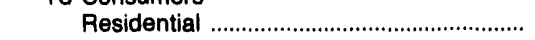 & 0 & 0 & 0 & 0 & 0 \\
\hline 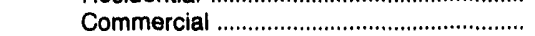 & 0 & 0 & 0 & 0 & 0 \\
\hline 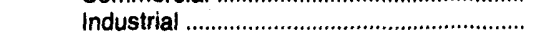 & 0 & 0 & 0 & 0 & 0 \\
\hline Vehicle Fuel & 0 & 0 & 0 & 0 & 0 \\
\hline 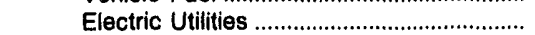 & 0 & 0 & $1,929,965$ & 0 & 0 \\
\hline 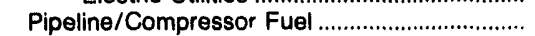 & 0 & $1,315,144$ & 0 & 86,090 & 601,394 \\
\hline Other Disposition & 88 & 11,571 & 0 & 0 & 0 \\
\hline Unaccounted For & $-2,721$ & $-359,489$ & -6 & 298,294 & 192,054 \\
\hline 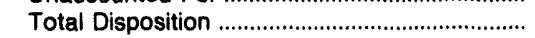 & $4,871,102$ & $265,135,495$ & $1,929,959$ & $16,646,876$ & $20,497,941$ \\
\hline
\end{tabular}

Source: Energy Information Administration (EIA), Form ElA-176, "Annual Report of Natural and Supplemental Gas Supply and Disposition." 
Table 29. MidCon Corp. Interstate Flows of Natural Gas, 1992 (Thousand Cubic Feet)

\begin{tabular}{|c|c|c|c|}
\hline Company and State & Volume & Company and State & 'slume \\
\hline 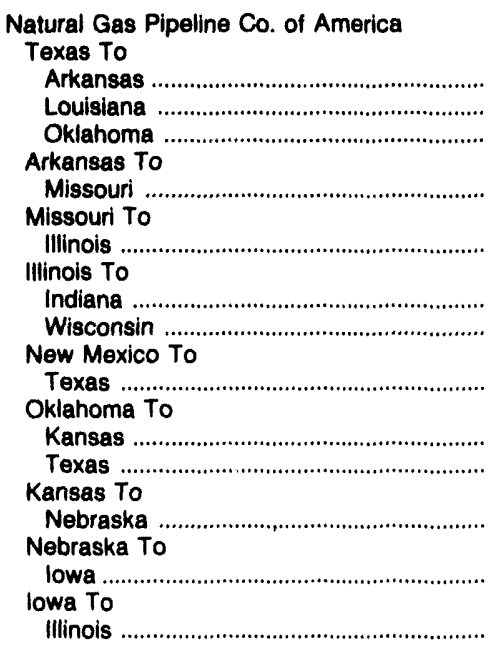 & $\begin{array}{r}272,832,246 \\
56,018,137 \\
164,818,955 \\
304,824,398 \\
302,246,110 \\
\\
173,638,299 \\
8,090,738 \\
40,057,003 \\
199,060,861 \\
197,252,810 \\
222,131,954 \\
287,212,973 \\
454,187,906\end{array}$ & 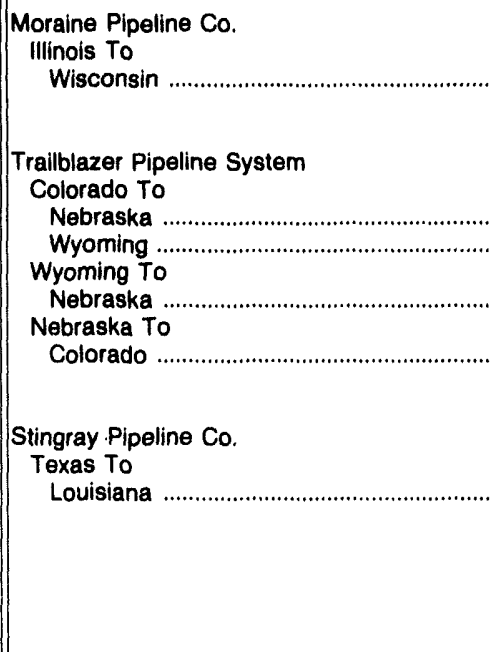 & $\begin{array}{r}115,725,114 \\
104,056,029 \\
104,052,758 \\
104,037,413\end{array}$ \\
\hline
\end{tabular}




\section{National Fuel Gas Co.}

National Fuel Gas Company engages in the production, transportation, storage, and distribution of natural gas in western New York, northwestern Pennsylvania, and southern Ontario, Canada. One of the company's subsidiaries, National Fuel Gas Supply Corporation, is an interstate pipeline and provides storage service. $\mathrm{Na}$ tional Fuel Gas Distribution Corporation, a National Fuel subsidiary, is a public utility and supplies natural gas to end users. Another subsidiary, Penn-York Energy Corporation (Penn-York Natural Gas Storage Company), provides underground gas storage service to nonaffiliated companies. Seneca Resources and Enıpire Exploration, subsidiaries of National Fuel, are en- gaged in the exploration and production of oil and natural gas from reserves in the United States and Canada.

National Fuel's interstate pipeline network interconnects with five long-line pipelines that provide service to the Northeastern United States markets. In addition, it interconnects with a large number of storage fields in the Pennsylvania and New York areas.

National Fuel is a major transporter of Canadian gas to consumers in the growing northeastern markets. The Niagara Spur Loop Project, a 49-mile, 30-inch pipeline completed in 1992, is jointly owned by Tennessee Gas and two other pipeline companies. The

Figure 22. National Fuel Gas Co., 1992

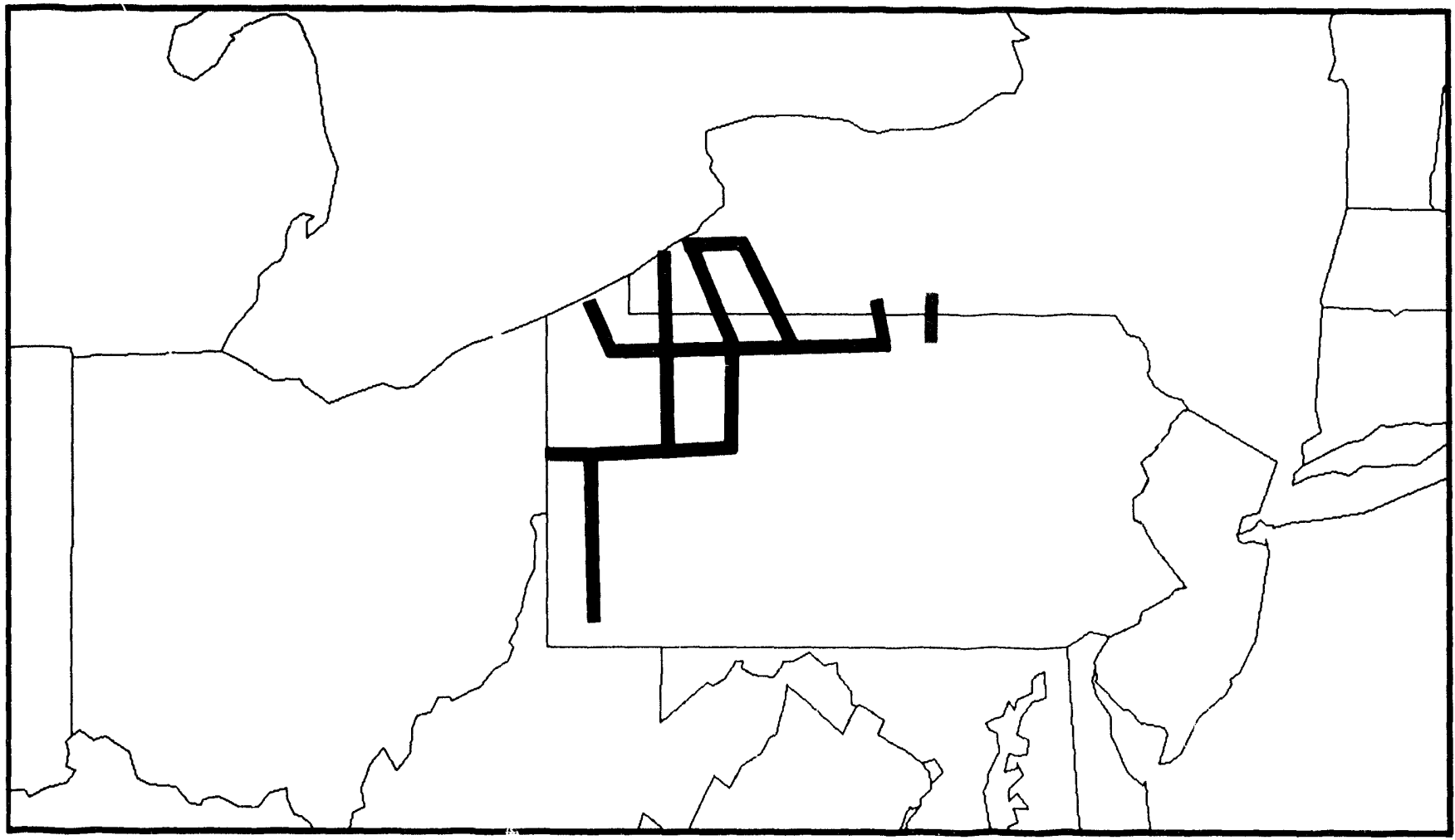

Source: Energy Information Administration (EIA), Form EIA-176, "Annual Report of Natural and Supplemental Gas Supply and Disposition." 
loop connects directly to TransCanada Pipelines Limited system in Ontario, Canada, and plans are currently under way for an expansion that will increase capacity an additional 69 million cubic feet per day.

The company became an open-access transporter under Federal Energy Regulatory Commission Order 500 in November 1990. As a downstream pipeline company, it has virtually no direct take-or-pay obligations. Any take-or-pay surcharges passed to it by its pipeline suppliers aic passed on to its end-use customers.

National Fuel's Gulf of Mexico offshore exploration program started five new wells during 1992 and brought all to completion. All five wells were brought on stream during 1993. National Fuel also completed its first horizontal well during 1993; more horizontal wells are under development.

In 1992, National completed a 62-megawatt cogeneration plant at the Outokumpu American Brass
Company in Buffalo, New York. In 1993, the company connected another cogeneration facility, the Oxbow Power Corporation at North Tonawanda, New York.

National Fuel delivers natural gas primarily to residential, commercial, and industrial customers, but is expanding that service to cogeneration customers. Several of the company's industrial customers have also recently switched from coal to natural gas. Other industrial applications include providing fuel for a kiln used for soil remediation in one of New York State's largest Superfund cleanups, fueling a waste-reduction device that reduces industrial sludge, and operating a natural gas refueling station in Tonowanda, New York. National Fuel promotes the marketing of natural gas as a vehicular fuel substituting for other more pollution prone fuels. In 1992 the company increased its own natural gas vehicle fleet by some 35 percent to a total of 280. Also in 1992 National added two new natural gas refueling stations. With the addition of these stations, National now services 14 private fleets. 
Table 30. National Fuel Gas Co. Natural Gas Data, 1992 (Thousand Cubic Feet)

\begin{tabular}{|c|c|c|c|c|c|c|}
\hline \multirow{2}{*}{ Supply/Disposition } & \multicolumn{2}{|c|}{ National Fuel Gas Supply Corp. } & \multicolumn{2}{|c|}{$\begin{array}{l}\text { National Fuel Gas Distribution } \\
\text { Corp. }\end{array}$} & \multicolumn{2}{|c|}{ Penn York Natural Gas Storage } \\
\hline & Pennsylvania & New York & Pennsylvania & New & York & Pennsylvania \\
\hline \multicolumn{7}{|l|}{ SUPPLY } \\
\hline $\begin{array}{l}\text { Produced Onsystem } \\
\text { Receipts }\end{array}$ & $3,856,730$ & 462,611 & 0 & 0 & 0 & 0 \\
\hline Purchases & $\begin{array}{r}48,861,106 \\
115,035,112\end{array}$ & $\begin{array}{l}21,540,665 \\
93,993,863\end{array}$ & $\begin{array}{l}35,346,852 \\
21,556,088\end{array}$ & $\begin{array}{l}90,602,392 \\
29,146,567\end{array}$ & $\begin{array}{l}0 \\
0\end{array}$ & $\begin{array}{r}0 \\
47,678,266\end{array}$ \\
\hline \multicolumn{7}{|l|}{ Interstate Movements } \\
\hline 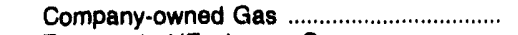 & 0 & 0 & 0 & 0 & 0 & 0 \\
\hline Transported/Exchange Gas ............................ & $13,896,300$ & 0 & 0 & 0 & $14,691,137$ & $8,954,973$ \\
\hline 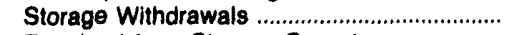 & $60,118,175$ & $24,122,918$ & 0 & 0 & $12,592,229$ & 0 \\
\hline Received from Storage Operators ..................... & 0 & 0 & 0 & 0 & 0 & $2,868,658$ \\
\hline 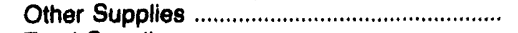 & 0 & 0 & 0 & 0 & 0 & 0 \\
\hline 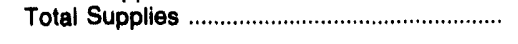 & $241,767,423$ & $140,120,057$ & $56,902,940$ & $119,748,959$ & $27,283,366$ & $59,50 t, 897$ \\
\hline \multicolumn{7}{|l|}{ DISPOSITION } \\
\hline Lease and Plant Use & 0 & 0 & 0 & 0 & 0 & 0 \\
\hline $\begin{array}{l}\text { Returned to Formations } \\
\text { Interstate Movements }\end{array}$ & 0 & 0 & 0 & 0 & 0 & 0 \\
\hline 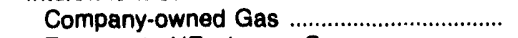 & 913,017 & 0 & 0 & 0 & 0 & 0 \\
\hline 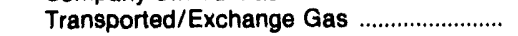 & 0 & $13,896,300$ & 0 & 0 & $8,954,973$ & $14,691,137$ \\
\hline Exchange Gas Deliveries ................................... & 918,179 & 0 & 0 & 0 & 0 & 0 \\
\hline $\begin{array}{l}\text { Storage Injections .......................................... } \\
\text { Deliveries of Company-owned Gas }\end{array}$ & $61,230,525$ & $19,213,344$ & 0 & 0 & $14,324,486$ & 0 \\
\hline 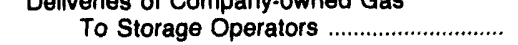 & 0 & 0 & 0 & 0 & 0 & 0 \\
\hline 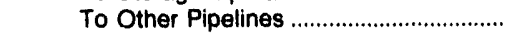 & 0 & 0 & 0 & 0 & 0 & 0 \\
\hline $\begin{array}{l}\text { To Consumers } \\
\text { Residential }\end{array}$ & 0 & & $25,263,269$ & $61,732,620$ & & \\
\hline 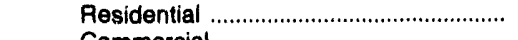 & $\begin{array}{l}0 \\
0\end{array}$ & $\begin{array}{l}0 \\
0\end{array}$ & $7,446,214$ & $18,030,602$ & $\begin{array}{l}0 \\
0\end{array}$ & 0 \\
\hline 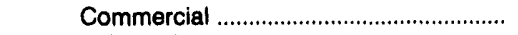 & & & 1230790 & 7,058087 & 0 & 0 \\
\hline Industrial & 0 & 0 & $1,230,790$ & $7,058,087$ & 0 & 0 \\
\hline 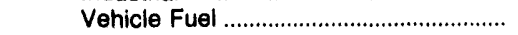 & 0 & 0 & 0 & 0 & 0 & 0 \\
\hline 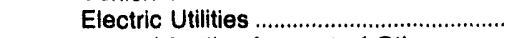 & 0 & 0 & 27,070 & 0 & 0 & 0 \\
\hline \multicolumn{7}{|l|}{ Transported for the Account of Others } \\
\hline 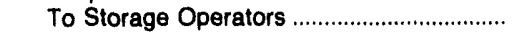 & 0 & 0 & 0 & 0 & 0 & $2,868,658$ \\
\hline 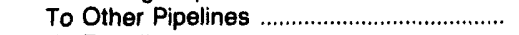 & 0 & 0 & 0 & 0 & $3,637,256$ & $40,569,392$ \\
\hline $\begin{array}{l}\text { To Resellers ................................................... } \\
\text { To Consumers }\end{array}$ & $137,735,893$ & $20,101,157$ & 0 & 0 & 0 & 0 \\
\hline 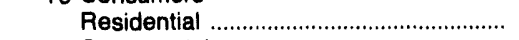 & 0 & 0 & 0 & 69,336 & 0 & 0 \\
\hline 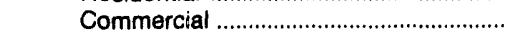 & 0 & 0 & $2,368,720$ & $6,512,071$ & 0 & 0 \\
\hline 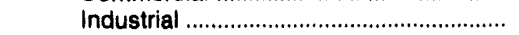 & 0 & 0 & $18,456,617$ & $21,853,240$ & 0 & 0 \\
\hline 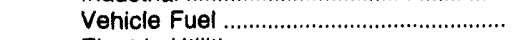 & 0 & 0 & 0 & 0 & 0 & 0 \\
\hline 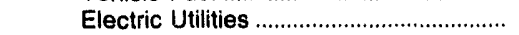 & 0 & 0 & 0 & 0 & 0 & 0 \\
\hline 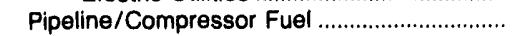 & $1,160,752$ & 154,093 & 770,332 & 859,449 & 366,651 & $1,372,710$ \\
\hline 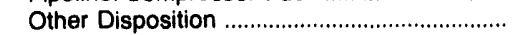 & 0 & 0 & 0 & 0 & 0 & 0 \\
\hline 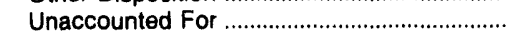 & $-716,402$ & $-1,475,588$ & $1,339,928$ & $3,633,554$ & 0 & 0 \\
\hline 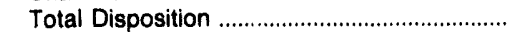 & $241,767,423$ & $140,120,057$ & $56,902,940$ & $119,748,959$ & $27,283,366$ & $59,501,897$ \\
\hline
\end{tabular}

Source: Energy Information Administration (EIA), Form ElA-176, "Annual Report of Natural and Supplemental Gas Supply and Disposition." 
Table 31. Natlonal Fuel Gas Co.

Interstate Flows of Natural Gas, 1992

(Thousand Cubic Feet)

\begin{tabular}{|c|c|}
\hline Company and State & Volume \\
\hline $\begin{array}{l}\text { National Fuel Gas Supply Corp. } \\
\text { Pennsylvania To } \\
\text { Ohio } \\
\text { New York To } \\
\text { Pennsylvania }\end{array}$ & $\begin{array}{r}813,017 \\
13,896,300\end{array}$ \\
\hline $\begin{array}{l}\text { Penn York Natural Gas Storage } \\
\text { New York To } \\
\text { Pennsylvania } \\
\text { Pennsylvania To } \\
\text { New York }\end{array}$ & $\begin{array}{r}8,954,973 \\
14,691,137\end{array}$ \\
\hline
\end{tabular}

Source: Energy Information Administration (EIA), Form ElA.176, "Annual Report of Natural and Supplemental Gas Supply and Disposition." 


\section{Niagara Mohawk Power Corp.}

Niagara Mohawk Power Corp. is an investor-owned combination gas and electric utility incorporated in New York in July 1937. The company operates in New York State and is principally engaged in the production and/or purchase, transmission, distribution and sale of electricity ( 85 percent of company revenues) and the purchase, distribution and sale of natural gas (15 percent of revenues).

The Company has several wholly owned direct and indirect subsidiaries. Opinac Energy Corporation, a Canadian-based subsidiary, owns Opinac Exploration Limited and Canadian Niagara Power Company, Limited. Opinac Energy Corporation and Opinac Explo- ration Limited engage in the exploration and development of oil and gas properties. Canadian Niagara Power generates electricity at its Niagara Falls, Ontario hydro-electric plant. HYDRO-CO Enterprises, Inc., another of the Company's subsidiaries, develops, owns and/or operates cogeneration and small power plants. These facilities are located both within and outside of the Company's service territory.

Niagara Mohawk Power Corporation distributes natural gas to a geographic area reaching from Syracuse to Albany. Not all of the Company's distribution areas are physically linked with one another by companyowned facilities. Nine separate distribution areas are

Figure 23. Niagara Mohawk Power Corp., 1992

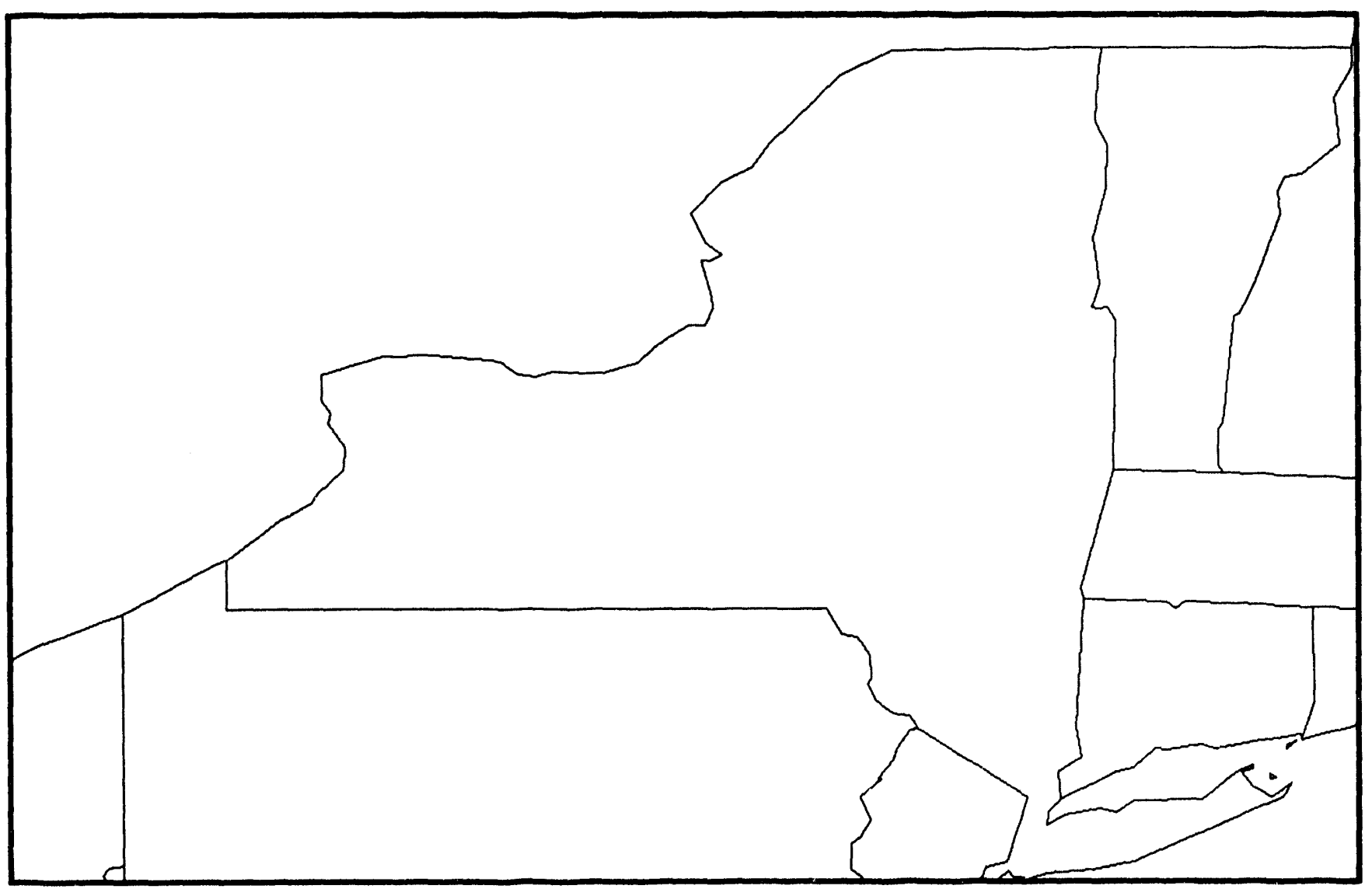

Source: Energy Information Administration (EIA), Form EIA-176, "Annual Report of Natural and Supplemental Gas Supply and Disposition."

Service Area 
connected directly with CNG Transmission Corporation (CNG), an interstate natural gas pipeline regulated by the Federal Energy Regulatory Commission (FERC).

In the fall of 1991, Niagara Mohawk entered into agreements with the Iroquois Gas Transmission System (Iroquois) and CNG Transmission Corporation to provide for delivery of Canadian gas. During 1992, about 19 percent of the Company's gas was transported on Iroquois. Presently, Canadian gas is shipped through the CNG system. The Company expects its system to be linked directly with Iroquois within a few years.

In August 1991, the Company entered into a merger agreement with Syracuse Suburban Gas Company with approximately 4,600 customers in two communities. The merger was approved by the New York State
Public Service C. ssion in April 1992 and completed in June.

During 1992, Niagara Mohawk moved more than 166 billion cubic feet of gas through its system for deliveries to both end users and resellers. The total natural gas to end users in 1992 was 156 billion cubic feet, with 34 percent to residential consumers, 30 percent to commercial consumers, and 26 percent to industrial customers. Niagara Mohawk delivered 16 billion cubic feet of gas (10 percent) to electric utilities. Most of the remaining supplies (11.6 billion cubic feet) were injected into storage facilities.

In partnership with Hess Oil Corporation, the company participated in the first installation of a public natural gas refueling station in its service territory. Three stations were slated to open in 1993, including one in Albany. 


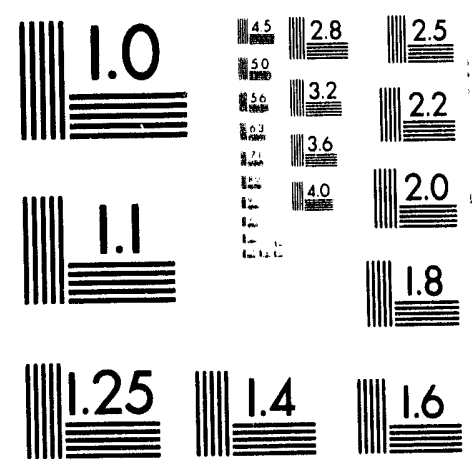



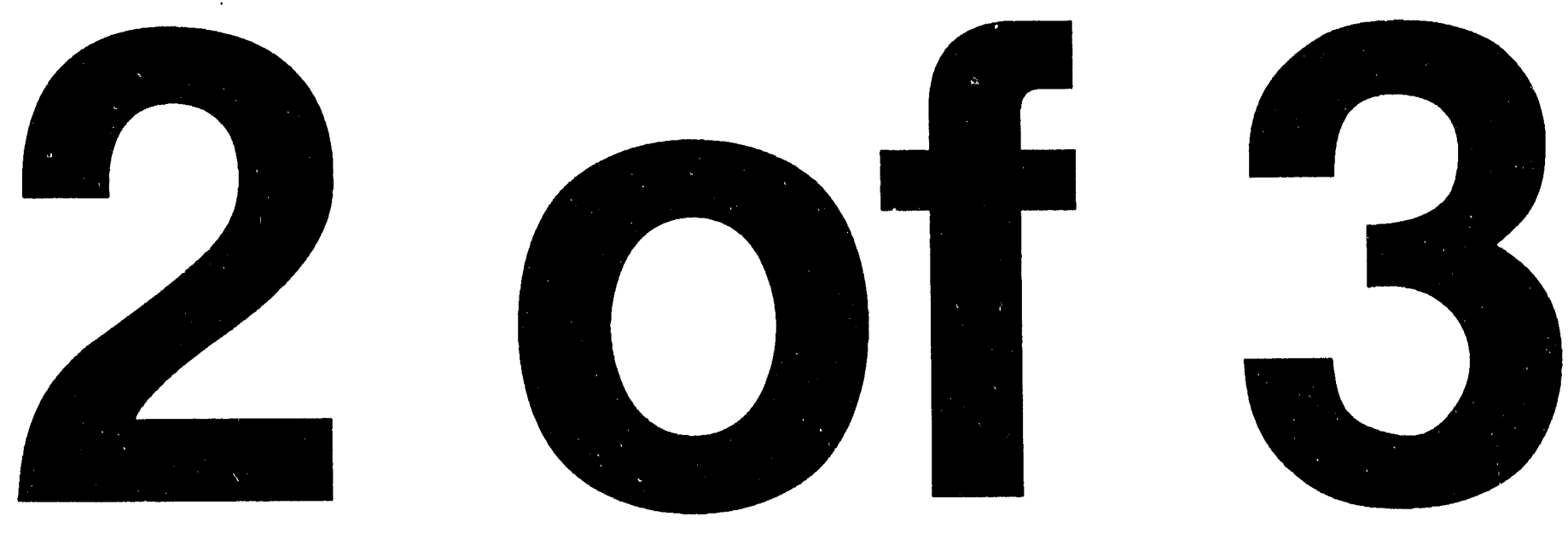
Table 32. Niagara Mohawk Power Corp. Natural Gas Data, 1992 (Thousand Cubic Feet)

\begin{tabular}{c|c}
\hline \multirow{3}{*}{ Supply/Disposition } & Niagara Mohawk Power Corp. \\
\cline { 2 - 2 } & New York \\
\hline
\end{tabular}

\section{SUPPLY}

Produced Onsystem .

Receipts

Purchases

Transported/Exchange Gas

$91,142,223$

Interstate Movements

Company-owned Gas

Transported/Exchange Gas

Storage Withdrawais

Received from Stora

$65,663,727$

Total Supplies

0
0
0
$9,219,727$
0
$166,025,677$

\section{DISPOSITION}

Lease and Plant Use

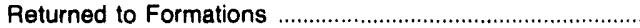

Interstate Movements

Company-owned Gas

Transported/Exchange Gas

Exchange Gas Deliveries

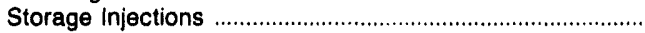

Deliveries of Company-owned Gas

To Storage Operators

To Other Pipelines

To Resellers

To Consumers

Residential

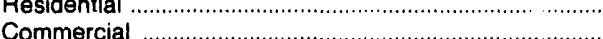

Industrial ..........

Electric Utilities

Transported for the Account of Others

To Storage Operators

To Other Pipelines

To Resellers

To Consumers

Residential

Venicle Fue

Electric Utilities

$166,025,677$

Pipeline/Compressor Fue

Other Disposition

Unaccounted For

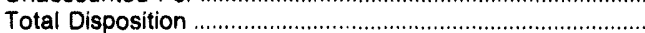

$11,550,169$

$1,715,722$

$52,327,891$

$21,404,775$

$1,655,367$

$16,044,400$

0
0

0

0

$25,665,230$

$38,925,009$

0

$166,025,677$

Source: Energy information Administration (EIA), Form EIA.176, "Annual Report of Natural and Supplemental Gas Supply and Disposition." 


\section{Northern Illinois Gas Co.}

Northern Illinois Gas Co., one of the Nation's largest gas distribution utilities, is a subsidiary of NICOR, Inc., a holding company. Northern Illinois delivers natural gas to more than 1.7 million customers in the northern third of Illinois, excluding the city of Chicago. It provides transportation service, gas storage and supply backup to more than 12,000 commercial and industrial customers that purchase their own gas supply. The company is connected to five interstate pipelines and has storage facilities that provide more than onethird of total normal winter needs.

NICOR Oil and Gas, another subsidiary, is engaged in gas and oil exploration and production in the United
States and Canada. The company's reserve and production operations are located primarily in the Ariadarko and Arkoma Basins of Oklahoma and the Gulf Coast areas of Texas and Louisiana. Its reserve at. 1 production volumes are approximately 80 percent natural gas and 20 percent oil.

In 1992, Northern Illinois Gas added approximately 27,100 customers. Large-scale residential and commercial developments are being built in Northern Illinois with more anticipated in the outlying communities of Chicago. The company expects to gain most of the new residential and commercial space-heating market. In 1993, Northern Illinois began delivering natural gas

Figure 24. Northern Illinois Gas Co., 1992

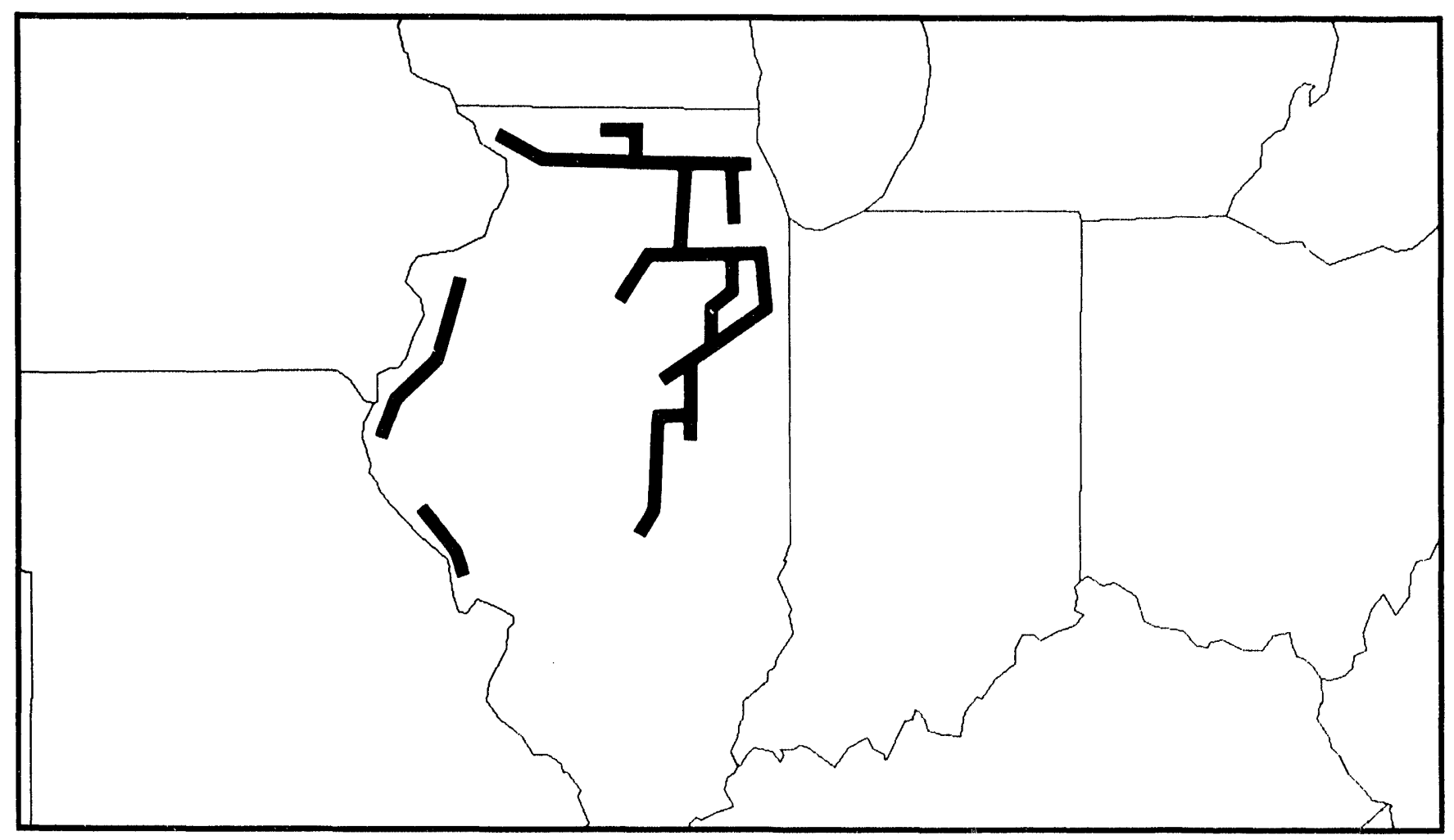

Source: Energy Information Administration (EIA), Form EIA-176, "Annual Report of Natural and Supplemental Gas Supply and Disposition."

Service Areas

Northern Illinois Gas Co. 
to Commonwealth Edison's largest electric-generating station. Previously, this facility operated entirely on fuel oil.

Northern Illinois has three primary areas of growth opportunities resulting from provisions of the Clean Air Act: large-tonnage gas air conditioning, conversion of industrial plants from coal to natural gas, and natural gas vehicles.

Northern Illinois also operates seven underground storage facilities, with about 165 billion cubic feet of total capacity. The company uses its storage principally to provid service to end users.

In February 1992, Amoco Oil Company in conjunction with Northern Illinois Gas opened the first compressed natural gas station available to the general public in the Chicago suburb of Warrenville. The facility will also be used to fuel CNG-powered vehicles, as will the Amoco Research Center in Naperville, Illinois.
On June 1, 1993, Northern Illinois Gas opened a new midwest market hub for natural gas, known as the Chicago Hub. Natural Gas Clearinghouse will administer the hub through its subsidiary, Hub Services, Inc. The Chicago Hub connects with five interstate pipelines: Natural Gas Pipeline of America, Northern Natural Gas, Panhandle Eastern Pipe Line, ANR Pipeline, and Midwestern Gas Transmission. The deregulation of the natural gas industry has created an interest in hubs, and Northern Illinois is the first local distribution company to operate one.

The Chicago Hub offers balancing, wheeling, parking. and title transfer services. Balancing is a service that matches buyers with transportation customers who are selling. Wheeling occurs when a shipper transports from one interstate pipeline to another, using a thirdparty. Parking provides an option for short-term storage. 
Table 33. Northern Illinols Gas Co. Natural Gas Data, 1992

(Thousand Cubic Feet)

\begin{tabular}{c|c}
\hline \multirow{2}{*}{ Supply/Disposition } & Northern Illinois Gas Co. \\
\cline { 2 - 2 } & Illinois \\
\hline
\end{tabular}

SUPPLY

\begin{tabular}{|c|c|}
\hline 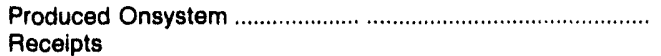 & 0 \\
\hline 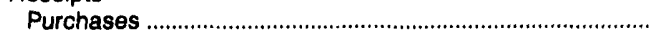 & $279,284,743$ \\
\hline 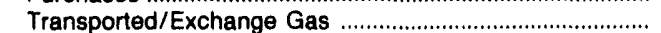 & $161,352,866$ \\
\hline Interstate Movements & \\
\hline 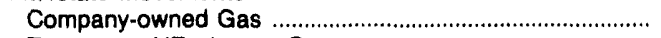 & 0 \\
\hline 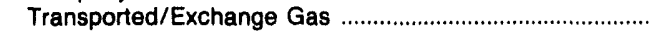 & 0 \\
\hline 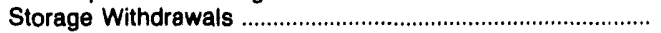 & $117,702,442$ \\
\hline 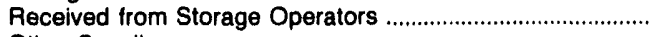 & $13,806,281$ \\
\hline Other Supplies & 0 \\
\hline 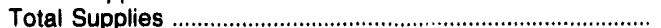 & $572,1,6,332$ \\
\hline
\end{tabular}

Total Supplies $\quad 572,1,6,332$

\section{DISPOSITION}

\begin{tabular}{|c|c|}
\hline $\begin{array}{l}\text { Lease and Plant Use } \\
\text { Returned to Formations } \\
\text { Interstate Movements }\end{array}$ & $\begin{array}{l}0 \\
0\end{array}$ \\
\hline 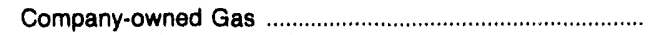 & 0 \\
\hline 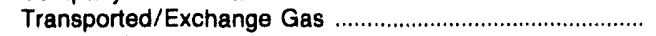 & 0 \\
\hline 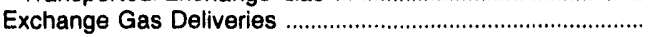 & 442,344 \\
\hline Storage Injections & $113,808,568$ \\
\hline Deliveries of Company-owned Gas & \\
\hline To Storage Operators & 0 \\
\hline 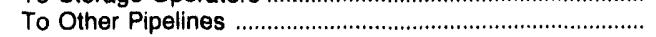 & 0 \\
\hline 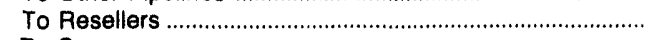 & 0 \\
\hline To Consumers & \\
\hline 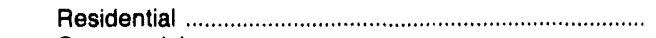 & $223,900,874$ \\
\hline 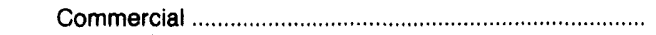 & $51,932,243$ \\
\hline 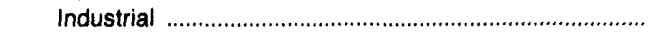 & $16,938,641$ \\
\hline 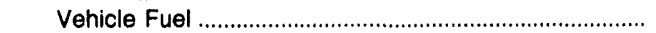 & 2,137 \\
\hline 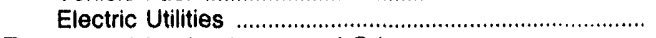 & 87,252 \\
\hline Transported for the Account of Others & \\
\hline 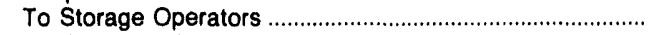 & \\
\hline To Other Pipelines & 0 \\
\hline 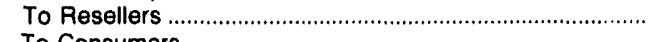 & 0 \\
\hline To Consumers & \\
\hline 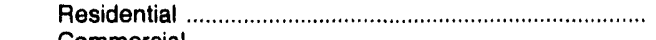 & $\begin{array}{r}6,105,095 \\
6914805\end{array}$ \\
\hline 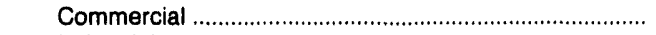 & $36,914,805$ \\
\hline Industrial & $112,020,505$ \\
\hline 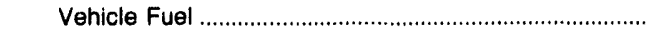 & 1.053 \\
\hline 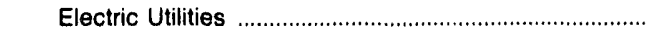 & $6,055,623$ \\
\hline 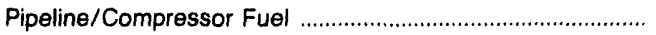 & $2,163,078$ \\
\hline 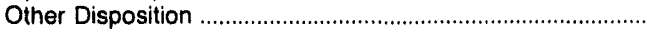 & \\
\hline Unaccounted For & $1,774,114$ \\
\hline Total Disposition & $572,146,332$ \\
\hline
\end{tabular}

Source: Energy Information Administration (EIA), Form EIA-176, "Annual Report of Natural and Supplemental Gas Supply and Disposition." 


\section{Northern Indiana Public Service Co.}

Northern Indiana Public Service Company delivers natural gas and electricity throughout the northern third of Indiana, a 12,000-square-mile area with a population of about 2.2 million. It is the largest gas company in Indiana with approximately 614,000 customers and the second largest electric company in the State. Northern Indiana is the principal subsidiary of NIPSCO Industries Inc., an energy-based holding company.

Another subsidiary, NIPSCO Energy Services Inc., coordinates the company's energy-related diversification ventures. It has four subsidiaries: NIPSCO Fuel Company Inc., investing in gas and oil exploration and development ventures; NIPSCO Energy Trading Corporation, engaged in gas and other energy-brokering; NI-TEX Inc., an intrastate natural gas transmission and gas supply company; and Triumph Natural Gas, Inc. Effective January 1993, NIPSCO Energy Services acquired a controlling interest in Triumph, a Dallas, Texas-based gas marketing company. Triumph is expected to help provide a variety of gas services to local gas distribution companies and industrial customers in the Midwest.

In February 1992, NIPSCO Industries Inc. purchased Kokomo Gas and Fuel Company, which serves the city of Kokomo, Indiana, and surrounding rural areas.

Figure 25. Northern Indiana Public Service Co., 1992

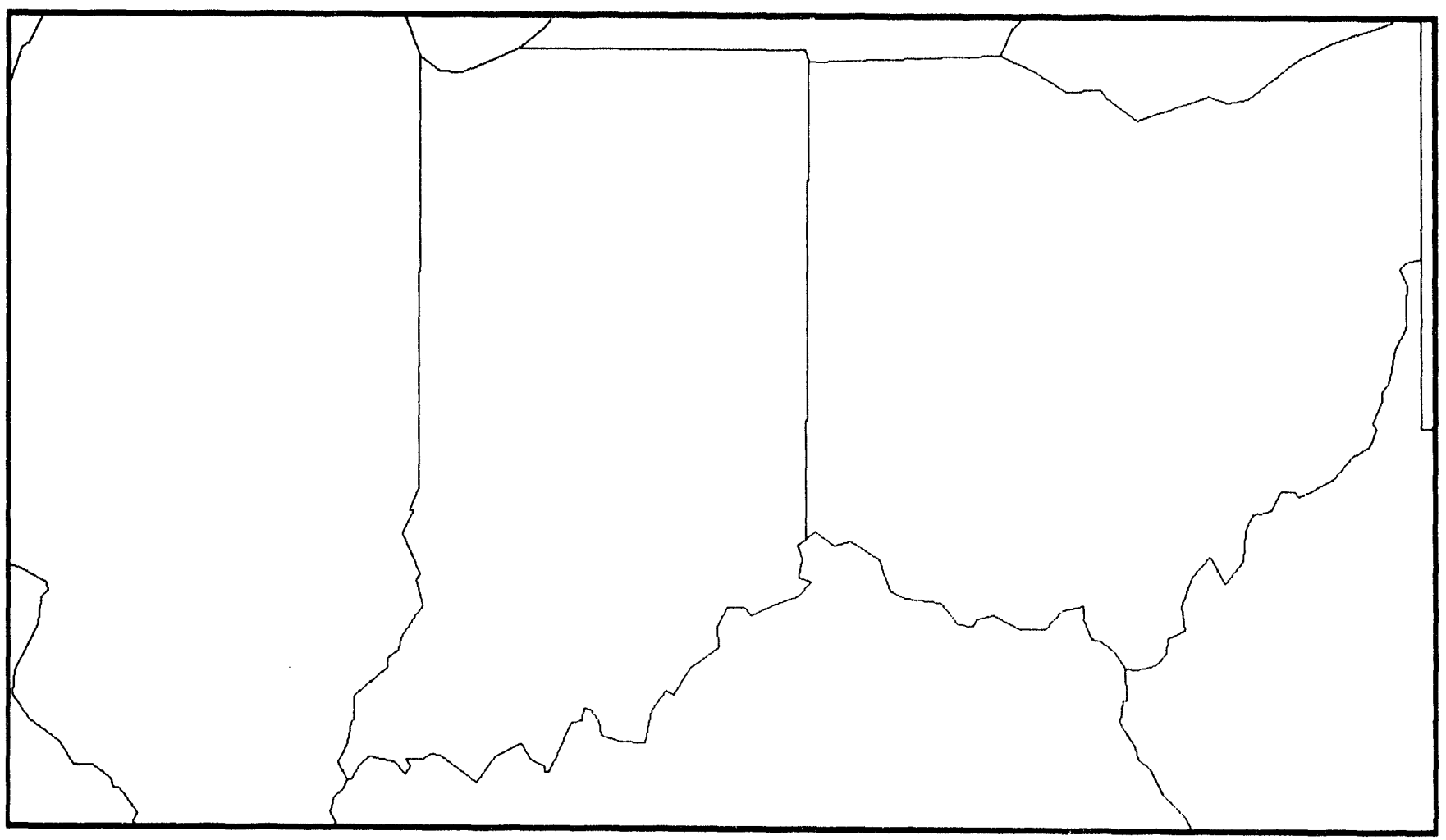

Source: Energy Information Administration (E|A), Form EIA-176, "Annual Report of Natural and Supplemental Gas Supply and Disposition."

Service Area 
Table 34. Northern Indiana Public Service Co. Natural Gas Data, 1992

(Thousand Cubic Feet)

\begin{tabular}{|c|c|c|}
\hline \multirow{2}{*}{ Supply/Disposition } & Northern Indiana Public Service Co. & Kokomo Gas \& Fuel Co. \\
\hline & \multicolumn{2}{|c|}{ Indiana } \\
\hline \multicolumn{3}{|l|}{ SUPPLY } \\
\hline \multicolumn{2}{|l|}{ Receipts } & 0 \\
\hline Purchases & $4,006,395$ & $1,430,066$ \\
\hline Transported/Exchange Gas. & $82,306,082$ & $6,101,754$ \\
\hline \multicolumn{3}{|l|}{ Interstate Movements } \\
\hline Company-owned Gas & $15,189,673$ & 0 \\
\hline Transported/Exchange Gas & $158,448,626$ & 0 \\
\hline Storage Withdrawals ............... & $7,395,650$ & 86,698 \\
\hline 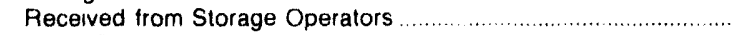 & 0 & 0 \\
\hline 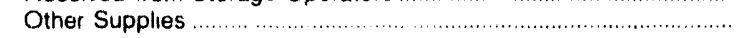 & 0 & 0 \\
\hline 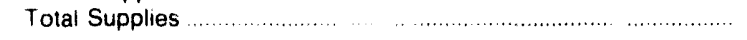 & $267,346,426$ & $7,618,518$ \\
\hline \multicolumn{3}{|l|}{ DISPOSITION } \\
\hline 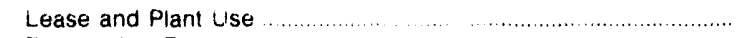 & 0 & 0 \\
\hline 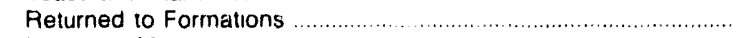 & 0 & 0 \\
\hline \multicolumn{3}{|l|}{ Interstate Movements } \\
\hline Company-owned Gas ...... & 0 & 0 \\
\hline 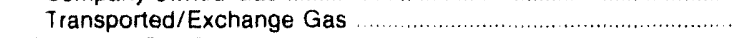 & 0 & 0 \\
\hline 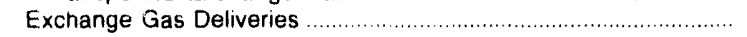 & 0 & 0 \\
\hline 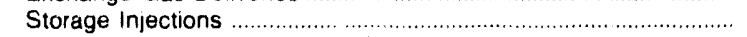 & $6,660,267$ & 99,517 \\
\hline \multicolumn{3}{|l|}{ Deliveries of Company-owned Gas } \\
\hline To Storage Operators ................... & 0 & 0 \\
\hline 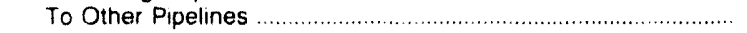 & 0 & 0 \\
\hline 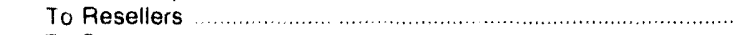 & 0 & 0 \\
\hline \multicolumn{3}{|l|}{ To Consumers } \\
\hline Residential .. & $66,154,058$ & $3,149,604$ \\
\hline (. & $26,058,936$ & $1,380,992$ \\
\hline 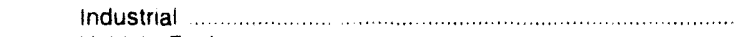 & $14,560,469$ & $1,342,051$ \\
\hline 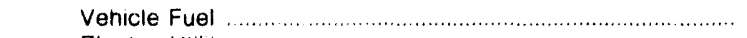 & 56,036 & 0 \\
\hline Electric Utilitıes & $1,248,515$ & 0 \\
\hline \multicolumn{3}{|l|}{ Transported for the Account of Others } \\
\hline To Storage Operators & 0 & 0 \\
\hline 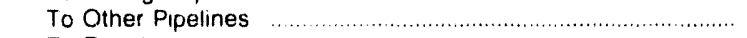 & 0 & 0 \\
\hline 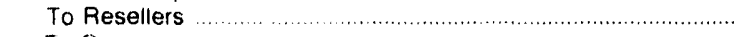 & 0 & 0 \\
\hline \multicolumn{3}{|l|}{ To Consumers } \\
\hline 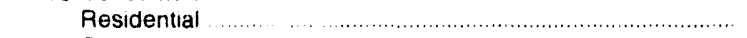 & 0 & 0 \\
\hline 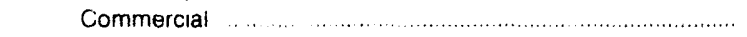 & 0 & 0 \\
\hline Industrıal & $145,584,929$ & $1,660,601$ \\
\hline Vehicle Fuel & 0 & 0 \\
\hline Electric Utilities & $6,128,632$ & 0 \\
\hline 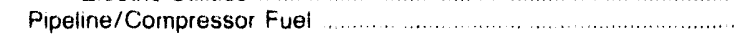 & 111,799 & 7,392 \\
\hline Other Disposition .... & 0 & 0 \\
\hline 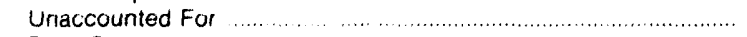 & 782,785 & $-21,639$ \\
\hline 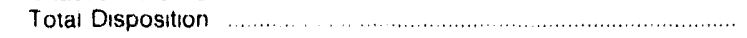 & $267,346,426$ & $7,618,518$ \\
\hline
\end{tabular}

Source. Energy Information Administration (EIA). Form EIA-176, "Annual Report of Natural and Supplemental Gas Supply and Disposition."

Also, in December 1992, NIPSCO signed an agreement to acquire Northern Indiana Fuel and Light Company which serves gas customers in northeastern Indiana.

The company's underground gas storage field at Royal Center, Indiana, has a storage capacity of 6.75 million decatherms. In addition, the Company has several gas storage service agreements which make possible the withdrawals of substantial quantities of gas from other storage facilities.

Gas is purchased from Natural Gas Pipeline Company of America, Midwestern Gas Transmission Company, Panhandle Eastern Pipeline Company, Trunkline Gas
Company, ANR Pipeline Company, and various producers under separate service agreements. In 1992 the company purchased approximately 31 percent of its gas supply through the spot market, usually on 30-day agreements.

Northern Indiana Public Service Company continues to pursue its interests in the natural gas vehicle market. Customers include the LaPorte Police Department, the AAA Medical Shuttle, and the University of Notre Dame. During 1992 they were supporting private natural gas vehicle fleets of 48 vehicles and 4 refueling stations in addition to their own 700-vehicle fleet and 17 refueling stations. 


\section{Northwest Natural Gas Co.}

Northwest Natural Gas Company is a diversified energy company that provides sales and transportation service to natural gas customers in Northwest Oregon and Southwest Washington. It also has three subsidiaries that produce and market natural gas and oil and support the development of other energy-related businesses.

Northwest Natural transports large amounts of customer-owned gas to industrial customers. More than half of the gas moved through its distribution system is for transportation customers who purchase their own gas and contract with Northwest Natural for transportation services. Agreements were reached with the majority of the company's large industrial customers to provide interruptible transportation at rates designed to compete with bypass costs. Under such agreements, which prohibit bypass costs, the company is able to keep its large industrial customer base substantially intact.

The prime gas supplier to Northwest Natural Gas Co. is the Northwest Pipeline Corp. A second supplier, starting in late 1993, is the Pacific Gas Transmission Co. (PGT). Northwest Natural reached an agreement with Portland General Electric Co. to acquire capacity on the PGT expansion to be used for electric generation

Figure 26. Northwest Natural Gas Co., 1992

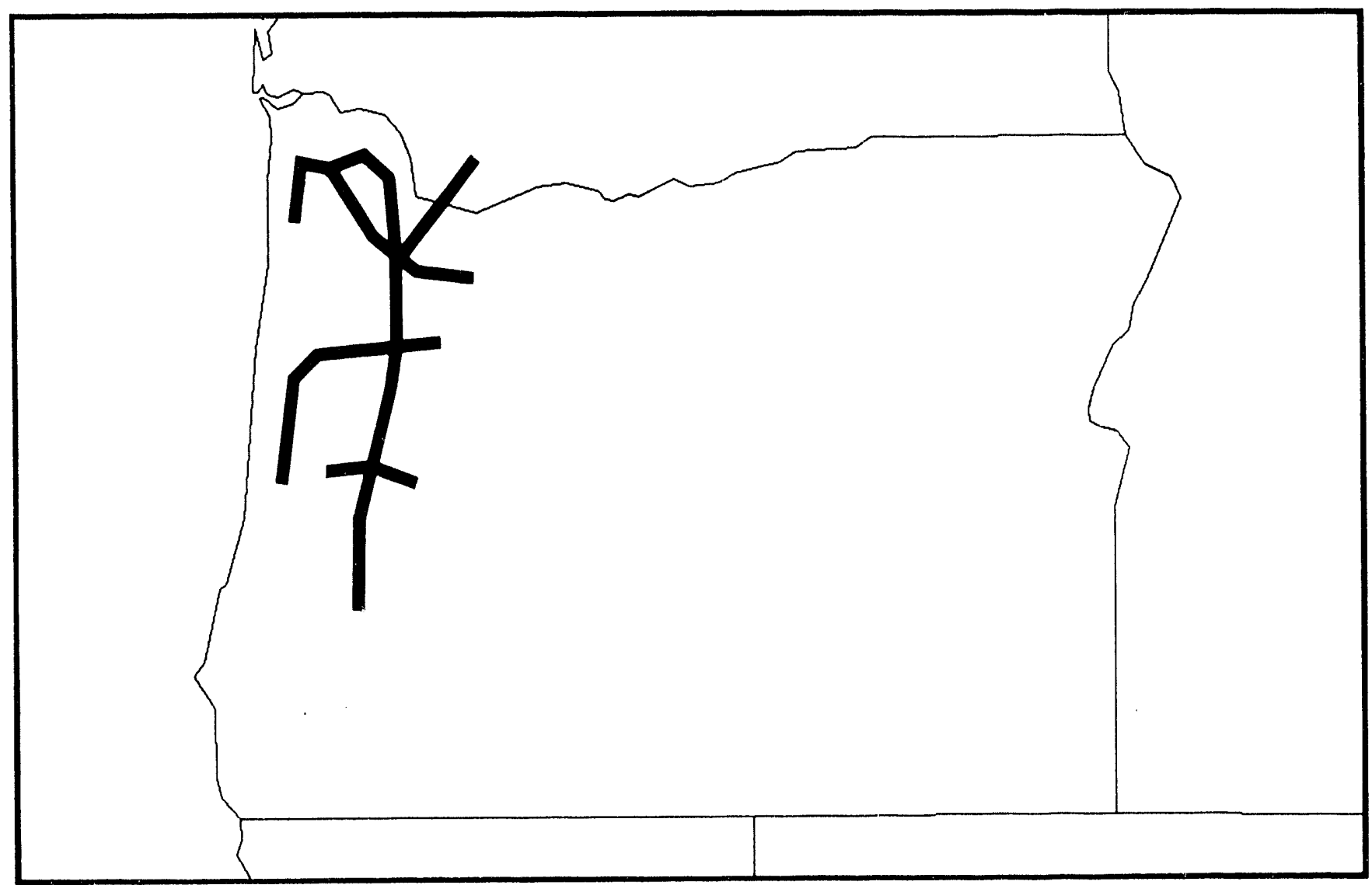

Source: Energy Information Administration (EIA), Form EIA-176, "Annual Report of Natural and Supplemental Gas Supply and Disposition." 
Table 35. Northwest Natural Gas Co. Natural Gas Data, 1992 (Thousand Cubic Feet)

\begin{tabular}{|c|c|c|}
\hline \multirow{2}{*}{ Supply/Disposition } & \multicolumn{2}{|c|}{ Northwest Natu : Gas Co. } \\
\hline & Oregon & Washington \\
\hline \multicolumn{3}{|l|}{ SUPPLY } \\
\hline \multicolumn{3}{|l|}{$\begin{array}{l}\text { Produced Onsystem } \\
\text { Receipts }\end{array}$} \\
\hline 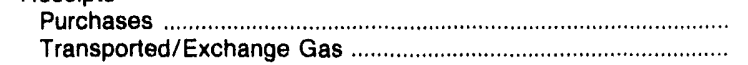 & $\begin{array}{l}41,730,595 \\
49,325,565\end{array}$ & $\begin{array}{l}2,280,808 \\
8,191,404\end{array}$ \\
\hline \multicolumn{3}{|l|}{ Interstate Movements } \\
\hline 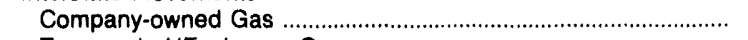 & 0 & 0 \\
\hline 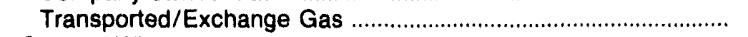 & 0 & 0 \\
\hline 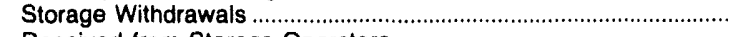 & $7,319,895$ & 0 \\
\hline 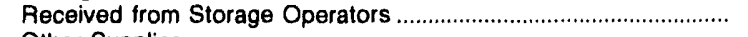 & 0 & 0 \\
\hline Other Supplies & 1,907 & 0 \\
\hline 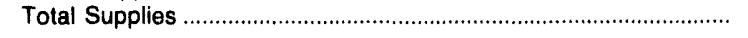 & $98,377,962$ & $10,472,212$ \\
\hline \multicolumn{3}{|l|}{ DISPOSITION } \\
\hline 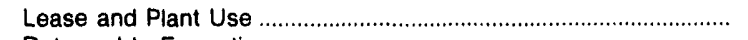 & 0 & 0 \\
\hline Returned to Formations & 0 & 0 \\
\hline \multicolumn{3}{|l|}{ Interstate Movements } \\
\hline 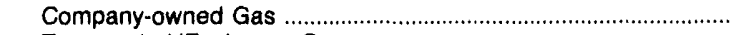 & 0 & 0 \\
\hline 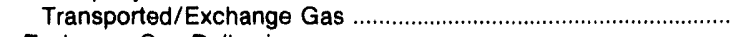 & 0 & 0 \\
\hline 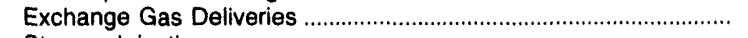 & 0 & 0 \\
\hline 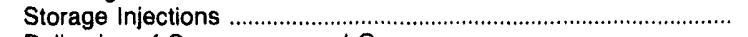 & $6,490,099$ & 0 \\
\hline \multicolumn{3}{|l|}{ Deliveries of Company-owned Gas } \\
\hline 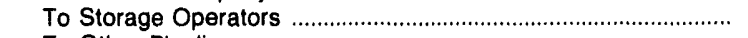 & 0 & 0 \\
\hline 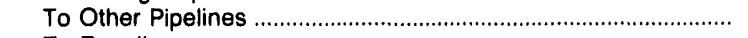 & 0 & 0 \\
\hline 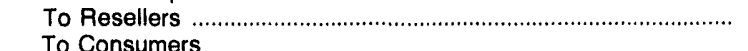 & 0 & 0 \\
\hline $\begin{array}{l}\text { To Consumers } \\
\text { Residential }\end{array}$ & $19,164,433$ & 766,939 \\
\hline 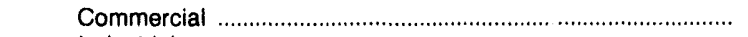 & $15,301,467$ & $1,124,226$ \\
\hline 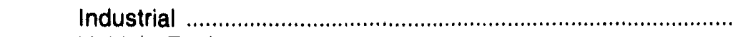 & $8,276,436$ & 437,742 \\
\hline 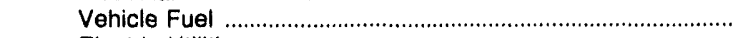 & 6,103 & 0 \\
\hline 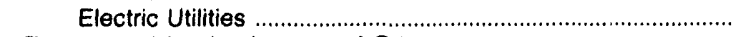 & 0 & 0 \\
\hline \multicolumn{3}{|l|}{ Transported for the Account of Others } \\
\hline To Storage Operators & 0 & 0 \\
\hline 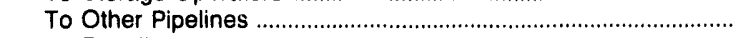 & 0 & 0 \\
\hline 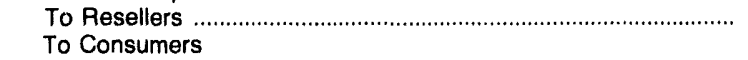 & 0 & 0 \\
\hline 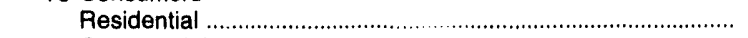 & 0 & 0 \\
\hline 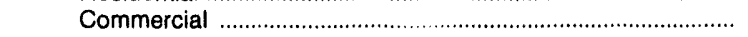 & 0 & 0 \\
\hline 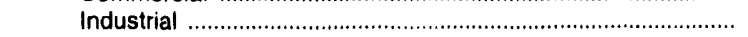 & $36,507,720$ & $8,191,404$ \\
\hline 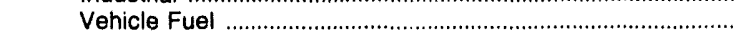 & 0 & 0 \\
\hline 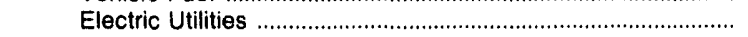 & $12,817,845$ & 0 \\
\hline 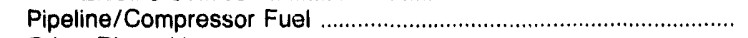 & 121,246 & 0 \\
\hline Other Disposition & 0 & 0 \\
\hline Unaccounted For & $-307,387$ & $-48,099$ \\
\hline 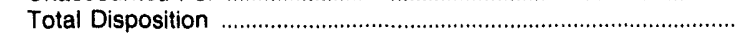 & $98,377,962$ & $10,472,212$ \\
\hline
\end{tabular}

Source: Energy Information Administration (EIA), Form EIA-176, "Annual Report of Natural and Supplemental Gas Supply and Disposition."

by Portland and to supply Northwest Natural's expanding needs.

The 18-mile Kelso Beaver Pipeline has been completed which gives Portland General direct access to North- west Pipeline. Also planned is a pipeline extension from Central Oregon to the Willamette Valley to be completed in 1995. This will connect directly to PGT so that natural gas will not have to be shipped via Northwest Pipeline. 


\section{ONEOK, Inc.}

Headquartered in Oklahoma, ONEOK, Inc., is a natural gas utility with a wide range of energy interests. It is made up of three major divisions. The Oklahoma Natural Gas Company handles the purchasing, distribution, and selling of natural gas and the leasing of pipeline capacity. The ONG Transmission Company is responsible for gathering, compressing, transporting, and storing natural gas. It is also responsible for the company's link to interstate transmission systems. The Energy Company is responsible for natural gas liquids extraction operations, oil and gas exploration and production, and contract drilling.
The Oklahoma Natural Gas Company owns 13,000 miles of distribution pipeline serving almost 700,000 customers in a service area that covers three-fourths of Oklahoma. A total of 281 communities in Oklahoma are served, with Oklahoma City and Tulsa being the two largest markets.

The ONG Transmission Company has 5,000 miles of gathering and transmission pipelines. The transmission system is connected to pipeline suppliers, processing plants, and wells in all the major producing areas in the State. Caney River Transmission Company, a subsidiary, owns a 25 percent interest in Ozark Gas Transmission System which serves the Arkoma Basin. An-

Figure 27. ONEOK, Inc., 1992

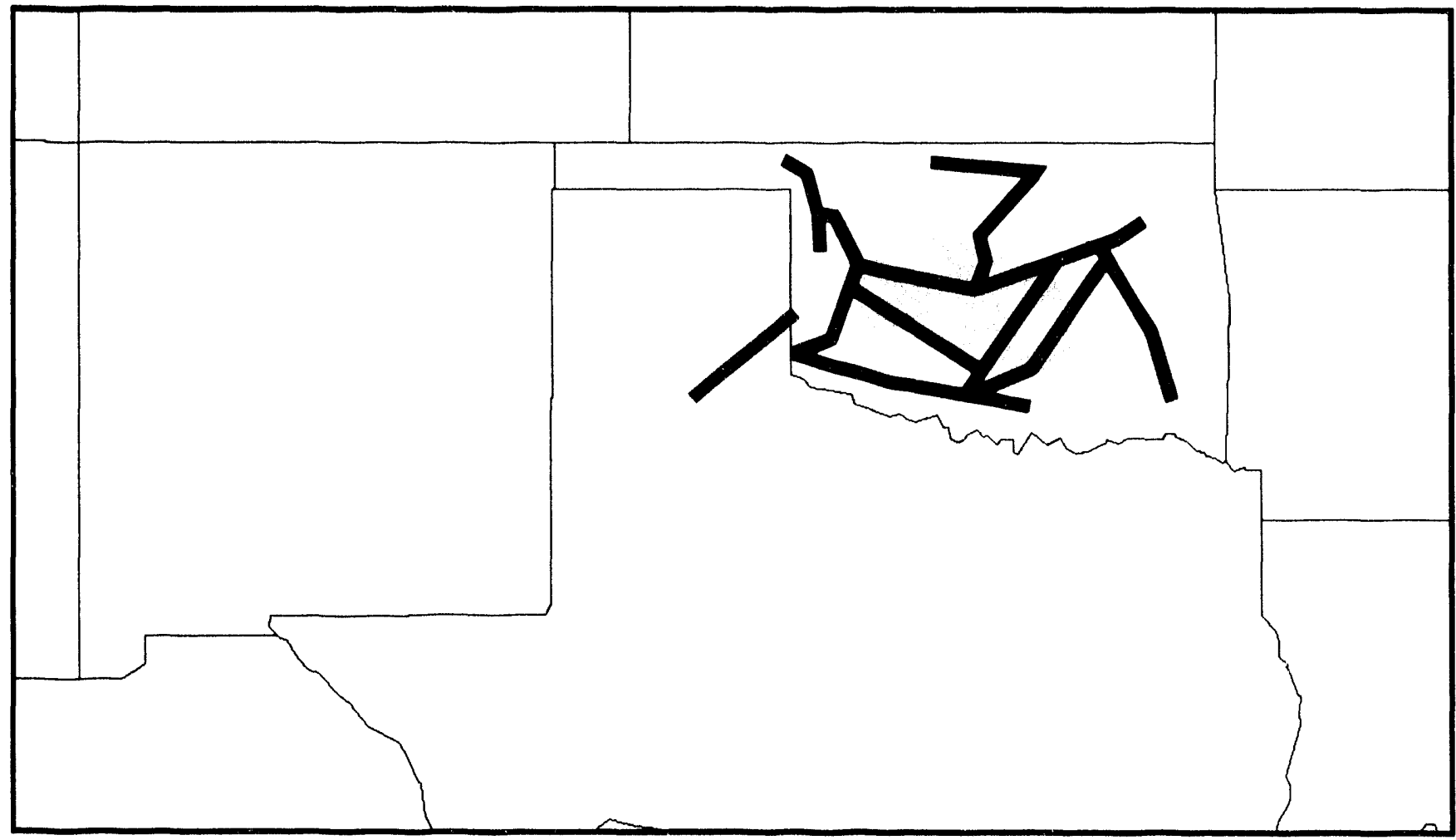

Source: Energy Information Administration (EIA), Form ElA-176, "Annual Report of iNatural and Supplemental Gas Supply and Disposition." 
other subsidiary, TransTex Pipeline Company, owns 25-percent interest in Red River Pipeline which serves the Anadarko Basin. ONG Western Inc., is a 525-mile transmission system connecting ONEOK's major pipeline system with the Anadarko Basin in western Oklahoma. ONG Sayre Storage Company purchases, stores, and delivers gas in western Oklahoma. ONG Red Oak Transmission Company purchases and delivers gas from southeastern Oklahoma to Tulsa.

Two subsidiaries of the Energy Companies--ONEOK Exploration Company and ONEOK Resource Company--are engaged in oil and gas exploration and production. Another subsidiary, ONEOK Gas Marketing Company, which was formed in September 1992, has entered into a partnership with Ward Gas Marketing Inc. The new partnership will market natural gas throughout the country.

The company operates five underground natural gas storage facilities. Oklahoma Natural Gas's withdrawals from storage on peak winter days can supply up to 50 percent of its system deliverability requirements.

Oklahoma Natural Gas helped pioneer the currently used technology for storing natural gas in depleted underground gas fields in the late 1930's. This year, ONEOK Drilling successfully participated in the State's first and the Nation's third research project to determine whether or not horizontally drilled withdrawal wells would increase gas deliverability from underground storage. There was a 650-percent improvement. The flow potential at the test site increased from 6 million cubic feet of gas to 45 million cubic feet of gas per day.

A new wholly owned subsidiary, ONEOK Technology Company, was created during 1992 to develop and market a new meter setting device. This technology would enable utilities to change meters while continuing the gas flow to customers' homes.

After 12 years of commitment to development of compressed natural gas as an alternate fuel, about 1,000 NGV's are operating in Oklahoma. This compares to 440 NGV's for ONEOK one year ago and to 35,000 NGV's currently operating throughout the United States. The U.S. Postal Service alone doubled its fleet from 400 to 800 becoming one of the Nation's largest NGV delivery fleets. Plans to convert 1,500 more postal vehicles in 1993 through an Oklahoma firm are underway.

With the help of Gas Research Institute (GRI), ONEOK hopes to further penetrate gas markets through new tecinnologies and products. Among these services and products are cogeneration systems, specialized commercial cooking equipment, and highefficiency chillers. By 1994, residential customers will be able to purchase a new 3-ton, economically efficient, natural gas-fired heat pump which will provide yearround space conditioning. The company continues to help commercial customers by marketing new comtuercial products and technological developments. For instance, this year GRI will introduce an infrared rangetop burner designed to heat large quantities twice as fast as current equipment. 
Table 36. ONEOK, Inc., Natural Gas Data, 1992

(Thousand Cubic Feet)

\begin{tabular}{|c|c|c|c|c|c|c|}
\hline \multirow[t]{2}{*}{ Supply/Disposition } & $\begin{array}{c}\text { Oklahoma } \\
\text { Natural Gas Co. }\end{array}$ & $\begin{array}{l}\text { ONG Sayre } \\
\text { Storage Co. }\end{array}$ & $\begin{array}{c}\text { ONG Red Oak } \\
\text { Transmission } \\
\text { Co. }\end{array}$ & $\begin{array}{l}\text { ONG Western, } \\
\text { Inc. }\end{array}$ & $\begin{array}{c}\text { Oktex } \\
\text { Pipeline Co. }\end{array}$ & \multirow{2}{*}{$\frac{\begin{array}{c}\text { Red River } \\
\text { Pipeline Co. }\end{array}}{\text { Texas }}$} \\
\hline & \multicolumn{5}{|c|}{ Oklahoma } & \\
\hline \multicolumn{7}{|l|}{ SUPPLY } \\
\hline \multicolumn{7}{|l|}{ Receipts } \\
\hline 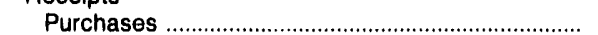 & $128,446,965$ & 176,850 & 0 & 14.454 .443 & 0 & 0 \\
\hline Transported/Exchange Gas ................................... & $189,669,641$ & $3,457,020$ & $57,135,213$ & $71,201,164$ & 0 & $11,796,652$ \\
\hline \multicolumn{7}{|l|}{ Interstate Movements } \\
\hline Company-owned Gas. & 0 & 0 & 0 & 0 & 0 & 0 \\
\hline 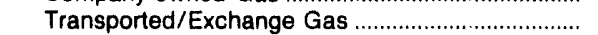 & 0 & 0 & 0 & 0 & $9,374,399$ & 0 \\
\hline 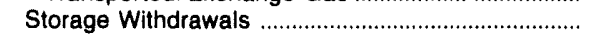 & $24,967,049$ & 0 & 0 & 0 & 0 & 0 \\
\hline Received from Storage Operators ............................... & $1,773,035$ & $1,773,035$ & 0 & 0 & 0 & 0 \\
\hline 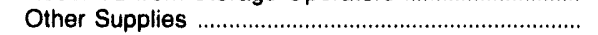 & 0 & 0 & 0 & 0 & 0 & 91,650 \\
\hline 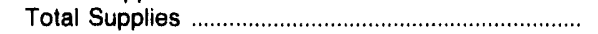 & $344,856,690$ & $5,406,905$ & $57,135,213$ & $85,655,607$ & $9,374,399$ & $11,888,302$ \\
\hline \multicolumn{7}{|l|}{ DISPOSITION } \\
\hline Lease and Plant Use. & 125,729 & 0 & 0 & 0 & 0 & 0 \\
\hline 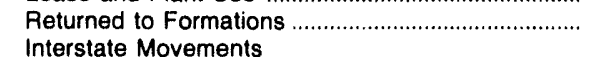 & 0 & 0 & 0 & 0 & 0 & 0 \\
\hline Company-owned Gas ................................................. & 0 & 0 & 0 & 0 & 0 & 0 \\
\hline Transported/Exchange Gas .......................................... & 0 & 0 & 0 & 0 & 0 & 0 \\
\hline 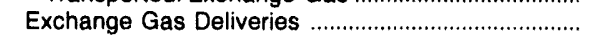 & $73,944,502$ & $4,252,145$ & $56,627,487$ & $72,047,920$ & 0 & 0 \\
\hline \multicolumn{7}{|l|}{ Deliveries of Company-owned Gas } \\
\hline To Storage Operators & 930,434 & 0 & 0 & 0 & 0 & 0 \\
\hline 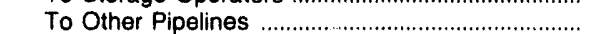 & & 0 & 0 & 0 & 0 & 0 \\
\hline 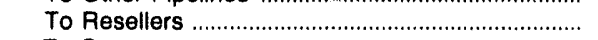 & $2,355,928$ & 176,850 & 0 & $14,454,443$ & 0 & 0 \\
\hline \multicolumn{7}{|l|}{ To Consumers } \\
\hline Residential .................................................... & $51,644,485$ & 0 & 0 & 0 & 0 & 0 \\
\hline 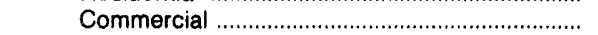 & $23,604,609$ & 0 & 0 & 0 & 0 & 0 \\
\hline 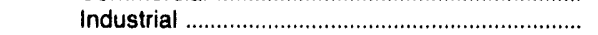 & $38,678,092$ & 0 & 0 & 0 & 0 & 0 \\
\hline 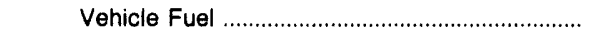 & 45,300 & 0 & 0 & 0 & 0 & 0 \\
\hline Electric Utilities ……………………………....... & $3,286,185$ & 0 & 0 & 0 & 0 & 0 \\
\hline \multicolumn{7}{|l|}{ Transported for the Account of Others } \\
\hline 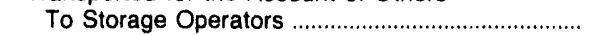 & 0 & 995,760 & 0 & 0 & 0 & 0 \\
\hline 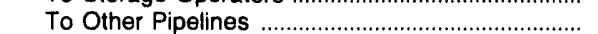 & 0 & 0 & 0 & 0 & 0 & $11,695,495$ \\
\hline 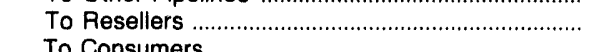 & 445,460 & 0 & 0 & 0 & $9,374,399$ & 0 \\
\hline $\begin{array}{l}\text { To Consumers } \\
\text { Residential }\end{array}$ & 0 & 0 & 0 & \multicolumn{3}{|c|}{ To Consumers } \\
\hline 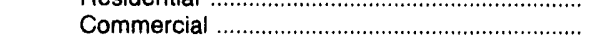 & $2,127,015$ & 0 & 0 & 0 & 0 & 0 \\
\hline 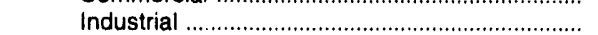 & $114,923,693$ & 0 & 0 & 0 & 0 & 0 \\
\hline 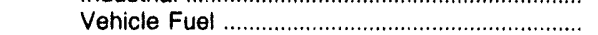 & 0 & 0 & 0 & 0 & 0 & 0 \\
\hline Electric Utilities ............................................ & $5,213,642$ & 0 & 0 & 0 & 0 & 0 \\
\hline 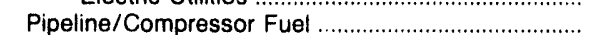 & 778,496 & 129 & 526 & 234 & 0 & 323,293 \\
\hline Other Disposition & 0 & 0 & 0 & 0 & 0 & 0 \\
\hline 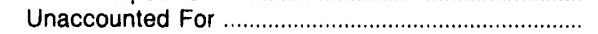 & $5,130,916$ & $-17,979$ & 507,200 & $-846,990$ & 0 & $-130,486$ \\
\hline 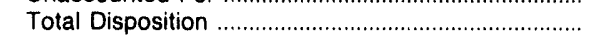 & $344,856,690$ & $5,406,905$ & $57,135,213$ & $85,655,607$ & $9,374,399$ & $11,888,302$ \\
\hline
\end{tabular}

Source: Energy Information Administration (E|A), Form ElA-176, "Annual Report of Natural and Supplemental Gas Supply and Disposition." 


\section{Pacific Gas and Electric Co.}

Pacific Gas and Electric (PG\&E), the Nation's largest investor-owned gas and electric company, has operations throughout northern and central California. The company provides service to more than 3 million natural gas residential customers and about 200,000 other natural gas $\mathrm{c} ! \cdot$ iomers. Its gas supplies come primarily from Canada, with lesser amounts from the Southwestern United States and California.

Pacific Gas Transmission (PGT), a wholly owned subsidiary of PG\&E, transports gas from Canada through the Pacific Northwest into California. Expansion of the pipeline from Alberta to California, due to be com- pleted in fourth quarter 1993, will bring additional Canadian gas to California and the Northwestern States.

In June 1993, PGT sold its interest, nearly 50 percent, in Alberta Natural Gas Company, Limited (ANG). This Canadian corporation is involved in production, purchase, and transportation of natural gas in Alberta, Canada.

PG\&E is a leading distr butor of natural gas to consumers, delivering 784 billion cubic feet of gas to consumers in 1992. Of that amount 35 percent, or 276 billion cubic feet, went to generate electricity.

Figure 28. Pacific Gas and Electric Co., 1992

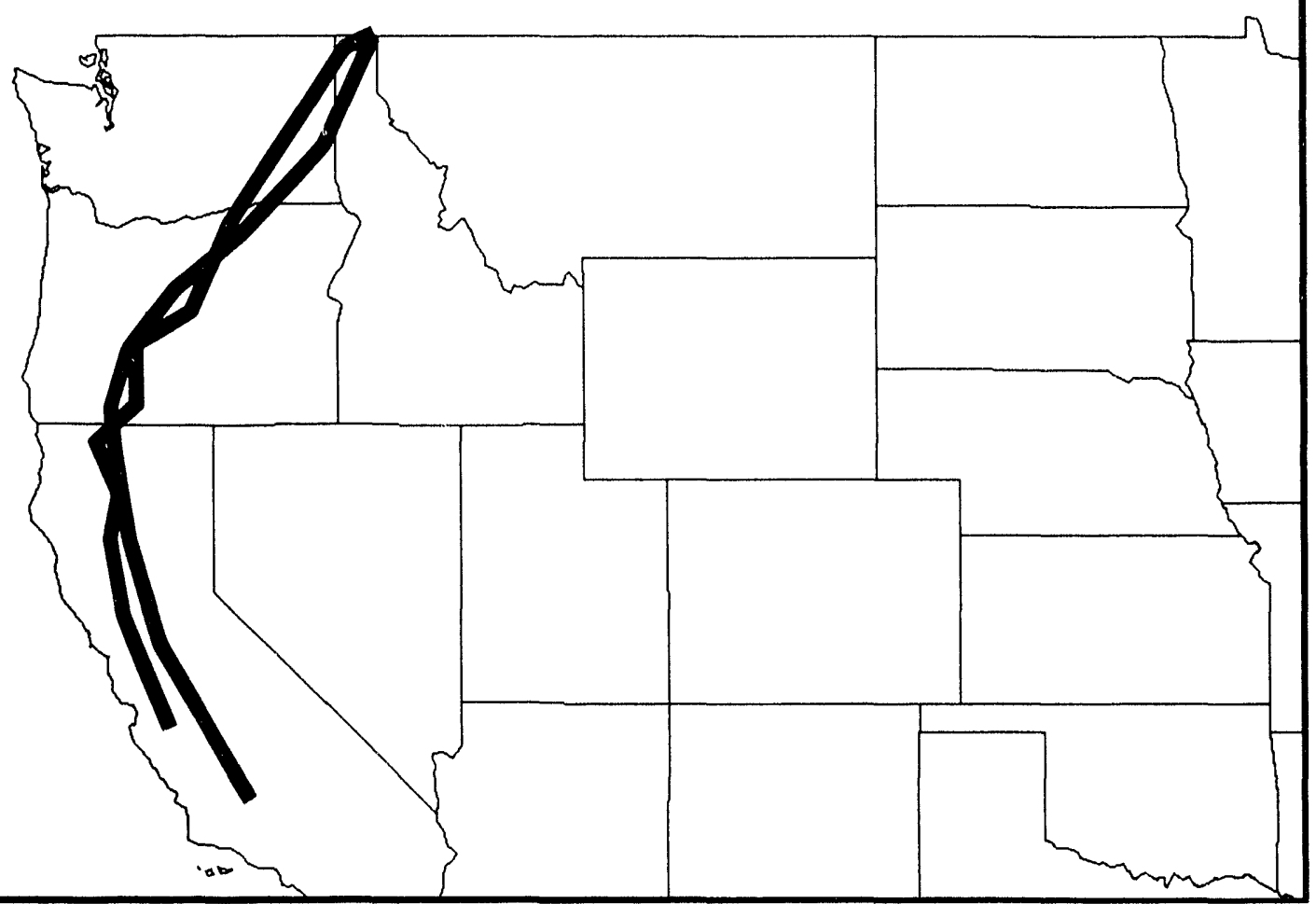

Source: Energy Information Administration (EIA), Form EIA-176, "Annual Report of Natural and Supplemental Gas Supply and Disposition." 
Table 37. Pacific Gas and Electric Co. Natural Gas Data, 1992

(Thousand Cubic Feet)

\begin{tabular}{|c|c|c|c|c|c|}
\hline \multirow{2}{*}{ Supply/Disposition } & \multirow{2}{*}{$\begin{array}{c}\begin{array}{c}\text { Pacific Gas \& } \\
\text { Electric Co. }\end{array} \\
\text { California }\end{array}$} & \multicolumn{4}{|c|}{ Pacific Gas Transmission Co. } \\
\hline & & Idaho & Washington & Oregon & Wyoming \\
\hline \multicolumn{6}{|l|}{ SUPPLY } \\
\hline \multicolumn{6}{|l|}{$\begin{array}{l}\text { Produced Onsystem } \\
\text { Receipts }\end{array}$} \\
\hline Purchases & $50,334,000$ & 0 & 0 & 0 & $2,051,640$ \\
\hline 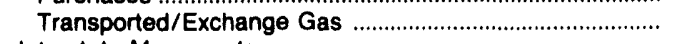 & $90,343,000$ & 0 & 0 & $12,278,066$ & 0 \\
\hline \multicolumn{6}{|l|}{ Interstate Movements } \\
\hline Company-owned Gas & $303,228,225$ & $308,990,291$ & 0 & 0 & 0 \\
\hline 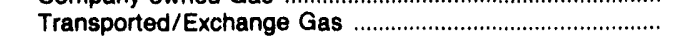 & $353,467,766$ & $189,232,017$ & $491,200,366$ & $449,670,029$ & 0 \\
\hline 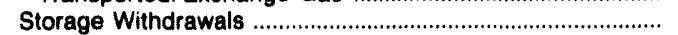 & $46,916,000$ & 0 & 0 & 0 & 0 \\
\hline Received from Storage Operators .................................... & 0 & 0 & 0 & 0 & 0 \\
\hline 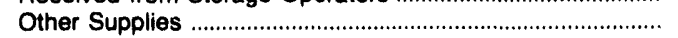 & 457,000 & 0 & 0 & 0 & 0 \\
\hline 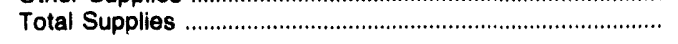 & $844,745,991$ & $498,222,308$ & $491,200,366$ & $461,948,095$ & $2,051,640$ \\
\hline \multicolumn{6}{|l|}{ DISPOSITION } \\
\hline 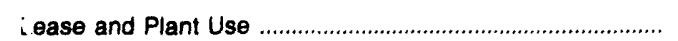 & 0 & 0 & 0 & 0 & 0 \\
\hline Returned to Formations …………………… & 0 & 0 & 0 & 0 & 0 \\
\hline Interstate Movements & & & & & \\
\hline Company-owned Gas & 0 & $307,300,907$ & $305,786,858$ & $303,228,225$ & 0 \\
\hline 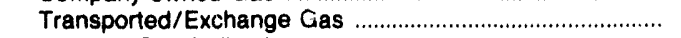 & 0 & $182,128,523$ & $145,654,107$ & $45,297,430$ & 0 \\
\hline 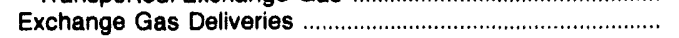 & 0 & 0 & 0 & 0 & 0 \\
\hline 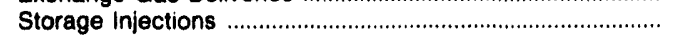 & $34,295,000$ & 0 & 0 & 0 & 0 \\
\hline \multicolumn{6}{|l|}{ Deliveries of Company-owneci Gas } \\
\hline 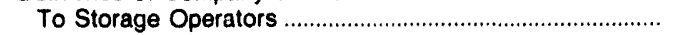 & 0 & 0 & 0 & 0 & 0 \\
\hline 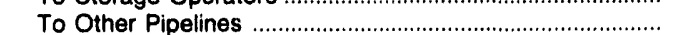 & 0 & 0 & 0 & 0 & $2,026,984$ \\
\hline To Resellers . & $13,627,062$ & 0 & 0 & 0 & 0 \\
\hline \multicolumn{6}{|l|}{ To Consumers } \\
\hline Residential & $191,208,015$ & 0 & 0 & 0 & 0 \\
\hline 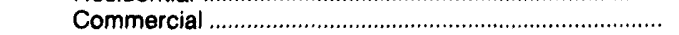 & $132,243,117$ & 0 & 0 & 0 & 0 \\
\hline 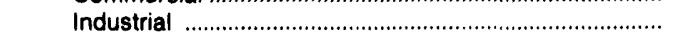 & $93,005,670$ & 0 & 0 & 0 & 0 \\
\hline 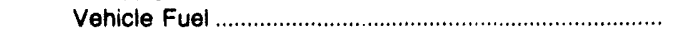 & 13,789 & 0 & 0 & 0 & 0 \\
\hline Electric Utillties ……………………………………........ & $127,880,488$ & 0 & 0 & 0 & 0 \\
\hline \multicolumn{6}{|l|}{ Transported for the Account of Others } \\
\hline 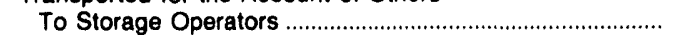 & 0 & 0 & 0 & 0 & 0 \\
\hline 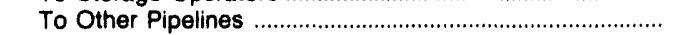 & $3,014,979$ & 724,411 & $37,323,383$ & $107,098,615$ & 0 \\
\hline \multirow{2}{*}{\multicolumn{6}{|c|}{ To Consumers }} \\
\hline & & & & & \\
\hline 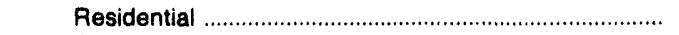 & 0 & 0 & 0 & 0 & 0 \\
\hline 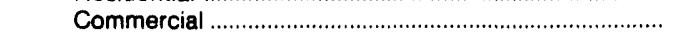 & $28,207,665$ & 0 & 0 & 0 & 0 \\
\hline 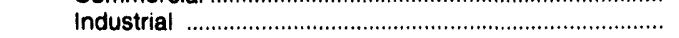 & $63,233,614$ & 0 & 0 & 0 & 0 \\
\hline 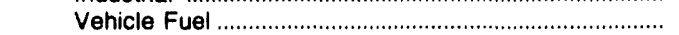 & 0 & 0 & 0 & 0 & 0 \\
\hline 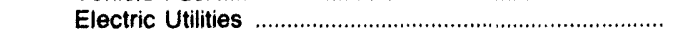 & $147,751,289$ & 0 & 0 & 0 & 0 \\
\hline 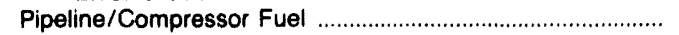 & $8,310,918$ & $2,776,640$ & $2,491,807$ & $6,515,731$ & 24,656 \\
\hline 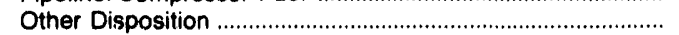 & 698,200 & 201,098 & 349,151 & 318,333 & 0 \\
\hline Unaccounted For ………………………………. & $1,256,185$ & $5,090,729$ & $-404,940$ & $-510,239$ & 0 \\
\hline 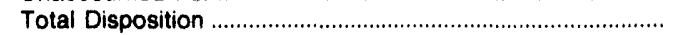 & $844,745,991$ & $498,222,308$ & $491,200,366$ & $461,948,095$ & $2,051,640$ \\
\hline
\end{tabular}

Source: Energy Information Administration (EIA), Form ElA-176, "Annual Report of Natural and Supplemental Gas Supply and Disposition."

Residential customers received 191 billion cubic feet of gas, while the commercial and industrial sectors received 160 and 156 cubic feet, respectively. In 1992, 40 percent of the deliveries to industrial customers were for the account of others, while PG\&E acted as the transporter for 18 percent of the commercial deliveries.

Nearly 20 years ago, PG\&E began experimenting with natural gas vehicles. By the end of the decade, PG\&E hopes to have 125,000 fleet vehicles operating on natural gas in northern and central California. The company also plans to have adequate refueling stations for all natural gas vehicles.
Because many more customers are buying their own gas supplies, PG\&E is becoming more of an intrastate transporter of gas rather than a marketer. It will no longer purchase as much gas and plans to sell its interest in pipelines and other natural gas facilities outside of California.

During 1993, the company announced a corporate restructuring and corresponding changes in the number and organization of employees. The planned workforce reduction of 3,000 positions by the end of 1995 represents a targeted downsizing of more than 11 percent. Half of that reduction will have taken place by the end of 1993, while the remainder is plannid to occur by the end of 1995. 
Table 38. Pacific Gas and Electric Co. Interstate

Flows of Natural Gas, 1992

(Thousand Cubic Feet)

\begin{tabular}{|c|c|}
\hline Company and State & Volume \\
\hline \multicolumn{2}{|l|}{$\begin{array}{l}\text { Pacific Gas \& Electric Co. } \\
\text { California From }\end{array}$} \\
\hline Arizona & $\begin{array}{l}309,941,272 \\
346,754,719\end{array}$ \\
\hline \multicolumn{2}{|l|}{$\begin{array}{l}\text { Pacific Gas Transmission Co. } \\
\text { Canada To }\end{array}$} \\
\hline $\begin{array}{l}\text { Idaho } \\
\text { Idaho To }\end{array}$ & $496,451,372$ \\
\hline $\begin{array}{l}\text { Washington } \\
\text { Washington To }\end{array}$ & $489,429,430$ \\
\hline $\begin{array}{l}\text { Idaho } \\
\text { Oregon } \\
\text { Oregon To }\end{array}$ & $\begin{array}{r}1,770,936 \\
449,670,029\end{array}$ \\
\hline 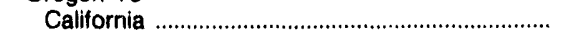 & $346,754,719$ \\
\hline 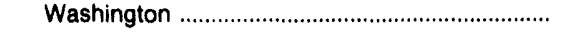 & $1,770,936$ \\
\hline
\end{tabular}

Source: Energy Information Administration (EIA), Form EIA-176, "Annual Report of Natural and Supplemental Gas Supply and Disposition." 


\section{Panhandle Eastern Corp.}

The Panhandle Eastern Corporation (PEC) is the parent company of subsidiaries including Texas Eastern Transmission Corporation (TETCO), Algonquin Gas Transmission Company, Panhandle Eastern Pipeline Company (PEPL), Trunkline Gas Company, Trunkline LNG Company, Centana Energy Corporation, Panhandle Trading Company, and Liberty Pipeline (30-percent owned).

Panhandle, at the inception of the Federal Energy Regulatory Commission's (FERC) Order 636, took a very aggressive approach to service restructuring; hence PEPL, TETCO, and Algonquin were among the first pipelines to receive FERC orders in response to their filings. Trunkline Gas Company, another PEC subsidiary, also received its restructuring order. National Steel Corporation, Great Lakes Division, became the first to use PEC's direct open-access service and was tr: ? first to sign up for proposed 636 service.

PEC has made an extensive commitment to expanding its services in the Northeast segment of the United States. In 1992, TETCO and Algonquin completed new transportation service that provides approximately 500 million cubic feet of natural gas per day to 16 northeast customers. By 1995, with additional phased-in expansion projects, 750 million cubic feet more per day will be available through long-term firm

Figure 29. Panhandle Eastern Corp., 1992

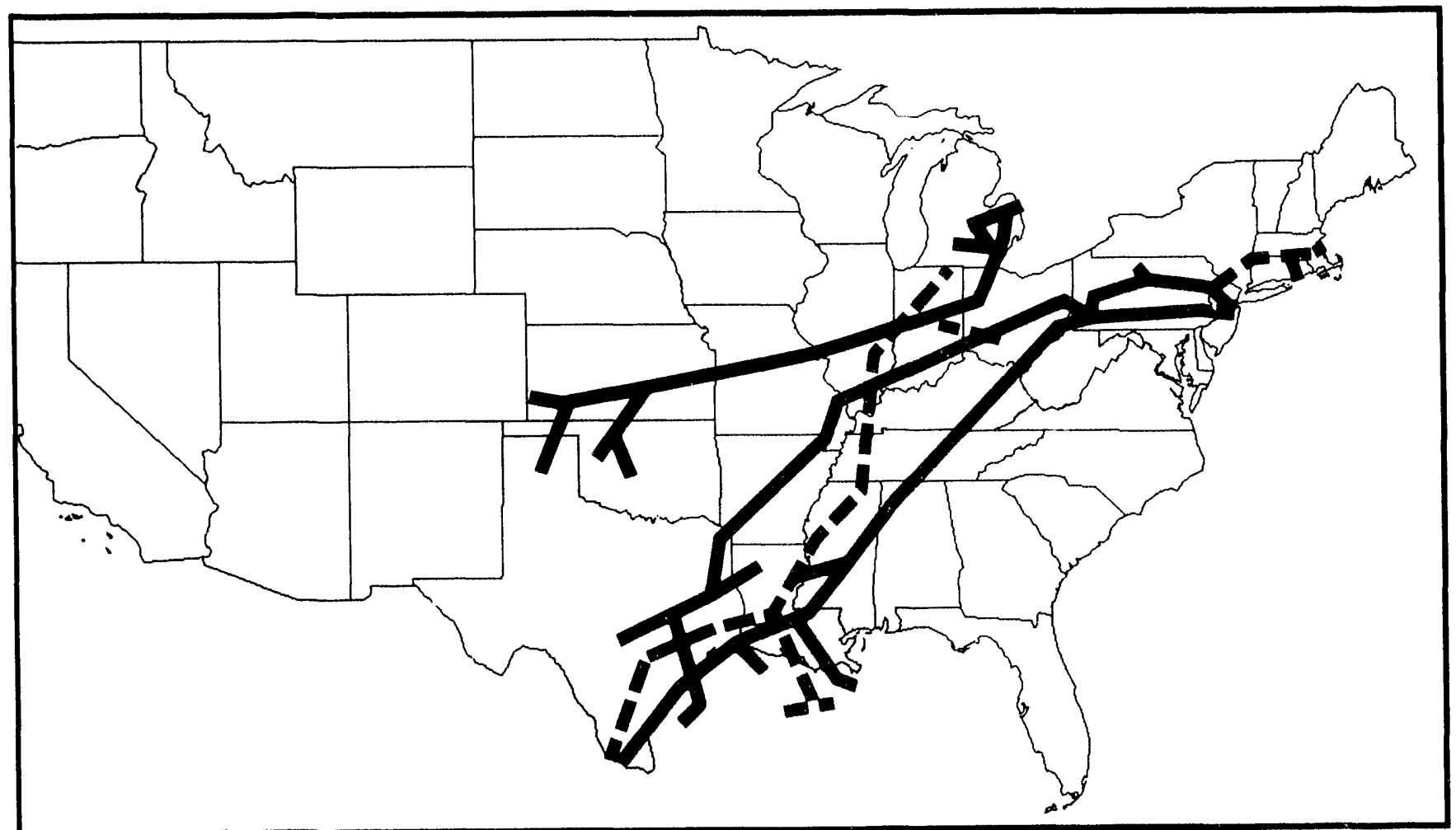

Source: Energy Information Administration (EIA), Form EIA-176, "Annual Report of Natural and Supplemental Gas Supply and Disposition."

Supply Areas
Panhandle Eastern Pipe Line Co. - Algonquin Gas Transmission Co.
Texas Eastern Transmission Corp.

- Trunkline Gas Co. 
Table 39. Panhandle Eastern Corp. Natural Gas Data, 1992

(Thousand Cubic Feet)

\begin{tabular}{|c|c|c|c|c|c|}
\hline \multirow{2}{*}{ Supply/Disposition } & \multicolumn{5}{|c|}{ Panhandle Eastern Pipe Line Co. } \\
\hline & Texas & Oklahoma & Wyoming & Colorado & Kansas \\
\hline \multicolumn{6}{|l|}{ SUPPLY } \\
\hline $\begin{array}{l}\text { Produced Onsystem } \\
\text { Receipts }\end{array}$ & 0 & 0 & 0 & 0 & 0 \\
\hline 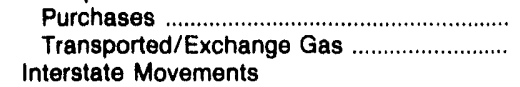 & $\begin{array}{r}1,425,138 \\
61,385,611\end{array}$ & $\begin{array}{r}4,820,489 \\
185,523,254\end{array}$ & $\begin{array}{r}3,163,437 \\
10,120,509\end{array}$ & $\begin{array}{r}7,249,063 \\
30,153,380\end{array}$ & $\begin{array}{r}25,098,816 \\
228,367,517\end{array}$ \\
\hline 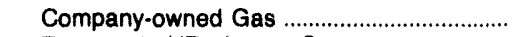 & 0 & 0 & 0 & 0 & 0 \\
\hline Transported/Exchange Gas .............................. & $15,303,251$ & $64,949,482$ & 0 & 0 & $234,376,358$ \\
\hline 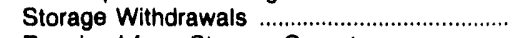 & 0 & $4,268,197$ & 0 & 0 & 0 \\
\hline Received from Storage Operators ..................... & 0 & 0 & 0 & 0 & $15,325,561$ \\
\hline 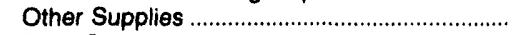 & 0 & 0 & 0 & 0 & 0 \\
\hline 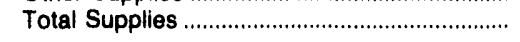 & $78,114,000$ & $259,561,422$ & $13,283,946$ & $37,402,443$ & $503,168,252$ \\
\hline \multicolumn{6}{|l|}{ DISPOSITION } \\
\hline 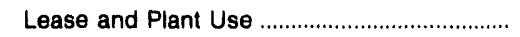 & 0 & 95,921 & 4,164 & 104,760 & 0 \\
\hline $\begin{array}{l}\text { Returned to Formations } \\
\text { Interstate Movements }\end{array}$ & 0 & 0 & 0 & 0 & 0 \\
\hline 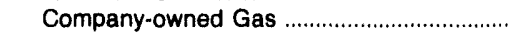 & 0 & 0 & 0 & 0 & 0 \\
\hline 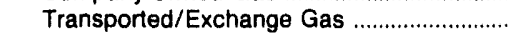 & $64,949,482$ & $249,679,609$ & 0 & 0 & $4,28,749,278$ \\
\hline Exchange Gas Deliveries .................................... & $8,941,377$ & 0 & $8,851,056$ & 0 & $8,196,395$ \\
\hline 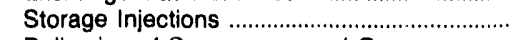 & 0 & $1,695,697$ & 0 & 0 & 0 \\
\hline \multicolumn{6}{|l|}{ Deliveries of Company-owned Gas } \\
\hline To Storage Operators & 0 & 0 & 0 & 0 & $5,116,725$ \\
\hline 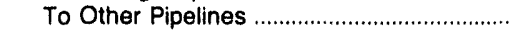 & 0 & 0 & 0 & 0 & 0 \\
\hline $\begin{array}{l}\text { To Resellers } \\
\text { To Consumers }\end{array}$ & 3,205 & 0 & 0 & 0 & $17,894,743$ \\
\hline 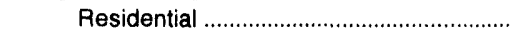 & 12,002 & 23,358 & 0 & 0 & 60,116 \\
\hline Commercial ............................................ & 816,822 & 582,873 & 0 & 25,382 & 785,869 \\
\hline 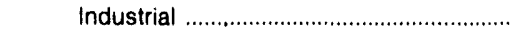 & 0 & 0 & 0 & 0 & 12,244 \\
\hline 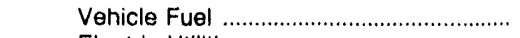 & 0 & 0 & 0 & 0 & 0 \\
\hline 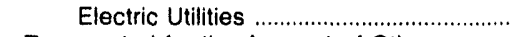 & 0 & 0 & 0 & 0 & 0 \\
\hline \multicolumn{6}{|l|}{ Transported for the Account of Others } \\
\hline 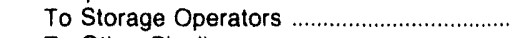 & 0 & 0 & 0 & 0 & 0 \\
\hline 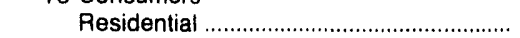 & 0 & 0 & 0 & 0 & 0 \\
\hline 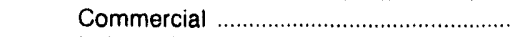 & 0 & 0 & 0 & 0 & 0 \\
\hline 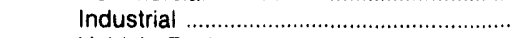 & 63,656 & 0 & 0 & 0 & $15,472,704$ \\
\hline 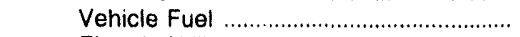 & 0 & 0 & 0 & 0 & 0 \\
\hline 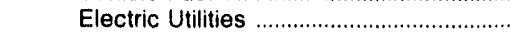 & 0 & 0 & 0 & 0 & 0 \\
\hline Pipeline/Compressor Fuel ................................. & 28,647 & 273,867 & 0 & 731,204 & $1,396,629$ \\
\hline Other Disposition & 0 & 0 & 0 & 0 & 0 \\
\hline Unaccounted For & $2,188,513$ & $3,942,030$ & 688,765 & $-2,272,890$ & $10,943,595$ \\
\hline 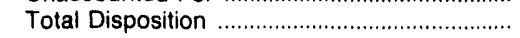 & $78,114,000$ & $259,561,422$ & $13,283,946$ & $37,402,443$ & $503,168,252$ \\
\hline
\end{tabular}

contracts. These services helped increase deliveries by 10 percent in 1992, in comparision to a 3 percent national increase. In concert with Liberty Pipeline, TETCO, and Algonquin, the company has filed applications with the FERC to gain approval for several projects in the New York/New Jersey area.

The Liberty Upstream Project, a joint venture between TE TCO and Liberty Pipeline Company, will construct a 38-mile pipeline interconnection between TETCO and an unnamed system in New Jersey to provide service to Long Island. Assuming FERC approval, the venture will cost 152 million dollars to complete and will provide approximately 500 million cubic feet per day of firm transportation service to the New York area in late 1994. TETCO along with PEPL, in another move aimed at service expansion in the Northeast, filed an application to supply Liberty with another 245 million cubic feet per day of firm transportation service.
The Integrated Transportation Program, a venture involving all of the Panhandle Eastern pipelines in the Northeast (Algonquin, Texas Eastern, Liberty Pipeline, and Panhandle Eastern) will deliver 261 million cubic feet per day of firm transportation service to TETCO and Algonquin customers beginning in November 1993.

The Elizabethtown/Eastern Shore project, involving TETCO and Trunkline, will provide 30 million cubic feet of firm transportation to the Eastern Shore Natural Gas Company. The facilities cost of this project is estimated at 39 million dollars.

Panhandle is also a participant in a number of joint ventures. The Northern Border pipeline project, in which the company holds over 22 percent interest, is an open-access pipeline joint venture with Northwest Alaskan and is the initial construction on what is known 
Table 39. Panhandle Eastern Corp. Natural Gas Data, 1992 (Continued)

(Thousand Cubic Feet)

\begin{tabular}{|c|c|c|c|c|c|}
\hline \multirow{2}{*}{ Supply/Disposition } & \multicolumn{5}{|c|}{ Panhandle Eastern Pipe Line Co. } \\
\hline & Missouri & Illinois & Indiana & Ohio & Michigan \\
\hline \multicolumn{6}{|l|}{ SUPPLY } \\
\hline $\begin{array}{l}\text { Produced Onsystem } \\
\text { Receipts }\end{array}$ & 0 & 0 & 0 & 0 & 0 \\
\hline Purchases & 0 & 0 & 0 & 0 & 0 \\
\hline 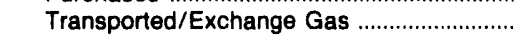 & 0 & $184,961,272$ & $17,493,590$ & $6,081,050$ & $19,045,438$ \\
\hline \multicolumn{6}{|l|}{ Interstate Movements } \\
\hline 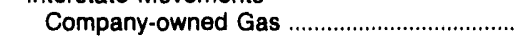 & 0 & 0 & 0 & 0 & 0 \\
\hline 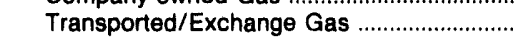 & $428,749,278$ & $378,586,292$ & $474,411,103$ & $283,512,334$ & $141,502,851$ \\
\hline Storage Withdrawals & 0 & $5,034,400$ & $\begin{array}{r}4,4,4100 \\
0\end{array}$ & $\begin{array}{r}200,012,004 \\
0\end{array}$ & $9,876,296$ \\
\hline 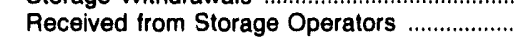 & 0 & 0 & 0 & 0 & $16,494,418$ \\
\hline Other Supplies & 0 & 0 & 0 & 0 & 0 \\
\hline 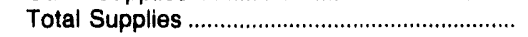 & $428,749,278$ & $568,581,964$ & $491,904,693$ & $289,593,384$ & $186,919,003$ \\
\hline \multicolumn{6}{|l|}{ DISPOSITION } \\
\hline 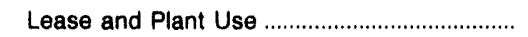 & 0 & 0 & 0 & 0 & 0 \\
\hline 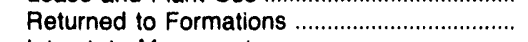 & 0 & 0 & 0 & 0 & 0 \\
\hline \multicolumn{6}{|l|}{ Interstate Movements } \\
\hline 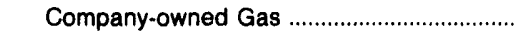 & 0 & 0 & 0 & 0 & 0 \\
\hline 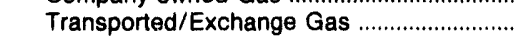 & $378,586,292$ & $474,411,103$ & $283,512,334$ & $141,502,851$ & $22,871,929$ \\
\hline 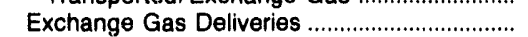 & 0 & 0 & $5,879,429$ & 0 & $2<, 0+1,0<0$ \\
\hline 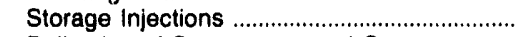 & 0 & $2,906,798$ & 0 & 0 & $5,723,722$ \\
\hline \multicolumn{6}{|l|}{ Deliveries of Company-owned Gas } \\
\hline To Storage Operators & 0 & 0 & 0 & 0 & $5,354,817$ \\
\hline 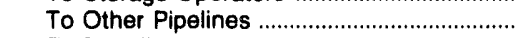 & 0 & 0 & 0 & 19,357 & 0 \\
\hline 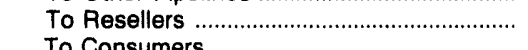 & $4,280,490$ & $9,202,346$ & $15,544,739$ & $4,591,250$ & $7,560,377$ \\
\hline $\begin{array}{l}\text { To Consumers } \\
\text { Residential }\end{array}$ & 101,388 & 0 & 0 & 0 & 0 \\
\hline 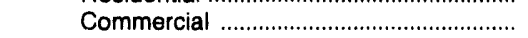 & 7,384 & 0 & 0 & 13,663 & 0 \\
\hline 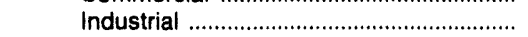 & 53,542 & 89,724 & 47,913 & 2,894 & 732 \\
\hline Vehicle Fuel & 0 & 0 & 0 & 0 & 0 \\
\hline 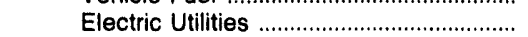 & 147 & 62,629 & 0 & 0 & 0 \\
\hline \multicolumn{6}{|l|}{ Transported for the Account of Others } \\
\hline 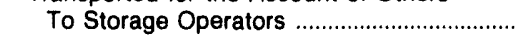 & 0 & 0 & 0 & 0 & 0 \\
\hline To Other Pipelines & 0 & 0 & $36,565,597$ & 0 & $12,903,133$ \\
\hline $\begin{array}{l}\text { To Resellers } \\
\text { To Consumers }\end{array}$ & $36,361,531$ & $52,784,892$ & $137,303,427$ & $129,266,754$ & $84,844,492$ \\
\hline 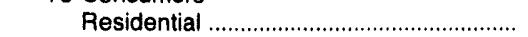 & 0 & 0 & 0 & 0 & 0 \\
\hline 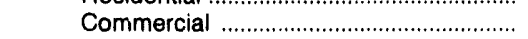 & 0 & 0 & 0 & 0 & 0 \\
\hline 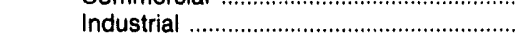 & $2,356,446$ & $23,117,550$ & $8,040,754$ & $12,422,823$ & $44,656,901$ \\
\hline 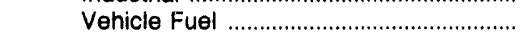 & 0 & 0 & 0 & 0 & 0 \\
\hline Electric Utilities & 0 & 0 & 0 & 0 & 0 \\
\hline 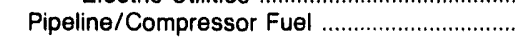 & 261,171 & 601,960 & 256,660 & 68,858 & 190,841 \\
\hline Other Disposition & 0 & 0 & 0 & 0 & $\begin{array}{r}100,041 \\
0\end{array}$ \\
\hline 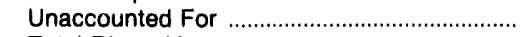 & $6,740,887$ & $5,404,962$ & $4,753,840$ & $1,704,934$ & $2,812,059$ \\
\hline 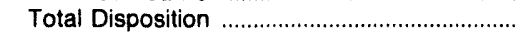 & $428,749,278$ & $568,581,964$ & $491,904,693$ & $289,593,384$ & $186,919,003$ \\
\hline
\end{tabular}

as the Alaska Natural Gas Transportation System (ANGTS). The pipeline will deliver Canadian gas through the Pan-Alberta Pipeline to the Northern Border.

The company holds a 14 percent interest in the Midland Cogeneration Venture in Michigan. Midland is the $\mathrm{Na}$ tion's largest cogeneration facility. National Methanol Company ( 25 percent owned) boasts the world's largest chemical grade methanol facility; it will produce in excess of 700,000 metric tons of methyl tertiary butyl ether (MTBE) per year. MTBE is an oxygenate which creates cleaner burning gasoline blends.

In a positive environmental move, Algonquin began providing 100 million cubic feet per day of natural gas to Boston Edison. Boston Edison will initially use natural gas 9 months of each year until it permanently converts to natural gas in 1995. And in the oildependent Northeast area, PEC will target residential markets for natural gas business for home heating and cooling, appliances, and home refueling stations for vehicles. 
Table 39. Panhandle Eastern Corp. Natural Gas Data, 1992 (Continued) (Thousand Cubic Feet)

\begin{tabular}{|c|c|c|c|c|c|}
\hline \multirow{2}{*}{ Supply/Disposition } & \multicolumn{5}{|c|}{ Texas Eastern Transmission Corp. } \\
\hline & Texas & Louisiana & Mississippi & Alabama & Tennessee \\
\hline \multicolumn{6}{|l|}{ SUPPLY } \\
\hline $\begin{array}{l}\text { Produced Onsystem } \\
\text { Receipts }\end{array}$ & 0 & 6,823 & 0 & 0 & 0 \\
\hline 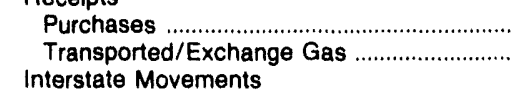 & $\begin{array}{r}24,358,831 \\
331,689,151\end{array}$ & $\begin{array}{r}69,985,680 \\
529,471,643\end{array}$ & $\begin{array}{l}11,017,093 \\
55,587,462\end{array}$ & $\begin{array}{r}0 \\
2,422,781\end{array}$ & $\begin{array}{r}0 \\
20,296\end{array}$ \\
\hline 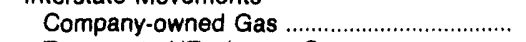 & 0 & 0 & 0 & 0 & 0 \\
\hline 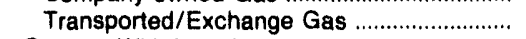 & 0 & $208,638,104$ & $535,937,428$ & $596,124,596$ & $594,933,927$ \\
\hline Storage Withdrawals & 0 & 0 & 0 & 0 & 0 \\
\hline 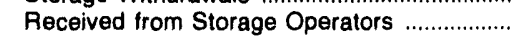 & 0 & 0 & 0 & 0 & 0 \\
\hline Other Supplies & 0 & 0 & 0 & 0 & 0 \\
\hline Total Supplies & $356,047,982$ & $808,102,250$ & $602,541.983$ & $598,547,377$ & $594,954,223$ \\
\hline \multicolumn{6}{|l|}{ DISPOSITION } \\
\hline 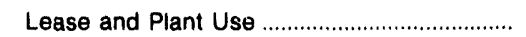 & 0 & $4,509,669$ & 0 & 0 & 0 \\
\hline $\begin{array}{l}\text { Peturned to Formations } \\
\text { Interstate Movements }\end{array}$ & 0 & 0 & 0 & 0 & 0 \\
\hline 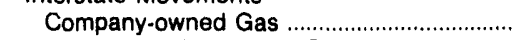 & 0 & 0 & 0 & 0 & 0 \\
\hline 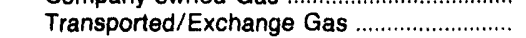 & $281,609,053$ & $535,937,428$ & $596,124,596$ & $594,933,927$ & $584,098,050$ \\
\hline 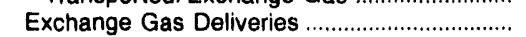 & 918,587 & $98,191,311$ & 12,176 & 0 & 0 \\
\hline \multicolumn{5}{|l|}{ Deliveries of Company-owned Gas } & 0 \\
\hline 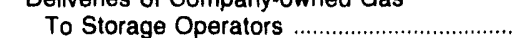 & 0 & 0 & 0 & 0 & 0 \\
\hline 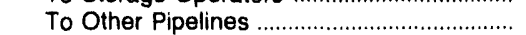 & 0 & 0 & 0 & 0 & 0 \\
\hline 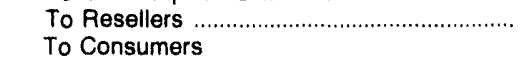 & 0 & 371,396 & 38,746 & 15,568 & 698,808 \\
\hline 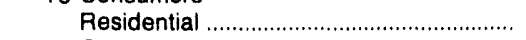 & 0 & 0 & 0 & 0 & 0 \\
\hline 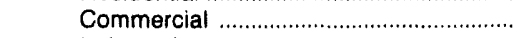 & 0 & 0 & 0 & 0 & 0 \\
\hline 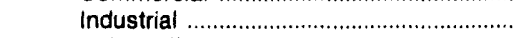 & 0 & 0 & 0 & 0 & 0 \\
\hline 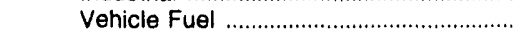 & 0 & 0 & 0 & 0 & 0 \\
\hline 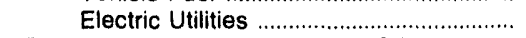 & 0 & 0 & 0 & 0 & 0 \\
\hline \multicolumn{6}{|l|}{ Transported for the Account of Others } \\
\hline 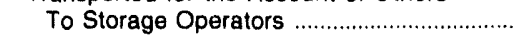 & 0 & 0 & 0 & 0 & 0 \\
\hline To Other Pipelines & $37,157,198$ & $107,054,843$ & 64,623 & 184,147 & $3,935,583$ \\
\hline 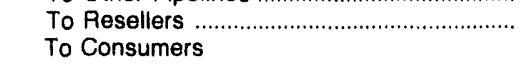 & $33,707,370$ & $56,590,269$ & $1,305,187$ & $1,603,729$ & $4,994,047$ \\
\hline 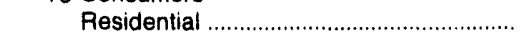 & 0 & 0 & 0 & 0 & 0 \\
\hline 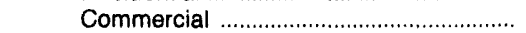 & 0 & 0 & 0 & 0 & 0 \\
\hline 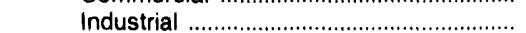 & 0 & 0 & 0 & 0 & 0 \\
\hline 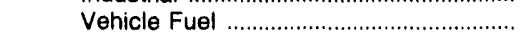 & 0 & 0 & 0 & 0 & 0 \\
\hline 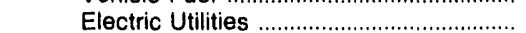 & 0 & 0 & 0 & 0 & 0 \\
\hline 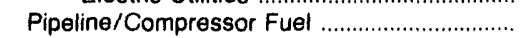 & $1,372,654$ & $4,387,672$ & $4,333,190$ & $1,704,954$ & 928,498 \\
\hline Other Disposition & 0 & 0 & 0 & 0 & 0 \\
\hline Unaccounted For & $1,283,120$ & $1,059,662$ & 663,465 & 105,052 & 299,237 \\
\hline Total Disposition ................................................... & $356,047,982$ & $808,102,250$ & $602,541,983$ & $598,547,377$ & $594,954,223$ \\
\hline
\end{tabular}


Table 39. Panhandle Eastern Corp. Natural Gas Data, 1992 (Continued) (Thousand Cubic Feet)

\begin{tabular}{l|l|l|l|l|}
\hline \multirow{2}{*}{ Supply/Disposition } & \multicolumn{3}{c}{ Texas Eastern Transmission Corp. } \\
\cline { 2 - 4 } & Kentucky & West Virginia & Arkansas & Missouri \\
\hline
\end{tabular}

SUPPLY

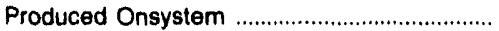
Receipts

Purchases ....................................................

Interstate Movements

Company-owned G

Transported/Exchange Gas

Storage Withdrawals

Storage Operators

Other Supplies

Total Supplies

\section{DISPOSITION}

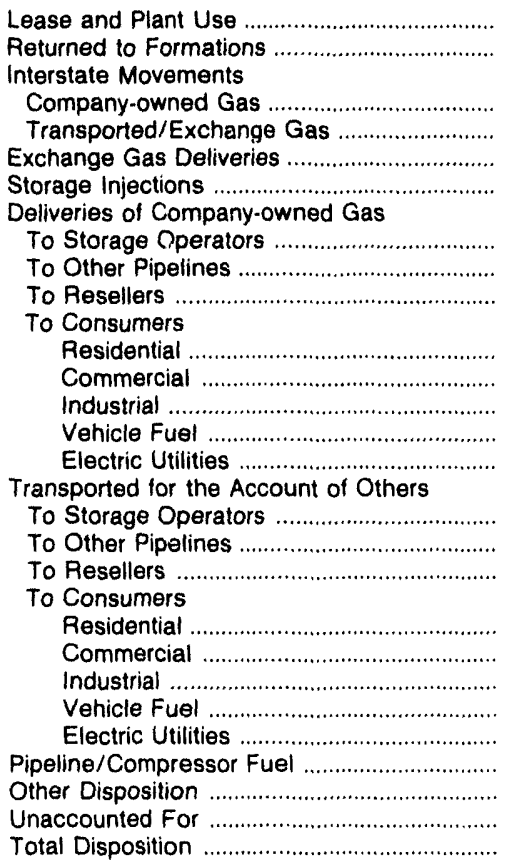

$\begin{array}{rrrrr}0 & 0 & 0 & 0 & 0 \\ 0 & & & 0 & 0 \\ 8,600,494 & 0 & 915,061 & 0 & 9,333,160 \\ 0 & 44,121 & 22,493,651 & 0 & 0 \\ 584,098,050 & 0 & 0 & 0 & 33,977,637 \\ 0 & 693,723,482 & 17,424,388 & 39,974,665 & 0 \\ 0 & 0 & 0 & 0 & 0 \\ 0 & 0 & 0 & 0 & 0 \\ 592,698,544 & 0 & 0 & 0 & 43,310,797\end{array}$

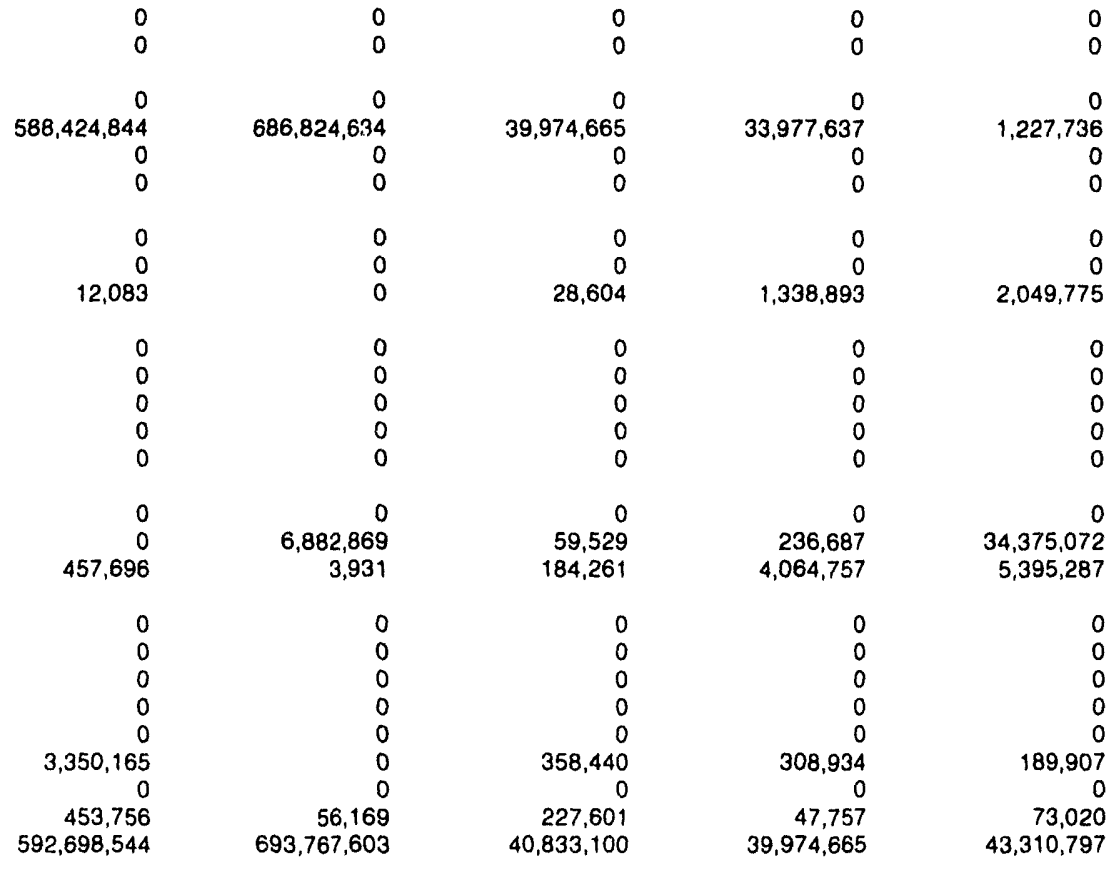


Table 39. Panhandle Eastern Corp. Natural Gas Data, 1992 (Continued) (Thousand Cubic Feet)

\begin{tabular}{|c|c|c|c|c|c|c|}
\hline \multirow{2}{*}{ Supply/Disposition } & \multicolumn{6}{|c|}{ Texas Eastern Transmission Corp. } \\
\hline & Indiana & Onio & Pennsylvania & New York & New Jersey & Maryland \\
\hline \multicolumn{7}{|l|}{ SUPPLY } \\
\hline $\begin{array}{l}\text { Produced Onsystem } \\
\text { Receipts }\end{array}$ & 0 & 0 & 17,152 & 0 & 0 & 0 \\
\hline $\begin{array}{l}\text { Purchases .... } \\
\text { Transported/Exchange Gas ............................ } \\
\text { Interstate Movements }\end{array}$ & $\begin{array}{r}331 \\
15,661,018\end{array}$ & $\begin{array}{r}127,108 \\
156,004,726\end{array}$ & $\begin{array}{r}31,163 \\
96,598,751\end{array}$ & $\begin{array}{r}0 \\
14,293,694\end{array}$ & $\begin{array}{r}0 \\
35,295,601\end{array}$ & $\begin{array}{l}0 \\
0\end{array}$ \\
\hline 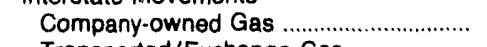 & 0 & 0 & 0 & 0 & 0 & 0 \\
\hline Transported/Exchange Gas ....................... & $1,227,736$ & $601,704,835$ & $703,786,536$ & $73,078,774$ & $404,242,866$ & $18,280,856$ \\
\hline 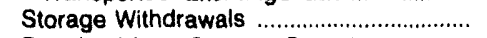 & 0 & 0 & 0 & 0 & 0 & $19,169,024$ \\
\hline Received from Storage Operators ............ & 0 & 0 & $21,718,959$ & 0 & 0 & 0 \\
\hline 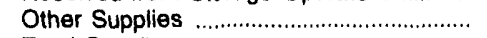 & 0 & 0 & 0 & 0 & 0 & 0 \\
\hline Total Supplies & $16,889,085$ & $757,836,669$ & $822,152,561$ & $87,372,468$ & $439,538,467$ & $37,449,880$ \\
\hline \multicolumn{7}{|l|}{ DISPOSITION } \\
\hline 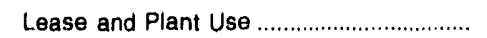 & 0 & 0 & 0 & 0 & 0 & 0 \\
\hline $\begin{array}{l}\text { Returned to Formations } \\
\text { Interstate Movements }\end{array}$ & 0 & 0 & 0 & 0 & 0 & 0 \\
\hline 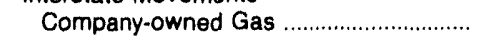 & 0 & 0 & 0 & 0 & 0 & 0 \\
\hline Transported/Exchange Gas ..................... & $13,279,991$ & $693,723,482$ & $422,523,722$ & 0 & $73,078,774$ & $16,961,902$ \\
\hline Exchange Gas Deliveries ............................. & 0 & 0 & $28,182,237$ & 0 & 0 & 0 \\
\hline $\begin{array}{l}\text { Storage Injections .............................................. } \\
\text { Deliveries of Company-owned }\end{array}$ & 0 & 0 & 0 & 0 & 0 & $19,501,840$ \\
\hline To Sturage Operators ............................. & 0 & 0 & $28,367,889$ & 0 & 0 & 0 \\
\hline 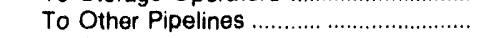 & 10,734 & 0 & $8,970.761$ & 0 & $17,561,909$ & 0 \\
\hline 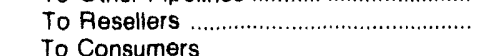 & 874,567 & $1,828,682$ & $23,276,202$ & $13,147,124$ & $27,219,192$ & 0 \\
\hline 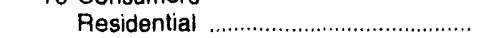 & 0 & 0 & 0 & 0 & 0 & 0 \\
\hline 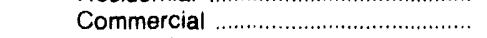 & 0 & 0 & 0 & 0 & 0 & 0 \\
\hline 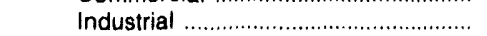 & 0 & 0 & 0 & 0 & 0 & 0 \\
\hline Vehicle Fuel ....................................... & 0 & 0 & 0 & 0 & 0 & 0 \\
\hline 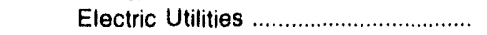 & 0 & 0 & 0 & 0 & 0 & 0 \\
\hline \multicolumn{7}{|l|}{ Transported for the Account of Others } \\
\hline To Storage Operators & 0 & 0 & 0 & 0 & 0 & 0 \\
\hline 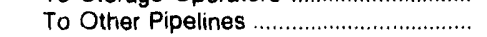 & 500,109 & $38,146,750$ & $103,097,950$ & $5,623,167$ & $66,398,607$ & 0 \\
\hline $\begin{array}{l}\text { To Resellers ............................................ } \\
\text { To Consumers }\end{array}$ & $1,839,203$ & $21,539,063$ & $193,650,664$ & $68,598,822$ & $254,416,819$ & 0 \\
\hline 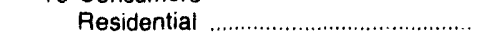 & 0 & 0 & 0 & 0 & 0 & 0 \\
\hline 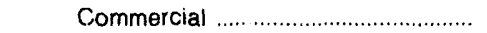 & 0 & 0 & 0 & 0 & 0 & 0 \\
\hline 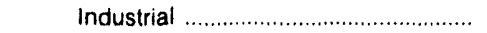 & 0 & 0 & 0 & 0 & 0 & 0 \\
\hline 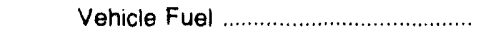 & 0 & 0 & 0 & 0 & 0 & 0 \\
\hline 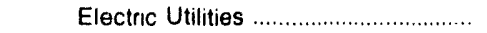 & 0 & 0 & 0 & 0 & 0 & 0 \\
\hline 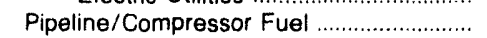 & 255,880 & $2,081,458$ & $12,872,178$ & 0 & 699,372 & 560,676 \\
\hline 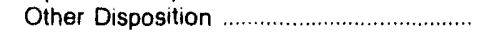 & 0 & 0 & 0 & 0 & 0 & 0 \\
\hline 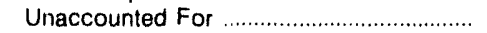 & 128,601 & 517,234 & $1,210,958$ & 3,355 & 163,794 & 425,462 \\
\hline 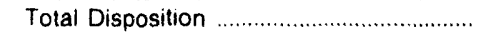 & $16,889,085$ & $757,836,669$ & $822,152,561$ & $87,372,468$ & $439,538,467$ & $37,449,880$ \\
\hline
\end{tabular}


Table 39. Panhandle Eastern Corp. Natural Gas Data, 1992 (Continued)

(Thousand Cubic Feet)

\begin{tabular}{l|c|c|c|c|c}
\hline \multirow{2}{*}{ Supply/Disposition } & \multicolumn{4}{|c}{ Algonquin Gas Transmission Co. } \\
\cline { 2 - 6 } & New Jersey & New York & Connecticut & Rhode Island & Massachusetts \\
\hline
\end{tabular}

SUPPLY

Produced Onsystem ......................................

Receipts

Purchases

Transported/Exchange Gas ........................

Interstate Movements

Company-owned Gas

Transported/Exchange Gas

Storage Withdrawals

Received from Storage Operators

Other Supplies ....

Total Supplies

$\begin{array}{rr}0 & 0 \\ 16,671,937 & 0 \\ 229,606,088 & 0 \\ 0 & 0 \\ 0 & 211,513,392 \\ 0 & 0 \\ 0 & 0 \\ 0 & 0 \\ 246,278,025 & 211,513,392\end{array}$

0
0
0
0
$212,991,996$
0
0
0
$212,991,996$

$\begin{array}{rr}0 & 0 \\ 0 & 0 \\ 0 & 5,184,823 \\ 0 & 0 \\ 160,559,825 & 132,485,669 \\ 0 & 0 \\ 0 & 0 \\ 0 & 0 \\ 160,559,825 & 137,670,492\end{array}$

\section{DISPOSITION}

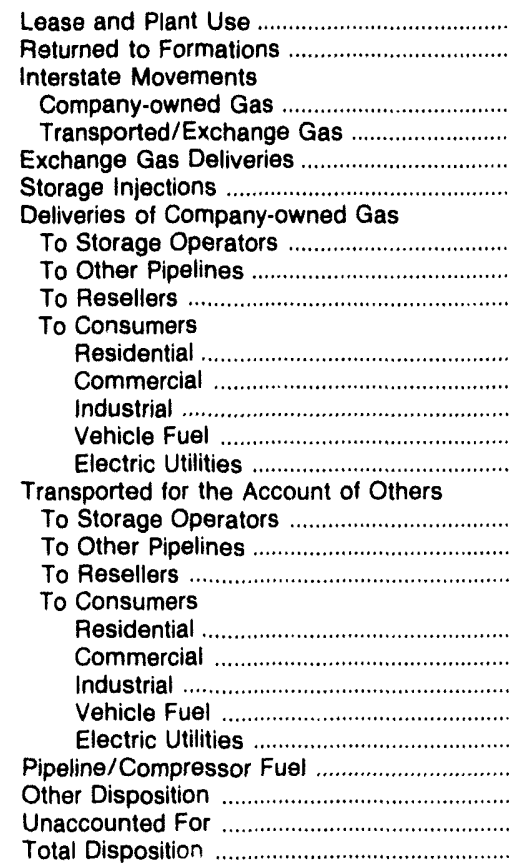

\begin{tabular}{|c|c|c|c|c|}
\hline 0 & 0 & 0 & 0 & 0 \\
\hline 0 & 0 & 0 & 0 & 0 \\
\hline $\begin{array}{r}9,717,060 \\
201,796,332\end{array}$ & $\begin{array}{r}9,256,982 \\
203,735,014\end{array}$ & $\begin{array}{r}6,313,475 \\
154,246,350\end{array}$ & $\begin{array}{r}3,652,669 \\
128,833,000\end{array}$ & $\begin{array}{l}0 \\
0\end{array}$ \\
\hline $4,442,025$ & 0 & $\begin{array}{r}104,240,000 \\
0\end{array}$ & $\begin{array}{r}120,000,000 \\
0\end{array}$ & 0 \\
\hline 0 & 0 & 0 & 0 & 0 \\
\hline 0 & 0 & 0 & 0 & 0 \\
\hline 0 & 0 & 0 & 0 & 0 \\
\hline 246,068 & 460,079 & $2,943,507$ & $2,660,806$ & $3,652,669$ \\
\hline 0 & 0 & 0 & 0 & 0 \\
\hline 0 & 0 & 0 & 0 & 0 \\
\hline 0 & 0 & 0 & 0 & 0 \\
\hline 0 & 0 & 0 & 0 & 0 \\
\hline 0 & 0 & 0 & 0 & 0 \\
\hline 0 & 0 & 0 & 0 & 0 \\
\hline 0 & 0 & 0 & 0 & 0 \\
\hline 0 & $27,274,986$ & $48,963,589$ & $24,159,221$ & $110,752,461$ \\
\hline 0 & 0 & 0 & 0 & 0 \\
\hline 0 & 0 & 0 & 0 & 0 \\
\hline 0 & 0 & 0 & 993,581 & $20,607,740$ \\
\hline 0 & 0 & 0 & 0 & 0 \\
\hline 0 & 0 & 0 & 0 & $2,668,592$ \\
\hline 79,608 & 804,704 & 558,853 & 278,633 & 77,718 \\
\hline 0 & 0 & 0 & 0 & 0 \\
\hline $29,996,932$ & $-30,018,373$ & $-33,778$ & $-18,085$ & $-88,688$ \\
\hline $246,278,025$ & $211,513,392$ & $212,991,996$ & $160,559,825$ & $137,670,492$ \\
\hline
\end{tabular}


Table 39. Panhandle Eastern Corp. Natural Gas Data, 1992 (Continued)

(Thousand Cubic Feet)

\begin{tabular}{|c|c|c|c|c|c|c|}
\hline \multirow{2}{*}{ Supp'y/Disposition } & \multicolumn{6}{|c|}{ Trunkline Gas Co. } \\
\hline & Texas & Louisiana & Arkansas & Mississippi & Tennessee & Kentucky \\
\hline \multicolumn{7}{|l|}{ SUPPLY } \\
\hline $\begin{array}{l}\text { Produced Onsystem } \\
\text { Receipts }\end{array}$ & 0 & 0 & 0 & 0 & 0 & 0 \\
\hline 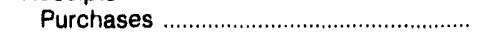 & $4,455,600$ & $45,420,427$ & 0 & 0 & 0 & 0 \\
\hline $\begin{array}{l}\text { Transported/Exchange Gas ...................... } \\
\text { Interstate Movements }\end{array}$ & $112,604,963$ & $574,121,474$ & 0 & 0 & 1,277 & 0 \\
\hline 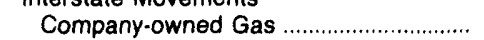 & 0 & 0 & 0 & 0 & 0 & 0 \\
\hline Transported/Exchange Gas ...................... & 0 & $99,022,261$ & $431,308,053$ & $431,285,642$ & $428,257,488$ & $390,783,317$ \\
\hline 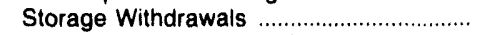 & 0 & $8,027,578$ & 0 & 0 & 0 & 0 \\
\hline Received from Storage Operators ........... & 0 & 0 & 0 & 0 & 0 & 0 \\
\hline Other Supplies & 0 & 0 & 0 & 0 & 0 & 0 \\
\hline Total Supplies & $117,060,563$ & $726,591,740$ & $431,308,053$ & $431,285,642$ & $428,258,765$ & $390,783,317$ \\
\hline \multicolumn{7}{|l|}{ DISPOSITION } \\
\hline 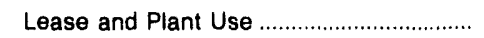 & 0 & $14,254,983$ & 0 & 0 & 0 & 0 \\
\hline $\begin{array}{l}\text { Returned to Formations ................................ } \\
\text { Interstate Movements }\end{array}$ & 0 & 0 & 0 & 0 & 0 & 0 \\
\hline 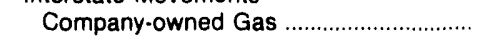 & 0 & 0 & 0 & 0 & 0 & 0 \\
\hline Transported/Exchange Gas ..................... & $99,022,261$ & $431,308,053$ & $431,285,642$ & $428,257,488$ & $390,783,317$ & $390,367,840$ \\
\hline 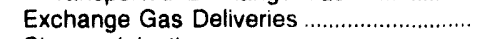 & 0 & 0 & 0 & 0 & 0 & 0 \\
\hline Storage injections & 0 & $9,792,900$ & 0 & 0 & 0 & 0 \\
\hline \multicolumn{7}{|l|}{ Deliveries of Company-owned Gas } \\
\hline 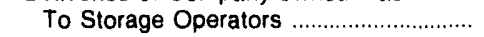 & 0 & 0 & 0 & 0 & 0 & 0 \\
\hline 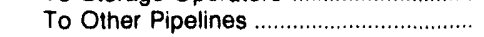 & 0 & 0 & 0 & 0 & 0 & 0 \\
\hline $\begin{array}{l}\text { To Resellers ............................................. } \\
\text { To Consumers }\end{array}$ & 0 & 56,603 & 0 & 621.477 & 346,994 & 13,618 \\
\hline 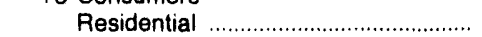 & 0 & 0 & 0 & 0 & 0 & 0 \\
\hline 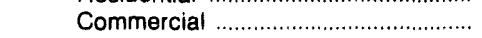 & 76,259 & 10,180 & 0 & 0 & 0 & 0 \\
\hline 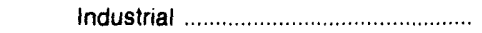 & 1,496 & 29,411 & 0 & 0 & 4,681 & 0 \\
\hline 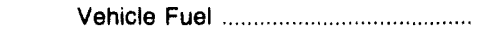 & 0 & 0 & 0 & 0 & 0 & 0 \\
\hline 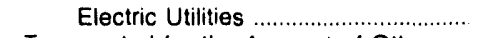 & 0 & 0 & 0 & 0 & 0 & 0 \\
\hline \multicolumn{7}{|l|}{ Transported for the Account of Others } \\
\hline 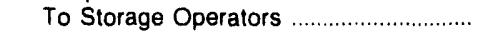 & 0 & 0 & 0 & 0 & 0 & 0 \\
\hline 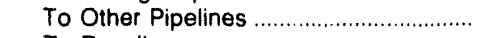 & $16,786,295$ & $266,849,373$ & 6,466 & 431,868 & $36,073,415$ & 361,082 \\
\hline 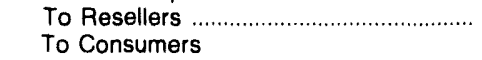 & 0 & 0 & 0 & 0 & 0 & 0 \\
\hline Residential . . . . . . & 0 & 0 & 0 & 0 & 0 & 0 \\
\hline 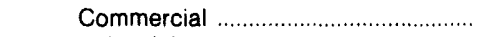 & 0 & 0 & 0 & 0 & 0 & 0 \\
\hline 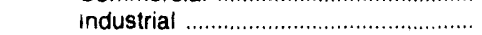 & 0 & 0 & 0 & 0 & 0 & 0 \\
\hline 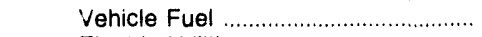 & 0 & 0 & 0 & 0 & 0 & 0 \\
\hline 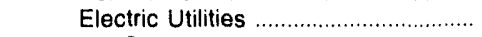 & 0 & 0 & 0 & 0 & 0 & 0 \\
\hline Pipeline/Compressor Fuel ............................ & 967,741 & $3,785,077$ & 0 & $1,852,373$ & 961,376 & 0 \\
\hline 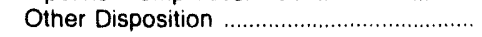 & 0 & 0 & 0 & 0 & 0 & 0 \\
\hline Unaccounted For & 206,511 & 505,160 & 15,945 & 122,436 & 88,982 & 40,777 \\
\hline 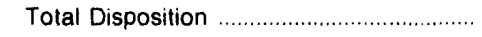 & $117,060,563$ & $726,591,740$ & $431,308,053$ & $431,285,642$ & $428,258,765$ & $390,783,317$ \\
\hline
\end{tabular}


Table 39. Panhandle Eastern Corp. Natural Gas Data, 1992 (Continued) (Thousand Cubic Feet)

\begin{tabular}{|c|c|c|c|c|c|}
\hline \multirow{2}{*}{ Supply/Disposition } & \multicolumn{3}{|c|}{ Trunkline Gas Co. } & \multirow{2}{*}{$\begin{array}{c}\text { Trunkline LNG Co. } \\
\text { Louisiana }\end{array}$} & \multirow{2}{*}{$\begin{array}{c}\text { Southwest Gas } \\
\text { Storage Co. } \\
\text { Kansas }\end{array}$} \\
\hline & Illinois & Indiana & Onio & & \\
\hline \multicolumn{6}{|l|}{ SUPPLY } \\
\hline $\begin{array}{l}\text { Produced Onsystem } \\
\text { Receipts }\end{array}$ & \multicolumn{4}{|c|}{ Receipts } & 0 \\
\hline Purchases & 0 & 0 & 0 & 0 & 0 \\
\hline Transported/Exchange Gas ............................. & $3,547,095$ & $78,367,154$ & $69,263,878$ & 0 & $5,116,725$ \\
\hline \multicolumn{6}{|l|}{ Interstate Movements } \\
\hline 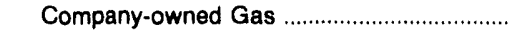 & 0 & 0 & 0 & 0 & 0 \\
\hline 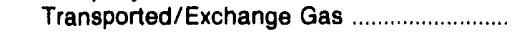 & $390,367,840$ & $187,639,177$ & $75,209,116$ & $12,637,191$ & 0 \\
\hline 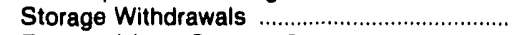 & 0 & 0 & 0 & $12,097,444$ & $15,406,305$ \\
\hline Received from Storage Operators .................... & 0 & 0 & 0 & 0 & 0 \\
\hline 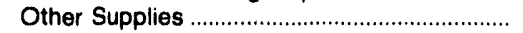 & 0 & 0 & 0 & 0 & 0 \\
\hline 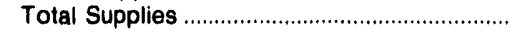 & $393,914,935$ & $266,006,331$ & $144,472,994$ & $24,734,635$ & $20,523,030$ \\
\hline 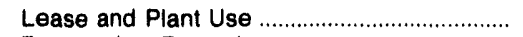 & 0 & 0 & 0 & 595,306 & 0 \\
\hline 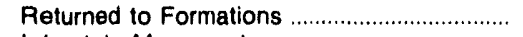 & 0 & 0 & 0 & 0 & 0 \\
\hline Interstate Movements & & & & & \\
\hline 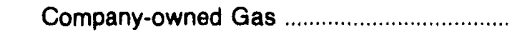 & 0 & $88,591,898$ & 0 & 0 & 0 \\
\hline 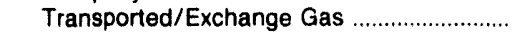 & $187,639,177$ & $134,696,273$ & 0 & 0 & 0 \\
\hline Exchange Gas Deliveries ..................................... & 0 & 0 & 0 & 0 & 0 \\
\hline 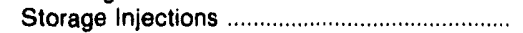 & 0 & 0 & 0 & $12,545,014$ & $6,545,074$ \\
\hline \multicolumn{6}{|l|}{ Deliveries of Company-owned Gas } \\
\hline 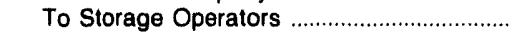 & 0 & 0 & 0 & 0 & 0 \\
\hline 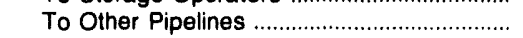 & 0 & 0 & 0 & 0 & 0 \\
\hline 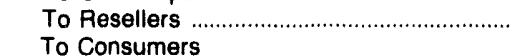 & $3,271,613$ & $1,160,980$ & 0 & $11,437,108$ & 0 \\
\hline 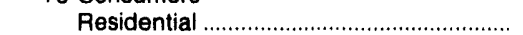 & 0 & 0 & 0 & 0 & 0 \\
\hline 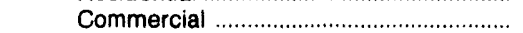 & 0 & 0 & 0 & 0 & 0 \\
\hline 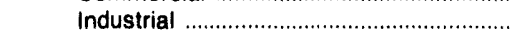 & 0 & 0 & 0 & 1,372 & 0 \\
\hline 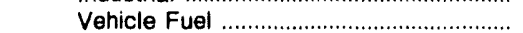 & 0 & 0 & 0 & 0 & 0 \\
\hline 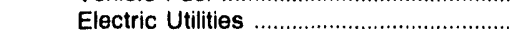 & 0 & 0 & 0 & 0 & 0 \\
\hline To Resellers & 0 & 0 & 0 & 0 & 0 \\
\hline \multicolumn{6}{|l|}{ To Consumers } \\
\hline 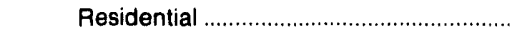 & 0 & 0 & 0 & 0 & 0 \\
\hline 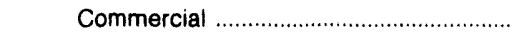 & 0 & 0 & 0 & 0 & 0 \\
\hline 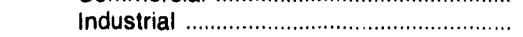 & 0 & 0 & 0 & 0 & 0 \\
\hline 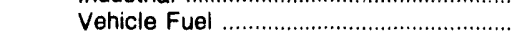 & 0 & 0 & 0 & 0 & 0 \\
\hline 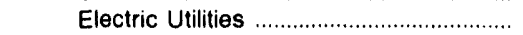 & 0 & 0 & 0 & 0 & 0 \\
\hline Pipeline/Compressor Fuel & $1,396,718$ & 304,889 & 0 & 63,658 & 0 \\
\hline 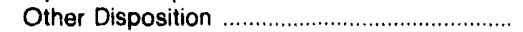 & 0 & 0 & 0 & 0 & 0 \\
\hline 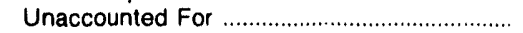 & 192,370 & $-9,219$ & $-428,125$ & 92,177 & $-1,348,449$ \\
\hline 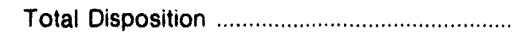 & $393,914,935$ & $266,006,331$ & $144,472,994$ & $24,734,635$ & $20,523,030$ \\
\hline
\end{tabular}

Source: Energy Information Administration (EIA), Form ElA-176, "Annual Report of Natural and Supplemental Gas Supply and Disposition." 
Table 40. Panhandle Eastern Corp. Interstate Flows of Natural Gas, 1992

(Thousand Cubic Feet)

\begin{tabular}{|c|c|c|c|}
\hline Company and State & Volume & Company and State & Volume \\
\hline \multicolumn{3}{|l|}{$\begin{array}{l}\text { Panhandle Eastern Pipe Line Co. } \\
\text { Texas To }\end{array}$} & \\
\hline Kansas & $\begin{array}{r}234,376,358 \\
15,303,251\end{array}$ & $\begin{array}{l}\text { Ohio } \\
\text { Onio To }\end{array}$ & $13,279,991$ \\
\hline $\begin{array}{l}\text { Kansas To } \\
\text { Missouri }\end{array}$ & $428,749,278$ & $\begin{array}{l}\text { West Virginia } \\
\text { Pennsylvania To }\end{array}$ & $693,723,482$ \\
\hline Missouri To & & 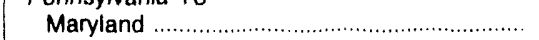 & $18,280,856$ \\
\hline 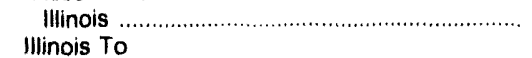 & $378,586,292$ & $\begin{array}{l}\text { New Jersey } \\
\text { New Jersey To }\end{array}$ & $404,242,866$ \\
\hline $\begin{array}{l}\text { Indiana ... } \\
\text { Indiana To }\end{array}$ & $474,411,103$ & $\begin{array}{l}\text { New York } \\
\text { Maryland To }\end{array}$ & $73,078,774$ \\
\hline $\begin{array}{l}\text { Ohio } \\
\text { Ohio To }\end{array}$ & $283,512,334$ & 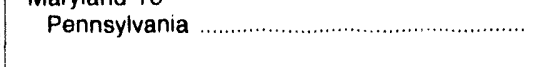 & $16,961,902$ \\
\hline Michigan ... & $141,502,851$ & & \\
\hline \multirow[t]{2}{*}{$\begin{array}{l}\text { Michigan To } \\
\text { Canada ..... }\end{array}$} & $22,871,929$ & $\begin{array}{l}\text { Algonquin Gas Transmission Co. } \\
\text { New Jersey To }\end{array}$ & \\
\hline & & $\begin{array}{l}\text { New York } \\
\text { New York To }\end{array}$ & $211,513,392$ \\
\hline $\begin{array}{l}\text { Texas Eastern Transmission Corp. } \\
\text { Texas To }\end{array}$ & & $\begin{array}{l}\text { Connecticut } \\
\text { Connecticut To }\end{array}$ & $212,991,996$ \\
\hline Arkansas & $17,424,388$ & Rhode Island. & $160,559,825$ \\
\hline 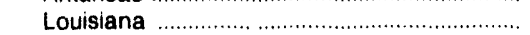 & $208,638,104$ & Rhode Island To & \\
\hline Mexico & $55,546,561$ & Massachusetts . & $132,485,669$ \\
\hline \multicolumn{4}{|l|}{ Louisiana To } \\
\hline $\begin{array}{l}\text { Mississippi } \\
\text { Mississippi To }\end{array}$ & $535,937,428$ & Trunkline Gas Co. & \\
\hline Alabama ................... & $596,124,596$ & $\begin{array}{l}\text { Texas To } \\
\text { Tex }\end{array}$ & \\
\hline \multicolumn{2}{|l|}{ Alabama To } & Louisiana & $99,022,261$ \\
\hline Tennessee. & $594,933,927$ & Louisiana To & \\
\hline \multicolumn{2}{|l|}{ Tennessee To } & Arkansas .... & $431,308,053$ \\
\hline Kentucky .......... & $584,098,050$ & Arkansas To & \\
\hline \multicolumn{2}{|l|}{ Kentucky To } & Mississippi & $431,285,642$ \\
\hline Ohio ............... & $588,424,844$ & Mississippi To & \\
\hline \multicolumn{2}{|l|}{ West Virginia To } & Tennessee .. & $428,257,488$ \\
\hline Pennsylvania ... & $686,824,634$ & Tennessee To & \\
\hline \multicolumn{2}{|l|}{$\begin{array}{l}\text { Pennsylvania } \\
\text { Arkansas To }\end{array}$} & Kentucky ...... & $390,783,317$ \\
\hline Missouri ..... & $39,974,665$ & Kentucky To & \\
\hline \multicolumn{2}{|l|}{ Missouri To } & Illinois ........ & $390,367,840$ \\
\hline lli & 33.977 .637 & Illinois To & \\
\hline \multirow{5}{*}{$\begin{array}{l}\text { Mlli } \\
\text { Illinols To } \\
\text { Indiana }\end{array}$} & & . & $187,639,177$ \\
\hline & $1,227,736$ & Indiana To & \\
\hline & & Ohio ................... & $298,497,287$ \\
\hline & & $\begin{array}{l}\text { Trunkline LNG Co. } \\
\text { Algeria To }\end{array}$ & \\
\hline & & Louisiana & $12,637,191$ \\
\hline
\end{tabular}

Source: Energy Intormation Administration (EIA), Form EIA-176, "Annual Report of Natural and Supplemental Gas Supply and Disposition." 


\section{Peoples Gas Light \& Coke Co.}

Peoples Energy Corporation is the holding company for the Peoples Gas Light and Coke Company (Peoples Gas) and North Shore Gas Company (North Shore Gas). These utilities are primarily engaged in the purchase, production, storage, distribution, sale, and transportation of natural gas in two of the major gasconsuming markets in the Nation. Peoples Gas has approximately 844,000 residential, commercial, and industrial retail sales, and transportation customers within the city of Chicago. North Shore Gas, based in Waukegan, Illinois, has more than 121,000 residential, commercial, and industrial retail sales and transportation customers in 54 Northeastern Illinois communities. Natural gas is the predominate fuel for cooking, heating water, and drying clothes in this area and heats 93 percent of the homes.

During 1992, the Company took several steps to enhance its supply position including signing some firm contracts with producers. North Shore began construction of a 14-mile pipeline that will tie into the transmission line operated by its supplying pipeline company. Peoples Gas started a 3-year drilling program to add 20 wells at its underground storage field. This will allow withdrawal of a greater amount of gas on peak days.

Figure 30. Peoples Gas Light \& Coke Co., 1992

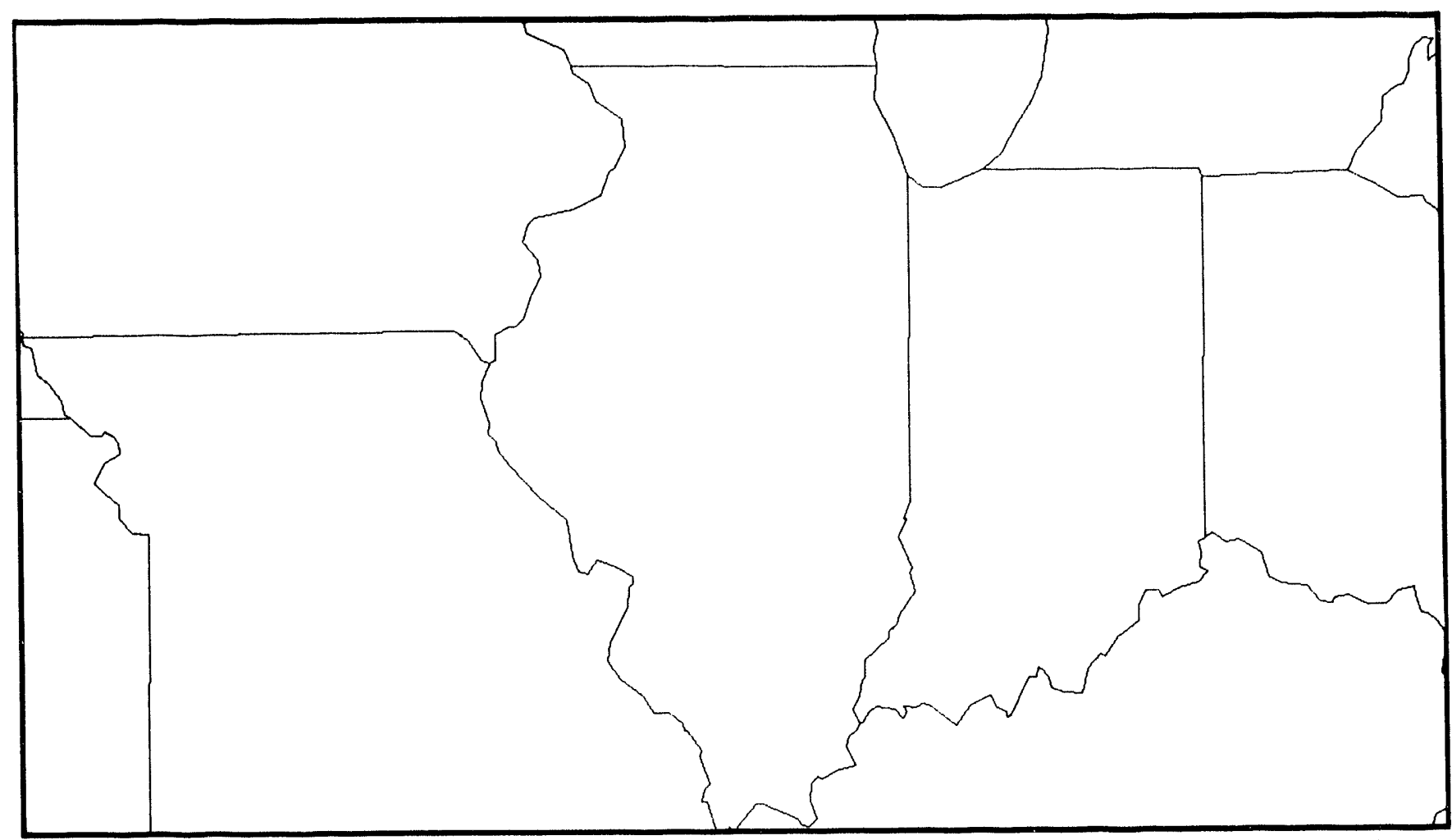

Source: Energy Information Administration (E|A), Form ElA-176, "Annual Report of Natural and Supplemental Gas Supply and Disposition."

Service Area 
Table 41. Peoples Gas Light \& Coke Co. Natural Gas Data, 1992 (Thousand Cubic Feet)

\begin{tabular}{l|l|l}
\hline \multirow{2}{*}{ Supply/Disposition } & Peoples Gas Light \& Coke Co. & North Shore Gas Co. \\
\cline { 2 - 3 } & & \multicolumn{1}{|c|}{ Ilinois } \\
\hline
\end{tabular}

\section{SUPPLY}

Produced Onsystem Receipts

Purchases

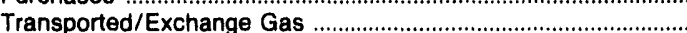

Interstate Movements

Company-owned Gas

Transported/Exchange Gas

Storage Withdrawals

Other Supplies

Total Supplies

\section{DISPOSITION}

Lease and Plant Use...

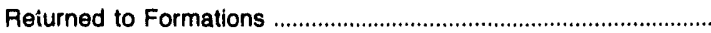

Interstate Movements

Company-owned Gas

Transported/Exchange Gas

Exchange Gas Deliveries

Storage Injections

Deliveries of Company-owned Gas

To Storage Operators

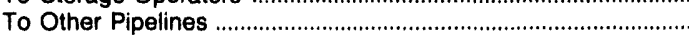

To Resellers

To Consumers

Residential.

Commercia

Industrial

Vehicle Fuel.

Electric Utilities

Transported for the Account of Others

To Storage Operators

To Other Pipelines

To Consiumers

Residential

Commercial .....

Industrial

Vehicle Fuel

Electric Utilities

Compressor Fuel

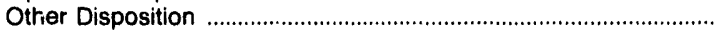

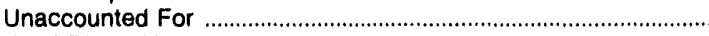

Total Disposition
0

0

$141,247,060$
$86,409,453$
0
0
$29,407,171$
$28,099,731$
$8,022,183$
$293,185,598$

$23,054,908$

$11,699,640$

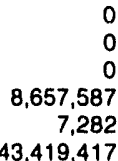

$43,419,417$

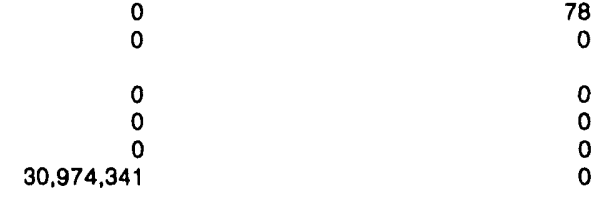

$25,786,110$

0
0

$119,334,962$

$21,552,228$

$6,137,509$

131,528

0
0

$2,246,296$

$22,907,274$

$33,223,248$

$27,856,083$

0

648,339

$1,237,387$

$1,150,293$

$293,185,598$
$8,737,727$

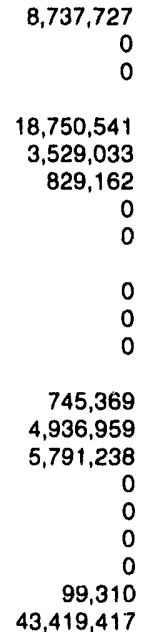

Source: Energy Information Administration (EIA), Form EIA-176, "Annual Report of Natural and Supplemental Gas Supply and Disposition."

Peoples is actively pursuing cogeneration applications where natural gas is used to generate electricity and heat. Eight Peoples Gas customers installed cogeneration units and it is expected that two more will be installed in 1993. The largest is a 13-megawatt facility at the University of Illinois in Chicago. Cogeneration systems currently in operation or under construction represent an annual gas load of more than one billion cubic feet.

Peoples continued to promote new gas applications such as natural gas vehicles (NGVs), gas cooling, and fuel cells. The Chicago area has the Nation's largest concentration of fleet vehicles. Peoples uses natural gas in 400 of their own vehicles, some of which are factory-built to run exclusively on natural gas. Amoco Oil Company equipped two local stations in Chicago and a western suburb with natural gas fueling systems. Amoco plans to provide similar systems at four other Chicago stations in 1993.

Peoples is also pursuing new applications involving gas cooling systems, gas heat pumps, and fuel cells. Peoples Gas will install its first fuel cell unit in 1993. These units use natural gas to create electricity through a combustion-free chemical reaction. 


\section{Public Service Co. of Colorado}

Public Service Company of Colorado engages in the generation, purchase, transmission, distribution, and sale of natural gas in the Rocky Mountain region, primarily in Colorado. The company provides gas to an estimated population of 2.7 million people, approximately 1.9 million of whom live in the Denver area. The company operates an extensive pipeline system of more than 13,300 miles of service and distribution pipes.

Public Service of Colorado owns all of the outstanding stock of Cheyenne Light, Fuel and Power Co., which serves Cheyenne and southeastern Wyoming. Public Service also owns Fuel Resources Development Co., Natural Fuels Co., Bannock Center Co., Welton Prop- erties., PS Colorado Credit Corp., and P.S.R. Investment Inc. In January 1993, the company expanded its natural gas systems by merging with the Western Gas Supply Company. The company divested most of its real estate holdings in order to concentrate on providing energy services.

In 1992 the company began the task of removing spent fuel from the core of its closed Fort St. Vrain nuclear power plant. The facility will be used to store the spent fuel until a Federal facility is available. The company is evaluating plans to convert the plant into a gas-fired facility if the work is completed as expected in 1995.

Figure 31. Public Service Co. of Colorado, 1992

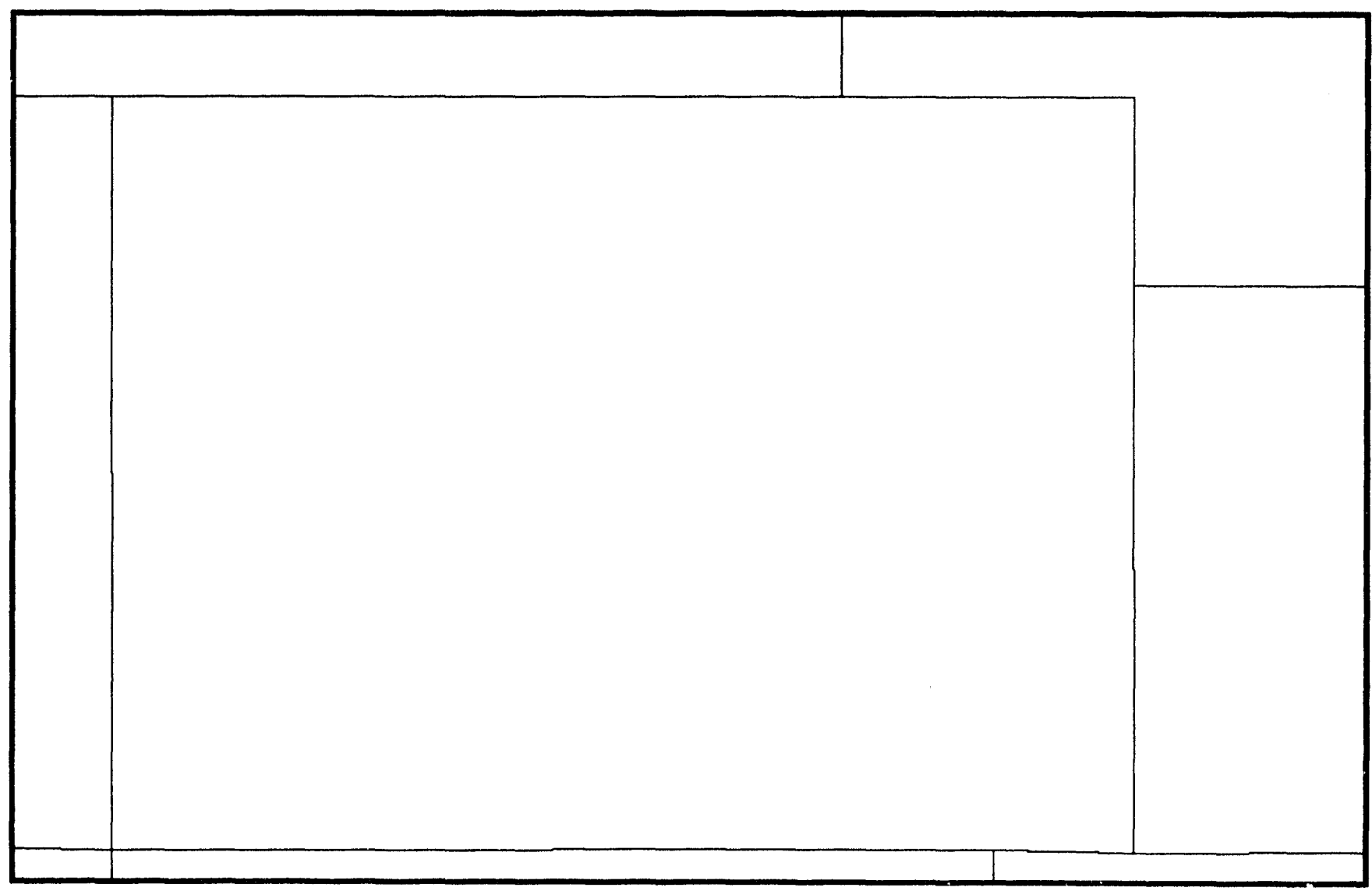

Source: Energy Information Administration (EIA), Form EIA-176, "Annual Report of Natural and Supplemental Gas Supply and Dispositic .." 
Table 42. Public Service Co. of Colorado Natural Gas Data, 1992 (Thousand Cubic Feet)

\begin{tabular}{|c|c|c|c|}
\hline \multirow{2}{*}{ Supply/Disposition } & $\begin{array}{c}\text { Public Service Co. of } \\
\text { Colorado }\end{array}$ & Western Gas Supply Co. & \multirow{2}{*}{$\begin{array}{c}\begin{array}{c}\text { Cheyenne Light Fuel and } \\
\text { Power Co. }\end{array} \\
\text { Wyoming }\end{array}$} \\
\hline & \multicolumn{2}{|c|}{ Colorado } & \\
\hline \multicolumn{4}{|l|}{ SUPPLY } \\
\hline $\begin{array}{l}\text { Produced Onsystem } \\
\text { Receipts }\end{array}$ & 0 & 0 & 0 \\
\hline 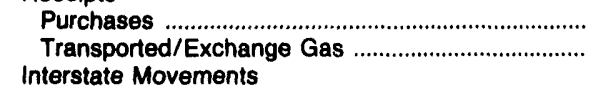 & $\begin{array}{r}124,550,803 \\
19,886,008\end{array}$ & $\begin{array}{l}30,068,399 \\
88,245,574\end{array}$ & $\begin{array}{l}5,993,184 \\
9,278,808\end{array}$ \\
\hline 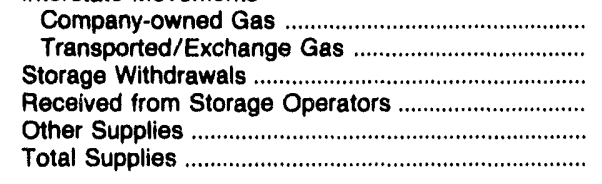 & $\begin{array}{r}0 \\
0 \\
1,349,929 \\
0 \\
0 \\
145,786,740\end{array}$ & $\begin{array}{r}0 \\
0 \\
3,668,198 \\
0 \\
325,401 \\
122,307,572\end{array}$ & $\begin{array}{r}0 \\
0 \\
0 \\
0 \\
0 \\
13,271,992\end{array}$ \\
\hline \multicolumn{4}{|l|}{ DISPOSITION } \\
\hline $\begin{array}{l}\text { Lease and Plant Use } \\
\text { Returned to Formations } \\
\text { Interstate Movements }\end{array}$ & $\begin{array}{l}0 \\
0\end{array}$ & $\begin{array}{r}471,748 \\
0\end{array}$ & $\begin{array}{l}0 \\
0\end{array}$ \\
\hline 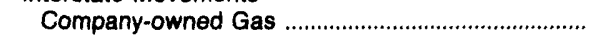 & 0 & 0 & 0 \\
\hline 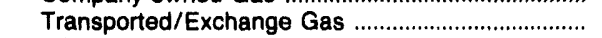 & 0 & 0 & 0 \\
\hline 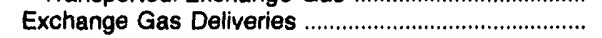 & 0 & 0 & 0 \\
\hline \multicolumn{4}{|l|}{ Deliveries of Company-owned Gas } \\
\hline 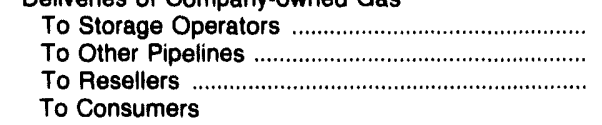 & $\begin{array}{l}0 \\
0 \\
0\end{array}$ & $\begin{array}{r}0 \\
0 \\
26,228,713\end{array}$ & $\begin{array}{l}0 \\
0 \\
0\end{array}$ \\
\hline 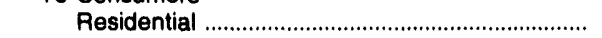 & $71,816,826$ & 0 & $2,118,459$ \\
\hline 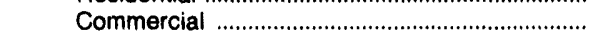 & $47,387,252$ & 0 & $1,296,350$ \\
\hline 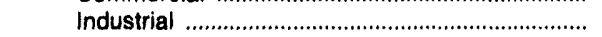 & 718,531 & 150,870 & 629,628 \\
\hline 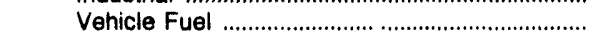 & 0 & 0 & 0 \\
\hline 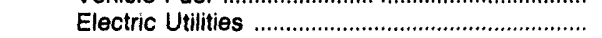 & 0 & 194,006 & 0 \\
\hline \multicolumn{4}{|l|}{ Transported for the Account of Others } \\
\hline To Storage Operators & 0 & 0 & 0 \\
\hline To Other Pipelines & 0 & $44,268,971$ & 0 \\
\hline $\begin{array}{l}\text { To Resellers } \\
\text { To Consumers }\end{array}$ & 0 & $29,299,214$ & 0 \\
\hline 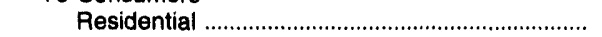 & 0 & 0 & 0 \\
\hline 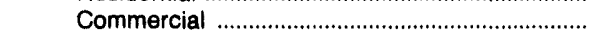 & 0 & 0 & 0 \\
\hline 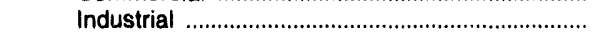 & $19,488,287$ & $12,761,966$ & $9,093,232$ \\
\hline 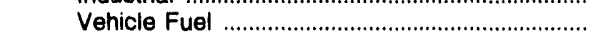 & 0 & 11,908 & $\begin{array}{r}0,000,20 \\
0\end{array}$ \\
\hline 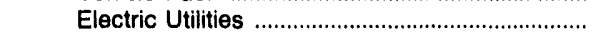 & 0 & 834,759 & 0 \\
\hline 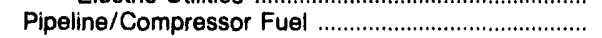 & 0 & $1,314,438$ & 0 \\
\hline 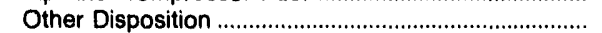 & 0 & 0 & 0 \\
\hline Unaccounted For & $4,930,039$ & $3,139,068$ & 134,323 \\
\hline 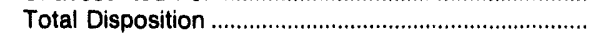 & $145,786,740$ & $122,307,572$ & $13,271,992$ \\
\hline
\end{tabular}

Source: Energy Information Administration (EIA), Form ElA-176, "Annual Report of Natural and Supplemental Gas Supply and Disposition."

The Public Service Co. of Colorado has actively pursued a policy that promotes the use of natural gas as an alternative fuel for vehicles. The company has converted company fleet vehicles to natural gas and is currently a participant in the building of natural gas refueling stations. In 1992, Public Service ended a project that would convert landfill methane gas into diesel fuel.

The U.S. Forest Service recognized Public Service in 1992 as one of the best utility companies in the country in its tree planting efforts. 


\section{Public Service Electric and Gas Co.}

Public Service Electric and Gas Company (PSE\&G), incorporated in 1924, is a regulated combined electric and gas utility providing electric and gas service to more than 2 million customers in New Jersey. PSE\&G is the largest utility in New Jersey and one of the largest combined electric and gas companies in the United States. The PSE\&G electric and gas service area is a corridor of approximately 2,300 square miles running diagonally across New Jersey from Bergen County in the northeast to an area below Camden in the southwest. The PSE\&G natural gas system includes more than 14,900 miles of distribution line, 3,574 miles of plastic mains, and 14,133 miles of service line. The company has one liquefied natural gas storage plant for peak shaving.

During 1992, PSE\&G provided service to approximately 1.9 million electric customers and 1.5 million gas customers in areas of New Jersey where approximately 5.5 million persons reside. PSE\&G's natural gas deliveries to residential, commercial, industrial, and electric utility customers represented 68 percent of the natural gas consumed in New Jersey during 1992. The company converted more than 8,800 residences from oil heat to natural gas during the year. Additionally, industrial and commercial conversions accounted for sales of almost 5 million cubic feet of natural gas.

Figure 32. Public Service Electric and Gas Co., 1992

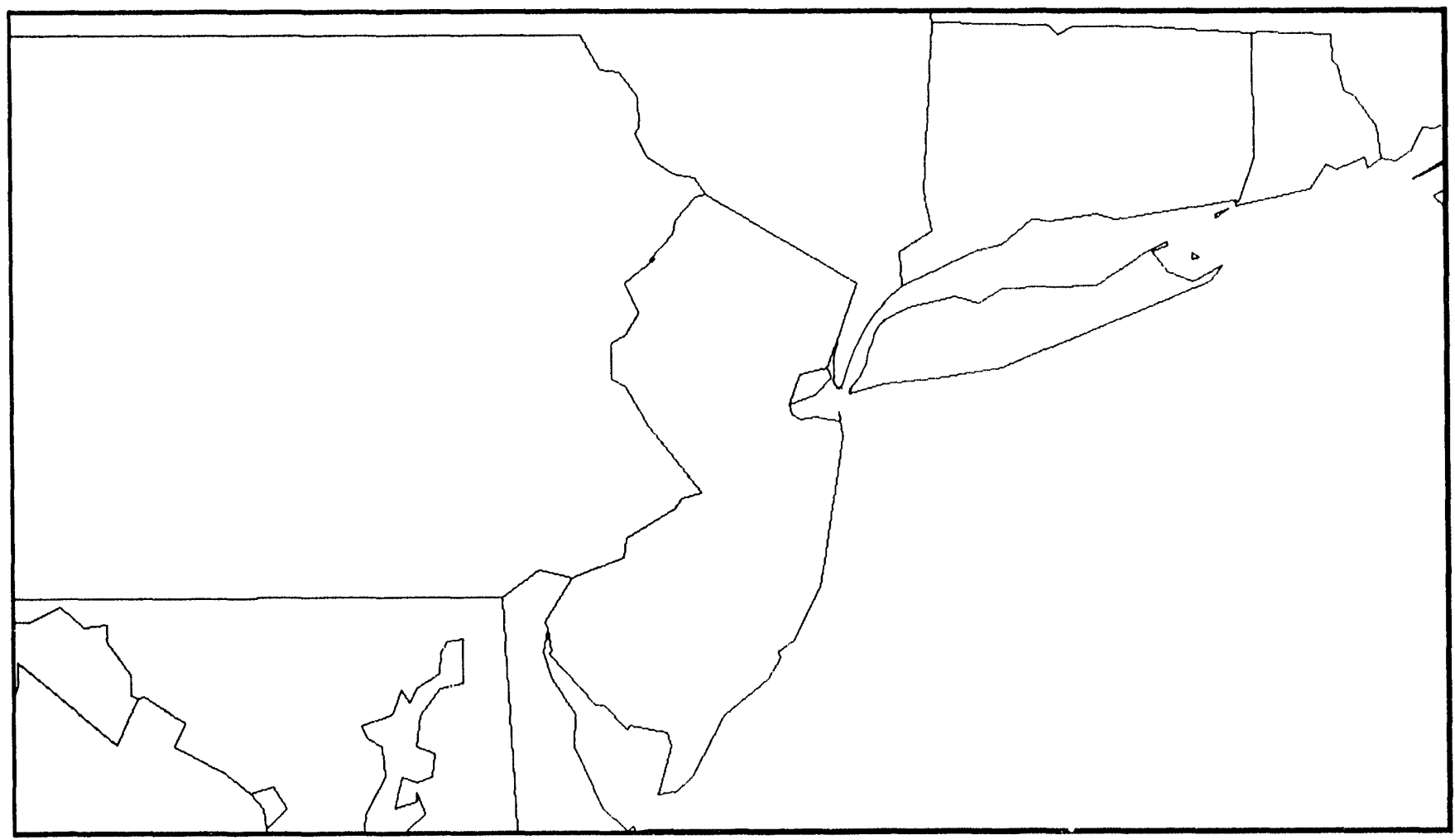

Source: Energy Information Administration (EIA), Form ElA. 176, "Annual Report of Natural and Supplemental Gas Supply and Disposition "

Service Area 
Total gas sold and transported to consumers increased 20 percent from 1991 to 1992 . In the same period, gas delivered to industrial consumers more than doubled (107 percent). Cogeneration sales and deliveries were the largest contributors to the increase in industrial sales and transportation service. At year-end 1992, subsidiary Community Energy Alternatives Inc., had invested in 19 cogeneration or power plants, of which 15 were in operation. Construction continued on the Newark Bay Cogeneration Facility, which will be fueled by 10 billion cubic feet of natural gas with a capacity of 137 megawatts. Construction also continued on the JFK Airport Cogeneration Facility, which is fueled by natural gas and has a 100-megawatt capacity.

PSE\&G purchases all of its natural gas from others. These supplies were transported to New Jersey by Transcontinental Gas Pipeline Corporation, Texas Eastern Transmission Corporation, Tennessee Gas Pipeline Company, and Energy Development Corporation. Gas is also purchased from refineries and other sources.

In continued support of the use of natural gas vehicles (NGV), PSE\&G operates a NGV compressor at NJ
Bell Telephone Company's Newark office to service Bell's fleet of 25 NGV's while working to develop a local public refueling infrastructure. In support of the State's plan to convert 100 vehicles to natural gas, PSE\&G began construction of a refueling station at the Department of Transportation's headquarters in Ewing Township. The company also provided refueling units to Princeton University's Plasma Physics Lab to service its eight NGV vans. PSE\&G also is seeking regulatory approval to construct a compressed natural gas refueling station at a public gasoline station.

PSE\&G continued to market natural gas in other areas. A new high-tech air-conditioner, using a natural gas fueled engine to drive the compressor and chiller, was successfully tested and is now in commercial production. The company also continued to study heat pumps powered by natural gas driven engines.

During the summer of 1992, PSE\&G switched to natural gas at two of its coal plants, which helped reduce the emissions of oxides of nitrogen by half. The fuel switch also helped eliminate nearly 100 percent of sulfur dioxide emissions as well as significant amounts of carbon dioxide emissions. 


\section{Questar Corp.}

Questar Corporation engages in the exploration, production, transmission, storage, and distribution of natural gas in the Rocky Mountain and Midcontinent regions. Exploration and production is carried out by three subsidiaries: Wexco Company, Celsius Energy Company, and Universal Resource Corporation. Questar Pipeline Company operates an interstate natural gas gathering and transmission system serving Colorado, Utah, and Wyoming. This subsidiary also owns and operates an underground storage facility in northern Utah. Mountain Fuel Supply Company provides natural gas distribution service in Utah, Wyoming, and Idaho, serving 530,000 customers.

Mountain Fuel Supply has been working on the buildin z of natural gas refueling stations for the last 3 years. There are now more than 12 public refueling stations in its service area. Questar Corporation has more than 500 natural gas powered vehicles in its fleet and is promoting the adoption of natural gas vehicles by other fleet owners.

Figure 33. Questar Corp., 1992

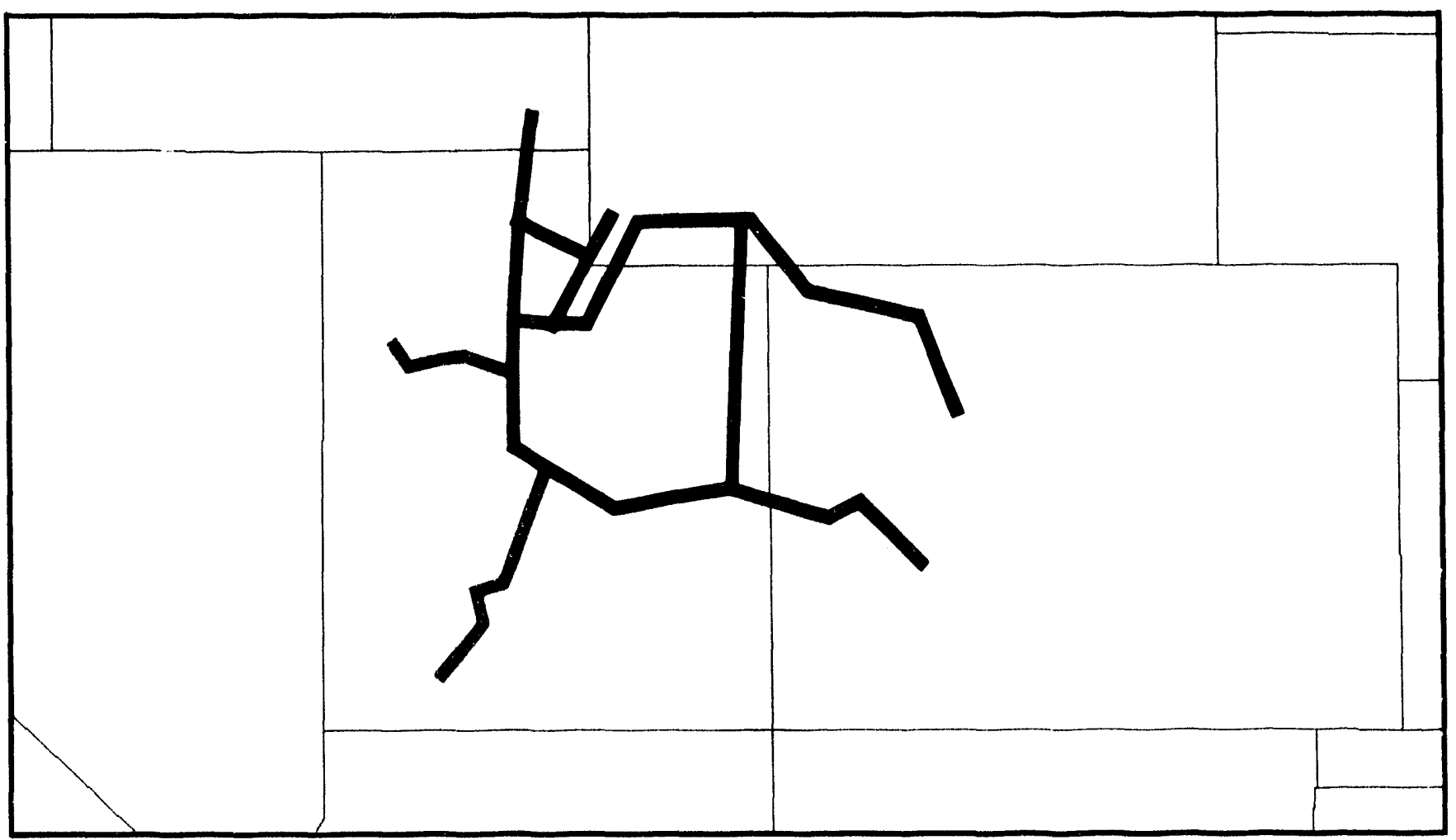

Source: Energy Information Administration (E|A), Form ElA-176, "Annual Report of Natural and Supplemental Gas Supply and Disposition." 
Table 44. Questar Corp. Natural Gas Data, 1992 (Thousand Cubic Feet)

\begin{tabular}{l|c|c|c|c|c|c|}
\hline \multirow{2}{*}{ Supply/Disposition } & \multicolumn{3}{|c|}{ Questar Pipeline Co. } & \multicolumn{2}{|c}{ Mountain Fuel Supply Co. } \\
\cline { 2 - 5 } & Colorado & Utah & Wyoming & Utah & Wyoming \\
\hline
\end{tabular}

SUPPLY

Produced Onsystem ............................................ Receipts

Purchases .........................................................

Transported/Exchange Gas .........................

Interstate Movements

Company-owned Gas

Transported/Exchange Gas

Storage Withdrawals

Received from Storage Operators

Other Supplies

Total Supplies

\section{DISPOSITION}

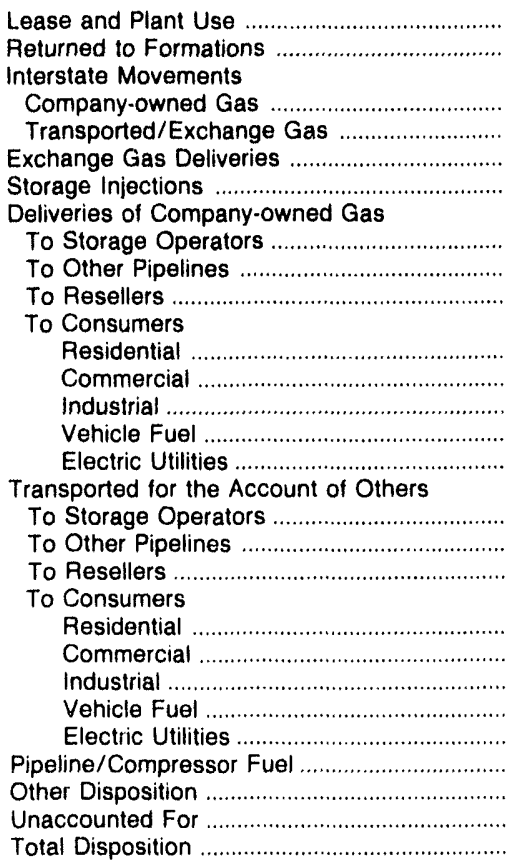

0

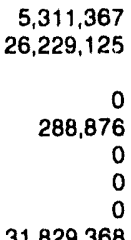

$31,829,368$

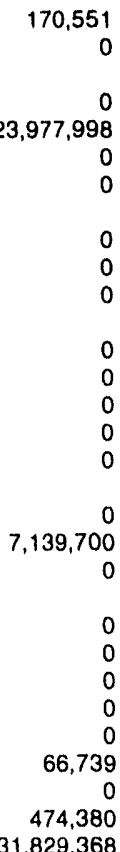

0

$25,028,658$
$48,432,890$
0
0
$99,076,115$
$26,372,625$
0
0
$198,910,288$

$198,910,288$
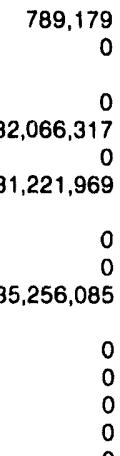

0
$105,803,611$

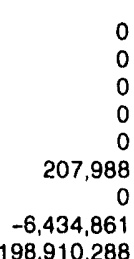

0

$17,971,175$
$136,455,158$
0
$45,399,157$
899,304
0
0
$200,724,794$

$200,724,794$

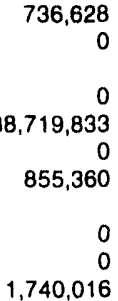

$1,740,016$

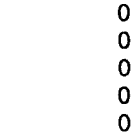

0
$104,485,637$

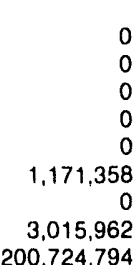

0

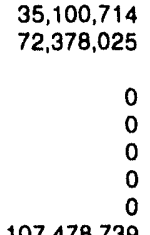

$107,478,739$

$8,210,263$

$1,748,023$

$6,462,240$
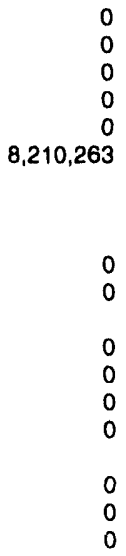

$\begin{array}{rr}44,356,971 & 1,948,379 \\ 16,225,787 & 1,277,579 \\ 4,606,065 & 291,220 \\ 15,331 & 10,022 \\ 28,809 & 0\end{array}$

28,809

022
0

$\begin{array}{ll}0 & 0 \\ 0 & 0 \\ 0 & 0\end{array}$

$\begin{array}{rr}0 & 0 \\ 0 & 0 \\ 36,086,988 & 4,929,957 \\ 0 & 0 \\ 5,434,352 & 0 \\ 381,057 & 6,316 \\ 0 & 0 \\ 260,578 & -253,210 \\ 107,478,739 & 8,210,263\end{array}$

Questar is a one-third owner in FuelMaker Corporation, which markets a vehicle refueling application for natural gas vehicles. It can refuel a vehicle in about 5 hours and can be located at a customer's home or business. Each unit can refuel either one or two vehicles, so it is appropriate for use by small businesses for use in refueling their fleets as well as by householders who would use to it refuel their own automobiles. This refueling application is being marketed around the world. 
Table 44. Questar Corp. Natural Gas Data, 1992 (Continued) (Thousand Cubic Feet)

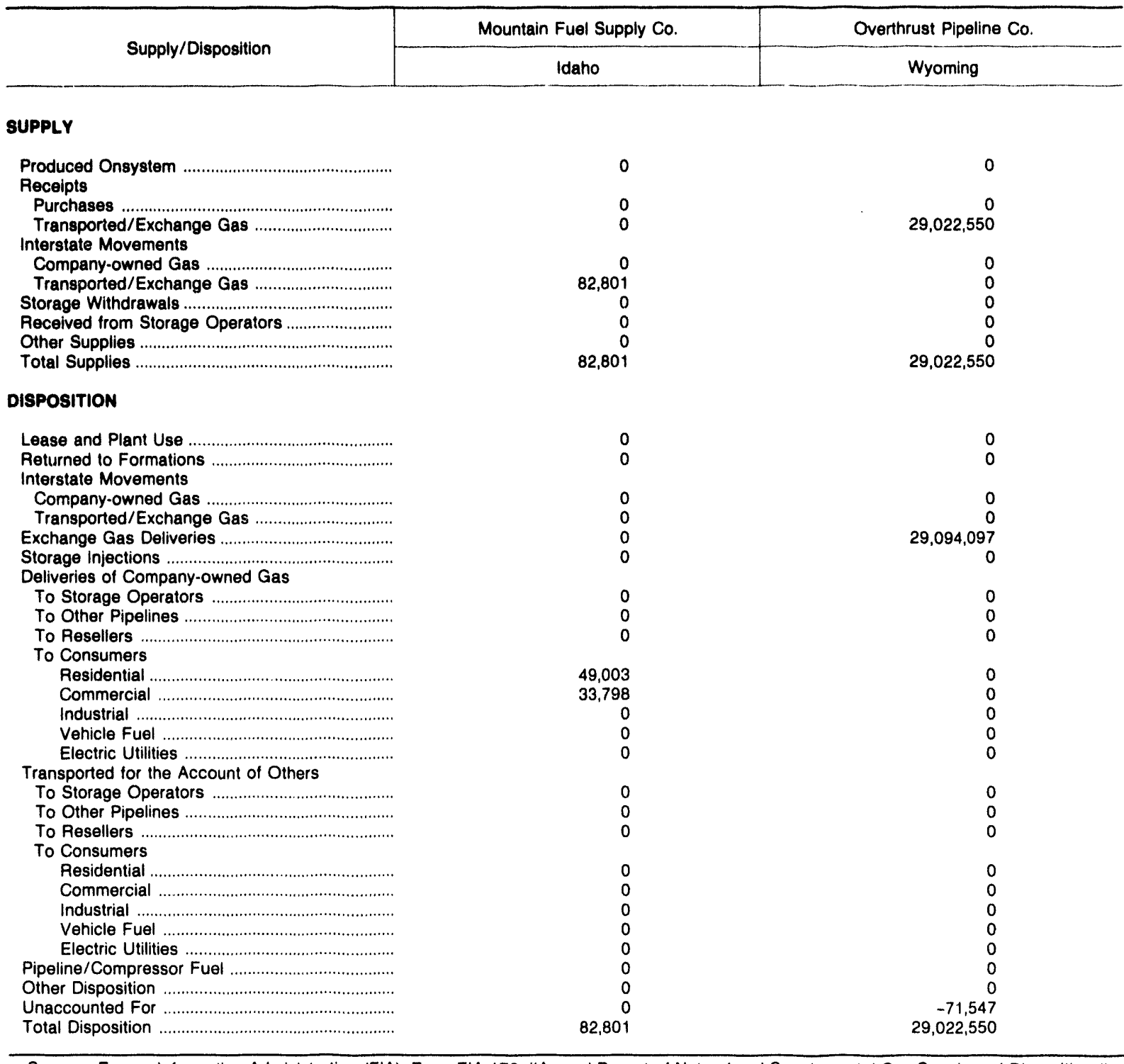

Source: Energy Information Administration (EIA), Form ElA-176, "Annual Report of Natural and Supplemental Gas Supply and Disposition." 


\section{Sabine Pipe Line Co.}

Sabine Pipe Line Company, a wholly owned subsidiary of Texaco Inc., is responsible for transporting natural gas from Henry, Louisiana to Port Arthur, Texas. In 1964 , Sabine was originally created as a cost-of-service pipeline. From 1964 to the mid-1980's Sabine continued to transport primarily for Texaco and affiliated companies.

In 1987, a pipeline exchange was created near Henry, known as the Henry Hub, and Sabine became an openaccess transporter. The Henry Hub is a major gas interchange center with 11 interconnecting pipeline systems that were put into service on May 1, 1988. Sabine and Texaco jointly own the hub facilities. In 1989, the largest development of Sabine's history occurred when the New York Mercantile Exchange (NYMEX) designated the Henry Hub as a delivery location for their Natural Gas Futures Contract. NYMEX trading began on April 13, 1990.

The Houston-based HNG storage facility will provide up to 500 million British thermal units per day withdratval capacity and in excess of 150 million British thermal units of injection capability to the Northeast and Southeast United States. The service will be available through direct connections to Sabine Pipe Line and its Henry Hub distribution system and several other pipelines.

Figure 34. Sabine Pipe Line Co., 1992

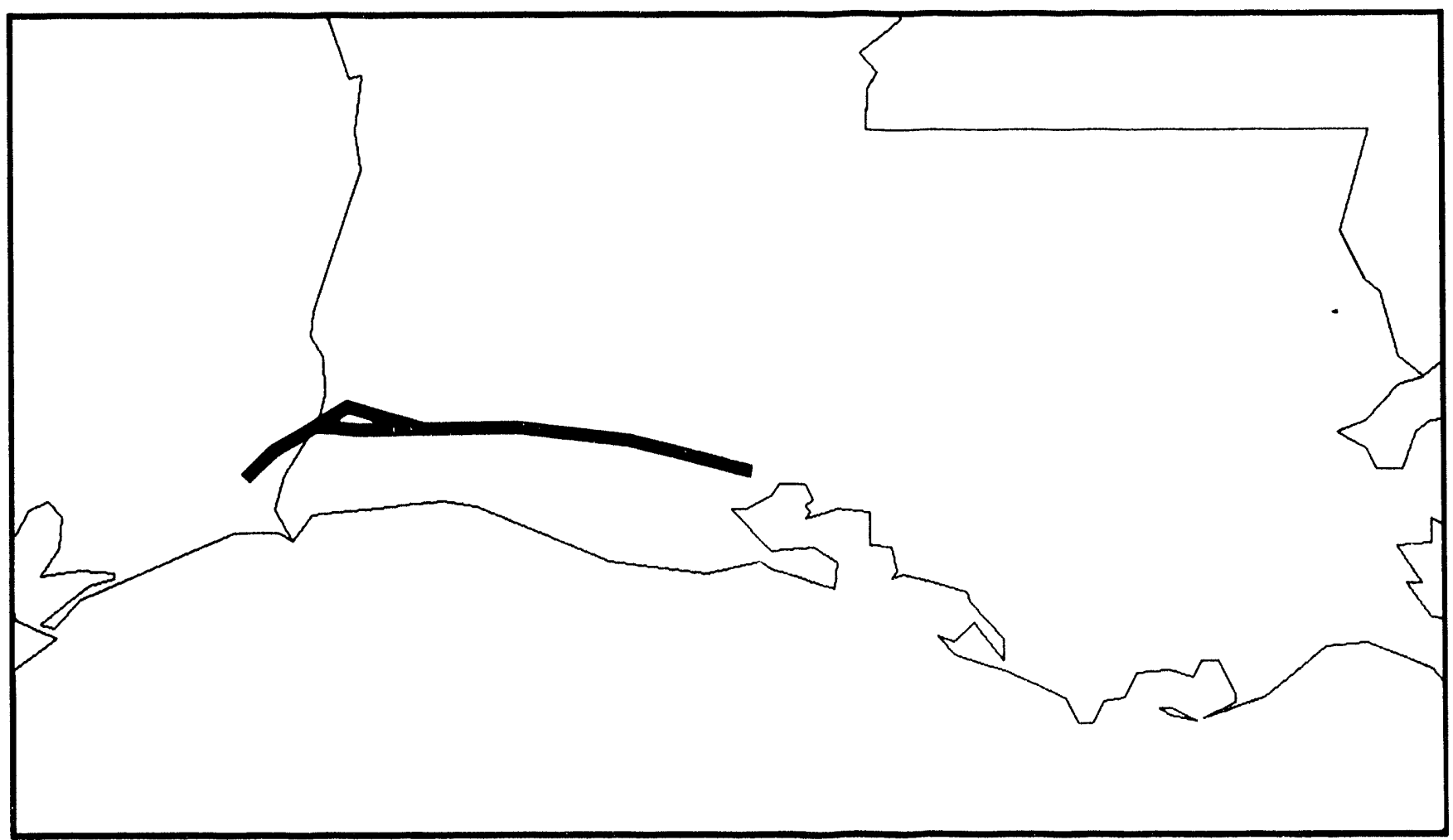

Source: Energy Information Administration (E|A), Form EiA-176, "Annual Report of Natural and Supplemental Gas Supply and Disposition." 
Table 46. Sablne Plpe Line Co. Natural Gas Data, 1992 (Thousand Cubic Feet)

\begin{tabular}{|c|c|c|c|c|}
\hline \multirow{2}{*}{ Supply/Disposition } & \multicolumn{2}{|c|}{ Sabine Pipe Line Co. } & $\begin{array}{l}\text { Riverway Gas Pipeline } \\
\text { Co. }\end{array}$ & $\begin{array}{l}\text { Bridgeline Gas } \\
\text { Distribution Co. }\end{array}$ \\
\hline & Loulsiana & Texas & Low & \\
\hline \multicolumn{5}{|l|}{ SUPPLY } \\
\hline $\begin{array}{l}\text { Produced Onsystem } \\
\text { Receipts }\end{array}$ & 0 & 0 & 0 & 0 \\
\hline 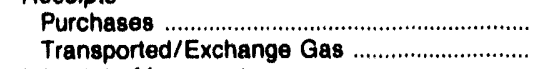 & $\begin{array}{r}0 \\
144,069,35 !\end{array}$ & $\begin{array}{r}0 \\
11,071,552\end{array}$ & $\begin{array}{r}0 \\
7,029,449\end{array}$ & $\begin{array}{r}97,070,088 \\
160,545,688\end{array}$ \\
\hline \multicolumn{5}{|l|}{ Interstate Movements } \\
\hline 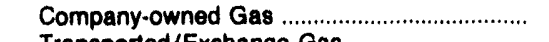 & 0 & 0 & 0 & 0 \\
\hline 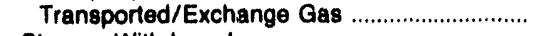 & $4,970,543$ & $5,754,910$ & 0 & 0 \\
\hline 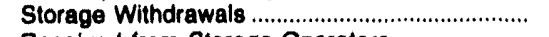 & 0 & 0 & 0 & $7,857,861$ \\
\hline Received from Storage Operators ........................ & 0 & 0 & 0 & 0 \\
\hline 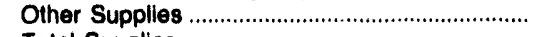 & 0 & 0 & 0 & 0 \\
\hline 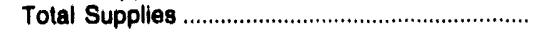 & $149,039,894$ & $16,826,462$ & $7,029,449$ & $265,473,617$ \\
\hline \multicolumn{5}{|l|}{ DIBPOSITION } \\
\hline Lease and Plant Use & 0 & 0 & 0 & 0 \\
\hline 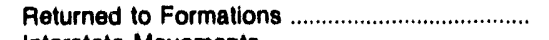 & 0 & 0 & 0 & 0 \\
\hline Interstate Movements & & & & \\
\hline 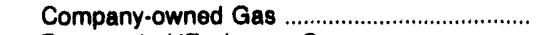 & 0 & 0 & 0 & 0 \\
\hline 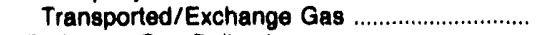 & $5,754,910$ & $4,970,543$ & 0 & 0 \\
\hline 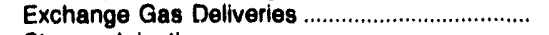 & 0 & 0 & 0 & $66,820,811$ \\
\hline Storage Injections & 0 & 0 & 0 & $5,830,645$ \\
\hline \multicolumn{5}{|l|}{ Deliveries of Company-owned Gas } \\
\hline 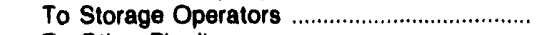 & 0 & 0 & 0 & 0 \\
\hline 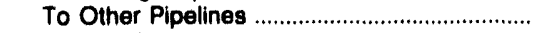 & 0 & 0 & 0 & 0 \\
\hline 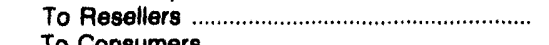 & 0 & 0 & 0 & 0 \\
\hline To Consumers & & & & \\
\hline 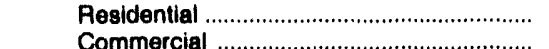 & 0 & 0 & 0 & 0 \\
\hline Commercial ................................................... & 0 & 0 & 0 & 0 \\
\hline 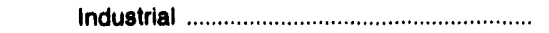 & 0 & 0 & 0 & $117,180,765$ \\
\hline 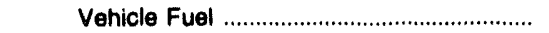 & 0 & 0 & 0 & 0 \\
\hline Electric Utilities & 0 & 0 & $4,048,752$ & $11,655,818$ \\
\hline \multicolumn{5}{|l|}{ Transported for the Account of Others } \\
\hline 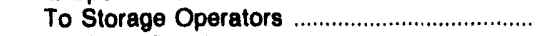 & $\because \quad 0$ & 0 & 0 & 0 \\
\hline 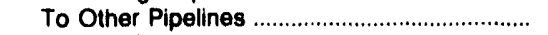 & $143,951,993$ & $11,506,485$ & 0 & 0 \\
\hline 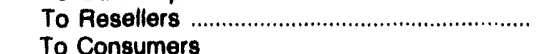 & 0 & 0 & 0 & 0 \\
\hline To Consumers & 0 & 0 & 0 & 0 \\
\hline 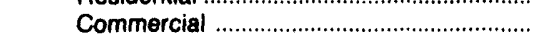 & 0 & 0 & 0 & 0 \\
\hline 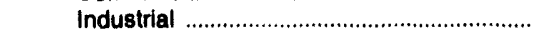 & 7,227 & 0 & 0 & $18,882,925$ \\
\hline 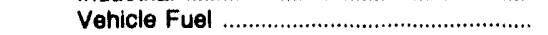 & 0 & 0 & 0 & 0 \\
\hline 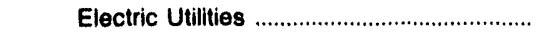 & 0 & 0 & $2,980,697$ & $45,015,634$ \\
\hline 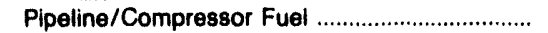 & 0 & 0 & 0 & 0 \\
\hline 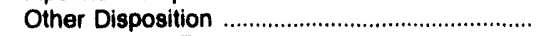 & 0 & 0 & 0 & 0 \\
\hline 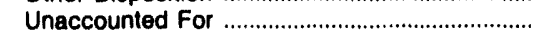 & $-674,236$ & 349,434 & 0 & 86,919 \\
\hline 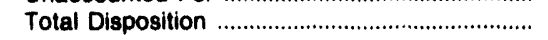 & $149,039,894$ & $16,826,462$ & $7,029,449$ & $265,473,617$ \\
\hline
\end{tabular}

Source: Energy Information Administration (EIA), Form ElA-176, "Annual Report of Natural and Supplemental Gas Supply and Disposition."

In September 1992, Sabine completed one interconnect to its system (Rio Bravo) to connect with Sabine's pipeline in Orange County, Texas. Sabine also operates 18.7 miles of offshore line and 173 miles of onshore mainline from Vermilion Parish, Louisiana, to Texaco's refinery in Jefferson County, Texas.
On August 25, 1992, Sabine facilities were forced to close for 1 day, due to the lack of supply caused by Hurricane Andrew. However, the facility suffered no major damage and resumed operation the following day. 


\section{San Diego Gas and Electric Co.}

Founded in 1881, San Diego Gas \& Electric is a public utility corporation, operating in the State of California. The company serves customers in both San Diego and Orange Counties in southern California. Electric energy is purchased, generated, and provided to $1,122,000$ customers in both counties. Natural gas is purchased and distributed to 687,000 customers in San Diego County.

SDG\&E purchases natural gas for resale to customers and also for fuel in electric generating plants. Gas is received through two transmission pipelines that have a combined nominal capacity of $\mathbf{4 0 0}$ million cubic feet per day. Spot-market suppliers and suppliers under short-term contracts are the primary sources of SDG\&E's natural gas.

SDG\&E purchased 103 billion cubic feet of natural gas in 1992. Coming from suppliers in New Mexico, Oklahoma, and Texas, the gas was transported to SDG\&E by El Paso Natural Gas, Transwestern Pipeline, and Southern California Gas Company.

After having been awarded 50 million cubic feet per day of interstate capacity on Pacific Gas Transmission's pipeline in 1991, SDG\&E also formed other interstate contracts. SDG\&E entered into four Canadian natural gas supply contracts. They also entered into transpor-

Figure 35. San Diego Gas and Electric Co., 1992

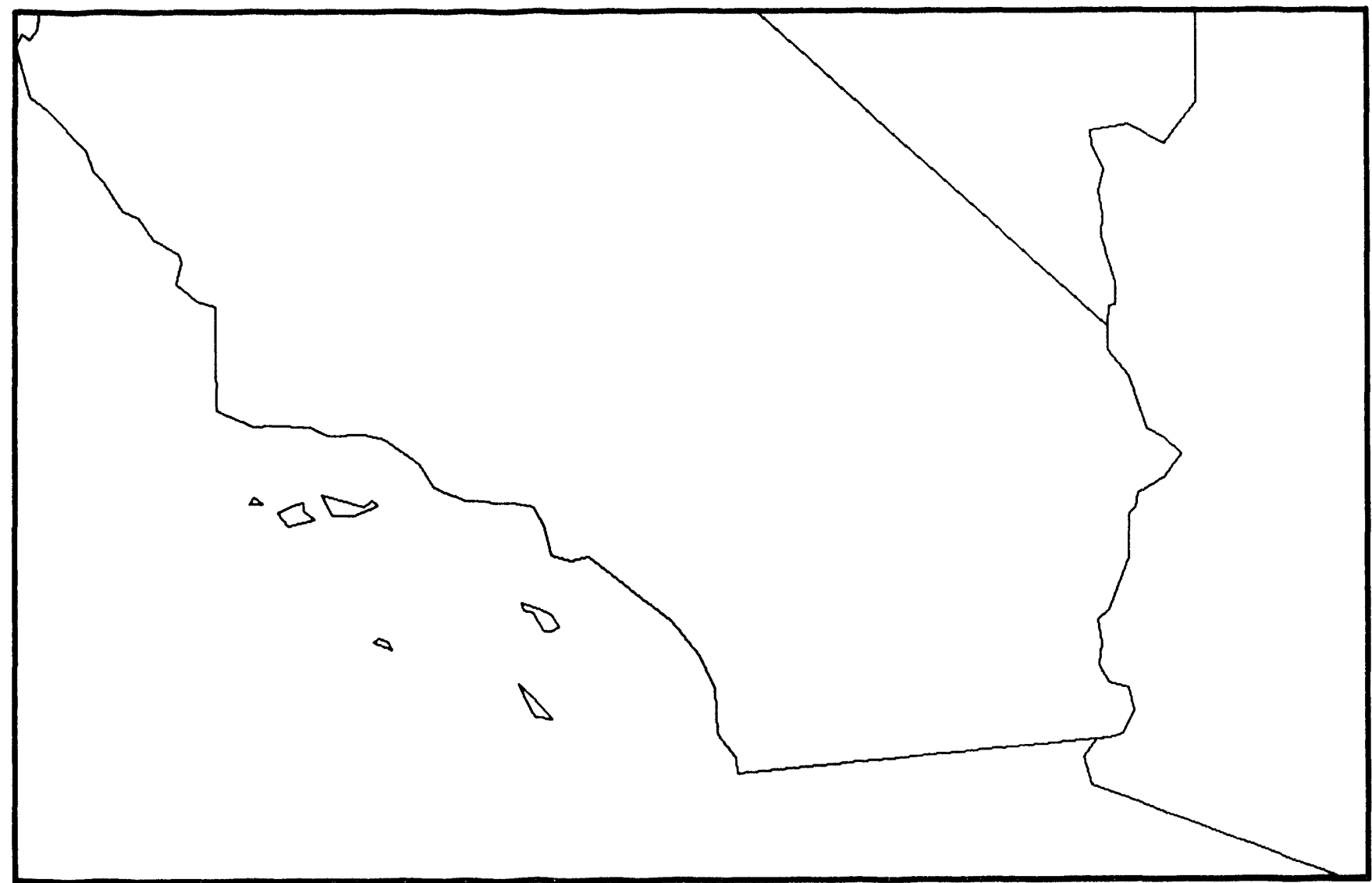

Source: Energy Information Administration (EIA), Form EIA-176, "Annual Report of Natural and Supplemental Gas Supply and Disposition." 
Table 47. San Diego Gas \& Electric Co. Natural Gas Data, 1992 (Thousand Cubic Feet)

\begin{tabular}{c|c}
\hline \multirow{2}{*}{ Supply/Disposition } & San Diego Gas \& Electric Co. \\
\cline { 2 - 2 } & Callfornia \\
\hline
\end{tabular}

SUPPLY

Produced Onsystem

Receipts

Purchases

Transported/Exchango Gas

Interstate Movements

Company-owned Gas

Transported/Exchange Gas

Storage Withdrawals

Received from Storage Operators

Other Supplies

Total Supplies

Disposition

Lease and Plant Use

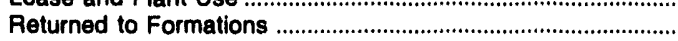

Interstate Movements

Company-owned Gas

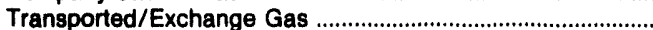

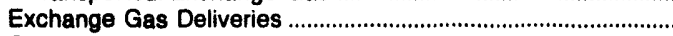

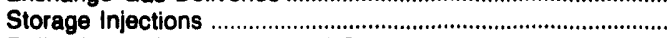

Deliveries of Company-owned Gas

To Storage Operators

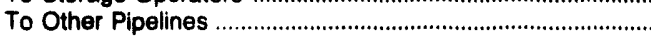

To Resellers.

To Consumers

Residential

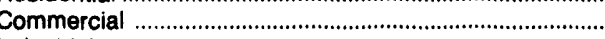

Industrial

Vehicle Fuel .

Electric Utilities

Transported for the Account of Others

To Storage Operators

To Other Pipelines.

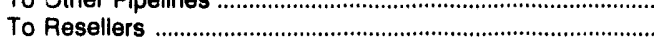

To Consumers

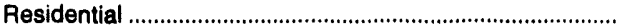

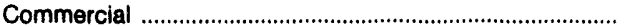

Industrial

Vehicle Fuel

Electric Utilities

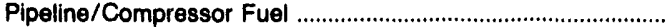

Other Disposition

Unaccounted Fo

\section{0}

$102,893,786$

$8,499,706$
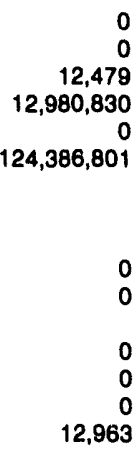

$11,500,837$

0

$29,819,374$

$9,501,595$

$16,402,890$

8,356

$47,540,078$

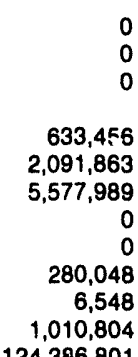

Source: Energy Information Administration (EIA), Form ElA-176, "Annual Report of Natural and Supplemental Gas Supply and Disposition."

tation agreements with Alberta Natural Gas, Pacific Ga Transmission, and Pacific Gas and Electric to transport gas from the Canadian border to the California border.

SDG\&E along with Southern California Gas Company (SoCal) has put together a proposal to work with the Mexican Government in a program intended to improve the air quality in the Baja region. This region does not have access to natural gas, and the construction of a pipeline from SoCal's service territory could provide the necessary resources. The benefits for SDG\&E's customers if the project is approved are improved reliability, reduced air emissions in the San Diego air basin, and lowered rates.

SDG\&E has also been active in promoting alternate fuel vehicles. It has been involved with electric, solar, and natural gas vehicles. During 1992, it opened 2 new public natural gas refueling stations. There are also 11 private refueling stations for companies that have their own fleets. 


\section{Southern California Gas Co.}

Southern California Gas Company (SOCAL) is a public utility owning and operating the Nation's largest natural gas distribution system. The company provides gas service throughout Southern and Central California. The parent company of SOCAL, Pacific Enterprises, also owns Pacific Interstate Pipeline Company, which transports natural gas for resale to SOCAL. Pacific Interstate, in turn, owns Pacific Offshore Pipeline Company.

Pacific Enterprises' in 'erstate transportation system primarily moves gas originating in Western Canada, while the offshore segments bring gas produced in the
Santa Barbara offshore area to the SOCAL distribution area, supplying 27 percent of the company's needs.

The SOCAL service area includes 535 communities within approximately 23,000 square miles. In addition to its direct service area, SOCAL delivers gas for resale to the distribution systems of Long Beach and the San Diego Gas and Electric Company.

In 1992, SOCAL and San Diego Gas and Electric proposed construction of a pipeline to transport natural gas from Southern California to Baja California. Government-owned electric utilities in the Mexican Baja region would be the customers for that gas.

Figure 36. Southern California Gas Co., 1992

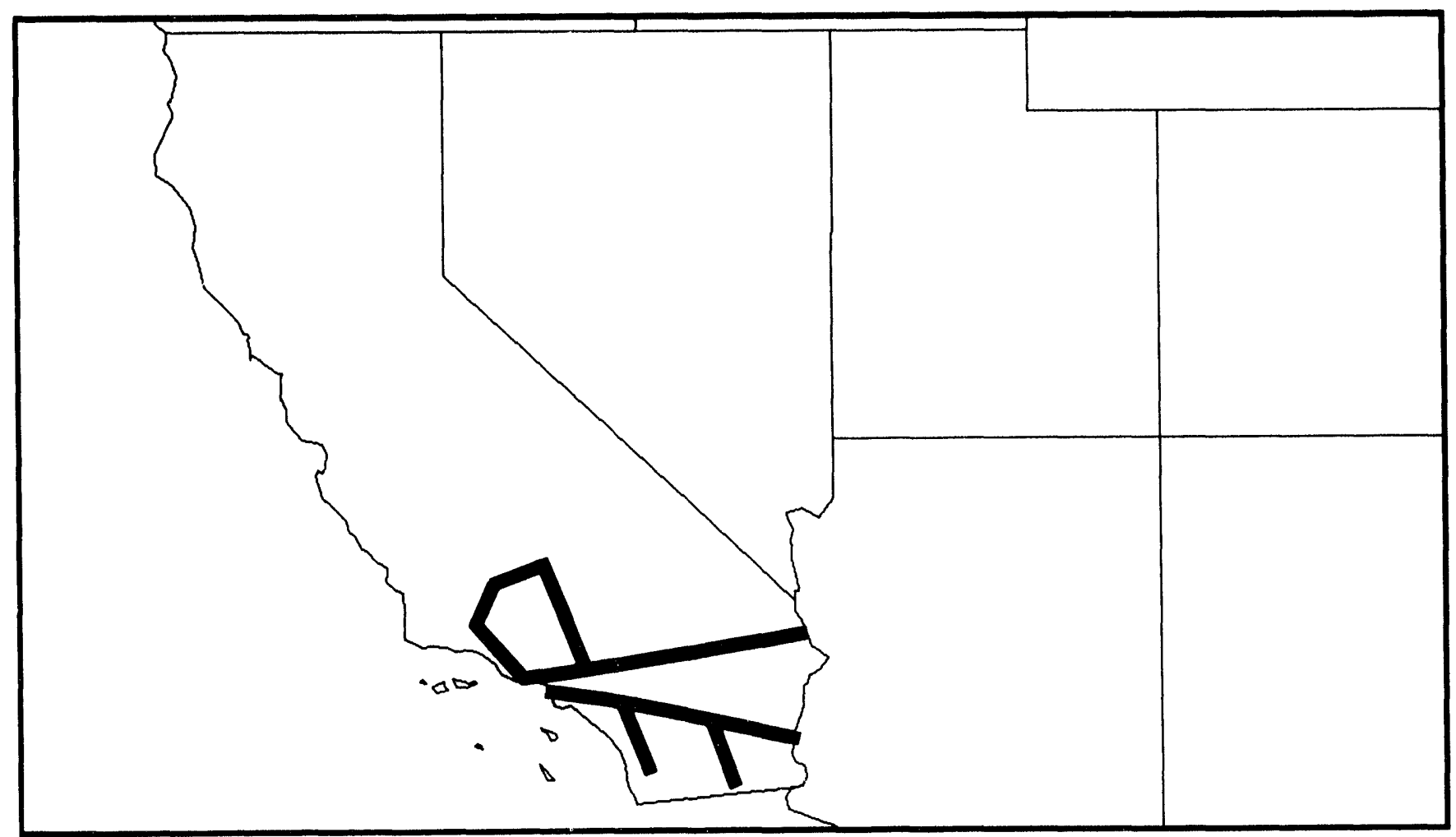

Source: Energy Infermation Administration (EIA), Form ElA-176, "Annual Report of Natural and Supplemental Gas Supply and Disposition." 
Table 48. Southern Callfornla Gas Co. Natural Gas Data, 1992 (Thousand Cubic Feet)

\begin{tabular}{l|l|l}
\hline \multirow{2}{*}{ Supply/Disposition } & Southern California Gas Co. & Pacific Offshore Pipeline Co. \\
\cline { 2 - 3 } & \multicolumn{2}{|c}{ Callifornia } \\
\hline
\end{tabular}

SUPPLY

Produced Onsystem

Receipts

Purchases

Transported/Exchange Gas

Interstate Movements

Company-owned Gas

Transported/Exchange Gas

.

Storage Withdrawals

Received from Storage Operators

Other Supplies .

Total Supplies

\section{DISPOSITION}

Lease and Plant Use

Returned to Formations

Interstate Movements

Company-owned Gas

Transported/Exchange Gas ...

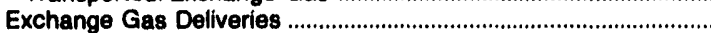

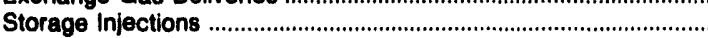

Deliveries of Company-owned Gas

To Storage Operators

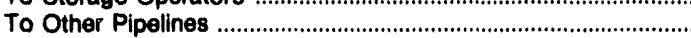

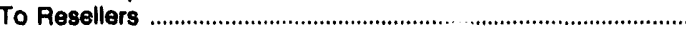

To Consumers

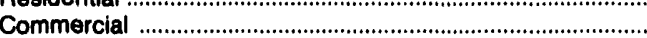

Industrial ......

Vehicle Fuel

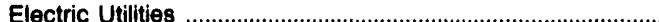

Transported for the Account of Others

To Storage Operators

(1)

To Resellers

To Consumers

Residential ...

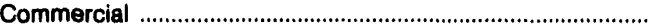

Industrial

Vehicle Fuel

Electric Utilities

Pipeline/Compressor Fuel

Other Disposition

Unaccounted For
19,474

$107,332,013$

$180,909,500$

$253,263,970$

$459,786,411$

$128,106,333$

0
0

$1,129,417,701$

$\begin{array}{rr}0 & 1,417,422 \\ 0 & 0 \\ 0 & 0 \\ 0 & 0 \\ 23,887,597 & 0 \\ 113,727,723 & 0 \\ 0 & 0 \\ 0 & 0 \\ 0 & 11,213,704\end{array}$

$241,052,167$

$64,404,452$

$36,189,806$

89,941

0
0
$149,232,495$

$2,868,276$

$42,445,235$

$217,897,841$

$220,551,576$

$6,138,625$

$10,931,867$

$1,129,417,701$
$12,608,055$

0

$12,608,055$

$11,213,704$

Source: Energy Information Administration (EIA), Form EIA.176, "Annual Report of Natural and Supplemental Gas Supply and Disposition."

SOCAL owns and operates underground natural gas storage facilities and continues to provide storage for all noncore customers on a bid basis. This allows the customers to purchase gas for injection into storage when prices are low and supplies plentiful, later withdrawing the volurnes when prices are higher, supplies less plentiful, and their needs greater.

During 1992, SOCAL moved more that a trillion cubic feet of gas through its system for deliveries to end users and to resellers. Pacific Offshore Pipeline Company delivered 11 billion cubic feet of gas for resale by other companies. The company delivered 244 billion cubic feet, 106 billion cubic feet, and 253 billion cubic feet of gas to residential, commercial, and industrial consumers, respectively.
SOCAL continues to be actively involved with natural gas vehicles. The company added 130 GMC Sierra pickup trucks to its fleet during 1992. The Sierra is the first truck manufactured to operate on natural gas, rather than being retrofitted for natural gas. During 1993 the company added more small trucks to its fleet, making it one of the largest users of exclusively natural gas fueled trucks in the Nation. The company's fleet also includes natural gas fueled automobiles and vans.

The company itself maintains 6 refueling stations. During 1992, 18 other refueling stations were opened to provide high-speed fillups to various fleets and to the general public. In addition, one refueling facility was opened at a retail gasoline service station. 


\section{Southern Natural Gas Co.}

Southern Natural Gas Company is a wholly owned subsidiary of Sonat Inc. Other subsidiaries of Sonat include the Citrus Corporation and South Georgia Natural Gas Company. Southern Natural Gas Company is the major pipeline supplier of natural gas to the Southeastern United States. The Citrus Corporation, 50-percent owned by Sonat, is involved in natural gas transmission and marketing. Florida Gas Transmission Company, a subsidiary of the Citrus Corporation, is the principal pipeline supplier of natural gas to Florida. Southern Natural Gas Company owns 50 percent of Bear Creek Storage Company and 100 percent of Sea Robin Pipeline Company.
Another Sonat subsidiary, Sonat Energy Services, provides natural gas marketing services through Sonat Marketing Company, and gathering and intrastate pipeline services through Sonat Intrastate Alabama, Inc. Sonat has an interest in approximately 14,000 miles of natural gas pipelines in Texas, Louisiana, Mississippi, Alabama, Georgia, Tennessee, and South Carolina.

During 1992, Southern Natural was successful in developing new markets within its service area. Deliveries of up to 20 million cubic feet of gas per day began to the world's second largest sulphur mine, located offshore Louisiana. Also, an application was filed with FERC to add approximately 40 million cubic feet of

Flgure 37. Southern Natural Gas Co., 1992

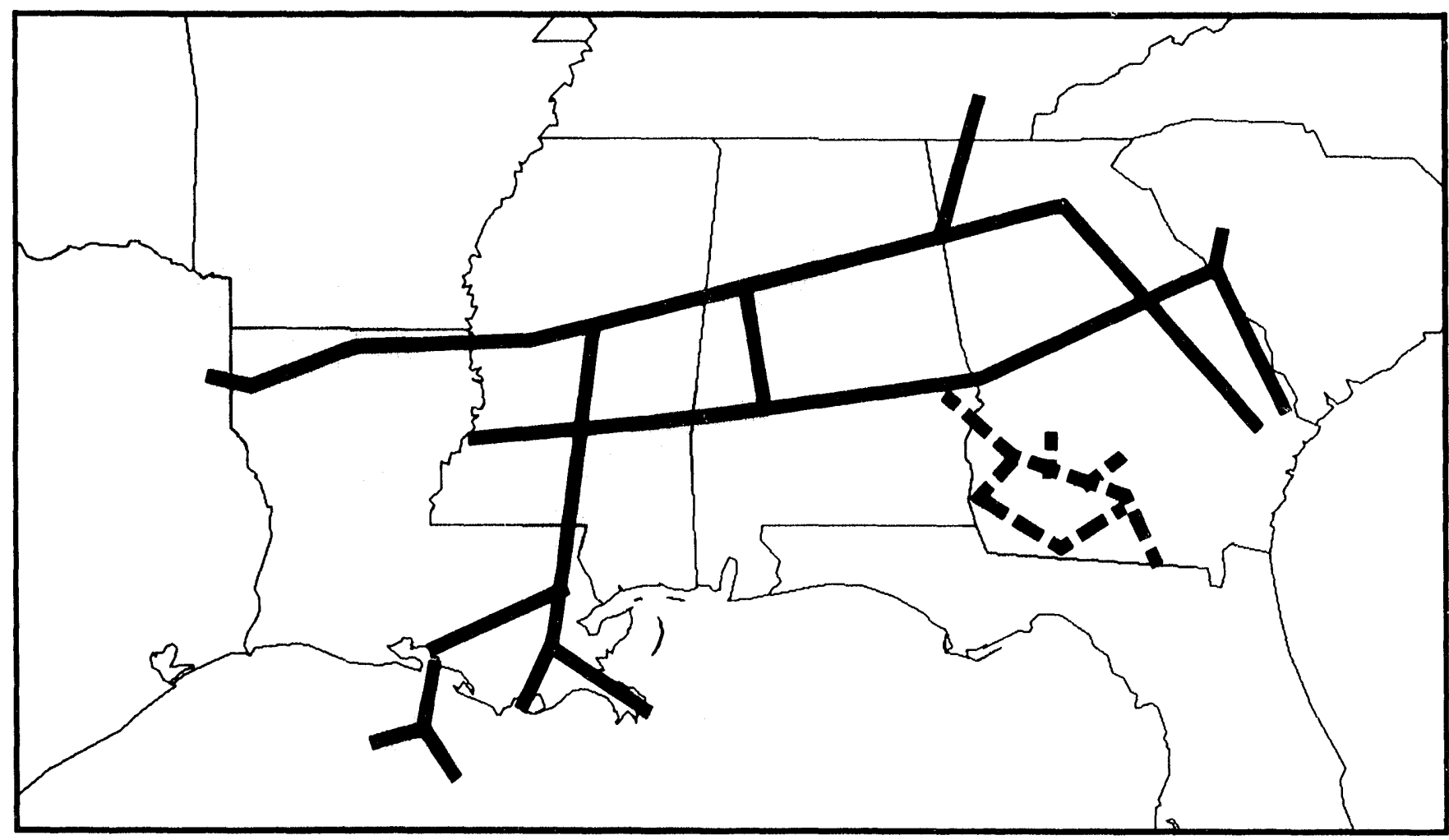

Source: Energy Information Administration (EIA), Form EIA-176, "Annual Report of Natural and Supplemental Gas Supply and Disposition."

Supply Areas

Service Area
Southern Natural Gas Co.

m South Georgia Natural Gas Co.
Sea Robin Pipeline Co. 
Table 49. Southern Natural Gas Co. Natural Gas Data, 1992 (Thousand Cubic Feet)

\begin{tabular}{|c|c|c|c|c|c|c|}
\hline \multirow{2}{*}{ Supply/Disposition } & \multicolumn{6}{|c|}{ Southern Natural Gas Co. } \\
\hline & Texas & Louisiana & Mississippi & Alabama & Georgia & South Carolina \\
\hline \multicolumn{7}{|l|}{ SUPPLY } \\
\hline $\begin{array}{l}\text { Produced Onsystem } \\
\text { Receipts }\end{array}$ & 0 & 0 & 0 & 0 & 0 & 0 \\
\hline 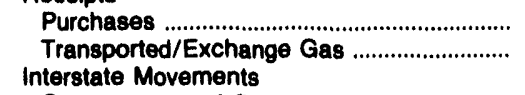 & $\begin{array}{r}0 \\
13,572,428\end{array}$ & $\begin{array}{r}37,007,895 \\
505,825,232\end{array}$ & $\begin{array}{r}7,174,435 \\
25,122,844\end{array}$ & $\begin{array}{l}23,295,043 \\
23,747,482\end{array}$ & $\begin{array}{l}0 \\
0\end{array}$ & $\begin{array}{l}0 \\
0\end{array}$ \\
\hline 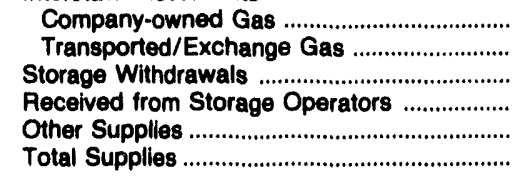 & $\begin{array}{r}0 \\
0 \\
0 \\
0 \\
0 \\
13,572,428\end{array}$ & $\begin{array}{r}0 \\
13,572,428 \\
0 \\
27,386,754 \\
0 \\
0 \\
583,792,309\end{array}$ & $\begin{array}{r}0 \\
448,785,927 \\
29,913,349 \\
0 \\
0 \\
510,896,555\end{array}$ & $\begin{array}{r}0 \\
447,498,035 \\
0 \\
0 \\
0 \\
494,540,560\end{array}$ & $\begin{array}{r}0 \\
337,637,966 \\
0 \\
0 \\
0 \\
337,637,966\end{array}$ & $\begin{array}{r}0 \\
81,040,302 \\
0 \\
0 \\
0 \\
81,040,302\end{array}$ \\
\hline \multicolumn{7}{|l|}{ DISPOSITION } \\
\hline 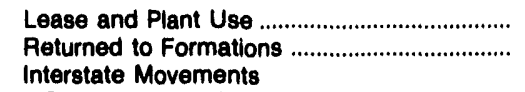 & $\begin{array}{l}0 \\
0\end{array}$ & $\begin{array}{l}0 \\
0\end{array}$ & $\begin{array}{l}0 \\
0\end{array}$ & $\begin{array}{l}0 \\
0\end{array}$ & $\begin{array}{l}0 \\
0\end{array}$ & $\begin{array}{l}0 \\
0\end{array}$ \\
\hline 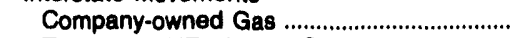 & 0 & 0 & 0 & 0 & 0 & 0 \\
\hline Transported/Exchange Gas ............................. & $13,572,428$ & $448,785,927$ & $447,498,035$ & $337,637,966$ & $86,639,023$ & 0 \\
\hline 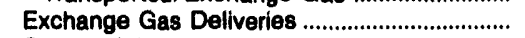 & 0 & $85,723,091$ & $17,662,889$ & $96,204,987$ & $175,025,015$ & $64,668,656$ \\
\hline $\begin{array}{l}\text { Storage Injections ................................................... } \\
\text { Deliveries of Company-owned Gas }\end{array}$ & 0 & 0 & $31,963,212$ & 0 & 0 & 0 \\
\hline 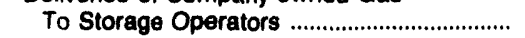 & 0 & $22,044,926$ & 0 & 0 & 0 & 0 \\
\hline 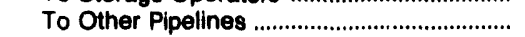 & 0 & 0 & 0 & 0 & 0 & 0 \\
\hline $\begin{array}{l}\text { To Resellers ..................................................... } \\
\text { To Consumers }\end{array}$ & 0 & 37,573 & $2,534,396$ & $28,708,814$ & $61,069,967$ & $14,041,208$ \\
\hline 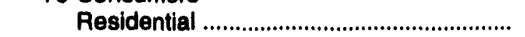 & 0 & 0 & 0 & 0 & 0 & 0 \\
\hline 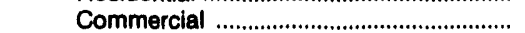 & 0 & 9,313 & 17,896 & 301 & 538 & 0 \\
\hline 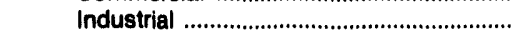 & 0 & 200 & 9,987 & 33,710 & 7,639 & 8 \\
\hline 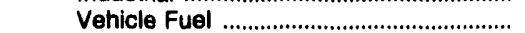 & 0 & 0 & 0 & 0 & 0 & 0 \\
\hline 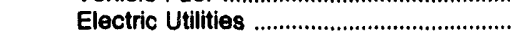 & 0 & 0 & 0 & 0 & 0 & 0 \\
\hline \multicolumn{7}{|l|}{ Transported for the Account of Others } \\
\hline 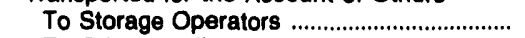 & 0 & 0 & 0 & 0 & 0 & 0 \\
\hline To Other Pipelines & 0 & 0 & 0 & 0 & 0 & 0 \\
\hline 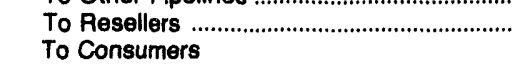 & 0 & 0 & 0 & 0 & 0 & 0 \\
\hline 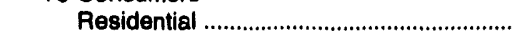 & 0 & 0 & 0 & 0 & 0 & 0 \\
\hline 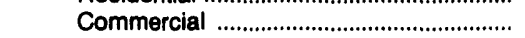 & 0 & 0 & 0 & 0 & 0 & 0 \\
\hline Industrial & 0 & $21,098,644$ & $7,214,570$ & $27,288,134$ & $12,422,185$ & $1,941,477$ \\
\hline 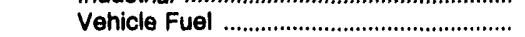 & 0 & 0 & 0 & 0 & 0 & 0 \\
\hline 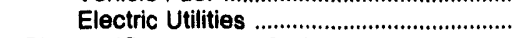 & 0 & 0 & 0 & 95,648 & 0 & 0 \\
\hline 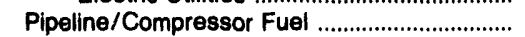 & 0 & $3,803,795$ & $3,741,015$ & $3,779,702$ & $1,263,056$ & 0 \\
\hline 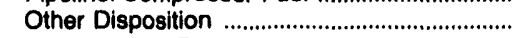 & 0 & 19,887 & 49,794 & 38,245 & 5,874 & 0 \\
\hline 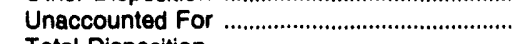 & 0 & $2,268,953$ & 304,761 & 753,053 & $1,204,669$ & 388,853 \\
\hline 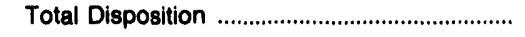 & $13,572,428$ & $583,792,309$ & $510,996,555$ & $494,540,560$ & $337,637,966$ & $81,040,302$ \\
\hline
\end{tabular}

firm daily capacity to northern Florida and southwestern Georgia, where demand is growing from electric generation and industrial customers.

Completing a fifth full year of its Cooperative Marketing Program in 1992, Southern Natural is actively working with its customers to develop additional gas demand in traditional markets. The funding and technical support for the development and commercialization of new technologies and gas usage, including gasfueled cooling, industrial process application, natural gas vehicles, and residential heat pumps will be provided by this program.

The Sonat Energy Services Company entered the independent power generation business. A 50-50 joint venture that will construct, own, and operate natural gas-fueled independent power plants in the United
States, Canada, and Mexico was announced in June 1992 by Sonat and The AES Corporation.

Sonat Ventures Inc. made progress in natural gas vehicle (NGV) conversion and refueling, and packaged cogeneration. The Company is pursuing opportunities to open NGV refueling centers in Alabama, Florida, Georgia, and South Carolina. To reduce the cost of its electric and stream requirements through the installation of cogeneration systems, the company is working with industrial and commercial concerns in the Southeast.

Completion of a major expansion of Florida Gas Transmission's system is expected in late 1994. Phase III, a 530 million cubic feet per day expansion, is being constructed primarily for electric generation customers. It will increase firm capacity by almost 60 percent. 
Table 49. Southern Natural Gas Co. Natural Gas Data, 1992 (Continued) (Thousand Cubic Feet)

\begin{tabular}{|c|c|c|c|c|c|c|}
\hline \multirow{2}{*}{ Supply/Disposition } & \multirow{2}{*}{$\begin{array}{c}\begin{array}{c}\text { Southern Natural } \\
\text { Gas Co. }\end{array} \\
\text { Tennessee }\end{array}$} & Bear Creek & Sea Robin & \multicolumn{3}{|c|}{ South Georgia Natural Gas Co. } \\
\hline & & \multicolumn{2}{|c|}{ Louisiana } & Alabama & Georgla & Florida \\
\hline \multicolumn{7}{|l|}{ SUPPLY } \\
\hline $\begin{array}{l}\text { Produced Onsystem } \\
\text { Receipts }\end{array}$ & 0 & 0 & 0 & 0 & 0 & 0 \\
\hline Purchases & 0 & 0 & 73,137 & 878,701 & 0 & 0 \\
\hline 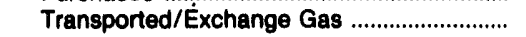 & 0 & $50,786,281$ & $290,355,774$ & $33,178,930$ & 0 & 0 \\
\hline \multicolumn{7}{|l|}{ Interstate Movements } \\
\hline 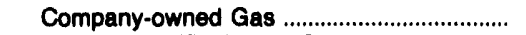 & 0 & 0 & 0 & 0 & 0 & 0 \\
\hline 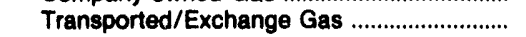 & $5,598,721$ & 0 & 0 & 0 & $34,024,439$ & $13,797,511$ \\
\hline 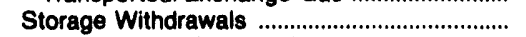 & 0 & $50,458,569$ & 0 & 0 & 0 & 0 \\
\hline 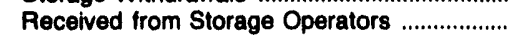 & 0 & 0 & 0 & 0 & 0 & 0 \\
\hline 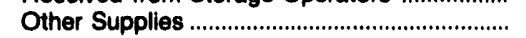 & 0 & 0 & 0 & 0 & 0 & 0 \\
\hline Total Supplies & $5,598,721$ & $101,244,850$ & $290,428,911$ & $34,057,631$ & $34,024,439$ & $13,797,511$ \\
\hline \multicolumn{7}{|l|}{ DISPOSITION } \\
\hline 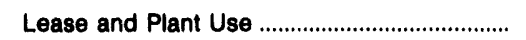 & 0 & 0 & 0 & 0 & 0 & 0 \\
\hline $\begin{array}{l}\text { Returned to Formations } \\
\text { Interstate Movements }\end{array}$ & 0 & 0 & 0 & 0 & 0 & 0 \\
\hline 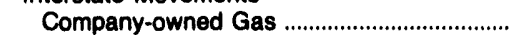 & 0 & 0 & 0 & 0 & 0 & 0 \\
\hline 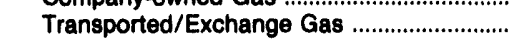 & 0 & 0 & 0 & $34,024,439$ & $13,797,511$ & 0 \\
\hline 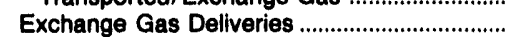 & $3,494,377$ & $50,458,569$ & $281,318,877$ & 0 & 0 & 0 \\
\hline 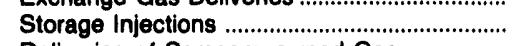 & 0 & $50,786,281$ & 0 & 0 & 0 & 0 \\
\hline \multicolumn{7}{|l|}{ Deliveries of Company-owned Gas } \\
\hline 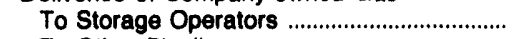 & 0 & 0 & 0 & 0 & 0 & 0 \\
\hline 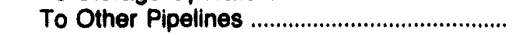 & 0 & 0 & 0 & 0 & 0 & 0 \\
\hline $\begin{array}{l}\text { To Resellers } \\
\text { To Consumers }\end{array}$ & $2,077,473$ & 0 & 0 & 0 & 832,262 & 50,479 \\
\hline 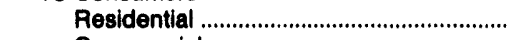 & 0 & 0 & 0 & 0 & 0 & 0 \\
\hline 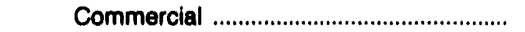 & 0 & 0 & 0 & 0 & 0 & 0 \\
\hline 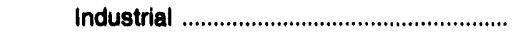 & 0 & 0 & 0 & 0 & 12,963 & 2,473 \\
\hline 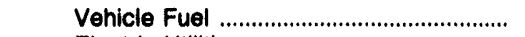 & 0 & 0 & 0 & 0 & 0 & 0 \\
\hline 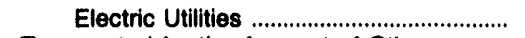 & 0 & 0 & 0 & 0 & 0 & 0 \\
\hline \multicolumn{7}{|l|}{ Transported for the Account of Others } \\
\hline 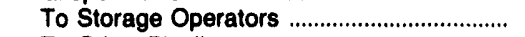 & 0 & 0 & 0 & 0 & 0 & 0 \\
\hline 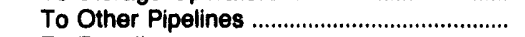 & 0 & 0 & $9,107,973$ & 0 & 0 & 0 \\
\hline 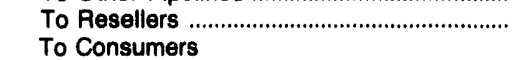 & 0 & 0 & 0 & 0 & $13,245,110$ & $11,204,156$ \\
\hline 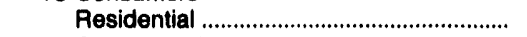 & 0 & 0 & 0 & 0 & 0 & 0 \\
\hline 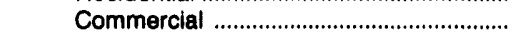 & 0 & 0 & 0 & 0 & 0 & 0 \\
\hline Industrial & 0 & 0 & 0 & 0 & $6,008,500$ & $2,476,018$ \\
\hline 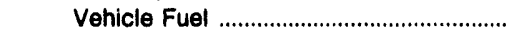 & 0 & 0 & 0 & 0 & 0 & 0 \\
\hline 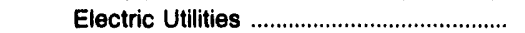 & 0 & 0 & 0 & 0 & 0 & 13,492 \\
\hline Pipeline/Compressor Fuel ................................. & 0 & 0 & 2,680 & 33,070 & 53,485 & 0 \\
\hline 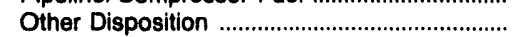 & 0 & 0 & 0 & 0 & 0 & 0 \\
\hline Unaccounted For & 26,871 & 0 & -619 & 122 & 74,608 & 50,893 \\
\hline 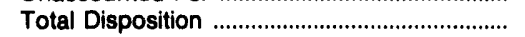 & $5,598,721$ & $101,244,850$ & $290,428,911$ & $34,057,631$ & $34,024,439$ & $13,797,511$ \\
\hline
\end{tabular}

Source: Energy Information Administration (EIA), Form EIA-176, "Annual Report of Natural and Supplemental Gas Supply and Disposition." 
Table 50. Southern Natural Gas Co.

Interstate Flows of Natural Gas, 1992

(Thousand Cubic Feet)

\begin{tabular}{|c|c|}
\hline Company and State & Volume \\
\hline 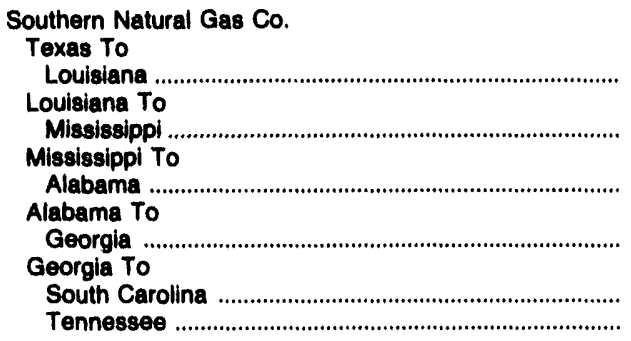 & $\begin{array}{r}13,572,428 \\
448,785,927 \\
447,498,035 \\
337,637,966 \\
\\
81,040,302 \\
5,598,721\end{array}$ \\
\hline $\begin{array}{l}\text { South Georgia Natural Gas Co. } \\
\text { Alabama To } \\
\text { Georgia } \\
\text { Georgia To } \\
\text { Florida }\end{array}$ & $\begin{array}{l}34,024,439 \\
13,797,511\end{array}$ \\
\hline
\end{tabular}

Source: Energy Information Administration (EIA), Form EIA-176, "Annual Report of Natural and Supplemental Gas Supply and Disposition." 


\section{Southwest Gas Corp.}

Southwest Gas Corporation (Southwest) provides natural gas transmission and distribution services in Arizona, Nevada, and California. Southwest purchases, distributes, and transports natural gas to approximately 897,000 residential, commercial, and industrial customers in Arizona, Nevada, and California.

The residential sector made up 93 percent of the company's total customer base in 1992. Communities served by Southwest include Las Vegas and Carson City in Nevada; Victorville, Barstow, and Big Bear in California; and Phoenix and Tuscon in Arizona. During 1992 on a system-wide basis, more than 2,000 residential customers converted from other fuels to natural gas.
Southwest has a high market penetration in the new single-family housing market in its service area, capturing over 90 percent.

Early in 1993, Southwest's gas transmission and storage subsidiary, Paiute Pipeline Company, which provides transportation service of natural gas to Southwest and to the Washington Water Power Company and the Sierra Pacific Power Company, completed a $\$ 33.3$ million pipeline reinforcement project. The Paiute project included the upgrading of its three existing compressor stations, the installation of 12.4 miles of pipeline near Reno, 2.7 miles of pipeline in North Lake Tahoe, 1

Figure 38. Southwest Gas Corp., 1992

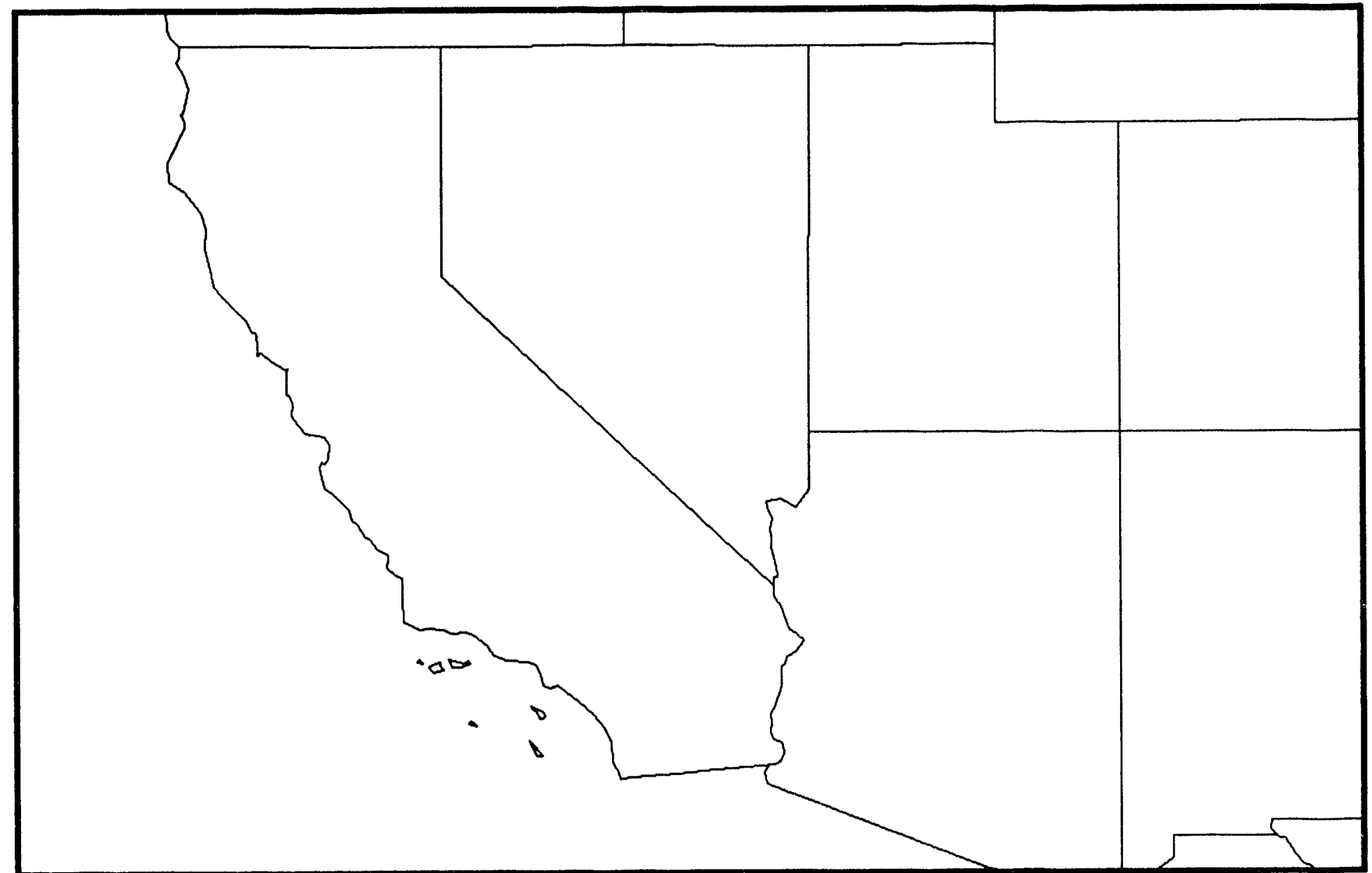

Source: Energy Information Administration (EIA), Form EIA-176, "Annual Report of Natural and Supplemental Gas Supply and Disposition." 


\begin{tabular}{|c|c|c|c|}
\hline \multirow{2}{*}{ Supply/Disposition } & \multicolumn{3}{|c|}{ Southwest Gas Corp. } \\
\hline & Arizona & Nevada & California \\
\hline \multicolumn{4}{|l|}{ SUPPLY } \\
\hline $\begin{array}{l}\text { Produced Onsystem } \\
\text { Receipts }\end{array}$ & 0 & 0 & 0 \\
\hline 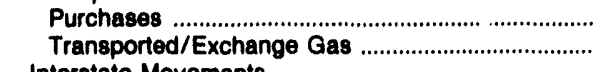 & $\begin{array}{r}286,543 \\
54,973,833\end{array}$ & $\begin{array}{r}0 \\
3,478,458\end{array}$ & $\begin{array}{l}7,337,857 \\
1,414,819\end{array}$ \\
\hline \multicolumn{4}{|l|}{ Interstate Movements } \\
\hline 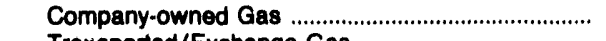 & 0 & $1,669,556$ & 0 \\
\hline 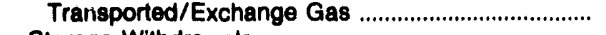 & 0 & $72,998,940$ & 836,045 \\
\hline 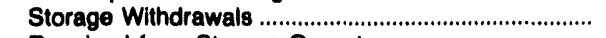 & 0 & 154,741 & 0 \\
\hline 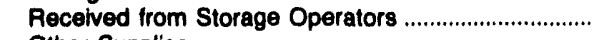 & 0 & 0 & 182,107 \\
\hline Other Supplies & 0 & 30,008 & 0 \\
\hline Total Supplies & $55,270,376$ & $78,331,703$ & $9,770,828$ \\
\hline \multicolumn{4}{|l|}{ DISPOSITION } \\
\hline 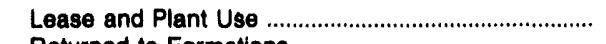 & 0 & 0 & 0 \\
\hline $\begin{array}{l}\text { Returned to Formations } \\
\text { Interstate Movements }\end{array}$ & 0 & 0 & 0 \\
\hline 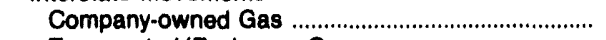 & 0 & 836,045 & 0 \\
\hline 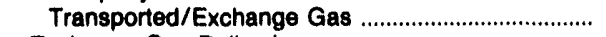 & 0 & 0 & 0 \\
\hline 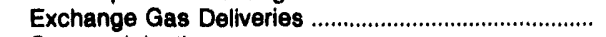 & 0 & 0 & 0 \\
\hline 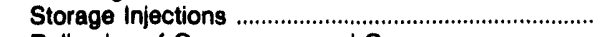 & 0 & 83,481 & 0 \\
\hline \multicolumn{4}{|l|}{ Deliveries of Company-owned Gas } \\
\hline To Storage Operators & 0 & 0 & 274,653 \\
\hline 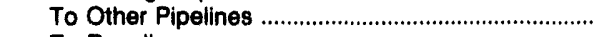 & 0 & 0 & 0 \\
\hline 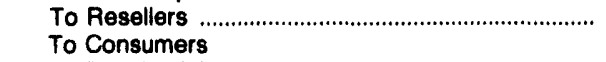 & 34,331 & 0 & 0 \\
\hline 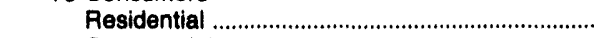 & $22,120,820$ & $13,781,539$ & $5,248,298$ \\
\hline 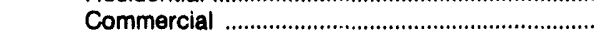 & $19,515,912$ & $9,653,833$ & $2,064,298$ \\
\hline 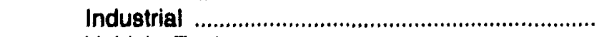 & $5,310,889$ & 470,318 & $1,543,074$ \\
\hline 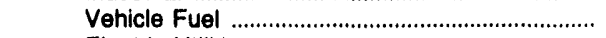 & 45,523 & 12,016 & 0 \\
\hline 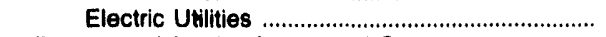 & 26,445 & 226,954 & 0 \\
\hline \multicolumn{4}{|l|}{ Transported for the Account of Others } \\
\hline 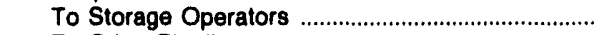 & 0 & 0 & 0 \\
\hline 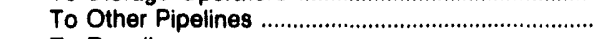 & 0 & 0 & 0 \\
\hline 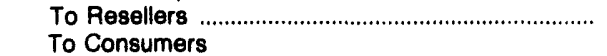 & 0 & $15,663,166$ & 0 \\
\hline 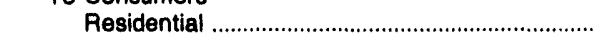 & 0 & 0 & 0 \\
\hline 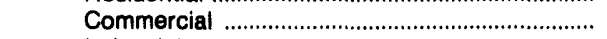 & $1,486,030$ & $1,658,152$ & 23,911 \\
\hline 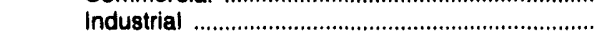 & $4,702,621$ & $5,604,157$ & $1,140,964$ \\
\hline 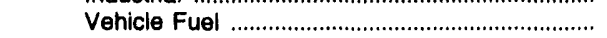 & 0 & 0 & 0 \\
\hline Electric Utilities & $2,516,343$ & $28,674,634$ & 0 \\
\hline Pipeline/Compressor Fuel ............................................ & 0 & 68,697 & 0 \\
\hline 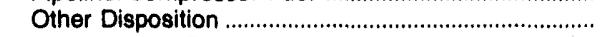 & 0 & 0 & 0 \\
\hline Unaccounted For & $-488,538$ & $1,598,711$ & $-524,370$ \\
\hline Total Disposition & $55,270,376$ & $78,331,703$ & $8,770,828$ \\
\hline
\end{tabular}

Source: Energy Information Administration (EIA), Form EIA-176, "Annual Report of Natural and Supplemental Gas Supply and Disposition."

mile of pipeline in South Lake Tahoe, and 26.3 miles of pipeline in the Elko, Nevada area.

Southwest also has taken a high-profile role in the promotion of natural gas vehicles (NGV) for fleet operations. Working with equipment manufacturers, fleet operators, and local governments, it helped to construct the first public NGV refueling station in Phoenix, Arizona. Through this facility, which was scheduled to go on line in late 1993, Southwest will provide natural gas to Phoenix and its surrounding jurisdictions.
The company is encouraging other service areas to develop public NGV refueling sites. At the end of 1992 nearly 1,000 NGV's were operating in the Southwest Gas service area. That total includes 600 of Southwest's own fleet.

Nevada Cogeneration Associates (NCA) opened two 85-megawatt cogeneration facilities which will both be supplied by Southwest Gar. The two facilities will require a supply of approximately 11 billion cubic feet of natural gas per year. The beneficiary of the electricity generated from these facilities will be Nevada Power Company. The resultant steam from the process will be sold to Georgia Pacific and PABCO Gypsum. 
Table 52. Southwest Gas Corp. Interstate Flows

of Natural Gas, 1992

(Thousand Cubic Feet)

\begin{tabular}{|c|c|}
\hline Company and State & Volume \\
\hline \multicolumn{2}{|l|}{$\begin{array}{l}\text { Southwest Gas Corp. } \\
\text { Arizona To }\end{array}$} \\
\hline 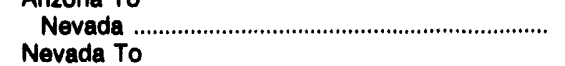 & $34,375,819$ \\
\hline 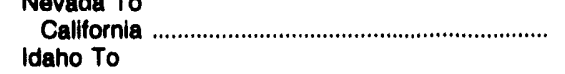 & 836,045 \\
\hline 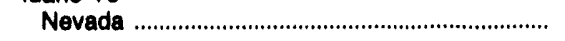 & $40,292,677$ \\
\hline
\end{tabular}

Source: Energy Information Administration (EIA), Form EIA-176, "Annual Report of Natural and Supplemental Gas Supply and Disposition." 


\section{Tenneco, Inc.}

Tenneco Gas is one of the largest natural gas transmission companies in the United States. The company increased its natural gas deliveries in 1992 to 2.9 trillion cubic feet, due mainly to its two new pipelines: Kern River which links southwestern Wyoming with southcentral California, and Iroquois, which moves Canadian gas to New England. Tenneco Gas' interstate pipeline operations include the pipeline systems of Tennessee Gas Pipeline, East Tennessee Natural Gas, and Midwestern Gas Transmission. Viking Gas Transmission, which had formerly been a part of Tenneco, was sold to Northern States Power Company in 1993. Tenneco now holds interests in more than 20,000 miles of pipeline in 31 States.
Construction was completed in 1992 on Tennessee Gas Pipeline's Electric Generation Transportation Project (ELGEN). This mainline looping and compression expansion project enables Tenneco to transport 51 million cubic feet of gas per day for independent power and generation plants in Massachusetts and New York.

Since Tenneco operates almost exclusively as an interstate transporter, it had relatively small volumes of deliveries to consumers in 1992. Tennessee Gas Pipeline delivered small volumes to commercial and industrial consumers in Texas, Louisiana, and Mississippi. In New York and Rhode Island, Tennessee Gas Pipeline delivered gas directly to independent power producers and

Figure 39. Tenneco, Inc., 1992

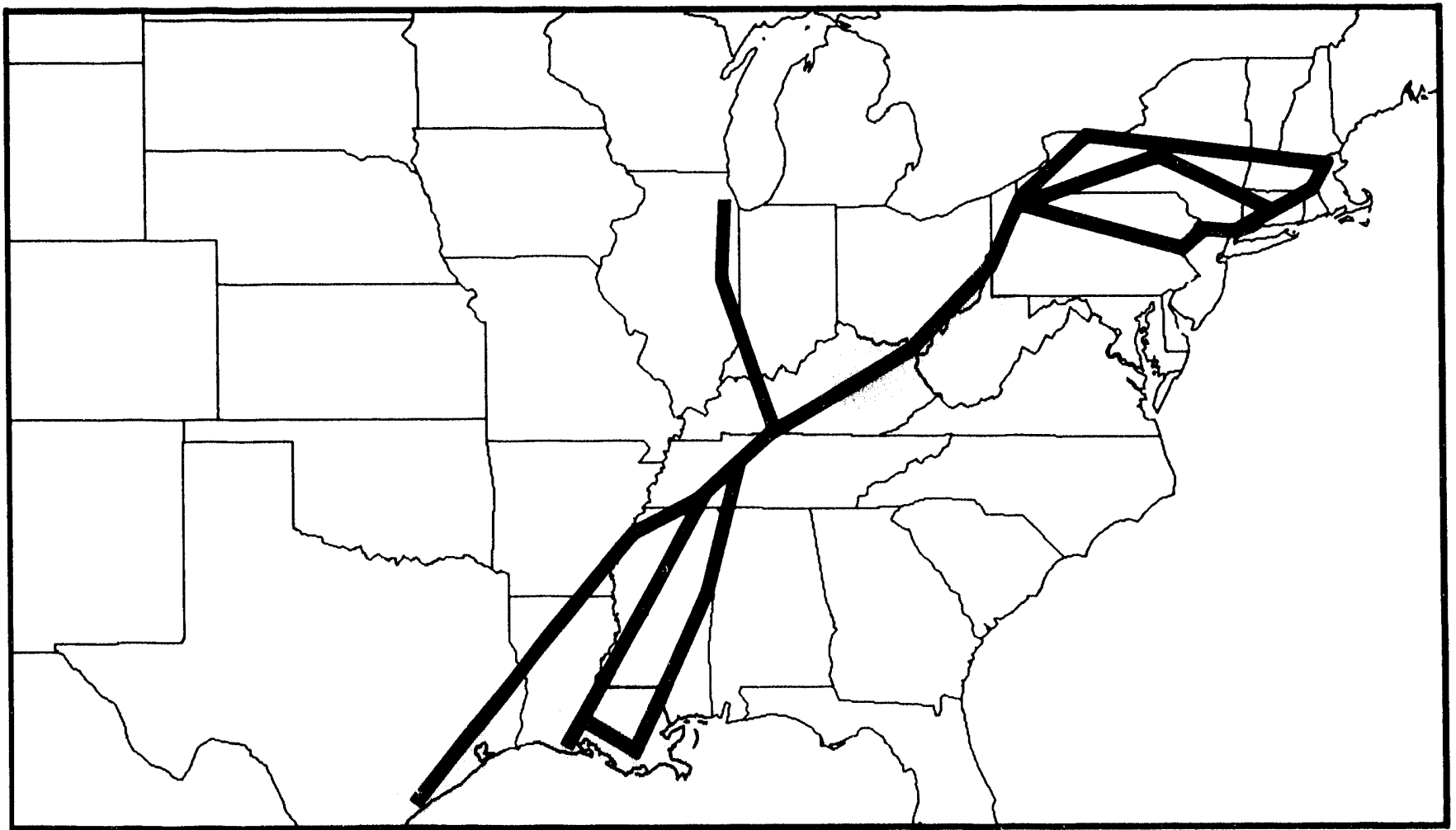

Source: Energy Information Administration (EIA), Form EIA-176, "Annual Report of Natural and Supplemental Gas Supply and Disposition." 
Table 53. Tenneco, Inc., Natural Gas Data, 1992 (Thousand Cubic Feet)

\begin{tabular}{|c|c|c|c|c|c|}
\hline \multirow{2}{*}{ Supply/Disposition } & \multicolumn{5}{|c|}{ Tennessee Gas Pipeline Co. } \\
\hline & Texas & Loulisiana & Arkansas & Mississippi & Alabama \\
\hline \multicolumn{6}{|l|}{ SUPPLY } \\
\hline $\begin{array}{l}\text { Produced Onsystem } \\
\text { Recelpts }\end{array}$ & 0 & $2,201,063$ & 0 & 0 & 0 \\
\hline 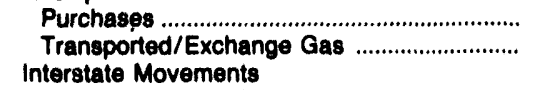 & $\begin{array}{r}14,480,770 \\
343,234,155\end{array}$ & $\begin{array}{r}34,628,034 \\
1,068,584,118\end{array}$ & $\begin{array}{l}0 \\
0\end{array}$ & $\begin{array}{r}180,341 \\
11,604,982\end{array}$ & $\begin{array}{r}2,740 \\
10,436,338\end{array}$ \\
\hline Company-owned Gas ....................................... & 0 & 0 & 0 & 0 & 0 \\
\hline Transported/Exchange Gas .............................. & 0 & $326,208,858$ & $368,012,427$ & $1,088,734,094$ & $476,926,317$ \\
\hline 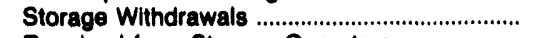 & 0 & 0 & 0 & 0 & 0 \\
\hline Recelved from Storage Operators ........................ & 0 & $35,175,597$ & 0 & 0 & 0 \\
\hline Other Supplies & $\begin{array}{r}0 \\
357714925\end{array}$ & $\begin{array}{r}0 \\
1.466797670\end{array}$ & $\begin{array}{r}0 \\
368.012,427\end{array}$ & $\begin{array}{r}0 \\
1,100.519 .417\end{array}$ & $\begin{array}{r}0 \\
487365.395\end{array}$ \\
\hline \multicolumn{6}{|l|}{ DIBPOSITION } \\
\hline 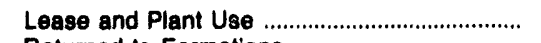 & 0 & 55,778 & 0 & 0 & 0 \\
\hline 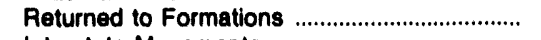 & 0 & 0 & 0 & 0 & 0 \\
\hline Interstate Movements & & & & & \\
\hline 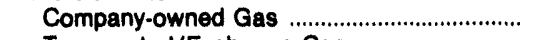 & $14,314,306$ & $56,912,584$ & $19,181,907$ & $55,766,792$ & $25,460,038$ \\
\hline 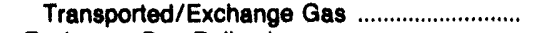 & $311,894,552$ & $1,031,881,579$ & $348,770,451$ & $946,389,790$ & $422,162,192$ \\
\hline 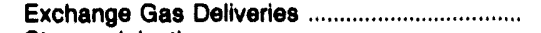 & $3,258,529$ & $106,504,435$ & 0 & $14,665,019$ & 333,232 \\
\hline 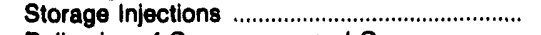 & 0 & 0 & 0 & 0 & 0 \\
\hline \multicolumn{6}{|l|}{ Deliveries of Company-owned Gas } \\
\hline 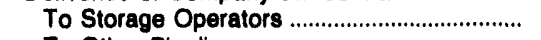 & 0 & $29,240,702$ & 0 & 0 & 0 \\
\hline 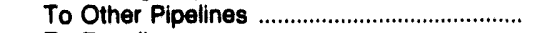 & 0 & 0 & 54,546 & 0 & $1,074,174$ \\
\hline 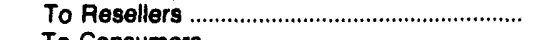 & 1,316 & 73,838 & 0 & $1,196,387$ & 7,944 \\
\hline $\begin{array}{l}\text { To Consumers } \\
\text { Residential }\end{array}$ & & & & & \\
\hline $\begin{array}{l}\text { Residential } \\
\text { Commercial }\end{array}$ & $\begin{array}{r}0 \\
165148\end{array}$ & $\begin{array}{r}0 \\
36.098\end{array}$ & 0 & 0 & 0 \\
\hline $\begin{array}{l}\text { Commercial } \\
\text { Industrial }\end{array}$ & 165,148 & 36,098 & 0 & $\begin{array}{r}0 \\
0\end{array}$ & 0 \\
\hline & 0 & 0 & 0 & 75,200 & 0 \\
\hline 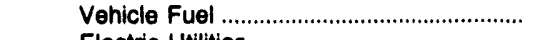 & 0 & 0 & 0 & 0 & 0 \\
\hline 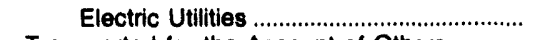 & 0 & 0 & 0 & 0 & 0 \\
\hline \multicolumn{6}{|l|}{ Transported for the Account of Others } \\
\hline 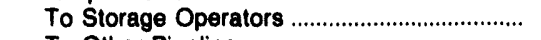 & 0 & 204,773 & 0 & 0 & 0 \\
\hline 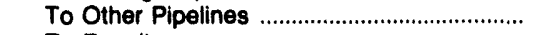 & $22,435,417$ & $228,369,910$ & 5,296 & $72,751,494$ & $35,406,847$ \\
\hline $\begin{array}{l}\text { To Resellers ..................................................... } \\
\text { To Consumers }\end{array}$ & 0 & 0 & 0 & 0 & 0 \\
\hline 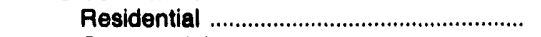 & 0 & 0 & 0 & 0 & 0 \\
\hline 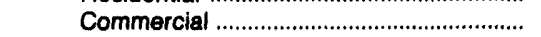 & 0 & 0 & 0 & 0 & 0 \\
\hline 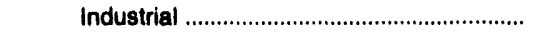 & 0 & 0 & 0 & 0 & 0 \\
\hline 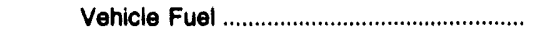 & 0 & 0 & 0 & 0 & 0 \\
\hline 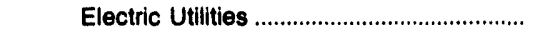 & 0 & 0 & 0 & 0 & 0 \\
\hline Pipeline/Compressor Fuel ....................................... & $2,979,934$ & $9,891,282$ & 0 & $7,738,598$ & $2,653,191$ \\
\hline 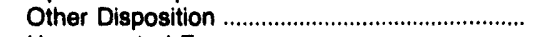 & 0 & 0 & 0 & 0 & \\
\hline Unaccounted For & $2,665,723$ & $3,626,691$ & 227 & $1,936,137$ & 267,777 \\
\hline 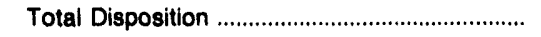 & $357,714,925$ & $1,466,797,670$ & $368,012,427$ & $1,100,519,417$ & $487,365,395$ \\
\hline
\end{tabular}

cogeneration facilities. East Tennessee Gas Co. delivered 20.4 billion cubic feet to commercial and industrial consumers in Tennessee. Channel Industries delivered 142.5 billion cubic feet of natural gas to industrial cus- tomers in Texas. Creole Gas Pipeline Corp. sold and delivered 21.3 billion cubic feet of gas to industrial and electric utility consumers in Louisiana. 
Table 53. Tenneco, Inc., Natural Gas Data, 1992 (Continued) (Thousand Cubic Feet)

\begin{tabular}{l|c|c|c|c|c|}
\hline \multirow{2}{*}{ Supply/Disposition } & \multicolumn{4}{|c}{ Tennessee Gas Pipeline Co. } \\
\cline { 2 - 6 } & Tennessee & Kentucky & Ohio & West Virginia & Pennsylvania \\
\hline
\end{tabular}

\section{SUPPLY}

Produced Onsystem

Peceipts

Purchases

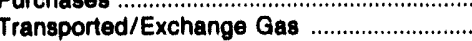

Interstate Movements

Company-owned Gas

Transported/Exchange Gas .........................

Storage Withdrawals

Received from Storage Operators

Other Supplies

Total Supplies

\section{DISPOSITION}

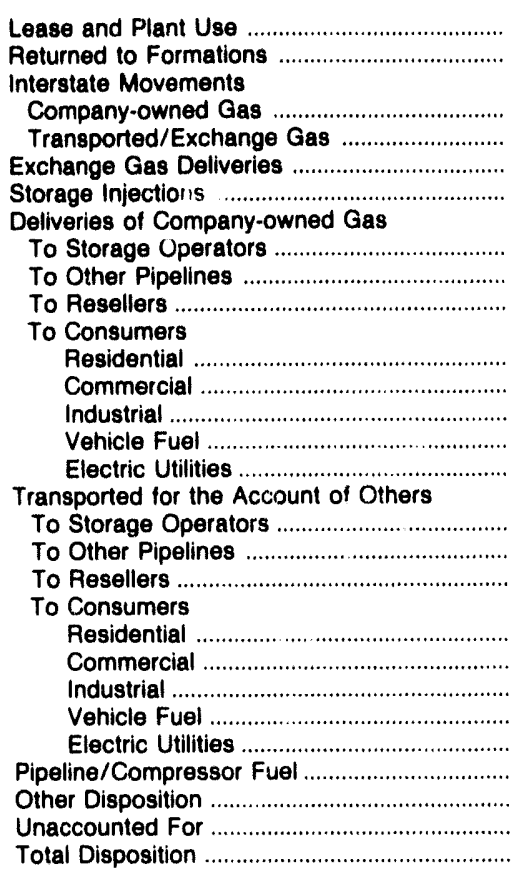

\begin{tabular}{|c|c|c|c|c|}
\hline 0 & 0 & 0 & 0 & 0 \\
\hline $\begin{array}{r}0 \\
1,801,836\end{array}$ & $\begin{array}{r}0 \\
2,390,537\end{array}$ & $\begin{array}{r}29,109 \\
4,561,380\end{array}$ & $\begin{array}{r}0 \\
7,163,240\end{array}$ & $\begin{array}{r}0 \\
47,295,017\end{array}$ \\
\hline $\begin{array}{r}0 \\
972,852,495 \\
0 \\
0 \\
0 \\
974,654,331\end{array}$ & $\begin{array}{r}0 \\
813,668,905 \\
0 \\
0 \\
0 \\
816,059,442\end{array}$ & $\begin{array}{r}0 \\
494,607,661 \\
0 \\
0 \\
0 \\
499,198,150\end{array}$ & $\begin{array}{r}0 \\
161,046,028 \\
0 \\
5,249,452 \\
0 \\
173,458,720\end{array}$ & $\begin{array}{r}0 \\
440,618,195 \\
0 \\
0 \\
57,482,192 \\
0 \\
545,395,404\end{array}$ \\
\hline
\end{tabular}

$793,751,214$

$1,400,687$

$30,438,407$

$4,331,316$

$1,034,669$

$3,302,293$

$17,135,940$

$638,517,749$

$3,937,156$

0

0

0
0
0
0

0
$116,892,826$

0
$143,103,822$

143,103,822

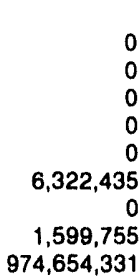

47,700 0

$47,700,713$

$17,132,677$

$423,485,518$

$6,460,686$

0
0
32,372

$3,695,445$

6,302

0
0
290,096
0

$$
\begin{aligned}
& 0 \\
& 0 \\
& 0 \\
& 0 \\
& 0
\end{aligned}
$$

$169,249,803$

$20,019,378$ $233,553,113$

$52,444,509$ $209,898,650$

$17,585,176$ $2,975,963$ $1,609,221$

0
0
0
0
0
$3,326,768$
0
$1,059,416$
$499,198,150$
$1,769,999$

0

0
0
02
0
04


Table 53. Tenneco, Inc., Natural Gas Data, 1992 (Continued) (Thousand Cubic Feet)

\begin{tabular}{|c|c|c|c|c|c|c|}
\hline \multirow{2}{*}{ Supply/Disposition } & \multicolumn{6}{|c|}{ Tennessee Gas Pipeline Co. } \\
\hline & New York & New Jersey & Connecticut & Phode lsland & Massachusetts & New Hampshire \\
\hline \multicolumn{7}{|l|}{ SUPPLY } \\
\hline $\begin{array}{l}\text { Produced Onsystem ........................................... } \\
\text { Recelpts }\end{array}$ & 0 & 0 & 0 & 0 & 0 & 0 \\
\hline 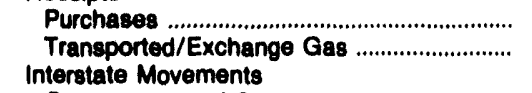 & $\begin{array}{r}0 \\
59,346,275\end{array}$ & $\begin{array}{r}0 \\
2,639,839\end{array}$ & $\begin{array}{r}0 \\
15,409,318\end{array}$ & $\begin{array}{r}0 \\
1,260,920\end{array}$ & $\begin{array}{r}0 \\
9,195,888\end{array}$ & $\begin{array}{r}0 \\
296,784\end{array}$ \\
\hline 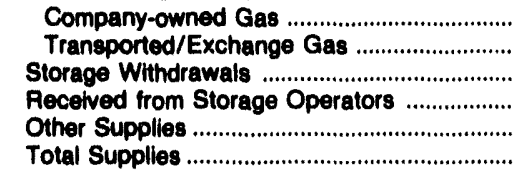 & $\begin{array}{r}10,738,426 \\
439,332,855 \\
0 \\
4,980,568 \\
0 \\
514,398,124\end{array}$ & $\begin{array}{r}0 \\
91,820,106 \\
0 \\
0 \\
0 \\
94,459,945\end{array}$ & $\begin{array}{r}0 \\
40,719,412 \\
0 \\
0 \\
0 \\
56,128,730\end{array}$ & $\begin{array}{r}0 \\
44,266,538 \\
0 \\
0 \\
0 \\
45,527,458\end{array}$ & $\begin{array}{r}0 \\
202,330,657 \\
0 \\
0 \\
0 \\
211,526,545\end{array}$ & $\begin{array}{r}0 \\
11,953,853 \\
0 \\
0 \\
0 \\
12,250,637\end{array}$ \\
\hline \multicolumn{7}{|l|}{ DISPOSITION } \\
\hline 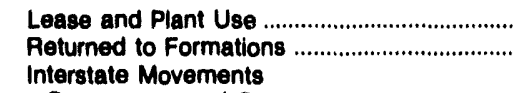 & $\begin{array}{l}0 \\
0\end{array}$ & $\begin{array}{l}0 \\
0\end{array}$ & $\begin{array}{l}0 \\
0\end{array}$ & $\begin{array}{l}0 \\
0\end{array}$ & $\begin{array}{l}0 \\
0\end{array}$ & $\begin{array}{l}0 \\
0\end{array}$ \\
\hline 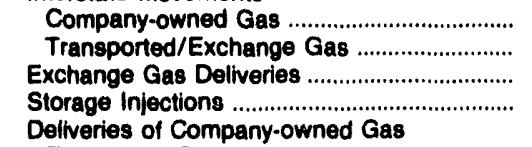 & $\begin{array}{r}59,250,544 \\
181,356,360 \\
222,674 \\
0\end{array}$ & $\begin{array}{r}17,691,534 \\
26,924,938 \\
341,435 \\
0\end{array}$ & $\begin{array}{r}0 \\
0 \\
1,842,641 \\
0\end{array}$ & $\begin{array}{l}0 \\
0 \\
0 \\
0\end{array}$ & $\begin{array}{r}23,291,829 \\
37,705,513 \\
155,718 \\
0\end{array}$ & $\begin{array}{r}0 \\
0 \\
88,567 \\
0\end{array}$ \\
\hline 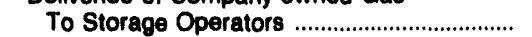 & $2,303,274$ & 0 & 0 & 0 & 0 & 0 \\
\hline 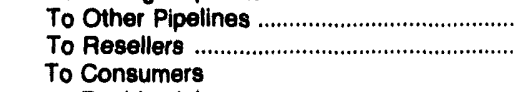 & $\begin{array}{l}4,588,189 \\
1,357,452\end{array}$ & $\begin{array}{l}247,399 \\
416,645\end{array}$ & $\begin{array}{r}0 \\
4,685,999\end{array}$ & $\begin{array}{r}0 \\
2,114,988\end{array}$ & $\begin{array}{r}5,525,809 \\
21,007,206\end{array}$ & $\begin{array}{r}0 \\
2,482,147\end{array}$ \\
\hline 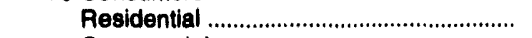 & 0 & 0 & 0 & 0 & 0 & 0 \\
\hline 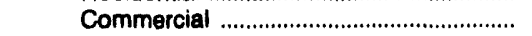 & 0 & 0 & 0 & 0 & 0 & 0 \\
\hline 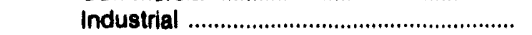 & 0 & 0 & 0 & 0 & 0 & 0 \\
\hline Vehicle Fuel & 0 & 0 & 0 & 0 & 0 & 0 \\
\hline $\begin{array}{l}\text { Electric Utilities ................................... } \\
\text { Transported for the Account of Others }\end{array}$ & 0 & 0 & 0 & 0 & 0 & 0 \\
\hline 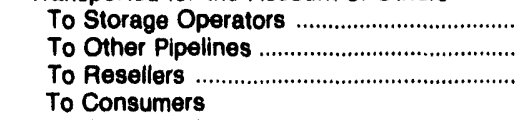 & $\begin{array}{r}2,397,383 \\
246,796,429 \\
0\end{array}$ & $\begin{array}{r}0 \\
48,577,926 \\
0\end{array}$ & $\begin{array}{r}0 \\
49,455,929 \\
0\end{array}$ & $\begin{array}{r}0 \\
7,163,950 \\
0\end{array}$ & $\begin{array}{r}0 \\
122,622,602 \\
0\end{array}$ & $\begin{array}{r}0 \\
9,579,327 \\
0\end{array}$ \\
\hline 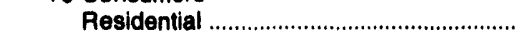 & 0 & 0 & 0 & 0 & 0 & 0 \\
\hline 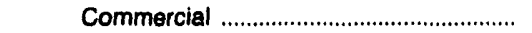 & 0 & 0 & 0 & 0 & 0 & 0 \\
\hline 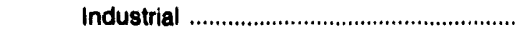 & $4,975,131$ & 0 & 0 & $36,241,320$ & 0 & 0 \\
\hline 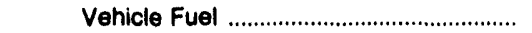 & 0 & 0 & 0 & 0 & 0 & 0 \\
\hline 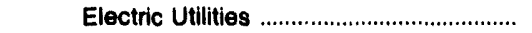 & 0 & 0 & 0 & 0 & 0 & 0 \\
\hline Pipeline/Compressor Fuel ..................................... & $2,754,655$ & 179,281 & 5,738 & 40 & 584,243 & 0 \\
\hline 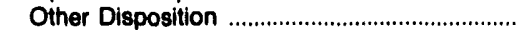 & 0 & 0 & 0 & 0 & 0 & 0 \\
\hline $\begin{array}{l}\text { Unaccounted For } \\
\text { Total Disposition }\end{array}$ & $\begin{array}{r}8,396,033 \\
514,398,124\end{array}$ & $\begin{array}{r}80,787 \\
94,459,945\end{array}$ & $\begin{array}{r}138,423 \\
56,128,730\end{array}$ & $\begin{array}{r}7,160 \\
45,527,458\end{array}$ & $\begin{array}{r}633,625 \\
211,526,545\end{array}$ & $\begin{array}{r}100,596 \\
12,250,637\end{array}$ \\
\hline
\end{tabular}


Table 53. Tenneco, Inc., Natural Gas Data, 1992 (Continued) (Thousand Cubic Feet)

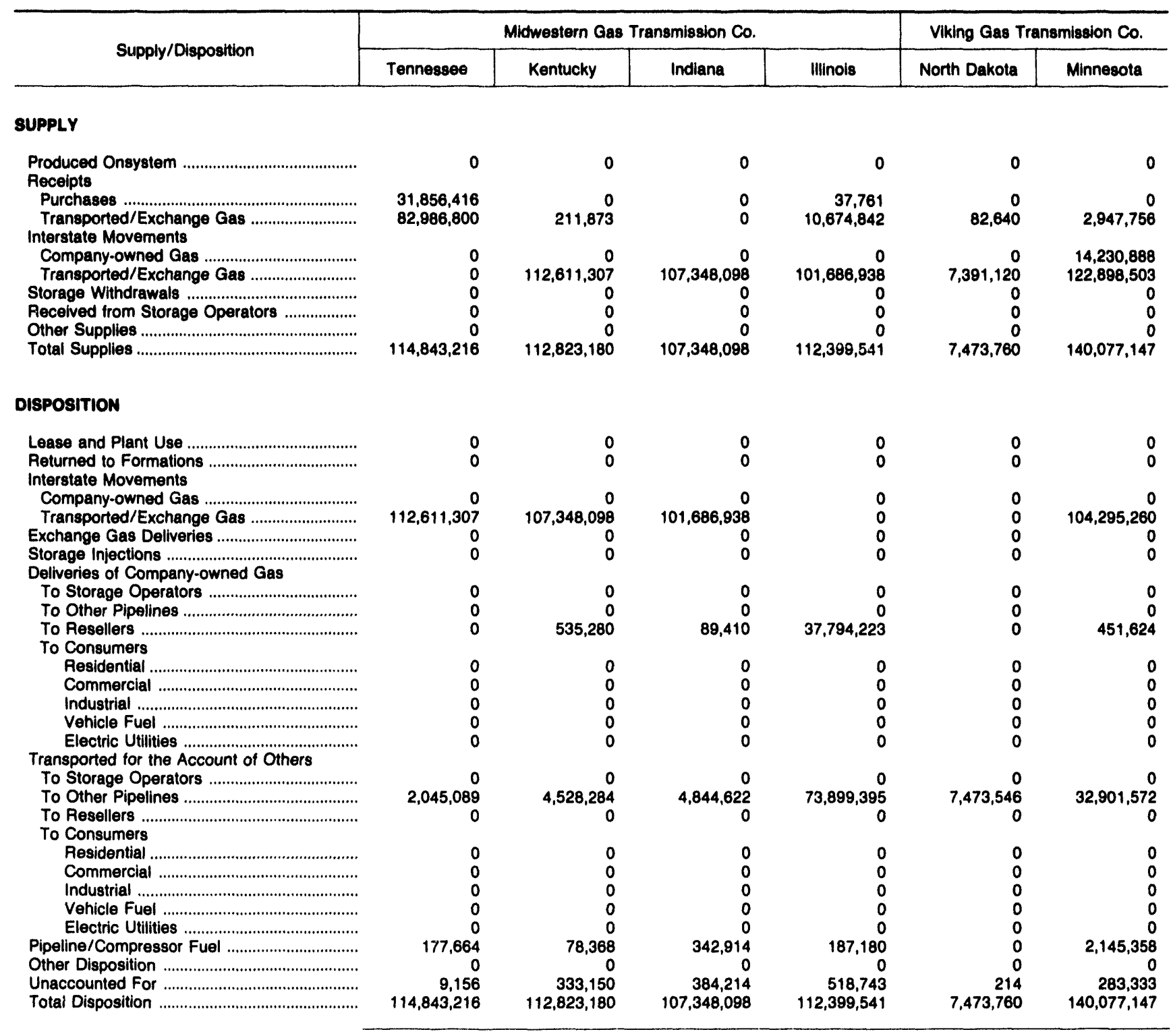


Table 53. Tenneco, Inc., Natural Gas Data, 1992 (Continued) (Thousand Cubic Feet)

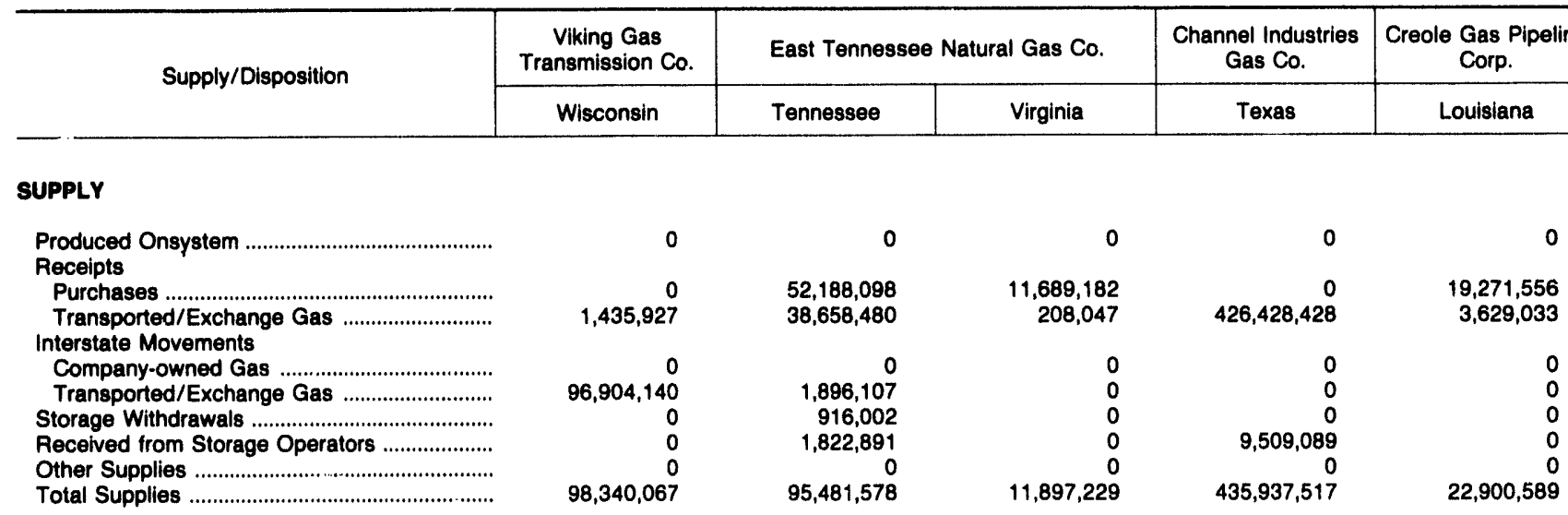

\section{DISPOSITION}

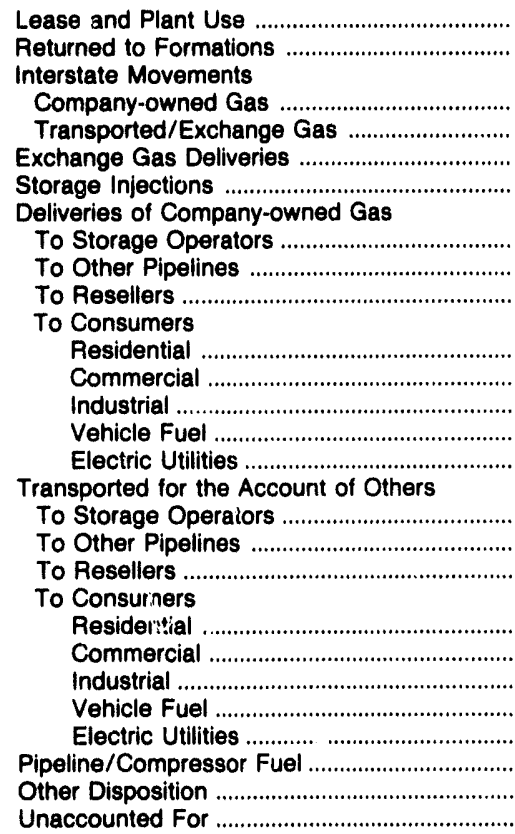

\begin{tabular}{|c|c|c|c|c|}
\hline $\begin{array}{l}0 \\
0\end{array}$ & $\begin{array}{l}0 \\
0\end{array}$ & $\begin{array}{l}0 \\
0\end{array}$ & $\begin{array}{l}0 \\
0\end{array}$ & $\begin{array}{l}0 \\
0\end{array}$ \\
\hline $\begin{array}{l}0 \\
0 \\
0 \\
0\end{array}$ & $\begin{array}{r}0 \\
0 \\
0 \\
995,733\end{array}$ & $\begin{array}{r}0 \\
1,896,107 \\
0 \\
0\end{array}$ & $\begin{array}{l}0 \\
0 \\
0 \\
0\end{array}$ & $\begin{array}{l}0 \\
0 \\
0 \\
0\end{array}$ \\
\hline $\begin{array}{r}0 \\
0 \\
13,662,555\end{array}$ & $\begin{array}{r}0 \\
0 \\
46,202,554\end{array}$ & $\begin{array}{r}0 \\
0 \\
7,241,626\end{array}$ & $\begin{array}{l}0 \\
0 \\
0\end{array}$ & $\begin{array}{l}0 \\
0 \\
0\end{array}$ \\
\hline $\begin{array}{l}0 \\
0 \\
0 \\
0 \\
0\end{array}$ & $\begin{array}{r}0 \\
30,328 \\
10,877,255 \\
0 \\
0\end{array}$ & $\begin{array}{l}0 \\
0 \\
0 \\
0 \\
0\end{array}$ & $\begin{array}{l}0 \\
0 \\
0 \\
0 \\
0\end{array}$ & $\begin{array}{r}0 \\
0 \\
15,491,059 \\
0 \\
6,775,356\end{array}$ \\
\hline $\begin{array}{r}0 \\
84,274,879 \\
0\end{array}$ & $\begin{array}{r}0 \\
0 \\
26,757,122\end{array}$ & $\begin{array}{r}0 \\
0 \\
2,553,991\end{array}$ & $\begin{array}{r}8,710,579 \\
227,373,625 \\
31,152\end{array}$ & $\begin{array}{l}0 \\
0 \\
0\end{array}$ \\
\hline $\begin{array}{r}0 \\
0 \\
0 \\
0 \\
0 \\
295,235 \\
0 \\
107,398 \\
98,340,067\end{array}$ & $\begin{array}{r}0 \\
0 \\
9,531,471 \\
0 \\
0 \\
1,315,492 \\
0 \\
-228,377 \\
95,481,578\end{array}$ & $\begin{array}{r}0 \\
0 \\
0 \\
0 \\
0 \\
252,764 \\
0 \\
-47,259 \\
11,897,229\end{array}$ & $\begin{array}{r}0 \\
15,934 \\
142,520,903 \\
0 \\
0 \\
54,341,376 \\
539,278 \\
8,930 \\
2,395,740 \\
435,937,517\end{array}$ & $\begin{array}{r}0 \\
0 \\
398,909 \\
0 \\
0 \\
0 \\
0 \\
235,265 \\
22,900,589\end{array}$ \\
\hline
\end{tabular}

Source: Energy Information Administration (EIA), Form ElA-176, "Annual Report of Natural and Supplemental Gas Supply and Disposition." 
Table 54. Tenneco, Inc., Interstate Flows of Natural Gas, 1992

(Thousand Cubic Feet)

\begin{tabular}{|c|c|c|c|}
\hline Company and State & Volume & Company and State & Volume \\
\hline \multirow{2}{*}{\multicolumn{2}{|c|}{$\begin{array}{l}\text { Tennessee Gas Pipeline Co. } \\
\text { Texas To }\end{array}$}} & \multirow{2}{*}{\multicolumn{2}{|c|}{$\begin{array}{l}\text { Tennessee Gas Pipeline Co. } \\
\text { Massachusetts To }\end{array}$}} \\
\hline & & & \\
\hline $\begin{array}{l}\text { Louisiana } \\
\text { Louisiana To }\end{array}$ & $326,208,858$ & 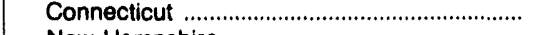 & $2,443,165$ \\
\hline & & 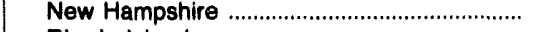 & $26,241,492$ \\
\hline Arkansas & $\begin{array}{l}368,012,427 \\
720,781,736\end{array}$ & 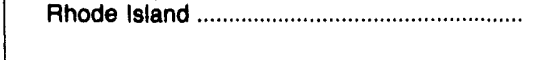 & $44,266,538$ \\
\hline \multicolumn{4}{|l|}{ Arkansas To } \\
\hline 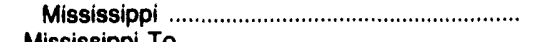 & $367,952,358$ & Midwestern Gas Transmiszion Co. & \\
\hline $\begin{array}{l}\text { Mississippi To } \\
\text { Alabama }\end{array}$ & & Tennessee To & \\
\hline $\begin{array}{l}\text { Alabama } \\
\text { Tennessee }\end{array}$ & $476,926,317$ & 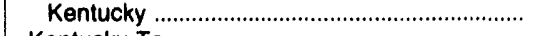 & $112,611,307$ \\
\hline $\begin{array}{l}\text { Tennessee } \\
\text { Alabama To }\end{array}$ & $525,230,265$ & Kentucky To & \\
\hline \multicolumn{2}{|l|}{ Alabama To } & 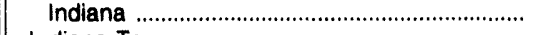 & $107,348,098$ \\
\hline 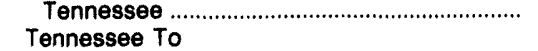 & $447,622,230$ & Indiana To & \\
\hline \multicolumn{2}{|l|}{ Tennessee To } & 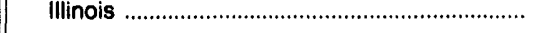 & $101,686,938$ \\
\hline $\begin{array}{l}\text { Kentucky ............................. } \\
\text { Kentucky To }\end{array}$ & $813,668,905$ & & \\
\hline \multicolumn{4}{|l|}{ Kentucky To } \\
\hline Ohio West Virginia & $\begin{array}{l}494,607,661 \\
161,046,028\end{array}$ & $\begin{array}{l}\text { East Tennessee Natural Gas Co. } \\
\text { Virginia To }\end{array}$ & \\
\hline \multicolumn{2}{|l|}{ Ohio To } & 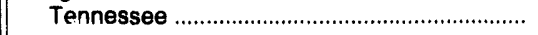 & $1,896,107$ \\
\hline \multicolumn{4}{|l|}{$\begin{array}{l}\text { Pennsylvania ... } \\
\text { Pennsylvania To }\end{array}$} \\
\hline New Jersey & $\begin{array}{r}91,820,106 \\
170,523,053\end{array}$ & $\begin{array}{l}\text { Viking Gas Transmission Co. } \\
\text { Canada To }\end{array}$ & \\
\hline \multicolumn{2}{|l|}{ New York To } & 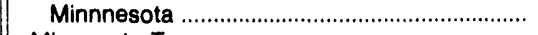 & $137,129,391$ \\
\hline 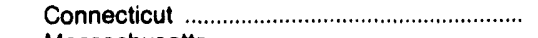 & $38,276,247$ & Minnesota To & \\
\hline 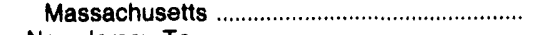 & $202,330,657$ & 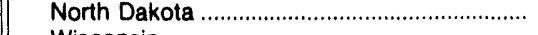 & $7,391,120$ \\
\hline \multicolumn{2}{|l|}{ New Jersey To } & 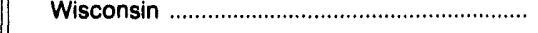 & $96,904,140$ \\
\hline 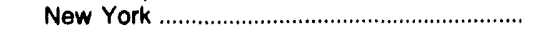 & $44,616,472$ & & \\
\hline
\end{tabular}




\section{Transco Gas Co.}

Transco Gas Company (Transco) is primarily engaged in natural gas pipeline services, natural gas and natural gas liquids processing and marketing, and power generation. Transco has investments in natural gas, oil and gas exploration and production, and coal mining and marketing operations.

Transco's pipeline business is principally conducted through Transcontinental Gas Pipe Line Corporation (TGPL) and Texas Gas Transmission Corporation. These companies buy, sell, and transport natural gas from the Gulf of Mexico and the Gulf Coast region to markets in the eastern half of the United States through their respective 10,000-mile and 6,200-mile interstate pipeline systems. The company's markets include 11 Southeastern and Atlantic States, New York City, and Pennsylvania. TGPL has storage capacity in five underground storage fields and operates fields for others located near its pipeline system.

In 1992, Transco owned and operated a 95-mile intrastate pipeline with a 250 million cubic feet per day capacity from Alabama's Black Warrior Basin to the Transcontinental mainline. This coalbed methane project involved 500 wells and was designed to extract commercial quantities of natural gas from coal seams. In 1993, Transco sold its coldbed methane properties to one of its subsidiaries, TECO Coal Bed Methane.

Figure 40. Transco Gas Co., 1992

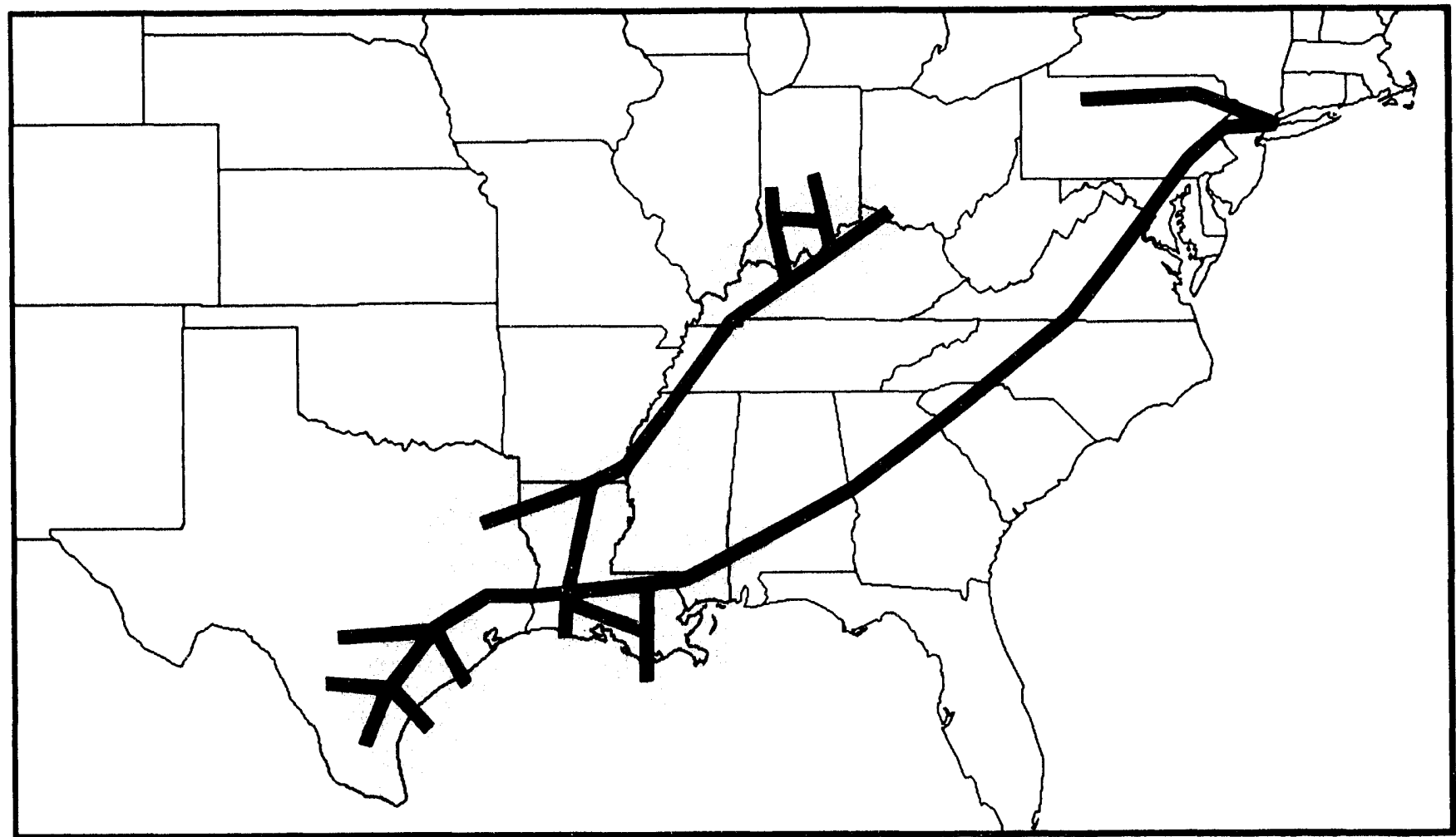

Source: Energy Information Administration (EIA), Form EIA-176, "Annual Report of Natural and Supplemental Gas Supply and Disposition." 


\begin{tabular}{|c|c|c|c|c|c|}
\hline \multirow{2}{*}{ Supply/Disposition } & \multicolumn{5}{|c|}{ Transcontinental Gas Pipe Line Corp. } \\
\hline & Texas & Louisiana & Mississippi & Alabama & Georgia \\
\hline \multicolumn{6}{|l|}{ SUPPLY } \\
\hline $\begin{array}{l}\text { Produced Onsystem } \\
\text { Receipts }\end{array}$ & 0 & 0 & 0 & 0 & 0 \\
\hline 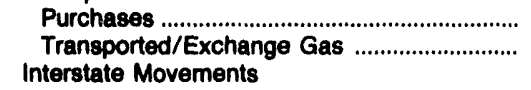 & $\begin{array}{r}47,447,852 \\
462,975,280\end{array}$ & $\begin{array}{r}87,516,120 \\
542,635,384\end{array}$ & $\begin{array}{r}28,013,238 \\
213,345,851\end{array}$ & $\begin{array}{r}9,493,456 \\
114,801,688\end{array}$ & $\begin{array}{r}0 \\
434,136\end{array}$ \\
\hline 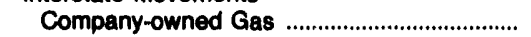 & 0 & 0 & 0 & 0 & 0 \\
\hline 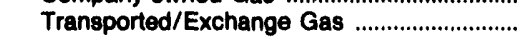 & 0 & $301,556,146$ & $714,642,182$ & $951,010,815$ & $1,046,643,109$ \\
\hline Storage Withdrawals & 0 & $49,064,930$ & $9,534,568$ & 0 & 0 \\
\hline 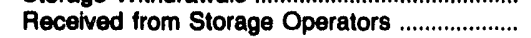 & 0 & 0 & 0 & 0 & 0 \\
\hline 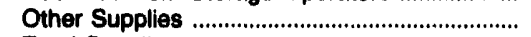 & 0 & 0 & 0 & 0 & 0 \\
\hline Total Supplies & $510,423,132$ & $980,772,580$ & $965,535,839$ & $1,075,305,959$ & $1,047,077,245$ \\
\hline \multicolumn{6}{|l|}{ DISPOSITION } \\
\hline 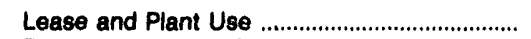 & $3,740,738$ & $19,754,165$ & 0 & 0 & 0 \\
\hline $\begin{array}{l}\text { Returned to Formations } \\
\text { Interstate Movements }\end{array}$ & 0 & 0 & 0 & 0 & 0 \\
\hline 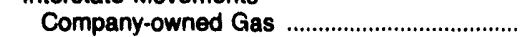 & 0 & 0 & 0 & 0 & 0 \\
\hline 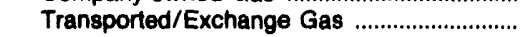 & $301,556,146$ & $714,642,182$ & $951,010,815$ & $1,046,643,109$ & $984,908,269$ \\
\hline 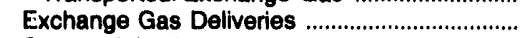 & $137,747,156$ & $172,677,863$ & 25,232 & 19,787 & 0 \\
\hline $\begin{array}{l}\text { Storage Injections ......................................... } \\
\text { Deliveries of Company-owned }\end{array}$ & 0 & $47,405,797$ & $8,837,145$ & 0 & 0 \\
\hline 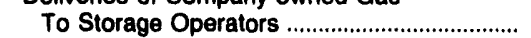 & 0 & 0 & 0 & 0 & 0 \\
\hline 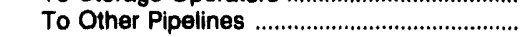 & 0 & 0 & 0 & 0 & 0 \\
\hline 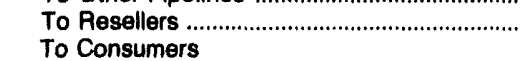 & 0 & 0 & 0 & 11,225 & 37 \\
\hline 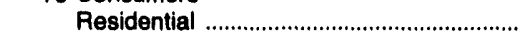 & 0 & 0 & 0 & 0 & 0 \\
\hline 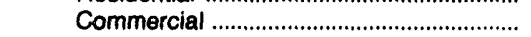 & 0 & 0 & 0 & 0 & 0 \\
\hline 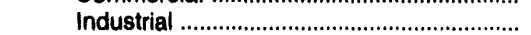 & 0 & 0 & 0 & 0 & 0 \\
\hline Vehicle Fuel & 0 & 0 & 0 & 0 & 0 \\
\hline 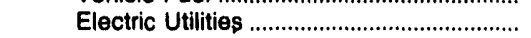 & 0 & 0 & 0 & 0 & 0 \\
\hline \multicolumn{6}{|l|}{ Transported for the Account of Others } \\
\hline To Storage Operators .................................... & 0 & 0 & 0 & 0 & 0 \\
\hline To Other Pipelines & $32,040,609$ & $15,803,727$ & 0 & 0 & 6,343 \\
\hline 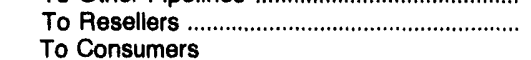 & $32,856,114$ & $5,646,726$ & 289,665 & $19,016,592$ & $56,739,133$ \\
\hline 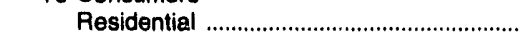 & 0 & 0 & 0 & 0 & 0 \\
\hline 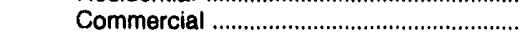 & 0 & 0 & 0 & 0 & 0 \\
\hline 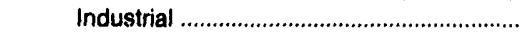 & 0 & 0 & 0 & 0 & 0 \\
\hline 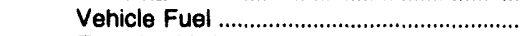 & 0 & 0 & 0 & 0 & 0 \\
\hline 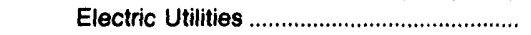 & 0 & 0 & 0 & 0 & 0 \\
\hline 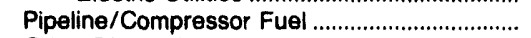 & $2,482,369$ & $4,842,120$ & $5,372,982$ & $9,615,246$ & $5,423,463$ \\
\hline Other Disposition & 0 & 0 & 0 & 0 & 0 \\
\hline 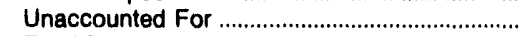 & 0 & 0 & 0 & 0 & 0 \\
\hline Total Disposition & $510,423,132$ & $980,772,580$ & $965,535,839$ & $1,075,305,959$ & $1,047,077,245$ \\
\hline
\end{tabular}

For some time TGPL along with Texas Gas has provided unbundled services to its customers in compliance with FERC's Order 636, permitting customers full flexibility in purchasing gas from their supplier of choice while still accessing transportation and storage services provided by TGPL. In December 1992, TGPL and Texas Gas Transmission Corporation (Texas Gas) filed plans with FERC which would enable Transco to realign its gas-marketing business under a newly formed subsidiary, Transco Gas Marketing Company (TGMC). TGMC manages all gas-marketing operations, including the certified gas sales made by TGPL.

Texas Gas' main gas transmission system extends from the Louisiana Gulf Coast gas supply areas to Indiana and Ohio. Texas Gas also has indirect market access to Northeast markets through interconnections with Columbia Gas Transmission Corporation, Consoli- dated Natural Gas Transmission Corporation (CNG), and Texas Eastern Transmission Corporation.

In 1992, Transco completed its TGPL, Texas Gas, and CNG project, one of the largest new projects to deliver natural gas to the northeast markets in over 20 years. Transco also formed a partnership with two interstate pipelines and three New York distribution companies to form the Liberty Pipeline Company. The Liberty Pipeline will be constructed between New Jersey and Long Island and will provide additional service for firm domestic gas in the New York City market area. Completion is scheduled for 1994. In addition, TGPL also plans to expand its upstream Leidy Line capacity to transport gas to the Liberty Pipeline.

In 1993, Transco announced two new Southeast expansion projects that would replace the original Blue Ridge proposal which was disapproved by FERC. 
Table 55. Transco Gas Co. Natural Gas Data, 1992 (Continued) (Thousand Cubic Feet)

\begin{tabular}{|c|c|c|c|c|c|}
\hline \multirow{2}{*}{ Supply/Disposition } & \multicolumn{5}{|c|}{ Transcontinental Gas Pipe Line Corp. } \\
\hline & South Carolina & North Carolina & Virginia & Maryland & Pennsylvania \\
\hline \multicolumn{6}{|l|}{ SUPPLY } \\
\hline $\begin{array}{l}\text { Produced Onsystem } \\
\text { Receipts }\end{array}$ & 0 & 0 & 0 & 0 & 0 \\
\hline 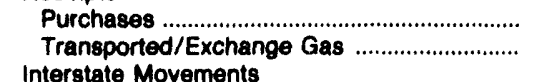 & $\begin{array}{l}0 \\
0\end{array}$ & $\begin{array}{l}0 \\
0\end{array}$ & $\begin{array}{r}0 \\
1,169,892\end{array}$ & $\begin{array}{l}0 \\
0\end{array}$ & $\begin{array}{r}0 \\
176,984,625\end{array}$ \\
\hline 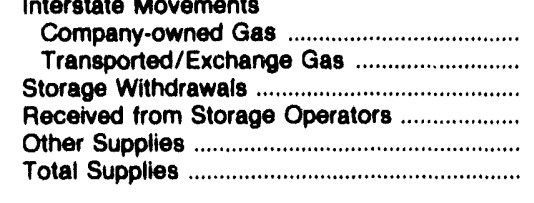 & $\begin{array}{r}0 \\
984,908,269 \\
0 \\
0 \\
0 \\
984,908,269\end{array}$ & $\begin{array}{r}0 \\
937,086,015 \\
0 \\
0 \\
0 \\
937,086,015\end{array}$ & $\begin{array}{r}0 \\
752,237,271 \\
0 \\
0 \\
0 \\
753,407,163\end{array}$ & $\begin{array}{r}0 \\
679,963,114 \\
0 \\
0 \\
0 \\
679,963,114\end{array}$ & $\begin{array}{r}0 \\
687,211,458 \\
0 \\
0 \\
0 \\
844,206,083\end{array}$ \\
\hline \multicolumn{6}{|l|}{ DISPOSITION } \\
\hline 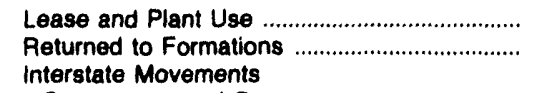 & $\begin{array}{l}0 \\
0\end{array}$ & $\begin{array}{l}0 \\
0\end{array}$ & $\begin{array}{l}0 \\
0\end{array}$ & $\begin{array}{l}0 \\
0\end{array}$ & $\begin{array}{l}0 \\
0\end{array}$ \\
\hline 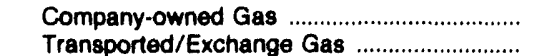 & $\begin{array}{r}0 \\
937,086,015\end{array}$ & $\begin{array}{r}0 \\
752,237,271\end{array}$ & $\begin{array}{r}0 \\
679,963,114\end{array}$ & $\begin{array}{r}0 \\
667,211,458\end{array}$ & $\begin{array}{r}0 \\
590,357,870\end{array}$ \\
\hline 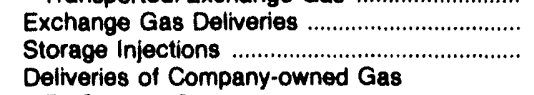 & $\begin{array}{l}0 \\
0\end{array}$ & $\begin{array}{l}0 \\
0\end{array}$ & $\begin{array}{l}0 \\
0\end{array}$ & $\begin{array}{r}0 \\
0\end{array}$ & $\begin{array}{l}0 \\
0\end{array}$ \\
\hline 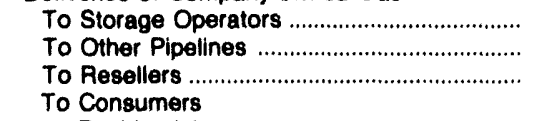 & $\begin{array}{r}0 \\
0 \\
7,092\end{array}$ & $\begin{array}{r}0 \\
0 \\
7.264\end{array}$ & $\begin{array}{l}0 \\
0 \\
0\end{array}$ & $\begin{array}{l}0 \\
0 \\
0\end{array}$ & $\begin{array}{l}0 \\
0 \\
0\end{array}$ \\
\hline 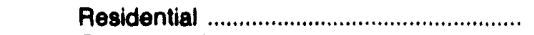 & 0 & 0 & 0 & 0 & 0 \\
\hline 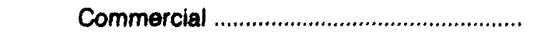 & 0 & 0 & 0 & 0 & 0 \\
\hline 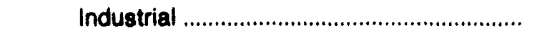 & 0 & 0 & 0 & 0 & 0 \\
\hline 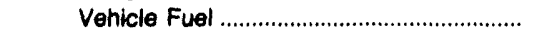 & 0 & 0 & 0 & 0 & 0 \\
\hline 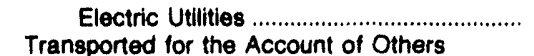 & 0 & 0 & 0 & 0 & 0 \\
\hline 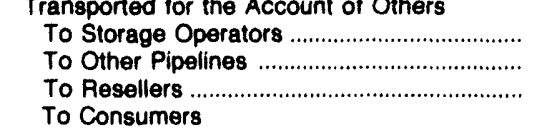 & $\begin{array}{r}0 \\
0 \\
43,483,043\end{array}$ & $\begin{array}{r}0 \\
0 \\
178,616,582\end{array}$ & $\begin{array}{r}0 \\
4,372,624 \\
63,358,355\end{array}$ & $\begin{array}{r}0 \\
518,082 \\
10,450,380\end{array}$ & $\begin{array}{r}0 \\
24,557,272 \\
212,849,348\end{array}$ \\
\hline 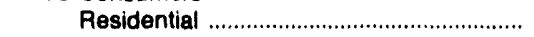 & 0 & 0 & 0 & 0 & 0 \\
\hline 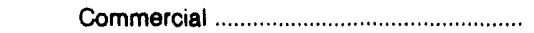 & 0 & 0 & 0 & 0 & 0 \\
\hline 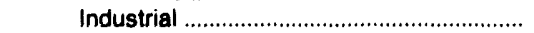 & $1,804,256$ & 0 & 0 & 0 & $12,095,357$ \\
\hline 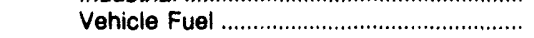 & 0 & 0 & 0 & 0 & 0 \\
\hline 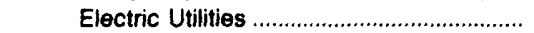 & 0 & 0 & 0 & 0 & 0 \\
\hline 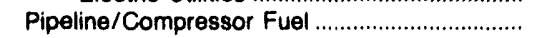 & $2,527,863$ & $6,224,898$ & $5,713,070$ & $1,783,194$ & $4,346,236$ \\
\hline 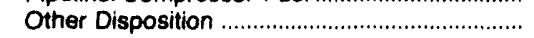 & 0 & 0 & 0 & 0 & 0 \\
\hline 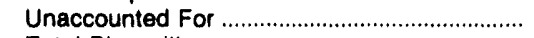 & 0 & 0 & 0 & 0 & 0 \\
\hline 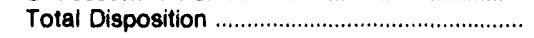 & $984,908,269$ & $937,086,015$ & $753,407,163$ & $679,963,114$ & $844,208,083$ \\
\hline
\end{tabular}

These projects would go into service in three stages, including approximately 25 miles of replacement pipeline and looping; in addition to the installation of facilities to increase compression on the line by approximately 70,000 horsepower.

Upon approval by FERC, the first phase would provide 35 million cubic feet per day of incremental capacity by late 1995, and the final 50 million cubic feet per day by late 1996 .

In 1992, Transco sold its Transco Energy Ventures (TEVCO) subsidiary to National Power America, which owns and operates as well as develops and builds cogeneration and independent power plants. Transco also began the Hartwell project in Georgia, a 300-megawatt gas-fired cogeneration facility, and the Mecklenburg project, a 132 megawatt cogeneration plant in Virginia. Texas Gas began construction on a 424-megawatt cogeneration facility at Oyster Creek, Texas.

TGPL's total market area deliveries in 1992 were 17.4 billion cubic feet, slightly lower than 17.9 billion cubic feet in 1991. Deliveries for Texas Gas in 1992 totaled 1.8 billion cubic feet, slightly higher than the 1.6 billion cubic feet recorded in 1991 . 
Table 55. Transco Gas Co. Natural Gas Data, 1992 (Continued) (Thousand Cubic Feet)

\begin{tabular}{|c|c|c|c|c|c|}
\hline \multirow{2}{*}{ Supply/Disposition } & \multicolumn{2}{|c|}{ Transcontinental Gas Pipe Line Corp. } & \multicolumn{3}{|c|}{ Texas Gas Transmission Corp. } \\
\hline & New Jersey & New York & Texas & Louisiana & Arkansas \\
\hline \multicolumn{6}{|l|}{ SUPPLY } \\
\hline $\begin{array}{l}\text { Produced Onsystem } \\
\text { Receipts }\end{array}$ & 0 & 0 & 0 & 0 & 0 \\
\hline 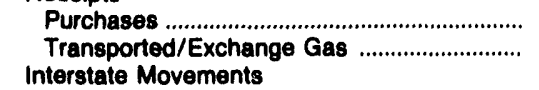 & $\begin{array}{r}0 \\
23,010,878\end{array}$ & $\begin{array}{l}0 \\
0\end{array}$ & $\begin{array}{r}2,663,773 \\
47,480,457\end{array}$ & $\begin{array}{r}27,953,638 \\
603,661,067\end{array}$ & $\begin{array}{r}384,927 \\
14,258,053\end{array}$ \\
\hline 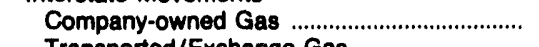 & 0 & $\begin{array}{r}0 \\
0\end{array}$ & 0 & $\begin{array}{r}0 \\
0\end{array}$ & $\begin{array}{r}0 \\
0\end{array}$ \\
\hline Transported/Exchange Gas ............................... & $572,714,330$ & $298,922,273$ & 0 & $46,580,811$ & $457,847,729$ \\
\hline 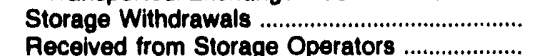 & $\begin{array}{r}1,481,269 \\
0\end{array}$ & $\begin{array}{l}0 \\
0\end{array}$ & $\begin{array}{l}0 \\
0\end{array}$ & $\begin{array}{l}0 \\
0\end{array}$ & $\begin{array}{l}0 \\
0\end{array}$ \\
\hline 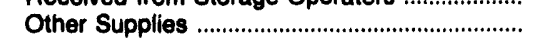 & 0 & 0 & 0 & 0 & 0 \\
\hline Total Supplies & $597,206,477$ & $298,922,273$ & $50,144,230$ & $678,195,516$ & $472,490,709$ \\
\hline \multicolumn{6}{|l|}{ DISPOSITION } \\
\hline 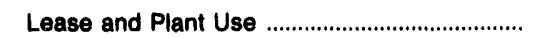 & 0 & 0 & 0 & 0 & 0 \\
\hline $\begin{array}{l}\text { Returned to Formations } \\
\text { Interstate Movements }\end{array}$ & 0 & 0 & 0 & 0 & 0 \\
\hline 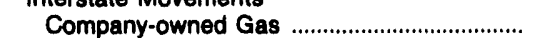 & 0 & 0 & 0 & 0 & 0 \\
\hline 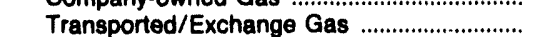 & $298,922,273$ & 0 & $46,580,811$ & $457,847,729$ & $471,569,194$ \\
\hline 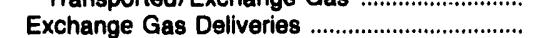 & $\begin{array}{r}200,0<2,210 \\
0\end{array}$ & 0 & 17,576 & $23,312,722$ & 0 \\
\hline 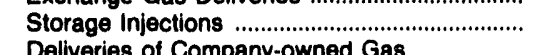 & $1,746,462$ & 0 & 0 & 0 & 0 \\
\hline $\begin{array}{l}\text { Deliveries of Company-owned Gas } \\
\text { To Storage Operators }\end{array}$ & & & & & \\
\hline To Storage Operators ......................................... & 0 & 0 & 0 & 0 & 0 \\
\hline 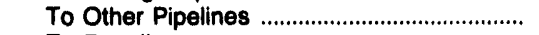 & 0 & 0 & 0 & 0 & 474,391 \\
\hline 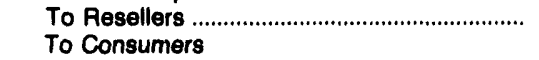 & 0 & 0 & 0 & 417,555 & 64,837 \\
\hline 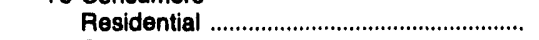 & 0 & 0 & 0 & 0 & 0 \\
\hline 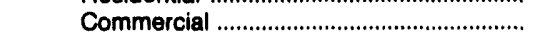 & 0 & 0 & 0 & 0 & 0 \\
\hline 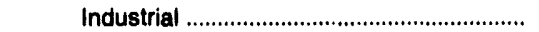 & 0 & 0 & 0 & 0 & 0 \\
\hline 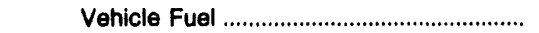 & 0 & 0 & 0 & 0 & 0 \\
\hline 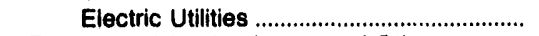 & 0 & 0 & 0 & 0 & 0 \\
\hline \multicolumn{6}{|l|}{ Transported for the Account of Others } \\
\hline 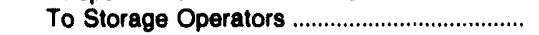 & 0 & 0 & 0 & 0 & 0 \\
\hline To Other Pipelines & $7,865,026$ & 0 & 457,897 & $114,283,674$ & 0 \\
\hline 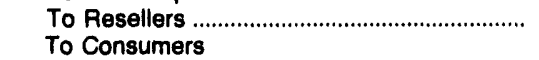 & $284,668,785$ & $299,912,950$ & $3,105,307$ & $70,161,507$ & 196,570 \\
\hline 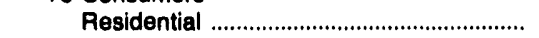 & 0 & 0 & 0 & 0 & 0 \\
\hline 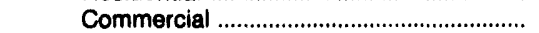 & 0 & 0 & 0 & 0 & 0 \\
\hline 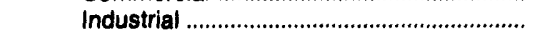 & $3,549,047$ & 0 & 0 & $12,279,023$ & 0 \\
\hline 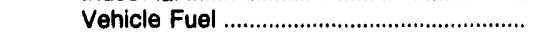 & 0 & 0 & 0 & 0 & 0 \\
\hline 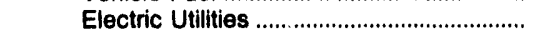 & 0 & 0 & 0 & 0 & 190,905 \\
\hline Pipeline/Compressor Fuel .................................... & 454,884 & 0 & 0 & $1,066,259$ & 0 \\
\hline 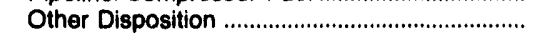 & 0 & 418,902 & 0 & 0 & 0 \\
\hline 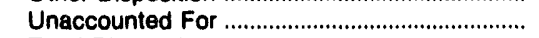 & 0 & $-1,409,579$ & $-17,361$ & $-1,172,953$ & $-5,188$ \\
\hline 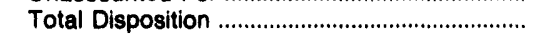 & $597,206,477$ & $298,922,273$ & $50,144,230$ & $678,195,516$ & $472,490,709$ \\
\hline
\end{tabular}


Table 55. Transco Gas Co. Natural Gas Data, 1992 (Continued) (Thousand Cubic Feet)

\begin{tabular}{|c|c|c|c|c|c|c|}
\hline \multirow{2}{*}{ Supply/Disposition } & \multicolumn{6}{|c|}{ Texas Gas Transmissiun Corp. } \\
\hline & Mississippi & Tennessee & Kentucky & Illinois & Indiana & Ohio \\
\hline \multicolumn{7}{|l|}{ SUPPLY } \\
\hline 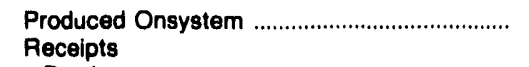 & 0 & 0 & 2,227 & 0 & 0 & 0 \\
\hline 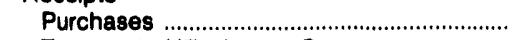 & 964,845 & 24,294 & 51,975 & 244 & 0 & 0 \\
\hline 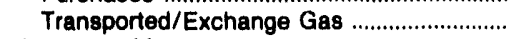 & 0 & $1,438,079$ & $3,972,416$ & 74 & 42,022 & 13,794 \\
\hline \multicolumn{7}{|l|}{ Interstate Movements } \\
\hline 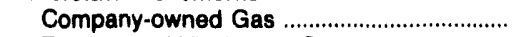 & 0 & 0 & 0 & 0 & 0 & 0 \\
\hline Transported/Exchange Gas ........................... & $471,569,194$ & $449,830,411$ & $403,896,617$ & $10,955,657$ & $290,359,979$ & $194,306,180$ \\
\hline 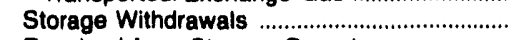 & 0 & 0 & $26,477,463$ & 0 & $4,661,959$ & 0 \\
\hline Received from Storage Operators .................. & 0 & 0 & 0 & 0 & 0 & 0 \\
\hline 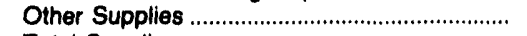 & 0 & 0 & 0 & 0 & 0 & 0 \\
\hline 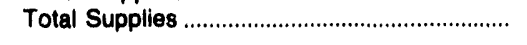 & $472,534,039$ & $451,292,784$ & $434,400,698$ & $10,955,975$ & $295,063,960$ & $194,319,974$ \\
\hline \multicolumn{7}{|l|}{ DISPOSITION } \\
\hline 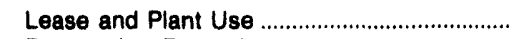 & 0 & 0 & 0 & 0 & 0 & 0 \\
\hline $\begin{array}{l}\text { Returned to Formations } \\
\text { Interstate Movements }\end{array}$ & 0 & 0 & 0 & 0 & 0 & 0 \\
\hline 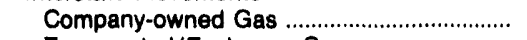 & 0 & 0 & 0 & 0 & 0 & 0 \\
\hline 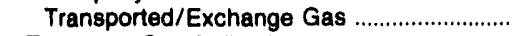 & $449,830,411$ & $403,896,617$ & $290,359,979$ & 0 & $205,261,837$ & 0 \\
\hline Exchange Gas Deliveries .................................. & 0 & 2,604 & 0 & 0 & 0 & 0 \\
\hline \multicolumn{6}{|l|}{ Deliveries of Company-owned Gas } & 0 \\
\hline 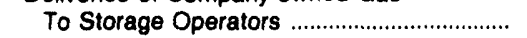 & 0 & 0 & 0 & 0 & 0 & 0 \\
\hline 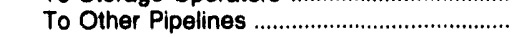 & $3,347,151$ & 0 & 0 & 0 & 0 & 0 \\
\hline $\begin{array}{l}\text { To Resellers } \\
\text { To Consumers }\end{array}$ & $2,804,152$ & $12,682,014$ & $33,702,848$ & $1,776,336$ & $20,453,761$ & $4,658,083$ \\
\hline 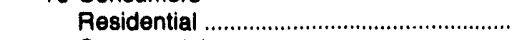 & 0 & 0 & 0 & 0 & 0 & 0 \\
\hline 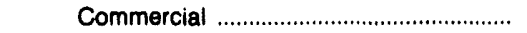 & 0 & 0 & 0 & 0 & 0 & 0 \\
\hline 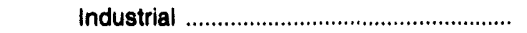 & 0 & 0 & 0 & 0 & 0 & 0 \\
\hline 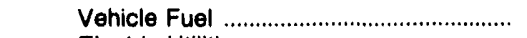 & 0 & 0 & 0 & 0 & 0 & 0 \\
\hline 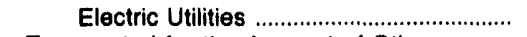 & 0 & 0 & 0 & 0 & 0 & 0 \\
\hline \multicolumn{7}{|l|}{ Transported for the Account of Others } \\
\hline 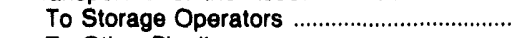 & 0 & 0 & 0 & 0 & 0 & 0 \\
\hline 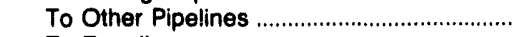 & 0 & 0 & 0 & 0 & 0 & $75,744,112$ \\
\hline 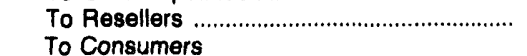 & $10,546,687$ & $25,408,035$ & $70,640,269$ & $9,179,639$ & $64,360,844$ & $113,937,610$ \\
\hline 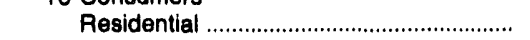 & 0 & 0 & 0 & 0 & 0 & 0 \\
\hline 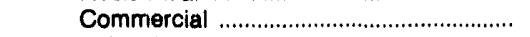 & 0 & 0 & 749,541 & 0 & 0 & 0 \\
\hline 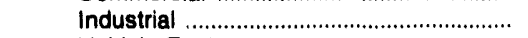 & 0 & $8,718,810$ & $4,762,045$ & 0 & 686,580 & $1,347,445$ \\
\hline 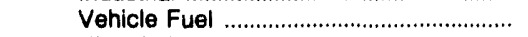 & 0 & 0 & 0 & 0 & 0 & 0 \\
\hline 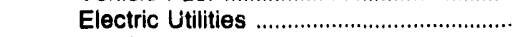 & $4,730,878$ & 0 & 0 & 0 & 0 & 0 \\
\hline Pipeline/Compressor Fuel ................................... & $1,394,731$ & 846,767 & $1,371,293$ & 0 & 198,929 & 0 \\
\hline 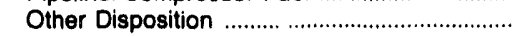 & 0 & 0 & 0 & 0 & 0 & 0 \\
\hline 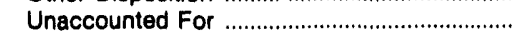 & $-119,971$ & $-262,063$ & $-615,030$ & 0 & $-478,685$ & $-1,367,276$ \\
\hline 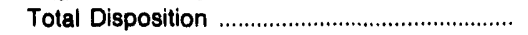 & $472,534,039$ & $451,292,784$ & $434,400,698$ & $10,955,975$ & $295,063,960$ & $194,319,974$ \\
\hline
\end{tabular}

Source: Energy Information Administration (EIA), Form EIA-176, "Annual Report of Natural and Supplemental Gas Supply and Disposition." 
Table 56. Transco Gas Co. Interstate Flows of Natural Gas, 1992 (Thousand Cubic Feet)

\begin{tabular}{|c|c|c|c|}
\hline Company and State & Volume & Company and State & Volume \\
\hline \multicolumn{2}{|l|}{$\begin{array}{l}\text { Transcontinental Gas Pipe Line Corp. } \\
\text { Texas To }\end{array}$} & \multicolumn{2}{|l|}{$\begin{array}{l}\text { Texas Gas Transmission Corp. } \\
\text { Texas To }\end{array}$} \\
\hline 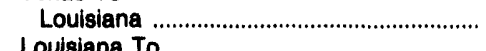 & $301,556,146$ & 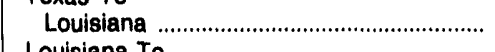 & $46,580,811$ \\
\hline & & & \\
\hline $\begin{array}{l}\text { Mississippi } \\
\text { Mississippi To }\end{array}$ & $714,642,182$ & $\begin{array}{l}\text { Arkansas ............................................... } \\
\text { Arkansas To }\end{array}$ & $457,847,729$ \\
\hline $\begin{array}{l}\text { Alabama } \\
\text { Alabama To }\end{array}$ & $951,010,815$ & 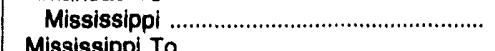 & $471,569,194$ \\
\hline Georgia & $1,046,643,109$ & 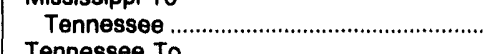 & $449,830,411$ \\
\hline $\begin{array}{l}\text { South Carolina } \\
\text { South Carolina To }\end{array}$ & $984,908,269$ & 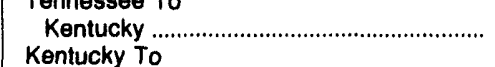 & $403,896,617$ \\
\hline $\begin{array}{l}\text { North Carolina } \\
\text { North Carolina To }\end{array}$ & $937,086,015$ & 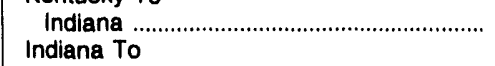 & $290,359,979$ \\
\hline $\begin{array}{l}\text { Virginia } \\
\text { Virginia To }\end{array}$ & $752,237,271$ & $\begin{array}{l}\text { Illinois } \\
\text { Ohio }\end{array}$ & $\begin{array}{r}10,955,657 \\
194,306,180\end{array}$ \\
\hline $\begin{array}{l}\text { Maryland } \\
\text { Maryland To }\end{array}$ & $679,963,114$ & & \\
\hline $\begin{array}{l}\text { Pennsylvania } \\
\text { Pennsylvania To }\end{array}$ & $667,211,458$ & & \\
\hline $\begin{array}{l}\text { Delaware } \\
\text { New Jersey } \\
\text { New Jersey To }\end{array}$ & $\begin{array}{r}17,643,540 \\
572,714,330\end{array}$ & & \\
\hline 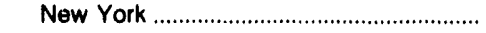 & $298,922,273$ & & \\
\hline
\end{tabular}




\section{Valero Energy Corp.}

Valero Energy Corporation is a diversified firm that supplies natural gas to varied markets while also offering pipeline transportation services. The company's natural gas operations are handled by a network of subsidiaries operating in Texas. These subsidiaries, referred to as Valero Gas Partners Limited Partnership (VGP LP), operate a 7,200-mile network of gathering, transmission, and distribution pipelines within Texas. Other natural gas operations within the State include gas processing, underground storage, and distribution to consumers. VGP LP's network of pipelines give Valero access to gas from all producing areas in Texas except the Panhandle region and to gas produced in Oklahoma.
In 1991, Mexico adopted new air pollution regulations which forced power generation and industrial users to burn more natural gas. In 1992 Valero Gas Pipeline LP completed a 3.5-mile pipeline link beneath the Rio Grande River to allow Valero to export up to 400 million cubic feet of gas per day to Mexico's Petroleos Mexicanos (PEMEX). PEMEX is Mexico's State controlled oil company. This is the largest capacity pipeline connection to Mexico built to date, and Valero delivers more gas to Mexico than any other exporter in the United States.

Figure 41. Valero Energy Corp., 1992

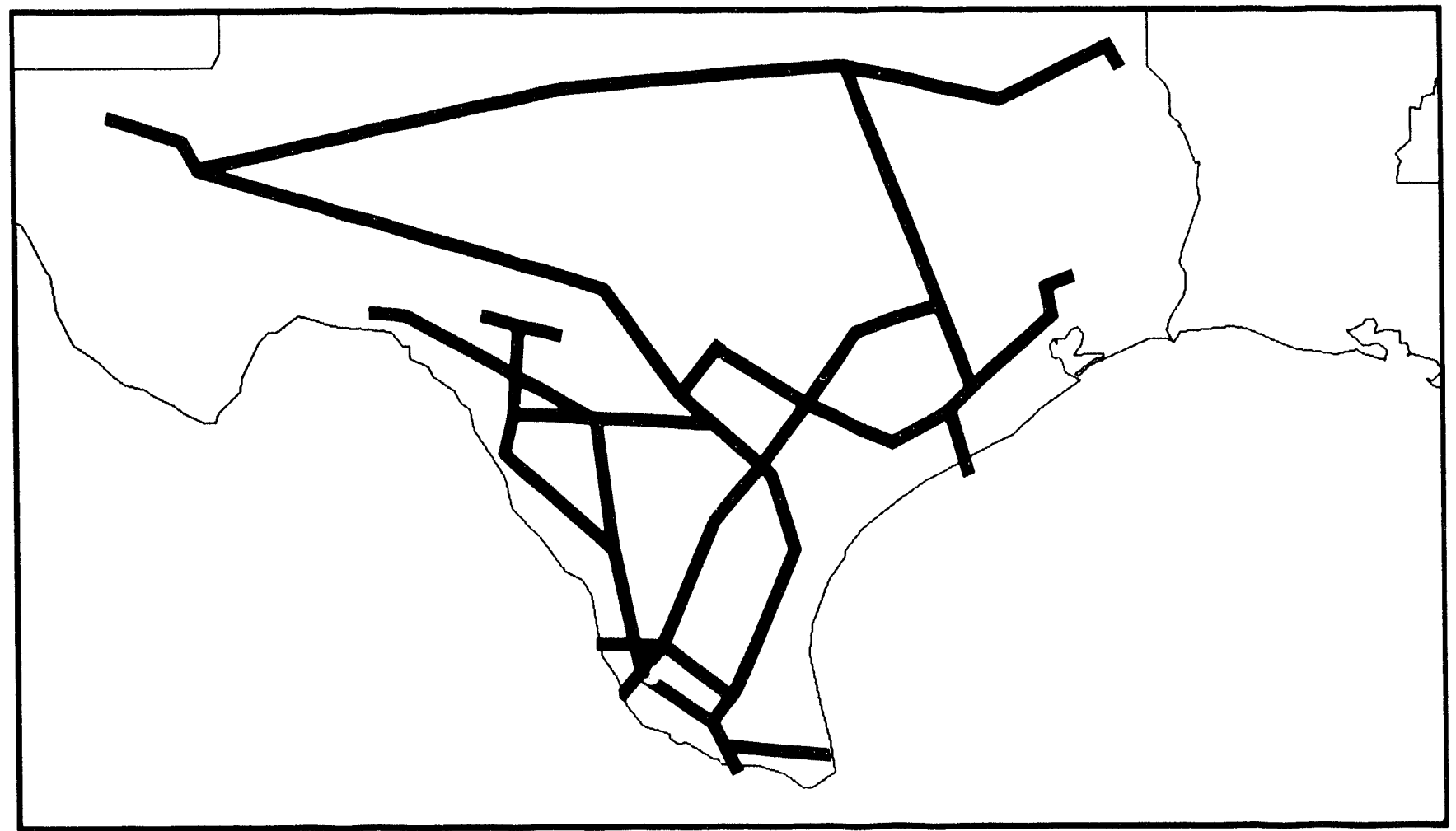

Source: Energy Information Administration (E|A), Form EIA-176, "Annual Report of Natural and Supplemental Gas Supply and Disposition." 


\begin{tabular}{|c|c|c|c|c|c|}
\hline \multirow{2}{*}{ Supply/Disposition } & $\begin{array}{l}\text { Valero interstate } \\
\text { Transmission Co. }\end{array}$ & $\begin{array}{l}\text { Valero Transmission } \\
\text { Limited Partnership }\end{array}$ & Valero Gas Storage & $\begin{array}{l}\text { Val Gas Limited } \\
\text { Partnership }\end{array}$ & $\begin{array}{l}\text { V.H.C. Plpeline } \\
\text { Limited Partnership }\end{array}$ \\
\hline & \multicolumn{5}{|c|}{ Texas } \\
\hline \multicolumn{6}{|l|}{ SUPPLY } \\
\hline 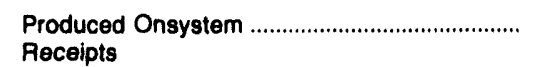 & 0 & 0 & 0 & 0 & 0 \\
\hline 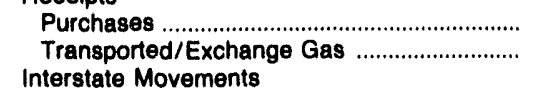 & $\begin{array}{r}8,232,653 \\
59,867,056\end{array}$ & $\begin{array}{r}22,347,722 \\
736,440,322\end{array}$ & $\begin{array}{r}0 \\
15,828,250\end{array}$ & $\begin{array}{l}12,847,258 \\
15,639,447\end{array}$ & $\begin{array}{r}0 \\
9,645,536\end{array}$ \\
\hline 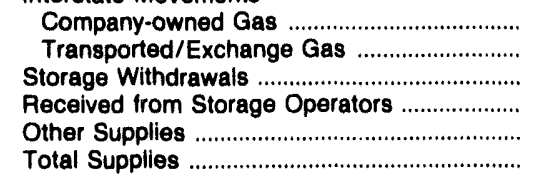 & $\begin{array}{r}0 \\
0 \\
0 \\
0 \\
0 \\
68,099,709\end{array}$ & $\begin{array}{r}0 \\
0 \\
0 \\
0 \\
0 \\
758,788,044\end{array}$ & $\begin{array}{r}0 \\
0 \\
15,638,301 \\
0 \\
0 \\
31,466,551\end{array}$ & $\begin{array}{r}0 \\
0 \\
0 \\
0 \\
0 \\
28,486,705\end{array}$ & $\begin{array}{r}0 \\
0 \\
0 \\
0 \\
0 \\
9,645,536\end{array}$ \\
\hline \multicolumn{6}{|l|}{ DISPOSITION } \\
\hline 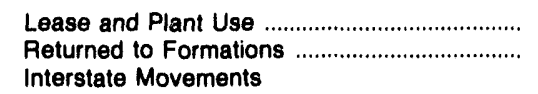 & $\begin{array}{l}0 \\
0\end{array}$ & $\begin{array}{r}1,144,892 \\
0\end{array}$ & $\begin{array}{l}0 \\
0\end{array}$ & $\begin{array}{l}0 \\
0\end{array}$ & $\begin{array}{l}0 \\
0\end{array}$ \\
\hline 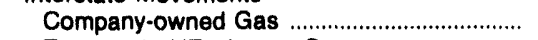 & 0 & 0 & 0 & 0 & 0 \\
\hline 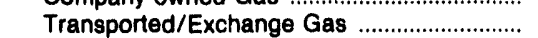 & 0 & $22,772,718$ & 0 & 0 & 0 \\
\hline 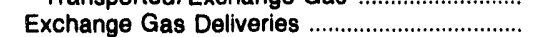 & 502,143 & $15,826,833$ & $15,638,301$ & 0 & 0 \\
\hline $\begin{array}{l}\text { Storage Injections } \\
\text { Deliveries of Company-owned Gas }\end{array}$ & 0 & 0 & $15,828,250$ & 0 & 0 \\
\hline 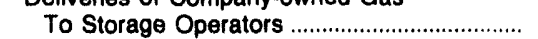 & 0 & 0 & 0 & 0 & 0 \\
\hline 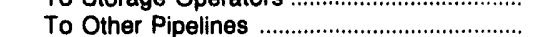 & $8,232,653$ & 0 & 0 & 0 & 0 \\
\hline 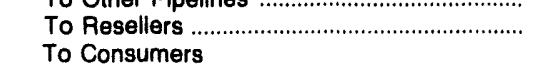 & $\begin{array}{r}0,20<, 000 \\
0\end{array}$ & $21,703,316$ & 0 & 739,161 & 0 \\
\hline 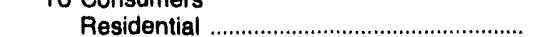 & 0 & 3,255 & 0 & 0 & 0 \\
\hline 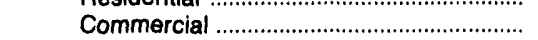 & 0 & 37,498 & 0 & 0 & 0 \\
\hline 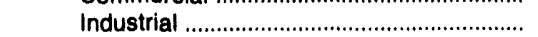 & 0 & 146,416 & 0 & $3,201,194$ & 0 \\
\hline 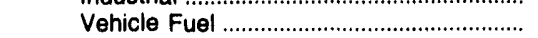 & 0 & 0 & 0 & 0 & 0 \\
\hline 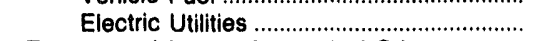 & 0 & $6,753,210$ & 0 & $6,809,183$ & 0 \\
\hline \multicolumn{6}{|l|}{ Transported for the Account of Others } \\
\hline 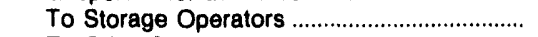 & 0 & 0 & 0 & 0 & 0 \\
\hline 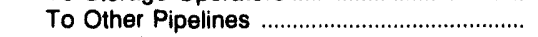 & $59,125,892$ & $572,731,015$ & 0 & $15,639,447$ & $9,645,536$ \\
\hline 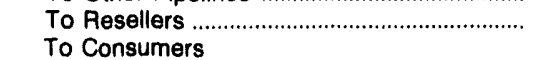 & 0 & 0 & 0 & $1,845,911$ & 0 \\
\hline 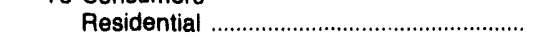 & 0 & 0 & 0 & 0 & 0 \\
\hline 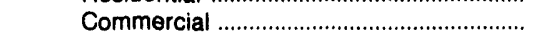 & 0 & $3,085,978$ & 0 & 0 & 0 \\
\hline 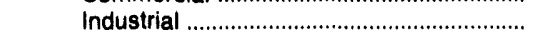 & 0 & $19,018,306$ & 0 & 0 & 0 \\
\hline 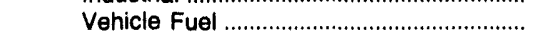 & 0 & 0 & 0 & 0 & 0 \\
\hline 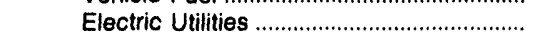 & 0 & $93,216,372$ & 0 & 0 & 0 \\
\hline 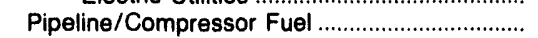 & 143,867 & $5,525,248$ & 0 & 66,550 & 0 \\
\hline Other Disposition & 0 & 0 & 0 & 0 & 0 \\
\hline 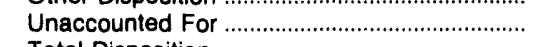 & 95,154 & $-3,177,013$ & 0 & 185,259 & 0 \\
\hline Total Disposition & $68,099,709$ & $758,788,044$ & $31,466,551$ & $28,486,705$ & $9,645,536$ \\
\hline
\end{tabular}

Gas in Valero's pipelines flow from the company's East Texas supply areas to interconnections with interstate pipelines serving markets in the Northeastern United States. Valero has 34 interconnections with 12 interstate pipelines in Texas.

Valero reported lower than normal gas sales in 1990 due to unusually warm weather and due to the startup of two nuclear generating plants. Sales in 1991 and 1992 continued at low levels which, according to Valero, are due to excess pipeline capacity and surplus deliverability. Valero notes that more gas-fired power plants are being built in the United States, a reversal from the trend of building coal-fired or nuclear plants. The company states that potential demand for natural gas to generate electricity could increase by 60 percent by 1996 .
The subsidiaries that comprise VGP LP are Valero Interstate Transmission Co.; Valero Transmission Limited Partnership; Valero Gas Storage; Val Gas Limited Partnership; V.H.C. Pipeline Limited Partnership; Val Gas Co.; Val Gathering Limited Partnership; and Rio Grande Valley Gas Co.

Valero Transmission Limited Partnership, the largest of Valero's natural gas subsidiaries, reported total supplies of 759 billion cubic feet in 1992. The largest portion, almost 75 percent, was delivered to other pipelines in the State. Deliveries to consumers, both companyowned gas and gas delivered for the account of others, totaled 122 billion cubic feet, or 16 percent of supply.

Other Valero subsidiaries were engaged primarily in intrastate transportation of natural gas with deliveries to interconnections with interstate pipeline companies 
Table 57. Valero Energy Corp. Natural Gas Data, 1992 (Continued) (Thousand Cubic Feet)

\begin{tabular}{l|c|c}
\hline \multirow{2}{*}{ Supply/Disposition } & Val Gas Co. & Val Gathering Limited Partnership \\
\cline { 2 - 3 } & & Texas \\
\hline
\end{tabular}

\section{UPPLY}

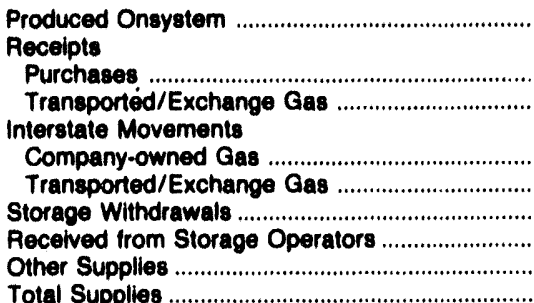

$\begin{array}{rr}0 & 0 \\ 80,170 & 0 \\ 4,727,883 & 19,167,255 \\ 0 & 0 \\ 0 & 0 \\ 0 & 0 \\ 0 & 0 \\ 0 & 0 \\ 4,808,053 & 18,167,255\end{array}$

\section{DIsPosition}

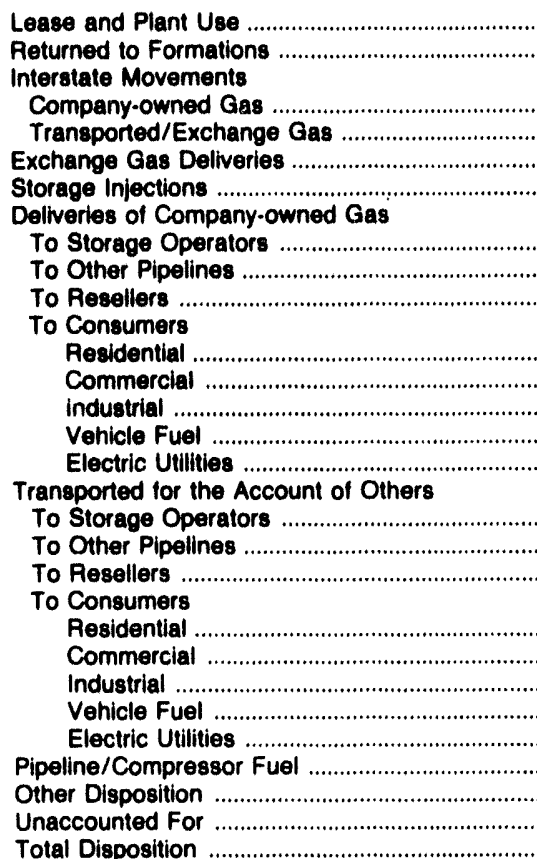

$\begin{array}{rr}0 & 0 \\ 0 & 0 \\ 0 & 0 \\ 0 & 0 \\ 0 & 0 \\ 0 & 0 \\ 0 & 0 \\ 0 & 0 \\ 80,170 & 0 \\ 0 & 0 \\ 0 & 0 \\ 0 & 0 \\ 0 & 0 \\ 0 & 0 \\ 0 & 0 \\ 4,727,883 & 0 \\ 0 & 0 \\ 0 & 0,167,255 \\ 0 & 0 \\ 0 & 0 \\ 0 & 0 \\ 0 & 0 \\ 0 & 0 \\ 0 & 0 \\ 0 & 0 \\ 4,808,053 & 0 \\ & 0 \\ & 0 \\ 0 & 0167,255\end{array}$

Source: Energy Information Administration (EIA), Form EIA.176, "Annual Report of Natural and Suppiemental Gas Supply and Disposition."

serving markets nationwide. Valero Gas Storage operates an underground natural gas storage field located in Wharton County, Texas. Val Gas Limited Partner- ship reported sales to electric utility and industrial consumers. 


\section{Washington Gas Light Co.}

Washington Gas Light Company has been providing services to the Washington, D.C., area for over 100 years. The service area of Washington Gas and its subsidiaries spans from West Virginia in the Shenandoah Mountains to Maryland east of the Chesapeake Bay. This area includes the District of Columbia, suburban Maryland, and Northern Virginia. Natural gas service is provided to over 680,000 customer meters. The Winchester, Virginia and Martinsburg, West Virginia service areas are covered by the Shenandoah Gas distribution subsidiary. Frederick Gas (another subsidiary) serves the Frederick, Maryland area.
The majority of Washington Gas' business is based on sales to residential and small commercial customers. Sales to apartments, universities, government, and hospital buildings comprise the large commercial business for the company. Five percent of Washington Gas' annual sales during 1992 were purchased by the Potomac Electric Power Company for electricity generation.

Washington Gas provides a substantial amount of gas to the Federal Government. Government policies are encouraging the increased use of natural gas. Most notably, the clean air legislation is having an impact on

Figure 42. Washington Gas Light Co., 1992

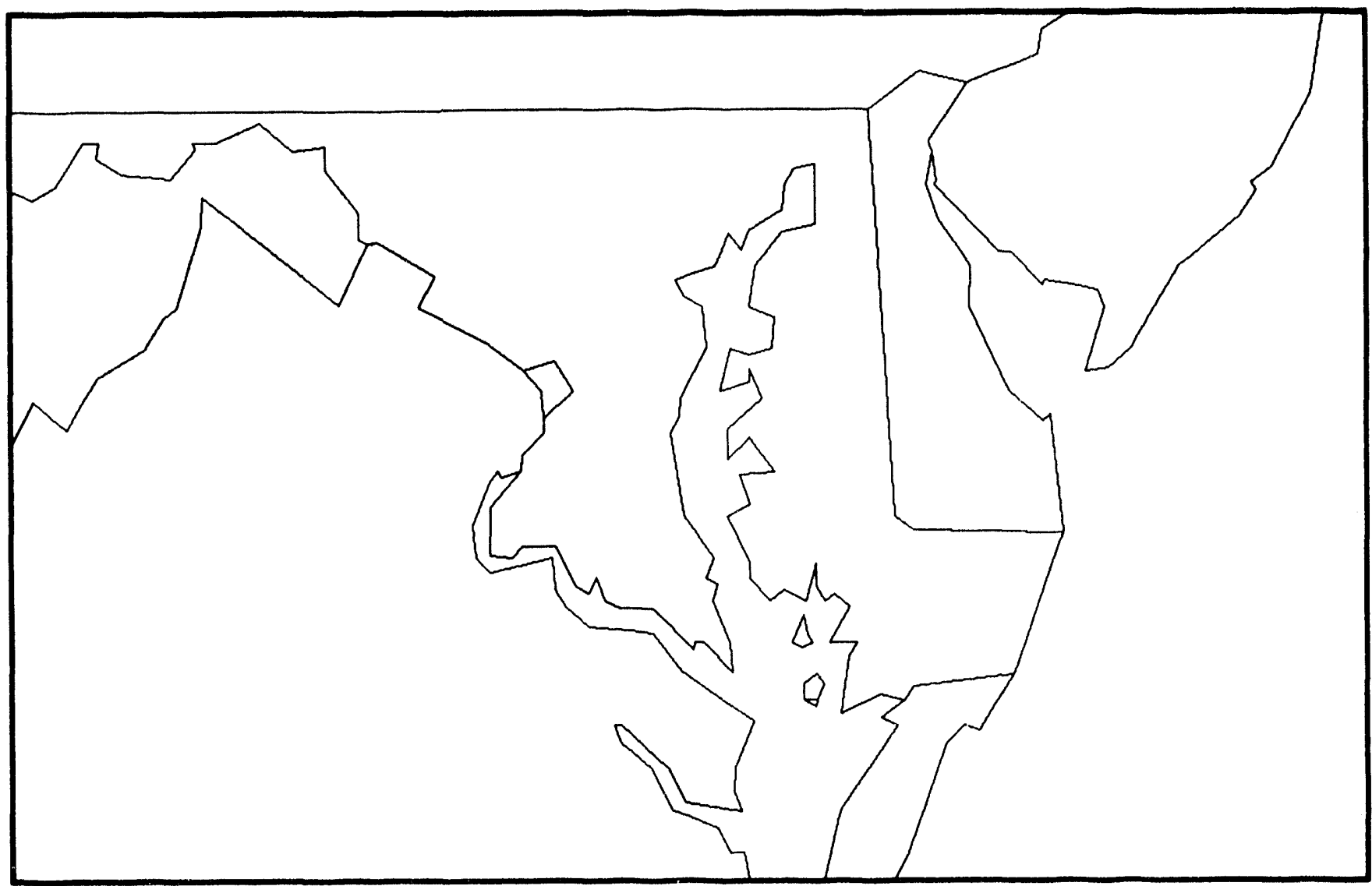

Source: Energy Information Administration (EIA), Form EIA-176, "Annual Report of Natural and Supplemental Gas Supply and Disposition." 
Table 58. Washington Gas Light Co. Natural Gas Data, 1992

(Thousand Cubic Feet)

\begin{tabular}{|c|c|c|c|c|c|}
\hline \multirow{2}{*}{ Supply/Disposition } & \multicolumn{3}{|c|}{ Washington Gas Light Co. } & \multicolumn{2}{|c|}{ Shenandoah Gas Co. } \\
\hline & Virginia & D.C. & Maryland & Virginia & West Virginia \\
\hline \multicolumn{6}{|l|}{ SUPPLY } \\
\hline $\begin{array}{l}\text { Produced Onsystem } \\
\text { Receipts }\end{array}$ & 0 & 0 & 0 & 0 & 0 \\
\hline 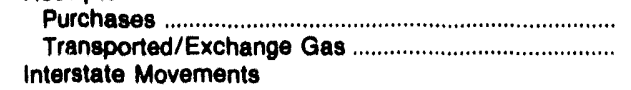 & $\begin{array}{l}15,814,023 \\
53,058,324\end{array}$ & $\begin{array}{r}0 \\
155,032\end{array}$ & $\begin{array}{l}26,100,376 \\
36,116,200\end{array}$ & $\begin{array}{l}1,632,705 \\
3,420,787\end{array}$ & $\begin{array}{l}0 \\
0\end{array}$ \\
\hline 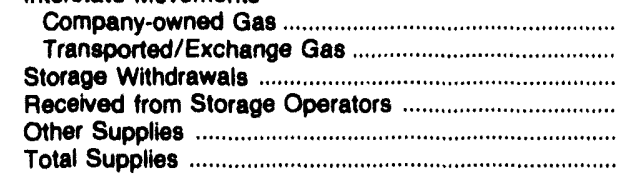 & $\begin{array}{r}0 \\
0 \\
0 \\
0 \\
13,997 \\
68,886,344\end{array}$ & $\begin{array}{r}0 \\
33,421,602 \\
0 \\
0 \\
0 \\
33,576,634\end{array}$ & $\begin{array}{r}0 \\
6,631,289 \\
0 \\
0 \\
36,830 \\
68,884,695\end{array}$ & $\begin{array}{r}0 \\
0 \\
0 \\
0 \\
0 \\
5,053,492\end{array}$ & $\begin{array}{r}0 \\
2,198,435 \\
0 \\
0 \\
0 \\
2,198,435\end{array}$ \\
\hline \multicolumn{6}{|l|}{ DISPOSITION } \\
\hline 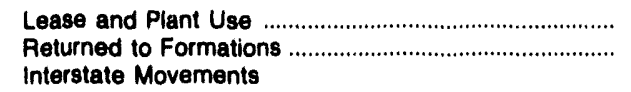 & $\begin{array}{l}0 \\
0\end{array}$ & $\begin{array}{l}0 \\
0\end{array}$ & $\begin{array}{l}0 \\
0\end{array}$ & $\begin{array}{l}0 \\
0\end{array}$ & $\begin{array}{l}0 \\
0\end{array}$ \\
\hline 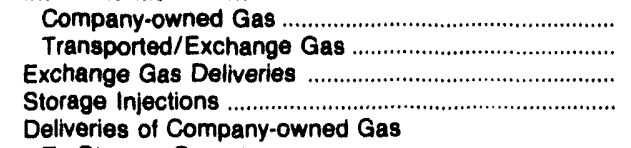 & $\begin{array}{r}0 \\
28,706,841 \\
0 \\
0\end{array}$ & $\begin{array}{l}0 \\
0 \\
0 \\
0\end{array}$ & $\begin{array}{r}0 \\
11,346,050 \\
0 \\
3,010\end{array}$ & $\begin{array}{r}2,198,435 \\
0 \\
0 \\
0\end{array}$ & $\begin{array}{l}0 \\
0 \\
0 \\
0\end{array}$ \\
\hline 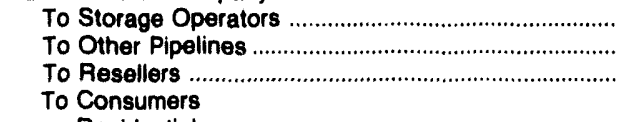 & $\begin{array}{l}0 \\
0 \\
0\end{array}$ & $\begin{array}{l}0 \\
0 \\
0\end{array}$ & $\begin{array}{l}0 \\
0 \\
0\end{array}$ & $\begin{array}{l}0 \\
0 \\
0\end{array}$ & $\begin{array}{l}0 \\
0 \\
0\end{array}$ \\
\hline 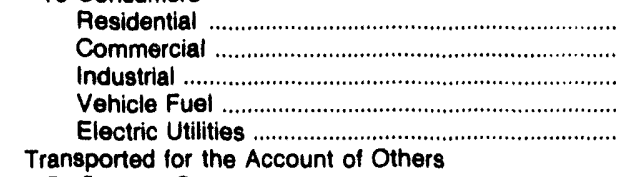 & $\begin{array}{r}25,080,604 \\
13,296,253 \\
0 \\
0 \\
0\end{array}$ & $\begin{array}{r}16,587,064 \\
15,948,225 \\
0 \\
0 \\
0\end{array}$ & $\begin{array}{r}33,457,606 \\
16,291,544 \\
0 \\
0 \\
6,631,289\end{array}$ & $\begin{array}{r}443,392 \\
2,248,046 \\
0 \\
0 \\
0\end{array}$ & $\begin{array}{r}226,804 \\
1,895,8 \times 6 \\
0 \\
0 \\
0\end{array}$ \\
\hline 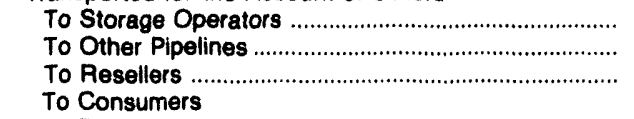 & $\begin{array}{l}0 \\
0 \\
0\end{array}$ & $\begin{array}{l}0 \\
0 \\
0\end{array}$ & $\begin{array}{l}0 \\
0 \\
0\end{array}$ & $\begin{array}{l}0 \\
0 \\
0\end{array}$ & $\begin{array}{l}0 \\
0 \\
0\end{array}$ \\
\hline 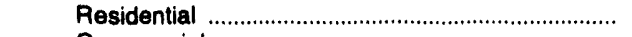 & 0 & 0 & 0 & 0 & 0 \\
\hline 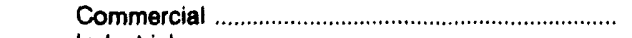 & 890,008 & 155,032 & 170,780 & 67,248 & 0 \\
\hline Industrial & 0 & 0 & 0 & 0 & 0 \\
\hline 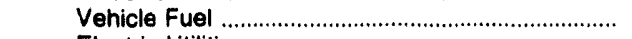 & 0 & 0 & 0 & 0 & 0 \\
\hline 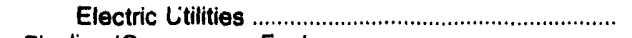 & 0 & 0 & 0 & 0 & 0 \\
\hline 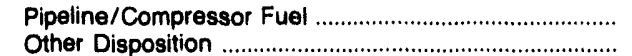 & $\begin{array}{r}181,310 \\
0\end{array}$ & $\begin{array}{r}266,305 \\
0\end{array}$ & $\begin{array}{r}42,392 \\
0\end{array}$ & $\begin{array}{r}6,575 \\
0\end{array}$ & $\begin{array}{r}2,487 \\
0\end{array}$ \\
\hline $\begin{array}{l}\text { Unaccounted For } \\
\text { Total Disposition }\end{array}$ & $\begin{array}{r}731,328 \\
68,886,344\end{array}$ & $\begin{array}{r}620,008 \\
33,576,634\end{array}$ & $\begin{array}{r}942,024 \\
68,884,695\end{array}$ & $\begin{array}{r}89,796 \\
5,053,492\end{array}$ & $\begin{array}{r}73,338 \\
2,198,435\end{array}$ \\
\hline
\end{tabular}

the use of natural gas. Vehicle fleets are presently being converted to natural gas and other alternative fuels.

Three natural gas pipelines serve Washington Gas. Columbia Gas Transmission's pipeline goes through the Virginia, Maryland, and West Virginia portions of Washington Gas' service area. CNG Transmission's pipeline goes through the Frederick, Maryland, and Northern Virginia portions of the companies' service area. Transco's pipeline goes through the Virginia and Maryland portions of the companies' service area. Columbia Gas Tranmission has filed for bankruptcy and therefore is operating under federal bankruptcy laws. This action has produced no adverse effects in their service to Washington Gas. The bankruptcy court's approval of the rejection of high-cost gas contracts has resulted in reduced cost of gas provided by Columbia Gas Transmission.
Washington Gas is able to meet nearly two-thirds of its extreme weather needs from storage and from company-owned facilities. Washington Gas owns two propane-air plants for peak needs and a gas storage facility in Hampshire, West Virginia.

Washington Gas worked with local organizations (both Government and private) in the Washington, D.C. metropolitan area, to encourage the use of natural gas vehicles. The company joined with Mobil Oil to open a public natural gas refueling station in Virginia; consulted with Arlington County in Virginia to convert seven of its fleet vehicles to natural gas; and worked with the Washington Metropolitian Area Transit Authority to pilot test 29 of its support service vehicles on natural gas. Washington, D.C. Public Schools acquired 10 natural gas powered school buses for its fleet. The buses were purchased through a U.S. Department of Energy grant. 
Table 58. Washington Gas Llght Co. Natural Gas Data, 1992 (Continued) (Thousand Cubic Feet)

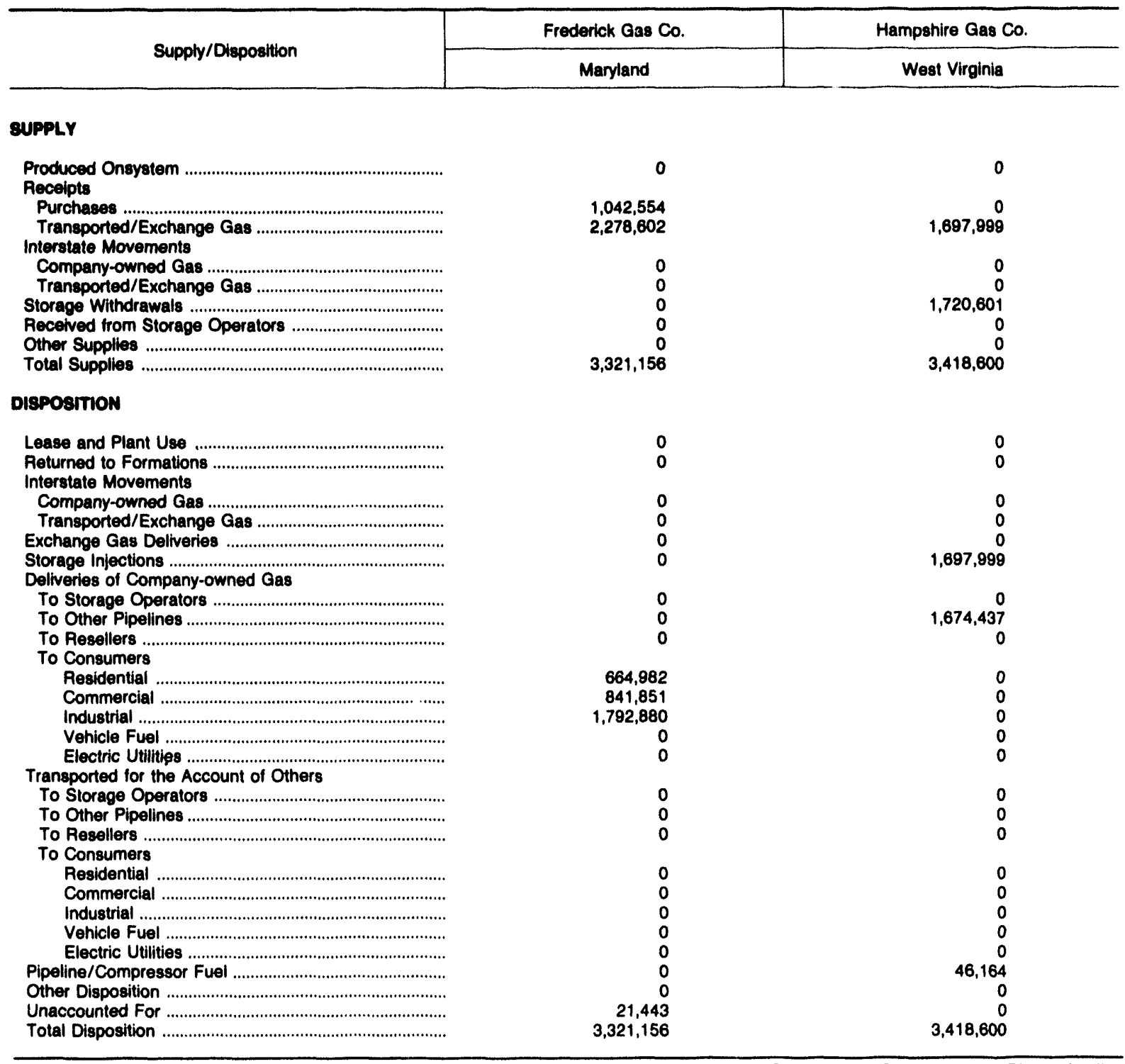

Source: Energy Information Administration (EIA), Form EIA-176, "Annual Report of Natural and Supplemental Gas Supply and Disposition." 
Table 59. Washington Gas Light Co.

Interstate Flows of Natural Gas, 1992

(Thousand Cubic Feet)

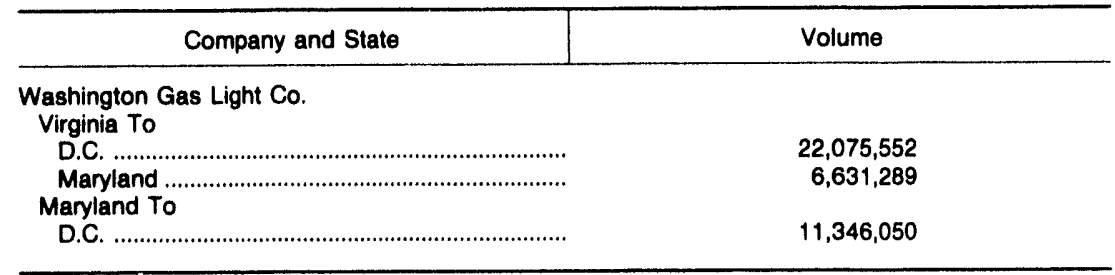

Source: Energy Information Administration (EIA), Form EIA-176, "Annual Report of Natural and Supplemental Gas Supply and Disposition." 


\section{Western Resources, Inc.}

In March 1992, the Kansas Power and Light Company officially merged with Kansas Gas and Electric. As a result of the merger, the two utility companies were renamed Western Resources, Inc. In this agreement, Kansas Gas and Electric became a wholly owned subsidiary of Western Resources.

The company is a combination natural gas and electric utility, serving customers in Kansas, Missouri, and Oklahoma. The company has a wholly owned subsidiary, Astra Resources, that is involved in several separate energy-related activities. These include Rangeline Corporation, a gas marketer; Contract Compression, a provider of natural gas compression service for producers in New Mexico, Texas, Louisiana, the Gulf of Mexico, and Mississippi; and TRIARK Gas Gathering, a provider of gas gathering and processing services in the Arkoma Basin.

Western Resources, Inc., operates an intrastate natural gas transmission pipeline system in Kansas and purchases from interstate pipeline companies for distribution in the three States where it conducts business. Western owns a natural gas underground storage field in south central Kansas and leases other storage capacity in Michigan.

Figure 43. Western Resources, Inc., 1992

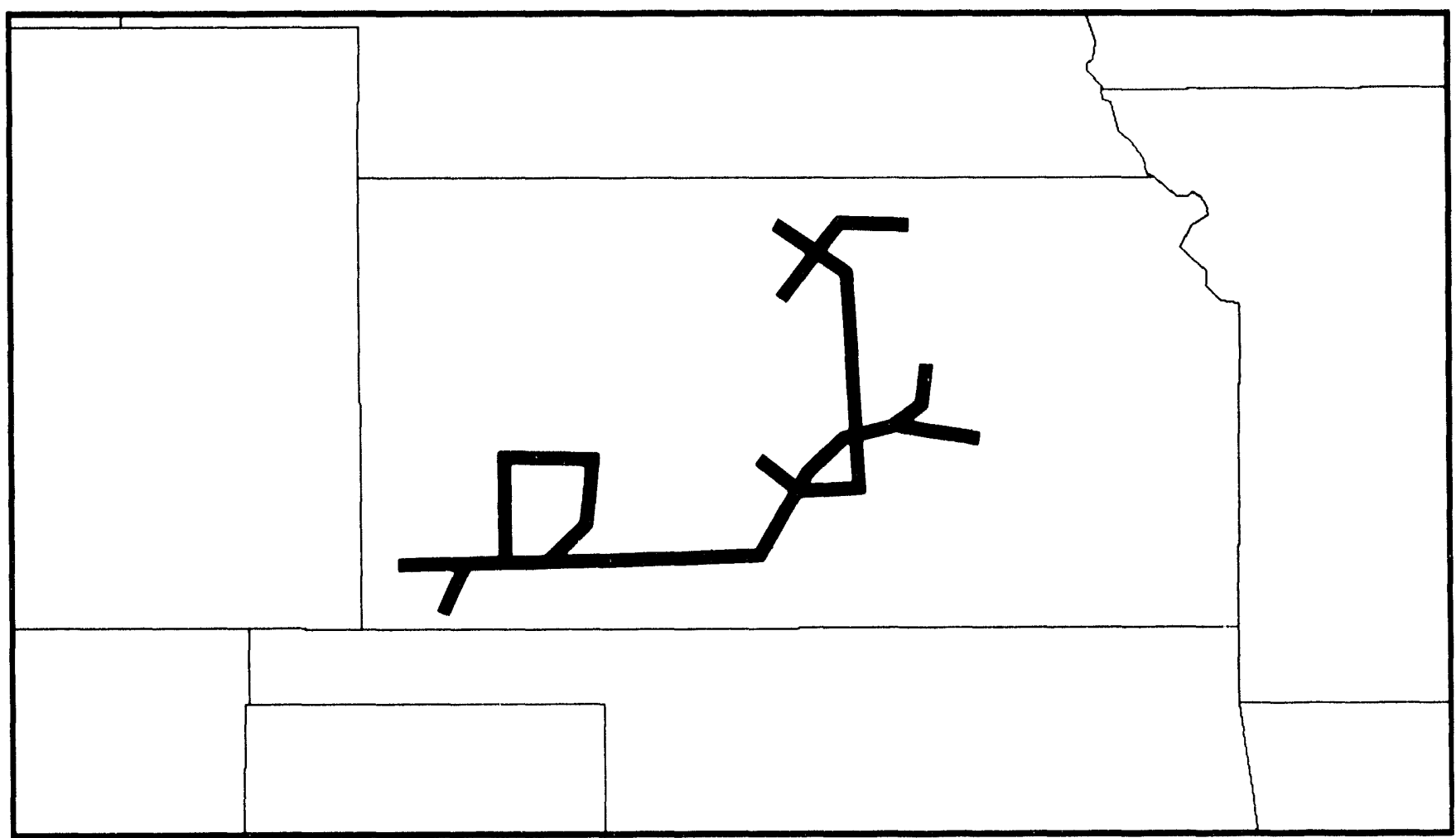

Source: Energy Information Administration (E|A), Form EIA-176, "Annual Report of Natural and Supplemental Gas Supply and Disposition." 
Table 60. Western Resources Inc., Natural Gas Data, 1992 (Thousand Cubic Feet)

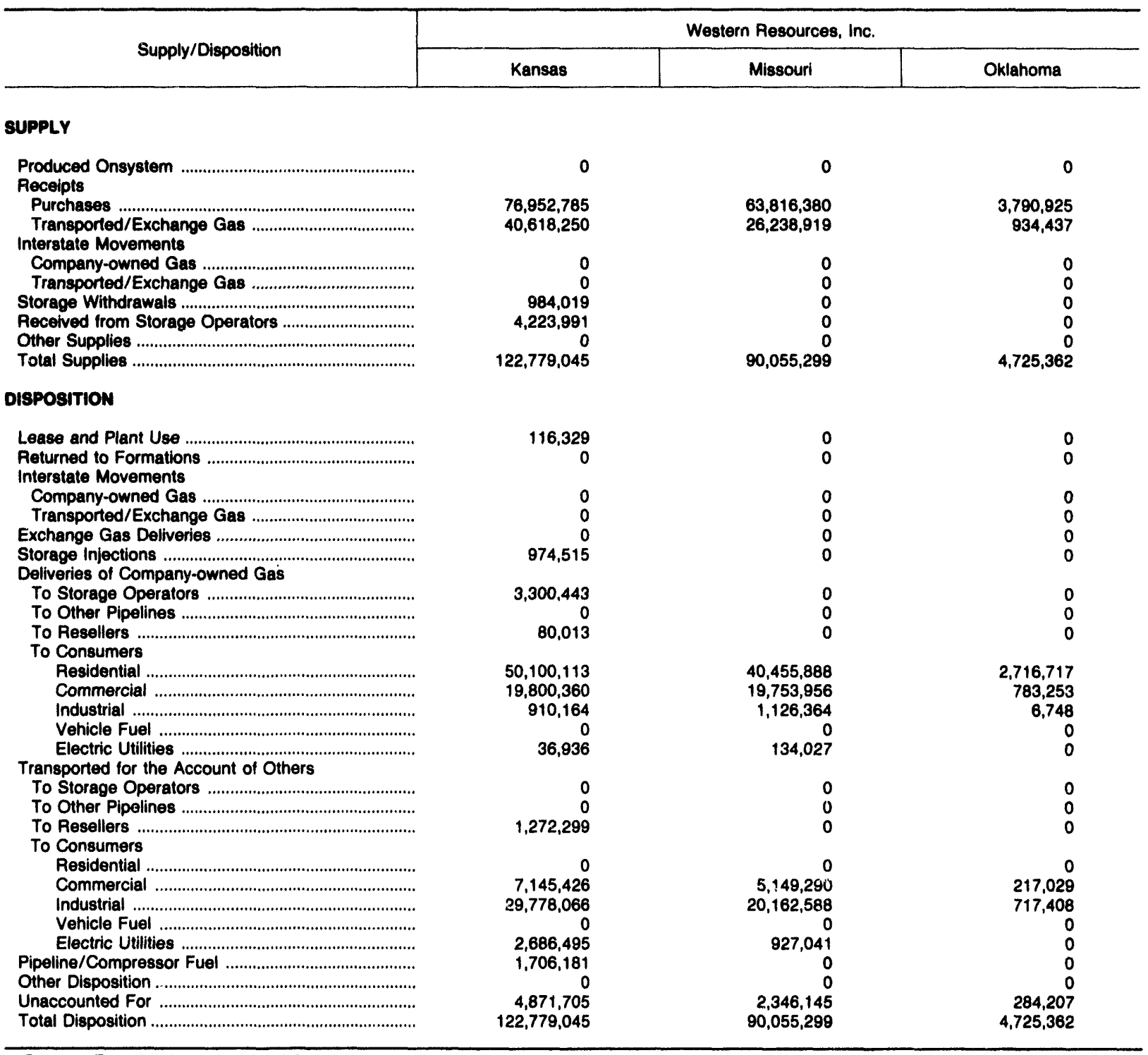

Source: Energy Information Administration (ElA), Form ElA-176, "Annual Report of Natural and Supplemental Gas Supply and Disposition."

Natural gas is distributed by Western Resources in Kansas, Missouri, and Oklahoma in 519 communities with slightly more than 1 million customers. In 1992, the company delivered 92 billion cubic feet of natural gas to residential customers, 52 billion cubic feet to commercial customers, and 52 billion cubic feet to industrial customers. In addition, they also delivered a small volume to resellers in Kansas.

Western Resources provides natural gas to an Amocorun retail compressed natural gas (CNG) fueling sta- tion. Presently, the company includes a fleet of 21 dedicated natural gas fueled vehicles and expects to add 40 to 50 more natural gas vehicles through normal replacements in 1993.

Western Resources has agreed to sell its Missouri natural gas properties and operations to Southern Union Gas. The service area covers 460,000 Missouri customers, about 42 percent of the existing customer base of Western Resources. 


\section{The Williams Companies, Inc.}

The Williams Companies, Inc., provides regional pipeline, gathering, and processing services. Its natural gas subsidiaries include Northwest Pipeline Corporation and Williams Natural Gas Co. It also owns 50 percent of Kern River Pipeline Co. In addition, it owns 2 gas gathering and processing systems located in the San Juan Basin of New Mexico and Colorado and the Rocky Mountain producing area of Wyoming.

Northwest Pipeline is a 3,500-mile pipeline system that connects Canada and the Pacific Northwest with the Rocky Mountain area. Kern River provides gas supplies to the California market. Northwest completed a mainline expansion to 2.5 billion cubic feet in 1993 and is planning a second expansion in 1995. Kern River will also be expanded by up to 30 percent by adding compression. Kern River first went into operation in February 1992 and by July 1992 was operating at full capacity.

The Manzanares and Opal gas gathering and processing facilities serving the San Juan Basin of Colorado and New Mexico and south west Wyoming, respectively have expanded. Processing capacity on each of the systems has expanded to 575 million cubic feet per day. Prior to the expansion the Manzanares had a processing capacity of 440 million cubic feet per day and the Opal facility had a capacity of 425 million cubic feet per

Figure 44. The Williams Companies, Inc., 1992

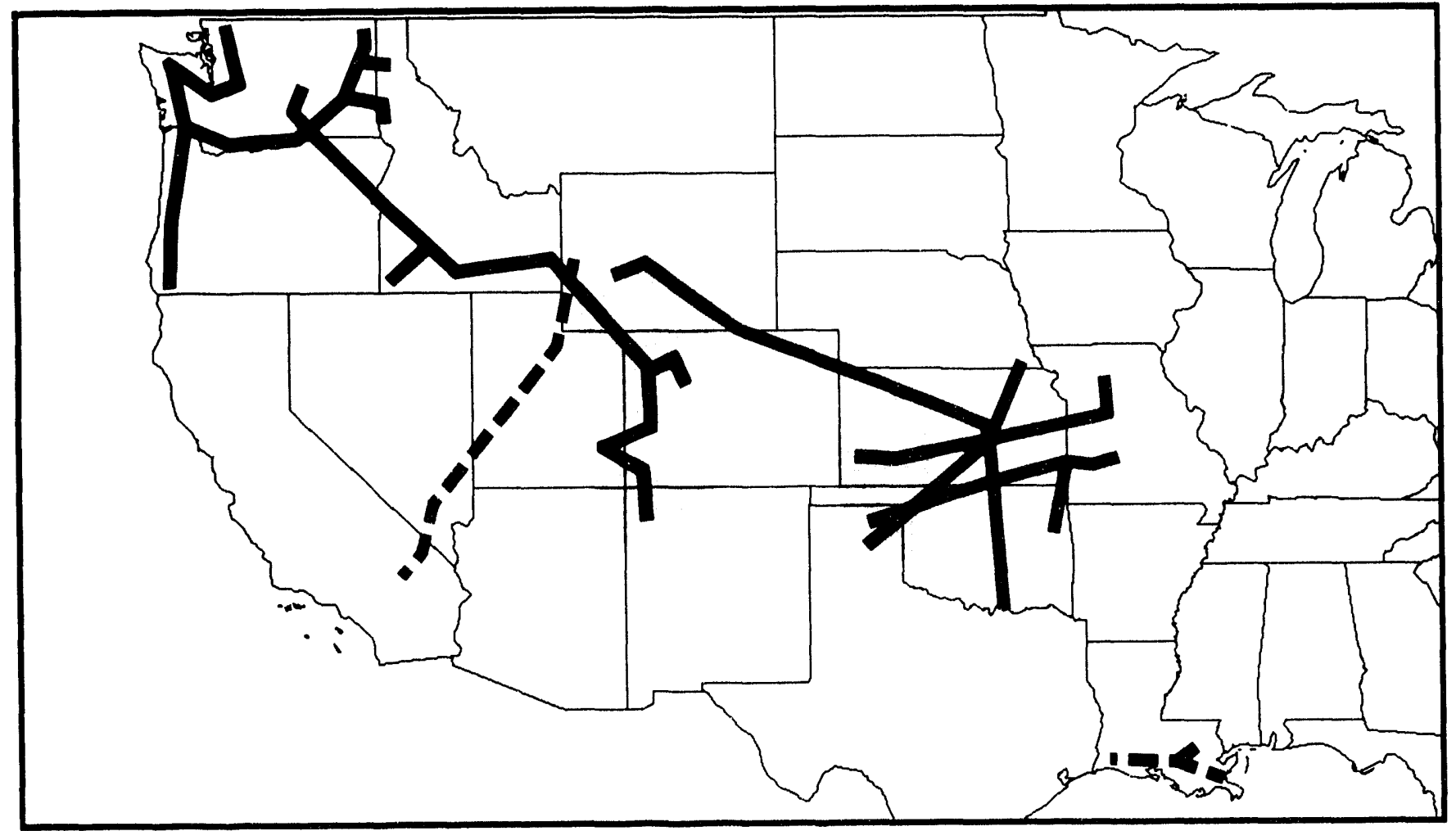

Source: Energy Information Administration (EIA), Form EIA-176, "Annual Report of Natural and Supplemental Gas Supply and Disposition."

Supply Areas

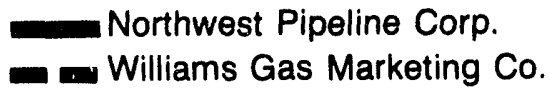

Williams Natural Gas Co.
Kern River Pipeline 
Table 61. The Williams Companies, Inc., Natural Gas Data, 1992 (Thousand Cubic Feet)

\begin{tabular}{|c|c|c|c|c|c|}
\hline \multirow{2}{*}{ Supply/Disposition } & \multicolumn{5}{|c|}{ Williams Natural Gas Co. } \\
\hline & Texas & Oklahoma & Wyoming & Colorado & Kansas \\
\hline \multicolumn{6}{|l|}{ SUPPLY } \\
\hline $\begin{array}{l}\text { Produced Onsystem } \\
\text { Receipts }\end{array}$ & 0 & 0 & 0 & 0 & 0 \\
\hline 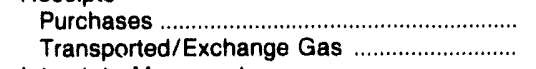 & $\begin{array}{r}6,877,224 \\
12,938,942\end{array}$ & $\begin{array}{l}39,604,503 \\
75,638,085\end{array}$ & $\begin{array}{r}4,345,325 \\
46,387,623\end{array}$ & $\begin{array}{r}740,679 \\
2,776,440\end{array}$ & $\begin{array}{r}22,938,584 \\
170,376,637\end{array}$ \\
\hline \multicolumn{6}{|l|}{ Interstate Movements } \\
\hline 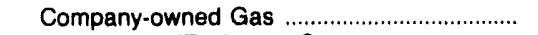 & 0 & 0 & 0 & 0 & 0 \\
\hline 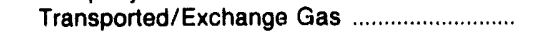 & $4,556,293$ & $39,101,368$ & 0 & $46,019,777$ & $151,624,314$ \\
\hline 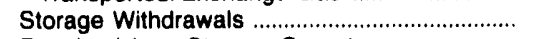 & 0 & $10,516,097$ & 0 & 0 & $40,000,601$ \\
\hline Received from Storage Operators ....................... & 0 & 0 & 0 & 0 & 0 \\
\hline 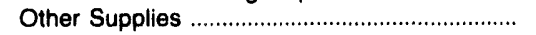 & 0 & 0 & 0 & 0 & 0 \\
\hline 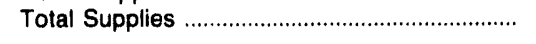 & $24,372,459$ & $164,860,053$ & $50,732,948$ & $49,536,896$ & $384,940,136$ \\
\hline \multicolumn{6}{|l|}{ DISPOSITION } \\
\hline Lease and Plant Use & 213,535 & 122,548 & 252,243 & 0 & 0 \\
\hline $\begin{array}{l}\text { Returned to Formations } \\
\text { Interstate Movements }\end{array}$ & 0 & 0 & 0 & 0 & 0 \\
\hline 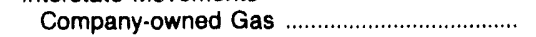 & 0 & 0 & 0 & 0 & 0 \\
\hline 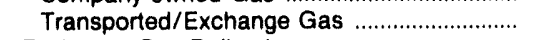 & $17,529,199$ & $119,761,277$ & $46,019,777$ & $49,149,545$ & $104,553,421$ \\
\hline 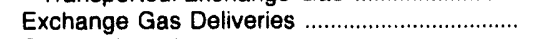 & $1,573,070$ & $1,082,615$ & 658,301 & 0 & $4,615,332$ \\
\hline 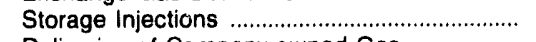 & 0 & $10,576,856$ & 0 & 0 & $35,949,970$ \\
\hline \multicolumn{6}{|l|}{ Deliveries of Company-owned Gas } \\
\hline 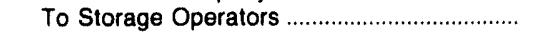 & 0 & 0 & 0 & 0 & 0 \\
\hline 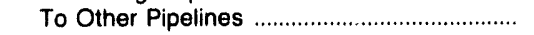 & 0 & 0 & 0 & 0 & 0 \\
\hline 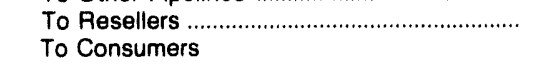 & 82 & $2,114,613$ & 0 & 17,169 & $29,801,457$ \\
\hline 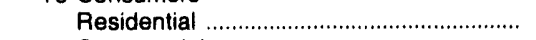 & 4,203 & 14,460 & 0 & 0 & 31,300 \\
\hline 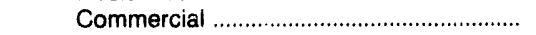 & 355 & 25,886 & 0 & 0 & 75,814 \\
\hline 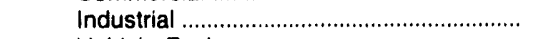 & 7,797 & 31,257 & 0 & 0 & 833,659 \\
\hline 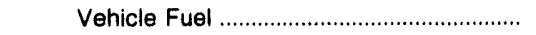 & 0 & 0 & 0 & 0 & 0 \\
\hline 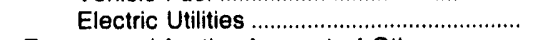 & 0 & 0 & 0 & 0 & 34,590 \\
\hline \multicolumn{6}{|l|}{ Transported for the Account of Others } \\
\hline 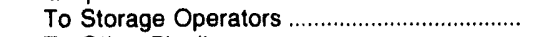 & 0 & 0 & 0 & 0 & 0 \\
\hline 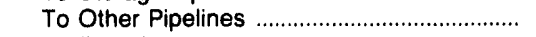 & 0 & 0 & 0 & 0 & 0 \\
\hline 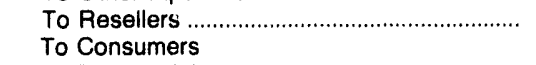 & $4,492,062$ & $22,825,412$ & $3,186,858$ & 6,575 & $143,980,322$ \\
\hline 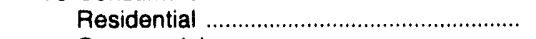 & 0 & 0 & 0 & 0 & 0 \\
\hline 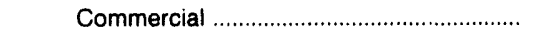 & 0 & 140,935 & 0 & 0 & 95,443 \\
\hline 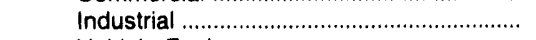 & 21,129 & $5,062,250$ & 0 & 0 & $51,873,614$ \\
\hline 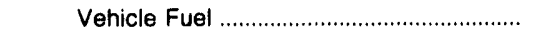 & 0 & 0 & 0 & 0 & 0 \\
\hline 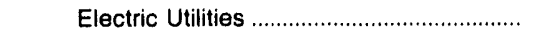 & 0 & 0 & 0 & 0 & $3,389,658$ \\
\hline 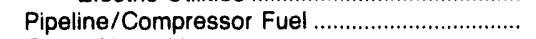 & 433,904 & $2,402,181$ & 494,796 & 295,898 & $8,255,262$ \\
\hline 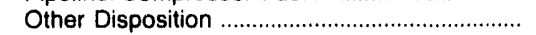 & 0 & 0 & 0 & 0 & 0 \\
\hline 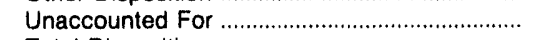 & 97,123 & 699,763 & 120,973 & 67,709 & $1,450,294$ \\
\hline 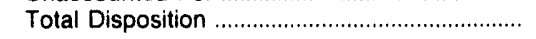 & $24,372,459$ & $164,860,053$ & $50,732,948$ & $49,536,896$ & $384,940,136$ \\
\hline
\end{tabular}

day. The Opal plant feeds a hub serving 3 pipeline companies including Kern River. The hub at Blanco, New Mexico serves 4 pipelines and is fed by the Manzanares system. Williams is planning to expand the Milagro processing plant on the Manzanares system to 750 million cubic feet per day to help meet the demand at the Blanco hub.

Williams Natural Gas Company serves seven midcontinent States. The company operates a 9,300-mile pipeline system receiving supplies from Wyoming, Kansas, Oklahoma, Colorado, and Texas. Gathering, storing, and transporting natural gas are the major in- terests of the company. Amoco Production Company is Williams Natural Gas Company's largest supplier. In December 1992 these two companies extended an agreement that ensures that Amoco will continue to supply gas on this pipeline.

William's gas storage facilities are among the largest in the gas industry. A horizontal well was construcred at one of William's storage fields in Kansas. Preiiminary tests indicate a significant increase in this wells' deliverability when compared to that of conventional vertical wells. 
Table 61. The Williams Companies, Inc., Natural Gas Data, 1992 (Continued) (Thousand Cubic Feet)

\begin{tabular}{|c|c|c|c|c|c|}
\hline \multirow{2}{*}{ Supply/Disposition } & \multicolumn{2}{|c|}{ Williams Natural Gas Co. } & \multicolumn{3}{|c|}{ Northwest Pipeline Corp. } \\
\hline & Missouri & Nebraska & Washington & Oregon & Idaho \\
\hline \multicolumn{6}{|l|}{ SUPPLY } \\
\hline 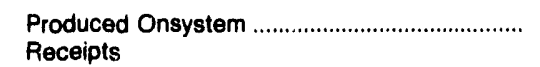 & 0 & 0 & 0 & 0 & 0 \\
\hline 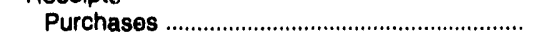 & 59,624 & 0 & 0 & 0 & 0 \\
\hline 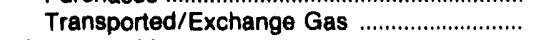 & 212,628 & 0 & $7,493,053$ & $93,426,789$ & 0 \\
\hline \multicolumn{6}{|l|}{ Interstate Movements } \\
\hline 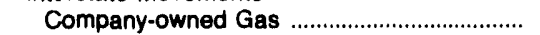 & 0 & 0 & 0 & 0 & 0 \\
\hline 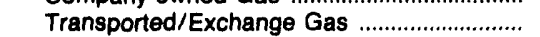 & $95,323,097$ & 885,314 & $270,477,206$ & $91,531,105$ & $101,735,317$ \\
\hline 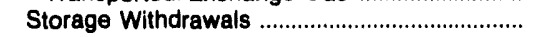 & 0 & 0 & 0 & 0 & 0 \\
\hline Received from Storage Operators .................... & 0 & 0 & $18,786,209$ & 0 & 0 \\
\hline 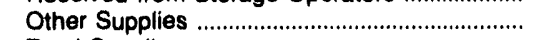 & 0 & 0 & 0 & 0 & 0 \\
\hline 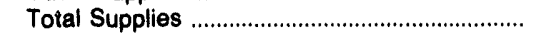 & $95,595,349$ & 885,314 & $296,756,468$ & $184,957,894$ & $101,735,317$ \\
\hline \multicolumn{6}{|l|}{ DISPOSITION } \\
\hline 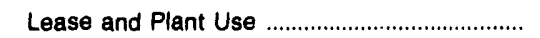 & 0 & 0 & 0 & 0 & 0 \\
\hline $\begin{array}{l}\text { Returned to Formations } \\
\text { Interstate Movements }\end{array}$ & 0 & 0 & 0 & 0 & 0 \\
\hline 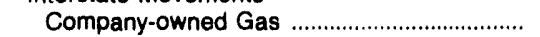 & 0 & 0 & 0 & 0 & 0 \\
\hline 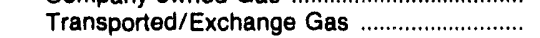 & 496,944 & 0 & $91,531,105$ & $101,735,317$ & $54,412,653$ \\
\hline 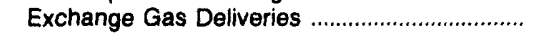 & 0 & 0 & 0 & 0 & 0 \\
\hline Storage Injections & 0 & 0 & 0 & 0 & 0 \\
\hline \multicolumn{6}{|l|}{ Deliveries of Company-owned Gas } \\
\hline 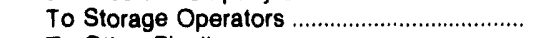 & 0 & 0 & $5,406,774$ & 0 & 0 \\
\hline 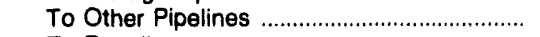 & 0 & 0 & 0 & 0 & 0 \\
\hline $\begin{array}{l}\text { To Resellers ............................................................ } \\
\text { To Consumers }\end{array}$ & $33,244,716$ & 235,689 & $16,526,359$ & 822,482 & $1,256,454$ \\
\hline 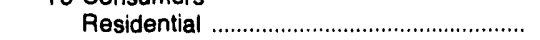 & 4,597 & 0 & 0 & 0 & 0 \\
\hline 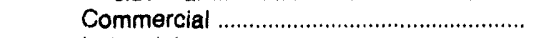 & 31,526 & 0 & 0 & 0 & 0 \\
\hline 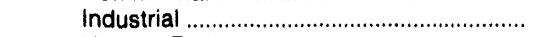 & 13,239 & 3,418 & 0 & 0 & 0 \\
\hline 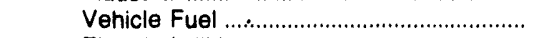 & 0 & 0 & 0 & 0 & 0 \\
\hline 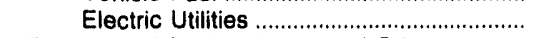 & 492 & 0 & 0 & 0 & 0 \\
\hline \multicolumn{6}{|l|}{ Transported for the Account of Others } \\
\hline 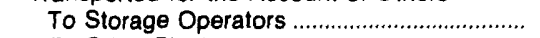 & 0 & 0 & $6,083,030$ & 0 & 0 \\
\hline 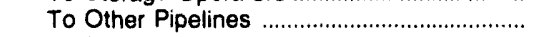 & 0 & 0 & 0 & 0 & 0 \\
\hline 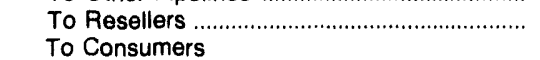 & $60,349,759$ & 645,213 & $168,526,582$ & $77,540,914$ & $45,883,104$ \\
\hline 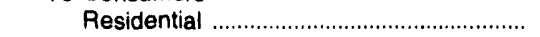 & 0 & 0 & 0 & 0 & 0 \\
\hline 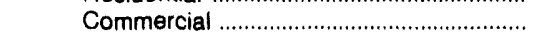 & 14,630 & 0 & 0 & 0 & 0 \\
\hline 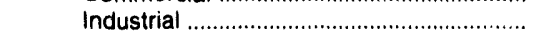 & $1,209,866$ & 0 & $8,536,425$ & $4,855,485$ & 0 \\
\hline 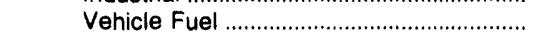 & 0 & 0 & 0 & 0 & 0 \\
\hline 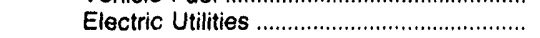 & 0 & 0 & 0 & 0 & 0 \\
\hline 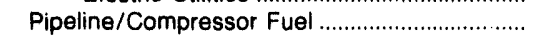 & 65,993 & 0 & 563,369 & 172,922 & 361.165 \\
\hline Other Disposition & 0 & 0 & 0 & 0 & 0 \\
\hline 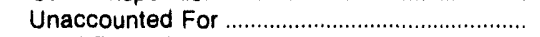 & 163,587 & 994 & $-417,176$ & $-169,226$ & $-178,059$ \\
\hline 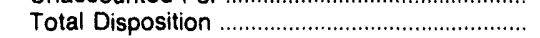 & $95,595,349$ & 885,314 & $296,756,468$ & $184,957,894$ & $101,735,317$ \\
\hline
\end{tabular}


Table 61. The Williams Companles, Inc., Natural Gas Data, 1992 (Continued) (Thousand Cubic Feet)

\begin{tabular}{|c|c|c|c|c|c|}
\hline \multirow{2}{*}{ Supply/Disposition } & \multicolumn{4}{|c|}{ Northwest Pipeline Corp. } & \multirow{2}{*}{$\begin{array}{r}\begin{array}{r}\text { Williams Gas } \\
\text { Marketing Co }\end{array} \\
\text { Oklahoma }\end{array}$} \\
\hline & Wyoming & Utah & Colorado & New Mexico & \\
\hline \multicolumn{6}{|l|}{ SUPPLY } \\
\hline $\begin{array}{l}\text { Produced Onsystem } \\
\text { Peceipts }\end{array}$ & 0 & 0 & 0 & 0 & 0 \\
\hline $\begin{array}{l}\text { Purchases } \\
\text { Transported/Exchange Gas ............................... } \\
\text { Interstate Movements }\end{array}$ & $\begin{array}{r}2,237,991 \\
218,740,462\end{array}$ & $\begin{array}{r}0 \\
6,473,592\end{array}$ & $\begin{array}{r}0 \\
44,718,619\end{array}$ & $\begin{array}{r}0 \\
86,055,737\end{array}$ & $\begin{array}{r}873,669 \\
0\end{array}$ \\
\hline 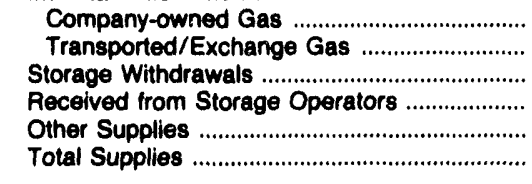 & $\begin{array}{r}0 \\
14,119,976 \\
0 \\
0 \\
0 \\
235,098,429\end{array}$ & $\begin{array}{r}0 \\
44,074,225 \\
0 \\
13,891,164 \\
0 \\
64,438,981\end{array}$ & $\begin{array}{r}0 \\
77,702,975 \\
0 \\
0 \\
0 \\
122,421,594\end{array}$ & $\begin{array}{r}0 \\
0 \\
0 \\
0 \\
0 \\
86,055,737\end{array}$ & $\begin{array}{r}0 \\
0 \\
0 \\
0 \\
0 \\
873,669\end{array}$ \\
\hline \multicolumn{6}{|l|}{ DISPOSITION } \\
\hline 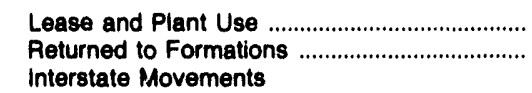 & $\begin{array}{r}2,834,665 \\
0\end{array}$ & $\begin{array}{l}0 \\
0\end{array}$ & $\begin{array}{r}5,326,885 \\
0\end{array}$ & $\begin{array}{l}0 \\
0\end{array}$ & $\begin{array}{l}0 \\
0\end{array}$ \\
\hline 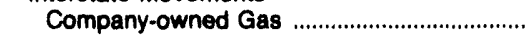 & 0 & 0 & 0 & 0 & 0 \\
\hline 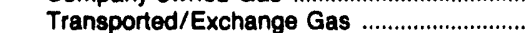 & $44,074,225$ & $54,498,936$ & 0 & $23,204,039$ & 0 \\
\hline 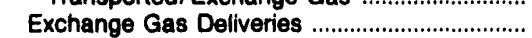 & 0 & 0 & 0 & $\begin{array}{r}0,20,000 \\
0\end{array}$ & 0 \\
\hline $\begin{array}{l}\text { Storage Injections ................................................ } \\
\text { Deliveries of Company-owned Gas }\end{array}$ & 0 & 0 & 0 & 0 & 0 \\
\hline 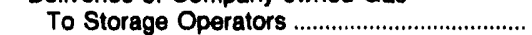 & 0 & $3,310,111$ & 0 & 0 & 0 \\
\hline To Other Pipelines & 0 & 0 & 0 & 0 & 0 \\
\hline 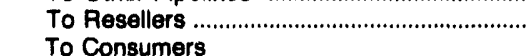 & 15,865 & 15,831 & 131,391 & 0 & 0 \\
\hline 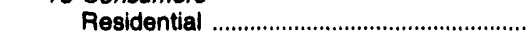 & 0 & 0 & 0 & 0 & 0 \\
\hline 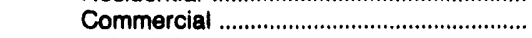 & 0 & 0 & 0 & 0 & 0 \\
\hline 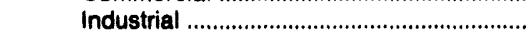 & 1,925 & 0 & 1,169 & 0 & 873,669 \\
\hline Vehicle Fuel & 0 & 0 & 0 & 0 & 0 \\
\hline 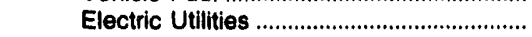 & 0 & 0 & 0 & 0 & 0 \\
\hline Transported for the Account of Others & & & & & \\
\hline 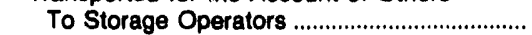 & 0 & $1,763,791$ & 0 & 0 & 0 \\
\hline 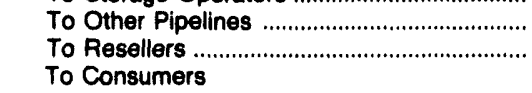 & $\begin{array}{r}182,639,683 \\
4,373,176\end{array}$ & $\begin{array}{r}0 \\
4,715,988\end{array}$ & $\begin{array}{l}93,079,296 \\
22,193,433\end{array}$ & $\begin{array}{r}52,894,427 \\
8,734,621\end{array}$ & $\begin{array}{l}0 \\
0\end{array}$ \\
\hline 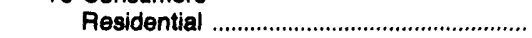 & 0 & 0 & 0 & 0 & 0 \\
\hline 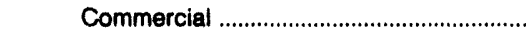 & 0 & 0 & 0 & 0 & 0 \\
\hline 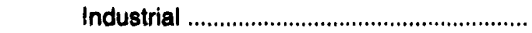 & 0 & 0 & 0 & 0 & 0 \\
\hline 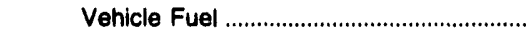 & 0 & 0 & 0 & 0 & 0 \\
\hline 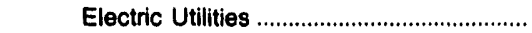 & 0 & 0 & 0 & 0 & 0 \\
\hline Pipeline/Compressor Fuel .................................. & $1,547,242$ & 154,470 & $1,938,300$ & $1,350,499$ & 0 \\
\hline 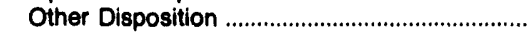 & 0 & 0 & 0 & 0 & 0 \\
\hline Unaccounted For & $-388,352$ & $-20,146$ & $-248,880$ & $-127,849$ & 0 \\
\hline Total Disposition & $235,098,429$ & $64,438,981$ & $122,421,594$ & $86,055,737$ & 873,669 \\
\hline
\end{tabular}


Table 61. The Williams Companies, Inc., Natural Gas Data, 1992 (Continued) (Thousand Cubic Feet)

\begin{tabular}{l|l|l|l|l|l|}
\hline \multirow{2}{*}{ Supply/Disposition } & \multicolumn{3}{|c|}{ Kern River Gas Transmission Co. } \\
\cline { 2 - 5 } & Wyoming & Utah & Nevada & California & Loulsiana \\
\hline
\end{tabular}

\section{SUPPLY}

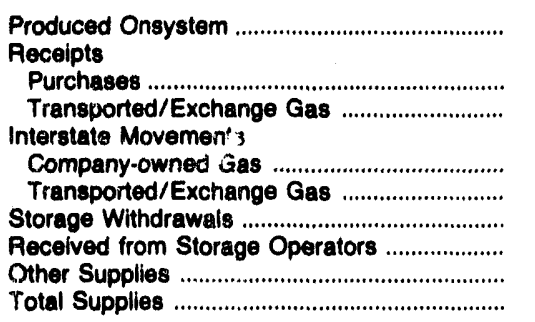

Yotal Supplies

\section{DISPOSITION}

\begin{tabular}{|c|c|c|c|c|}
\hline 0 & 0 & 0 & 0 & 0 \\
\hline $\begin{array}{r}0 \\
187,429,255\end{array}$ & $\begin{array}{l}0 \\
0\end{array}$ & $\begin{array}{l}0 \\
0\end{array}$ & $\begin{array}{l}0 \\
0\end{array}$ & $\begin{array}{r}3,536 \\
312,286,188\end{array}$ \\
\hline $\begin{array}{r}0 \\
0 \\
0 \\
0 \\
0 \\
187,429,255\end{array}$ & $\begin{array}{r}0 \\
186,226,122 \\
0 \\
0 \\
7,490 \\
186,233,612\end{array}$ & $\begin{array}{r}0 \\
185,230,734 \\
0 \\
0 \\
119,324 \\
185,350,058\end{array}$ & $\begin{array}{r}0 \\
179,996,223 \\
0 \\
0 \\
1,354,419 \\
181,350,642\end{array}$ & $\begin{array}{r}0 \\
0 \\
0 \\
0 \\
0 \\
312,289,724\end{array}$ \\
\hline $\begin{array}{l}0 \\
0\end{array}$ & $\begin{array}{l}0 \\
0\end{array}$ & $\begin{array}{l}0 \\
0\end{array}$ & $\begin{array}{l}0 \\
0\end{array}$ & $\begin{array}{l}0 \\
0\end{array}$ \\
\hline $\begin{array}{r}0 \\
186,226,122 \\
0 \\
0\end{array}$ & $\begin{array}{r}0 \\
185,230,734 \\
0 \\
0\end{array}$ & $\begin{array}{r}0 \\
179,996,223 \\
0 \\
0\end{array}$ & $\begin{array}{l}0 \\
0 \\
0 \\
0\end{array}$ & $\begin{array}{l}0 \\
0 \\
0 \\
0\end{array}$ \\
\hline $\begin{array}{l}0 \\
0 \\
0\end{array}$ & $\begin{array}{l}0 \\
0 \\
0\end{array}$ & $\begin{array}{l}0 \\
0 \\
0\end{array}$ & $\begin{array}{l}0 \\
0 \\
0\end{array}$ & $\begin{array}{r}0 \\
0 \\
3,536\end{array}$ \\
\hline $\begin{array}{l}0 \\
0 \\
0 \\
0 \\
0\end{array}$ & $\begin{array}{l}0 \\
0 \\
0 \\
0 \\
0\end{array}$ & $\begin{array}{l}0 \\
0 \\
0 \\
0 \\
0\end{array}$ & $\begin{array}{l}0 \\
0 \\
0 \\
0 \\
0\end{array}$ & $\begin{array}{l}0 \\
0 \\
0 \\
0 \\
0\end{array}$ \\
\hline $\begin{array}{r}0 \\
0 \\
113,183\end{array}$ & $\begin{array}{r}0 \\
0 \\
484,168\end{array}$ & $\begin{array}{r}0 \\
0 \\
1,986,959\end{array}$ & $\begin{array}{r}0 \\
0 \\
99,791,894\end{array}$ & $\begin{array}{r}0 \\
310,828,864 \\
0\end{array}$ \\
\hline $\begin{array}{r}0 \\
0 \\
0 \\
0 \\
0 \\
971,648 \\
118,302 \\
0 \\
187,429,255\end{array}$ & $\begin{array}{r}0 \\
0 \\
0 \\
0 \\
0 \\
513,696 \\
5,014 \\
0 \\
186,233,612\end{array}$ & $\begin{array}{r}0 \\
0 \\
2,965,314 \\
0 \\
0 \\
401,562 \\
0 \\
0 \\
185,350,058\end{array}$ & $\begin{array}{r}0 \\
0 \\
60,302,905 \\
0 \\
21,078,981 \\
0 \\
176,862 \\
0 \\
181,350,642\end{array}$ & $\begin{array}{r}0 \\
0 \\
0 \\
0 \\
0 \\
795,179 \\
67,095 \\
595,050 \\
312,289,724\end{array}$ \\
\hline
\end{tabular}

Source: Energy Information Administration (ElA), Form ElA-176, "Annual Report of Netural and Supplemental Gas Supply and Disposition." 
Table 62. The Williams Companies, Inc., Interstate Flows of Natural Gas, 1992 (Thousand Cubic Feet)

\begin{tabular}{|c|c|c|c|}
\hline Company and State & Volume & Company and State & Volume \\
\hline 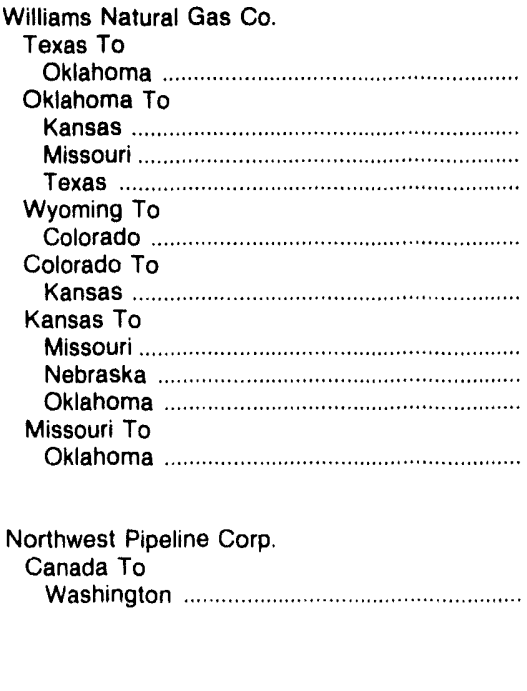 & $\begin{array}{r}17,529,199 \\
102,474,769 \\
12,730,215 \\
4,556,293 \\
46,019,777 \\
49,149,545 \\
82,592,882 \\
885,314 \\
21,075,225 \\
496,944\end{array}$ & 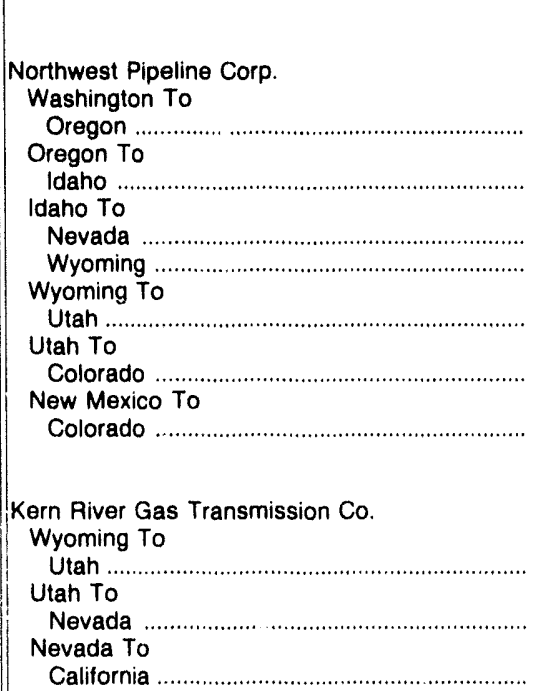 & $\begin{array}{r}91,531,105 \\
101,735,317 \\
40,292,677 \\
14,119,976 \\
44,074,225 \\
54,498,936 \\
23,204,039\end{array}$ \\
\hline
\end{tabular}

Source: Energy Information Administration (EIA), Form ElA-176, "Annual Report of Natural and Supplemental Gas Supply and Disposition." 


\section{Williston Basin Interstate Pipeline Co.}

Williston Basin Interstate Pipeline Company is a wholly owned subsidiary of MDU Resources Group, Inc. MDU has five subsidiary companies: MontanaDakota Utilities Company, Knife River Coal Mining Company, Prairielands Energy Marketing, Inc., Fidelity Oil Group, and Williston Basin Interstate Pipeline Company. These companies are involved in electric and natural gas services, coal and aggregate mining operations, energy marketing, oil and natural gas production and natural gas pipelines.

Natural gas production, sales to resellers, and underground storage are Williston Basin's primary activities. In 1993, the natural gas transportation services, pro- vided through Williston Basin's pipeline system, will extend into Canada in addition to the current services in Montana, North Dakota, South Dakota and Wyoming. Six other pipeline systems located in Wyoming, Montana, and North Dakota, are connected to the Williston Basin system, extending the transportation of natural gas supplies throughout the Nation.

The company owns and operates over 4,100 miles of pipeline, and 29 compressor stations. The five natural gas basins, from which natural gas supplies are produced from owned reserves or acquired from producers and processors, are located near the Williston Basin system.

Figure 45. Williston Basin Interstate Pipeline Co., 1992

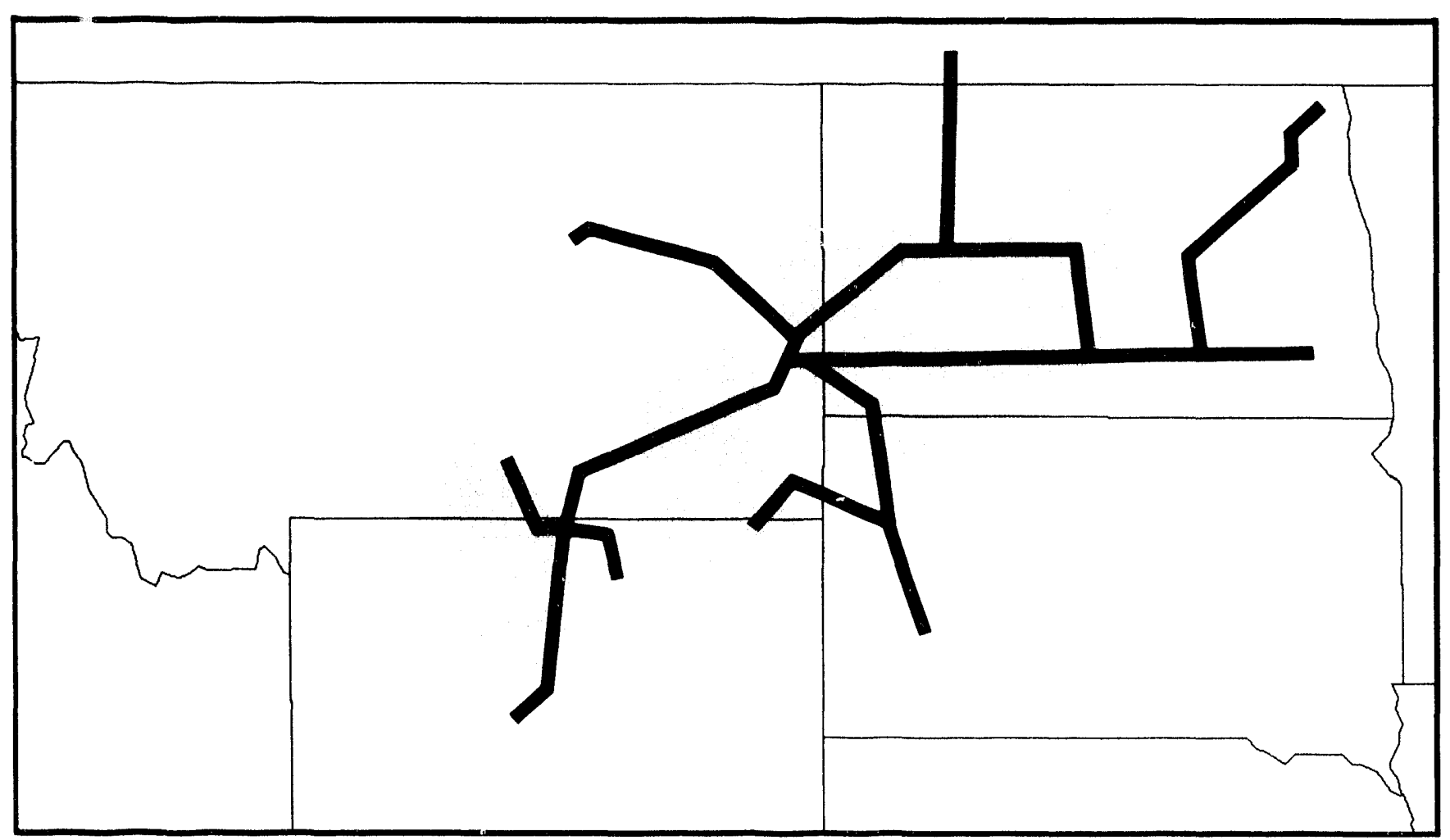

Source: Energy Information Administration (EIA). Form EIA-176, "Annual Report of Natural and Supplemental Gas Supply and Disposition." 
Table 63. Williaton Basin Interstate Pipeline Co. Natural Cas Data, 1992 (Thousand Cubic Feet)

\begin{tabular}{|c|c|c|c|c|}
\hline \multirow{2}{*}{ Supply/Disposition } & \multicolumn{4}{|c|}{ Williston Basin Interstate Pipeline Co. } \\
\hline & Montana & North Dakota & South Dakota & Wyoming \\
\hline \multicolumn{5}{|l|}{ EUPPLY } \\
\hline $\begin{array}{l}\text { Produced Onsystem } \\
\text { Recelpte }\end{array}$ & 0 & 0 & 0 & 0 \\
\hline 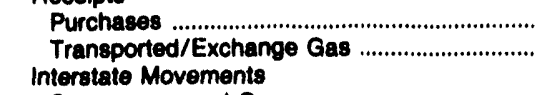 & $\begin{array}{l}5,256,741 \\
7,629,860\end{array}$ & $\begin{array}{r}3,975,283 \\
29,583,704\end{array}$ & $\begin{array}{l}262,860 \\
751,147\end{array}$ & $\begin{array}{l}7,411,496 \\
7,627,823\end{array}$ \\
\hline 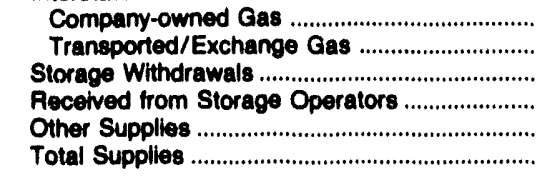 & $\begin{array}{r}0 \\
21,604,747 \\
18,158,251 \\
0 \\
0 \\
52,649,599\end{array}$ & $\begin{array}{r}0 \\
10,880,480 \\
0 \\
0 \\
0 \\
44,439,467\end{array}$ & $\begin{array}{r}0 \\
6,969,268 \\
0 \\
0 \\
0 \\
7,983,275\end{array}$ & $\begin{array}{r}0 \\
14,427,862 \\
10,908,974 \\
0 \\
0 \\
40,376,155\end{array}$ \\
\hline \multicolumn{5}{|l|}{ DIsposition } \\
\hline 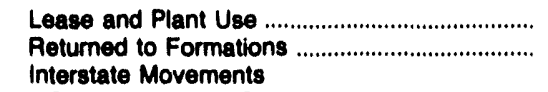 & $\begin{array}{l}0 \\
0\end{array}$ & $\begin{array}{r}68,375 \\
0\end{array}$ & $\begin{array}{l}0 \\
0\end{array}$ & $\begin{array}{r}74,822 \\
0\end{array}$ \\
\hline Company-owned Gas .................................. & 0 & $\begin{array}{r}0 \\
0\end{array}$ & 0 & 0 \\
\hline Transported/Exchange Gas ............................... & $31,612,171$ & $13,353,173$ & 665,439 & $8,251,574$ \\
\hline Exchange Gas Deliveries ......................................... & 0 & 0 & 0 & 0 \\
\hline $\begin{array}{l}\text { Storage Injections } \\
\text { Delveries of Company-owned Gas }\end{array}$ & $6,026,623$ & 0 & 0 & $2,123,274$ \\
\hline 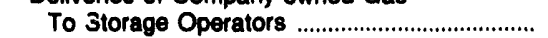 & 0 & 0 & 0 & 0 \\
\hline 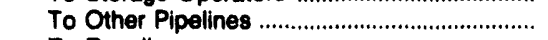 & 0 & 0 & 0 & 0 \\
\hline $\begin{array}{l}\text { To Resellers } \\
\text { To Consumers }\end{array}$ & $4,775,405$ & $6,936,640$ & $2,408,865$ & $1,867,869$ \\
\hline 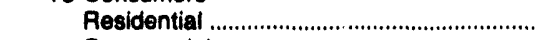 & 0 & 0 & 0 & 0 \\
\hline 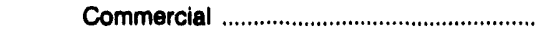 & 0 & 0 & 0 & 0 \\
\hline 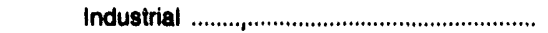 & 0 & 0 & 0 & 0 \\
\hline 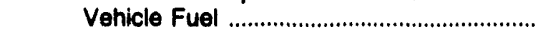 & 0 & 0 & 0 & 0 \\
\hline 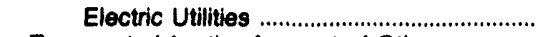 & 0 & 0 & 0 & 0 \\
\hline Transported for the Account of Others & & & & \\
\hline To Storage Operators ......................................... & 0 & 0 & 0 & 0 \\
\hline 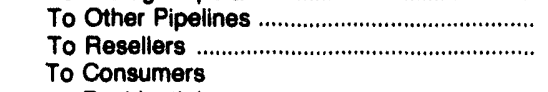 & $\begin{array}{r}48,609 \\
7,685,581\end{array}$ & $\begin{array}{r}13,334,697 \\
9,368,596\end{array}$ & $\begin{array}{r}0 \\
4,353,196\end{array}$ & $\begin{array}{r}24,836,345 \\
2,897,203\end{array}$ \\
\hline 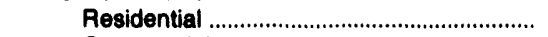 & 0 & 0 & 0 & 0 \\
\hline 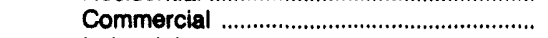 & 0 & 0 & 0 & 0 \\
\hline 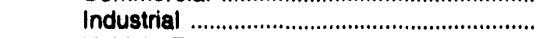 & 47,191 & $1,127,387$ & 499,466 & 4,848 \\
\hline 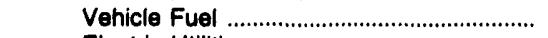 & 0 & 0 & 0 & 0 \\
\hline 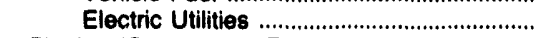 & 0 & 0 & 0 & 0 \\
\hline Pipeline/Compressor Fuel ..................................... & $1,634,481$ & 388,637 & 60,890 & 623,230 \\
\hline 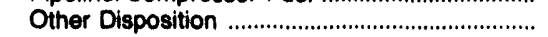 & 0 & 0 & 0 & 0 \\
\hline $\begin{array}{l}\text { Unaccounted For } \\
\text { Total Disposition }\end{array}$ & $\begin{array}{r}819,528 \\
52,649,599\end{array}$ & $\begin{array}{r}-138,038 \\
44,439,467\end{array}$ & $\begin{array}{r}-4,581 \\
7,983,275\end{array}$ & $\begin{array}{r}-303,010 \\
40,376,155\end{array}$ \\
\hline
\end{tabular}

During 1992 Williston Basin began a pipeline construction project to link its pipeline with Canadian natural gas supply sources. Williston Basin also increased its market by including eastern North Dakota. The link with this area was accomplished by the construction of a 49-mile extension to the pipeline.

Montana was the primary supplier of natural gas for Williston Basin in 1992, with 52.6 billion cubic feet. Natural gas transported for others to pipelines and resellers accounted for a significant portion (51 percent) of the 44.4 billion cubic feet of gas supplied to North Dakota markets.

In the Wyoming markets more than one-half of the gas transported by Williston Basin was for other pipelines.
In the South Dakota markets 55 percent of Williston's operations were dedicated to the transportation of gas for resellers.

In October 1992, Williston Basin began sales of the natural gas inventory held under a repurchase commitment. From its inception through the end of 1992, approximately 7 percent of the total volume was sold, and sales are continuing in 1993.

The Montana-Dakota Utilities Company has 10 natural gas vehicle refueling stations operating in its service area. Over 400 natural gas vehicles are operating by natural gas supplied through these refueling stations. Four additional refueling stations were planned in the region in 1993. 
Table 63. Williston Basin Interstate Pipeline Co. Natural Gas Data, 1992 (Continued) (Thousand Cubic Feet)

\begin{tabular}{|c|c|c|c|c|}
\hline \multirow{2}{*}{ Supply/Disposition } & \multicolumn{4}{|c|}{ Montana-Dakota Utilities Co. } \\
\hline & Montana & North Dakota & South Dakota & Wyoming \\
\hline \multicolumn{5}{|l|}{ BUPPLY } \\
\hline \multicolumn{5}{|l|}{ 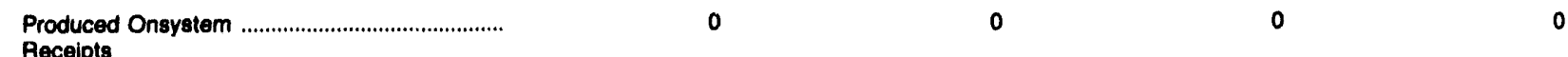 } \\
\hline Purchases & $\begin{array}{l}8,274,314 \\
4,209,059\end{array}$ & $\begin{array}{r}11,776,303 \\
4,516,279\end{array}$ & $\begin{array}{l}4,414,490 \\
2,347,511\end{array}$ & $\begin{array}{l}1,848,103 \\
1,841,184\end{array}$ \\
\hline \multicolumn{5}{|l|}{ Interstate Movements } \\
\hline 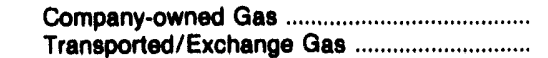 & $\begin{array}{l}0 \\
0\end{array}$ & $\begin{array}{l}0 \\
0\end{array}$ & $\begin{array}{l}0 \\
0\end{array}$ & $\begin{array}{l}0 \\
0\end{array}$ \\
\hline Storage Withdrawals & 0 & 0 & 0 & 0 \\
\hline 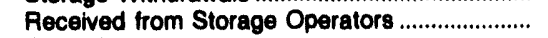 & 0 & 0 & 0 & 0 \\
\hline Other Supplies & 0 & 0 & 0 & 0 \\
\hline 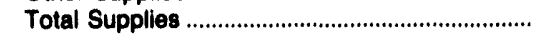 & $12,483,373$ & $16,292,582$ & $6,762,001$ & $3,789,287$ \\
\hline \multicolumn{5}{|l|}{ DISPOSITION } \\
\hline Lease and Plant Use & 0 & 0 & 0 & 0 \\
\hline Returned to Formations ............................................. & 0 & 0 & 0 & 0 \\
\hline \multicolumn{5}{|l|}{ 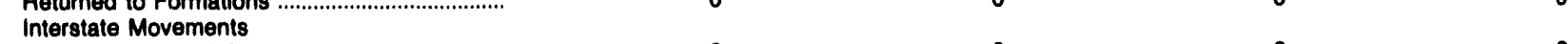 } \\
\hline 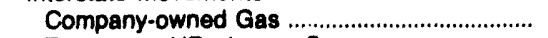 & 0 & 0 & 0 & 0 \\
\hline 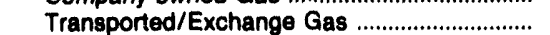 & 0 & 0 & 0 & 0 \\
\hline 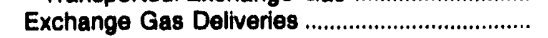 & 0 & 0 & 0 & 0 \\
\hline Storage Injections & 0 & 0 & 0 & 0 \\
\hline \multicolumn{5}{|l|}{ Deliveries of Company-owned Gas } \\
\hline To Storage Operators ............................................ & 0 & 0 & 0 & 0 \\
\hline 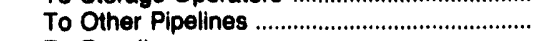 & 0 & 0 & 0 & 0 \\
\hline \multirow{2}{*}{\multicolumn{2}{|c|}{ To Consumers }} & & 0 & 0 \\
\hline & $5,154,432$ & $7,344,247$ & $2,637,001$ & $1,076,678$ \\
\hline 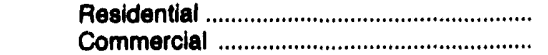 & $2,694,191$ & $3,991,098$ & $1,480,454$ & 691,414 \\
\hline 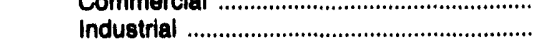 & 24,387 & 38,499 & 157,613 & 29,389 \\
\hline 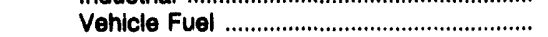 & 2,107 & 3,422 & 4,806 & 8 \\
\hline 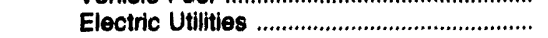 & 12,465 & 4,736 & 0 & 0 \\
\hline \multicolumn{5}{|l|}{ Transported for the Account of Others } \\
\hline 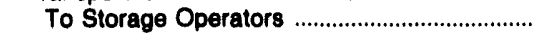 & 0 & 0 & 0 & 0 \\
\hline 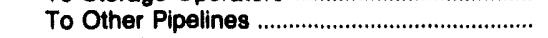 & 0 & 0 & 0 & 0 \\
\hline 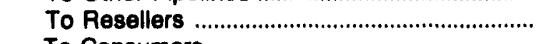 & 0 & 0 & 0 & 0 \\
\hline \multicolumn{5}{|l|}{ To Consumers } \\
\hline 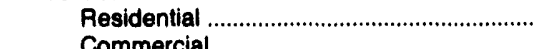 & & $2.070,317$ & 911.490 & $\begin{array}{r}u \\
53.818\end{array}$ \\
\hline & $\begin{array}{r}262,512 \\
3,847,558\end{array}$ & $2,445,962$ & 727,251 & $\begin{array}{r}53,818 \\
1887,366\end{array}$ \\
\hline & $\begin{array}{r}3,847,558 \\
0\end{array}$ & $2,440,000$ & $\begin{array}{r}727,251 \\
0\end{array}$ & $\begin{array}{r}1,887,366 \\
0\end{array}$ \\
\hline 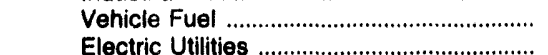 & $\begin{array}{r}0 \\
98,989\end{array}$ & 0 & 708.770 & 0 \\
\hline & $\begin{array}{r}98,989 \\
0\end{array}$ & 0 & 108, 0 & 0 \\
\hline Pipeline/Compressor Fuel ................................... & $\begin{array}{l}0 \\
0\end{array}$ & 0 & 0 & $\begin{array}{l}0 \\
0\end{array}$ \\
\hline 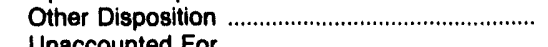 & $\begin{array}{r}0 \\
386732\end{array}$ & & & \\
\hline $\begin{array}{l}\text { Unaccounted For } \\
\text { Total Disposition }\end{array}$ & $\begin{array}{r}386,732 \\
12,483,373\end{array}$ & $\begin{array}{r}394,301 \\
16,292,582\end{array}$ & $\begin{array}{r}134,616 \\
6,762,001\end{array}$ & $\begin{array}{r}50,614 \\
3,789,287\end{array}$ \\
\hline
\end{tabular}

Source: Energy Information Administration (EIA), Form ElA-176, "Annual Report of Natural and Supplemental Gas Supply and Disposition." 
Table 64. Williston Basin Interstate Plpeline Co. Interstate Flows of Natural Gas, 1992 (Thousand Cubic Feet)

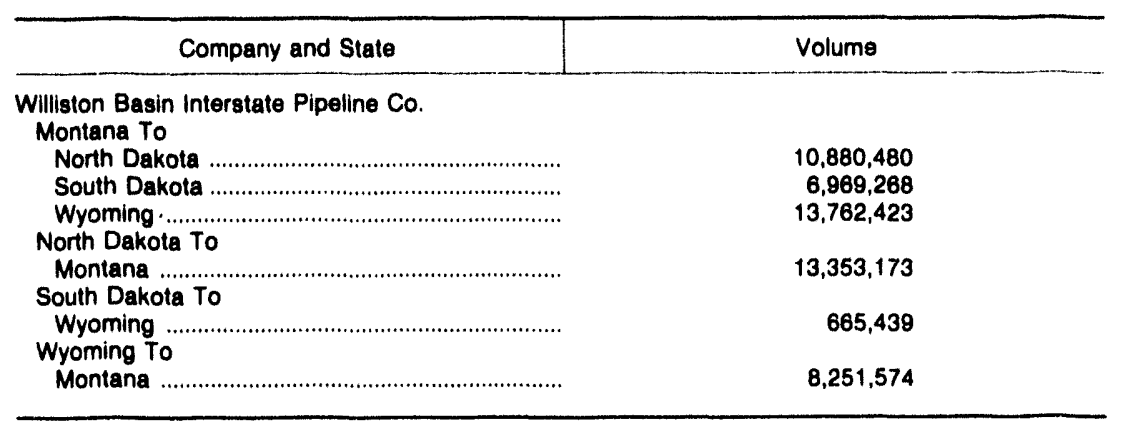

Source: Energy Information Administration (EIA), Form EIA-176, "Annual Report of Natural and Supplemental Gas Supply and Disposition." 


\section{Wisconsin Gas Co.}

Wisconsin Gas Company is the largest subsidiary of WICOR, Inc., which is also the parent of Sta-Rite Industries, a pump and water-processing manufacturer; and Wexco of Delaware, an investor in developing oil and gas reserves. Wisconsin Gas is the oldest gas distributor in Wisconsin, dating back to 1852 . Over 90 percent of its customers are residential with the remainder being commercial and industrial.

Wisconsin Gas added over 10,000 new customers during 1992 and hopes to add at least 9,000 per year for the next several years. It has made advances in the commercial sector by concentrating on the food service equipment and water heating markets. In the in- dustrial sector, food processing, metalworking, and papermaking are areas of interest. Wisconsin Gas is using a combination of flexible rates and customized gas-burning technologies to attract new customers. These technologies help cut the pollutants emitted by these industries.

Wisconsin Gas is also pursuing new markets. There are approximately 50,000 fleet vehicles in its service area who are potential customers for natural gas vehicles. In addition, there are 3 cogeneration projects being pursued in 1993 which would add substantially to the gas sales of the company.

Figure 46. Wisconsin Gas Co., 1992

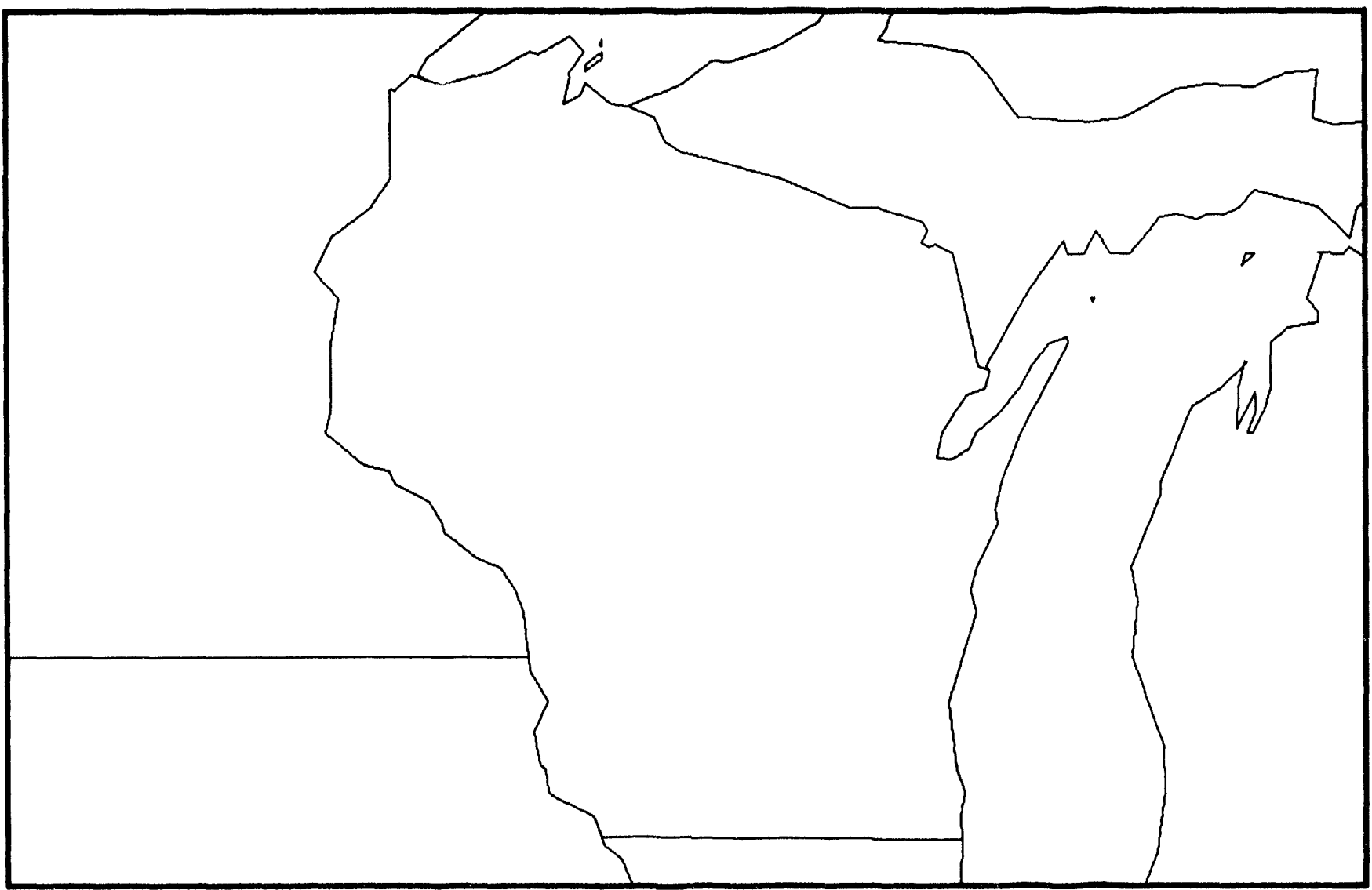

Source: Energy Information Administration (EIA), Form EIA-176, "Annual Report of Natural and Supplemental Gas Supply and Disposition." 
Table 65. Wisconsin Gas Co. Natural Gas Data, 1992 (Thousand Cubic Feet)

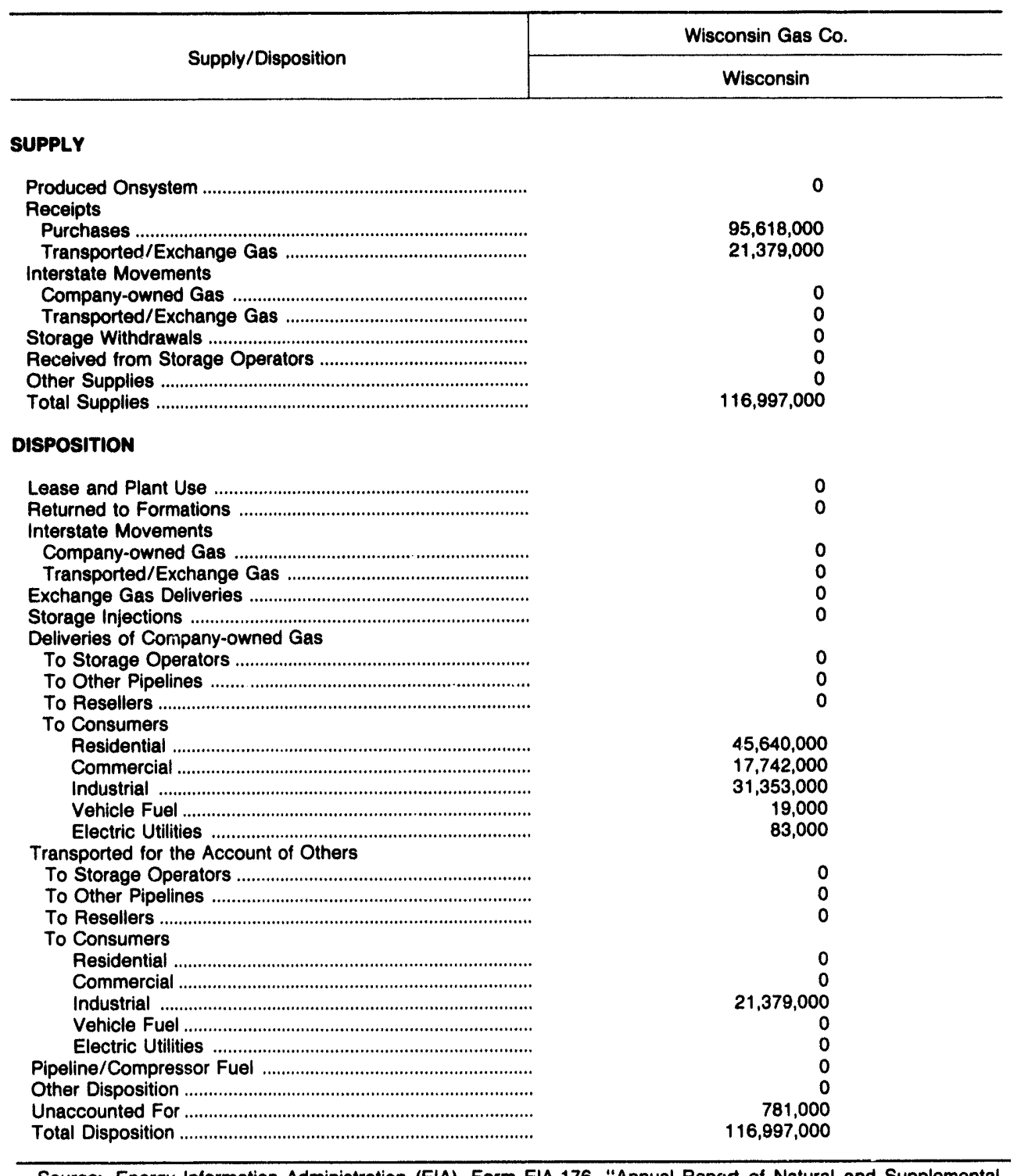

Source: Energy Information Administration (EIA), Form EIA-176, "Annual Report of Natural and Supplemental Gas Supply and Disposition." 
Appendix A

\section{Summary of} Data Collection and Report Methodology 


\section{Summary of Data Collection and Report Methodology}

The data for the Natural Gas Annual 1991 Supplement: Company Profiles are taken from Form EIA-176, "Annual Report of Natural and Supplemental Gas Supply and Disposition." A copy of the form is shown as Figure A1. Other sources of information include industry literature and corporate annual reports to shareholders.

The companies appearing in this report are major interstate natural gas pipeline companies, large distribution companies, or combination companies with both pipeline and distribution operations. The report contains case profiles of 45 corporate families. They were selected in a multistep process using knowledge of the industry and specific information included on Form EIA-176 submissions. First, the interstate pipeline companies (representing distinct corporate families) with the greatest reported volumes of gas transported were selected. Other companies not in the same corporate family as any of the first group were selected from the top companies in volumes delivered to end users. Finally, additional companies belonging to the same corporate family as companies in either of the first two groups were included in the profiles.

\section{Data Collection Operations}

\section{Survey Design}

The original version of Form EIA-176 was approved in 1980 with a mandatory response requirement. Prior to 1980 , published data were based on voluntary responses to Bureau of Mines, U.S. Department of the Interior predecessor Forms BOM-6-1340-A and BOM-6-1341-A of the same title.

In 1982, the scope of the revised EIA-176 survey was expanded to collect the number of electric utility consumers in each State, volumes of gas transported to industrial and electric utility consumers, detailed information on volumes transported across State borders by the respondent for others and for the responding company, and detailed information on other disposition. These changes were incorporated to provide more complete survey information with a minimal change in respondent burden. The 1982 revision of the Form EIA- 176 continues to be the basis for the current version of this form.

In 1988, the Form EIA-176 was revised to include data collection for deliveries of natural gas to commercial consumers for the account of others. The revised form was approved for use during report years 1987 through 1989. A short version of Form EIA-176 was also approved in 1988. Companies engaged in purchase and delivery activities but not in transportation and storage activities may file the short form. Usually, these companies are municipals handling small volumes of gas.

In 1990, the Form EIA-176 was revised to include more detailed information for gas withdrawn from storage facilities, gas added to storage facilities, deliveries of company-owned natural gas and natural gas transported for the account of others. The revised form was approved for use beginning witl. report year 1990. Data reported on this form are no longer collected under a confidentiality agreement with respondents. Response to the form continues to be mandatory.

In February 1993, forr is for report year 1992 were mailed to all identified interstate natural gas pipeline companies; intrastate natural gas pipeline companies; investor and municipally owned natural gas distributors; underground natural gas storage operators; synthetic natural gas plant operators; field, well, or processing-plant operators that deliver natural gas directly to consumers (including their own industrial facilities) other than for lease or plant use or processing; and field, well, or processing-plant operators that transport gas to, across, or from a State border through field or gathering facilities. Detailed instructions for completing the form were included in each survey package. Completed forms were returned to the Data Operations Branch of the Reserves and Natural Gas Division, where each was checked for errors, corrected as necessary, and processed into computer-generated State and national data summaries. 


\section{Response Statistics}

Each company and its parent company or subsidiaries were required to file if they met the survey specifications. The original mailing totaled 2,104 questionnaire packages. To this original mailing, 6 names were added and 28 were deleted as a result of the survey processing. Additions were the result of comparisons of the mailing list to other survey mailing lists. Deletions result from post office returns and determinations that companies were out of business, sold, or not within the scope of the survey. After all updates, the survey universe was 2,091 responses from approximately 1,800 companies.

\section{Report Methodology}

\section{Natural Gas Consumed as a Vehicle Fuel}

Data on deliveries of natural gas for use as a vehicle fuel were collected for the first time in 1990.

\section{Natural Gas Unaccounted For}

Natural gas unaccounted for represents the difference between the sum of the components of natural gas supply and the sum of the components of natural gas disposition. When this calculation results in a negative quantity, the natural gas unaccounted for represents an excess of reported supply in relation to reported disposition, and positive quantities indicate the opposite situation.

The differences between supply and demand represent quantities lost, the net result of gas company conversions of flow data metered at varying temperature and pressure conditions to a standard temperature and pressure base, metering inaccuracies, the effect of variations in company accounting and billing practices, and differences between billing cycle and calendar-period time frames.

A listing of parent companies along with their affiliates is shown on the following page. A copy of Form EIA-176 follows the listing. Table A1 shows the company profile data elements with their corresponding line numbers from the Form EIA-176. Table A2 provides an index of affiliate companies with their associated parent company. 
The following list presents the parent companies along with their affiliates featured in the Natural Gas Annual 1992 Supplement: Company Profiles

Arkla, Inc.

Arkansas Louisiana Gas Co.

Arkla Energy Resources, Inc. Entex Div. of Arkla, Inc. Industrial Gas Supply Corp. Louisiana Intrastate Gas Co. Minnegasco, Inc. Mississippi River Transmission Corp. Tuscaloosa Pipeline Co. Unit Gas Transmission Co.

Atlanta Gas Light Co.

Chatanooga Gas Co.

Baltimore Gas and Electric Co.

Brooklyn Union Gas Co.

Boston Gas Co.

Coastal Corp.

ANR Pipeline Co.

ANR Production Co.

ANR Storage Co.

Coastal Gas Gathering Co.

Colorado Interstate Gas Co.

Eaton Rapids Gas Storage System

Great Lakes Gas Transmission Ltd.

High Island Offshore System

Steuben Gas Storage Co.

U-T Offshore System

Wyoming Interstate Co.

Columbia Gas System, Inc.

Columbia Gas of Kentucky

Columbia Gas of Maryland

Columbia Gas of Ohio

Columbia Gas of Pennsylvania

Columbia Gas Transmission Corp.

Columbia Gulf Transmission Corp.

Columbia LNG Corp.

Commonwealth Gas Service Inc.
Delhi Gas Pipeline Corp.

Inland Gas Co.

Nueces Co.

Ozark Gas Transmission System

Consolidated Edison Co. of New York, Inc.

Consolidated Natural Gas Co.

CNG Transmission Corp.

East Ohio Gas Co.

Hope Gas, Inc.

Peoples Natural Gas Co.

River Gas Co.

Virginia Natural Gas, Inc.

West Ohio Gas Co.

Consumers Power Co.

Michigan Gas Storage Co.

El Paso Natural Gas Co.

Mojave Pipeline Co.

Enron Corp.

Black Marlin Pipeline Co.

Enron Industrial Natural Gas Co.

Florida Gas Transmission Co.

Houston Pipe Line Co.

Intratex Gas Co.

Northern Border Pipeline Co.

Northern Natural Gas Co.

Transwestern Pipeline Co.

Valley Pipeline Inc.

Equitable Resources, Inc.

Equitable Gas Co.

Equitrans, Inc.

Kentucky West Virginia Gas Co.

Gas Company of New Mexico

Iroquois Gas Transmission System 
K N Energy, Inc.

Northern Gas Co.

Northern Gas of Wyoming

RMNG Gathering Co.

Rocky Mountain Natural Gas Co.

Rocky Mountain Natural Gas Div.

TCP Gathering

Koch Gateway Pipeline Co.

Lone Star Gas Co.

National Pipeline Co.

Michigan Consolidated Gas Co.

Citizens Gas Fuel Co.

MichCon Gás Co.

MidCon Corp.

Kansas Gas Supply Corp.

MidCon Texas Pipeline Co.

Moraine Pipeline Co.

Natural Gas Pipeline Co. of America

Palo Duro Pipeline Co.

Stingray Pipeline Co.

Texas Industrial Energy Co.

Trailblazer Pipeline System

United Texas Transmission Co.

National Fuel Gas Co.

National Fuel Gas Distribution Corp.

National Fuel Gas Supply Corp.

Penn York Natural Gas Storage Co.

Niagara Mohawk Power Corp.

Northern Illinois Gas Co.

Northern Indiana Public Service Co.

Kokomo Gas and Fuel Co.

Northwest Natural Gas Co.

ONEOK, Inc.

Oklahoma Natural Gas Co.

Oktex Pipeline Co.

ONG Red Oak Transmission Co.

ONG Sayre Storage Co.

ONG Western, Inc.

Red River Pipeline Co.

Pacific Gas \& Electric Co.

Pacific Gas Transmission Co.
Panhandle Eastern Corp.

Algonquin Gas Transmission Co. Panhandle Eastern Pipe Line Co.

Southwest Gas Storage Co.

Texas Eastern Transmission Corp.

Trunkline Gas Co.

Trunkline LNG Co.

Peoples Gas Light and Coke Co.

North Shore Gas Co.

Public Service Co. of Colorado

Cheyenne Light Fuel and Power Co.

Western Gas Supply Co.

Public Service Electric and Gas Co.

Questar Corp.

Mountain Fuel Supply Co.

Overthrust Pipeline Co.

Questar Pipeline Co.

Sabine Pipe Line Co.

Bridgeline Gas Distribution Co.

Riverway Gas Pipeline Co.

San Diego Gas and Electric Co.

Southern California Gas Co.

Pacific Interstate Transmission Co.

Pacific Offshore Pipeline Co.

Southern Natural Gas Co.

Bear Creek Storage Co.

Sea Robin Pipeline Co.

South Georgia Natural Gas Co.

Southwest Gas Corp.

Tenneco, Inc.

Channel Industries Gas Co.

Creole Gas Pipeline Corp.

East Tennessee Natural Gas Co.

Midwestern Gas Transmission Co.

Tennessee Gas Pipeline Co.

Viking Gas Transmission Co.

Transco Gas Co.

Texas Gas Transmission Corp.

Transcontinental Gas Pipe Line Corp. 
Valero Energy Corp.

Val Gas Co.

Val Gas Limited Partnership

Val Gathering Limited Partnership

Valero Gas Storage

Valero Interstate Transmission Co.

Valero Transmission Limited Partnership

V.H.C. Pipeline Limited Partnership

Washington Gas Light Co.

Frederick Gas Co.

Hampshire Gas Co.

Shenandoah Gas Co.

Western Resources, Inc.

Williams Companies, Inc., The

Kern River Gas Transmission Co.

Louisiana Resources Co.

Northwest Pipeline Corp.

Williams Gas Marketing Co.

Williams Natural Gas Co.

Williston Basin Interstate Pipeline Co.

Montana-Dakota Utilities Co.

Wisconsin Gas Co. 
Figure A1. Form EIA-176

E1A.176 (Revised 1991)

U.S. DEPARTMENT OF ENEAGY

Form Approved

\title{
ENEAGY INFORMATION ADMINISTRATION
}

\section{ANNUAL REPORT OF NATURAL AND SUPPLEMENTAL GAS SUPPLY AND DISPOSITION, $19 \square$}

\begin{abstract}
Thle report lo mendetory under the Foderel Energy Adminlstration Act of 1974 (Public Low 93.275 ). Fallure to report may result in criminel fines, civil penaitles, and other enctione provided by low. See Soctlon VI of the Inetructions for confldentiality statement. Public reporting burden for this collec. tlon of Informatlon ls eat Imated to everage 19.8 hours per respones, Including the time of reviewing ingtructions, saarching existing dete sources. gathering and mainteining the dete neoded, ind completing and reviowing the colloction of intormation. Sond the Energy information Administation, oftice of Stetleticel Stenderde E1.73, Mail Station 2F.08; Forrentel, 1000 Independence Ave SW, Washington DC 20585; end to the Oftice of Intormation and Reguletary Affalro, Offlce of Menagement and Budget, Weshington DC 20503.
\end{abstract}

\section{EIA USE}

Affix mailing label or entef mail address

AESPONDENT COPY.

Retain for your files.

Control (ID) No.

Name

Street or Post Otfice Box

City, State, Zip Code :

Attention

PART 1: IDENTIFICATION

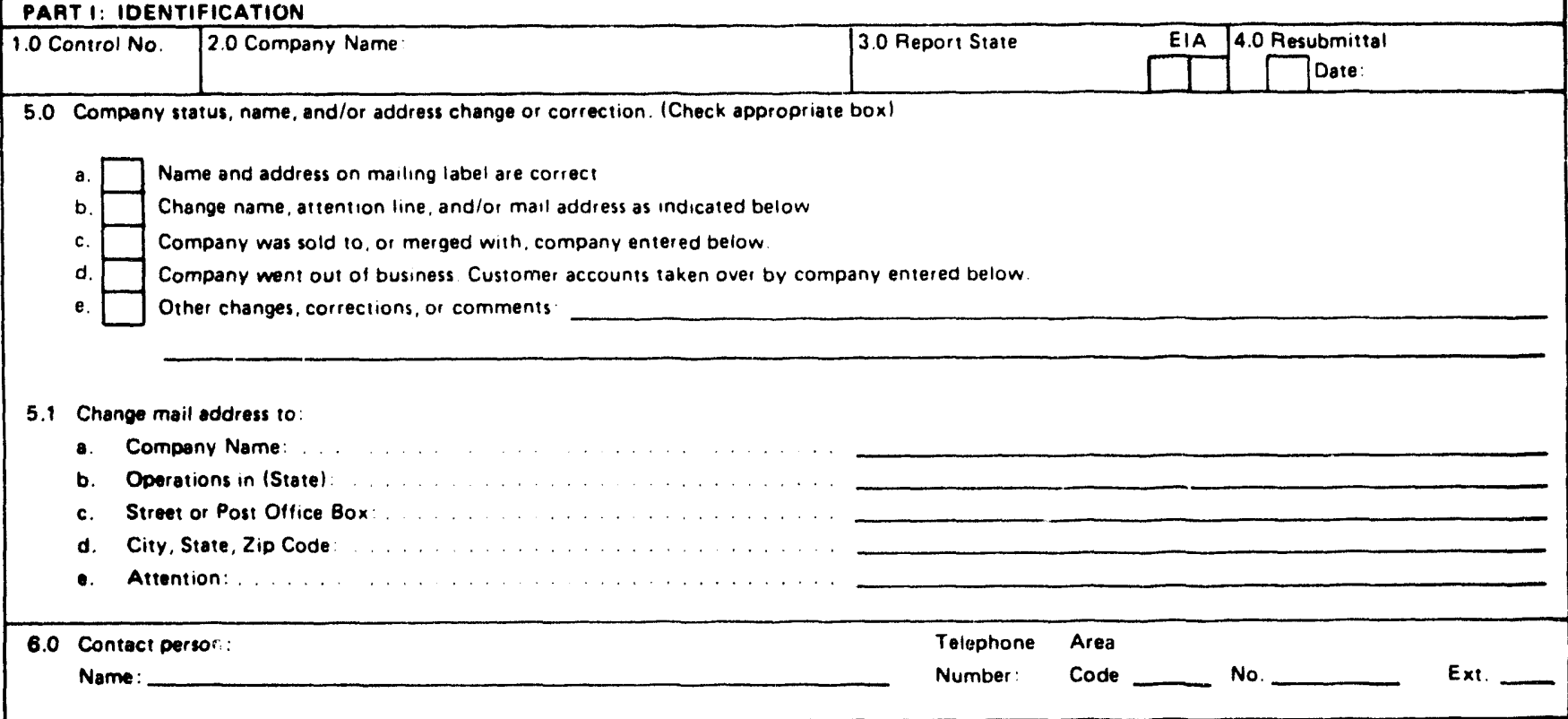

PART II: CERTIFICATION AND DISCLOSURE STATEMENT

1.0 I certify that (Check appropriate box):

a. The information provided herein and appended hereto is true and accurate or, where indicated on the form, reasonable estimates to the best of my knowledge.

b. My company does not meet any of the criteria set forth in Section II, "Who must submit," of the instructions and is therefore not required to complete and submit a Form ElA.176 for the report State.

\begin{tabular}{|l|l|}
\hline 2.0 Name & 3.0 Title \\
\hline 4.0 Signature & 5.0 rgte \\
\hline $\begin{array}{l}\text { Tith } 18, \text { USC 1001, makes it a crime for any person knowingly and willingly to make to any agency or department of the United States any false. fictitious } \\
\text { or fraudulent statements as to any matter within its jurisdiction. }\end{array}$ \\
\hline
\end{tabular}


EIA.176, ANNUAL REPORT OF NATURAL AND SUPPLEMENTAL GAS SUPPLY AND DISPOSITION, 19

\begin{tabular}{|l|l|l|l|}
\hline 1.0 Control No. & 2.0 Company Name & 3.0 Report State & Ela 4.0 Resubmitral \\
\hline
\end{tabular}

\begin{tabular}{|l}
\hline PART III: TYPE OF COMPANY AND GAS ACTIVITIES OPERATED IN THE REPORT STATE \\
\hline 1.0 TYPe of Company (check One) \\
\hline
\end{tabular}

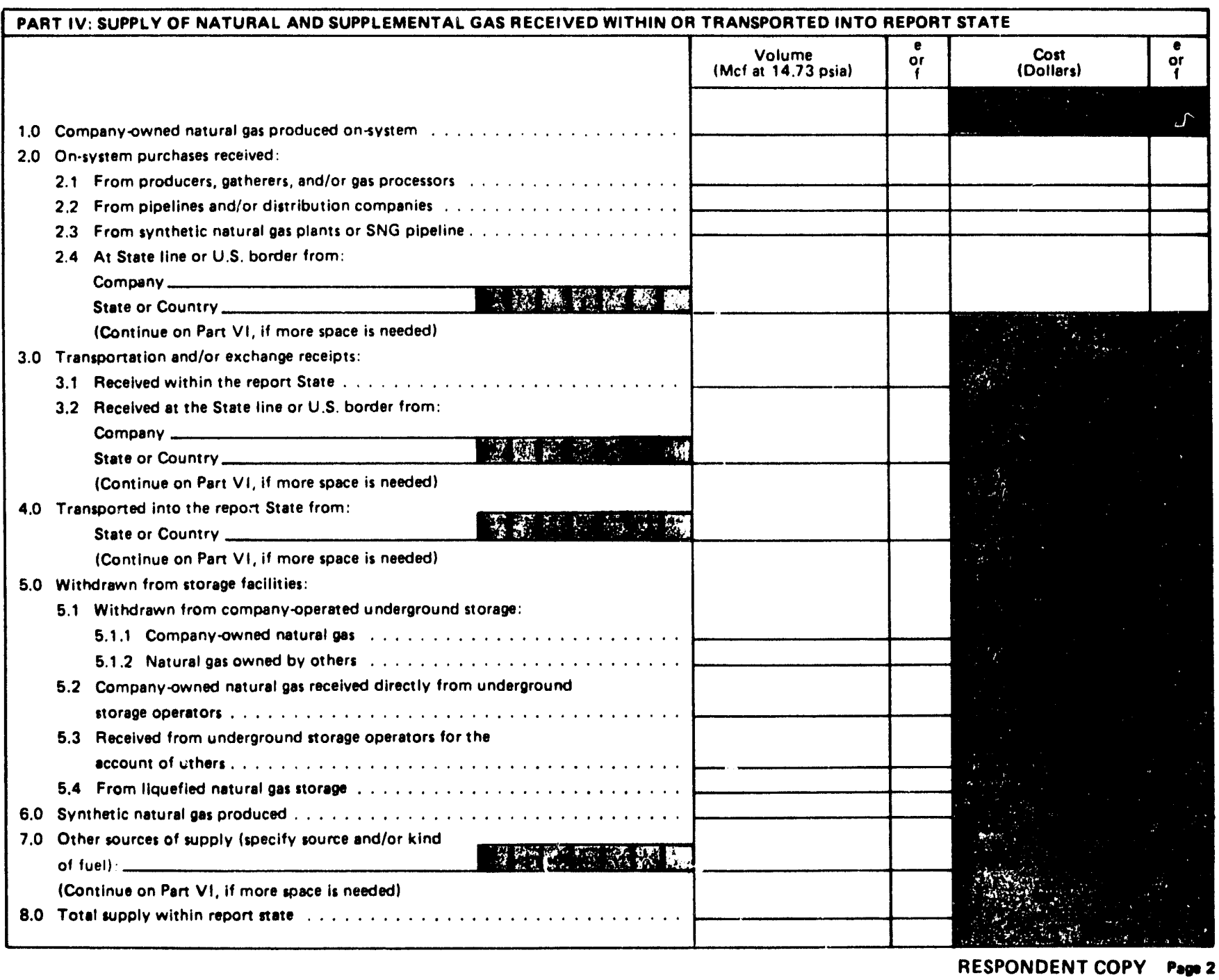


EIA-176, ANNUAL REPORT OF NATURAL AND SUPPLEMENTAL GAS SUPPLY AND DISPOSITION, 19

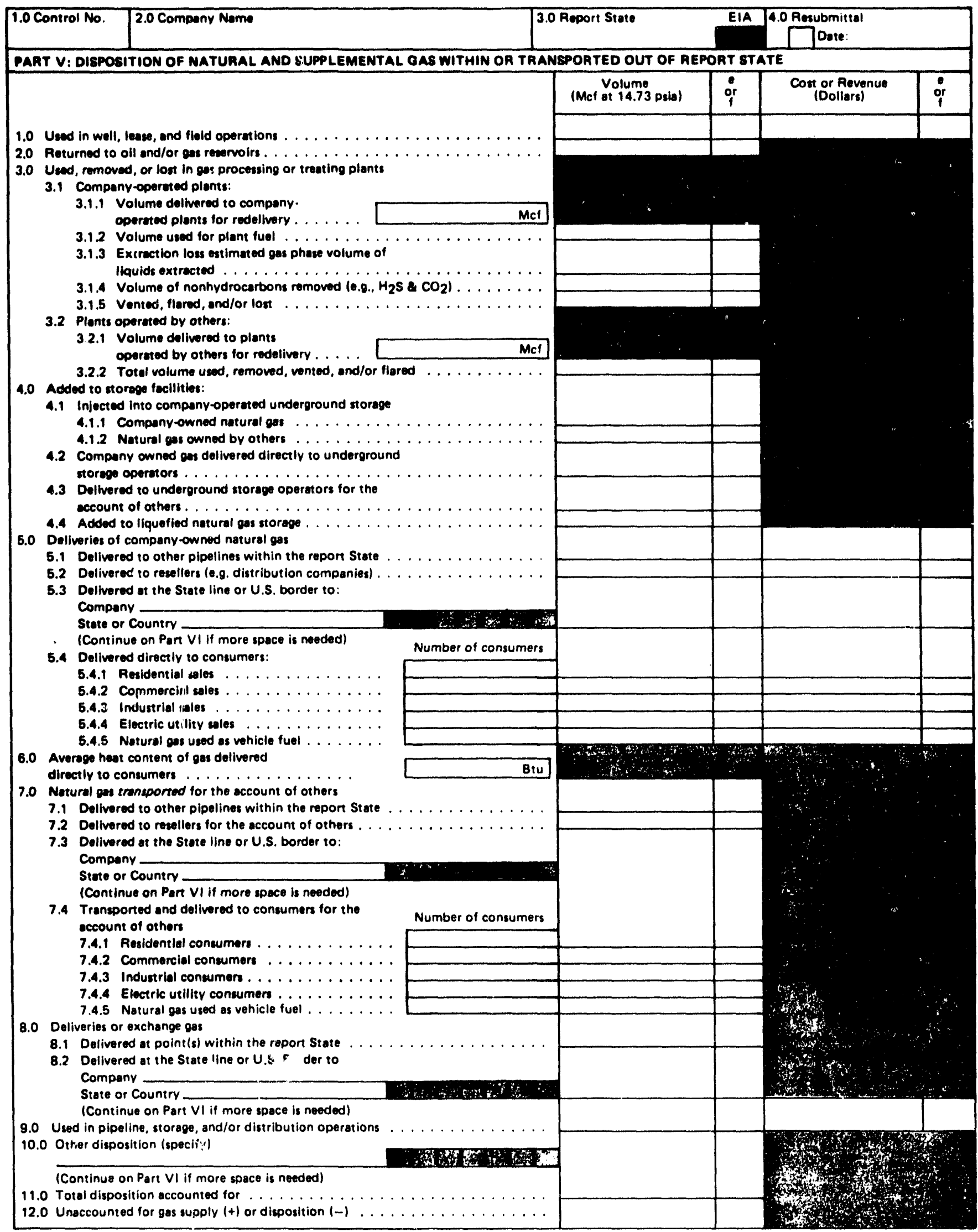

RESPONDENT COPY Pago 3 
EIA.176, ANNUAL REPORT OF NATURAL AND SUPPLEMENTAL GAS SUPPLY AND DISPOSITION, 19

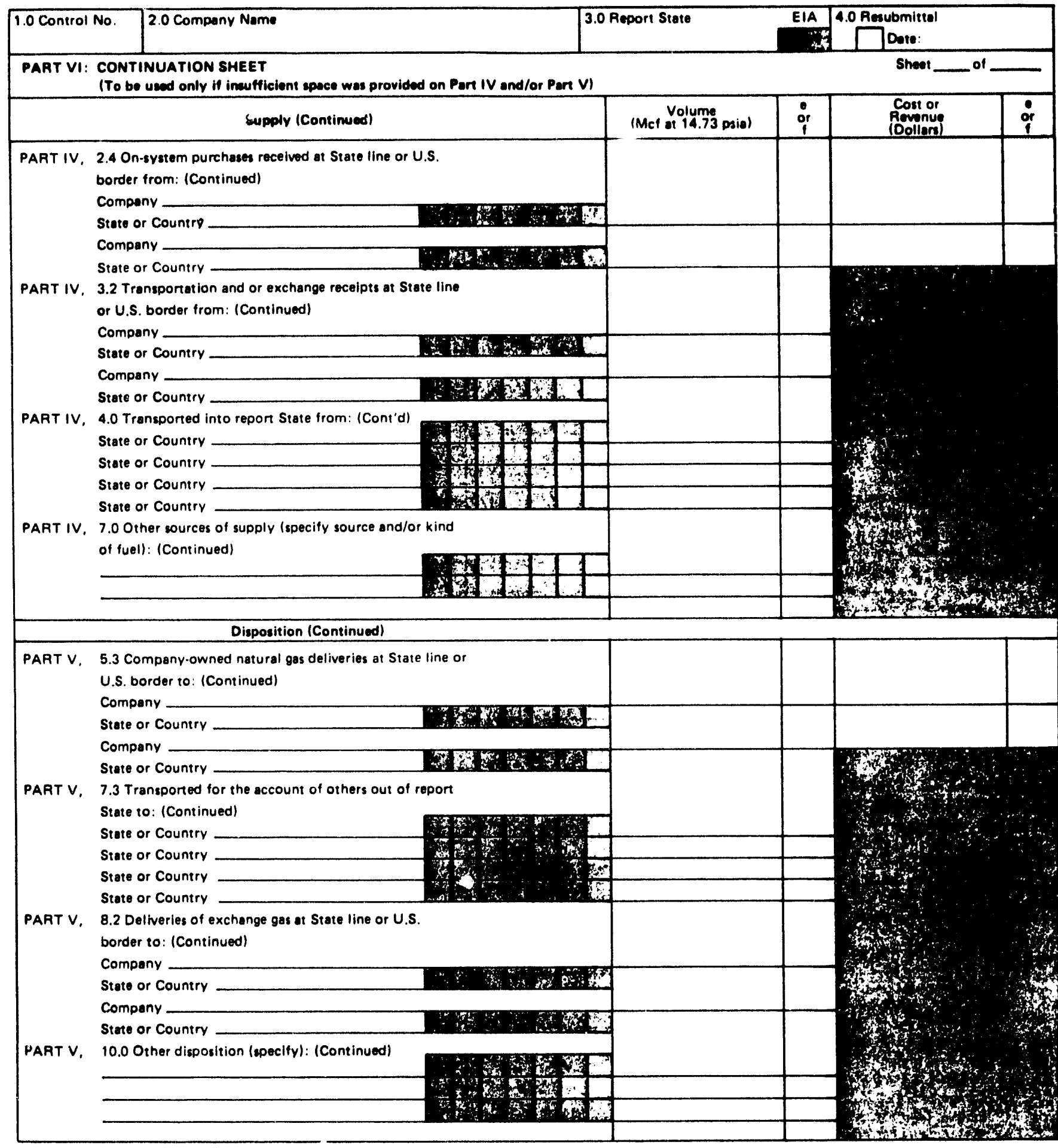


EIA.176, ANNUAL REPORT OF NATURAL AND SUPPLEMENTAL GAS SUPPLY AND DISPOSITION, 19 D

\begin{tabular}{|c|c|c|c|c|}
\hline 10 Control No. & 2.0 Compeny Nams & 3.0 Aecont Stute & EIA & $\begin{array}{l}4.0 \text { Acesubmittal } \\
\text { Doste: }\end{array}$ \\
\hline
\end{tabular}

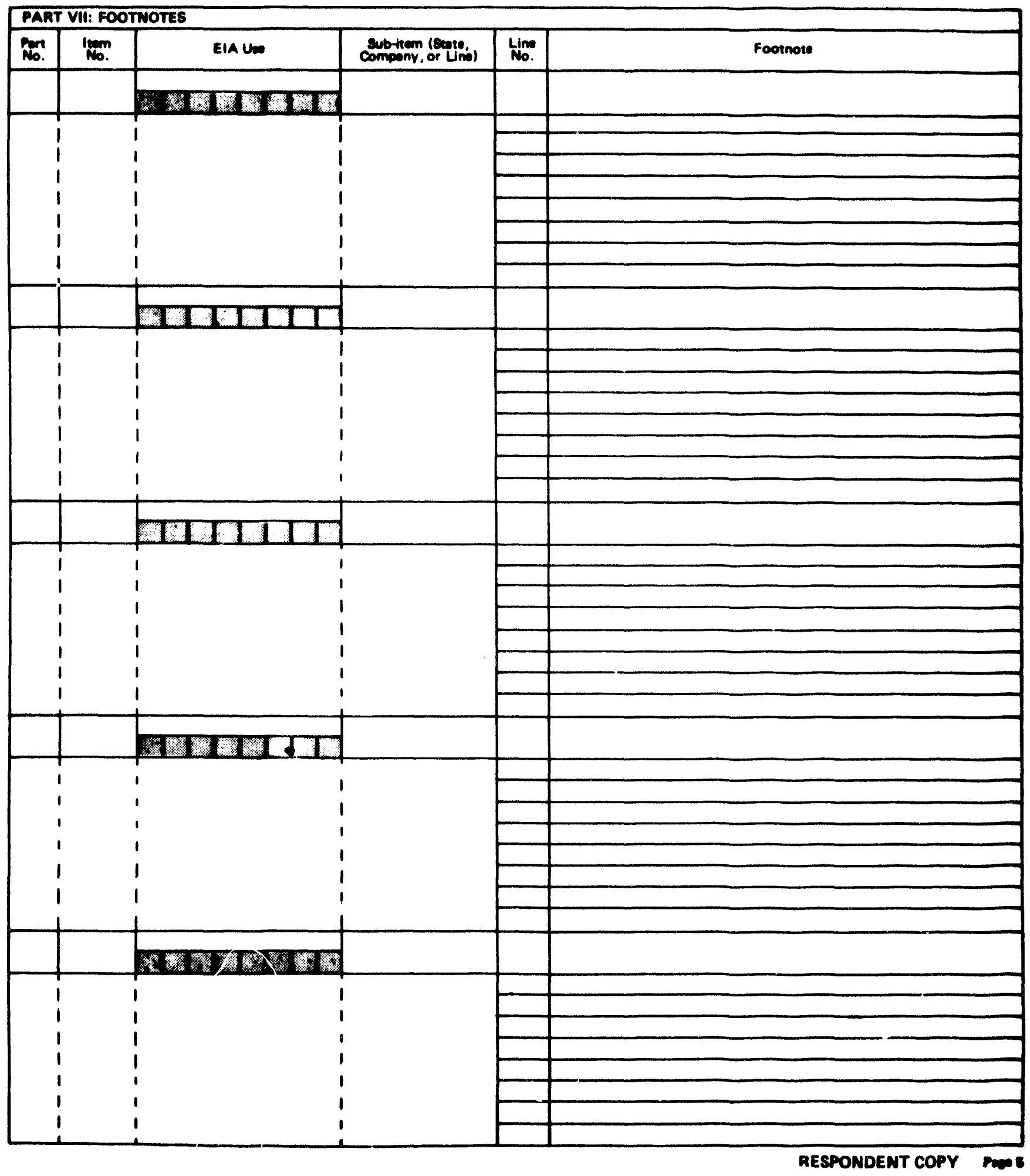


Table A1. Company Proflle Data Elements

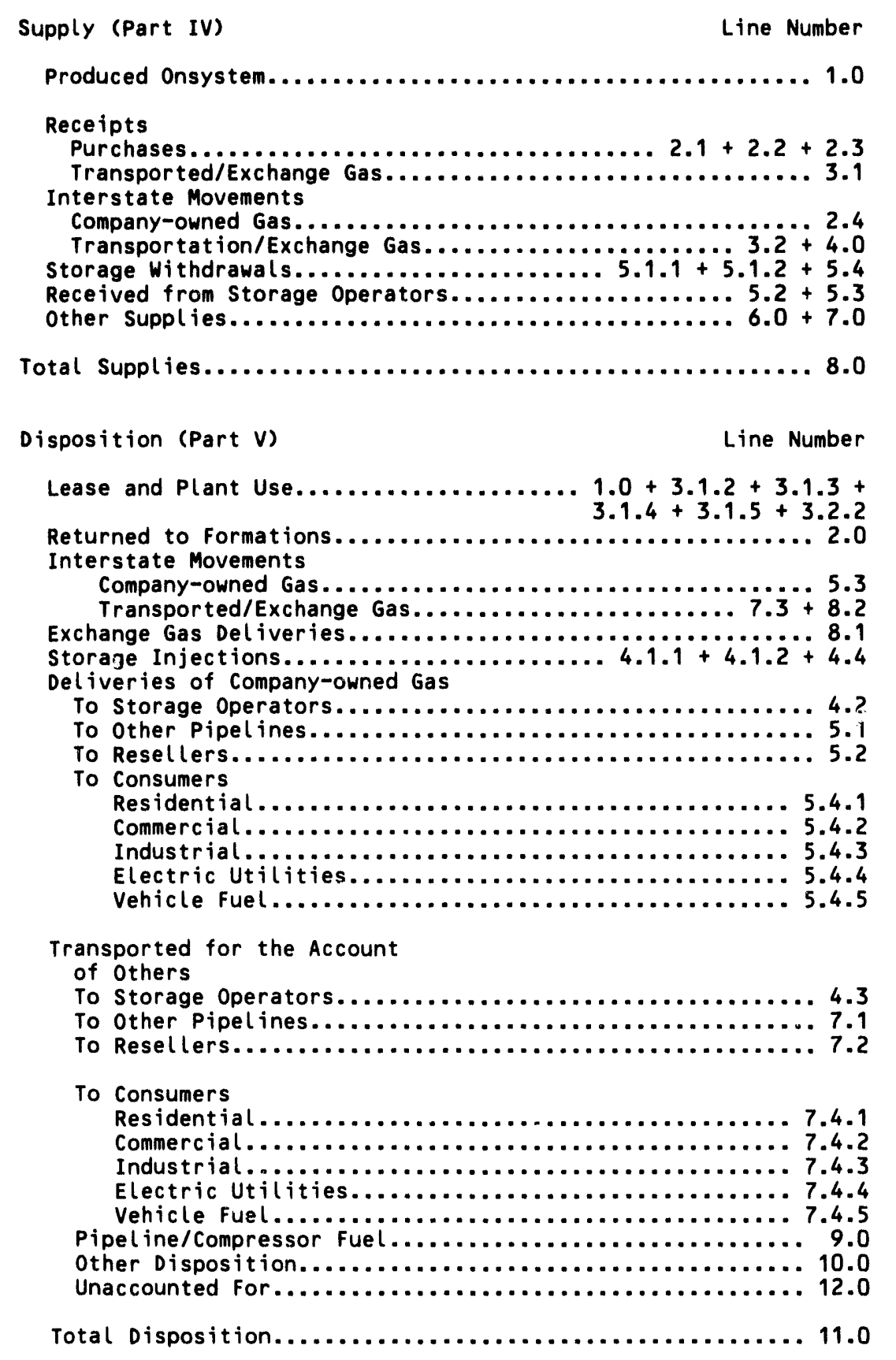

Source: Energy Information Administration (EIA), Form EIA-176, "Annual Report of Natural and Supplemental Gas Supply and Disposition." 
Table A2. Alphabetical Listing of Affiliate Companies

Affiliate Company Parent Company

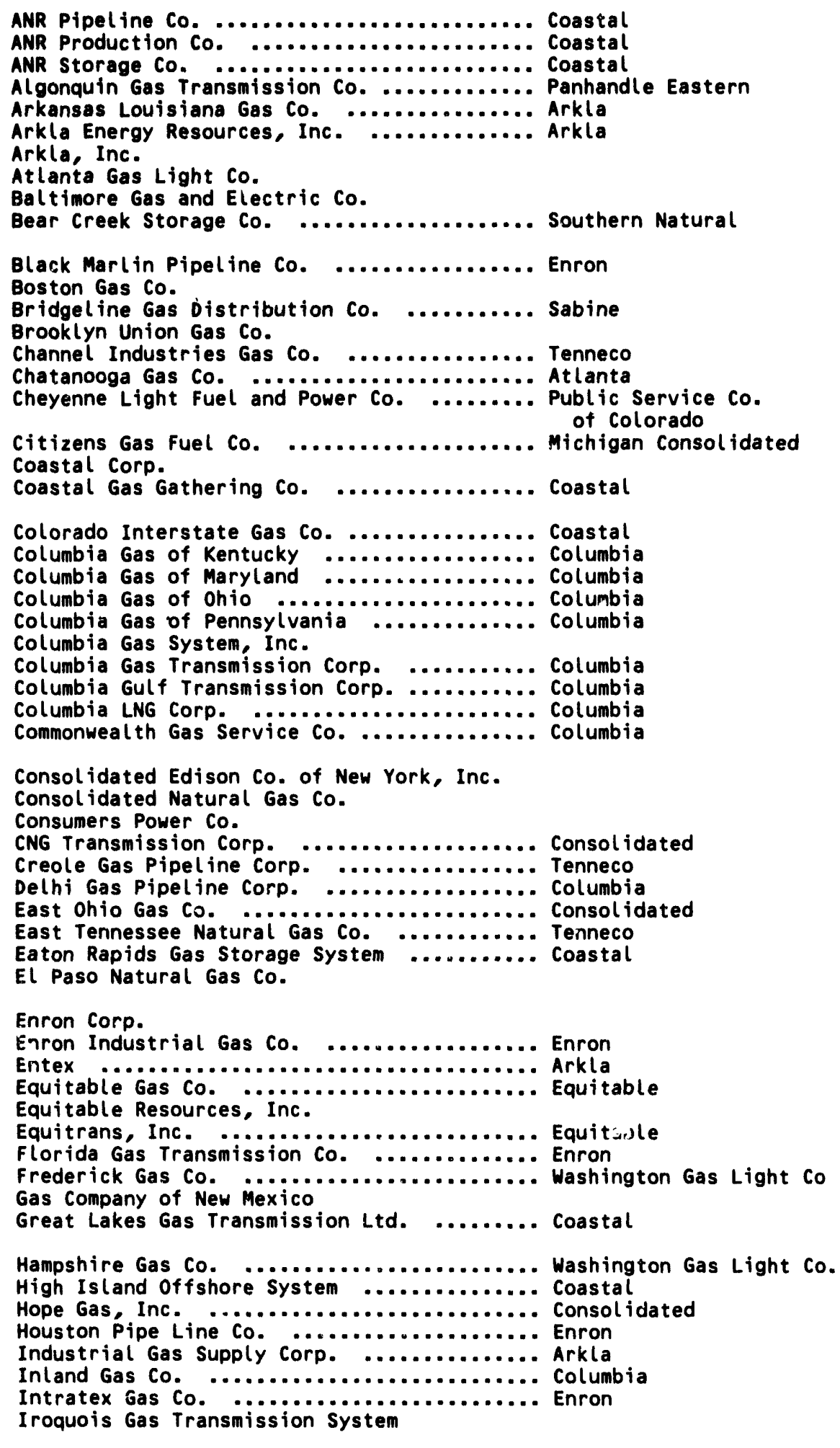

see footnotes at end of table. 


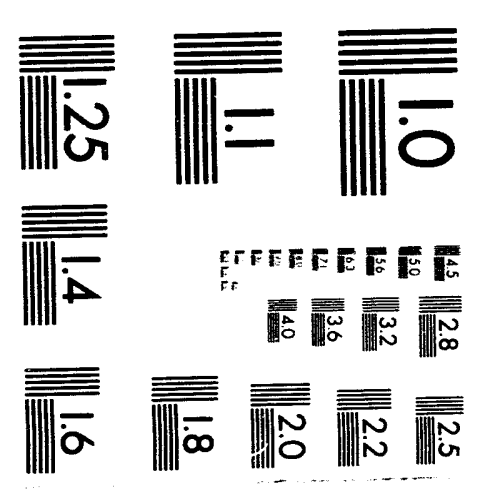



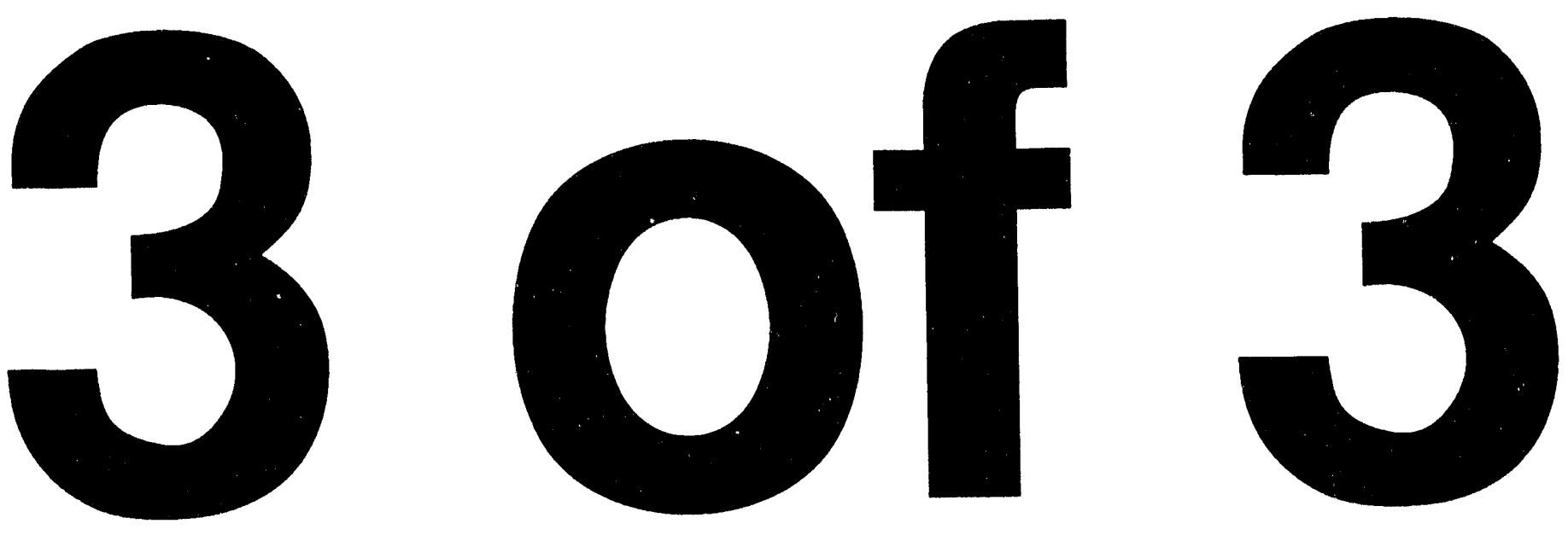


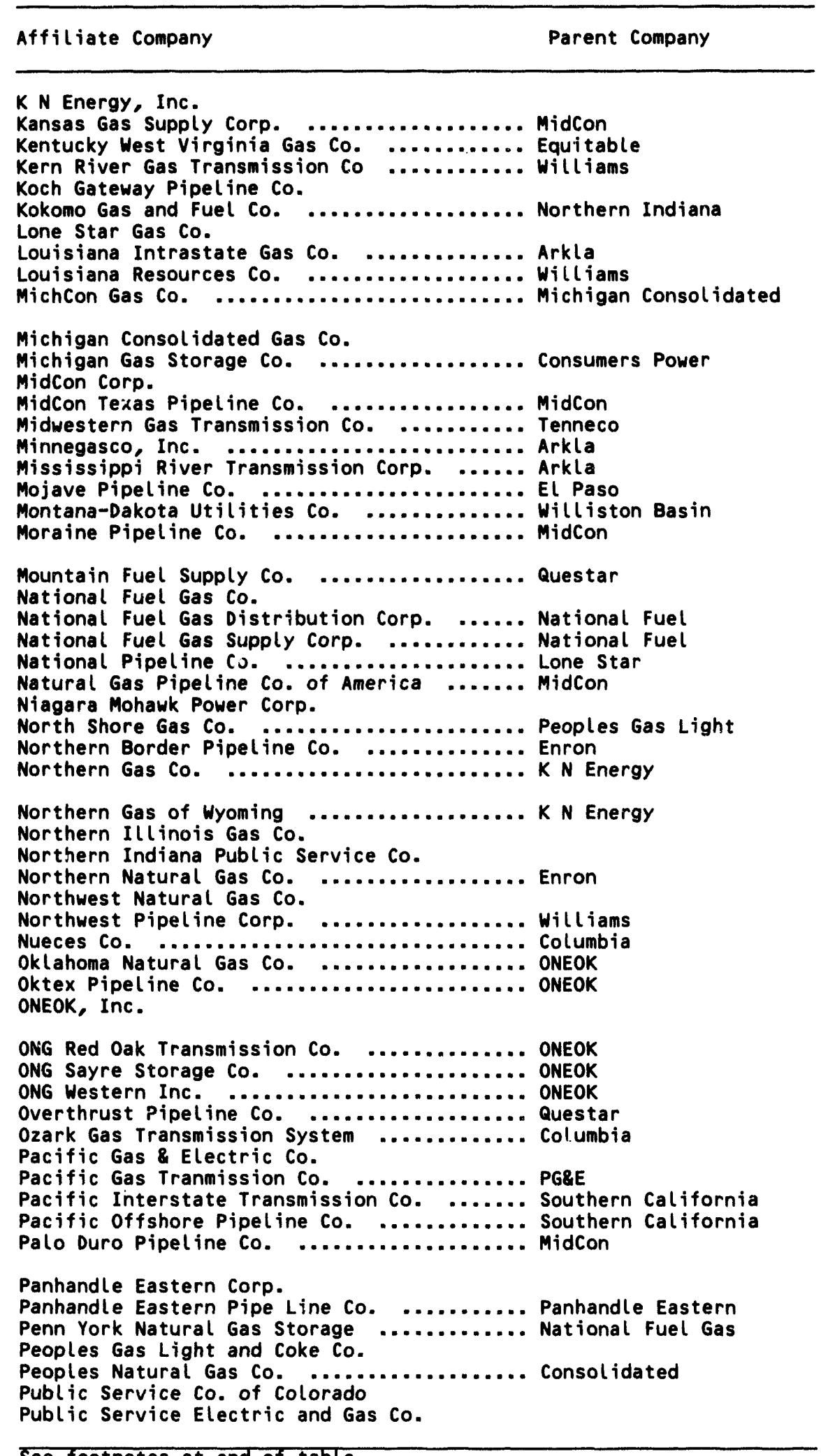

See footnotes at end of table. 
Questar corp.

Questar Pipeline Co. ................... Questar

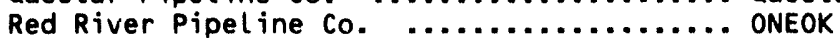

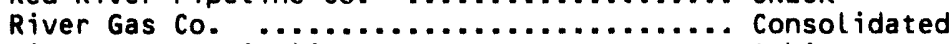

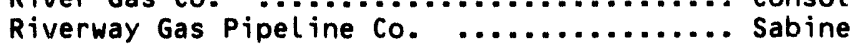

RMNG Gathering Co. ................... K N Energy

Rocky Mountain Naturai Gas Co. .............. $N$ Energy

Rocky Mountain Natural Gas Div. ........... K N Energy

Sabine Pipe Line Co.

San Diego Gas and Electric Co.

Sea Robin Pipeline Co. ................ Southern Natural

Shenandoah Gas Co. ................... Washington Gas Light Co

South Georgia Natural Gas Co. ............ Southern Natural

Southern California Gas Co.

Southern Natural Gas Co.

Southwest Gas Corp.

Southwest Gas Storage Co. ............... Panhandle Eastern

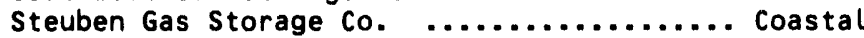

Stingray Pipeline Co. .................. MidCon

TCP Gathering ...................... K $N$ Energy

Tenneco, Inc.

Tennessee Gas Pipeline Co. .............. Tenneco

Texas Eastern Transmission Corp. .......... Panhandle Eastern

Texas Gas Transmission Corp. ............. Transco

Texas Industrial Energy Co. .............. MidCon

Trailblazer Pipeline System .............. MidCon

Transco Gas Co.

Transcontinentil Gas Pipe Line Corp. ....... Transco

Trariswestern Pipeline Co. ................. Er.ron

Trunkline Gas Co. .................... Panhandle Eastern

Trunkline LNG Co. ....................... Panhandle Eastern

Tuscaloosa Pipeline Co. ....................... Arkla

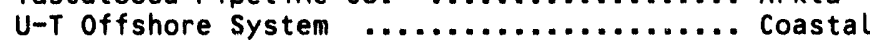

Unit Gas Transmission Co. ................. Arkla

United Texas Transmission $\mathrm{Co} . . . . . . . . . .$. . MidCon

Val Gas Co. .......................... Valero

Val Gas Limited Partnership .............. Valero

Val Gathering Limited Partnership .......... Valero

Valero Energy Corp.

Valero Gas Storage ................... Valero

Valero Interstate Transmission Co. ........ Valero

Valero Transmission Limited Partnership .... Valero

Valley Pipeline, Inc. .................... Enron

Viking Gas Transmission $\mathrm{Co} . . . . . . . . . . . . .$. . Tenneco

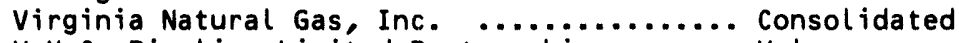

V.H.C. Pipel ine Limited Partnership ....... Valero

Washington Gas Light Co.

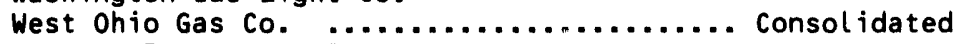

Western Resources, Inc.

Williams Companies, Inc., The

Williams Gas Marketing Co. ...............Williams

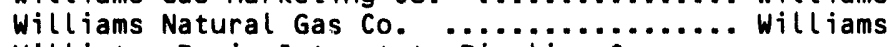

Williston Basin Interstate Pipeline Co.

Wiscons in Gas Co.

Wyoming Interstate co. .................. Coastal

Source: Energy Information Administration (EIA), Form EIA-176, "Annual Report of Natural and Supplemental Gas Supply and Disposition." 
Appendix B

Selected

Natural Gas and Related Reports 


\section{Appendix B}

\section{Selected Natural Gas and Related Reports}

\section{Recurring Natural Gas Reports}

- Natural Gas Monthly, DOE/EIA-0130. Published monthly.

\section{Other Reports Covering Natural Gas, Natural Gas Liquids, and Other Energy Sources}

- U.S. Crude Oil, Natural Gas, and Natural Gas Liquids Reserves - 1992 Annual Report, DOE/EIA-0216(91), September 1993.

- Monthly Energy Review, DOE/EIA-0035. Published monthly. Provides national aggregate data for natural gas, natural gas liquids, and other energy sources.

- Annual Report to Congress 1992, DOE/ EIA-0173(92), March 1993. Published annually.

- Annual Energy Outlook 1993, DOE/ EIA-0383(93), January 1993. Published annually.

- Annual Energy Review 1992, DOE/ EIA-0384(92), June 1993. Published annually.

- Short-Term Energy Outlook, DOE/EIA-0202. Published quarterly. Provides forecasts for next six quarters for natural gas and other energy sources.

- Statistics of Interstate Natural Gas Pipeline Companies 1991, DOE/EIA-0145(91), December 1992.

- Gas Supplies of Interstate Natural Gas Pipeline Companies 1991, DOE/EIA-0167(91), Decemiber 1992.

- Annual Outlook for Oil and Gas: 1991 DOE/EIA-0517(91), June 1991.
- State Energy Data Report, Consumption Estimates, 1960-1991, DOE/EIA-0214(91), May 1993.

- State Energy Price and Expenditure Report 1990, DOE/EIA-0376(90), September 1992.

\section{One-Time Reports}

- U.S. Production of Natural Gas from Tight Reservoirs DOE/EIA-TR-0574, October 1993.

- Natural Gas 1992: Issues and Trends DOE/EIA-0560(20), March 1993.

- Natural Gas Productive Capacity for the Lower 48 States 1982 through 1993, DOE/EIA-0542(93), March 1993.

- Geologic Distributions of U.S. Oil and Gas, DOE/ EIA-0557, July 1992.

- Capacity and Service on the Interstate Natural Gas Pipeline System 1990, DOE/EIA-0556, June 1992.

- Effects of Interruptible Natural Gas Service: Winter 1989-1990, SR/OG-91-01, June 1991.

- The Outlook for Natural Gas Imports: Supporting Analysis for the National Energy Strategy, SR/ NES/90-06, January 1991.

- The Domestic Oil and Gas Recoverable Resource Base: Supporting Analysis for the National Energy Strategy, SR/NES/90-05, December 1990.

\section{Reference Reports}

- Directory of Energy Data Collection Forms, DOE/ EIA-0249(92), January 1993.

- Oil and Gas Field Code Master List, 1992, EIA-0370(92), December 1992. 


\section{Glossary}

Cofiring: The process of burning natural gas in conjunction with another fuel to reduce air pollutants.

Cogeneration: The simultaneous generation of steam and electricity from one fuel.

Commercial Consumption: Natural gas used by nonmanufacturing establishments or agencies primarily engaged in the sale of goods or services. Included are such establishments as hotels, restaurants, wholesale and retail stores, and other service enterprises; gas used by establishments engaged in agriculture, forestry, and fisheries; and gas used by local, State, and Federal agencies engaged in nonmanufacturing activities.

Compressed Natural Gas (CNG): Natural gas which is comprised primarily of methane, compressed to a pressure at or above 2,400 pounds per square inch and stored in special high pressure containers. It is used as a fuel for natural gas powered vehicles.

Compressor Station: Any combination of facilities which supplies the energy to move gas in transmission lines or into storage by increasing the pressure.

Delivered: The physical transfer of natural, synthetic, and/or supplemental gas from facilities operated by the responding company to facilities operated by others or to consumers.

Distribution Use: Natural gas used as fuel in the respondent's operations.

Electric Utilities: Establishments primarily engaged in the generation, transmission, and/or distribution of electricity for sale or resale.
Electric Utility Consumption: Natural gas used for gross generation, providing standby service, start-up and/or flame stabilization.

Exchange Agreement: A contractual agreement whereby one company agrees to deliver gas either directly or through intermediates to another company at one location, or in one time period, in exchange for the delivery by the second company to the first company of an equivalent volume or heat content at a different location or time period.

Exports: Natural gas deliveries out of the continental United States and Alaska to foreign countries.

Imports: Gas receipts into the United States from a foreign country.

Industrial Consumers: Establishments engaged in a process which creates or changes raw or unfinished materials into another form or product. Generation of electricity, other than by electric utilities, is included.

Industrial Consumption: Natural gas used by manufacturing and mining establishments for heat, power, and chemical feedstock.

Lease and Plant Fuel: Natural gas used in well, field, and lease operations (such as gas used in drilling operations, heaters, dehydrators, and field compressors), and as fuel in natural gas-processing plants.

Natural Gas: A mixture of hydrocarbon compounds and small quantities of various nonhydrocarbons existing in the gaseous phase or in solution with crude oil in natural underground reservoirs at reservoir conditions. 
Onsystem: Any point on or directly interconnected with, a transportation, storage, or distribution system operated by a natural gas company.

Pipeline: A continuous pipe conduit, complete with such equipment as valves, compressor stations, communications systems, and meters, for transporting natural and/or supplemental gas from one point to another, usually from a point in or beyond the producing field or processing plant to another pipeline or to points of use. Also refers to a company operating such facilities.

Pipeline Fuel: Gas consumed in the operation of pipelines, primarily in compressors.

Reburn: An advanced cofiring technique using natural gas to reduce pollution from electric power plants.

Receipts: Gas physically transferred into the responding company's transportation, storage, and/or distribution facilities.

Repressuring: The injection of gas into oil or gas reservoir formations to effect greater ultimate recovery.

Residential Consumption: Natural gas used in private dwellings, including apartments, for heating, air conditioning, cooking, water heating, and other household uses.
Storage Additions: Volumes of gas injected or otherwise added to underground natural gas reservoirs or liquefied natural gas storage.

Storage Withdrawals: Volumes of gas withdrawn from underground storage or liquefied natural gas storage.

Supplemental Gaseous Fuels Supplies: Synthetic natural gas, propane-air, coke oven gas, refinery gas, biomass gas, air injected for Btu stabilization, and manufactured gas commingled and distributed with natural gas.

Unaccounted For: Represents differences between the sum of the components of natural gas supply and the sum of the components of natural gas disposition. These differences may be due to quantities lost or to the effects of data-reporting problems. Reporting problems include differences due to the net result of conversions of flow data metered at varying temperature and pressure bases and converted to a standard temperature and pressure base; the effect of variations in company accounting and billing practices; differences between billing cycle and calendar period time frames; and imbalances resulting from the merger of data reporting systems that vary in scope, format, definitions, and type of respondents.

Underground Storage: The storage of natural gas in underground reservoirs at a different location from which it was produced. 

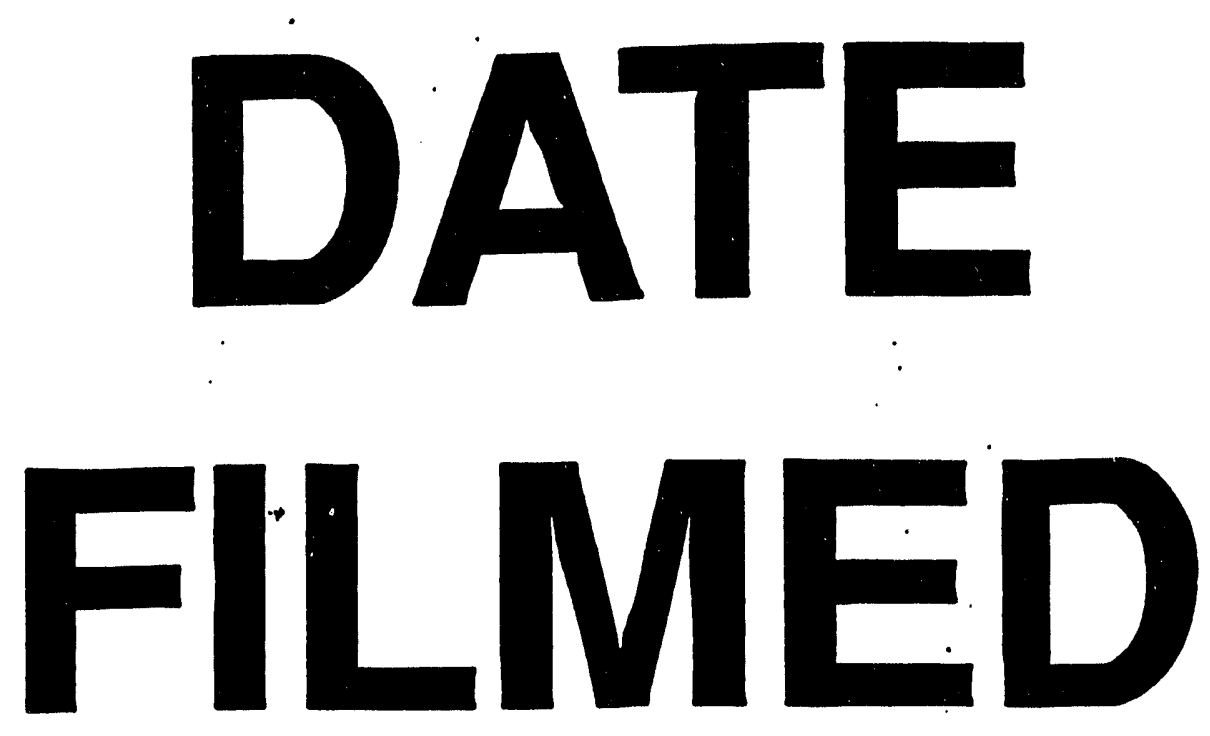

$3 / 23 / 94$
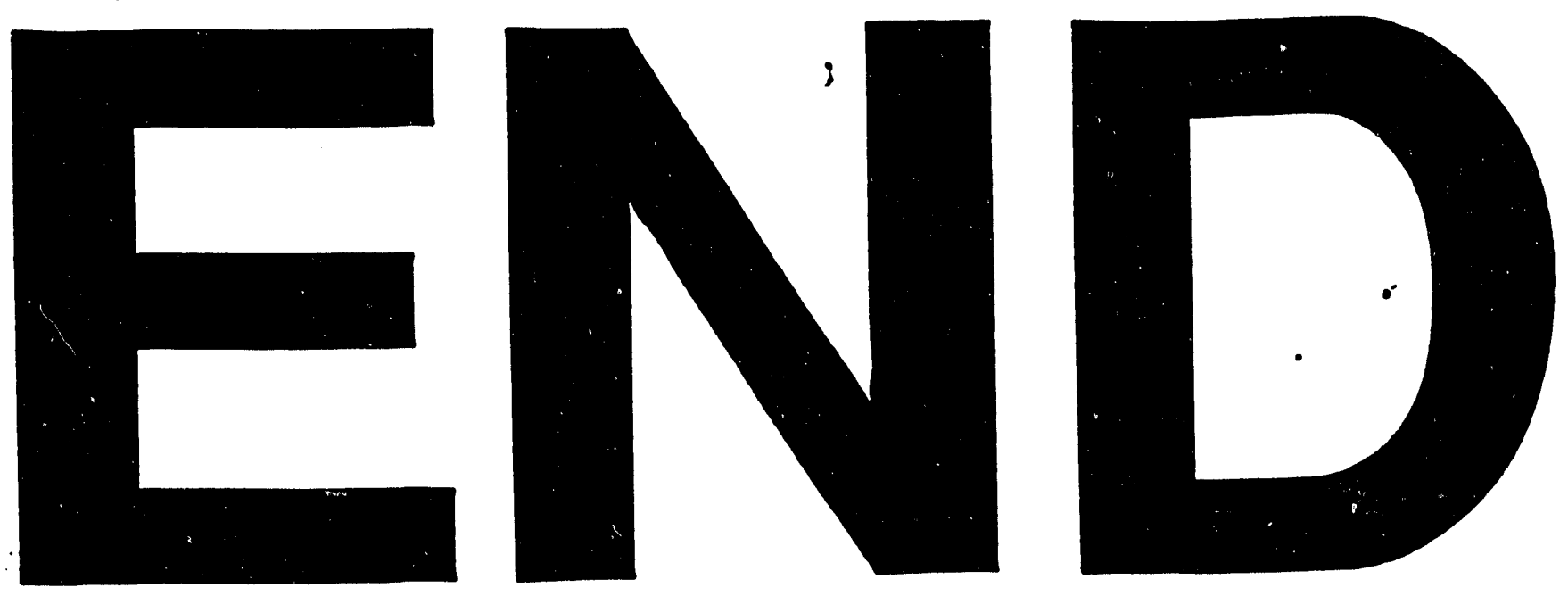
